

\section{Studies by the U.S. Geological Survey in Alaska, 2000}

Frederic H. Wilson and John P. Galloway, Editors

U.S. Geological Survey Professional Paper 1662 


\section{U.S. Department of the Interior}

Gale A. Norton, Secretary

\section{U.S. Geological Survey}

Charles G. Groat, Director

Any use of trade, product, or firm names in this publication is for descriptive purposes only and does not imply endorsement by the U.S. Government.

U.S. Geological Survey, Reston, Virginia: 2002

For additional copies please contact:

\section{USGS Information Services}

\section{Box 25286}

Denver, CO 80225

This report and any updates to it are available at http://geopubs.wr.usgs.gov/prof-paper/p1662/

Additional USGS publications can be found at http://geology.usgs.gov/products.html

For more information about the USGS and its products:

Telephone: 1-888-ASK-USGS (1-888-275-8747)

World Wide Web: http://www.usgs.gov/

Cataloging-in-Publication data is on file with the Library of Congress

Published in the Western Region, Menlo Park, California Manuscript approved for publication, February 14, 2002

Text edited by George A. Havach, James W. Hendley II, and Peter H. Stauffer Production and design by Susan Mayfield and Sara Boore 


\section{Contents}



By Fredric H. Wilson and John P. Galloway

\section{GEOLOGIC FRAMEWORK}

East-Central Alaska

Geochemistry and Age Constraints on Metamorphism and Deformation in the

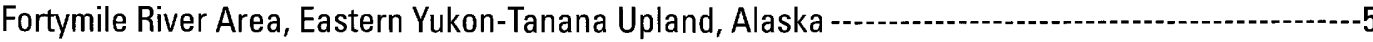

By Warren C. Day, John N. Aleinikoff, and Bruce Gamble

\section{South-Central Alaska}

Stratigraphy, Age, and Geochemistry of Tertiary Volcanic Rocks and Associated

Synorogenic Deposits, Mount McKinley Quadrangle, Alaska

By Ronald B. Cole and Paul W. Layer

Stratigraphy and Provenance Data from the Upper Jurassic to Upper Cretaceous Kahiltna

Assemblage of South-Central Alaska

By Kevin R. Eastham and Kenneth D. Ridgway

\section{Southwestern Alaska}

Late Triassic (Norian) Mollusks from the Taylor Mountains Quadrangle, Southwestern Alaska

By Christopher A. McRoberts and Robert B. Blodgett

\section{Southeastern Alaska}

Notes on the Bedrock Geology and Geography of the Stikine Icefield, Coast Mountains Complex,

Southeastern Alaska

By David A. Brew and Richard M. Friedman

\section{HAZARDS}

\section{Southwestern Alaska}

Mount Griggs: A Compositionally Distinctive Quaternary Stratovolcano Behind the Main

Volcanic Line in Katmai National Park

By Wes Hildreth, Judy Fierstein, Marvin A. Lanphere, and David F. Siems

\section{ENVIRONMENT AND CLIMATE}

\section{Northern Alaska}

Treeline Biogeochemistry and Dynamics, Noatak National Preserve, Alaska

By Robert Stottlemyer, Dan Binkley, and Heidi Steltzer

\section{South-Central Alaska}

Environmental Geochemical Study of the Slate Creek Antimony Deposit, Kantishna Hills,

Denali National Park and Preserve, Alaska-

By Robert G. Eppinger, Paul H. Briggs, James G. Crock, Allen L. Meier,

Stephen J. Sutley, and Peter M. Theodorakos

\section{BIBLIOGRAPHIES}

U.S. Geological Survey Reports on Alaska Released in 2000

Compiled by John P. Galloway

Reports on Alaska in Non-USGS Publications Released in 2000 That Include

U.S. Geological Survey Authors

Compiled by John P. Galloway 



\section{Contributors}

\section{Anchorage}

Gamble, Bruce M.

Wilson, Frederic H.

U.S. Geological Survey

4200 University Drive

Anchorage, AK 99508

\section{Denver}

Aleinikoff, John N., Mail Stop 963

Briggs, Paul H., Mail Stop 973

Crock, James C., Mail Stop 973

Eppinger, Robert G., Mail 973

Day, Warren, C., Mail Stop 973

Meier, Allen L., Mail Stop 973

Siems, David F., Mail Stop 973

Sutley, Stephen J., Mail Stop 973

Theodorakos, Peter M., Mail Stop 973

U.S. Geological Survey

P.O. Box 25046, Mail Stop _

Denver Federal Center

Denver, CO 80225

\section{Fort Collins}

Stottlemyer, Robert

U.S. Geological Survey

240 W. Prospect Rd.

Fort Collins, CO 80526

\section{Menlo Park}

Brew, David A., Mail Stop 901

Fierstein, Judy, Mail Stop 910

Galloway, John P., Mail Stop 901

Hildreth, Wes, Mail Stop 910

Lanphere, Marvin, Mail Stop 937

U.S. Geological Survey

345 Middlefield Rd., Mail Stop -

Menlo Park, CA 94025

\section{Others}

Binkley, Dan

Department of Forest Sciences

Colorado State University

Fort Collins, CO 80523

Blodgett, Robert B.

Department of Zoology

Oregon State University

Corvallis, OR 97331

Cole, Ronald B.

Department of Geology

Allegheny College

Meadville, PA 16335

Eastham, Kevin R.

Department of Earth and Atmospheric Sciences

Purdue University

West Lafayette, IN 47907-1397

Friedman, Richard M.

Department of Earth and Ocean Sciences

University of British Columbia

Vancouver, B.C. V6T 1Z4 Canada

Layer, Paul W.

Department of Geology

University of Alaska

Fairbanks, AK 99775

McRoberts, Christopher A.

Department of Geology

State University of New York

Cortland, NY 13045

Ridgway, Kenneth D.

Department of Earth and Atmospheric Sciences

Purdue University

West Lafayette, IN 47907-1397

Steltzer, Heidi

Department of Forest Sciences

Colorado State University

Fort Collins, CO 80523 



\title{
Studies by the U.S. Geological Survey in Alaska, 2000
}

\author{
Frederic H. Wilson and John P. Galloway, Editors
}

\section{Introduction}

\section{By Frederic H. Wilson and John P. Galloway}

The collection of eight papers that follow continue the series ${ }^{1}$ of U.S. Geological Survey (USGS) investigative reports in Alaska under the broad umbrella of the geologic sciences. The series presents new and sometimes-preliminary findings that are of interest to earth scientists in academia, government, and industry; to land and resource managers; and to the general public. Reports presented in Studies by the U.S. Geological Survey in Alaska cover a broad spectrum of topics from various parts of the State (fig. 1), serving to emphasize the diversity of USGS efforts to meet the Nation's needs for earth-science information in Alaska.

The papers in this volume are organized under the topics Geologic Framework, Resources, and Environment and Climate. This organization is intended to reflect the scope and objectives of current USGS geologic programs in Alaska. In particular, Geologic Framework studies provide background information that is the scientific basis for present and future earth-science investigations.

Day and others discuss the geochemistry of and age constraints on metamorphism and deformation in the Fortymile River area, eastern Yukon-Tanana upland. Determining the age of deposition of many of the major rock types within the Fortymile River area is a major challenge for understanding the geologic evolution of the Yukon-Tanana lithotectonic terrane of east-central Alaska. New geochemical data have helped to characterize the bedrock units, along with new U$\mathrm{Pb}$ zircon ages on two critical units within the Fortymile River area. U-Pb-isotopic data on zircons from the early $\left(\right.$ pre- $\mathrm{D}_{1}$ ) Steele Creek Dome Orthogneiss, as well as from a late-tectonic (late- $\mathrm{D}_{2}$ ) epidote-bearing leucogranite intrusion, help constrain the youngest possible age for supracrustal rocks and regional $\mathrm{D}_{2}$ deformation. The Steele Creek Dome Orthogneiss crystallized at $343 \pm 4$ $\mathrm{Ma}$, indicating that the supracrustal sequence is partly at least Early Mississippian in age. The leucogranite crystallized during the waning states of $\mathrm{D}_{2}$ deformation at $196 \pm 4 \mathrm{Ma}$. U-Pb data on this Early Jurassic leucogranite also show that the inherited zircons have a complex history, with analyses yielding ages of $359 \pm 5$ and $232 \pm 7 \mathrm{Ma}$. These data confirm earlier ${ }^{40} \mathrm{Ar} /{ }^{39} \mathrm{Ar}$ ages that suggest an Early Jurassic timing for the intense regional $\mathrm{D}_{2}$ metamorphism and tectonism.

Cole and Layer present new field, petrographic, and geochemical data on two Tertiary volcanic-rock units and underlying sedimentary rocks in the southeast corner of the Mount McKinley quadrangle. The volcanic-rock units include late Paleocene and early Eocene rocks of the Foraker Glacier and the late Eocene and early Oligocene Mount Galen Volcanics. New ${ }^{40} \mathrm{Ar} /{ }^{39} \mathrm{Ar}$ data on two samples from the lower part of volcanic rocks of the Foraker Glacier yield ages of $56.9 \pm 0.2$ and 5.55 $\pm 0.1 \mathrm{Ma}$. Volcanic rocks of the Foraker Glacier unconformably overlie a 550-m-thick sequence of Late Cretaceous(?) sedimentary rocks that dip steeply north and unconformably overlie Paleozoic metamorphic rocks with a schistosity that dips steeply south. The Mount Galen

${ }^{1}$ From 1975 through 1988, Geologic Studies in Alaska was published as a series of USGS Circulars, which were titled The United States Geological Survey in Alaska: Accomplishments During 19xx. From 1989 to 1994, the series was published as more formal USGS Bulletins. As a result of a reorganization in 1995 of USGS publications, the series is now being published as USGS Professional Papers. 
Volcanics consists of basaltic, andesitic, dacitic, and rhyolitic lavas and dacite, and rhyolite tuff and tuff breccia. New ${ }^{40} \mathrm{Ar} /{ }^{39} \mathrm{Ar}$ data on a basaltic andesite flow $46 \mathrm{~m}$ above the base of the Mount Galen Volcanics yield an age of $43.8 \pm 0.5 \mathrm{Ma}$. The Mount Galen Volcanics is enriched in $\mathrm{Ba}$, $\mathrm{Th}$, Sr, and light rare-earth elements, has high $\mathrm{Ba} / \mathrm{Ta}$ ratios, and exhibits a distinct paired $\mathrm{Nb}$ Ta-depletion trend, all of which are common characteristics of subduction-related volcanic rocks. Cole and Layer interpret that the Late Cretaceous(?) sedimentary rocks record uplift and shortening during the final stages of accretion of the Wrangellia composite terrane to southern Alaska. Volcanic rocks of the Foraker Glacier represent the final phase of Late Cretaceous and early Tertiary Alaska-Talkeetna Mountains magmatism, which ended with suturing of the Wrangellia composite terrane. The Mount Galen Volcanics is part of the northern section of the Eocene to Oligocene Alaska-Aleutian arc that crosscuts older igneous rocks of the region.

Eastham and Ridgway present stratigraphic and provenance data which suggest that thousands of meters of Upper Jurassic to Upper Cretaceous strata which have been grouped together as the Kahiltna assemblage in south-central Alaska may actually represent several different sedimentary basins. The Kahiltna assemblage in the Alaska Range is separated from the Kahlitna assemblage in the Clearwater and Talkeetna Mountains by a large thrust block of Paleozoic and Mesozoic strata known as the Chulitna terrane. Easthman and Ridgway interpret the lithofacies of the Chulitna terrane as representing deposition on a bathymetric high relative to submarinefan lithofacies of the Kahiltna assemblage in the Talkeetna Mountains and Alaska Range.

McRoberts and Blodgett describe a diverse molluscan fauna of silicified fossils from two localities in the Taylor Mountain D-3 quadrangle. The molluscan fauna consists of a least 8 species of bivalves, including one new species, Cassianella cordillerana McRoberts n.sp., and at least 11 species of gastropods, including two new species, Neritaria nuetzeli Blodgett n.sp. and Andangularia wilsoni Blodgett $\mathrm{n}$.sp. Bivalve and gastropod affinities suggest an early Norian age, with taxonomic similarities to several southern Alaskan lithotectonic terranes (for example, Alexander and Chulitna), as well as to the South American Cordillera of Peru.

Mount Griggs, the highest peak in Katmai National Park, is a fumarolically active andesitic stratovolcano that stands $12 \mathrm{~km}$ behind the main volcanic chain of the Alaska Peninsula range crest. (Hildreth and others, report). K-Ar ages indicate that the volcano is as old at $292 \pm 11 \mathrm{ka}$ and thus predates inception of the nearby volcanic-front centers. Geochemical analyses of lava flows exposed on Mount Griggs and a few near-vent scoria bombs define a typical Ti-poor, medium-K calc-alkaline arc suite that shows little systematic change over time. Relative to eruptive products of the nearby volcanic-front centers, those of Mount Griggs are slightly depleted in $\mathrm{Fe}$, generally enriched in $\mathrm{Rb}, \mathrm{Sr}, \mathrm{Al}$, and $\mathrm{P}$, and consistently enriched in $\mathrm{K}$ and $\mathrm{Zr}$. The magmatic plumbing system of Mount Griggs is independent of those beneath the main volcanic chain, probably all the way to mantle depths.

Brew and Friedman present recent field studies and published and unpublished data on adjacent areas which show that the Stikine Icefield, part of the Coast Mountains of southeastern Alaska, is underlain by five generalized map: (1) locally foliated and prophyritic granodiorite, (2) foliated tonalite, (3) migmatitic rocks, (4) unfoliated tonalite and granodiorite, and (5) polymetamorphic rocks.

Stottlemyer and others discuss treeline biogeochemistry and dynamics in Noatak National Preserve, Alaska. The objective of their study was to gain an understanding of treeline dynamics, structure, and function and to examine the effects of global climate change-in particular, soil temperature, moisture, and nitrogen availability — on ecosystem processes within an 800-ha watershed in a boreal biome.

Eppinger and others present a detailed environmental-geochemical study of the Slate Creek antimony deposit in the Kantishna Hills, Denali National Park and Preserve, Alaska. The purpose of their study was to focus on identifying and characterizing the environmental and geochemical signatures associated with this historical mining area. Samples collected included water, stream sediment, rock, and soil from upstream and downstream of the mineralized area. Natural springs present within the mineralized area, but outside the disturbed minesite, suggest premining spring waters that naturally ranged from acidic to neutral $\mathrm{pH}$, had relatively high conductivities, had varying high total dissolved solids, were iron rich, and were metalliferous.

Two bibliographies at the end of the volume list reports covering Alaska earth-science topics in USGS publications during 2000 and reports about Alaska by USGS authors in non-USGS publications during the same period. 


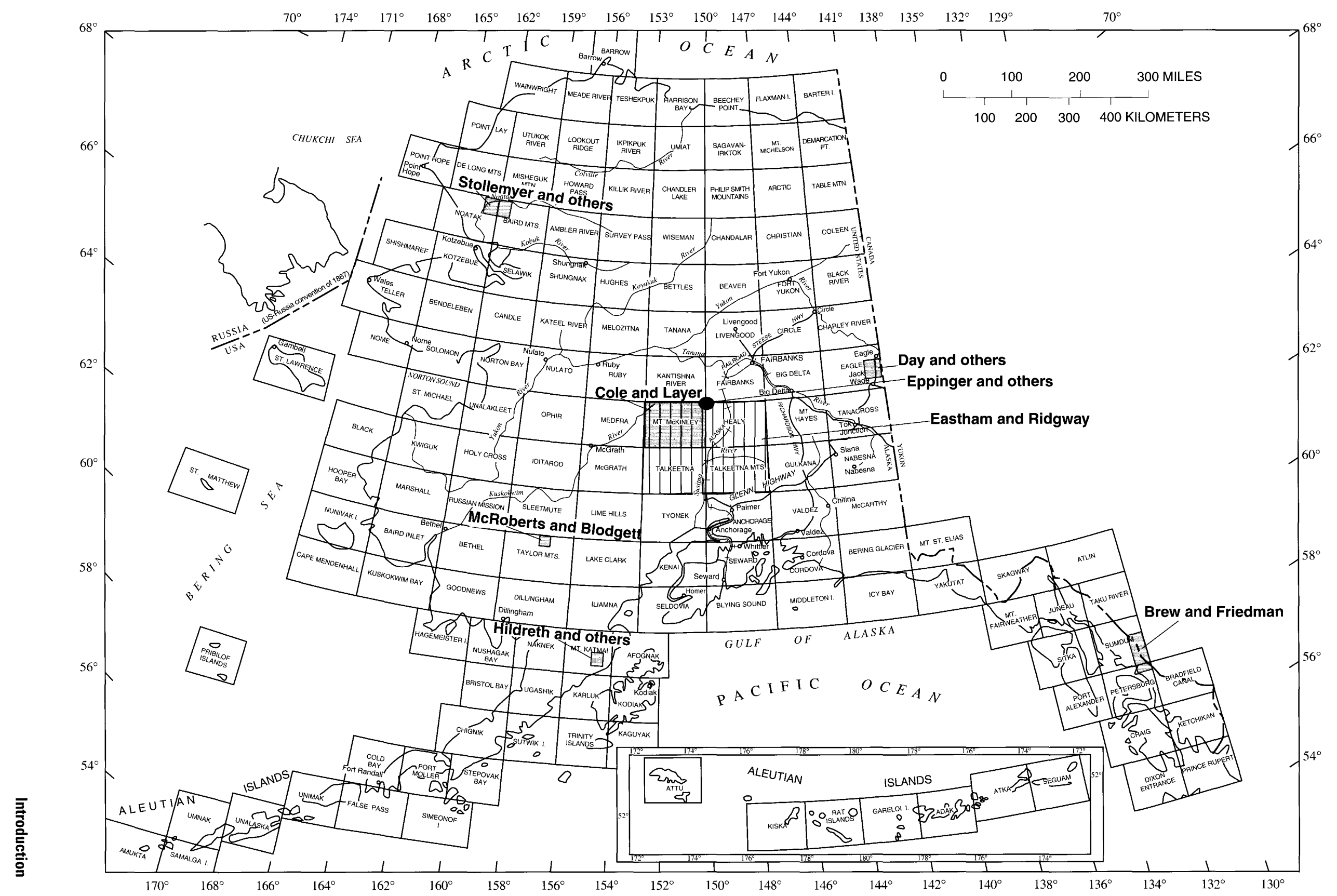

$\omega \quad$ Figure 1. Index map of Alaska showing 1:250,000-scale quadrangles and locations of study areas discussed in this volume. 



\title{
Geochemistry and Age Constraints on Metamorphism and Deformation in the Fortymile River Area, Eastern Yukon-Tanana Upland, Alaska
}

\author{
By Warren C. Day, John N. Aleinikoff, and Bruce Gamble
}

\section{Abstract}

Determining the age of deposition for many of the major rock types within the Fortymile River area is a major challenge for understanding the geologic evolution of the Yukon-Tanana tectonostratigraphic terrane of east-central Alaska. Intense dynamic metamorphism and associated recrystallization, several periods of ductile deformation, and poor outcrops conspire to conceal the age of the rocks in this important region. Definitive fossil evidence in the marble units has been obliterated; felsic gneissic horizons in the sequence could be either volcanic or intrusive in origin. To help resolve some of these issues, we present new geochemical data to further characterize the bedrock assemblage in the Fortymile River area and to address the origin of the major rock units. In addition, new U-Pb-isotopic data on zircons from the early (pre- $\mathrm{D}_{1}$ ) Steele Creek Dome Orthogneiss and from a late tectonic (late- $\mathrm{D}_{2}$ ) epidote-bearing leucogranite intrusion help constrain the youngest possible age for the supracrustal rocks, as well as the date of regional $\mathrm{D}_{2}$ deformation. The Steele Creek Dome Orthogneiss crystallized at $343 \pm 4 \mathrm{Ma}$, indicating that the supracrustal sequence is partly at least Early Mississippian. The leucogranite crystallized during the waning stages of $\mathrm{D}_{2}$ deformation at $196 \pm 4 \mathrm{Ma}$. $\mathrm{U}-\mathrm{Pb}$ data on this Early Jurassic leucogranite also indicate that the inherited zircons have a complex history, with analyses yielding ages of $359 \pm 5$ and $232 \pm 7 \mathrm{Ma}$. Our data confirm earlier ${ }^{40} \mathrm{Ar} /{ }^{39} \mathrm{Ar}$ ages that suggest an Early Jurassic date for the intense regional $\mathrm{D}_{2}$ metamorphism and tectonism. However, although we have determined that the sedimentary and volcanic rocks are at least as old as Early Mississippian, the date of deposition for the major supracrustal rock packages in the Fortymile River area of the Yukon-Tanana terrane still remains a major question.

\section{Introduction}

This research has resulted from a joint effort by the U.S. Geological Survey (USGS) and the Alaska Department of
Natural Resources (ADNR)'s Division of Mining, Land, and Water to establish the baseline geology, as well as the geochemistry of the rocks, soil, and plants and the surface-water quality, of the Fortymile River mining district of east-central Alaska. As part of that effort, we present new data on the geochemical composition and age constraints for rocks of the Fortymile River area. Reliable age data on the protoliths of the metamorphic rocks are some of the most important missing pieces of the puzzle in our understanding of the geologic evolution of the Fortymile River area. To that end, we have obtained new geochemical data to help characterize the bedrock units, and determined new U-Pb zircon ages on two critical units, within the Fortymile River area. These new data, coupled with the pioneering work by Foster (1969, 1976) and Foster and others (1985), as well as the later work by Hansen and others (1991), Dusel-Bacon and others (1993, 1995), Hansen and Dusel-Bacon (1998), and Dusel-Bacon and Cooper (1999), are critical in constraining the ages of bedrock, as well as in dating the ductile deformation, in the vast Yukon-Tanana upland. The geologic time scale of Haq and Van Eysigna (1998) as compiled by Wilson (2001) was used for this report.

\section{Previous Work}

Historically, the Fortymile River corridor was an important entry point for mineral exploration, trapping, and commerce during the early days of settlement of the Alaska-Yukon region. Gold placer miners traveled from the Yukon River up the Fortymile River and established communities at Fortymile, Yukon Territory, as well as such settlements as Steele Creek and Chicken, Alaska. Mertie (1938) presented the first regional perspective on the geologic setting of the Yukon-Tanana upland, including the Fortymile River area. Yeend (1996) provided an overview of the historical development of the region, as well as a characterization of the placer resources of the Fortymile River area. Foster (1969, 1976), Foster and O'Leary (1982), Wilson and others (1985), Dusel-Bacon and Hansen (1992), Mortensen (1992), Dusel-Bacon and others (1993), 
Foster and others (1994), Dusel-Bacon and others (1995), and Hansen and Dusel-Bacon (1998) reported on a series of geologic studies that have led to a better understanding of the regional geologic setting.

In 1997, the USGS initiated a joint research project with the ADNR to assess the effects of placer mining on the water quality of the Fortymile River (Gough and others, 1997; Wanty and others, 2000), as well as to establish the geologic framework of the area (Day and others, 2000 ), along with the geochemistry of soil, rock, selected vegetation, and surface waters in the area (Crock and others, 1999, 2000). Wanty and others studied the effects of suction dredging in the Fortymile River and bulldozeroperated placer mining on water quality in the area. The reconnaissance geologic study by Day and others (2000) outlined the bedrock types and compositions, as well as the polyphase deformational history, of the area. Their study showed that the earliest recognized ductile deformation $\left(D_{1}\right)$ resulted in isoclinal $F_{1}$ folding, a strong regional schistosity $\left(\mathrm{S}_{1}\right)$, and an $\mathrm{L}_{1}$ mineral lineation that is locally preserved. The second episode of ductile deformation $\left(\mathrm{D}_{2}\right)$ was associated with intense regional high-grade metamorphism (Dusel-Bacon and others, 1995), tight to isoclinal $\mathrm{F}_{2}$ folding with coaxial $\mathrm{L}_{2}$ lineations, and a weak $\mathrm{S}_{2}$ cleavage that is axially planar to the $\mathrm{F}_{2}$ folds. The $\mathrm{L}_{2}$ lineations occur both as stretching and mineral lineations that, where preserved together, are coaxial to the $F_{2}$ folds. The youngest recognized folding event $\left(\mathrm{D}_{3}\right)$ folded the earlier ductile fabric elements about north- and south-plunging, eastwardvergent open $\mathrm{F}_{3}$ folds, which have neither any recognizable axial planar cleavage nor mineral lineations. High-angle brittle faults represent the latest episode of deformation (Newberry and Burns, 2000; Szumigala and others, 2000a), variously uplifting the region along north- to northeasttrending block-bounding faults.

New research by the ADNR's Division of Geological and Geophysical Surveys, as reported by Szumigala (2000), Szumigala and others $(2000 \mathrm{a}, \mathrm{b})$, and Werdon and others (2000), is leading to a clearer understanding of the detailed bedrock geology in the Fortymile River area. Their map patterns show continuous horizons of mafic metavolcanic rocks interlayered with biotite schist and gneissic rocks, all of which have undergone an early episode of deformation ( $D_{1}$ of Day and others, 2000). They recognized that this early episode of deformation formed large-scale isoclinal to recumbent folds that were refolded during a subsequent ductile event ( $D_{2}$ of Day and others, 2000). Their mapping further shows that several pulses of intrusions subsequently invaded the supracrustal rocks. Tonalite (for example, the Steele Creek Dome Orthogneiss) and leucogranite bodies crosscut the supracrustal rocks, but some of these bodies have a penetrative tectonic fabric ( $\mathrm{D}_{2}$ of Day and others, 2000), and so their emplacement preceded the regional high-grade dynamothermal recrystallization event discussed by Dusel-Bacon and others (1995). The plutonic rocks help constrain the regional tectonic history inasmuch as they represent temporal piercing points and record the stages of penetrative tectonic fabrics.

\section{Geologic Setting}

The Fortymile River area is underlain by several lithotectonic stratigraphic packages (see Dusel-Bacon and others, 1995; Hansen and Dusel-Bacon, 1998). This chapter addresses the geochemistry and geochronology of the "Taylor Mountain assemblage" of Hansen and Dusel-Bacon (1998), one of the most widespread lithotectonic assemblages in the Yukon-Tanana tectonostratigraphic terrane of east-central Alaska (fig. 1). In their report on the bedrock geology of the area, Day and others (2000) followed the terrane terminology established by Hansen and Dusel-Bacon (1998) and referred to the medium- to high-grade metamorphic rocks of the area as belonging to the Taylor Mountain assemblage. However, because of the potential confusion that can arise when discussing both the Taylor Mountain batholith, which is a Late Triassic granitoid body, and metamorphic rocks of the "Taylor Mountain assemblage," which extends far beyond the Taylor Mountain area, we, like other workers (Cynthia Dusel-Bacon, written commun., 2001), now refer to these rocks as the "Fortymile River assemblage."

The Fortymile River assemblage is made up of highgrade metamorphic, polydeformed supracrustal rocks that were intruded by tonalite, trondhjemite, ultramafic rocks, and monzodiorite-diorite-quartz diorite. The metasedimentary and metavolcanic(?) supracrustal rocks include biotite schist and siliciclastic metasedimentary rocks, quartzite, marble, and metagabbro and hornblende-biotite schist of basaltic composition (Dusel-Bacon and Cooper, 1999). The ages of the protoliths of the Fortymile River assemblage are poorly constrained. The intense regional dynamic recrystallization that accompanied high-grade metamorphism (Dusel-Bacon and others, 1995) has almost completely destroyed primary textures within the supracrustal rocks, and so standard fossil studies are almost hopeless. Foster (1976) assigned the metasedimentary rocks to the Paleozoic, using as evidence sparse, poorly preserved crinoid stems at a locality to the west of the Fortymile River area.

Although the primary ages of the protoliths and early (pre-Cretaceous) intrusive rocks are poorly known, cooling ages for the peak metamorphic event have been determined by using both $\mathrm{K}-\mathrm{Ar}$ (Wilson and others, 1985) and ${ }^{40} \mathrm{Ar} /{ }^{39} \mathrm{Ar}$ (Cushing, 1984; Hansen and others, 1991) techniques. Wilson and others (1985) reported ages of 175 to $182 \mathrm{Ma}$ on biotite and hornblende in amphibolite and gneiss from the Wade Creek area (fig. 2). Cushing's ${ }^{40} \mathrm{Ar} /{ }^{39} \mathrm{Ar}$ analysis showed that the metamorphic hornblende ranges in age from 187 to 204 $\mathrm{Ma}$, the muscovite from 185 to $191 \mathrm{Ma}$, and the biotite from 186 to $188 \mathrm{Ma}$. Hansen and others (1991) analyzed hornblende and biotite from rocks in the Fortymile River area and reported ${ }^{40} \mathrm{Ar} /{ }^{39} \mathrm{Ar}$ ages on hornblende of approximately $187 \mathrm{Ma}$ and on biotite of approximately $186 \mathrm{Ma}$. These data indicate that the Fortymile River assemblage underwent dynamic metamorphism and recrystallization and then cooled rapidly past the ${ }^{40} \mathrm{Ar} /{ }^{39} \mathrm{Ar}$ hornblende and mica blocking temperatures by about $185 \mathrm{Ma}$ (Early Jurassic). Newberry and others (1998) provided a regional context for plutonism and mineralization by using 
${ }^{40} \mathrm{Ar} /{ }^{39} \mathrm{Ar}$ analysis of 20 samples from throughout the YukonTanana terrane. They concluded that a regionally extensive Late Triassic and Early Jurassic episode of granitic magmatism occurred within the eastern part of the Yukon-Tanana terrane, followed by mid-Cretaceous calc-alkalic igneous activity.

Szumigala and others $(2000 \mathrm{a}, \mathrm{b})$ reported new ${ }^{40} \mathrm{Ar} /$ ${ }^{39} \mathrm{Ar}$ analyses of several plutonic rocks in the Fortymile
River area, primarily near Chicken, Alaska. One sample (BL06790; Szumigala and others, 2000b, table 3), from a monzodiorite intrusion north of the confluence of the North and South Forks of the Fortymile River (fig. 2), yielded a hornblende plateau age of $194 \pm 2 \mathrm{Ma}$. This intrusion represents one of several weakly to moderately foliated monzodioritic to quartz dioritic bodies that crosscut the regional


Figure 1. Geologic map of tectonic assemblage of the Yukon-Tanana tectonostratigraphic terrane, east-central Alaska, showing approximate outline of the Fortymile area (fig. 2). Modified after Hansen and Dusel-Bacon (1998). 
tectonic $\mathrm{S}_{1}$ fabric preserved in metamorphosed sedimentary and volcanic country rocks of the Fortymile River assemblage. Day and others (2000) postulated that this intrusive suite was emplaced during the waning stages of peak regional Early
Jurassic $\mathrm{D}_{2}$ tectonism. The importance of this designation is discussed below within the context of the new U-Pb zircon age for a $\mathrm{D}_{2}$ leucogranite body exposed along the Fortymile River east of Canyon Creek.

$141^{\circ} 50$

$141^{\circ} 40^{\prime}$

$141^{\circ} 30^{\prime}$

$141^{\circ} 20^{\prime}$

$141^{\circ} 10^{\prime}$

$141^{\circ} 0^{\prime}$

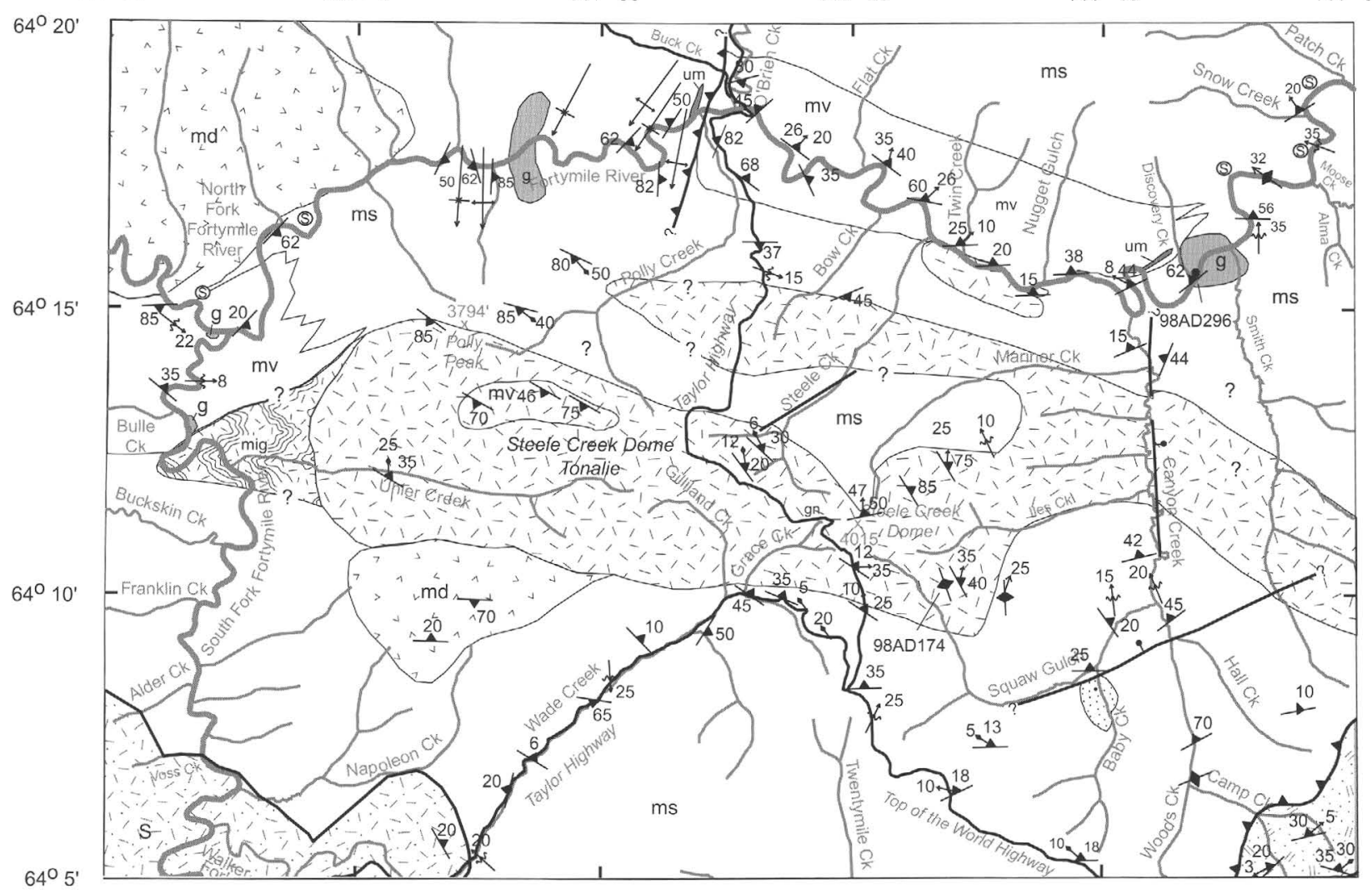

EXPLANATION

SEDIMENTARY ROCKS

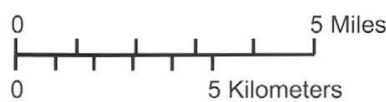

Map Symbols

Detrital rocks of Baby Creek

INTRUSIVE ROCKS

Posttectonic
intrusive rocks
Pretectonic to
syntectonic
intrusive rocks

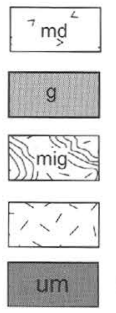

onzodiorite to diorite-Nonfoliated to weakly foliated hornblende monzodioriteto quartz diorite

Leucogranite to trondhjemite - Foliated peraluminous biotite-muscovite granodiroite, granite, and trondhjemite

Migmatite-Supracrustal rocks invaded by biotite-hornblende tonalite to granite neosome

Steele Creek Dome Tonalite-Hornblende-biotite tonalitic orthogneiss with local enclaves of paragneiss country rock

Ultramafic intrusion-Metamorphosed pyroxenite-peridotite intrusion

\section{SUPRACRUSTAL ROCKS}

\section{Fortymile River assemblage}

\begin{tabular}{|c|}
\hline $\mathrm{mv}$ \\
\hline (s) \\
\hline $\mathrm{ms}$ \\
\hline
\end{tabular}

Outcrop of sulfide-rich siliciclastic metasedimentary horizon within metasedimentary-rock unit

Metasedimentary rocks - Biotite schist, marble, quartzite, metapelite, sulfide-bearing siliciclastic metasedimentary rocks, and minor hornblene-biotite schist

18. Strike and dip of foliation

- Strike of vertical foliation

10 - Trend and plunge of mineral lineation

, 15 Trend and plunge of stretching lineation

$\longleftarrow$ Trace and plunge of axis of antiform

$\longleftarrow$ Trace and plunge of axis of synform

$\xi 25$ Trend and plunge of minor fold

- Contact-Approximate

Normal fault-Bar and ball on downthrown side

ـ Thrust fault- Teeth on upper plate

Figure 2. Simplified bedrock geologic map of the Fortymile River area, east-central Alaska (see fig. 1 for location). 


\section{Geochemistry}

The data discussed here were published in two previous reports: The 97xx sample series used here is from the report by Crock and others (1999), and the 98xx sample series from the report by Crock and others (2000). These combined data sets are discussed here to more fully describe the bedrock geochemistry of the region.

\section{Metavolcanic Rocks}

Hornblende-biotite schist and amphibolite of basaltic composition form an important part of the early supracrustalrock package of the Fortymile River assemblage. The protolith of the mafic schists is thought to be basaltic flows, tuffs, and (or) dikes that were erupted in the original pretectonic host environment; however, the regional metamorphic recrystallization does not allow for a confident classification of the primary mode of deposition. Day and others (2000) recognized two distinct suites of mafic metavolcanic rocks (figs. $3 A, 3 B$ ) on the basis of geochemistry: a light-rare-earth-element (REE)depleted suite (group I) and a light-REE-enriched suite (group II). Group I mafic metavolcanic rocks have light-REE contents with depleted light-REE and relatively flat middle- and heavyREE patterns (fig. 3A). Group II mafic metavolcanic rocks are relatively enriched in light REEs, with a general negative slope with decreasing chondrite-normalized REE patterns through heavy REEs (fig. $3 A$ ). Although temporal control on the eruption and (or) intrusion of these suites is poorly constrained, the
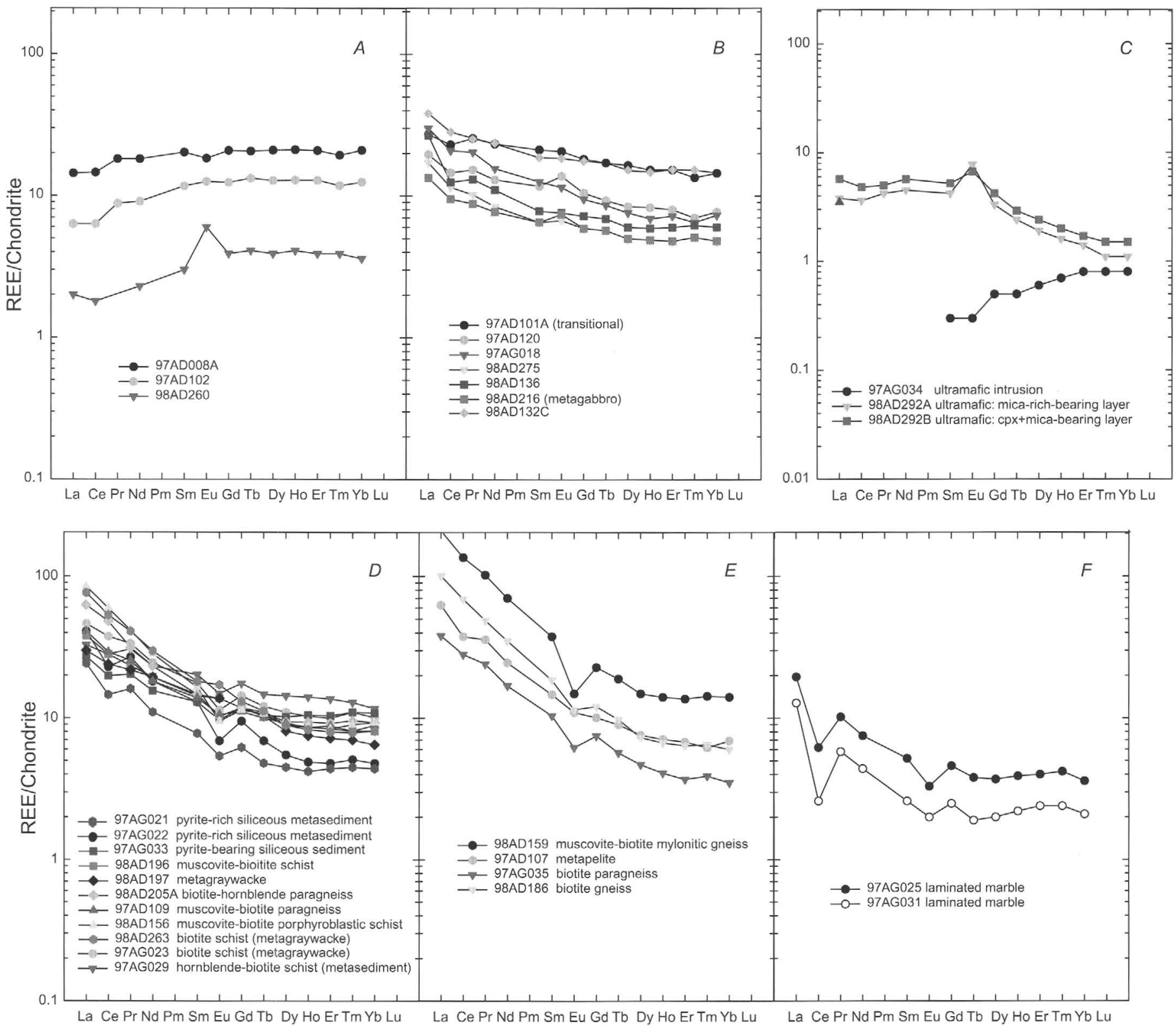

Figure 3. Chondrite-normalized rare-earth-element diagrams for metamorphosed supracrustal rocks of the Fortymile River assemblage. $A$, Group I mafic metavolcanic(?) rocks. $B$, Group II mafic metavolcanic(?) rocks. $C$, Metamorphosed ultramafic rocks. $D$, Siliciclastic metasedimentary rocks (now biotite schist). E, Paragneiss. F, Laminated marble. Data from Crock and others (1999, 2000). 
field evidence is consistent with a coeval history, implying that two distinct mantle sources were being tapped, possibly concurrently, during their (pre- $\mathrm{D}_{1}$ ) eruption and (or) intrusion.

In their study of regional metabasaltic rocks from the Yukon-Tanana upland, Dusel-Bacon and Cooper (1999) also deduced two geochemical groups (tholeiitic and calc-alkalic). They concluded that minor- and trace-element abundances indicate that the metabasaltic rocks formed in a volcanic-arc environment. Such a paleoenvironment is supported by field evidence, such as the close spatial association of the metabasaltic rocks with marble, metagraywacke, quartzite, and chert horizons, which, in aggregate, is consistent with an arc or marginal-plate setting.

\section{Ultramafic Rocks}

Ultramafic bodies intruded the supracrustal rocks of the Fortymile River assemblage (Foster, 1976). Two such ultramafic bodies are exposed along the Fortymile River west of O'Brien Creek and downstream from the mouth of Canyon Creek (fig. 2). Both intrusions show evidence of regional metamorphism and deformation, suggesting that they were emplaced at least before $\mathrm{D}_{2}$ and, probably, pre- $\mathrm{D}_{1}$ tectonism. One sample from the ultramafic body near O'Brien Creek (sample 97AG034, fig. 3C) has a relatively depleted light-REE pattern (concentrations are below detection limits) and middleREE contents. The ultramafic body exposed downstream from Canyon Creek is a layered pyroxenite intrusion with varying amounts of biotite (phlogopite?) alteration. Two samples from the intrusion near Canyon Creek have relatively elevated lightREE patterns, a positive Eu anomaly, and negatively sloping middle- and heavy-REE patterns (fig. 3C). The ultramafic body near O'Brien Creek (sample 97AG034) may represent a mafic cumulate phase petrogenetically related to the group I mafic metavolcanic rocks, whereas the pyroxenite body near Canyon Creek (samples 98AD292A, 98AD292B) may be related to the group II mafic volcanic rocks.

\section{Rocks with Presumed Sedimentary Protoliths}

Interlayered with the mafic metavolcanic rocks in supracrustal rocks of the Fortymile River assemblage are horizons of biotite schist - whose protolith probably ranged from graywacke to silicic epiclastic sedimentary rocks - as well as felsic paragneiss and marble. The REE distributions observed in samples of biotite schist, felsic paragneiss, and marble from the Fortymile River area are plotted in figures $3 D, 3 E$, and $3 F$, respectively. The variations in REE composition of the biotite schist are wide but generally typical of those of Phanerozoic metagraywacke, as reported by Taylor and McLennon (1985). The light-REE contents range from approximately 30 to 90 times chondritic values, and the heavy-REE components of their patterns are relatively flat.

The felsic paragneiss horizons occur interlayered with other supracrustal rocks. These horizons consist of strongly foliated, medium- to fine-grained gray biotite gneiss with compositional layering. The protolith for these felsic paragneiss could be either sedimentary or volcanic layers, however, inasmuch as their primary depositional textures are not preserved, owing to the intensive metamorphic $\left(\mathrm{D}_{1}, \mathrm{D}_{2}\right)$ recrystallization. Day and others (2000) noted a distinct absence of demonstrable felsic metavolcanic rocks within high-grade metamorphic rocks of the Fortymile River area. The REE abundances vary widely but overlap those observed in rocks more readily identified as metasedimentary in origin (figs. $3 D, 3 E$ ).

Marble commonly is laminated, with metamorphosed clay-rich horizons and thin quartzite horizons. The marble horizons represent metamorphosed carbonate mud and quartz sand-rich interlayers deposited as lithoclastic wackestone, algal beds, and carbonate reef deposits (Day and others, 2000). The REE contents of two marble samples are plotted in figure $3 F$. The overall REE contents of these samples are as low as 20 times chondritic values for light REEs, with pronounced negative $\mathrm{Ce}$ and $\mathrm{Eu}$ anomalies and flat heavy-REE patterns 2 and 4 times chondritic values. Ce can exist in nature in either a $3+$ or $4+$ valence state. In marine environments, $\mathrm{Ce}^{4+}$ is the dominant valence, and $\mathrm{Ce}$ is thought to precipitate onto the sea floor in manganese nodules (Goldberg, 1961; Fleet, 1984), leaving a relative negative $\mathrm{Ce}$ anomaly in seawater. Thus, the negative Ce anomaly preserved in these marble samples could represent original Ce depletion in the paleoceanic seawater. The negative Eu anomaly in the marble is less readily explainable but probably also reflects a relative Eu depletion in the local seawater at the time of deposition of the carbonate protoliths.

\section{Steele Creek Dome Orthogneiss and Related Rocks}

Day and others (2000) defined the Steele Creek Dome Tonalite as a body, emplaced before $\mathrm{D}_{1}$ tectonism, made up of tonalite with rafts of supracrustal xenoliths. Subsequent detailed mapping by D.J. Szumigala and coworkers from the Alaska Division of Geological and Geophysical Survey (D.J. Szumigala, unpub. data, 2000), however, has shown that a distinct tonalite intrusion makes up Steele Creek Dome and that several other tonalitic horizons are interlayered with (intrude?) the supracrustal sequence. Their work indicates that the unit is more areally restricted than shown on the bedrock geologic map (fig. 2). As such, the tonalitic samples originally presented by Day and others (2000) as the Steele Creek Dome Tonalite may be petrogenetically related but are not from a single, conterminous intrusion. Therefore, the informally named Steele Creek Dome Tonalite (Day and others, 2000, 2001) is abandoned and herein named the "Steele Creek Dome Orthogneiss."

Each of Day and others' (2000) samples shares similar mesoscopic characteristics, in that they are composed of gray biotite-hornblende tonalite to granodiorite with a mediumgrained, foliated texture. REE patterns (fig. 4A) vary widely, but all the samples have relatively elevated light-REE contents, varying Eu anomalies, and flat to depleted heavy-REE 
patterns. The $\mathrm{SiO}_{2}$ content of the samples ranges from 63.6 to 75.7 weight percent (fig. $4 A$ ). The least evolved (lowest $\mathrm{SiO}_{2}$ content) samples (98AD277, 63.6 weight percent $\mathrm{SiO}_{2}$; 97AG027, 63.7 weight percent $\mathrm{SiO}_{2}$, respectively) have simi- lar REE patterns that fall in the midrange. The more evolved samples (with higher $\mathrm{SiO}_{2}$ contents) have divergent REE patterns: The most highly evolved samples are either enriched (sample 98AD178, 70.7 weight percent $\mathrm{SiO}_{2}$ ) or relatively
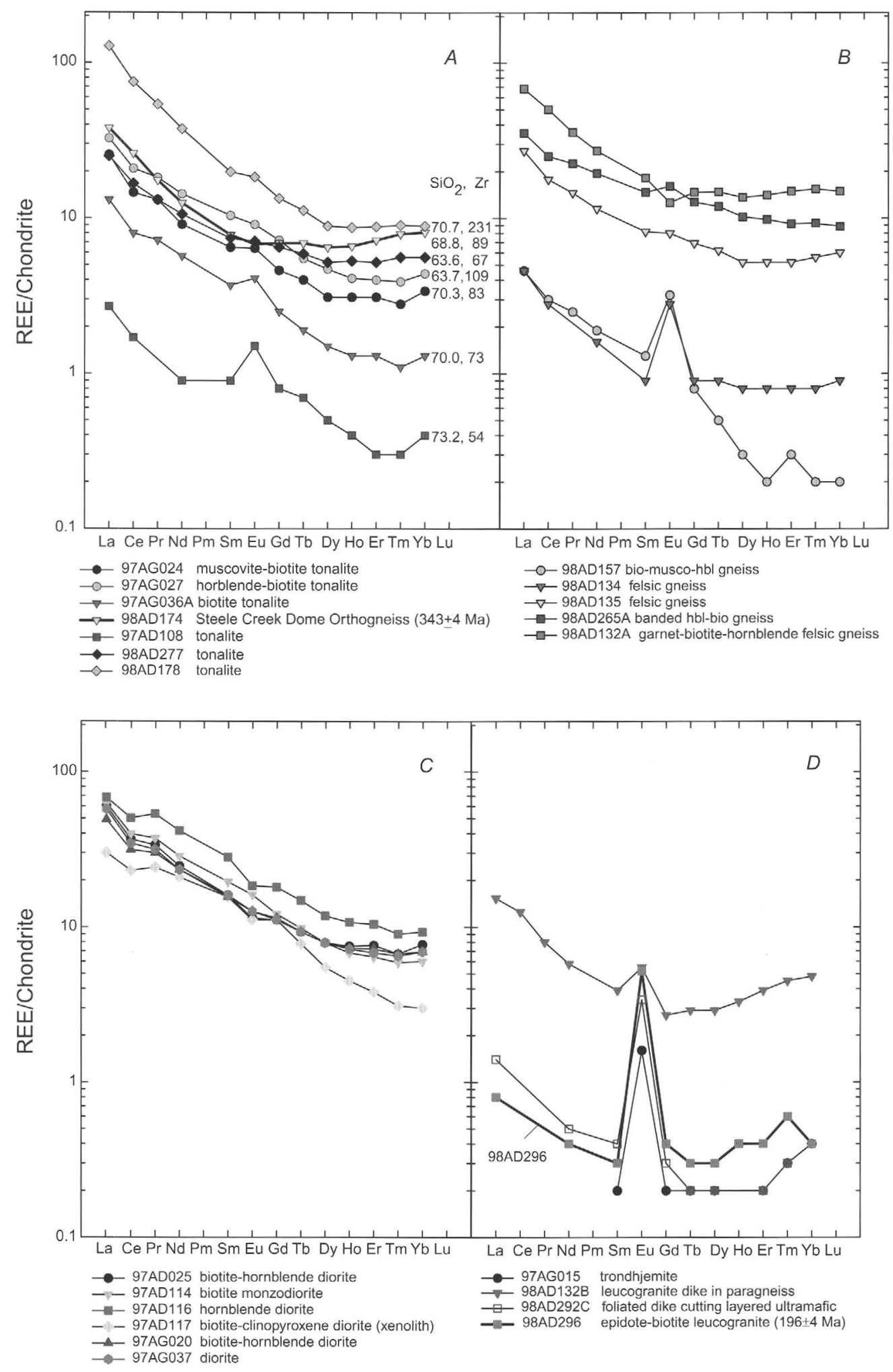

Figure 4. Chondrite-normalized rare-earth-element diagrams for intrusive rocks of the Fortymile River assemblage. $A$, Steele Creek Dome Orthogneiss. $B$, Monzodiorite-diorite to quartz diorite suite. $C$, Horizons of felsic orthogneiss within the supracrustal rocks. $D$, Leucogranite intrusions. Data from Crock and others $(1999,2000)$. 
depleted (sample 97AD108, 73.2 weight percent $\mathrm{SiO}_{2}$ ) in total REE content.

There are two possible explanations for the apparent symmetry between the $\mathrm{SiO}_{2}$ and total REE contents of this rock suite: One is that the $\mathrm{SiO}_{2}$ and total REE contents are completely fortuitous; the other is that an underlying petrogenetic process links the samples. In the second explanation, the apparent symmetry may reflect intrusion of material from a common parental source that was sampled at different stages of crystal fractionation. Typically, as crystal fractionation proceeds, REEs are partitioned into the silicate melt, assuming that enough of a trace mineral with a high affinity (mineral distribution coefficient, $K_{\mathrm{d}}{ }^{\text {mineral }}>1$ ) for REEs (for example, zircon, monazite, or apatite) has not crystallized in the bulk fractionated material such that the whole-rock distribution coefficient for the REEs is minimal $\left(K_{\mathrm{d}}{ }^{\text {wholerock }}<<1\right)$. When a mineral such as monazite or zircon becomes stable, REEs partition into the residual solid, leaving the resulting silicate melt relatively depleted in REEs, yet its $\mathrm{SiO}_{2}$ content will continue to increase as crystal fractionation proceeds.

Support for the second explanation is evident in the $\mathrm{Zr}$ data (fig. 4A), where the least highly evolved (lowest $\mathrm{SiO}_{2}$ content) samples (97AG024, 98AD277, 97AG027, 98AD174) generally have intermediate $\mathrm{Zr}$ contents, ranging from 67 to 109 parts per million. One of the more highly evolved samples (98AD178) has the highest $\mathrm{Zr}$ content (231 parts per million, fig. 4A). The samples with the lowest REE contents have high $\mathrm{SiO}_{2}$ but relatively low $\mathrm{Zr}$ contents (samples 97AG036A, 97AD108). In addition, these samples have relatively high modal feldspar contents (Day and others, 2000, table 1). Therefore, the least evolved samples (97AG024, 98AD277, 97AG027, 98AD174) could represent earlier melts that evolved by crystal fractionation into compositions like that of the high $\mathrm{SiO}_{2}$ and $\mathrm{Zr}$ contents in sample 98AD178. As crystal fractionation proceeded, zircon crystallization would result in a depletion of $\mathrm{Zr}$ (and the REEs) in the melt, yet the $\mathrm{SiO}_{2}$ content in the melt will continue to increase, yielding melts that would look something like samples 97AG036A and 97AD108.

Felsic orthogneiss forms interlayers, as much as several meters thick, within supracrustal rocks of the Fortymile River area. The felsic orthogneiss shows no textural evidence for a sedimentary origin, such as the relict sedimentary structures seen in the equally deformed and metamorphosed biotite schist, which had a graywacke protolith. On the basis of REE contents, these rocks fall into two categories: one with relatively high and another with both relatively low REE contents and pronounced positive Eu anomalies (fig. 4B). These ranges, which are seen in rocks mapped as the Steele Creek Dome Orthogneiss (fig. 4A), may represent tonalitic to granitic intrusive sills or dikes that predated $\mathrm{D}_{1}$ tectonism.

Alternatively, the felsic orthogneiss could represent felsic volcanic rocks that are interlayered within the supracrustal sequence. This second explanation could have significant ramifications, inasmuch as precise, reliable geochronologic (U-Pb zircon) data for the age of deposition for the entire supracrustal sequence are absent. As such, the interlayers of felsic orthogneiss are prime targets for further investigation, although deciding between a volcanic or intrusive lineage will be difficult.

\section{Leucogranite and Trondhjemite Bodies}

Leucogranite and trondhjemite occur throughout the Fortymile River area as small intrusions and late-stage dikes that consist of weakly to moderately foliated, light-gray, mediumgrained rocks containing biotite and, locally, garnet and epidote. The moderate to weak tectonic foliation and absence of tectonic lineation indicate that the dikes probably were not affected by the entire regional ductile deformational history and, thus, postdate the intense $\mathrm{D}_{1}$ deformation event. REE patterns are unique in that they have relatively low total REE contents, with a marked positive Eu anomaly (fig. $4 D$ ) reflecting their high feldspar and low mafic- and accessory-mineral contents. Zircon mineral separates from one such intrusion (sample 98AD296, table 1) were analyzed by using the U-Pb method (see below).

\section{Geochronologic Data}

\section{Method}

Zircons were extracted from samples weighing 2 to $5 \mathrm{~kg}$, using routine mineral-separation techniques, including crushing and pulverizing, followed by separation with a Wilfley table, Frantz magnetic separator, and methylene iodide. Individually hand-picked zircons were mounted in epoxy, ground to nearly half-thickness by using 1500 -grit wet-dry sandpaper, and polished with 6 - and $1-\mu \mathrm{m}$ abrasive. Each grain was photographed in transmitted and reflected light and imaged in cathodoluminescence. All isotopic analyses were done on the USGS/Stanford sensitive-high-resolution-ion-microprobe reverse-geometry (SHRIMP RG) instrument at Stanford University during a 36 -hour session. The primary oxygen-ion beam operated at about $8 \mathrm{nA}$ and excavated a pit about $25 \mu \mathrm{m}$ in diameter and $1 \mu \mathrm{m}$ deep. The magnet was cycled through the mass stations six times per analysis. Elemental fractionation was corrected by analyzing a zircon of known age (standard R33, 418 Ma; Roland Mundil, unpub. data, 1999) every fourth analysis. The age of each sample was determined by calculating the weighted average of ${ }^{206} \mathrm{~Pb} /{ }^{238} \mathrm{U}$ ages, which accounts for the analytical errors. Raw data were reduced and plotted by using the Squid and Isoplot/Ex programs of Ludwig $(1999,2001)$; age errors were calculated at the 95-percentconfidence limit.

\section{Sample Descriptions and Results}

The new geochronologic data presented here help constrain the youngest possible age of the protoliths for the supracrustal rocks of the Fortymile River assemblage by dating two intrusive phases using the SHRIMP RG technique on zircon mineral separates. One sample (98AD174, table 1) was from the type locality for the Steele Creek Dome Orthogneiss. The 
Table 1. Radiometric data on zircons from granitoids of east-central Alaska, using the sensitive-high-resolution-ion-microprobe reverse-geometry (SHRIMP RG) U-Pb analytical method.

[Sample locations: $98 \mathrm{AD} 174$, lat $64.1708^{\circ} \mathrm{N}$., long $141.2716^{\circ} \mathrm{W}$; $98 \mathrm{AD} 296$, lat $64.3604^{\circ} \mathrm{N}$., long $141.1179^{\circ} \mathrm{W}$. U contents are \pm 20 percent. ${ }^{206} \mathrm{~Pb} /{ }^{238} \mathrm{U}$, ${ }^{238} \mathrm{U} /{ }^{206} \mathrm{~Pb}$ and ${ }^{207} \mathrm{~Pb} /{ }^{206} \mathrm{~Pb}$ ratios, corrected for common $\mathrm{Pb}$, are based on the model of Stacey and Kramers (1975); errors are $\pm 1 \sigma$. Constants: ${ }^{235} \lambda=9.8485 \times 10^{-10} \mathrm{yr}{ }^{-1}$,

${ }^{238} \lambda=1.55125 \times 10^{-10} \mathrm{yr}^{-1},{ }^{238} \mathrm{U} / 235 \mathrm{U}=137 / 88 \mathrm{~mol} / \mathrm{mol}$ ( Steiger and Jäger, 1977)]

\begin{tabular}{|c|c|c|c|c|c|c|c|c|c|c|c|}
\hline Sample & $\begin{array}{l}\text { Measured } \\
{ }^{204} \mathrm{~Pb} \text { ratio } \\
{ }^{206} \mathrm{~Pb}\end{array}$ & $\begin{array}{l}\text { Measured } \\
{ }^{207} \mathrm{~Pb} \text { ratio } \\
{ }^{206} \mathrm{~Pb}\end{array}$ & $\begin{array}{c}\% \\
\text { common } \\
{ }^{206} \mathrm{~Pb}\end{array}$ & $\underset{(\mathrm{ppm})}{\mathbf{U}}$ & $\begin{array}{l}\mathrm{Th} / \mathrm{U} \\
\text { ratio }\end{array}$ & $\begin{array}{l}\frac{{ }^{206} \mathrm{~Pb} \text { age }}{{ }^{238} \mathrm{U}(\mathrm{Ma})}\end{array}$ & $\begin{array}{l}\text { Error } \\
\text { (Ma) }\end{array}$ & $\frac{{ }^{238} \mathrm{U} \text { ratio }}{{ }^{206} \mathrm{~Pb}}$ & $\begin{array}{r}\text { Error } \\
\text { (pct) }\end{array}$ & ${ }^{207} \mathrm{~Pb}$ ratio & $\begin{array}{r}\text { Error } \\
(\mathrm{pct})\end{array}$ \\
\hline
\end{tabular}

Sample 98AD174, Steele Creek Dome Orthogneiss

\begin{tabular}{|c|c|c|c|c|c|c|c|c|c|c|c|}
\hline AD174-1.1 & 0.00031 & 0.056 & 0.58 & 310 & 0.53 & 18.12 & 1.5 & 0.0509 & 4 & 347.4 & 5.2 \\
\hline AD 174-2.1 & - & .058 & 0 & 202 & .3 & 18.17 & 1.6 & .0585 & 2.9 & 343.2 & 5.6 \\
\hline AD 174-3.1 & - & .058 & 0 & 214 & .34 & 18.06 & 1.6 & .058 & 2.8 & 345.5 & 5.5 \\
\hline $\mathrm{AD} 174-4.1$ & - & .059 & 0 & 153 & .35 & 18.24 & 1.8 & .0591 & 4.1 & 341.7 & 6 \\
\hline AD $174-5.1$ & .00038 & .056 & .7 & 227 & .48 & 18.6 & 2.1 & .0499 & 6 & 338.9 & 6.9 \\
\hline AD $174-6.1$ & .00026 & .055 & .48 & 446 & .48 & 17.97 & 1.5 & .0516 & 3 & 350 & 5.1 \\
\hline $\mathrm{AD} 174-7.1$ & - & .056 & 0 & 307 & .51 & 19.44 & 2.2 & .056 & 3 & 322.1 & 7.1 \\
\hline $\mathrm{AD} 174-8.1$ & - & .059 & 0 & 144 & .3 & 18.22 & 1.7 & .0592 & 5.1 & 341.9 & 6 \\
\hline AD $174-9.1$ & 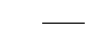 & .059 & 0 & 225 & .39 & 18.45 & 1.8 & .0593 & 2.8 & 337.7 & 6.1 \\
\hline AD $174-10.1$ & .00048 & .059 & .88 & 200 & .36 & 19.05 & 1.7 & .0518 & 8.7 & 330.4 & 5.4 \\
\hline AD $174-11.1$ & .00045 & .054 & .83 & 235 & .37 & 18.63 & 1.6 & .0474 & 8.3 & 339.5 & 5.3 \\
\hline AD $174-12.1$ & .00048 & .058 & .87 & 189 & .32 & 17.92 & 1.6 & .0509 & 6.6 & 351.2 & 5.6 \\
\hline AD $174-13.1$ & - & .056 & 0 & 369 & .57 & 18.21 & 1.5 & .056 & 2.8 & 343.5 & 5.1 \\
\hline AD $174-14.1$ & - & .054 & 0 & 164 & .41 & 18.01 & 1.7 & .0541 & 3.3 & 348.1 & 5.8 \\
\hline
\end{tabular}

Sample 98AD296, leucogranite

\begin{tabular}{|c|c|c|c|c|c|c|c|c|c|c|c|}
\hline AD296-1.1 & 0.00091 & 0.059 & 1.67 & 205 & 0 & 32.55 & 1.8 & 0.0456 & 12.5 & 196.1 & 3.4 \\
\hline AD296-2.1 & .00024 & .056 & .45 & 265 & 0 & 32.92 & 1.7 & .0521 & 5 & 192.4 & 3.2 \\
\hline AD296-3.1 & .00055 & .052 & 1.02 & 390 & 0 & 33.11 & 2.2 & .0442 & 11.8 & 193.2 & 4.2 \\
\hline AD296-4.1 & {[} & .053 & 0 & 1,123 & .75 & 17.45 & 1.4 & .0532 & 1.2 & 359.4 & 4.8 \\
\hline AD296-5.1 & .00034 & .058 & .62 & 188 & .38 & 30.4 & 1.8 & .0526 & 6.4 & 208.1 & 3.6 \\
\hline AD296-6.1 & .00018 & .054 & .33 & 580 & .01 & 31.38 & 1.7 & .0512 & 3.8 & 201.9 & 3.4 \\
\hline AD296-7.1 & .00013 & .051 & .24 & 592 & 0 & 27.32 & 2.8 & .0491 & 3.7 & 232.3 & 6.5 \\
\hline AD296-8.1 & .00036 & .057 & .67 & 544 & 0 & 33.2 & 1.8 & .0513 & 4.7 & 191 & 3.4 \\
\hline AD296-9.1 & .00021 & .052 & .38 & 5,842 & .02 & 31.98 & 1.4 & .0493 & 2.3 & 198.7 & 2.7 \\
\hline AD296-10.1 & .0042 & .105 & 7.73 & 80 & 0 & 40.89 & 3.6 & .0422 & 42.2 & 157.1 & 5.3 \\
\hline AD296-11.1 & .00021 & .052 & .39 & 1,439 & .01 & 33.42 & 1.4 & .0488 & 2.9 & 190.3 & 2.6 \\
\hline AD296-12.1 & .00054 & .052 & 1 & 658 & 0 & 32.13 & 1.8 & .0442 & 7 & 199 & 3.6 \\
\hline AD296-13.1 & - & .05 & 0 & 529 & 0 & 31.9 & 3.2 & .0498 & 2.5 & 199 & 6.4 \\
\hline
\end{tabular}

sample is a gray, medium-grained, foliated biotite-hornblende tonalite (fig. $5 A$ ). The ductile fabric is thought to include $\mathrm{D}_{1}$ deformation, and so the age of this sample provides a minimum age for protoliths of the metamorphosed supracrustal sequence in the Fortymile River area. Likewise, the age of the Steele Creek Dome Orthogneiss represents a maximum age of the regional $\mathrm{D}_{1}$ tectonic event.

The other sample (98AD296, table 1) was from a leucogranite body exposed along the Fortymile River downstream from Canyon Creek (fig. 2). This weakly foliated intrusion is composed of medium-grained epidote-bearing biotite leucogranite (fig. $5 B$ ). The epidote forms equant, subhedral crystals, as large as $1 \mathrm{~mm}$ in diameter (fig. $5 B$ ), which crystallized either before or during the peak of high-pressure metamorphism $\left(D_{2}\right)$. As such, the epidote could be a primary magmatic phase indicating a moderately high pressure (Zen and Hammerstrom, 1984; Hammerstrom and Zen, 1992) of emplacement regime for the leucogranite corresponding to lower-crustal depths, consistent with the conclusions of DuselBacon and others (1995) for the high-pressure nature of the regional Jurassic metamorphism.
The weak foliation indicates that the leucogranite intrusion was emplaced after the main pulses of intense $D_{1}$ and $D_{2}$ ductile deformation. However, a considerable amount of recrystallization is evident in the groundmass, as well as in some porphyroclasts (fig. $5 B$ ), indicating that the intrusion underwent some dynamic recrystallization during $\mathrm{D}_{2}$ tectonism. The weak foliation in combination with the evidence of recrystallization indicates that the leucogranite body was emplaced, at the earliest, during the waning stages of the $\mathrm{D}_{2}$ tectonism.

Two populations of zircons (elongate and equant) from sample 98AD174 (tonalitic orthogneiss) were analyzed. Cathodoluminescence images of all zircons from this sample show concentric oscillatory zoning, typical of an igneous origin. Most of the grains are light brown, clear, and uncracked and contain a few acicular inclusions. Individual ${ }^{206} \mathrm{~Pb} /{ }^{238} \mathrm{U}$ ages and uncertainties from 13 of 14 grains were averaged to obtain an age of $343 \pm 4 \mathrm{Ma}$ (fig. 6). No differences in isotopic systematics or $U$ contents were detected between the two populations (table 1). One analysis was excluded from the weighted average calculation because it gave a slightly younger age of $322 \mathrm{Ma}$. Because this analysis is from the center of a euhe- 



Figure 5. Photomicrographs of samples from the Fortymile River area, east-central Alaska, dated by using sensitivehigh-resolution-ion-microprobe reverse-geometry $\mathrm{U}-\mathrm{Pb}$ method. Bar in each photomicrograph is $0.5 \mathrm{~mm}$ long. $A$ (plane light) and $B$ (crosspolarized light), Sample of Steele Creek Dome Orthogneiss with foliation preserved in biotite $(A)$, as well as mortared texture between quartz and feldspar $(B)$ recording dynamic recrystallization. $C$ (crosspolarized light), Sample 98AD296 (table 1), showing nonfoliated texture of a late- $D_{2}$ leucogranite body exposed along the Fortymile River near mouth of Canyon Creek. Note recrystallization (late $\mathrm{D}_{2}$ ) of feldspar porphyroblast (center right) and equigranular epidote (lower left). bio, biotite; epi, epidote; f, feldspar; hbl, hornblende. dral grain, we suspect that this age is due to minor $\mathrm{Pb}$ loss, rather than representing an additional event.

Zircons from sample 98AD296 (leucogranite) are medium to dark brown, euhedral, prismatic, and highly fractured (fig. 7). Many contain cores visible in cathodoluminescence and transmitted-light images. The numerous cracks made it difficult to find areas suitable for SHRIMP $\mathrm{RG}$ analysis. Individual ${ }^{206} \mathrm{~Pb} /{ }^{238} \mathrm{U}$ ages and uncertainties from 10 analyses were averaged to obtain an age of 196 4 Ma (fig. 6). The relatively high uncertainty probably is due to scatter in the data caused by varying degrees of $\mathrm{Pb}$ loss from unavoidable cracks. Thus, this age is a minimum age for the leucogranite. Two older ages were measured: analyses 4.1 and 7.1 (table 1) gave ages of $359 \pm 5$ and $232 \pm 7 \mathrm{Ma}$, respectively. Analysis 4.1 is of a grain that appears to be a xenocryst; it has a different morphology (that is, it is lighter brown, less cracked, and more stubby) than all the other analyzed zircons from sample 98AD296. Analysis 7.1 is from a rounded core of a cracked grain; the core probably is inherited and acted as a seed around which igneous zircon crystallized at about $196 \mathrm{Ma}$. Analysis 10.1 (age, 157 \pm 5 $\mathrm{Ma}$; table 1) is from the uncracked tip of a zircon. This area of the zircon has a $U$ content of only $80 \mathrm{ppm}$, much lower than the rest of the grain (as shown by contrasting zoning in cathodoluminescence). This tip appears to be a different generation of zircon than most other grains in sample 98AD296, and because it is undamaged, the young age may represent a distinct event in the region, although more data are needed to verify this hypothesis.

\section{Discussion and Conclusions}

The new data presented here place important constraints on the age of the protolith of the metamorphosed supracrustal sequence and on our understanding of the tectonism of the Fortymile River assemblage, as well as of the tectonic and plutonic history of the broader Yukon-Tanana tectonic terrane of Alaska. The assemblage is at least as old as the $343 \pm 4 \mathrm{Ma}$ (Early Mississippian) Steele Creek Dome Orthogneiss. Foster (1976) observed crinoid stems in carbonates, indicating that the sequence is probably no older than Cambrian. A study of the morphology of zircons from the horizons of felsic gneiss interlayered within the metamorphic sequence may help constrain their volcanic or sedimentary origin. Even if the protoliths of the felsic gneiss are found to be sedimentary (if the zircons are detrital), because the area is thought to have been developed as juvenile crust in an island-arc sequence, the detrital zircons could reflect the age of volcanism and so yield an important age for the Fortymile River tectonic assemblage. Regardless, the Early Mississippian age presented here yields the oldest possible age for regional deformation, inasmuch as the tonalite was deformed during both $\mathrm{D}_{1}$ and $\mathrm{D}_{2}$ events.

Aleinikoff and others (1987) dated an augen gneiss from west of the Fortymile River area in the Big Delta 1:250,000 
quadrangle north of Delta Junction, Alaska (unit O, fig. 1) at approximately $343 \mathrm{Ma}$. This augen gneiss, which is part of the Yukon-Tanana upland tectonites as defined by Hansen and Dusel-Bacon (1998), is essentially equivalent in age to the Steele Creek Dome Orthogneiss. Mortensen (1992) discussed the pre-middle Mesozoic tectonic evolution of the Yukon-Tanana terrane throughout Alaska and Canada. He outlined three main pulses of magmatism, with episodes in



Figure 6. Tera-Wasserburg plots of U-Pb-isotopic data for zircons from the Fortymile River area, east-central Alaska. A, Sample 98AD174 (table 1). B, Sample 98AD296 (table 1). Error ellipses, 16; weighted average error bars, $2 \sigma$. Filled error bars, corresponding to filled error ellipses, were used in weighted-average calculations. MSWD, mean square of weighted deviates. 
Devonian and Mississippian, mid-Permian, and Late Triassic and Early Jurassic time. Creaser and others (1999) dated eclogites from the eastern part of the Yukon-Tanana terrane in Canada and noted that their basaltic protoliths had diverse origins. They found that eclogites from the Stewart Lake and Simpson Range were generated in a subduction environment and record Mississippian high-pressure metamorphism. Eclogites from Faro, the Ross River, and Last Peak had both midplate basalt and normal midoceanic-ridge basaltic (n-MORB) protoliths with small subduction components and record Permian high-pressure metamorphism and cooling. The Mississippian Steele Creek Dome Orthogneiss was emplaced during the regional Devonian and Mississippian plutonism and deformation observed in the Delta Junction area (Aleinikoff and others, 1987), as well as in Canada (Mortensen, 1992; Creaser and others, 1999). The D, tectonic fabrics could have been formed either during the Devonian and Mississippian regional event or during the Permian highpressure regional metamorphism.
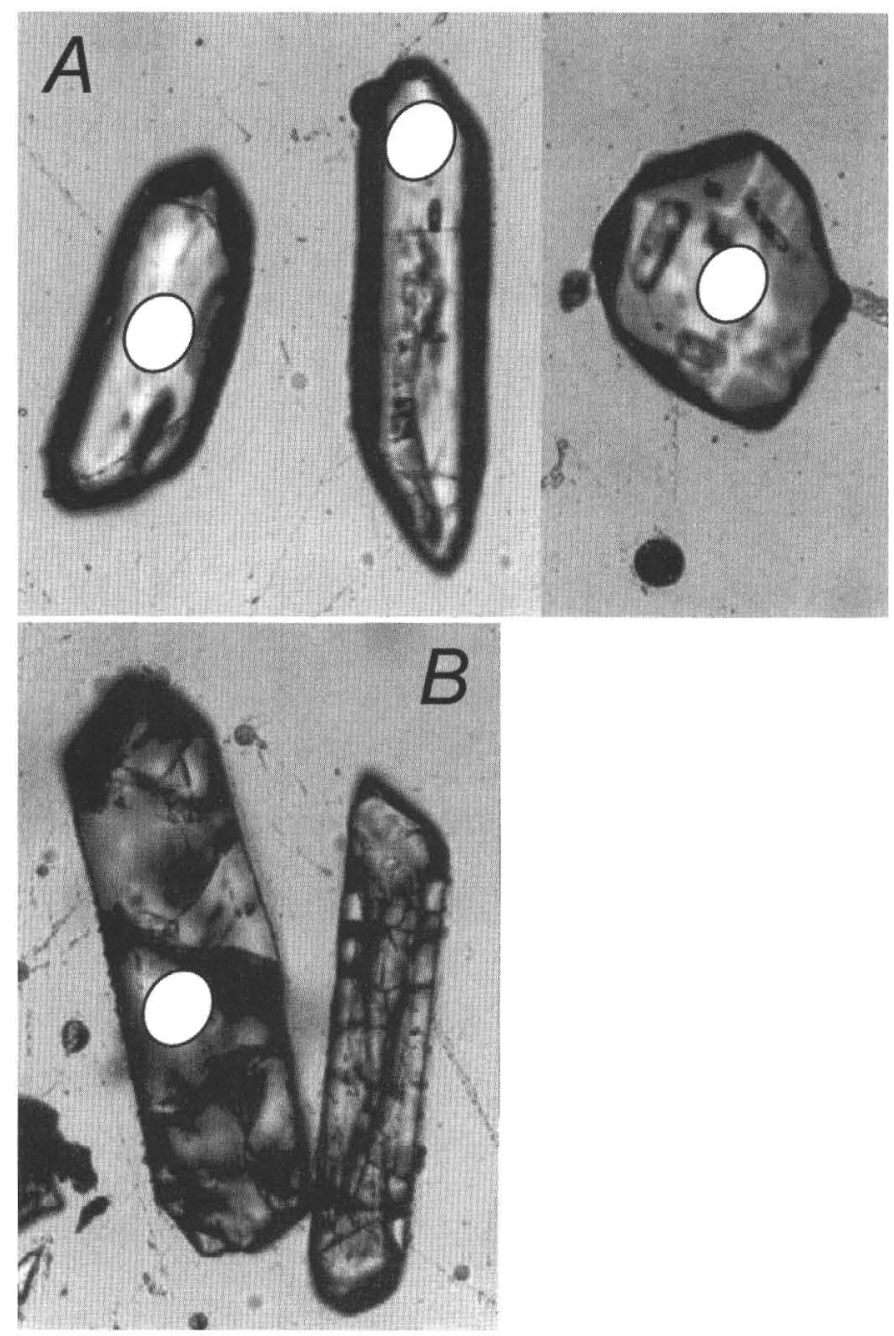

Figure 7. Representative zircons in dated samples from the Fortymile River area, east-central Alaska. White ellipses show locations of sensitive-high-resolution-ion-microprobe reverse-geometry analyses. $A$, Sample 98AD174 (table 1), showing elongate and equant zircons. $B$, Sample 98AD296 (table 1).
The 196 \pm 4-Ma crystallization age for leucogranite is essentially equivalent to the $\mathrm{K}-\mathrm{Ar}$ and ${ }^{40} \mathrm{Ar} /{ }^{39} \mathrm{Ar}$ ages reported previously (Cushing, 1984; Wilson and others, 1985; Hansen and others, 1991) for the Jurassic regional tectonometamorphic event that affected the Fortymile River assemblage (Hansen and Dusel-Bacon, 1998). It is also equivalent to the age of emplacement of the granitic to granodioritic Chicken pluton (Szumigala and others, 2000a, b), exposed immediately to the southwest of the study area near Chicken, Alaska, and the Jurassic Napoleon Creek pluton, which is a member of the monzodiorite-diorite-quartz diorite suite. These monzodioritic to quartz dioritic bodies are weakly foliated (Szumigala and others, 2000a), which we interpret as indicating emplacement during the waning stages of the regional Early Jurassic deformation $\left(D_{2}\right)$. The $157 \pm 5$-Ma age (analysis 10.1 ) may represent a postcrystallization age related to a still-unrecognized event.

\section{Acknowledgments}

This research was funded in part by the USGS Mineral Resources Program Baselines and Background Project. Additional funding from the ADNR's Division of Mining, Land, and Water was critical for supporting our fieldwork. Discussions with Cynthia Dusel-Bacon, Rainer Newberry, David Szumigala, Melanie Werdon, and Jim Mortensen were extremely helpful. Logistical support from June and Larry Taylor helped make the fieldwork possible as well as enjoyable. Reviews by Cynthia Dusel-Bacon, John Galloway, William Ridley, Douglas Stoeser, and Fredric Wilson greatly improved the manuscript.

\section{References Cited}

Aleinikoff, J.N., Dusel-Bacon, Cynthia, Foster, H.L., and Nokleberg, W.J., 1987, Lead isotopic fingerprinting of tectono-stratigraphic terranes, east-central Alaska: Canadian Journal of Earth Sciences, v. 24, no. 10, p. 2089-2098.

Creaser, R.A., Goodwin-Bell, J.S., and Erdmer, Philippe, 1999, Geochemical and Nd isotopic constraints for the origin of eclogite protoliths, northern Cordillera-implications for the Paleozoic tectonic evolution of the Yukon-Tanana terrane: Canadian Journal of Earth Sciences, v. 36, no. 10, p. 1697-1709.

Crock, J.G., Gough, L.P., Wanty, R.B., Day, W.C., Wang, B., Gamble, B.M., Henning, M.W., Brown, Z.A., and Meier, A.L., 1999, Regional geochemical results from the analyses of rock, water, soil, stream sediment, and vegetation samples-Fortymile River watershed, east-central, Alaska: U.S. Geological Survey Open-File Report 99-33, 82 p.

2000, Regional geochemical results from the analyses of rock, water, soil, stream sediment, and vegetation samplesFortymile River watershed, east-central Alaska, 1998 sampling: U.S. Geological Survey Open-File Report 00-511, 157 p.

Cushing, G.W., 1984, The tectonic evolution of the eastern YukonTanana upland, Alaska: Albany, State University of New York, M.S. thesis, $255 \mathrm{p}$. 
Day, W.C., Gamble, B.M., Henning, M.W., and Smith, B.D., 2000, Geologic setting of the Fortymile River area-polyphase deformational history within part of the eastern Yukon-Tanana upland of Alaska, in Kelley K.D., and Gough, L.P., eds., Geologic studies in Alaska by the U.S. Geological Survey, 1998: U.S. Geological Survey Professional Paper 1615, p. 65-82.

Dusel-Bacon, Cynthia, and Cooper, K.M., 1999, Trace-element geochemistry of metabasaltic rocks from the Yukon-Tanana upland and implications for the origin of tectonic assemblages in eastcentral Alaska: Canadian Journal of Earth Sciences, v. 36, no. 10, p. 1671-1695.

Dusel-Bacon, Cynthia, Csejtey, Bela, Jr., Foster, H.L., Doyle, E.0., Nokleberg, W.J., and Plafker, George, 1993, Distribution, facies, ages, and proposed tectonic associations of regionally metamorphosed rocks in east- and south-central Alaska: U.S. Geological Survey Professional Paper 1497-C, 73 p.

Dusel-Bacon, Cynthia, and Hansen, V.L., 1992, High-pressure amphibolite-facies metamorphism and deformation within the Yukon-Tanana and Taylor Mountain terranes, eastern Alaska, in Bradley, D.C., and Dusel-Bacon, Cynthia, eds., Geological studies in Alaska by the U.S. Geological Survey, 1991: U.S. Geological Survey Bulletin 2041, p. 140-159.

Dusel-Bacon, Cynthia, Hansen, V.L., and Scala, J.A., 1995, High-pressure amphibolite facies dynamic metamorphism and the Mesozoic tectonic evolution of an ancient continental margin, east-central Alaska: Journal of Metamorphic Geology, v. 13, no. 1, p. 9-24.

Fleet, A.J., 1984, Aqueous and sedimentary geochemistry of the rare earth elements, in Henderson, Paul, ed., Rare earth element geochemistry: Amsterdam, Elsevier, p. 343-374.

Foster, H.L., 1969, Reconnaissance geology of the Eagle A-1 and A-2 quadrangles, Alaska: U.S. Geological Survey Bulletin 1271-G, 30 p., scale 1:63,360.

1976, Geologic map of the Eagle quadrangle, Alaska: U.S. Geological Survey Miscellaneous Investigations Map I-922, scale 1:250,000.

Foster, H.L., Cushing, G.W., and Keith, T.E.C., 1985, Early Mesozoic tectonic history of the Boundary area, east-central Alaska: Geophysical Research Letters, v. 12, no. 9, p. 553-556.

Foster, H.L., Keith, T.E.C., and Menzie, W.D., 1994, Geology of the Yukon-Tanana area of east-central Alaska, in Plafker, George, and Berg, H.C., eds., The geology of Alaska, v. G-1 of The geology of North America: Boulder, Colo., Geological Society of America, p. 205-240.

Foster, H.L., and O'Leary, R.M., 1982, Gold found in bedrock of Lost Chicken Creek gold placer mine, Fortymile area, Alaska: U.S. Geological Survey Circular 844, p. 62-63.

Goldberg, E.D., 1961, Chemistry in the oceans in Oceanographyinvited lectures presented at the International Oceanography Congress, New York, 1959: American Association of the Advancement for Science Publication 67, p. 583-597.

Gough, L.P., Day, W.C., Crock, J.R., Gamble, B.M., and Henning, M.W., 1997, Placer gold mining in Alaska - cooperative studies on the effect of suction dredge operations on the Fortymile River: U.S. Geological Survey Fact Sheet FS-155-97, 4 p.

Hammerstrom, J.M., and Zen, E-an, 1992, Petrological characteristics of magmatic epidote-bearing granites of the Western Cordillera of America, in Brown, P.E., and Chappell, B.W., eds., The Second Hutton Symposium on the Origin of Granites and Related Rocks: Geological Society of America Special Paper 272, p. 490-491.

Hansen, V.L., and Dusel-Bacon, Cynthia, 1998, Structural and kinematic evolution of the Yukon-Tanana upland tectonites, east- central Alaska-a record of late Paleozoic to Mesozoic crustal assembly: Geological Society of America Bulletin, v. 110, no. 2, p. 211-230.

Hansen, V.L., Heizler, M.T., and Harrison, T.M., 1991, Mesozoic thermal evolution of the Yukon-Tanana composite terrane-new evidence from 40Ar/39Ar data: Tectonics, v. 10, no. 1, p. 51-76.

Haq, B.U., and Van Eysinga, F.W.B., 1998, Geological time table (5th ed.): New York, Elsevier Science.

Ludwig, K.R., 1999, User's manual for Isoplot/Ex version 2.00, a geochronological toolkit for Microsoft Excel: Berkeley, Calif., Berkeley Geochronology Center Special Publication No. 1, $46 \mathrm{p}$. 2001, Squid 1.02 - a user's manual: Berkeley, Calif., Berkeley Geochronology Center Special Publication 2, $21 \mathrm{p}$.

Mertie, J.B., Jr., 1938, Gold placers of the Fortymile, Eagle, and Circle districts, Alaska: U.S. Geological Survey Bulletin 897-C, p. 133-261.

Mortensen, J.K., 1992, Pre-Mid-Mesozoic tectonic evolution of the Yukon-Tanana terrane, Yukon and Alaska: Tectonics, v. 11, no. 4, p. 836-853.

Newberry, R.J., and Burns, L.E., 2000, Ohmygod, it's even uglier that we thought-an update on interior AK geology [abs.]: Alaska Miners Association Annual Meeting, p. 10-11.

Newberry, R.J., Layer, P.W., Burleigh, R.E., and Solie, D.N., 1998, New ${ }^{40} \mathrm{Ar} /{ }^{39} \mathrm{Ar}$ dates for intrusions and mineral prospects in the eastern Yukon-Tanana Terrane, Alaska-regional patterns and significance, in Gray, J.E., and Riehle, J.R., eds., Geologic studies in Alaska by the U.S. Geological Survey, 1996: U.S. Geological Survey Professional Paper 1595, p. 131-159.

Stacy, J.S., and Kramers, J.D., 1975, Approximation of terrestrial lead isotope evolution by a two-stage model: Earth and Planetary Science Letters, v. 26, no. 2, p. 207-226.

Steiger, R.H., and Jäger, Emilie, 1977, Subcommission on geochronology, convention on the use of decay constants in geo- and cosmochronology: Earth and Planetary Letters, v. 36, no. 3, p. 359-362.

Szumigala, D.J., 2000, Mineral-oriented geologic mapping of the Fortymile mining District: Alaska Geosurvey News, v. 4, no. 3, p. 1-5.

Szumigala, D.J., Newberry, R.J., Werdon, M.B., Finseth, B.A., and Pinney, D.S., 2000a, Preliminary geologic map of a portion of the Fortymile mining district, Alaska, 1999: Alaska Division of Geological and Geophysical Surveys Preliminary Interpretive Report 2000-6, scale 1:63,360.

Szumigala, D.J., Newberry, R.J., Werdon, M.B., Finseth, B.A., Pinney, D.S., and Flynn, R.L., 2000b, Major-oxide, minor-oxide, traceelement, and geochemical data from rocks collected in a portion of the Fortymile mining district, Alaska, 1999: Alaska Division of Geological and Geophysical Surveys Raw Data File 2000-1, 26 p., 2 sheets, scale 1:63,360.

Taylor, S.R., and McLennan, S.M., 1985, The continental crust; its composition and evolution: Oxford, U.K., Blackwell Scientific Publications, $312 \mathrm{p}$.

Wanty, R.B., Wang, Bronwen, Vohden, Jim, Briggs, P.H., and Meier, A.L., 2000, Regional baseline geochemistry and environmental effects of gold placer mining operations on the Fortymile River, eastern Alaska, in Kelley, K.D., and Gough, L.P., eds., Geological studies in Alaska by the U.S. Geological Survey, 1998: U.S. Geological Survey Professional Paper 1615, p. 101-110.

Werdon, M.B., Szumigala, D.J., Newberry, R.J., Grady, J.C., and Munly, W.C., 2000, Major oxide, minor oxide, trace element, rare-earth element, and geochemical data from rocks collected in Eagle and Tanacross Quadrangles, Alaska in 2000: Alaska Division of 
Geological and Geophysical Surveys Raw Data File 2000-4, 27 p., 3 sheets, scale 1:63,360.

Wilson, A.B., 2001, Compilation of various geologic time scales:

U.S. Geological Survey Open-File Report 01-52 [URL: http:

//greenwood.cr.usgs.gov/pub/open-file-reports/ofr-01-0052/].

Wilson, F.A., Smith, J.G., and Shew, Nora, 1985, Review of radiometric data from the Yukon Crystalline Terrane, Alaska and Yukon Territory: Canadian Journal of Earth Sciences, v. 22, no. 4, p. 525-537.

Yeend, W.E., 1996, Gold placers of the historical Fortymile River region, Alaska: U.S. Geological Survey Bulletin 2125, 75 p.

Zen, E-an, and Hammerstrom, J.M., 1984, Magmatic epidote and its petrologic significance: Geology, v. 12, no. 9, p. 515-518. 


\title{
Stratigraphy, Age, and Geochemistry of Tertiary Volcanic Rocks and Associated Synorogenic Deposits, Mount McKinley Quadrangle, Alaska
}

\author{
By Ronald B. Cole ${ }^{1}$ and Paul W. Layer ${ }^{2}$
}

\section{Abstract}

This chapter reports new field, petrographic, and geochemical data for two Tertiary volcanic units and underlying sedimentary rocks in the southeast corner of the Mount McKinley 1:250,000-scale quadrangle. The volcanic units include the late Paleocene and early Eocene volcanic rocks of Foraker Glacier and the late Eocene and early Oligocene Mount Galen Volcanics. New ${ }^{40} \mathrm{Ar} /{ }^{39} \mathrm{Ar}$ dating on two samples from the lower part of the volcanic rocks of Foraker Glacier yield ages of $56.9 \pm 0.2$ and $55.5 \pm 0.1 \mathrm{Ma}$. The volcanic rocks of Foraker Glacier unconformably overlie a 550-m-thick sequence of Late Cretaceous(?) sedimentary rocks that dip steeply north and unconformably overlie Paleozoic metamorphic rocks with a schistosity that dips steeply south. The sedimentary sequence includes a metamorphic-clast cobble-boulder alluvial-fan conglomerate overlain by fluvial and lacustrine conglomerate, sandstone, and mudstone. The coarse grain size and presence of bounding unconformities indicate that these sedimentary rocks fill a contractional basin and record pre-late Paleocene tectonic uplift of the adjacent Paleozoic metamorphic rocks. The overlying volcanic rocks of Foraker Glacier consist of a 200-m-thick interval of basalt and andesite lavas containing interbedded mudstone and volcaniclastic fluvial conglomerate overlain by $1,500 \mathrm{~m}$ of rhyolite lava and interbedded pyroclastic-flow deposits. The basalts are slightly depleted in incompatible trace elements (light rare-earth elements, $\mathrm{Rb}, \mathrm{Th}, \mathrm{K}$ ) and along with the andesites have high $\mathrm{Ba} / \mathrm{Ta}$ ratios $(464-1,160)$. The rhyolites are strongly enriched in light rare-earth elements (LREEs), $\mathrm{Rb}, \mathrm{Th}$, and $\mathrm{K}$, are depleted in $\mathrm{Sr}, \mathrm{P}$, and $\mathrm{Ti}$, and have low $\mathrm{Ba} / \mathrm{Ta}$ ratios (23-137), all of which indicate a combination of crustal assimilation and fractional crystallization in their petrogenesis.

The Mount Galen Volcanics consists of basalt, andesite, dacite, and rhyolite lavas and dacite and rhyolite tuff and tuff-breccia. New ${ }^{40} \mathrm{Ar} /{ }^{39} \mathrm{Ar}$ dating of a basaltic andesite flow

'Allegheny College, Meadville, Pa.

${ }^{2}$ University of Alaska, Fairbanks.
$46 \mathrm{~m}$ above the base of the Mount Galen Volcanics yields an age of $42.8 \pm 0.5 \mathrm{Ma}$. The Mount Galen Volcanics is enriched in $\mathrm{Ba}$, Th, Sr, and LREEs, has high $\mathrm{Ba} / \mathrm{Ta}$ ratios (446-3,734), and exhibits a distinct paired $\mathrm{Nb}$-Ta-depletion trend, all of which are common characteristics of subduction-related volcanic rocks.

We interpret that the Late Cretaceous(?) sedimentary rocks record uplift and shortening during the final stages of accretion of the Wrangellia composite terrane to southern Alaska. The volcanic rocks of Foraker Glacier represent the final phase of Late Cretaceous and early Tertiary Alaska Range-Talkeetna Mountains magmatism that ended with suturing of the Wrangellia composite terrane. The Foraker Glacier primary basaltic magmas were probably derived from a relatively depleted subcontinental mantle source; the rhyolites were then formed by partial melting of crustal rocks and fractional crystallization. The mantle source may have been a partially depleted remnant mantle wedge formed during earlier Kula Plate subduction beneath southern Alaska. The Mount Galen Volcanics is part of the northern segment of the Eocene and Oligocene Alaska-Aleutian arc that crosscuts older igneous rocks of the region.

\section{Introduction}

Periodic magmatism is an integral component in the tectonic history of the central Alaska Range. For example, two regional magmatic belts that overlap in the central Alaska Range include Late Cretaceous and early Tertiary rocks of the Alaska Range-Talkeetna Mountains belt and Eocene and Oligocene rocks of the Alaska-Aleutian belt (fig. 1). Each of these belts is generally interpreted to record magmatism that occurred in response to subduction beneath southern Alaska (Wallace and Engebretson, 1984; Moll-Stalcup, 1994). Whereas research has been done to investigate the plutonic rocks of the central Alaska Range (Reed and Lanphere, 1974; Lanphere and Reed, 1985; Reiners and others, 1996), there has been very little work published on the contemporaneous 


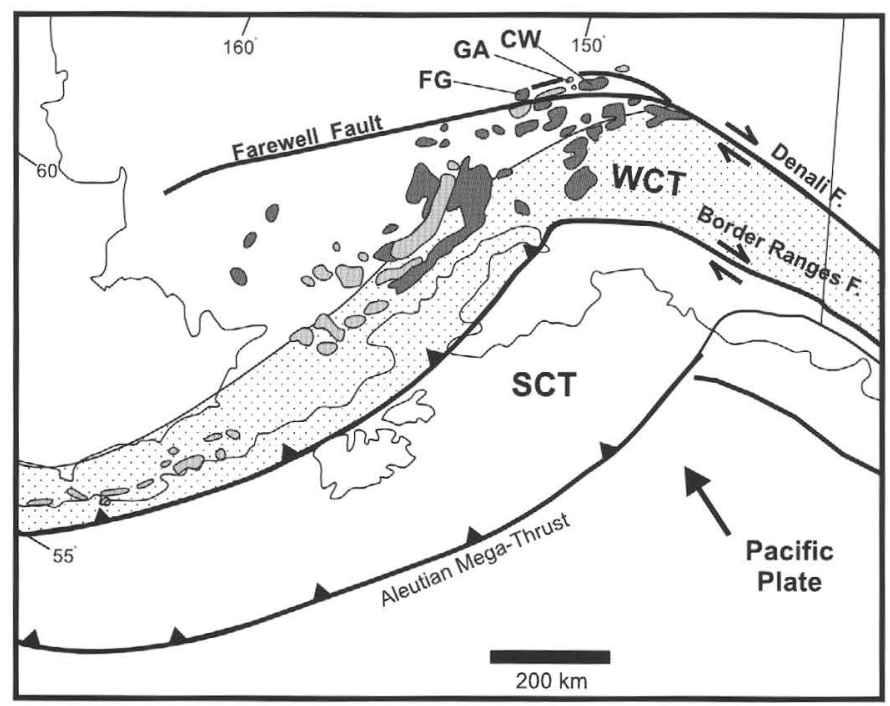

Alaska-Aleutian belt ( $45-30 \mathrm{Ma})$

Includes the Mount Galen Volcanics (42-35 Ma)

Alaska Range-Talkeetna Mountains belt (72-55 Ma)

Includes volcanic rocks of the upper part of the Cantwell Formation $(\sim 60-55 \mathrm{Ma}$

Figure 1. South-central Alaska, showing locations of regional magmatic belts, major faults, accreted-terrane assemblages, and map units: FG, volcanic rocks of Foraker Glacier; GA, Mount Galen Volcanics; CW, Cantwell Formation volcanic rocks; SCT, southern margin composite terrane; WCT, Wrangellia composite terrane (stippled area). Magmatic belts after MollStalcup and others (1994); composite terranes after Nokleberg and others (1994) and Plafker and others (1994). volcanic rocks (except for Decker and Gilbert, 1978). This chapter presents new stratigraphic, age, and geochemical data, along with a compilation of existing data, for Tertiary volcanic rocks that are exposed in the southern part of the Mount McKinley 1:250,000-scale quadrangle (fig. 2). Our main goals are to present a synthesis of Tertiary volcanism and related sedimentation in the Mount McKinley quadrangle and to provide a regional tectonic context for these events. In a broad sense, these volcanic rocks and underlying synorogenic sedimentary deposits provide a record of pre-late Paleocene tectonic uplift followed by two distinct volcanic episodes along the northwest flank of the ancestral Alaska Range. The first volcanic episode, which occurred during late Paleocene and early Eocene time, closely followed accretion of the Wrangellia composite terrane to southern Alaska (fig. 1). The Wrangellia composite terrane had a prolonged history of accretion to western Canada and southern Alaska extending from Late Jurassic through Late Cretaceous time (Stone and others, 1982; McClelland and others, 1992; Nokleberg and others, 1994). The final phase of accretion of the Wrangellia composite terrane, which is recorded in the study area by deformation in the Cantwell Basin, ended by late Paleocene time (Cole and others, 1999). The second volcanic episode, which occurred largely during early Oligocene time, can be correlated with the subduction-related Alaska-Aleutian magmatic belt.



Figure 2. Generalized geologic map of study area in south-central Alaska. Dashed lines denote boundaries of adjacent 1:250,000-scale quadrangles (italic names). Geology from Reed (1961), Reed and Nelson (1980), Csejtey and others (1992), and Wilson and others (1998). Radiometric ages are from this study (table 1). 


\section{Ages and Locations of Volcanic-Rock Units}

The Tertiary volcanic rocks described in this chapter are exposed in the southern part of the Mount McKinley quadrangle along the east and west sides of Foraker Glacier, the west side of the Muldrow Glacier terminus, and in the vicinity of Mount Galen (fig. 2). All of these rocks were mapped by Reed (1961) as part of the Cretaceous Cantwell Formation. We agree with his mapping that the volcanic rocks of Foraker Glacier are part of the Cantwell Formation, but the age of the Cantwell Formation has since been revised. Ridgway and others (1997) revised the age of the lower part of the Cantwell Formation to Late Cretaceous on the basis of the presence of late Campanian and early Maestrichtian pollen in sedimentary rocks (lithologically equivalent to unit Tes of Wolfe and Wahrhaftig, 1970). Cole and others (1999) revised the age of the upper part of the Cantwell Formation to late Paleocene and early Eocene on the basis of radiometric ages of volcanic rocks (lithologically equivalent to unit Tcv of Wolfe and Wahrhaftig, 1970). The new ${ }^{40} \mathrm{Ar} /{ }^{39} \mathrm{Ar}$-plateau ages reported here for the volcanic rocks of Foraker Glacier (fig. 3; table 1) indicate that these rocks are latest Paleocene and early Eocene, coeval with the upper part of the Cantwell Formation at the type area in the Healy quadrangle (Cole and others, 1999).

The volcanic rocks of the Mount Galen area are not part of the Cantwell Formation. These rocks were shown to be late Eocene and early Oligocene and were named the Mount Galen Volcanics by Decker and Gilbert (1978). Published K-Ar ages (Decker and Gilbert, 1978) for the Mount Galen Volcanics (table 1) range from $38.7 \pm 1.1$ to $41.2 \pm 1.2 \mathrm{Ma}$, with minimum ages of $34.8 \pm 1.4$ to $39.6 \pm 1.2 \mathrm{Ma}$. The new ${ }^{40} \mathrm{Ar} /{ }^{39} \mathrm{Ar}$-plateau age of $42.8 \pm 0.5 \mathrm{Ma}$ reported here for a basaltic andesite flow $46 \mathrm{~m}$ above the base of the Mount Galen Volcanics (sample GA1-46, tables 1-3) more precisely confirms a late Eocene age for the onset of Mount Galen volcanism. On the basis of the K-Ar ages reported by Decker and Gilbert and geochemical correlations of the present study, we concur with Decker and Gilbert that the volcanic rocks of the Muldrow Glacier area correlate with the Mount Galen Volcanics and are part of the late Eocene and early Oligocene group of rocks.

In summary, there are two age groups of volcanic rocks in the study area. The first group, the volcanic rocks of Foraker Glacier, are late Paleocene and early Eocene and occur in the Foraker Glacier area. The second group, the Mount Galen Volcanics, is late Eocene and early Oligocene and is exposed in the vicinity of Mount Galen and along the west side of the Muldrow Glacier terminus.

In addition to the volcanic-rock units of this study, several important plutonic-rock units occur in the study area. Significant late Paleocene and early Eocene plutonic rocks in the region include the McKinley sequence granites, as well as a series of compositionally zoned (peridotite to granite) plutons (Reed, 1961; Reed and Nelson, 1980; Lanphere and Reed, 1985; Reiners and others, 1996). Major plutons of Oligocene age include the Foraker and McGonnagal granites and granodiorites (Reed, 1961; Reed and Lanphere, 1974) and the Mount Eielson granodiorite (Reed, 1933; Decker and Gilbert,
1978). In addition, a poorly exposed fine-grained hornblende granite of unknown age is exposed north of the Mount Galen Volcanics (Reed, 1961).

\section{Volcanic Rocks of Foraker Glacier}

The late Paleocene and early Eocene volcanic rocks outcrop along the north flank of the Alaska Range in the vicinity of the McKinley Fault Zone (fig. 2). We studied these rocks along the west side of the Foraker Glacier (fig. 4), where the volcanic sequence is more than $2,000 \mathrm{~m}$ thick and unconformably overlies $610 \mathrm{~m}$ of sedimentary rocks (fig. 5). The sedimentary sequence beneath the volcanic rocks is significant because it records an episode of tectonic uplift and basin subsidence before volcanism.

\section{Late Cretaceous(?) Sedimentary Rocks}

\section{Lithology and Stratigraphy}

The base of the sedimentary sequence is a well-exposed angular unconformity above folded schist and metasedimentary rocks (fig. 6). The contact can be traced for several kilometers along strike (fig. 4). The stratigraphically lowest sedimentary unit is a $230-\mathrm{m}$-thick boulder to cobble conglomerate. This unit is coarsest in the lower $100 \mathrm{~m}$, where clasts typically range from 0.4 to $1.2 \mathrm{~m}$ in diameter, with maximum clast sizes of more than $2 \mathrm{~m}$ in diameter. This unit fines upward and is a cobble-pebble conglomerate in the uppermost 20 to $30 \mathrm{~m}$. Matrix consists of medium grained to pebbly sandstone. The conglomerate is poorly to moderately sorted, mostly clast supported, and occurs in poorly defined 1- to 5-m-thick beds. The bases of beds are typically scoured with a few to tens of centimeters of relief. Conglomerate beds range in texture from poorly organized and massive with randomly arranged clasts to well organized with imbricated clasts, planar crossbedding, and normal grading. The poorly organized conglomerate is more abundant than the wellorganized conglomerate. Interbedded throughout the conglomerate are 15- to 60-cm-thick, trough-cross-stratified, medium- to coarse-grained sandstone beds that are lenticular and typically reach a few meters in width. Also interbedded with the conglomerate are 30- to 60-cm-thick, dark-gray, pebbly mudstone beds. These beds are matrix supported, poorly sorted, and drape underlying conglomerate beds.

Clast composition of the lower conglomerate unit is almost entirely metamorphic (fig. 5). The metamorphic-rock clasts include muscovite-quartz schist, quartzite, and argillite, which are the same rock types as the metamorphic rocks that underlie the conglomerate. Paleoflow data, on the basis of conglomerate-clast imbrication, show a westward and southwestward drainage pattern (fig. 7).

Overlying the lower conglomerate unit are alternating intervals (ranging from about 65 to $115 \mathrm{~m}$ in thickness) of dark-gray mudstone, sandstone, and conglomerate (fig. 5). The 
mudstone intervals are mostly dark-gray shale with very thin to thin interbeds of siltstone. The siltstone displays horizontal, low-angle, and ripple cross-stratification. Some shale intervals contain abundant plant fragments. The sandstone-conglomerate intervals include medium- to coarse-grained gray to tan ("salt and pepper") lithic sandstone and pebble to cobble conglomerate with thin interbeds of dark-gray shale. The sandstone beds typically range from 0.3 to $1 \mathrm{~m}$ in thickness, and the conglomerate beds average 0.5 to $2 \mathrm{~m}$ in thickness. The sandstone beds commonly display trough cross-stratification and range in texture from massive to horizontally laminated. Pebbly sandstone lenses are common within the axial parts of large-scale troughs. The conglomerate beds are lenticular, well sorted, and clast supported and in some areas display well-developed clast imbrication. Average clasts range from 1 to $5 \mathrm{~cm}$ in diameter. The conglomerate beds typically have erosional bases and commonly grade upward into troughcross-stratified sandstone beds. Clasts in the upper conglomerate unit are primarily argillite, quartzite, and chert, with minor amounts of sandstone and schist.

The sedimentary rocks unconformably overlie folded Paleozoic metamorphic rocks of uncertain, possibly Devonian and Carboniferous age (Reed, 1961) and are overlain unconformably by the volcanic rocks of Foraker Glacier (fig. 4). Samples of mudstone from the middle and upper parts of the sedimentary sequence were analyzed for pollen but were found to be barren (S. Reid, written commun., 1999). Although a precise age control for these strata does not yet exist, a working hypothesis is that they are equivalent to the Late Cretaceous lower Cantwell Formation described and dated in the Healy quadrangle by Ridgway and others (1997). The strata beneath the volcanic rocks of Foraker Glacier are bounded below and above by unconformities, as is the lower part of the Cantwell Formation in the Healy quadrangle (Ridgway and others, 1997; Cole and others, 1999). Also, the sedimentary strata near Foraker Glacier and the lower Cantwell strata in the Healy quadrangle are overlain by coeval volcanic
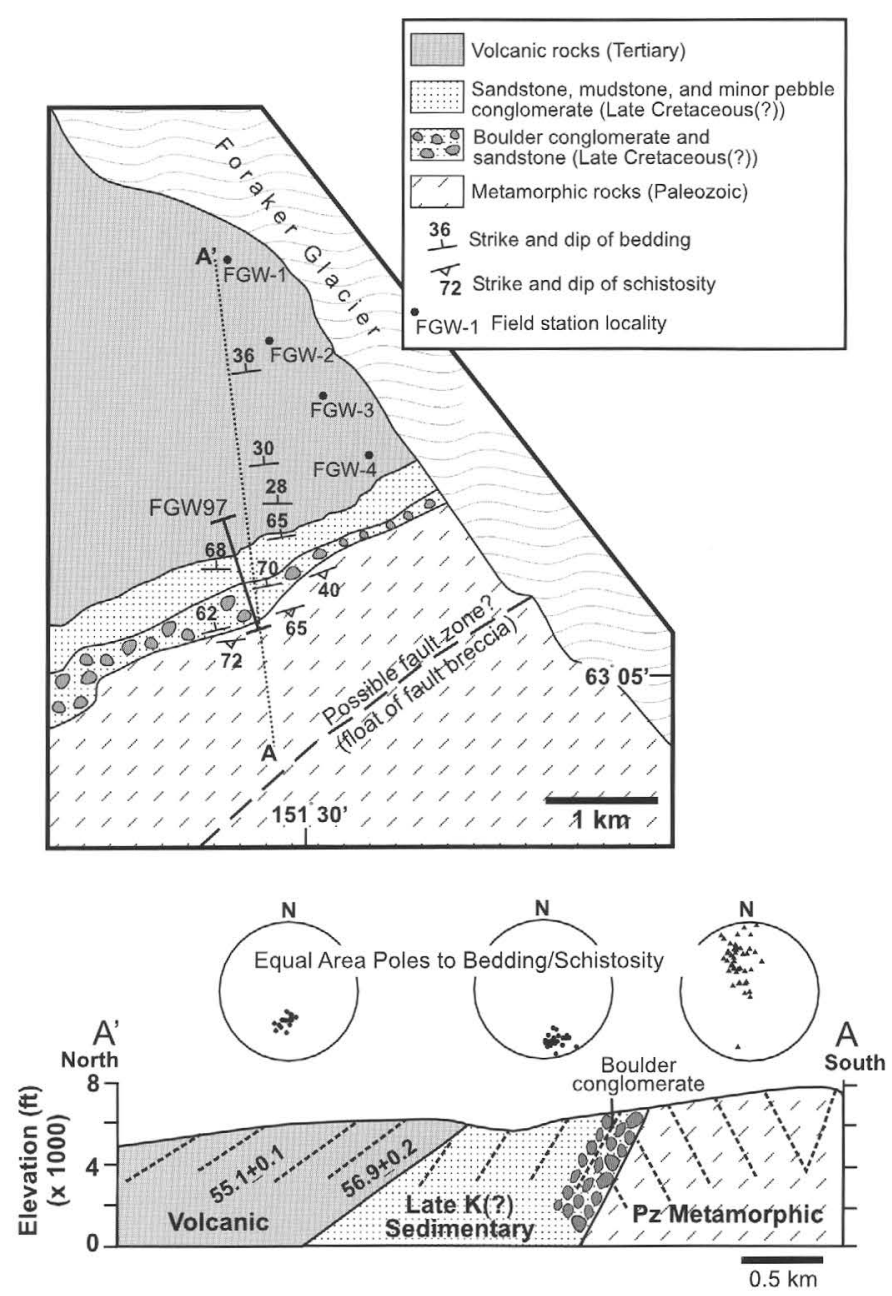

Figure 4. Generalized geologic map and cross section for units exposed in the Foraker Glacier area, south-central Alaska (fig. 2). FGW97, location of the composite stratigraphic column shown in figure 5. Stereonets are lower-hemisphere equal-area projections of poles to bedding for sedimentary- and volcanic-rock units and poles to youngest observable schistosity in metamorphic rocks.
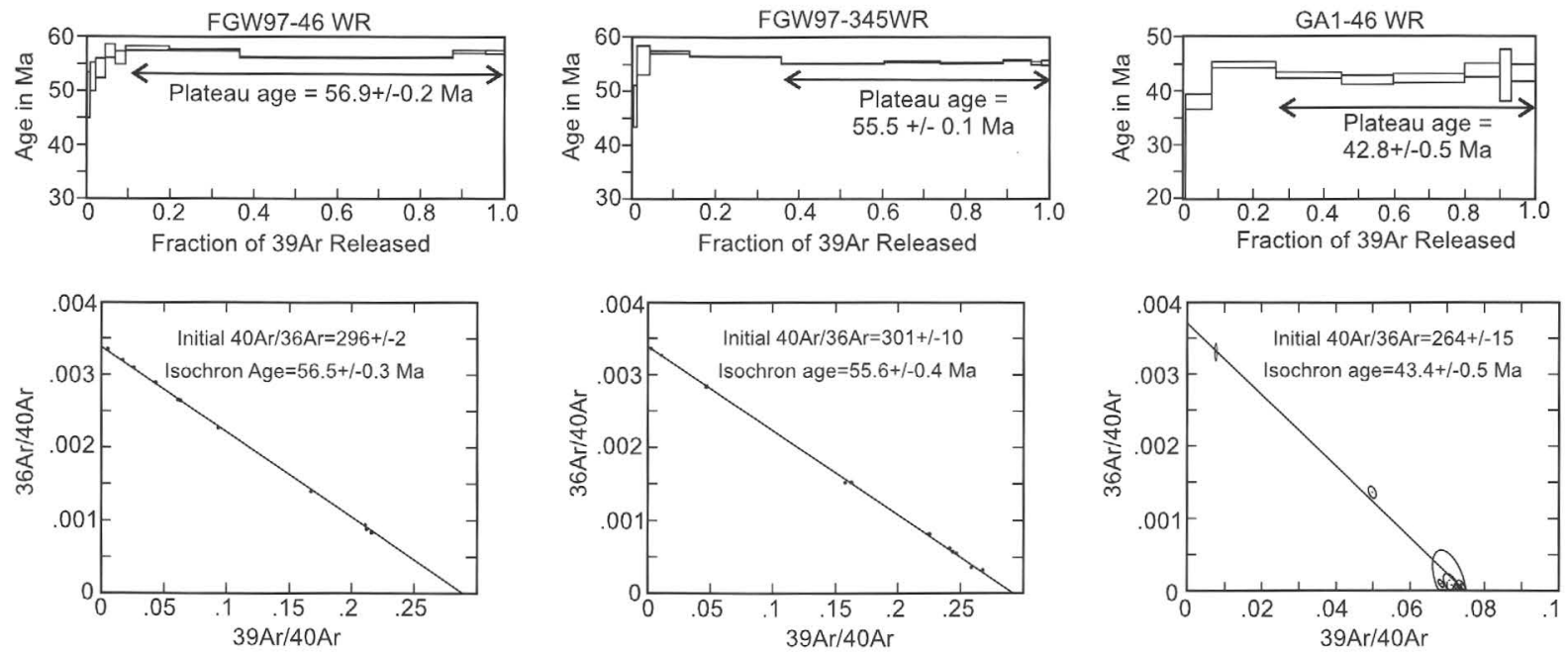

Figure 3. ${ }^{40} \mathrm{Ar} /{ }^{39} \mathrm{Ar}$-plateau ages and isochron plots for samples from the volcanic rocks of Foraker Glacier and the Mount Galen Volcanics. See figure 2 for locations and figures 8 and 12 for stratigraphic positions of samples. 
Table 1. Compilation of radiometric ages for volcanic rocks in the Mount McKinley quadrangle.

\begin{tabular}{|c|c|c|c|c|c|}
\hline Sample & Unit/location & Description & $\begin{array}{l}\text { Material } \\
\text { dated }^{1}\end{array}$ & $\operatorname{Age}(\mathrm{Ma})^{2}$ & Notes $^{3,4}$ \\
\hline \multicolumn{6}{|c|}{ This study $\left({ }^{40} \mathrm{Ar} /{ }^{39} \mathrm{Ar}\right.$ step heating) ${ }^{3}$} \\
\hline GA1-46 & $\begin{array}{l}\text { Mount Galen Volcanics. North } \\
\text { side of Mount Galen in the } \\
\text { Mount McKinley B-1 } \\
1: 63,360 \text {-scale quadrangle, lat } \\
63^{\circ} 28^{\prime} 19^{\prime \prime} \text { N., long } 150^{\circ} 21^{\prime} 22^{\prime \prime} \\
\text { W. }\end{array}$ & $\begin{array}{l}\text { Basalt, } 46 \mathrm{~m} \text { above the } \\
\text { base of the Mount } \\
\text { Galen Volcanics. }\end{array}$ & $\begin{array}{l}\text { W } \\
W\end{array}$ & $\begin{array}{l}\mathbf{4 2 . 8} \pm \mathbf{0 . 5} \\
43.4 \pm 0.5\end{array}$ & $\begin{array}{l}\text { Plateau age. } \\
\text { Isochron age. }\end{array}$ \\
\hline FGW-46 & $\begin{array}{l}\text { Volcanic rocks of Foraker. } \\
\text { Glacier/west side of Foraker } \\
\text { Glacier in the Mount } \\
\text { McKinley A-3 1:63,360-scale } \\
\text { quadrangle, lat } 63^{\circ} 05^{\prime} 45^{\prime \prime} \text { N., } \\
\text { long } 151^{\circ} 24^{\prime} 49^{\prime \prime} \mathrm{W} \text {. }\end{array}$ & $\begin{array}{l}\text { Basalt; } 46 \mathrm{~m} \text { above the } \\
\text { base of the volcanic } \\
\text { rocks of Foraker } \\
\text { Glacier. }\end{array}$ & $\begin{array}{l}\text { W } \\
W\end{array}$ & $\begin{array}{l}\mathbf{5 6 . 9} \pm \mathbf{0 . 2} \\
56.5 \pm 0.3\end{array}$ & $\begin{array}{l}\text { Plateau age. } \\
\text { Isochron age. }\end{array}$ \\
\hline FGW-345 & $\begin{array}{l}\text { Volcanic rocks of Foraker. } \\
\text { Glacier/west side of Foraker } \\
\text { Glacier in the Mount } \\
\text { McKinley A-3 1:63,360-scale } \\
\text { quadrangle, lat } 63^{\circ} 5^{\prime} 52^{\prime \prime} \text {, long } \\
151^{\circ} 24^{\prime} 53^{\prime \prime} \mathrm{W} \text {. }\end{array}$ & $\begin{array}{l}\text { Porphyritic rhyolite; } 345 \\
\text { m above the base of } \\
\text { the volcanic rocks of } \\
\text { Foraker Glacier. }\end{array}$ & $\begin{array}{l}\text { W } \\
\text { W } \\
\text { K } \\
\text { K }\end{array}$ & $\begin{array}{l}55.5 \pm 0.1 \\
55.6 \pm 0.4 \\
\mathbf{5 4 . 6 \pm 0 . 2} \\
55.4 \pm 0.3\end{array}$ & $\begin{array}{l}\text { Plateau age. } \\
\text { Isochron age. } \\
\text { Plateau age. } \\
\text { Isochron age. }\end{array}$ \\
\hline \multicolumn{6}{|c|}{ Previous K-Ar studies ${ }^{5}$} \\
\hline 1 & Mount Galen volcanics-- & Andesite --- & $\begin{array}{l}\mathrm{P} \\
\mathrm{H}\end{array}$ & $\begin{array}{l}41.1 \pm 1.2 \\
38.9 \pm 1.1\end{array}$ & $\begin{array}{l}{ }^{40} \mathrm{Ar}_{\text {rad }} d^{40} \mathrm{Ar}_{\text {total }}=0.652 \\
{ }^{40} \mathrm{Ar}_{\mathrm{rad}} /{ }^{40} \mathrm{Ar}_{\text {total }}=0.554\end{array}$ \\
\hline 2 & Mount Galen volcanics------------- & 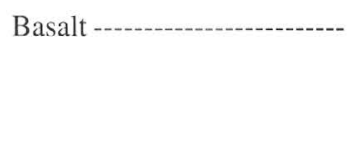 & $\mathrm{P}$ & $\begin{array}{c}34.8 \pm 1.4 \\
35.7 \pm 1.4 \\
\text { (minimum } \\
\text { ages) }\end{array}$ & $\begin{array}{l}{ }^{40} \mathrm{Ar}_{\text {rad }}{ }^{40} \mathrm{Ar}_{\text {total }}=0.734 \\
{ }^{40} \mathrm{Ar}_{\mathrm{rad}} /{ }^{40} \mathrm{Ar}_{\text {total }}=0.743\end{array}$ \\
\hline 3 & 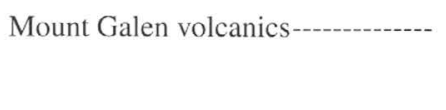 & 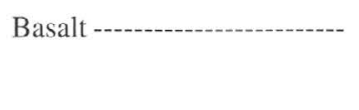 & $\mathrm{P}$ & $\begin{array}{c}39.6 \pm 1.2 \\
\text { (minimum } \\
\text { age })\end{array}$ & ${ }^{40} \mathrm{Ar}_{\text {rad }}{ }^{40} \mathrm{Ar}_{\text {total }}=0.481$ \\
\hline 6 & Mount Galen volcanics--- & Andesite --1-- & $\mathrm{H}$ & $38.7 \pm 1.1$ & ${ }^{40} \mathrm{Ar}_{\text {rad }} /{ }^{40} \mathrm{Ar}_{\text {total }}=0.435$ \\
\hline 4 & West side of Muldrow Glacier ----- & 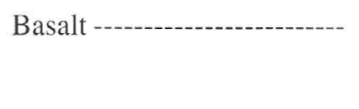 & $\mathrm{P}$ & $\begin{array}{l}33.1 \pm 1.0 \\
\text { (minimum } \\
\text { age) }\end{array}$ & ${ }^{40} \mathrm{Ar}_{\text {rad }}{ }^{40} \mathrm{Ar}_{\text {total }}=0.586$ \\
\hline
\end{tabular}

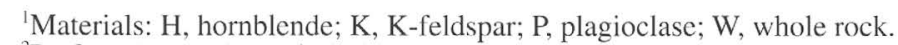

${ }^{2}$ Preferred ages shown in bold.

${ }^{3}$ Laser: Step-heated using an Ar-ion laser, measured on a VG3600 spectrometer. Furnace: Step-heated using a resistance-type furnace, measured on a Nuclide 6-60-SGA spectrometer.

${ }^{4} \mathrm{Ages}$ of this study were run against standard Mmbb-1 with an age of $513.9 \mathrm{Ma}$ and processed by using standards of Steiger and Jäger (1977). Error limits, $\pm 1 \sigma$. Analytical data and age spectra are available from the authors on request.

${ }_{5}^{5}$ Age data reported by Decker and Gilbert (1978) corrected according to Dalrymple (1979); sample numbers refer to map numbers of Decker and Gilbert (1978).

rocks. Finally, the sedimentary strata along Foraker Glacier contain lithofacies that are similar to the lower part of the Cantwell Formation in the Healy quadrangle.

\section{Interpretation}

We interpret these sedimentary strata to record a significant episode of tectonic uplift and basin subsidence before the onset of late Paleocene and early Eocene volcanism in the region. The very large clast size of the lower conglomerate unit indicates proximity to an uplifted source area, and the clast compositions, along with the basal angular unconformity, indicate that the underlying metamorphic rocks were part of this uplift. Collectively, the rocks in the lower conglomerate unit are typical of alluvial-fan deposits. We interpret the poorly organized conglomerate facies as the deposits of high-concentration stream floodflows and (or) noncohesive debris flows. 
The absence of internal stratification and the poor sorting of these deposits preclude dilute streamflow bedload deposition. Also, the absence of muddy matrix and the clast-supported fabric indicates deposition from high-concentration watersediment dispersions or fines-depleted debris flows (Costa, 1988). Similar types of deposits were described by Allen (1981), Nemec and Steel (1984), and DeCelles and others (1991) as thick sheets on alluvial-fan surfaces. The massive pebbly sandstone and the trough-crossbedded sandstone interbeds were most likely deposited during waning flood stages by hyperconcentrated flows and more dilute-phase streamflows (Pierson and Scott, 1985; Smith, 1986). The well-organized and imbricated conglomerate facies and trough-cross-stratified sandstone interbeds represent episodes of dilute-phase floodflows and streamflows, respectively (Costa, 1988).

The thick intervals of mudstone and sandstone-conglomerate that overlie the lower conglomerate unit probably represent a period of basin subsidence with intermittent episodes of renewed tectonic uplift and (or) shifting drainage systems. During this period, ponded environments (lakes, swamps) formed in the basin, and the mudstone intervals were deposited. The sandstone-conglomerate intervals represent the influx of braided fluvial systems into the ponded environments. This fluvial influx could represent progradation during periods of tectonic uplift, or simply changes in drainage patterns or source-rock types within the basin (for example, DeCelles and others, 1991).



Figure 5. Composite stratigraphic column for the Foraker Glacier area, south-central Alaska (fig. 2). Histograms show conglomerate-clast-count data. 

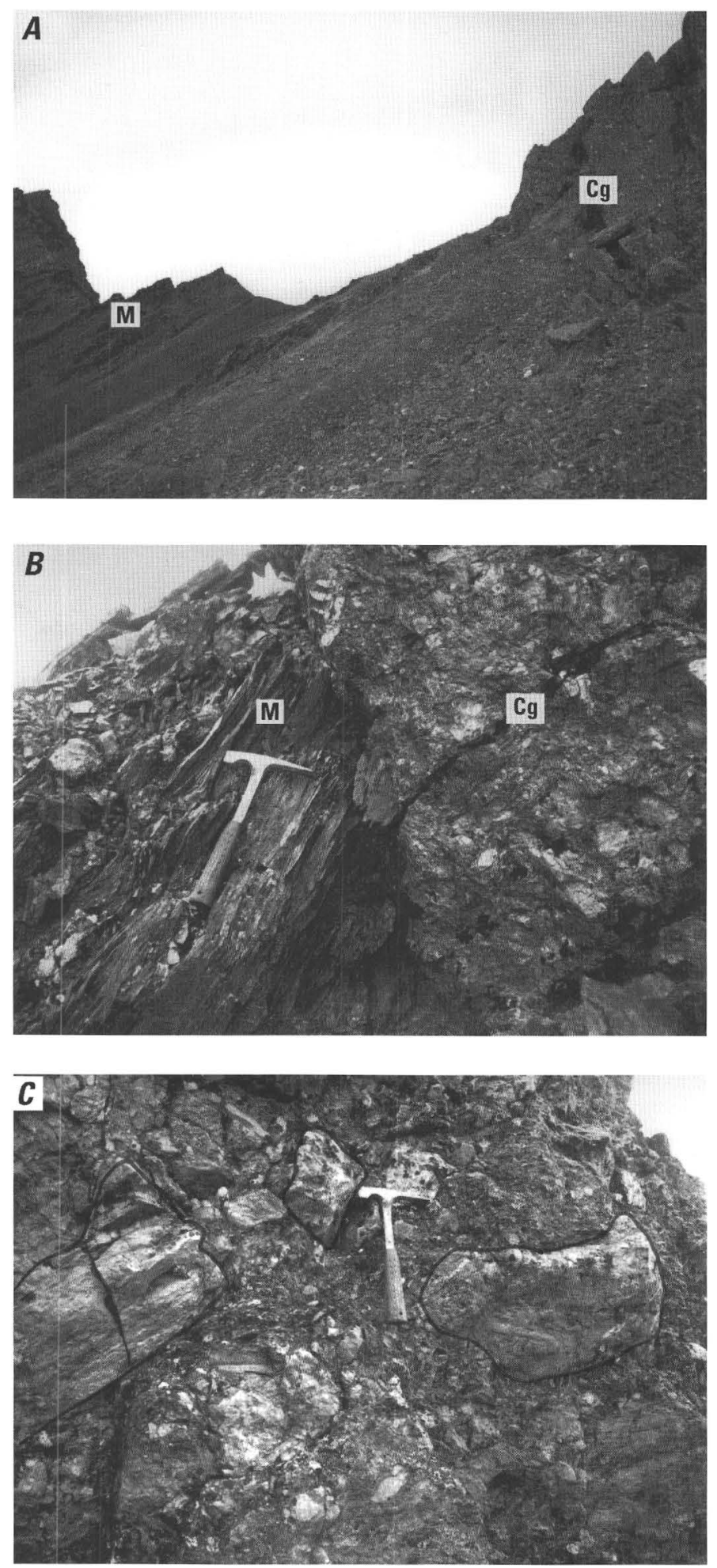

Figure 6. Paleozoic-Late Cretaceous(?) contact along west side of Foraker Glacier (fig. 2). $A$ and $B$, Nonconformable contact between south-dipping Paleozoic metamorphic rocks (M) and north-dipping Late Cretaceous(?) cobble to boulder conglomerate (Cg). C, Cobble to boulder conglomerate about $5 \mathrm{~m}$ above Paleozoic contact. Bouldersize metamorphic clasts are outlined.

\section{Volcanic Rocks}

\section{Lower Basalt-Andesite and Sedimentary Sequence}

The late Paleocene and early Eocene volcanic rocks are unconformable with the underlying sedimentary sequence and generally dip about $35^{\circ}-45^{\circ} \mathrm{N}$. (fig. 4). The lowermost part of the volcanic sequence includes basalt and andesite lavas that are interbedded with sedimentary rocks (figs. 8, 9). The andesite lavas and sedimentary rocks are present only in the lowest $100 \mathrm{~m}$ of this sequence. The basalt lavas are brown to dark gray in flows that range from 2 to $18 \mathrm{~m}$ in thickness (avg 5-6 $\mathrm{m}$ thick). Many flows are columnar jointed and have vesicular tops; some basalt flows have thin to thick scoriaceous upper zones that weather yellowred. In thin section, the basalt contains euhedral to subhedral plagioclase laths $\left(\mathrm{An}_{40}\right.$ to $\left.\mathrm{An}_{70}\right)$ with minor amounts of continuous zoning. Clinopyroxenes and olivine are present but are very fine grained and occupy interstices in the groundmass between the plagioclase laths. Needles and equant grains of opaque minerals (Fe-Ti oxides) are also present. There is some calcite replacement of plagioclase and some alteration of groundmass into clay minerals. The andesite lavas are less abundant than the basalt, occur in flows that range from 2 to $12 \mathrm{~m}$ in thickness, have tabular to lenticular bed shapes, are medium gray to brown, have few vesicles, and are typically porphyritic. The andesite consists almost entirely of plagioclase $\left(\mathrm{An}_{50}\right.$ to $\left.\mathrm{An}_{88}\right)$ with needles and equant grains of $\mathrm{Fe}$-Ti oxides and trace amounts of biotite. Plagioclase is euhedral to subhedral and commonly displays resorption textures and reaction rims. Continuous zoning is common. The

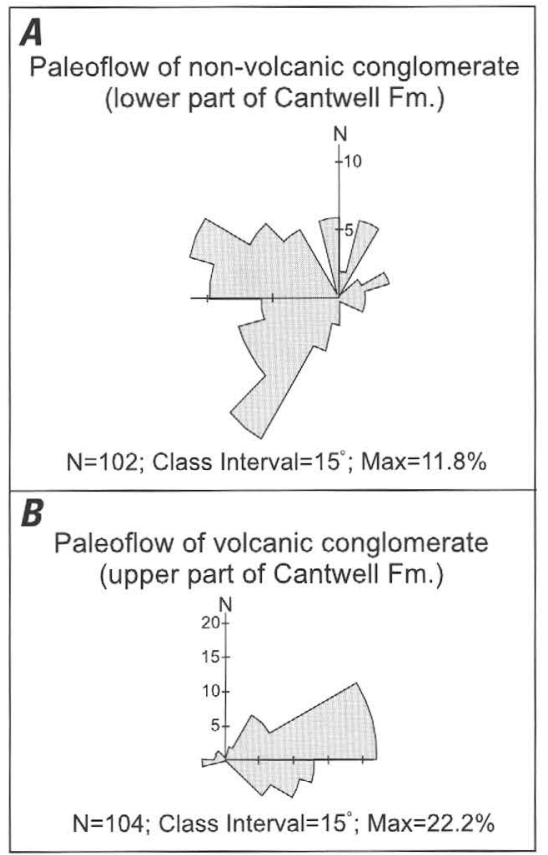

Figure 7. Paleocurrent rose diagrams for fluvial conglomerates along west side of Foraker Glacier (fig. 2), as measured from imbricated clasts and restored by using average bedding for each unit. $A$, Westward-directed paleoflow for cobble-boulder conglomerate within $100 \mathrm{~m}$ above Paleozoic metamorphic rocks. $B$, Eastwarddirected paleoflow for two intervals of pebble-cobble conglomerate within lowermost $72 \mathrm{~m}$ of volcanic-rock unit. 


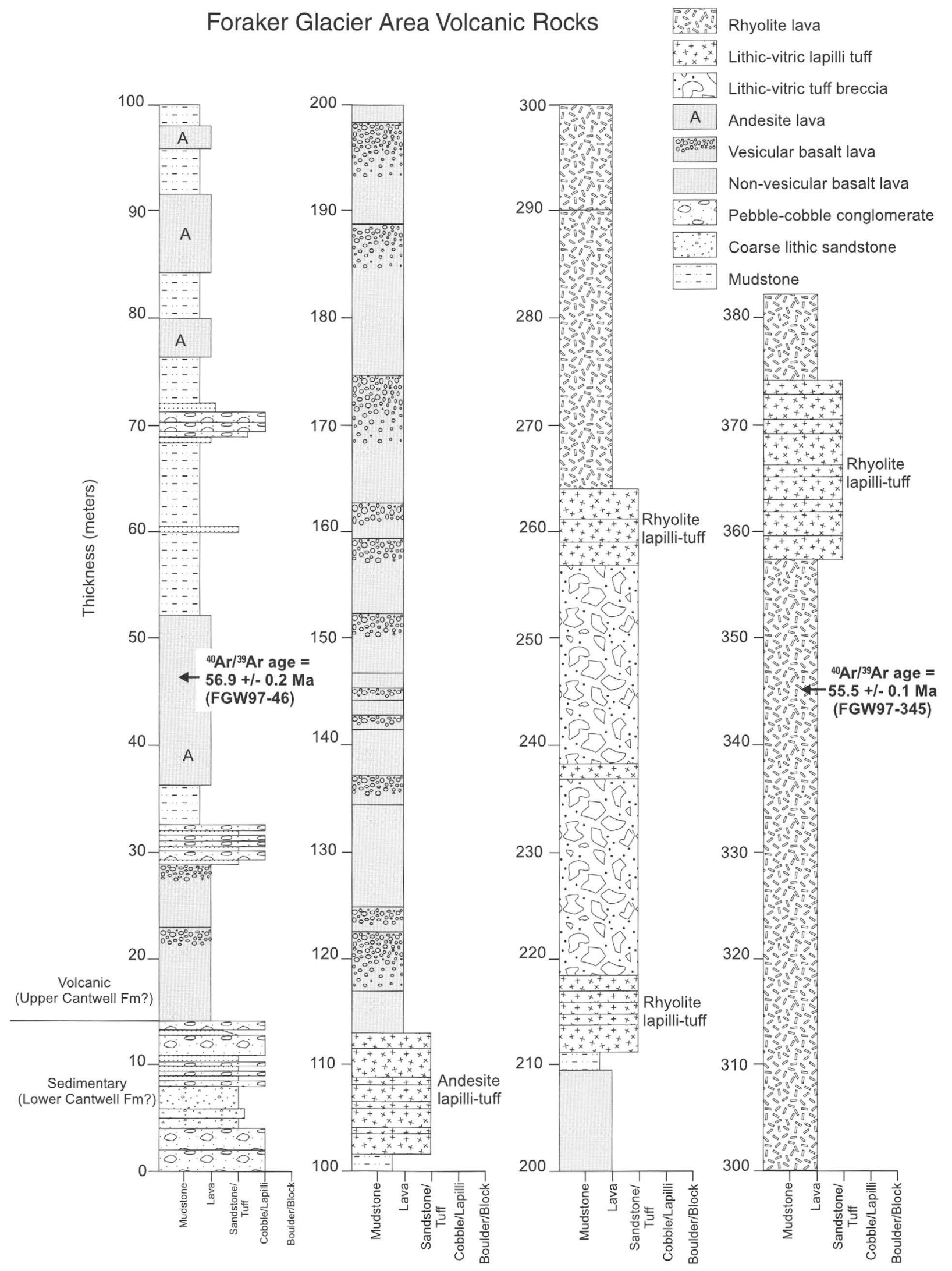

Figure 8. Detailed stratigraphic column for lowermost volcanic rocks of Foraker Glacier (fig. 2), measured bed by bed by using a Jacob staff. Note stratigraphic positions of two new ${ }^{40} \mathrm{Ar} /{ }^{39} \mathrm{Ar}$ radiometric ages reported in this study. 


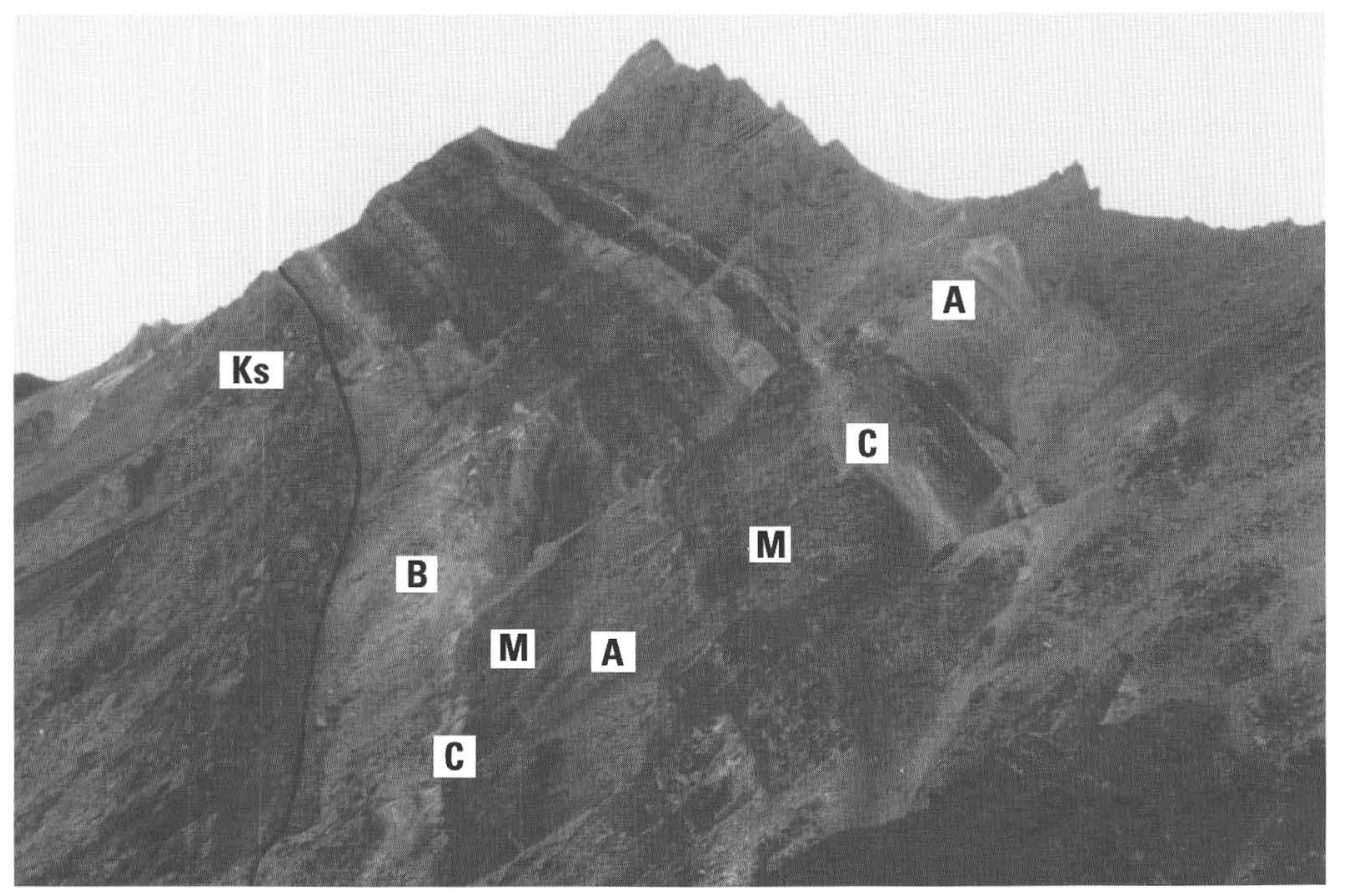

Figure 9. Lowermost interval of volcanic and sedimentary rocks exposed along west side of Foraker Glacier (fig. 2). Volcanic rocks sharply overlie interval of pebble-cobble conglomerate at top of Late Cretaceous(?) sedimentary rocks (Ks); contact is at about 14-m level in stratigraphic column (fig. 8). Tertiary volcanic and sedimentary units: $A$, andesite lava; $B$, basalt lava; $C$, conglomerate; $M$, mudstone with interbedded fine-grained sandstone.

groundmass consists of microcrystalline plagioclase, devitrified glass, and opaque minerals.

The sedimentary rocks interbedded with the basalt and andesite lavas include shale-siltstone and conglomerate intervals. The shale-siltstone intervals range from 3 to $9 \mathrm{~m}$ in thickness and include fissile dark-gray to black shale, with 0.5 - to 5 -cm-thick dark-gray siltstone to very fine sandstone beds. The siltstone and very fine sandstone beds display horizontal, low-angle, and climbing ripple laminations, and some beds contain groove and flute casts at their bases. All of these intervals contain abundant plant fragments and very thin (a few millimeters thick) coal seams. Two conglomerate intervals that are each about $6 \mathrm{~m}$ thick (fig. 8) consist of 0.3 - to 0.8 -m-thick beds of clast-supported, moderately sorted to well-sorted pebble-cobble conglomerate (clast size, avg $3-5 \mathrm{~cm}$, max $9-10 \mathrm{~cm}$ in diameter). The conglomerate ranges in texture from massive to imbricated and contains $0.2-$ to $0.5-\mathrm{m}$ thick interbeds of lenticular, trough-crossbedded coarse sandstone. The conglomerate contains 49 percent volcanic clasts (mostly medium-gray porphyritic felsic rhyolite-dacite), 42 percent metamorphic clasts (mostly quartzite), and 9 percent sandstone clasts (fig. 5). Paleoflow as measured from clast imbrication in the conglomerate intervals was eastward (fig. 7).

\section{Rhyolite Lavas and Pyroclastic Deposits}

Rhyolite lavas and pyroclastic deposits are the most abundant volcanic rocks in the Foraker Glacier area. At least 1,500 m of felsic volcanic rocks overlies the lower interval of intermediate and mafic lavas (figs. 4,5). The rhyolite lavas are medium to light gray and porphyritic, weather light gray and light purple, and occur as massive intervals with poorly defined bed contacts. Some intervals are flow banded and display red-gray wispy layering. The more massive intervals are columnar jointed. In thin section, the rocks show a groundmass of devitrified glass with spherulitic texture and microlites of feldspar and quartz. The phenocrysts include quartz, alkali feldspar, and biotite. The quartz is euhedral to subhedral, showing bipyramidal forms, and is commonly embayed. The alkali feldspar is mostly orthoclase $\left(2 \mathrm{~V}\right.$ angle, $\left.>60^{\circ}\right)$ in subhedral rectangular to equant grains. Graphic intergrowth with quartz and exsolution textures are common. The biotite is strongly oxidized and is present as only a small percentage of the modal mineralogy.

Two pyroclastic lithofacies occur within the volcanic sequence along Foraker Glacier. The first lithofacies is a thinbedded lithic-crystal lapilli tuff, and the second is a massive lithic tuff-breccia. The lapilli tuff is light to medium gray and occurs in 3- to 8-m-thick intervals that consist of 1- to 8-cm-thick horizontally laminated beds. Individual laminations within beds range from a few millimeters to $20 \mathrm{~mm}$ in thickness and consist of alternating fine and coarse couplets with finer grained crystal-lithic-rich bases and pumice-rich tops. Grain size in the first lithofacies is predominantly 1 to $5 \mathrm{~mm}$, with scattered thin and discontinuous lenses of lithic grains, as much as 2 to $3 \mathrm{~cm}$ in diameter. Parts of this lithofacies are welded and exhibit a strong eutaxitic texture defined by flattened and aligned pumice and glass shards. Two compositional types of the first lithofacies, andesitic and rhyolitic, can be defined on the basis of crystal composition. The andesitic lapilli tuff occurs in only one stratigraphic interval at the top of the basalt-andesite sedimentary sequence, 102 to $115 \mathrm{~m}$ above the base of the volcanic rocks (fig. 8). This first compositional type 
is characterized by crystals of quartz, plagioclase, and minor biotite and by pumice grains with large, thick-walled vesicles. The rhyolitic lapilli tuff is interbedded with the rhyolite lavas and includes crystals of quartz, alkali feldspar with exsolution and graphic textures, and rare plagioclase, with finely vesicular and wispy pumice grains. Both compositional types contain cuspate and bladed vitric shards (mostly devitrified) and include similar accidental lithic grain populations of basalt, schist, sandstone, and polycrystalline quartz. The second compositional type also contains lithic grains of porphyritic rhyolite (similar in texture and mineralogy to the rhyolite lavas).

The second lithofacies is white to light gray and occurs in 14to 20-m-thick intervals with poorly defined bedding contacts. This lithofacies, which typically overlies the first lithofacies (fig. 8), is massive and poorly sorted and exhibits inverse grading at the base of each interval. Quartz is the predominant crystal in the second lithofacies and is present as euhedral, subhedral, and broken or shattered grains. The groundmass consists of devitrified fine ash and relict cuspate shards. Lapilli to block-size lithic clasts (2-30 $\mathrm{cm}$ in diameter) are mostly laminated to welded rhyolitic lapilli tuff and porphyritic rhyolite (glassy groundmass with phenocrysts of quartz and alkali feldspar). A trace ( $<2$ volume percent) of nonvolcanic grains (sandstone and polycrystalline quartz) is present.

\section{Interpretation}

The late Paleocene and early Eocene volcanic episode in the Foraker Glacier area began with the outpouring of basalt and andesite lavas. These lavas flowed into a tectonically active basin, the fill of which is represented by the underlying sedimentary deposits. The presence of an angular unconformity at the base of the volcanic rocks implies that the area underwent an episode of uplift before volcanism; this uplift could have been partly caused by thermal doming associated with the onset of volcanism or might represent an episode of tectonic shortening that preceded volcanism. The absence of pyroclastic deposits in the lowermost part of the volcanic sequence suggests that the lavas were erupted from fissures within or close to the basin. We interpret the mudstone and siltstone deposits that are interbedded with the basalt and andesite lavas to represent background sedimentation within the basin between eruptions. The conglomerate intervals interbedded with the lowermost lavas contain an abundance of porphyritic rhyolite clasts; we interpret these conglomerates to represent synvolcanic sedimentation during the onset of felsic volcanism at a more distant ventsite. The lenticular shape of beds, well-developed imbrication of rounded clasts, clast-supported framework, and trough-crossbedded sandstone all indicate deposition from braided fluvial systems (Rust, 1972; Miall, 1977; Costa, 1988). These streams flowed eastward through the basin, possibly draining volcanic source areas to the west and southwest. The mixture of volcanic and metamorphic clasts implies that even during the onset of felsic volcanism there was continued erosion of metamorphic source rocks and (or) erosion of the Late Cretaceous(?) metamorphic-clast conglomerate.

The presence of the andesitic lapilli tuff interval interbedded with the basalt lavas is the first sign of explosive volcanism recorded in the basin. Explosive volcanism became most pronounced after the effusion of the basalt lavas when about $50 \mathrm{~m}$ of rhyolitic thin-bedded lapilli tuff and tuff breccia was deposited. The composition of the lapilli tuff and tuff breccia (vitric shards, pumice, euhedral to subhedral crystals, volcanic lithic grains, and only traces of nonvolcanic lithic grains), along with the presence of welding, indicates that these are primary pyroclastic deposits. We interpret these facies as pyroclastic-surge and pyroclastic-flow deposits, respectively. Pyroclastic surges are dilute, turbulent flows of hot gas and ash that form during explosive eruptions and can be independent or cogenetic with denser, high-concentration pyroclastic flows (Fisher, 1979; Wright and others, 1980). The andesitic lapilli tuff and the lowermost rhyolitic lapilli tuff (fig. 8) most likely represent pyroclastic-surge deposits that formed during relatively smaller pulses of explosive eruptions, possibly signaling the early growth of the felsic eruptive center. Intervals of pyroclasticsurge deposits have also been documented to mark the beginning of felsic eruptive episodes in other volcanic settings (for example, Cole and DeCelles, 1991). The laminations and alternating finecoarse couplets of this facies most likely represent traction-carpet sedimentation along the base of flows, similar to that of high-density turbidity flows (Lowe, 1982). Pyroclastic-flow deposits are commonly described in terms of flow units, which are produced during the passage of a single pyroclastic flow. Pyroclastic-flow units typically are inversely graded, with crudely laminated lower intervals (commonly tens of centimeters thick) and massive, poorly sorted upper zones (Sparks and others, 1973; Fisher, 1979). The second lithofacies includes at least two major pyroclastic-flow units but may consist of several amalgamated pyroclastic-flow deposits with poorly defined contacts. This episode of pyroclasticflow deposition marks a more explosive interval during the early phase of felsic volcanism. After this phase, the basin was inundated by rhyolite lavas and additional pyroclastic deposits. The ventsites for this phase of volcanism were most likely within a few kilometers of the basin because rhyolite lavas are highly viscous and typically flow no more than a few kilometers from their vents (Cas and Wright, 1987).

\section{Mount Galen Volcanics}

The Mount Galen Volcanics, of late Eocene and early Oligocene age, is exposed on the west side of the Muldrow Glacier terminus and in the Mount Galen area (fig. 2). The base of the volcanic sequence in the Muldrow Glacier area is not exposed, but in the Mount Galen area the volcanic rocks unconformably overlie interbedded sandstone and shale of the lower part of the Cantwell Formation. The rocks in these two areas are described separately below.

\section{Muldrow Glacier Area}

Approximately $280 \mathrm{~m}$ of volcanic rocks is exposed along the west side of the Muldrow Glacier terminus (figs. 10, 11). This exposure consists mostly of pyroclastic deposits with 


\section{Muldrow Glacier Area}
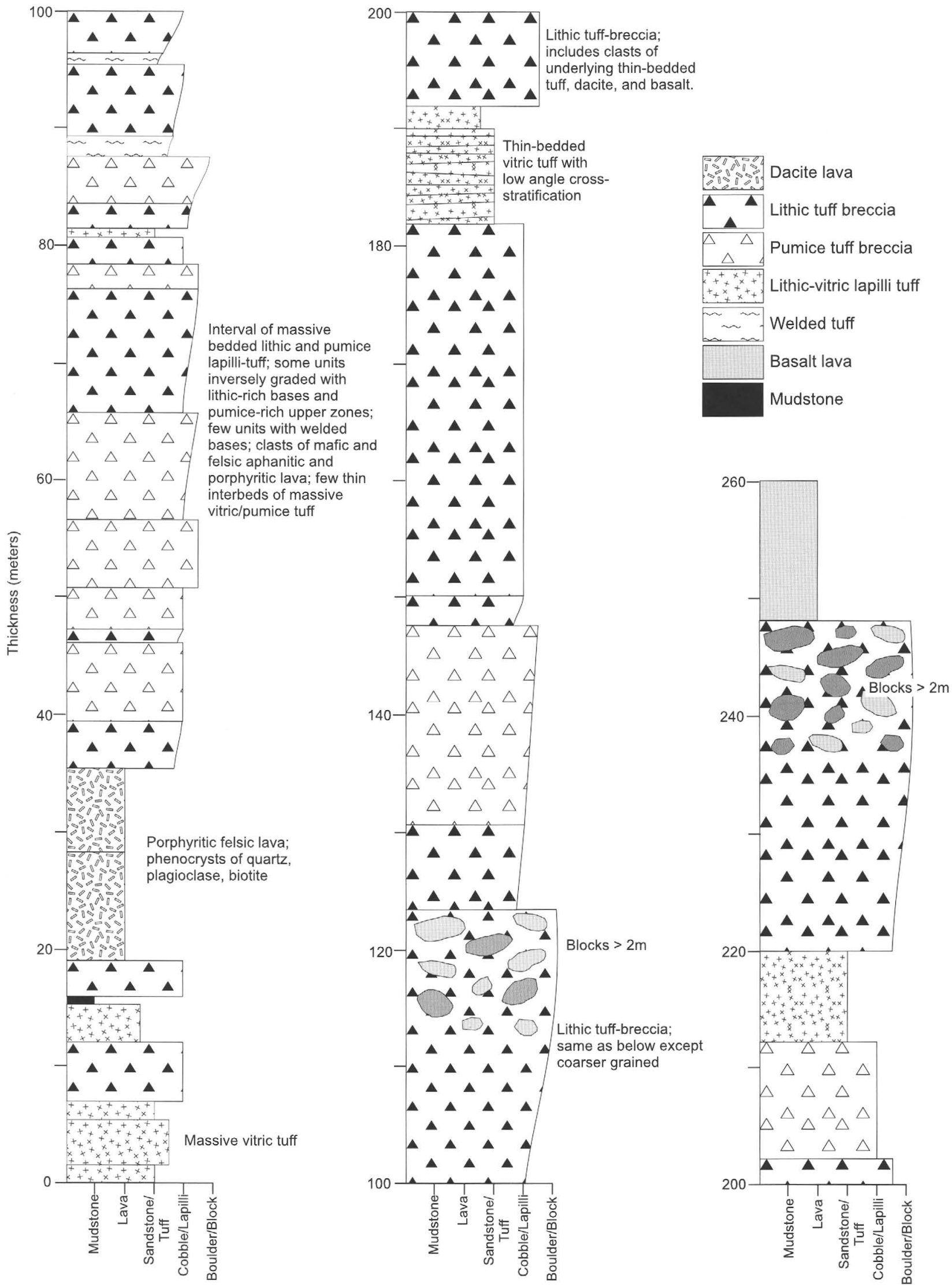

Figure 10. Stratigraphic column for the Mount Galen Volcanics exposed along west side of Muldrow Glacier terminus (fig. 2), measured bed by bed by using a Jacob staff. Light-shaded blocks, basalt; dark-shaded blocks, felsic lava. 



Figure 11. Characteristics of pyroclastic rocks in the Mount Galen Volcanics in Muldrow Glacier area (fig. 2). A, Exposed section of volcanic rocks, showing pyroclastic deposits capped by mafic lava (ML); view westward. $B$, Lithic-lapilli-tuff facies with clasts of porphyritic felsic lava (F) and basalt (B). C, Large block of basalt within lithic-tuff-breccia facies. D, Thin-bedded vitric-tuff facies.

intervals of felsic lavas (dacite and minor rhyolite) and basaltic lavas. All of these volcanic deposits show some degree of alteration; many of the pyroclastic deposits, especially finer grained tuff beds, are strongly altered to clay minerals and chlorite. Secondary pyrite is common in tuff deposits within the lower $50 \mathrm{~m}$ of the exposed volcanic sequence.

The felsic lavas, which occur in the stratigraphically lowest part of the exposure, are porphyritic, with phenocrysts of plagioclase, alkali feldspar, and quartz. The plagioclase is commonly euhedral, discontinuously zoned, and Na rich $\left(A n_{20}\right.$ to $\left.A n_{50}\right)$. The alkali feldspar is subhedral, with partial alteration to clay minerals, and displays graphic intergrowths with quartz. The groundmass ranges in texture from a devitrified glass to a microlitic trachyte. The basaltic lavas (basalt to basaltic andesite) occur near the top of the exposed volcanic sequence (figs. 10,11A). The rocks are aphanitic to porphyritic and consist mostly of plagioclase, with smaller amounts of altered pyroxene, opaque minerals, and devitrified glass in the spaces between plagioclase laths.

The pyroclastic deposits are primarily massive intervals of light-gray to light-purple lithic tuff-breccia and pumice lapilli tuff, with minor amounts of interbedded vitric tuff (fig. 10). The lithic tuff-breccia forms massive deposits that range from 1 to $32 \mathrm{~m}$ in thickness. The thicker intervals probably include amalgamated beds, but except for the bases and tops of each interval, bedding contacts within these deposits are poorly defined. Inverse grading is common at the bases of these deposits, and the upper parts typically are more pumiceous. The deposits are poorly sorted and contain angular to subrounded clasts (fig. 11B). The lithic clasts in these deposits typically range from 0.5 to $5 \mathrm{~cm}$ in diameter, but the two thickest deposits contain blocks as much as $2 \mathrm{~m}$ across (fig. 11C). Lithic-clast types include light-gray to light-purple porphyritic rhyolite (similar to the rhyolite in the lower part of the volcanic sequence), brown to dark-gray mafic aphanitic lava (basalt and basaltic andesite with intersertal and trachytic texture), light-gray pumice tuff, granite, and minor sandstone. Groundmass material is mostly devitrified glass containing wispy pumice grains, relict cuspate vitric shards, and crystals of plagioclase, quartz, and biotite.

The pumice-rich lapilli tuff occurs in 2- to 17-m-thick, poorly sorted intervals, some of which display inverse grading. These intervals are characterized by abundant pumice, which ranges in clast size from 0.5 to $10 \mathrm{~cm}$ across. Groundmass in the deposits consists of devitrified cuspate shards, wispy pumice, euhedral to subhedral plagioclase, and subhedral 
quartz. A small percentage of lithic grains in these deposits includes mostly aphanitic and porphyritic rhyolite and vitric tuff. Many intervals of the pumice-rich lapilli tuff are gradational with underlying lithic tuff-breccia deposits.

The vitric-tuff deposits are light to dark gray, yellow, and green and range from about $1 \mathrm{~m}$ to $8 \mathrm{~m}$ in thickness. These deposits form massive to thin-bedded intervals with horizontal and low-angle stratification (fig. 11D). The tuff deposits contain mostly devitrified cuspate shards and wispy pumice grains, with scattered quartz and plagioclase crystals.

The volcanic sequence near Muldrow Glacier records an episode of pyroclastic eruptions with intermittent lava flows. The lithic-tuff-breccia intervals that grade upward into pumice-rich lapilli tuff are typical of pyroclastic-flow deposits, in which the denser lithic clasts are commonly concentrated near the bases of flows, while pumice is rafted along the tops of flows (Walker, 1971; Sparks, 1976). The massive and thinbedded vitric tuff probably formed as pyroclastic-fallout and pyroclastic-surge deposits, respectively. The horizontal and low-angle stratification in the thin-bedded tuff is characteristic of low-density pyroclastic-surge deposits (Fisher, 1979). Pyroclastic-fallout deposits are typically massive, with even bed contacts (Fisher and Schmincke, 1984), similar to the characteristics observed for the massive vitric tuff facies.

\section{Mount Galen Area}

The Mount Galen Volcanics was first named and described by Decker and Gilbert (1978), who defined the type locality at Mount Galen in the northwest corner of the Mount McKinley B-1 1:63,360-scale quadrangle. The unit has a minimum thickness of $1,000 \mathrm{~m}$ and consists of basalt and andesite lavas and andesite to dacite pyroclastic deposits (Decker and Gilbert, 1978). We report a new reference stratigraphic section through the lower $250 \mathrm{~m}$ of the Mount Galen Volcanics (fig. 12), along with new geochemical data for these rocks (described below). The basalt lavas occur in beds a few meters to $30 \mathrm{~m}$ thick and are commonly columnar jointed. Many of the basalt and andesite lava flows exhibit brecciated and vesicular upper zones. In some places, the lavas appear as volcanic breccia and are most likely lava autobreccia deposits because the groundmass is identical to the clasts and vesicles crosscut clast and matrix boundaries. Decker and Gilbert described the basalts as holocrystalline and porphyritic, with phenocrysts of clinopyroxene, zoned plagioclase $\left(\mathrm{An}_{55}\right.$ to $\left.\mathrm{An} \mathrm{n}_{60}\right)$, magnetite, and olivine (listed in order of decreasing abundance). The basalt groundmass is mostly plagioclase microlites containing scattered Fe-Ti oxides and small amounts of devitrified glass. There are two varieties of andesite in the Mount Galen Volcanics: a hornblende andesite and a less abundant two-pyroxene andesite (Decker and Gilbert, 1978). The hornblende andesite is porphyritic, with a glassy to microcrystalline groundmass. The most abundant phenocryst is plagioclase $\left(\mathrm{An}_{52}\right.$ to $\left.\mathrm{An} \mathrm{n}_{65}\right)$, which occurs as euhedral to subhedral rectangular to blocky grains and commonly exhibits continuous zoning and resorption textures. Hornblende is commonly zoned and also shows resorption textures. The two-pyroxene andesite is porphyritic and includes euhedral to subhedral plagioclase, with oscillatory zoning and resorption textures, euhedral to subhedral and zoned hypersthene, euhedral to subhedral and twinned augite, and Fe-Ti oxides within a groundmass of microlitic plagioclase (Decker and Gilbert, 1978).

Pyroclastic deposits in volcanic rocks of the Mount Galen area include vitric-lithic tuff to lapilli tuff and lithic tuff-breccia. These deposits are most conspicuous in a thick interval above the lowermost lavas (fig. 12). A thick, massive vitric tuff also marks the base of the Mount Galen Volcanics in this area. The vitric-lithic lapilli tuff and tuff-breccia are similar in composition and vary mostly in grain size. The lapilli tuff contains lithic and pumice grains that are generally 1 to $4 \mathrm{~cm}$ across, and the tuff-breccia contains angular to subrounded lithic blocks as large as 1 to $5 \mathrm{~m}$ in diameter (fig. 13). The lapilli tuff occurs in thinner (1-4 m thick) intervals that display faint horizontal to low-angle stratification. The tuff breccia occurs in very thick (5-60 m thick) intervals that are massive and commonly are inversely graded in their lower third. Common lithic clasts in these deposits include hornblende and two-pyroxene andesite, basalt, vitric tuff, and felsic porphyritic lava (phenocrysts of plagioclase, biotite, and quartz in a microlitic and devitrified groundmass).

The Mount Galen Volcanics records an initial pyroclastic eruption (tuff layer at base) followed by effusion of basalt and andesite lavas. The lava eruptions were followed by an interval of explosive volcanism. The lithic lapilli tuff and tuff-breccia facies consist almost entirely of juvenile volcanic grains (vitric shards, euhedral-subhedral crystals, porphyritic lava) and are primary pyroclastic deposits. The thin-bedded and laminated lapilli-tuff facies most likely represents deposition from pyroclastic surges, and the tuff-breccia facies consists of deposits derived from dense pyroclastic flows generated by more explosive eruptions. (See sections above for discussions of these types of pyroclastic deposits.)

\section{Volcanic-Rock Geochemistry}

We report new major- and trace-element data on 14 samples from the volcanic rocks of Foraker Glacier and 17 samples from the Mount Galen Volcanics ( 9 from the Muldrow Glacier area and 8 from the Mount Galen area; tables 2, 3). These data are the first published geochemical analyses for volcanic rocks of the Foraker Glacier and Muldrow Glacier areas, and the first set of trace-element analyses for the Mount Galen Volcanics. Decker and Gilbert (1978) reported major-element data for six samples of the Mount Galen Volcanics.

Although all of these volcanic rocks are subalkalic, the volcanic rocks of Foraker Glacier and the Mount Galen Volcanics differ in major- and trace-element chemistry. On the basis of major-element chemistry, the volcanic rocks of Foraker Glacier are a basaltandesite-rhyolite suite, whereas the Mount Galen Volcanics is primarily a basaltic andesite-andesite-dacite suite, although minor basalt and rhyolite is present (fig. 14). In addition, the volcanic 

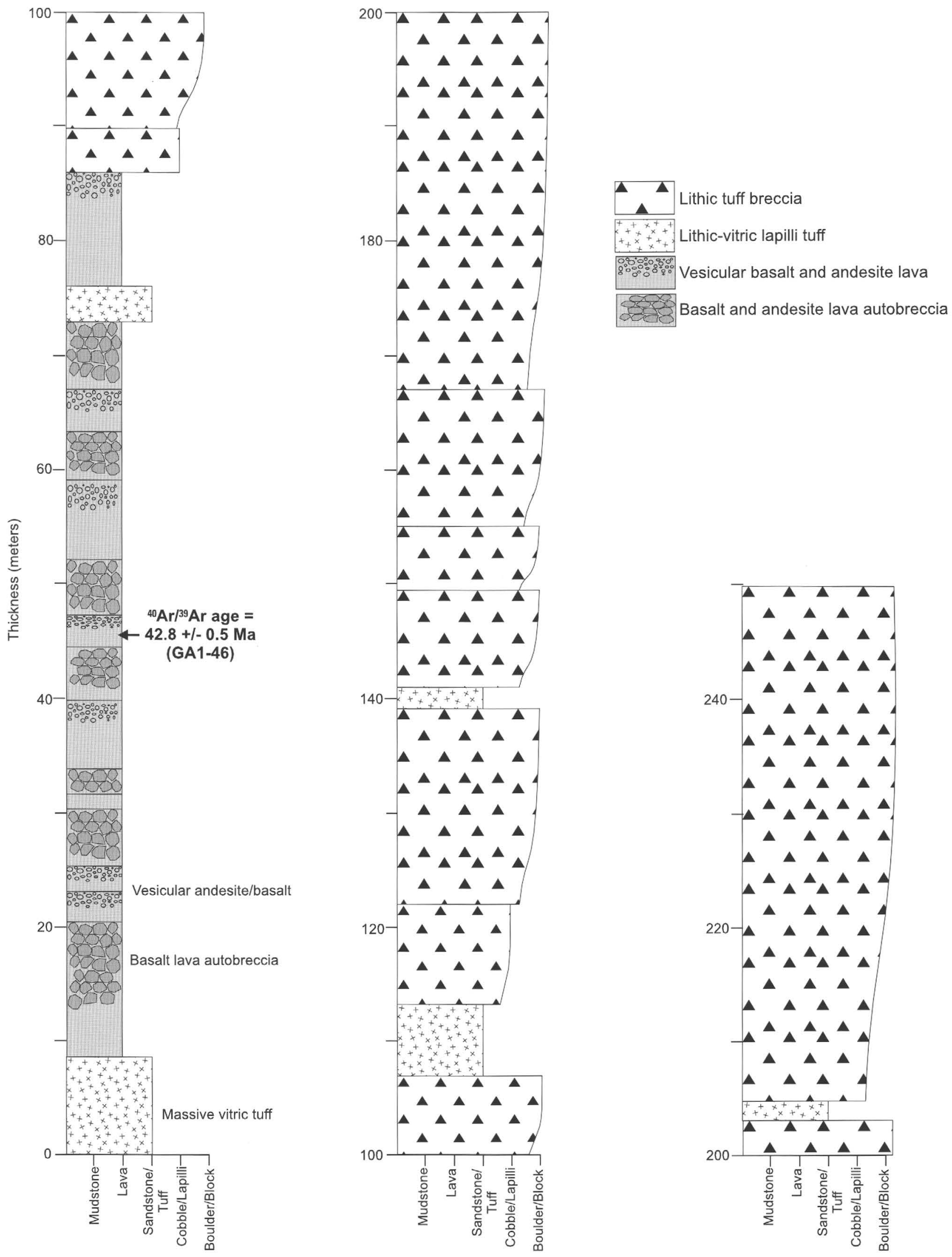

Figure 12. Stratigraphic column for the Mount Galen Volcanics exposed in type area (fig. 2), measured bed by bed by using a Jacob staff. Note stratigraphic position of new ${ }^{40} \mathrm{Ar} /{ }^{39} \mathrm{Ar}$ radiometric age reported in this study. 


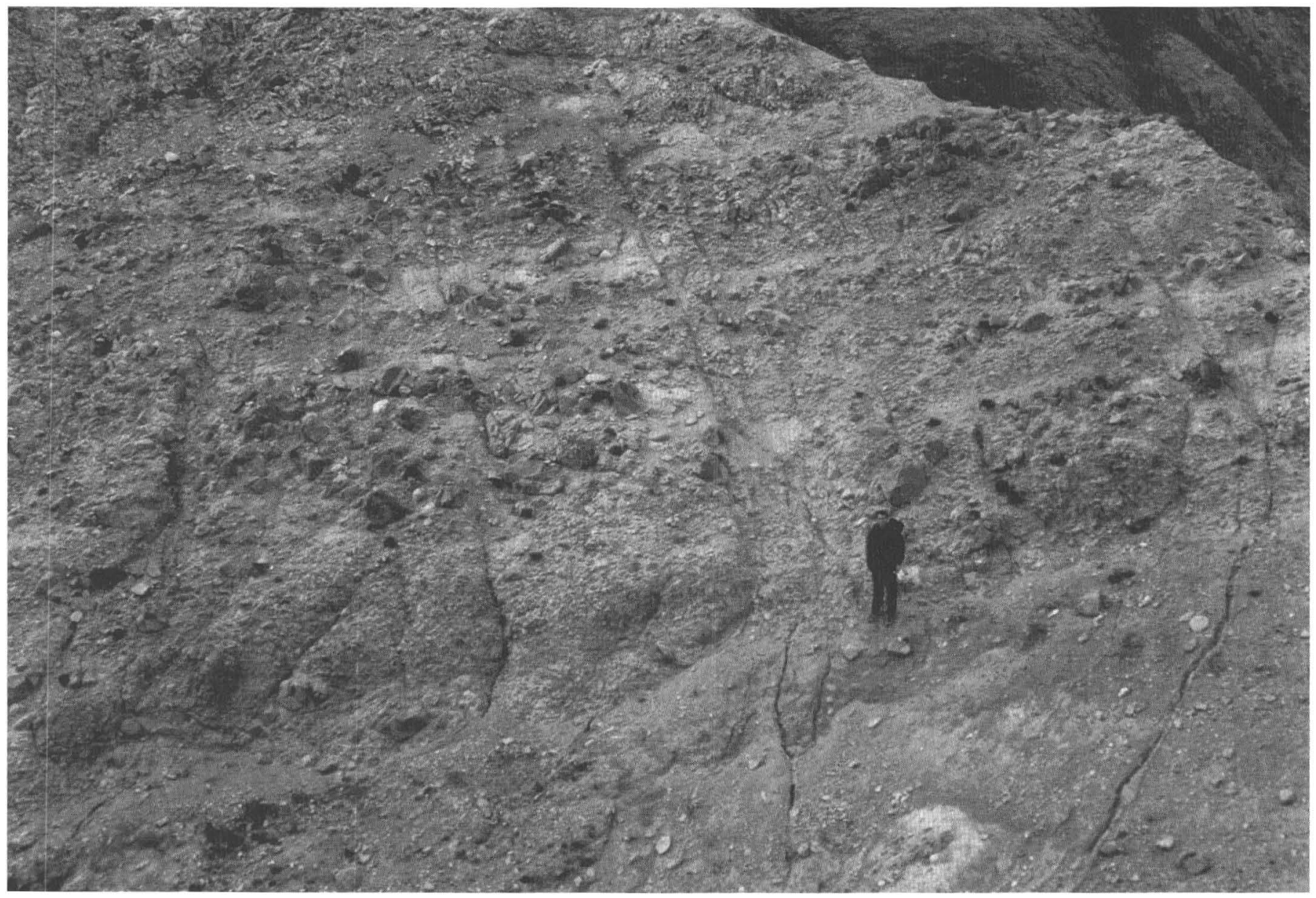

Figure 13. Lithic-tuff-breccia facies (pyroclastic-flow deposits) in the Mount Galen Volcanics at Mount Galen (fig. 2). Outcrop represents approximately 210-220-m interval in stratigraphic column (fig. 12).

rocks of Foraker Glacier and Mount Galen Volcanics have different $\mathrm{K}_{2} \mathrm{O}, \mathrm{Al}_{2} \mathrm{O}_{3}$, and $\mathrm{MgO}$ trends with respect to $\mathrm{SiO}_{2}$ (fig. 14).

All of the samples from each suite of rocks exhibit some degree of light-rare-earth-element (LREE) enrichment (fig. 15). Foraker Glacier rhyolites show greater LREE enrichment than do Foraker Glacier basalts, and one sample (FGW97-19, tables 2,3) of Foraker Glacier basalt shows an exceptionally low LREE enrichment (fig. 15). Foraker Glacier rhyolites display a marked negative Eu anomaly. Samples of Mount Galen basalt and andesite vary widely in rare-earth-element contents and display a marked positive Eu anomaly (fig. 15). Samples of Mount Galen dacite and rhyolite are more uniform in rareearth-element contents than are the basalts. Mount Galen dacites and rhyolites are not as enriched in LREEs as are Foraker Glacier rhyolites.

A comparison of trace-element contents using chondrite-normalized spider diagrams reveals some important differences between the volcanic rocks of Foraker Glacier and the Mount Galen Volcanics (fig. 16). The volcanic rocks of Foraker Glacier show a marked increase in $\mathrm{Rb}, \mathrm{Th}$, and $\mathrm{K}$ contents from the basalt to the rhyolite samples. For example, average $\mathrm{Rb} / \mathrm{Ba}$ ratios for Foraker Glacier basalts and basaltic andesites, andesites, and rhyolites are $0.02,0.1$, and 1.3, respectively. The Mount Galen Volcanics does not show the same systematic strong increases in $\mathrm{Rb}$, Th, and $\mathrm{K}$ contents between the mafic and felsic end members. (Average $\mathrm{Rb} / \mathrm{Ba}$ ratios for Oligocene basalts and basaltic andesites, andesites, and dacites and rhyolites are $0.03,0.09$, and 0.05 , respectively.) Another significant trace-element pattern is the systematic large decrease in $\mathrm{Sr}, \mathrm{P}$, and Ti contents between Foraker Glacier basalts, andesites, and rhyolites. In contrast, the Mount Galen Volcanics is enriched in $\mathrm{Sr}$ (especially the basalts and andesites) and shows smaller decreases in $\mathrm{P}$ and Ti contents from the mafic to felsic end members (fig. 16). Also, the Mount Galen basaltic through felsic samples show a pronounced $\mathrm{Nb}$-Ta-depletion trend that is absent in Foraker Glacier basalts and is only subtly expressed in Foraker Glacier andesites and rhyolites.

The geochemical data reveal different petrogenetic histories for the volcanic rocks of Foraker Glacier and the Mount Galen Volcanics. The volcanic rocks of Foraker Glacier were probably derived from a slightly depleted subcontinental lithospheric mantle source with some characteristics of subduction magmatism. Basalt sample FGW97-19 (tables 2, 3), from the stratigraphically lowest lava, is the most primitive sample from the volcanic rocks of Foraker Glacier and represents the least 
Table 2. Major-element composition of samples from the volcanic rocks of Foraker Glacier and the Mount Galen Volcanics.

[X-ray-fluorescence analyses in weight percent by Chemex Laboratories, Inc. LOI, Ioss on ignition]

\begin{tabular}{|c|c|c|c|c|c|c|c|c|c|c|c|c|}
\hline Sample & $\mathrm{SiO}_{2}$ & $\mathrm{Na}_{2} \mathrm{O}$ & $\mathrm{K}_{2} \mathrm{O}$ & $\mathrm{Al}_{2} \mathrm{O}_{3}$ & $\mathrm{MgO}$ & $\mathrm{Fe}_{2} \mathrm{O}_{3}$ & $\mathrm{CaO}$ & $\mathrm{MnO}$ & $\mathrm{TiO}_{2}$ & $\mathrm{P}_{2} 0_{5}$ & LOI & Total \\
\hline \multicolumn{13}{|c|}{ Volcanic rocks of Foraker Glacier (late Paleocene and early Eocene) } \\
\hline FGW97-19 & 47.93 & 3.30 & 0.32 & 15.54 & 5.98 & 10.21 & 4.86 & 0.11 & 1.90 & 0.16 & 7.59 & 97.90 \\
\hline FGW97-140 & 50.94 & 2.48 & 1.39 & 14.64 & 4.74 & 8.85 & 8.05 & .15 & 1.55 & .39 & 5.56 & 98.74 \\
\hline FGW97-121 & 51.94 & 2.29 & .38 & 15.52 & 4.03 & 9.07 & 7.64 & .13 & 1.59 & .37 & 6.00 & 98.96 \\
\hline FGW97-189.5 & 54.30 & 2.15 & 1.10 & 15.44 & 3.82 & 7.97 & 5.99 & .12 & 1.58 & .38 & 5.19 & 98.04 \\
\hline FGW97-154 & 55.81 & 2.14 & 1.56 & 14.58 & 3.99 & 8.19 & 6.25 & .11 & 1.56 & .33 & 5.04 & 99.56 \\
\hline FGW97-85 & 59.88 & 2.43 & 3.89 & 15.41 & 2.93 & 6.92 & 3.57 & .10 & 1.24 & .28 & 3.79 & 100.44 \\
\hline FGW97-46 & 60.76 & 3.20 & 3.83 & 14.62 & 2.35 & 6.16 & 3.11 & .10 & 1.20 & .26 & 4.53 & 100.12 \\
\hline FGW-1 & 71.76 & 2.18 & 5.79 & 12.22 & .23 & 1.90 & .31 & .02 & .10 & .02 & 5.40 & 99.92 \\
\hline FGW-3 & 72.84 & 3.34 & 5.60 & 12.72 & .10 & .86 & .43 & --- & .12 & .08 & 3.89 & 99.96 \\
\hline FGW-6 & 74.59 & 3.67 & 5.59 & 12.69 & .16 & 1.45 & .55 & .03 & .12 & .04 & 1.05 & 99.94 \\
\hline FGW-7f & 75.47 & 2.79 & 6.81 & 11.96 & .35 & 1.49 & .34 & .03 & .10 & .09 & .60 & 100.02 \\
\hline FGW97-291 & 77.91 & 2.52 & 5.23 & 12.44 & .05 & 1.29 & .63 & $<.01$ & .14 & .01 & .86 & 101.08 \\
\hline FGW97-345 & 78.43 & 1.89 & 6.26 & 12.14 & .04 & 1.02 & .16 & .01 & .13 & .01 & .82 & 100.91 \\
\hline FGW97-267 & 78.94 & 2.27 & 5.30 & 12.21 & .08 & 1.17 & .13 & .01 & .12 & .01 & 1.01 & 101.25 \\
\hline
\end{tabular}

Mount Galen Volcanics (late Eocene and early Oligocene)

\begin{tabular}{|c|c|c|c|c|c|c|c|c|c|c|c|c|}
\hline \multicolumn{13}{|c|}{ Muldrow Glacier area } \\
\hline MG1-220bc & 53.72 & 3.66 & 1.14 & 16.96 & 3.67 & 7.75 & 8.10 & 0.11 & 1.58 & 0.20 & 2.30 & 99.19 \\
\hline MG1-18a & 57.16 & 1.62 & 3.91 & 14.23 & 2.47 & 5.20 & 7.23 & .19 & .67 & .26 & 7.80 & 100.74 \\
\hline MG1-47.3 & 57.34 & 3.17 & 1.37 & 18.96 & .45 & 8.76 & 6.49 & .05 & 1.75 & .05 & .75 & 99.14 \\
\hline MG1-18 & 59.47 & .28 & 3.71 & 13.33 & 2.99 & 4.99 & 6.89 & .19 & .66 & .16 & 6.16 & 98.83 \\
\hline MG1-220GC & 61.45 & 3.22 & 2.08 & 17.26 & 1.93 & 4.41 & 4.86 & .10 & .58 & .18 & 2.80 & 98.87 \\
\hline MG1-40 & 64.81 & 2.07 & 5.41 & 14.17 & .29 & 1.11 & 1.91 & .02 & .11 & .10 & 8.65 & 98.66 \\
\hline MG1-220dc & 70.67 & 3.49 & 2.77 & 15.09 & .91 & 2.56 & 2.09 & .05 & .30 & .08 & 1.25 & 99.26 \\
\hline MG1-28.5 & 72.18 & 3.33 & 2.80 & 13.66 & .52 & 3.05 & 1.69 & .05 & .28 & .04 & 3.81 & 101.41 \\
\hline MG1-86C1 & 75.99 & 2.56 & 2.37 & 12.41 & 1.03 & 2.87 & .18 & .04 & .33 & .05 & 2.59 & 100.42 \\
\hline \multicolumn{13}{|c|}{ Mount Galen type area } \\
\hline GA $1-46$ & 52.73 & 3.09 & 1.33 & 18.82 & 3.06 & 8.90 & 7.52 & 0.24 & 1.25 & 0.20 & 1.88 & 99.02 \\
\hline GA1-31 & 53.99 & 3.39 & 1.30 & 18.45 & 2.22 & 8.13 & 7.41 & .25 & 1.31 & .18 & 1.81 & 98.44 \\
\hline GA $1-33$ & 54.49 & 3.21 & 1.26 & 20.22 & 2.11 & 9.12 & 8.30 & .19 & 1.29 & .35 & .42 & 100.96 \\
\hline GA1-123 & 59.83 & 3.40 & 1.04 & 17.81 & 2.06 & 4.23 & 5.04 & .10 & .67 & .12 & 5.01 & 99.31 \\
\hline GA1-148.3 & 63.58 & 3.51 & 1.56 & 15.97 & 1.77 & 4.06 & 4.32 & .08 & .66 & .19 & 3.88 & 99.58 \\
\hline GA1-100 & 65.28 & 3.76 & 2.19 & 17.23 & .60 & 3.04 & 4.47 & .03 & .72 & .14 & 1.72 & 99.18 \\
\hline $\mathrm{GA} 1-225 \mathrm{C}$ & 65.76 & 2.36 & 1.64 & 17.45 & 1.64 & 6.24 & 4.71 & .11 & .81 & .05 & .42 & 101.17 \\
\hline GA1-96.5 & 68.25 & 3.90 & 2.13 & 16.56 & .70 & 2.71 & 4.35 & .03 & .79 & .15 & 1.69 & 101.26 \\
\hline \multicolumn{13}{|c|}{ Mount Galen data from Decker and Gilbert (1978) } \\
\hline $1 b$ & 46.00 & 3.40 & 1.10 & 17.00 & 5.00 & 5.80 & 8.20 & 0.04 & 3.00 & 0.35 & --- & 89.89 \\
\hline 2 & 47.00 & 3.80 & 1.20 & 17.00 & 4.40 & 5.30 & 8.10 & .21 & 2.90 & .45 & --- & 90.36 \\
\hline 6 & 58.60 & 3.20 & .84 & 17.20 & 2.80 & 4.30 & 5.90 & .04 & .75 & .09 & --- & 93.72 \\
\hline 5 & 59.20 & 3.10 & .96 & 17.20 & 3.60 & 2.50 & 5.70 & .05 & .90 & .10 & --- & 93.31 \\
\hline 4 & 61.50 & 4.20 & 1.60 & 18.10 & 2.40 & 1.60 & 6.00 & .18 & .90 & .15 & --- & 96.63 \\
\hline 3 & 63.20 & 3.80 & 1.90 & 16.60 & 2.10 & 3.60 & 5.40 & .09 & .66 & .10 & --- & 97.45 \\
\hline 7 & 64.80 & 3.60 & 2.20 & 15.70 & 1.70 & 4.00 & 4.10 & .84 & .46 & .08 & --- & 97.48 \\
\hline 8 & 69.00 & 3.60 & 2.30 & 15.50 & 1.30 & 3.00 & 3.80 & .77 & .46 & .10 & --- & 99.83 \\
\hline
\end{tabular}


Table 3. Trace-element composition of samples from the volcanic rocks of Foraker Glacier and the Mount Galen Volcanics.

[Inductively coupled plasma mass-spectrometric analyses in parts per million by Chemex Laboratories, Inc.]

\begin{tabular}{|c|c|c|c|c|c|c|c|c|c|c|c|c|c|c|c|c|c|c|c|c|c|c|c|}
\hline Sample & $\mathrm{Ba}$ & $\mathrm{Ce}$ & Dy & Er & $\mathrm{Eu}$ & Gd & $\mathrm{Hf}$ & Ho & $\mathrm{La}$ & $\mathrm{Lu}$ & $\mathrm{Nb}$ & $\mathrm{Nd}$ & Pr & $\mathrm{Rb}$ & $\mathrm{Sm}$ & $\mathrm{Sr}$ & $\mathrm{Ta}$ & $\mathrm{Tb}$ & $\mathrm{Th}$ & $\mathrm{Tm}$ & $\mathrm{Y}$ & $\mathrm{Yb}$ & $\mathrm{Zr}$ \\
\hline
\end{tabular}

\section{Volcanic rocks of Foraker Glacier (late Paleocene and early Eocene)}

\begin{tabular}{|c|c|c|c|c|c|c|c|c|c|c|c|c|c|c|c|c|c|c|c|c|c|c|c|}
\hline FGW97-19 & 477 & 20.5 & 3.8 & 2.5 & 1.1 & 3.9 & 4 & 0.9 & 9 & 0.4 & 8 & 13.5 & 3 & 5.2 & 3.4 & 307 & 0.9 & 0.7 & 1 & 0.4 & 24 & 2.6 & 159 \\
\hline FGW97-140 & 928 & 64 & 5.5 & 3.1 & 1.8 & 6.4 & 6 & 1.2 & 31 & .4 & 21 & 30.5 & 7.6 & 24.6 & 6.4 & 415 & 2 & 1.1 & 7 & .5 & 30.5 & 2.9 & 244 \\
\hline FGW97-121 & 432.5 & 50.5 & 4.7 & 2.9 & 1.4 & 5.9 & 4 & .8 & 24 & .4 & 16.7 & 26 & 6.3 & 5.8 & 5 & 512 & .9 & .8 & 4 & .4 & 20.1 & 2.6 & 204 \\
\hline FGW97-189.5 & 747 & 66.5 & 5.5 & 3.4 & 2.1 & 6.7 & 7 & 1.2 & 32.5 & .4 & 19 & 33 & 8.2 & 19.6 & 6.8 & 392 & 1 & 1 & 8 & .4 & 35.5 & 3.3 & 277 \\
\hline FGW97-154 & 1,155 & 55.5 & 5.4 & 3 & 1.6 & 5.7 & 7 & 1.1 & 27 & .5 & 18 & 27.5 & 6.8 & 36.2 & 6 & 466 & 1 & .9 & 7 & .4 & 30 & 3.1 & 255 \\
\hline FGW97-85 & 1,160 & 63 & 5.6 & 3.4 & 1.9 & 6.8 & 7 & 1.1 & 30 & .4 & 15 & 31.5 & 7.7 & 103 & 7 & 275 & 1 & .9 & 9 & .5 & 32 & 3 & 248 \\
\hline FGW97-46 & 885 & 65.5 & 5.8 & 3.3 & 1.5 & 6.6 & 7 & 1.2 & 31 & .5 & 16 & 32.5 & 8.1 & 115.5 & 7.2 & 212 & 1.5 & 1 & 11 & .5 & 34.5 & 3.4 & 257 \\
\hline FGW-1 & 210 & 192.5 & 12.8 & 6.8 & .5 & 16.2 & 8 & 2.6 & 86 & 1.1 & 43 & 75 & 21.3 & 259 & 13.9 & 14.9 & 9 & 2.4 & 20 & 9 & 57.5 & 7 & 222 \\
\hline FGW97-291 & 184 & 155 & 8.8 & 5.3 & .4 & 10.6 & 7 & 1.7 & 76.5 & .8 & 22 & 66 & 17.6 & 236 & 12.1 & 15 & 2 & 1.7 & 25 & .7 & 51.5 & 4.9 & 191 \\
\hline FGW97-345 & 214 & 143 & 7.5 & 4.1 & .4 & 9.4 & 7 & 1.5 & 73 & 6 & 20 & 59 & 16.2 & 279 & 9.9 & 14 & 2 & 1.3 & 24 & .7 & 40.5 & 4.2 & 169.5 \\
\hline FGW97-267 & 206 & 108 & 6.7 & 4.2 & 3 & 7.9 & 6 & 1.3 & 53.5 & 6 & 19 & 45.5 & 12.5 & 242 & 8.7 & 14 & 1.5 & 1.2 & 20 & 6 & 39.5 & 3.9 & 151 \\
\hline
\end{tabular}

Mount Galen Volcanics (late Eocene and early Oligocene)

Muldrow Glacier area

\begin{tabular}{|c|c|c|c|c|c|c|c|c|c|c|c|c|c|c|c|c|c|c|c|c|c|c|c|}
\hline MG1-220bc & 443 & 22.5 & 4.4 & 2.6 & 1.4 & 4.3 & 3 & 0.8 & 10 & 0.4 & 7.6 & 14 & 3.1 & 16.3 & 3.4 & 290 & 0.5 & 0.6 & 2.8 & 0.3 & 23.8 & 2.6 & 160 \\
\hline MG1-47.3 & 556 & 9.5 & 2.1 & 1.9 & 1 & 1 & 3 & .4 & 5.5 & .3 & 7 & 4.5 & 1 & 19 & .9 & 387 & .4 & .1 & 2 & .3 & 17.5 & 2.4 & 160 \\
\hline MGl-18 & 403.5 & 25.5 & 2.7 & 1.9 & 1.1 & 3.4 & .9 & .5 & 11.5 & .2 & 4.9 & 15 & 3.2 & 118 & 2.4 & 229 & .3 & .4 & 3 & .1 & 12.3 & 1.6 & 81.5 \\
\hline MGl-220GC & 974 & 39 & 2.8 & 1.7 & 1.3 & 4.1 & 3 & .7 & 19.5 & .3 & 7 & 17 & 4.9 & 42 & 3.9 & 547 & 1.5 & .5 & 5 & .3 & 14 & 2 & 108 \\
\hline MG1-40 & 741 & 67 & 6.1 & 4.2 & .5 & 6.3 & 5 & 1.3 & 33 & .7 & 14 & 29 & 7.8 & 108 & 5.8 & 106.5 & 3.5 & 1 & 9 & .7 & 32 & 4.3 & 167 \\
\hline MG1-220dc & 1,307 & 28 & 1 & .7 & .5 & 1.8 & .9 & .1 & 14.5 & $<.1$ & 4.6 & 10 & 2.9 & 42.6 & 1.8 & 382 & .35 & .1 & 6.6 & $<.1$ & 7.3 & 1 & 83 \\
\hline MGl-28.5 & 1,095 & 40.5 & 2.3 & 1.5 & .6 & 2.9 & 4 & .5 & 21.5 & .3 & 7 & 15.5 & 4.5 & 62.2 & 3.4 & 417 & .5 & .4 & 8 & .2 & 15 & 1.5 & 92.5 \\
\hline MG1-86C1 & 539 & 22.5 & 1.6 & 1.1 & .3 & 1.5 & 3 & .3 & 11 & .2 & 5 & 8.5 & 2.6 & 71.4 & 1.7 & 295 & .5 & .2 & 5 & .1 & 11.5 & 1.3 & 83.5 \\
\hline
\end{tabular}

Mount Galen type area

\begin{tabular}{|c|c|c|c|c|c|c|c|c|c|c|c|c|c|c|c|c|c|c|c|c|c|c|c|}
\hline GA1-46 & 755.2 & 22.5 & 2.3 & 1.6 & 1.2 & 3 & 1 & 0.4 & 11 & 0.1 & 6.8 & 13.5 & 3.1 & 17.2 & 2.5 & 900 & 0.45 & 0.3 & 2.6 & 0.1 & 13.8 & 1.7 & 100 \\
\hline GA1-31 & 680 & 22.5 & 2.9 & 1.7 & 1.5 & 3 & 3 & .5 & 10.5 & .3 & 5 & 13.5 & 3.2 & 20 & 3.5 & 1,000 & .45 & .4 & 2 & .2 & 15 & 1.6 & 91 \\
\hline GAl-33 & 696 & 36.5 & 4.8 & 2.4 & 2.1 & 5.4 & 3 & .8 & 17.5 & .3 & 9 & 23 & 5.4 & 21.4 & 5.3 & 1,085 & 1.5 & .7 & 3 & .4 & 20.5 & 2.4 & 108 \\
\hline GAl-123 & 747.2 & 24.5 & 1.6 & 1 & 1.1 & 1.6 & 1 & .2 & 13 & .1 & 6.1 & 11.5 & 2.8 & 13.4 & 2 & 725 & .35 & .3 & 4.6 & $<.1$ & 8.6 & 1.1 & 92.5 \\
\hline GA1-148.3 & 846 & 35.5 & 2.4 & 1.2 & 1.1 & 2.9 & 3 & .4 & 17.5 & .1 & 6 & 17.5 & 4.2 & 16.8 & 3.5 & 666 & .4 & .4 & 5 & .1 & 12 & 1.1 & 108 \\
\hline GA1-100 & 1,117 & 31 & 1.7 & .9 & 1.3 & 2.8 & 2 & .2 & 16.5 & $<.1$ & 6.4 & 14 & 3.6 & 38.9 & 2.8 & 609 & .4 & .3 & 6.2 & $<.1$ & 8.3 & .6 & 109 \\
\hline GA1-225C & 891 & 39 & 2.6 & 1.5 & 1.3 & 3.7 & 3 & .5 & 21 & .3 & 8 & 19.5 & 4.7 & 22 & 4.1 & 598 & 2 & .5 & 6 & .2 & 12.5 & 1.7 & 106 \\
\hline GAl-96.5 & 1,000 & 35 & 2.1 & 1 & 1 & 2.8 & 3 & .4 & 18.5 & .1 & 6 & 16.5 & 4.2 & 43.6 & 3.2 & 635 & .45 & .4 & 5 & .1 & 10 & 1 & 96.5 \\
\hline
\end{tabular}




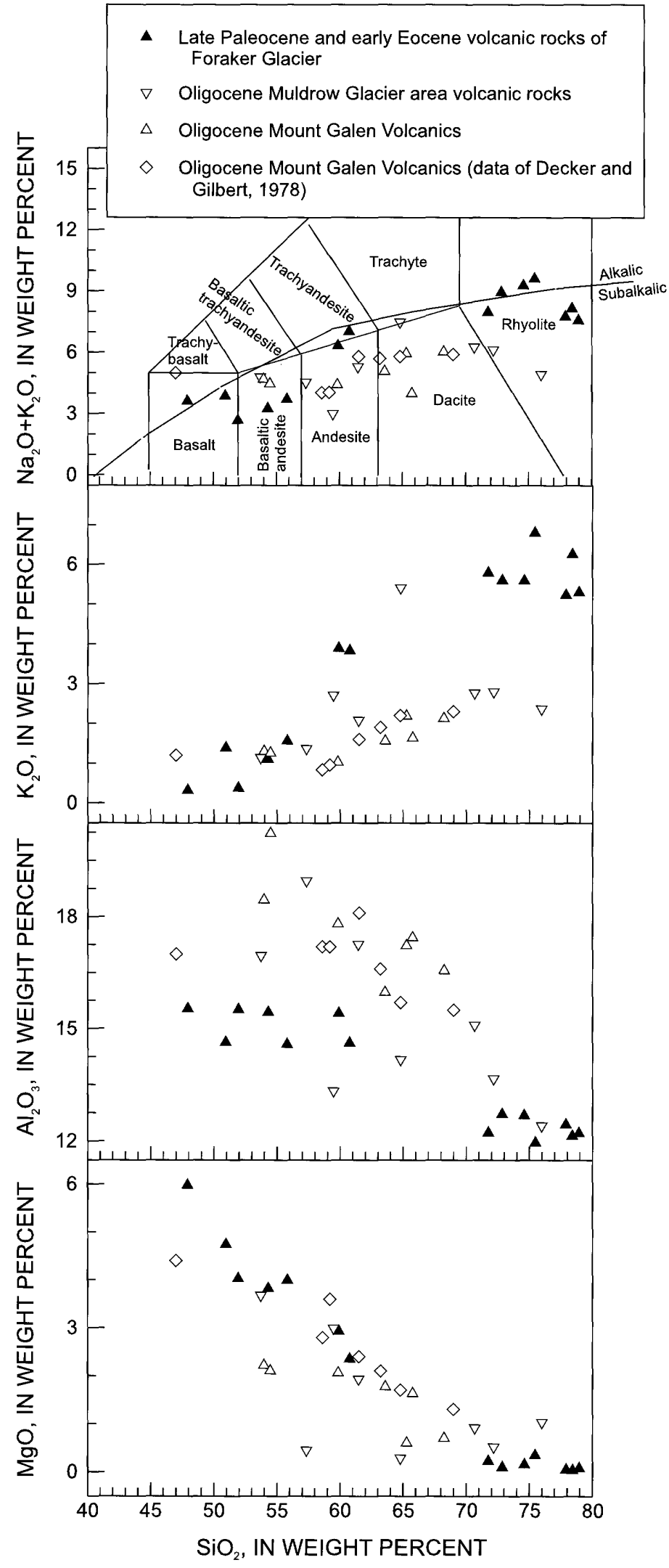

Figure 14. Major-element-variation diagrams for the volcanic rocks of Foraker Glacier and the Mount Galen Volcanics. Rock classifications after LeBas and others (1986).

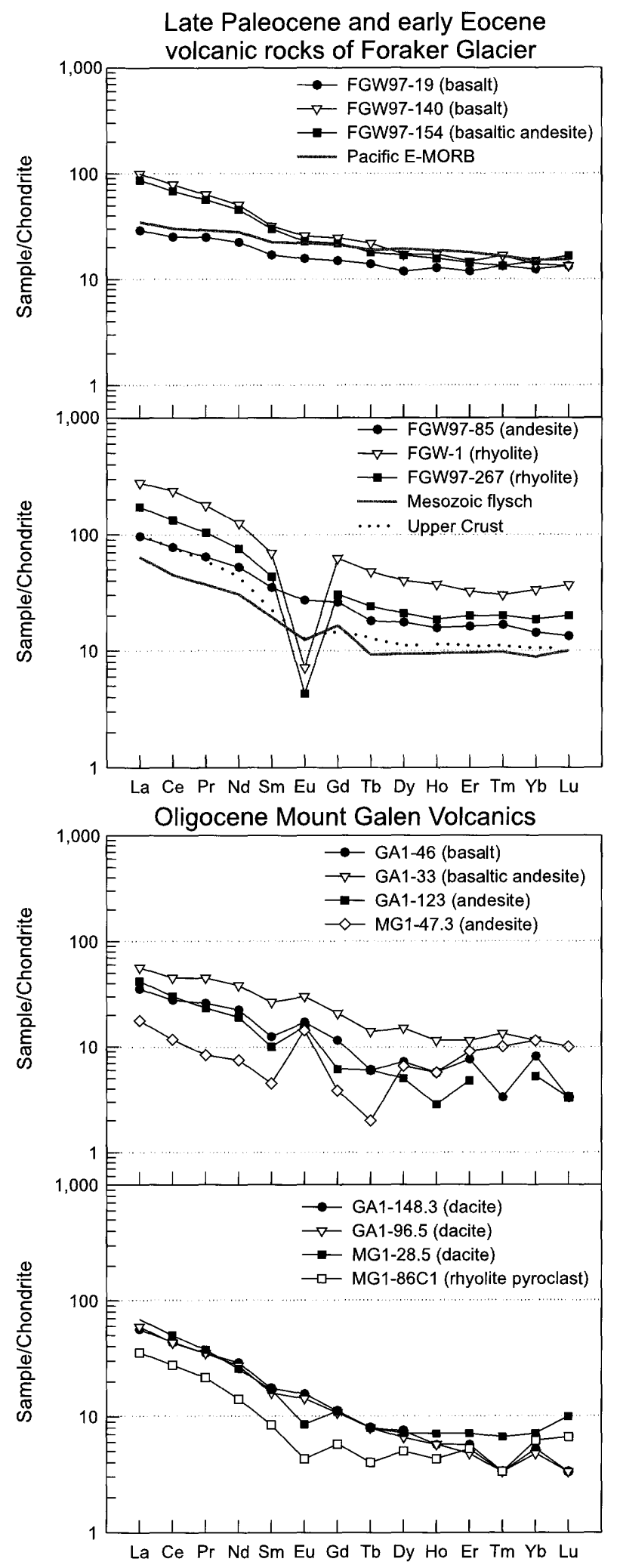

Figure 15. Chondrite-normalized rare-earth-element diagrams for samples of the volcanic rocks of Foraker Glacier and the Mount Galen Volcanics. Average compositions of Pacific enriched midoceanic-ridge basalt (E-MORB), Mesozoic flysch in the Mount McKinley area (fig. 2), and upper-crustal rocks from Klein and Langmuir (2000), Lanphere and Reed (1985), and Taylor and McLennan (1985), respectively; chondrite-normalizing values from Boynton (1984). 


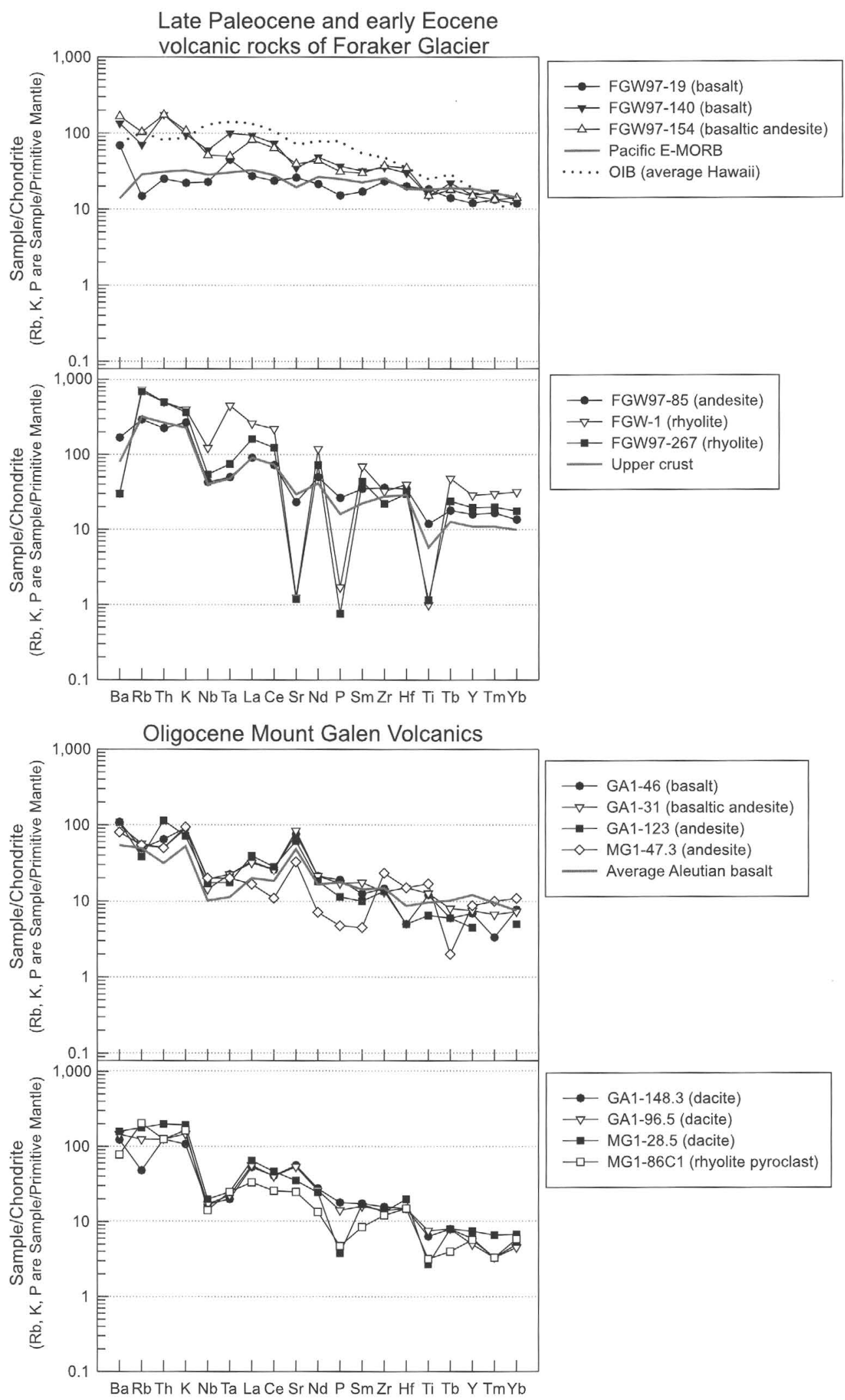

Figure 16. Normalized trace-element diagrams for samples of the volcanic rocks of Foraker Glacier and the Mount Galen Volcanics. Average compositions of Pacific enriched midoceanic-ridge basalt (E-MORB) from Klein and Langmuir (2000), of oceanic-island basalt (OIB) (Hawaii) from Spengler and Garcia (1988) and Sims and others (1999), of upper-crustal rocks from Taylor and McLennan (1985), and of Aleutian basalt from Kay and Kay (1994) and Fournelle and others (1994). Chondrite-normalizing values from Thompson and others (1984), and primitive-mantle-normalizing values from Sun (1980). 
evolved magma for these rocks. This sample exhibits only slight LREE enrichment and low contents of the incompatible elements $\mathrm{Rb}$, Th, and $\mathrm{K}$ (figs. 15, 16). The sample is similar in composition to enriched midoceanic-ridge basalts of the Pacific Ocean (E-MORB, fig. 16), with the notable exception of strongly elevated Ba content (fig. 16). Other Foraker Glacier basalts show more enriched trends than sample FGW97-19, with more LREE enrichment and higher Rb, $\mathrm{Th}$, and $\mathrm{K}$ contents. These more enriched basalts are superficially similar to oceanic-island basalts (OIB, fig. 16), but the basalts of Foraker Glacier have higher $\mathrm{La} / \mathrm{Nb}$ ratios than do oceanic-island basalts (OIB, fig. 17), suggesting that they did not form directly from asthenospheric mantle (Thompson and others, 1984; Fitton and others, 1988). Instead, the ranges of $\mathrm{Zr} / \mathrm{Nb}$ and $\mathrm{La} / \mathrm{Nb}$ ratios in Foraker Glacier basalts are similar to those in Miocene basalts derived from subduction-modified (hydrated) lithospheric-mantle sources beneath the Western United States (fig. 17; Fitton and others, 1988). The elevated $\mathrm{Ba}$ and Th contents of Foraker Glacier basalts also indicate the subduction-related processes whereby these elements become enriched in the lithospheric mantle wedge, possibly from subducted sedimentary rocks and the release of hydrous fluids from the downgoing slab (Kay, 1984; Thorpe and others, 1984). Foraker Glacier basalts and andesites also have high $\mathrm{Ba} / \mathrm{Ta}$ ratios (464-1,160); according to Gill (1981) a Ba/Ta ratio of $>450$ is a key characteristic of subduction-related volcanic rocks. Foraker Glacier basalts and andesites do not, however, show elevated $\mathrm{Sr}$ contents, which are typical of subduction-related arc rocks (Wilson and Davidson, 1984).

Foraker Glacier rhyolites were most likely formed by partial melting and assimilation of crustal rocks and evolved partly by fractional crystallization. A systematic increase in $\mathrm{La} / \mathrm{Nb}$ ratio from Foraker Glacier basalts to rhyolites is one indication of crustal contamination (fig. 18; Thompson and

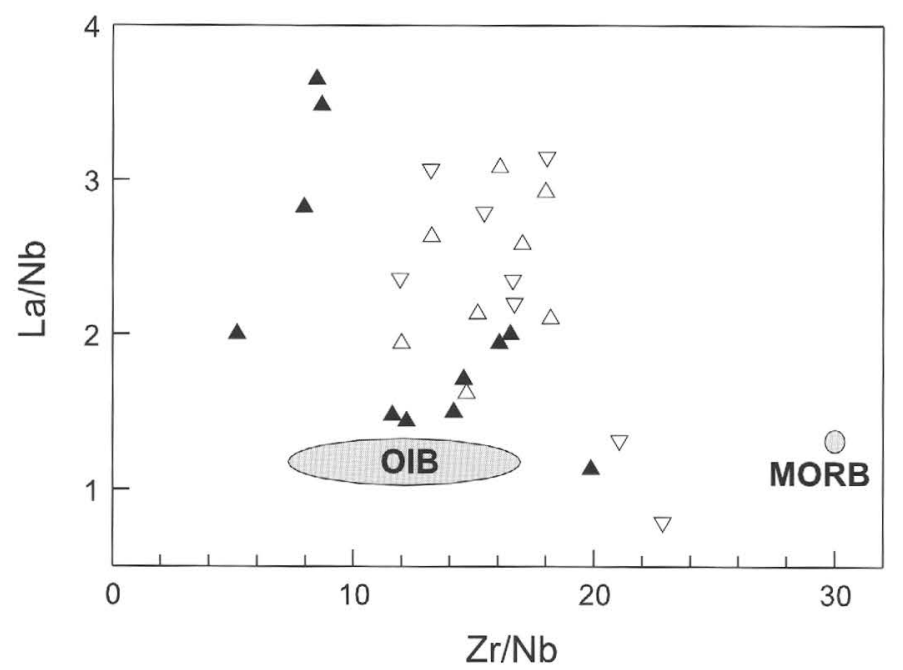

Figure 17. $\mathrm{La} / \mathrm{Nb}$ versus $\mathrm{Zr} / \mathrm{Nb}$ ratios in the volcanic rocks of Foraker Glacier and the Mount Galen Volcanics. Ranges for oceanic-island basalts (OIB) and midoceanic-ridge basalts (MORB) from Rollinson (1993, table 6.7). Same symbols as in figure 14. others, 1984). The rhyolites are strongly enriched in $\mathrm{Rb}, \mathrm{Th}$, and $\mathrm{K}$, as well as in LREEs, and are similar in composition to average upper continental crust (fig. 16). In contrast to Foraker Glacier basalts and andesites, the rhyolites have very low $\mathrm{Ba} / \mathrm{Ta}$ ratios (23-137), indicating that the rhyolites did not evolve directly from subduction magmas (for example, Gill, 1981). Instead, we interpret that the rhyolites were formed by partial melting of crustal rocks by the basaltic magmas and evolved by a combination of assimilation and fractional crystallization. Strong depletion of $\mathrm{Sr}, \mathrm{P}$, and Ti in the rhyolites indicates that fractional crystallization of plagioclase, apatite, and Fe-Ti oxides was important in their formation (fig. 16). The strong negative Eu anomaly in the rhyolites also supports fractional crystallization of plagioclase (fig. 15).

Mount Galen basalts and andesites have elevated $\mathrm{Ba}$, Th, and $\mathrm{Sr}$ contents and a marked paired depletion of $\mathrm{Nb}$ and $\mathrm{Ta}$ (fig. 16), all common characteristics of subduction-related volcanic rocks (Kay, 1984; Wilson and Davidson, 1984; Thorpe and others, 1984). Overall, these rocks have a trace-element pattern that is nearly identical to that of average Aleutian Arc basalt (fig. 16). Mount Galen dacites and rhyolites are similar in geochemical affinity to the basalts and andesites and display enrichments in $\mathrm{Rb}$, Th, and $\mathrm{Sr}$, as well as a distinctive $\mathrm{Nb}$-Ta trough (fig. 16). The dacites and rhyolites also show slight $\mathrm{P}$ and Ti depletion, indicating that they evolved partly by fractional crystallization. Except for one sample, the samples of the Mount Galen Volcanics have high $\mathrm{Ba} / \mathrm{Ta}$ ratios of 446 to 3,734: Dacite tuff sample MG1-40 has a $\mathrm{Ba} / \mathrm{Ta}$ ratio of 212 . We interpret that the Mount Galen Volcanics was formed as typical subduction-related magmas where basalts were derived by partial melting of an enriched mantle wedge and that the more felsic magmas evolved mostly by fractional crystallization of the mafic magmas. The low $\mathrm{Ba} / \mathrm{Ta}$ ratio of one dacite sample indicates that at least some of the felsic rocks were formed by partial melting and (or) assimilation of crustal rocks.

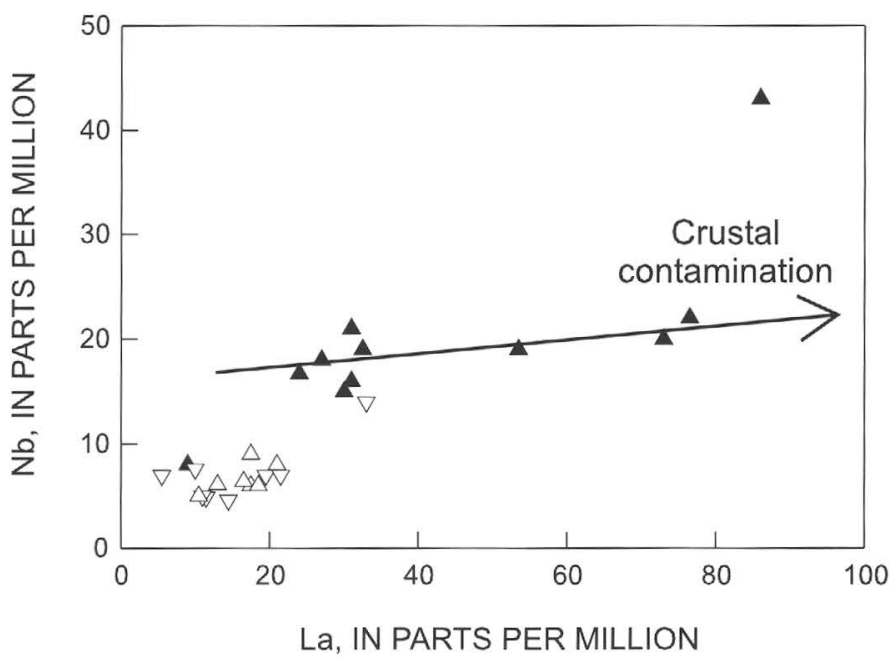

Figure 18. Nb versus La contents in the volcanic rocks of Foraker Glacier and the Mount Galen Volcanics. Same symbols as in figure 14. 


\section{Discussion}

The volcanic and sedimentary rocks described above record an important sequence of tectonic events that shaped the ancestral Alaska Range. The sedimentary rocks that underlie the late Paleocene and early Eocene volcanic rocks of Foraker Glacier record an episode of tectonic uplift and basin subsidence. This uplift most likely coincided with an undetermined amount of shortening of the underlying layers of Paleozoic metamorphic rocks (fig. 4). The present-day orientation of metamorphic foliation implies that this shortening was in response to north-south compression, but more regional data are needed to evaluate shortening direction(s) and potential crustal rotations. Nevertheless, a significant point is that the metamorphic rocks of this region were uplifted and eroded to form the overlying synorogenic conglomerate. Although the timing of this uplift event is not yet precisely constrained, it preceded late Paleocene and early Eocene volcanism in the region. The Foraker Glacier synorogenic sedimentary deposits probably correlate with the lower part of the Cantwell Formation to the east in the Healy quadrangle, which also underlies late Paleocene and early Eocene volcanic rocks. The lower part of the Cantwell Formation in the Healy quadrangle was deposited along the leading edge of northward-vergent thrust sheets that formed in response to accretion of the Wrangellia composite terrane (Ridgway and others, 1997). By analogy, we propose that the Foraker Glacier synorogenic deposits also record uplift in response to accretion of the Wrangellia composite terrane and represent a westward extension of the Cantwell Basin (fig. 19A). If the Foraker Glacier synorogenic deposits are part of the lower part of the Cantwell Formation, then the lowermost conglomerate is the coarsest lower Cantwell deposit yet documented (maximum clast sizes, $>2$ $\mathrm{m}$ in diameter). The very coarse grain size indicates that the Foraker Glacier conglomerates represent deposition near an area of uplift of the ancestral Alaska Range. Paleoflow data for Foraker Glacier conglomerates reveal westward drainage, opposite to the eastward-flowing drainages documented by Ridgway and others (1997) for the lower part of the Cantwell Formation in the Healy quadrangle. These paleoflow data might indicate that the Cantwell Basin was "segmented" into different drainage systems which could have formed adjacent to separate regions of uplift (fig. 19A). The Foraker Glacier synorogenic sedimentary rocks were then uplifted, as indicated by the angular unconformity between them and the overlying volcanic rocks (fig. 4). This unconformity, which is analogous to the contact between the lower and upper parts of the Cantwell Formation in the Healy quadrangle, most likely represents the final stage of compression due to suturing of the Wrangellia composite terrane (Cole and others, 1999).

Magmatism associated with the Alaska Range belt of Wallace and Engebretson (1984) or the Alaska RangeTalkeetna Mountains belt of Moll-Stalcup (1994) was occurring predominantly south of the Foraker Glacier area during the episode of synorogenic sedimentation. The latest phase of this magmatism is represented in the study area by the 55- to 60-Ma McKinley sequence plutons and the volcanic rocks of Foraker Glacier. These younger igneous rocks are geochemically distinct from older (60-72 Ma) rocks of the magmatic belt (generally higher $\mathrm{K}_{2} \mathrm{O}$, lower $\mathrm{Al}_{2} \mathrm{O}_{3}$, lower $\mathrm{Sr}$, and higher Nb contents; Lanphere and Reed, 1985; MollStalcup, 1994). Also, as shown in this chapter, the volcanic rocks of Foraker Glacier differ from rocks with "typical" subduction-related geochemical affinities. The volcanic rocks of Foraker Glacier and, by association, the other 55- to 60-Ma rocks in the belt most likely represent changes in the style of subduction magmatism caused by accretion of the Wrangellia composite terrane and the ensuing southward shift in the subduction zone (Wallace and Engebretson, 1984; Scholl and others, 1986). Coeval mafic magmas could have formed by partial melting of a remnant subduction-related mantle wedge, but Foraker Glacier basalts (especially sample FGW97-19, tables 2,3) are more depleted in incompatible elements than would be expected for arc basalts. Reiners and others (1996) documented gabbro xenoliths in Alaska Range plutons with typical depleted-mantle isotopic compositions; they proposed that the Alaska Range plutons ultimately had a depleted mantle source of primary magmas which then evolved by several processes of partial assimilation and fractional crystallization. Our results, in combination with the those of Reiners and others (1996), imply that if a subduction-related mantle wedge was a source of primary magmas for these rocks, then it was more depleted than would be predicted for continental-margin arcs (for example, Pearce and Parkinson, 1993). One possible source of depleted primary magmas could have been related to early Tertiary spreading-ridge subduction beneath southern Alaska (for example, Sisson and Pavlis, 1993; Bradley and others, 1993). In this scenario, a depleted mantle-slab window could have formed beneath south-central Alaska as the spreading ridge was consumed-a hypothesis that has been proposed to explain the origin of plutons along the south coast of Alaska (Bradley and others, 1993) but has not yet been tested for early Tertiary volcanism in interior Alaska. We neither support nor refute the ridge-subduction hypothesis at this time but merely present it to provide a more regional perspective of magmatic and tectonic events.

The felsic magmas that were erupted to form the Foraker Glacier rhyolites were derived by melting of crustal rocks and evolved partly by fractional crystallization. Two sets of crustal rocks in the region that could have been involved in the formation of the felsic magmas are Paleozoic metamorphic rocks and the Mesozoic Kahiltna assemblage flysch (fig. 2). On the basis of geochemical evidence, Lanphere and Reed (1985) and Reiners and others (1996) suggested that early Tertiary granitic rocks of the Alaska Range were formed by melting of the Kahiltna flysch. In particular, Reiners and others (1996) proposed that melting of the Kahiltna flysch was probably induced by an early stage of mica dehydration of the flysch caused by intrusion of mantle-derived mafic magmas. Foraker Glacier rhyolites are more enriched in rare-earth elements than is the Kahiltna flysch and are more similar in composition to average upper-crustal rocks (figs. 15, 16). Whereas partial melting and (or) assimilation of the Kahiltna flysch may have been involved in the formation of Foraker rhyolites, our data suggest 
that other, more enriched crustal sources were involved as well. In a study of Tertiary granitic rocks to the northeast of our study area (in the Yukon-Tanana terrane), Aleinikoff and others (2000) ruled out flysch as a likely source and proposed that the felsic magmas were derived from partial melting of Paleozoic rocks. Foraker Glacier rhyolites may reflect a mixed crustal component in which some combination of Paleozoic rocks and Mesozoic flysch was involved in forming felsic magmas; additional geochemical work on these rocks, especially isotopic analyses, is needed to test this hypothesis.
The geochemical and age data reveal that the volcanic rocks of Foraker Glacier were comagmatic with Cantwell volcanic rocks of the Healy quadrangle (Cole, 1998; Cole and others, 2000). Paleoflow data from volcanic conglomerate interbedded in the lower part of the volcanic rocks of Foraker Glacier show eastward transport away from a probable eruptive center. Eastward paleoflow directions were also recorded in volcanic conglomerates of the Healy quadrangle (fig. 19B; Slaugenhoup and others, 1997; Cole and others, 1999). We interpret that these late Paleocene and early Eocene volcanic


Figure 19. Paleogeographic cartoons showing inferred Late Cretaceous drainage systems $(A)$ and late Paleocene and early Eocene volcanic centers $(B)$ in the Cantwell Basin. Stippling, sedimentary rocks in lower part of the Cantwell Formation; gray shading, volcanic rocks in upper part of the Cantwell Formation. Gray arrows denote measured paleoflow directions; white arrows denote inferred drainage directions. Paleoflow data for the Healy quadrangle from the following sources: lower part of the Cantwell Formation, Trop (1996) and Ridgway and others (1997); upper part of the Cantwell Formation, Slaugenhoup and others (1997) and R.B. Cole (unpub. data). Paleoflow data shown for the Mount McKinley quadrangle are reported in text. Same map symbols as in figure 2. 
rocks (both in the Foraker Glacier area and in the Healy quadrangle) were most likely erupted from multiple ventsites close to the southern margin of the Cantwell Basin. During early stages of volcanism, fluvial deposystems drained from the ventsites into the Cantwell Basin and then flowed eastward along the central part of the basin (fig. 19B). During later stages of volcanism, primary volcanic rocks prograded into and filled the Cantwell Basin.

The Mount Galen Volcanics displays a geochemical pattern that is typical of arc rocks related to subduction processes. These rocks were most probably erupted along the north end of the Alaska-Aleutian subduction-related magmatic belt of Wallace and Engebretson (1984), which crosscut late Paleocene and early Eocene rocks in the study area. The Oligocene plutons in the region (Foraker, McGonnagal, and Eielson plutons) are also considered to be part of this magmatic belt (Reed and Lanphere, 1974; Decker and Gilbert, 1978; Moll-Stalcup, 1994).

\section{Conclusions}

1. Two episodes of Tertiary magmatism are recorded in the southern part of the Mount McKinley 1:250,000-scale quadrangle. (i) A late Paleocene and early Eocene episode occurred after tectonic uplift and accretion of the Wrangellia composite terrane to southern Alaska. The volcanic rocks exhibit some of the characteristics of typical subduction-related arc rocks, but the primary magmas were more depleted than were magmas formed from enriched mantle sources. Their petrogenesis was most likely influenced by processes associated with accretion of the Wrangellia composite terrane where the magmas may have been partly derived from a modified (relatively depleted) remnant subduction-related mantle wedge or may have been related to a depleted mantle-slab window that formed during early Tertiary ridge subduction beneath southern Alaska. (ii) A late Eocene and early Oligocene episode of magmatism produced volcanic rocks that exhibit geochemical characteristics which are typical of subduction-related arc rocks and are most likely a northward extension of the Aleutian-Alaska magmatic belt of Wallace and Engebretson (1984).

2. Before the late Paleocene and early Eocene magmatic event was a period of tectonic uplift during which Paleozoic metamorphic rocks were folded. Part of this shortening most likely occurred in response to north-south compression caused by accretion of the Wrangellia composite terrane. As a result of this uplift, cobble-boulder synorogenic conglomerate was deposited unconformably over the Paleozoic metamorphic rocks. The conglomerate fines upward into mostly sandstone and shale that record a period of basin subsidence before the onset of late Paleocene and early Eocene volcanism. These sedimentary strata are most likely equivalent to the lower part of the Cantwell Formation in the Healy quadrangle and represent a westward extension of the Cantwell Basin.

\section{Acknowledgments}

The field research for this project was initiated with helicopter and base-camp support by the U.S. Geological Survey; subsequent fieldwork was supported by grants to Ronald Cole from the donors of the Petroleum Research Fund, administered by the American Chemical Society, and from the National Science Foundation. We thank Phil Brease of Denali National Park and Preserve for field and permit support to conduct the fieldwork. Garret Slaugenhoup, Chris Turner, and Michael Walker provided field assistance. Alison Till, Dwight Bradley, and Steve Nelson provided discussions about the rocks in the Mount McKinley quadrangle. Dwight Bradley, Steve Nelson, and Ric Wilson reviewed the manuscript.

\section{References Cited}

Aleinikoff, J.N., Farmer, G.L., Rye, R.0., and Nokleberg, W.J., 2000, Isotopic evidence for the sources of Cretaceous and Tertiary granitic rocks, east-central Alaska-implications for the tectonic evolution of the Yukon-Tanana Terrane: Canadian Journal of Earth Sciences, v. 37, no. 6, p. 945-956.

Allen, P.A., 1981, Sediments and processes on a small stream-flow dominated, Devonian alluvial fan, Shetland Islands: Sedimentary Geology, v. 29, no. 1, p. 31-66.

Boynton, W.V., 1984, Geochemistry of the rare earth elements-meteorite studies, in Henderson, Paul, ed., Rare earth element geochemistry: Amsterdam, Elsevier, p. 63-114.

Bradley, D.C., Haeussler, P.J., and Kusky, T.M., 1993, Timing of Early Tertiary ridge subduction in southern Alaska, in Dusel-Bacon, Cynthia, and Till, A.B., eds., Geologic studies in Alaska by the U.S. Geological Survey, 1992: U.S. Geological Survey Bulletin 2068, p. 163-177.

Cas, R.A.F., and Wright, J.V., 1987, Volcanic successions-modern and ancient: London, Allen and Unwin, 528 p.

Cole, R.B., 1998, Early Tertiary post-subduction volcanism and deformation along the north side of the McKinley fault, Alaska: Geological Society of America Abstracts with Programs, v. 30, no. 7, p. 177.

Cole, R.B., and DeCelles, P.G., 1991, Subaerial to submarine transitions in early Miocene pyroclastic flow deposits, southern San Joaquin basin, California: Geological Society of America Bulletin, v. 103 , no. 2, p. 221-235.

Cole, R.B., Hooks, Benjamin, Turner, Christopher, and Slaugenhoup, Garret, 2000, Unroofing of metamorphic terranes and subsequent volcanism-Late Cretaceous(?)-early Tertiary basin evolution along the McKinley fault, McKinley $1^{\circ} \times 3^{\circ}$ quadrangle, Alaska [abs.]: Geological Society of America Abstracts with Programs, v. 32, p. A11.

Cole, R.B., Ridgway, K.D., Layer, P.W., and Drake, Jeffrey, 1999, Kinematics of basin development during the transition from terrane accretion to strike-slip tectonics, Late Cretaceous-early Tertiary Cantwell Formation, south central Alaska: Tectonics, v. 18, no. 6, p. 1224-1244.

Costa, J.E., 1988, Rheologic, geomorphic, and sedimentologic differentiation of water floods, hyperconcentrated flows, and debris flows, in Baker, V.R., Kochel, R.C., and Patton, P.C., eds., Flood geomorphology: New York, Wiley, p. 113-122. 
Csejtey, Bela, Jr., Mullen, M.W., Cox, D.P., and Stricker, G.D., 1992, Geology and geochronology of the Healy quadrangle, southcentral Alaska: U.S. Geological Survey Miscellaneous Investigation Series Map 1-1961, scale 1:250,000.

Dalrymple, G.B., 1979, Critical tables for conversion of K-Ar ages from old to new constraints: Geology, v. 7, no. 11, p. 558-560.

DeCelles, P.G., Gray, M.B., Ridgway, K.D., Cole, R.B., Srivastava, Praveen, Pequera, Nuria, and Pivnik, D.A., 1991, Kinematic history of a foreland uplift from Paleocene synorogenic conglomerate, Beartooth Range Wyoming and Montana: Geological Society of America Bulletin, v. 103, no. 11, p. 1458-1475.

Decker, J.E., and Gilbert, W.G., 1978, The Mount Galen volcanics-a new middle Tertiary volcanic formation in the central Alaska Range: Alaska Division of Geological and Geophysical Surveys Geologic Report 59, 11 p.

Fisher, R.V., 1979, Models for pyroclastic surges and pyroclastic flows: Journal of Volcanology and Geothermal Research, v. 6, no. 3-4, p. 305-318.

Fisher, R.V., and Schmincke, H.-U., 1984, Pyroclastic rocks: Berlin, Springer-Verlag, $472 \mathrm{p}$.

Fitton, J.G., James, D., Kempton, P.D., Ormerod, D.S., and Leeman, W.P., 1988, The role of lithospheric mantle in the generation of late Cenozoic basic magmas in the western United States, in Menzies, M.A., and Cox, K.G., eds., Oceanic and continental lithosphere-similarities and differences: Oxford, U.K., Clarendon Press, p. 331-349.

Fournelle, J.H., Marsh, B.D., and Myers, J.D., 1994, Age, character, and significance of Aleutian arc volcanism, in Plafker, George, and Berg, H.C., eds., The geology of Alaska, v. G-1 of The geology of North America: Boulder, Colo., Geological Society of America, p. 723-757.

Gill, J.B., 1981, Orogenic andesites and plate tectonics: New York, Springer-Verlag, $390 \mathrm{p}$.

Kay, R.W., 1984, Elemental abundances relevant to identification of magma sources: Royal Society of London Philosophical Transactions, ser. A, v. 310, no. 1514, p. 535-547.

Kay, S.M., and Kay, R.W., 1994, Aleutian magmas in space and time, in Plafker, George, and Berg, H.C., eds., The geology of Alaska, v. G-1 of The geology of North America: Boulder, Colo., Geological Society of America, p. 687-722.

Klein, E.M., and Langmuir, C.H., 2000, GERM [Geochemical Earth Reference Model] MORB data by ocean basin, depth, and MORB type: URL http://EarthRef.org/GERM/data/klein/MORB_ ocean.htm.

Lanphere, M.A., and Reed, B.L., 1985, The McKinley sequence of granitic rocks; $A$ key element in the accretionary history of southern Alaska: Journal of Geophysical Research, v. 90, no. B13, p. 11413-11430.

LeBas, M.J., Maitre, R.W., Streckeisen, A.L., and Zanettin, B.A., 1986, Chemical classification of volcanic rocks based on the total alkali-silica diagram: Journal of Petrology, v. 27, no. 3, p. $745-750$.

Lowe, D.R., 1982, Sediment gravity flows; II, Depositional models with special reference to the deposits of high-density turbidity currents: Journal of Sedimentary Petrology, v. 52, no. 1, p. 279-297.

McClelland, W.C., Gehrels, G.E., and Saleeby, J.B., 1992, Upper Jurassic-Lower Cretaceous basinal strata along the Cordilleran margin-implications for the accretionary history of the Alexander-Wrangellia-Peninsular terrane: Tectonics, v. 11, no. 4, p. 823-835.
Miall, A.D., 1977, A review of the braided-river depositional environment: Earth-Science Reviews, v. 13, no. 1, p. 1-62.

Moll-Stalcup, E.J., 1994, Latest Cretaceous and Cenozoic magmatism in mainland Alaska, in Plafker, George, and Berg, H.C., eds., The geology of Alaska, v. G-1 of The geology of North America: Boulder, Colo., Geological Society of America, p. 589-619.

Moll-Stalcup, E.J., Brew, D.A., and Vallier, T.L., 1994, Latest Cretaceous and Cenozoic magmatic rocks of Alaska, pl. 5 of Plafker, George, and Berg, H.C., eds., The geology of Alaska, v. G-1 of The geology of North America: Boulder, Colo., Geological Society of America, scale 1:2,500,000.

Nemec, Wojciech, and Steel, R.J., 1984, Alluvial and coastal conglomerates-their significant features and some comments on gravely mass-flow deposits, in Koster, E.H., and Steel, R.J., eds., Sedimentology of gravels and conglomerates: Canadian Society of Petroleum Geologists Memoir 10, p. 1-31.

Nokleberg, W.J., Plafker, George, and Wilson, F.H., 1994, Geology of south-central Alaska, in Plafker, George, and Berg. H.C., eds., The geology of Alaska, v. G-1 of The geology of North America: Boulder, Colo., Geological Society of America, p. 311-366.

Pearce, J.A., and Parkinson, I.J., 1993, Trace element models for mantle melting - application to volcanic arc petrogenesis, in Prichard, H.M., Alabaster, Tony, Harris, N.B.W., and Neary, C.R., eds., Magmatic processes and plate tectonics: Geological Society of London Special Publication 76, p. 373-403.

Pierson, T.C., and Scott, K.M., 1985, Downstream dilution of a lahartransition from debris flow to hyperconcentrated streamflow: Water Resources Research, v. 21, no. 10, p. 1511-1524.

Plafker, George, Moore, J.C., and Winkler, G.R., 1994, Geology of the southern Alaska margin, in Plafker, George, and Berg, H.C., eds., The geology of Alaska, v. G-1 of The geology of North America: Boulder, Colo., Geological Society of America, p. 389-449

Reed, B.L., and Lanphere, M.A., 1974, Offset plutons and history of movement along the McKinley segment of the Denali fault system, Alaska: Geological Society of America Bulletin, v. 85, no. 12, p. 1883-1892.

Reed, B.L., and Nelson, S.W., 1980, Geologic map of the Talkeetna quadrangle, Alaska: U.S. Geological Survey Miscellaneous Investigation Series Map I-1174, scale 1:250,000.

Reed, J.C., 1933, The Mount Eielson district, Alaska: U.S. Geological Survey Bulletin 849-D, p. 231-287.

Reed, J.C., Jr., 1961, Geology of the Mount McKinley quadrangle, Alaska: U.S. Geological Survey Bulletin 1108-A, 36 p., scale 1: 250,000 .

Reiners, P.W., Nelson, B.K., and Nelson, S.W., 1996, Evidence for multiple mechanisms of crustal contamination of magma from compositionally zoned plutons and associated ultramafic intrusions of the Alaska Range: Journal of Petrology, v. 37, no. 2, p. 261-292.

Ridgway, K.D., Trop, J.M., and Sweet, A.R., 1997, Thrust-top basin formation along a suture zone, Cantwell Basin, Alaska Rangeimplications for development of the Denali fault system: Geological Society of America Bulletin, v. 109, no. 5, p. 505-523.

Rollinson, H.R., 1993, Using geochemical data-evaluation, presentation, interpretation: Essex, U.K., Longman Scientific \& Technical, 352 p.

Rust, B.R., 1972, Structure and process in a braided river: Sedimentology, v. 18, no. 3-4, p. 221-245.

Scholl, D.W., Vallier, T.L., and Stevenson, A.J., 1986, Geologic evolution and petroleum geology of the Aleutian Ridge, in Scholl, D.W., Grantz, Arthur, and Vedder, J.G., eds., Geology and resource potential of the continental margin of western North America 
and adjacent ocean basins; Beaufort Sea to Baja California (Earth Science Series, v. 6): Houston, Tex., Circum-Pacific Council for Energy and Mineral Resources, p. 123-155.

Sims, K.W.W., DePaolo, D.J., Murrell, M.T., Baldridge, W.S., Goldstein, S.L., Clague, D.A., and Jull, M., 1999, Porosity of the melting zone and variations in the solid mantle upwelling rate beneath Hawaii; inferences from ${ }^{238} \mathrm{U}-{ }^{230} \mathrm{Th}-{ }^{226} \mathrm{Ra}$ and ${ }^{235} \mathrm{U}-{ }^{231} \mathrm{~Pb}$ disequilibria: Geochimica et Cosmochimica Acta, v. 63, no. 23-24, p. 4119-4138.

Sisson, V.B., and Pavlis, T.L., 1993, Geologic consequences of plate reorganization-an example from the Eocene Southern Alaska fore arc: Geology, v. 21, no. 10, p. 913-916.

Slaugenhoup, G.L., Cole, R.B., and Ridgway, K.D., 1997, Change from terrane accretion to volcanism along the McKinley fault as recorded by conglomerate of the Cretaceous-Eocene Cantwell Basin, south-central Alaska [abs.]: Geological Society of America Abstracts with Programs, v. 29, no. 1, p. 80.

Smith, G.A., 1986, Coarse-grained nonmarine volcaniclastic sediment-terminology and depositional process: Geological Society of America Bulletin, v. 97, no. 1, p. 1-10.

Sparks, R.S.J., 1976, Grain size variations in ignimbrites and implications for the transport of pyroclastic flows: Sedimentology, v. 23, no. 2, p. 147-188.

Sparks, R.S.J., Self, Stephen, and Walker, G.P.L., 1973, Products of ignimbrite eruptions: Geology, v. 1, no. 3, p. 115-118.

Spengler, S.R., and Garcia, M.0., 1988, Geochemistry of the Hawi lavas, Kohala Volcano, Hawaii: Contributions to Mineralogy and Petrology v. 99, no. 1, p. 90-104

Steiger, R.H., and Jäger, Emilie, compilers, 1977, Subcommission on geochronology-convention on the use of decay constants in geo- and cosmochronology: Earth and Planetary Science Letters, v. 36, no. 3, p. 359-362.

Stone, D.B., Panuska, B.C., and Packer, D.R., 1982, Paleolatitudes versus time for southern Alaska: Journal of Geophysical Research, v. 87, no. B5, p. 3697-3707.

Sun, S.-S., 1980, Lead isotopic study of young volcanic rocks from mid-ocean ridges, ocean islands and island arcs: Royal Society of London Philosophical Transactions, ser. A., v. 297, no. 1431, p. $409-445$.

Taylor, S.R., and McLennan, S.M., 1985, The continental crust; its composition and evolution: Oxford, U.K., Blackwell Scientific, $312 \mathrm{p}$.

Thompson, R.N., Morrison, M.A. Hendry, G.L., and Parry, S.J., 1984, An assessment of the relative roles of crust and mantle in magma genesis-an elemental approach: Royal Society of London Philosophical Transactions, ser. A, v. 310, no. 1514, p. 549-590.

Thorpe, R.S., Francis, P.W., and O'Callaghan, L.J., 1984, Relative roles of source composition, fractional crystallization and crustal contamination in the petrogenesis of Andean volcanic rocks: Royal Society of London Philosophical Transactions, ser. A, v. 310 , no. 1514, p. 675-692.

Trop, J.M., 1996, Sedimentological, provenance, and structural analysis of the lower Cantwell Formation, Cantwell Basin, central Alaska Range; implications for the development of a thrust-top basin: West Lafayette, Ind., Purdue University, M.S. thesis, $222 \mathrm{p}$.

Walker, G.P.L., 1971, Grain size characteristics of pyroclastic deposits: Journal of Geology, v. 79, no. 6, p. 696-714.

Wallace, W.K., and Engebretson, D.C., 1984, Relationship between plate motions and Late Cretaceous to Paleogene magmatism in southwestern Alaska: Tectonics, v. 3, no. 2, p. 295-315.

Wilson, F.H., Dover, J.H., Bradley, D.C., Weber, F.R., Bundtzen, T.K., and Haeussler, P.J., 1998, Geologic map of central (interior) Alaska: U.S. Geological Survey Open-File Report 98-133 [CD-ROM].

Wilson, Marjorie, and Davidson, J.P., 1984, The relative roles of crust and upper mantle in the generation of oceanic island arc magmas: Royal Society of London Philosophical Transactions, ser. A, v. 310, no. 1514, p. 661-674.

Wolfe, J.A., and Wahrhaftig, Clyde, 1970, The Cantwell Formation of the central Alaska Range, in Changes in stratigraphic nomenclature by the U.S. Geological Survey, 1968: U.S. Geological Survey Bulletin 1294-A, p. A41-A46.

Wright, J.V., Smith, A.L., and Self, Stephen, 1980, A working terminology of pyroclastic deposits: Journal of Volcanology and Geothermal Research, v. 8, no. 2-4, p. 315-336. 



\title{
Stratigraphic and Provenance Data from the Upper Jurassic to Upper Cretaceous Kahiltna Assemblage of South-Central Alaska
}

\author{
By Kevin R. Eastham ' and Kenneth D. Ridgway'
}

\section{Abstract}

Upper Jurassic to Upper Cretaceous marine sedimentary strata of the Kahiltna assemblage occur on the suture between the allochthonous Wrangellia composite terrane and the former Mesozoic continental margin of North America. The Kahiltna assemblage crops out in a northeast-southwesttrending belt that is about $800 \mathrm{~km}$ long and about $200 \mathrm{~km}$ wide in southern Alaska. Most previous studies described these strata as a monotonous, highly deformed "flysch" succession. We have measured a series of stratigraphic sections in the Kahiltna assemblage along a traverse from the south contact in the Clearwater and Talkeetna Mountains to the north contact in the Alaska Range. Our data suggest that the thousands of meters of Upper Jurassic to Upper Cretaceous strata which has been grouped together as the Kahiltna assemblage in south-central Alaska may actually represent several different sedimentary basins.

Proximal-distal lithofacies trends along the southern part of our traverse in the Clearwater and Talkeetna Mountains indicate deposition by predominately mud rich submarine-fan systems that transported sediment northwestward. Locally, adjacent to the Wrangellia composite terrane, the Kahiltna assemblage consists of proximal submarine-fan conglomerate and sandstone. Compositional data from proximal conglomerates in this area show a dominance of volcanic (greenstone) and sedimentary clasts that probably reflect unroofing of the Wrangellia composite terrane carried in the hanging wall of the nearby Talkeetna thrust fault.

Proximal-distal lithofacies trends in the Kahiltna assemblage along the northern part of our traverse suggest deposition by gravel- and sand-rich submarine-fan systems that transported sediment southwestward. Pebble-boulder conglomerates of the Alaska Range are dominated by sandstone, chert, and granitic clasts indicative of a source terrane rich in sedimentary and plutonic rocks. Possible source terranes for the Kahiltna assemblage of the Alaska Range are Paleozoic continental-margin strata north of the Denali Fault system.

'Purdue University.
The Kahiltna assemblage of the Alaska Range is separated from the Kahiltna assemblage of the Clearwater and Talkeetna Mountains by a large thrust block of Paleozoic and Mesozoic strata known as the Chulitna terrane. Upper Jurassic to Upper Cretaceous sedimentary strata, also mapped in previous studies as the Kahiltna assemblage, crop out in the Chulitna terrane. These strata are characterized by massive black shale, chert, and inplace fossiliferous limestone that are distinct from lithofacies of the Kahiltna assemblage of the Talkeetna Mountains and Alaska Range. We interpret the lithofacies of the Chulitna terrane as representing deposition on a bathymetric high relative to submarine-fan lithofacies of the Kahiltna assemblage in the Talkeetna Mountains and Alaska Range.

\section{Introduction}

Mesozoic strata of the Kahiltna assemblage in the Alaska Range and Talkeetna Mountains of southern Alaska provide a record of sedimentary-basin formation along an accretionary convergent margin. The Kahiltna assemblage consists of Upper Jurassic to Upper Cretaceous strata that occur between the allochthonous Wrangellia composite terrane and the former Mesozoic continental margin of North America-in other words, the Yukon-Tanana terrane (YT, fig. 1; Csejtey and others, 1982; Jones and others, 1982, 1986). The Wrangellia composite terrane consists of three tectonostratigraphic terranes: the Wrangellia, Peninsular, and Alexander terranes (Plafker and Berg, 1994). The thickness of the Kahiltna assemblage is unknown but is estimated to range from 4 to $10 \mathrm{~km}$. The only detailed study of the Kahiltna assemblage is from southwestern Alaska, where Wallace and others (1989) showed that the Kahiltna assemblage was derived from the Wrangellia composite terrane and that the basin formed on the suture zone between the Wrangellia composite terrane and North America. Previous studies of the Kahiltna assemblage in south-central Alaska have been in the context of regional-mapping projects (Csejtey and others, 1978; Reed and Nelson, 1980; Jones and others, 1982; Smith and others, 1988; Csejtey and 


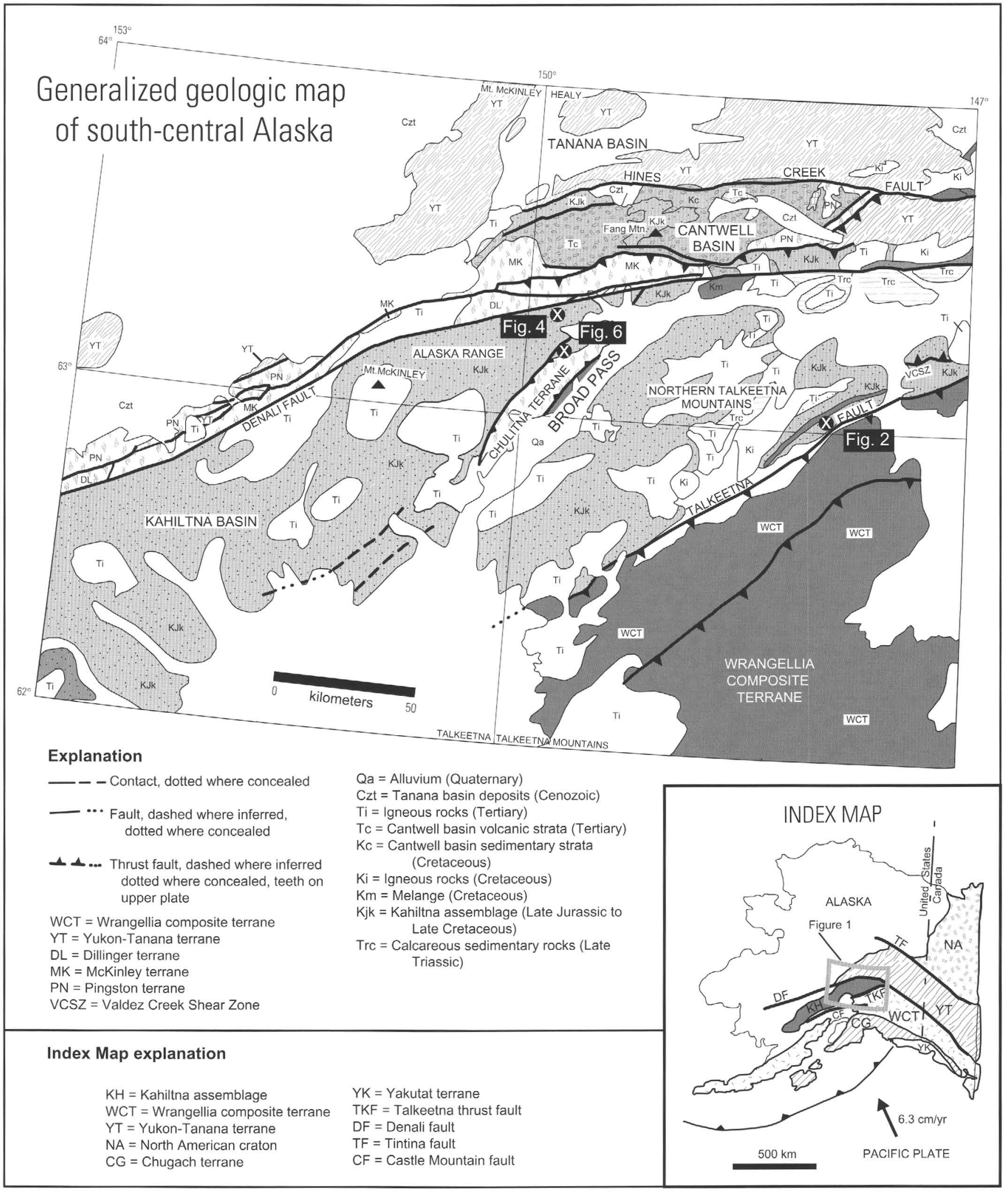

Figure 1. Generalized geologic map of south-central Alaska, showing locations of measured stratigraphic sections discussed in text. Note location of the Kahiltna assemblage (KJk) between late Mesozoic continental margin of North America (YT) and the Wrangellia composite terrane (WCT). Modified from K.D. Ridgway and others (unpub. data). 
others, 1992; Bundtzen and others, 1997; Wilson and others, 1998; Clautice and others, 1999). Csejtey and others (1992) described the Kahiltna assemblage in south-central Alaska as "a monotonous, intensely deformed and locally highly metamorphosed, probably several thousand meters thick, flyschlike turbidite sequence...dark-gray to black argillite, fine- to coarse-grained, generally dark gray lithic greywacke; dark-gray polymict pebble conglomerate; subordinate black chert-pebble conglomerate..." Our preliminary fieldwork, as part of the Talkeetna Mountains mapping project, found that the Kahiltna assemblage contains thick sections of conglomerate and coarse-grained sandstone, as well as "monotonous" fine-grained turbidite facies. We also found that the deformation varies widely in intensity, with much of it concentrated near igneous intrusions. Our study focused mainly on the Kahiltna assemblage exposed in the area between the Denali Fault and the Talkeetna thrust fault (fig. 1). Before our study, few measured stratigraphic sections and compositional data had been collected from the Kahiltna assemblage in southcentral Alaska. In this chapter, we present data to characterize the lithofacies, sedimentary structures, and provenance of the Kahiltna assemblage in three different areas of the outcrop belt: the northern Talkeetna Mountains, the southern Alaska Range, and the Chulitna terrane (fig. 1).

\section{Data}

\section{Talkeetna Mountains}

\section{Stratigraphy}

We measured a stratigraphic section of the Kahiltna assemblage from the Butte Creek area in the northern Talkeetna Mountains (fig. 2). The section is adjacent to the Talkeetna thrust fault and represents some of the southernmost Kahiltna assemblage deposits in the study area (fig. 1). In the Butte Creek area, the Kahiltna assemblage consists of three dominant lithofacies: pebble to boulder conglomerate, horizontally stratified sandstone, and laminated siltstone (fig. 2).

The conglomerate lithofacies occurs in discontinuous lenticular beds that are 20 to $50 \mathrm{~m}$ long and as much as 25 $\mathrm{m}$ thick. The conglomerate is clast supported, containing subrounded pebble- and cobble-size clasts. Internally, this lithofacies consists of normally graded, moderately sorted conglomerate in 0.5 - to 1.5 -m-thick packages that fine upward into siltstone (for example, 200-216 m, fig. 2). The conglomerate facies is commonly interbedded with laminated siltstone and shale that are tens of meters thick (230-297 m, fig. 2). The normal grading, overall grain size, and moderate sorting of the conglomerate lithofacies all suggests deposition by sandy to gravelly turbidity currents. Clast grading probably occurred as a result of a decrease in current velocity that allowed progressively smaller clasts to settle (for example, Hein, 1982). Imbrication of clasts is rare in these conglomerates. Also present in the Butte Creek section are ungraded, laterally discontinuous boulder conglomerates (308-334 m, fig. 2) that contain poorly sorted, subangular clasts ranging in size from 0.1 to more than $7 \mathrm{~m}$ across. We interpret the wide variation in clast sizes (especially the exceedingly large clasts), the angularity of the clasts, and the absence of grading as representing submarine-rockfall/ avalanche and debris-flow deposits that occurred in the proximal part of submarine-fan systems adjacent to submarine canyons (for example, Lowe, 1982; Stow and others, 1996).

The sandstone lithofacies is fine to coarse grained and commonly part of the upward-fining packages. Beds range from 10 to $50 \mathrm{~cm}$ in thickness, and the bases of the sandstone beds are generally sharp. Horizontal stratification is the most common sedimentary structure observed in the sandstones (360-429 m, fig. 2). Using the Bouma (1962) classification for turbidite deposits, the sandstone beds can be described as Ta (massive, graded sandstone), Tab (Ta unit overlain by horizontally laminated sandstone), and Tabd (Tab unit overlain by laminated siltstone and mudstone). Well-preserved pelecypods (Buchia) and ammonites were sampled $525 \mathrm{~m}$ from the base of the section in the sandstone facies (fig. 2).

We interpret the siltstone lithofacies (0-54, 230-297, and 476-522 m, fig. 2) as representing pelagic sedimentation and (or) very fine grained, low-density-turbidity-current deposition (Bouma, 1962).

\section{Provenance}

Clast composition changes upsection in conglomerates of the Butte Creek section. Low in the section, clasts are mainly of black argillite (53 volume percent), gray limestone (22 volume percent), and siltstone (11 volume percent) (fig. $3 A$ ). In the middle of the section, the clasts are dominantly of gray limestone ( 86 volume percent), and black argillite is much less abundant ( 9 volume percent) (fig. $3 B$ ). In the uppermost part of the section, clasts are mainly of volcanic rocks (greenstone, 60 volume percent) and chert (17 volume percent) (fig. $3 C$ ). We interpret the upsection compositional trend in the conglomerates from argillite-dominated, through limestone-dominated, to volcanic-rock (greenstone)-dominated clasts as representing the progressive unroofing of the nearby Wrangellia composite terrane. In this area of Alaska (fig. 1), the Wrangellia composite terrane is exposed in the hanging wall of the Talkeetna thrust fault and consists of more than 3,000 $\mathrm{m}$ of Triassic volcanic rocks (Nikolai Greenstone), overlain by $1,100 \mathrm{~m}$ of Triassic carbonate strata (Chitistone and Nizina Limestones) and capped by $600 \mathrm{~m}$ of Triassic and Jurassic argillite (McCarthy Formation) (Csejtey and others, 1978).

\section{Alaska Range}

\section{Stratigraphy}

In the southern Alaska Range, we measured a stratigraphic section of the Kahiltna assemblage in the Bull 


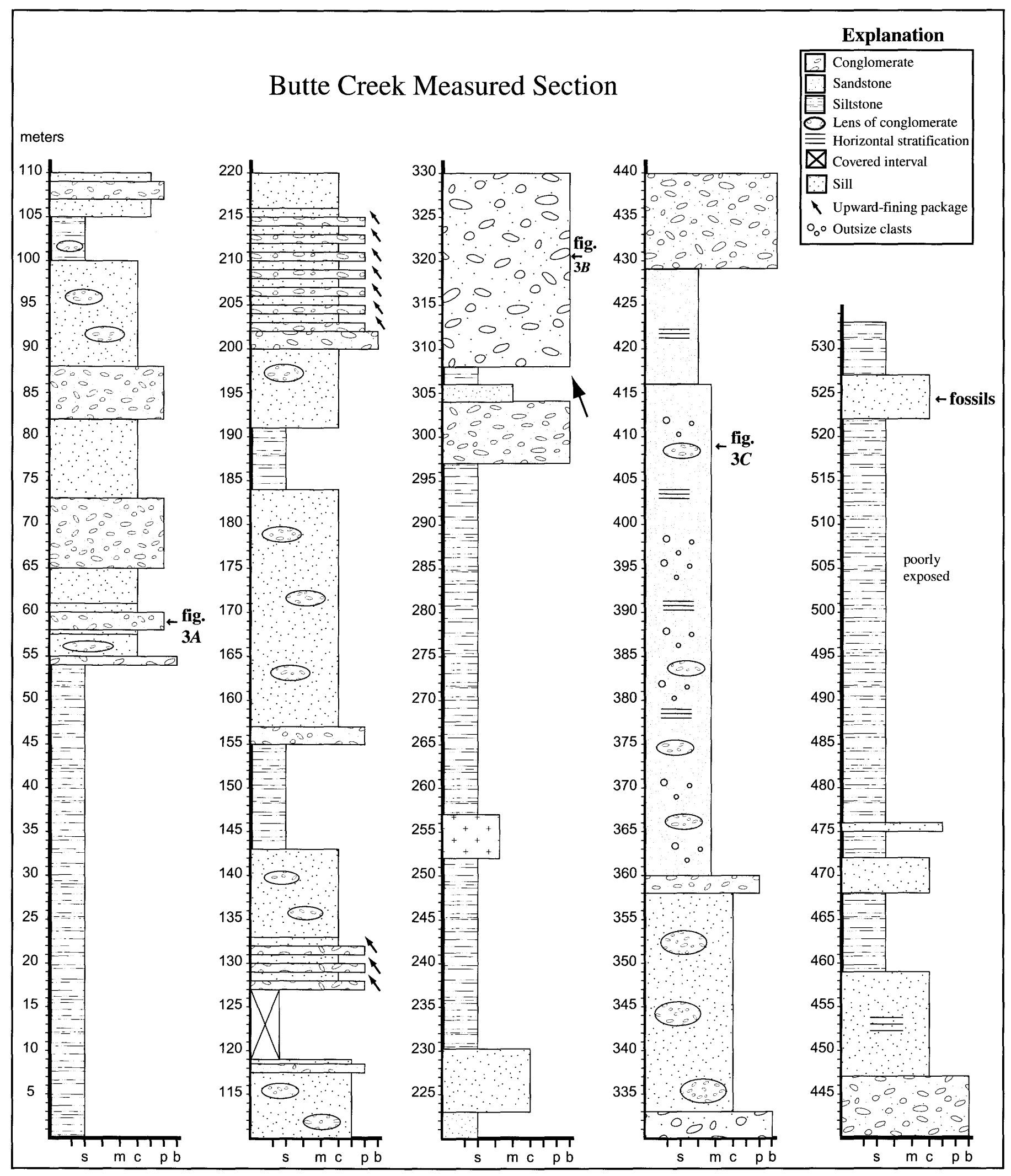

Figure 2. Log of measured stratigraphic section in the Butte Creek area of the northern Talkeetna Mountains, south-central Alaska (fig. 1). Grain sizes are listed on horizontal scales: $b$, boulder conglomerate; $c$, coarse-grained sandstone; $m$, medium-grained sandstone; $p$, pebble conglomerate; s, siltstone. 
River area (fig. 4). The section is immediately south of the Denali Fault and describes some of the northernmost deposits of the Kahiltna assemblage in the study area (fig. 1). Common lithofacies in this section include pebble to boulder conglomerate and upward-fining packages of sandstone, siltstone, and shale.

Massive, ungraded conglomerate beds, as much as 25 $\mathrm{m}$ thick (103-128 m, fig. 4), dominate the lower half of the stratigraphic section ( $0-145 \mathrm{~m}$, fig. 4). The conglomerates are generally poorly sorted, clast supported, and contain subrounded pebble to boulder clasts; imbrication is rare. We interpret these conglomerates as the deposits of subaqueous gravelly debris flows and gravelly turbidity flows (for example, Lowe, 1976a, 1982).

The upper half of the stratigraphic section consists mainly of tabular, upward-fining packages of sandstone, siltstone, and laminated mudstone. The upward-fining packages range in thickness from $0.5 \mathrm{~m}$ (204-216 m, fig. 4) to 2 m (154-190 m, fig. 4). Groove casts occur along the sharp, erosive basal contacts of these packages. The upward-fining packages are best described in terms of Bouma's (1962) classification of turbidite deposits. Most of the sandstones are normally graded, from very coarse sandstone at the base (Ta) upward into ripple-laminated, fine- to medium-grained sandstone (Tc) and laminated siltstone (Td). The grain size, normal grading, erosive bases, average bed thickness, and sedimentary structures indicate deposition by sandy, low-density turbidity currents (for example, Bouma, 1962; Middleton, 1967; Lowe, 1976b). Some of the units contain disarticulated pelecypods (190-216 m, fig. 4), but macrofossils are uncommon.

\section{Provenance}

The conglomerates in the Bull River section of the Alaska Range (fig. 1) contain clasts of argillite, tuff, granite, and minor chert, limestone, sandstone, and quartz (fig. 5). Upsection trends in clast composition are not apparent (fig. 5), suggesting a mixed igneous and sedimentary source terrane for these conglomerates. Csejtey and others (1992) reported Devonian conodonts from a limestone clast in conglomerate of the Bull River section. Our limited compositional data and Csejtey and others' (1992) Devonian age for this limestone clast suggest that one possible source terrane for the Kahiltna assemblage in the Alaska Range may be Paleozoic continental-margin strata inboard of the suture zone. For example, the Dillinger terrane on the north side of the Denali Fault (DL, fig. 1) contains Devonian limestones lithologically similar to limestone clasts in the Kahiltna assemblage (Csejtey and others, 1992). The Dillinger terrane, however, does not contain a source for the granitic clasts common in the Bull River section. To help identify possible source terrane(s) for clasts, we plan to obtain ages by radiometric dating of granitic clasts and radiolarian identification in chert clasts.

\section{Chulitna Terrane}

\section{Stratigraphy}

We also measured a stratigraphic section of the Kahiltna assemblage in the West Fork area of the Chulitna terrane (figs. 1, 6). The Chulitna terrane is a large thrust block of

A

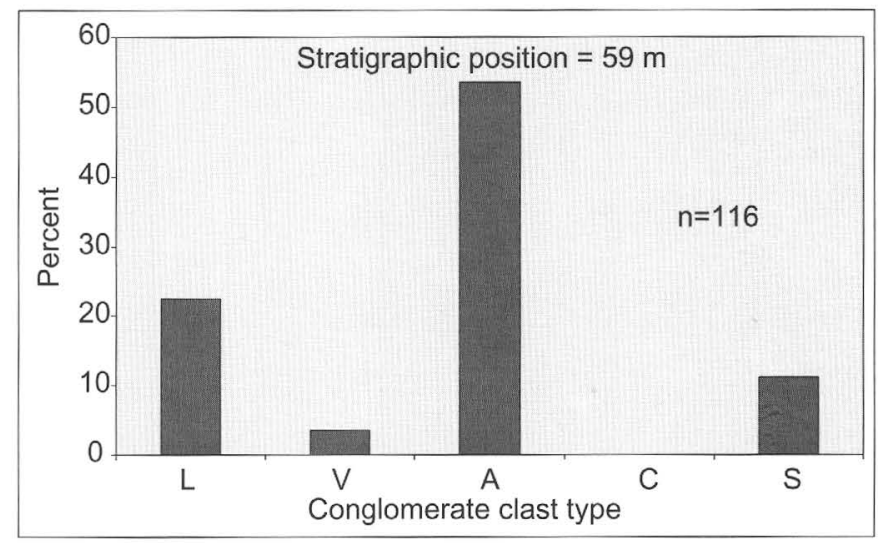

$B$

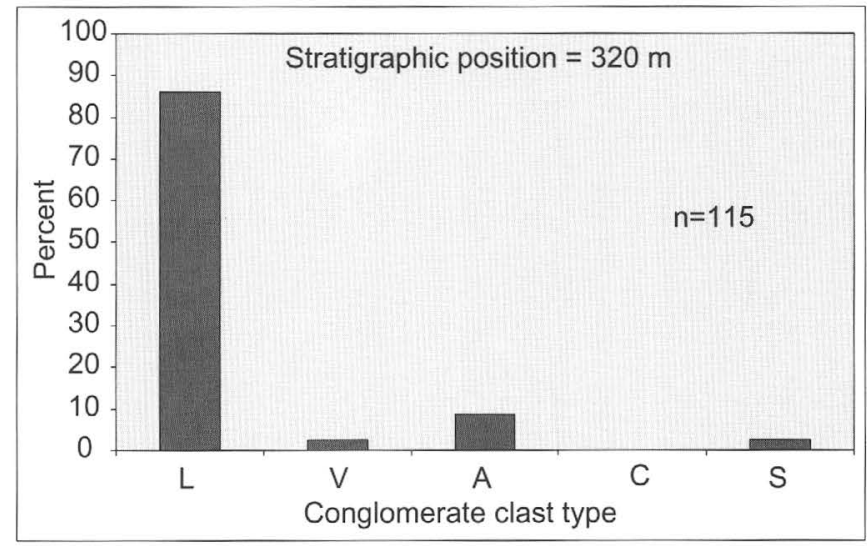

C

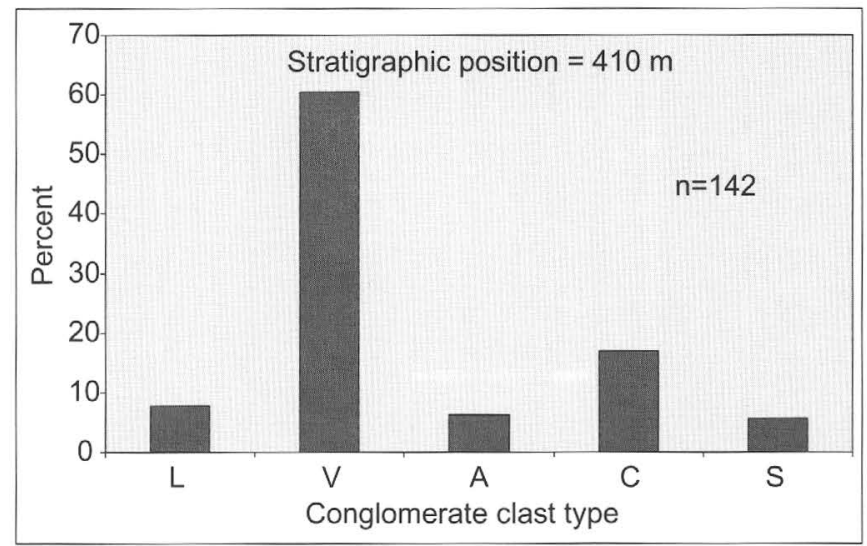

Figure 3. Clast-count data for conglomerates in Butte Creek measured section of the northern Talkeetna Mountains, south-central Alaska (fig. 1). Note upsection change in dominant clast composition from argillite through limestone to volcanic rocks. Stratigraphic position of clast count in measured section is shown in figure 2. Conglomerate clast types: $\mathrm{A}$, argillite; $\mathrm{C}$, chert; $\mathrm{L}$, limestone; $\mathrm{S}$, siltstone; $\mathrm{V}$, volcanic rocks. n, number of clasts counted. 


\section{Bull River Measured Section}


\begin{tabular}{|c|c|}
\hline & Explanation \\
\hline & Conglomerate \\
\hline & Sandstone \\
\hline & Siltstone \\
\hline & Shale \\
\hline 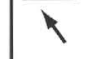 & Upward-fining package \\
\hline
\end{tabular}

meters

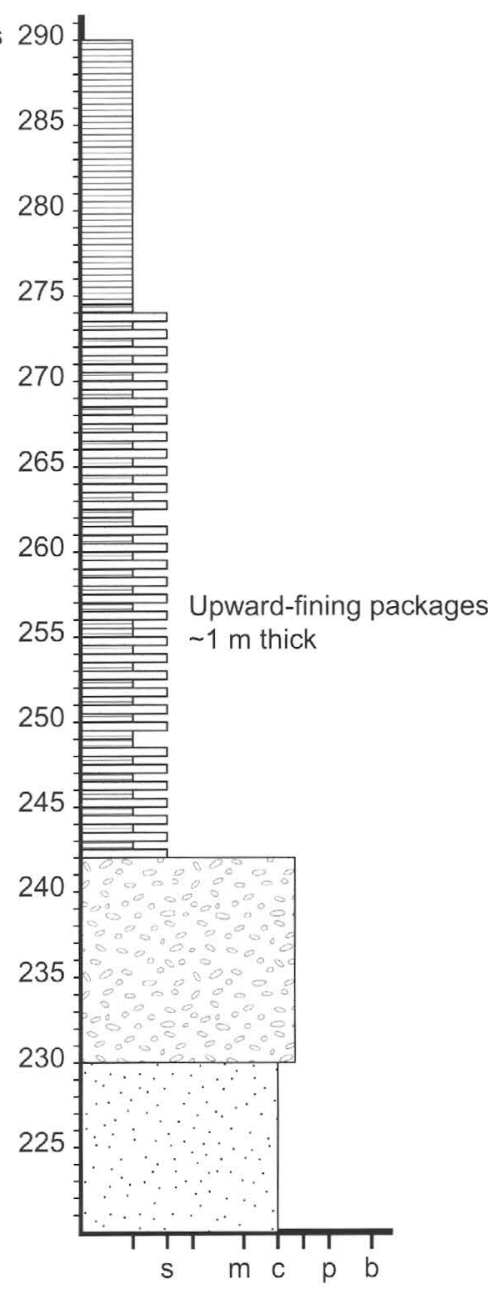

Figure 4. Log of measured stratigraphic section in the Bull River area of the southern Alaska Range, south-central Alaska (fig. 1). Coarsegrained deposits characterize lower part of section $(0-150 \mathrm{~m})$, whereas upward-fining packages dominate upper part (150-290 $\mathrm{m})$. Grain sizes are listed on horizontal scales: $b$, boulder conglomerate; $c$, coarse-grained sandstone; m, medium-grained sandstone; $p$, pebble conglomerate; s, siltstone. 
upper Paleozoic to lower Mesozoic strata between the northern Talkeetna Mountains and the southern Alaska Range (fig. 1; Jones and others, 1980). Locally, the Kahiltna assemblage disconformably overlies older strata of the Chulitna terrane (Clautice and others, 1999). Our measured section is in the northern part of the Chulitna terrane (fig. 1).

Our measured stratigraphic section consists of three main lithofacies: black shale, chert and cherty siltstone, and fossiliferous limestone (fig. 6). The shale lithofacies, which is the most common in the section (0-121 m, fig. 6), is massive, ungraded, and contains little sand- or gravel-size detritus. We interpret this lithofacies as the product of suspension fallout deposition. The siltstone lithofacies, which is the next most common, consists of gray to brown, laterally continuous, thin-bedded (5-15 cm thick) chert and cherty siltstone (154-168 m, fig. 6). We interpret this lithofacies as the product of biogenic sedimentation in a sediment-starved marine environment. The limestone lithofacies, which is characterized by the pelecypod Buchia, consists primarily of wellarticulated Buchia shells and contains little clastic detritus. As in the other lithofacies of this section, the limestone lacks grading and any distinct current-generated structures. These observations suggest that the limestones formed in place and are not transported storm deposits. Similar Buchia-rich limestones in east-central Alaska and the Yukon Territory have been interpreted to form in less than $125 \mathrm{~m}$ of water (Clautice and others, 1999).

The presence of black shale, chert, and inplace fossiliferous limestone suggests to us that the Kahiltna assemblage on the Chulitna terrane was deposited in a shallow $(<125$ $\mathrm{m}$ deep) marine environment in which pelecypod communities could flourish with little detrital sedimentation. We interpret the lithofacies of the Chulitna terrane to represent a bathymetric high relative to submarine-fan lithofacies of the Kahiltna assemblage in the Alaska Range and Talkeetna Mountains (fig. 1). Detrital sedimentation on this bathymetric high was mainly limited to pelagic suspension fallout of clay particles.

\section{Conclusions}

Our preliminary data suggest that the thousands of meters of Upper Jurassic to Upper Cretaceous strata that have been grouped together as the Kahiltna assemblage in south-central Alaska may actually represent several different sedimentary basins. The Kahiltna assemblage in the northern Talkeetna Mountains was deposited by mud-rich submarine-fan depositional systems that were sourced by a volcanic and sedimentary terrane. The most likely source terrane for these deposits is the Wrangellia composite terrane to the southeast in the hanging wall of the Talkeetna thrust fault (fig. 1). The Kahiltna assemblage in the southern Alaska Range was deposited by gravel- and sand-rich submarine-fan depositional systems that were sourced by a sedimentary and igneous terrane. Although we have not yet identified a spe- cific source terrane for these deposits, we suspect that they may have been derived from Paleozoic continental-margin strata inboard of the suture zone. The Kahiltna assemblage of the Chulitna terrane was deposited in a sediment-starved, shallow ( $<125 \mathrm{~m}$ deep)-marine environment relative to the deeper-marine, submarine-fan systems represented by the Kahiltna assemblage of the northern Talkeetna Mountains and southern Alaska Range. More measured stratigraphic sections and compositional data will be collected during the

A

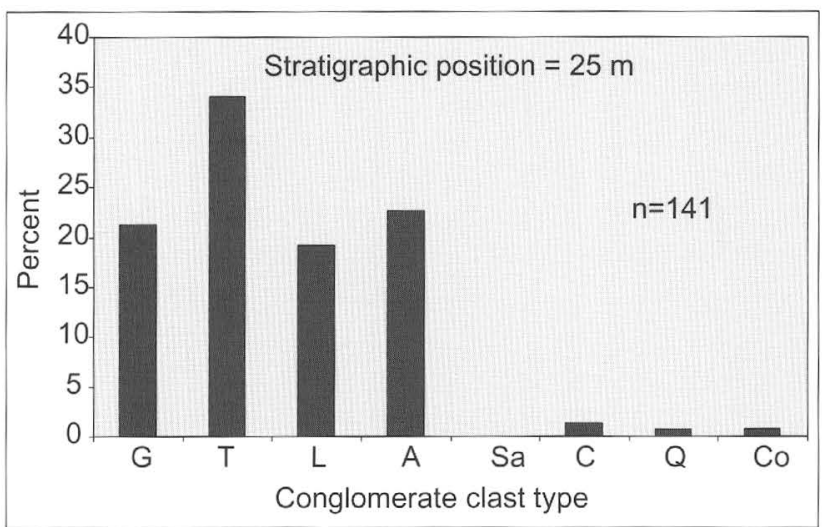

$B$

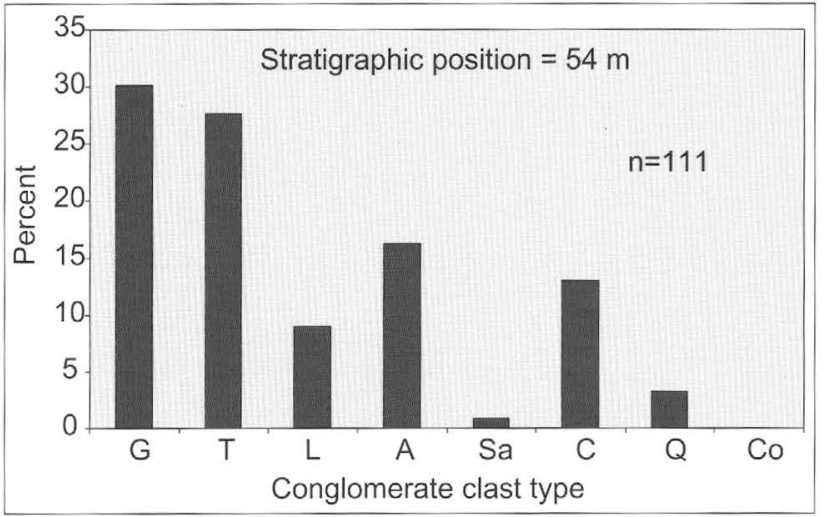

C

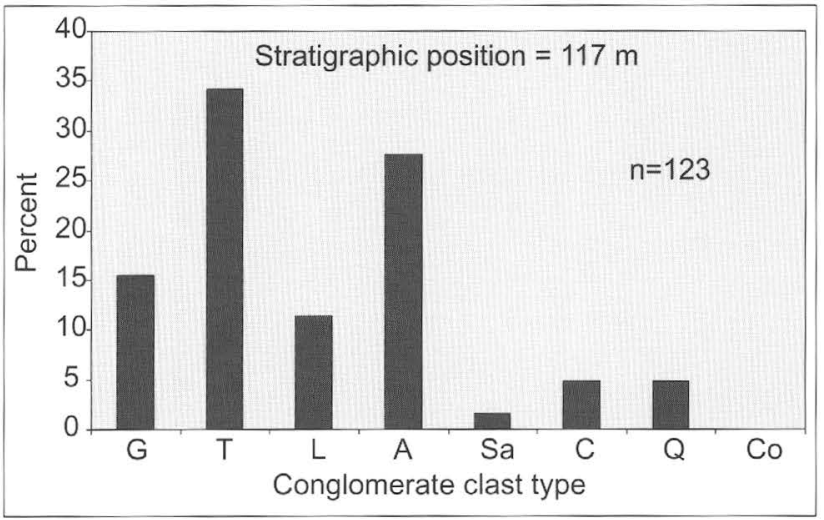

Figure 5. Clast-count data for conglomerates in Bull River measured section of the southern Alaska Range, south-central Alaska (fig. 1). Note that no apparent upsection trends occur in clast composition. Stratigraphic locations of clast counts are shown in figure 4. Conglomerate clast types: $\mathrm{A}$, argillite; $\mathrm{C}$, chert; $\mathrm{Co}$, conglomerate; $G$, granite; L, limestone; $Q$, quartz; Sa, sandstone; T, tuff. $n$, number of clasts counted. 
West Fork Measured Section

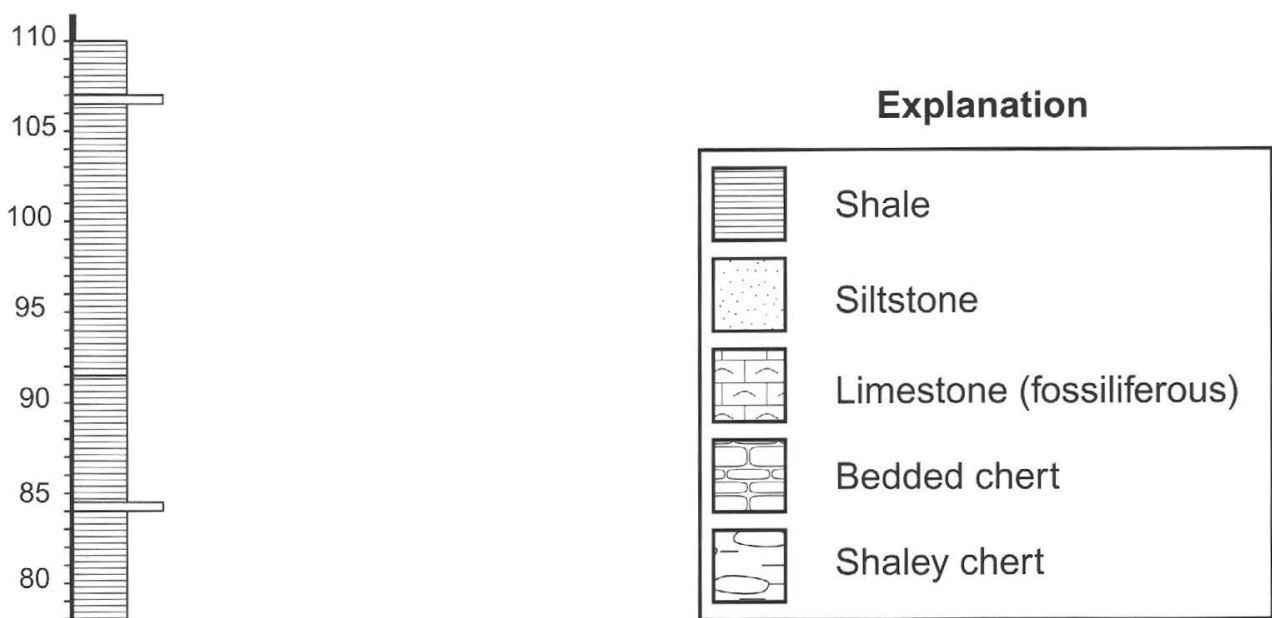

75

70

65

60

55

50

45

40

35

30

25

20

更

10

5

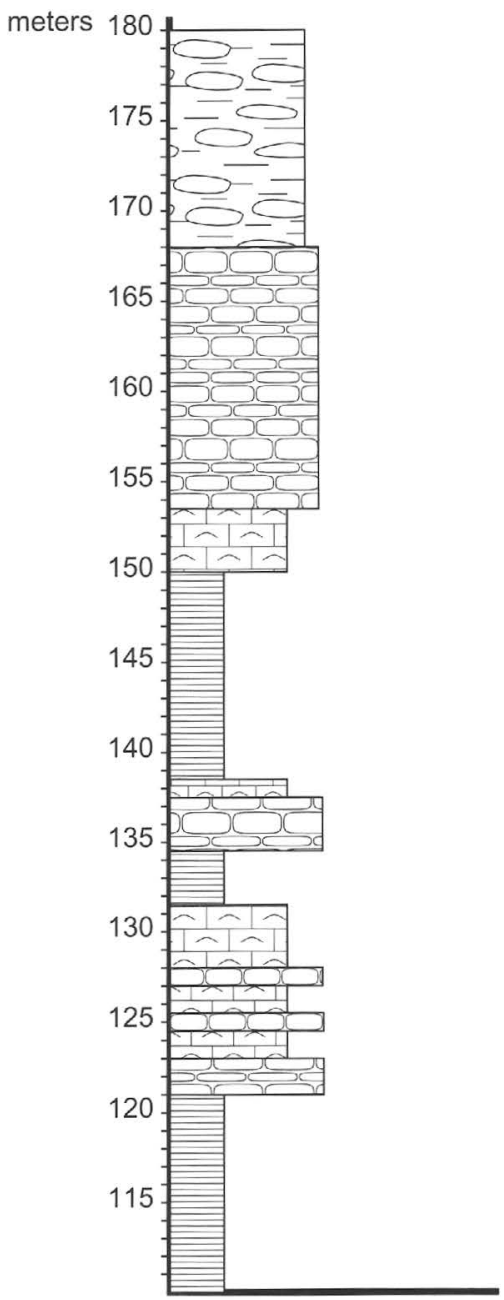

Figure 6. Log of measured stratigraphic section in the West Fork area of the Chulitna terrane, south-central Alaska (fig. 1). Section is characterized by shale, bedded chert, and fossiliferous limestone. 
2001 field season to better determine the configuration of the basin(s) represented by the Kahiltna assemblage in southcentral Alaska.

\section{Acknowledgments}

This research was supported by the U.S. Geological Survey (USGS), the National Science Foundation, and the American Association of Petroleum Geologists. We thank the members of the USGS' Talkeetna Mountains mapping project for many helpful suggestions and discussions on the Kahiltna assemblage. We thank Mark Lesh for assistance in the field. K.H. Clautice and T.K. Bundtzen provided valuable information on key outcrops. Ron Cole and Jeff Trop reviewed the manuscript.

\section{References Cited}

Bouma, A.H., 1962, Sedimentology of some flysch deposits; a graphic approach to facies interpretation: Amsterdam, Elsevier, $168 \mathrm{p}$.

Bundtzen, T.K., Harris, E.E., and Gilbert, W.G., 1997, Geologic map of the eastern half of the McGrath quadrangle, Alaska: Alaska Division of Geological and Geophysical Surveys, scale 1:125,000.

Clautice, K.H., Newberry, R.J., Blodgett, R.B., Bundtzen, T.K., Gage, B.G., Harris, E.E., Liss, S.A., Miller, M.L., Pinney, D.S., Reifenstuhl, R.R., Clough, J.G., Stone, D.B., and Whalen, M.T., 1999, Preliminary geologic map of the Healy A-6 quadrangle, south central Alaska: Alaska Division of Geological and Geophysical Surveys. Public-Data File 99-24a, scale 1:63,360.

Csejtey, Bela, Jr., Cox, D.P., and Evarts, R.C., 1982, The Cenozoic Denali fault system and the Cretaceous accretionary development of southern Alaska: Journal of Geophysical Research, v. 87, no. B5, p. 3741-3754.

Csejtey, Bela, Jr., Mullen, M.W., Cox, D.P., and Stricker, G.D., 1992, Geology and geochronology of the Healy quadrangle, southcentral Alaska: U.S. Geological Survey Miscellaneous Investigations Series Map 1-1961, scale 1:250,000, 2 sheets.

Csejtey, Bela, Jr., Nelson, W.H., Jones, D.L., Silberling, N.J., Dean, R.M., Morris, M.S., Lamphere, M.A., Smith, J.G., and Silberman, M.L., 1978, Reconnaissance geologic map and geochronology, Talkeetna Mountains quadrangle, northern part of Anchorage quadrangle, and southwest corner of Healy quadrangle, Alaska: U.S. Geological Survey Open-File Report 78-558-A, scale $1: 250,000,2$ sheets.
Hein, F.J., 1982, Depositional mechanisms of deep-sea coarse clastic sediments, Cap Enrage Formation, Quebec: Canadian Journal of Earth Sciences, v. 19, no. 2, p. 267-287.

Jones, D.L., Silberling, N.J., and Coney, P.J., 1986, Collision tectonics in the Cordillera of western North America; examples from Alaska, in Coward, M.P., and Ries, A.C., eds., Collision tectonics: Geological Society of London Special Publication 19, $p$. 367-387.

Jones, D.L., Silberling, N.J., Csejtey, Bela, Jr., Nelson, W.H., and Blome, C.D., 1980, Age and structural significance of ophiolites and adjoining rocks in the upper Chulitna district, south-central Alaska: U.S. Geological Survey Professional Paper 1121-A, p. A1-A21.

Jones, D.L., Silberling, N.J., Gilbert, W.G., and Coney, P.J., 1982, Character, distribution, and tectonic significance of accretionary terranes in the central Alaska Range: Journal of Geophysical Research, v. 87, no. B5, p. 3709-3717.

Lowe, D.R., 1976a, Grain flow and grain flow deposits: Journal of Sedimentary Petrology, v. 46, no. 1, p. 188-199.

-1976b, Subaqueous liquefied and fluidized sediment flows and their deposits: Sedimentology, v. 23, no. 3, p. 285-308.

1982, Sediment gravity flows: depositional models with special reference to the deposits of high-density turbidity currents: Journal of Sedimentary Petrology, v. 52, no. 1, p. 279-297.

Middleton, G.V., 1967, Experiments on density and turbidity currents, III-Deposition of sediment: Canadian Journal of Earth Sciences, v. 4, no. 3, p. 475-505.

Plafker, George, and Berg, H.C., 1994, Overview of the geology and tectonic evolution of Alaska, in Plafker, George, and Berg, H.C., eds., The geology of North America, v. G-1 of The geology of Alaska: Boulder, Colo., Geological Society of America, p. 989-1021.

Reed, B.L. and Nelson, S.W., 1980, Geologic map of the Talkeetna quadrangle, Alaska: U.S. Geological Survey Miscellaneous Investigations Series Map 1-1174, scale 1:250,000.

Smith, T.E., Albanese, M.D., and Kline, G.L., 1988, Geologic map of the Healy A-2 quadrangle, Alaska: Alaska Division of Geological and Geophysical Surveys Professional Report 95, scale 1: 63,360 .

Stow, D.A., Reading, H.G., and Collinson, J.D., 1996, Deep seas, in Reading, H.G., ed., Sedimentary environments; processes, facies and stratigraphy (3d ed.): Cambridge, Mass., Blackwell Science, p. 395-453.

Wallace, W.K., Hanks, C.L., and Rogers, J.F., 1989, The southern Kahiltna terrane; implications for the tectonic evolution of southwestern Alaska: Geological Society of America Bulletin, v. 101, no. 11, p. 1389-1407.

Wilson, F.H., Dover, J.H., Bradley, D.C., Weber, F.R., Bundtzen, T.K., and Haeussler, P.J., 1998, Geologic map of central (Interior) Alaska: U.S. Geological Survey Open-File Report 98-133, scale $1: 500,000,3$ sheets. 



\title{
Late Triassic (Norian) Mollusks From the Taylor Mountains Quadrangle, Southwestern Alaska
}

\author{
By Christopher A. McRoberts ${ }^{1}$ and Robert B. Blodgett ${ }^{2}$
}

\section{Abstract}

We describe a diverse molluscan fauna of silicified fossils from two localities in the Taylor Mountains D-3 quadrangle of southwestern Alaska. The molluscan fauna consists of at least 8 species of bivalves, including 1 new species, Cassianella cordillerana McRoberts n.sp., and at least 11 species of gastropods, including 2 new species, Neritaria nuetzeli Blodgett n.sp. and Andangularia wilsoni Blodgett n.sp. Bivalve and gastropod affinities suggest an early Norian age, with taxonomic similarities to several southern Alaskan tectonostratigraphic terranes (for example, Alexander and Chulitna), as well as to the South American Cordillera of Peru. The mollusks are associated with numerous brachiopods that also support a Norian age and similar biogeographic affinities.

\section{Introduction}

Late Triassic faunas have been reported at several sites in southwestern Alaska, but little descriptive work has been published on macrofossils from this part of the State. The published work includes descriptions and illustrations of scleractinian corals, spongiomorphs and the hydrozoan Heterastridium from Lake Iliamna by Smith (1927) and Stanley (1979), and monotid bivalves by Silberling and others (1997, pl. 2) from the vicinity of Puale Bay on the Alaska Peninsula. All of these occurrences are in the Peninsular terrane. In this chapter, we provide the first formal description and illustration of Late Triassic mollusks (bivalves and gastropods) from rocks of the Farewell terrane in the Taylor Mountains D-3 1: 63,360-scale quadrangle, southwestern Alaska (fig. 1). In addition, we discuss the broader paleogeographic implications of these fossils. Southern Alaska is composed of numerous accreted tectonostratigraphic (also referred to as lithotectonic) terranes (Jones and others, 1987; Silberling and others, 1994).

\footnotetext{
'State University of New York, Cortland.
}

${ }^{2}$ Oregon State University, Corvallis.
Such paleobiogeographic data as those presented herein are extremely useful in constraining the past geographic positions of these mobile terranes over time, and so are of utmost utility in unraveling the tectonic history of this part of Alaska.

\section{Geologic Setting}

The Farewell terrane of southwestern and west-central Alaska (fig. 1) was established by Decker and others (1994) as a tectonostratigraphic entity incorporating three previously named, genetically related terranes (Nixon Fork, Dillinger, and Mystic) that are relegated the status of subterranes of the Farewell terrane. The Farewell terrane is one of the largest terranes in southwestern Alaska, and recent evaluation of its biogeographically distinctive early and middle Paleozoic macrofaunas now indicates that it probably originated as a rifted continental-margin sequence derived from the Siberian Continent by a Devonian or slightly later rifting event (Blodgett and Brease, 1997; Blodgett, 1998; Blodgett and Boucot, 1999; Blodgett and others, in press; Dumoulin and others, in press).

Triassic strata of the Farewell terrane, which were deposited during the late Triassic, occur in two areas within the Nixon Fork subterrane and in one area of the Mystic subterrane. Upper Triassic strata of the Nixon Fork subterrane occur in the central part of the subterrane in the Medfra C-3 1:63,360-scale quadrangle (Patton and others, 1977, 1980; Silberling and others, 1997) and in the Taylor Mountains D-2 and D-3 quadrangles (fig. 1; Blodgett and others, 2000). Upper Triassic rocks of the Mystic subterrane occur in the Lime Hills C-6 1:63,360-scale quadrangle, where shale interbedded with a unit of pillow basalt and agglomerate has yielded ammonites and halobiid bivalves indicative of a late early to middle Norian age (Bundtzen and others, 1994).

Exposures in the Medfra $\mathrm{C}-3$ quadrangle are similar to those in the Taylor Mountains D-2 and D-3 quadrangles, consisting of a lower interval of carbonate and minor siltstone beds succeeded by a gradationally overlying interval of darkgray bedded chert. The chert is considered to be of latest Late 
Triassic and possibly Jurassic age. The most detailed description of the Medfra succession was provided by Silberling and others (1997, p. 9), who reported a thickness of about $60 \mathrm{~m}$ for the lower carbonate-dominated unit and of about $100 \mathrm{~m}$ for the bedded-chert unit. Only the lower carbonate unit has yielded an identifiable fossil fauna, determined to be of Norian age, consisting of the bivalves Monotis and Halobia and the hydrozoan Heterastridium (the northernmost occurrence of the genus in North America). Monotid bivalves from several different levels in a 5- to 10-m interval of this unit were illustrated by Grant-Mackie and Silberling (1990) and Silberling and others (1997). Massive interbeds within and immediately overlying this fossiliferous interval within the lower unit were interpreted by Silberling and others $(1997$, p. 9) to represent debris-flow deposits within a deep-water sequence. No fossil fauna has been reported from the gradationally overlying chert unit. The entire Upper Triassic succession is unconformably underlain by Permian sandy limestone, grit, limy sandstone, and mudstone (Patton and others, 1977, fig. 18).

The fossils described herein are all from Late Triassic exposures in the Taylor Mountains D-2 and D-3 1:63,360scale quadrangles, consisting of various rock types present in a deepening-upward succession, and differing from those in the Medfra quadrangle in being thicker and both lithologically

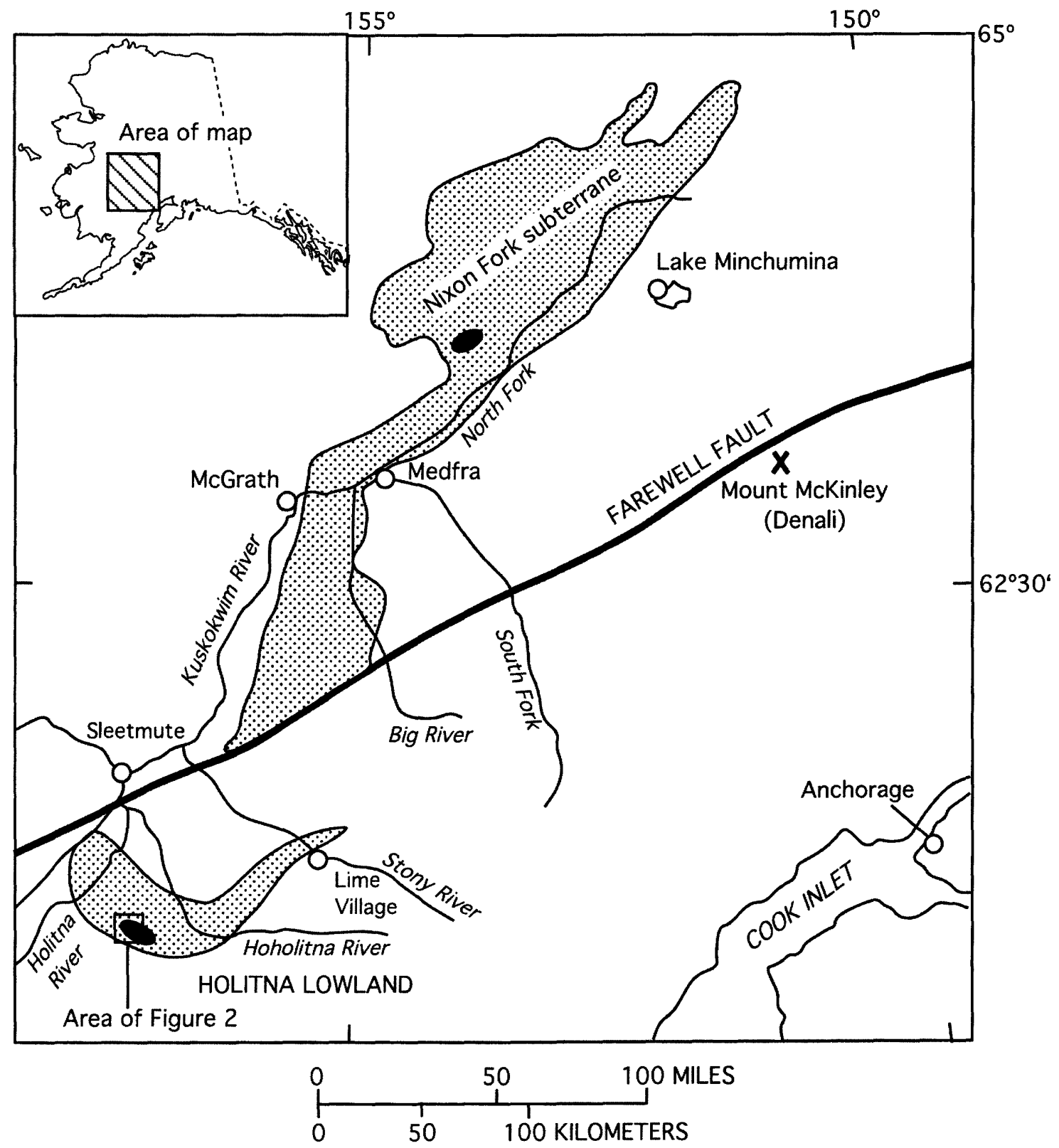

Figure 1. Study area in southwestern Alaska, showing locations of the Nixon Fork subterrane of the Farewell terrane (stippled areas) and two Upper Triassic outcrop belts referred to in text: (1) outcrop belt in the Taylor Mountains D-2 and D-3 quadrangles in the Holitna Lowland and (2) outcrop belt to the northeast in the northern Kuskokwim Mountains, Medfra C-3 quadrangle. Modified from Jacobson and others (1996). 
and paleontologically more diverse. The Taylor Mountains Triassic outcrop belt, on the basis of several brief reconnaissance surveys, appears to contain three primary units. The lowest exposed unit consists of distinctive white to light-gray lime packstone containing scleractinian corals, indeterminate hydrozoans, and inozoan sponges of Norian age. The corals identified by G.D. Stanley, Jr. (in Blodgett and others, 2000), include Astraeomorpha crassisepta, possibly Pamiroseris meriani, Rhaetiastraea $\mathrm{cf}$. $R$. vesiculosa, possibly "Margarosmilia" (M. chalyana?), ?Distichophyllia cf. D. norica, and Procycolites sp. This assemblage contains elements known from the Chulitna terrane of Alaska, other accreted terranes of western North America, and the former Tethys seaway. An excellent exposure of the Norian carbonates that is easily accessible by helicopter is situated in the $\mathrm{NE}^{1 / 4} \mathrm{SW}^{1 / 4} \mathrm{NE}^{1 / 4} \mathrm{sec}$. 20, T. 10 N., R. 42 W., Taylor Mountains D-3 quadrangle. This lowermost unit is situated just south of conspicuous exposures of an Upper Silurian algal barrier-reef complex (a westward extension of unit Sab of Blodgett and Wilson, 2001, exposed in the northern part of the Taylor Mountains D-1 quadrangle); however, whether the units are in depositional or fault contact remains unclear at this time.

The next succeeding unit recognized in the Upper Triassic succession consists of yellow-orange- to yellow-gray-weathering silty limestone containing a richly diverse, silicified macrofauna of bivalves, brachiopods, and gastropods of late Norian age. This chapter is focused on a paleontologic study of the bivalve/gastropod portion of this fauna from two separate localities $(1,2$, fig. 2$)$ in the Taylor Mountains D-3 1:

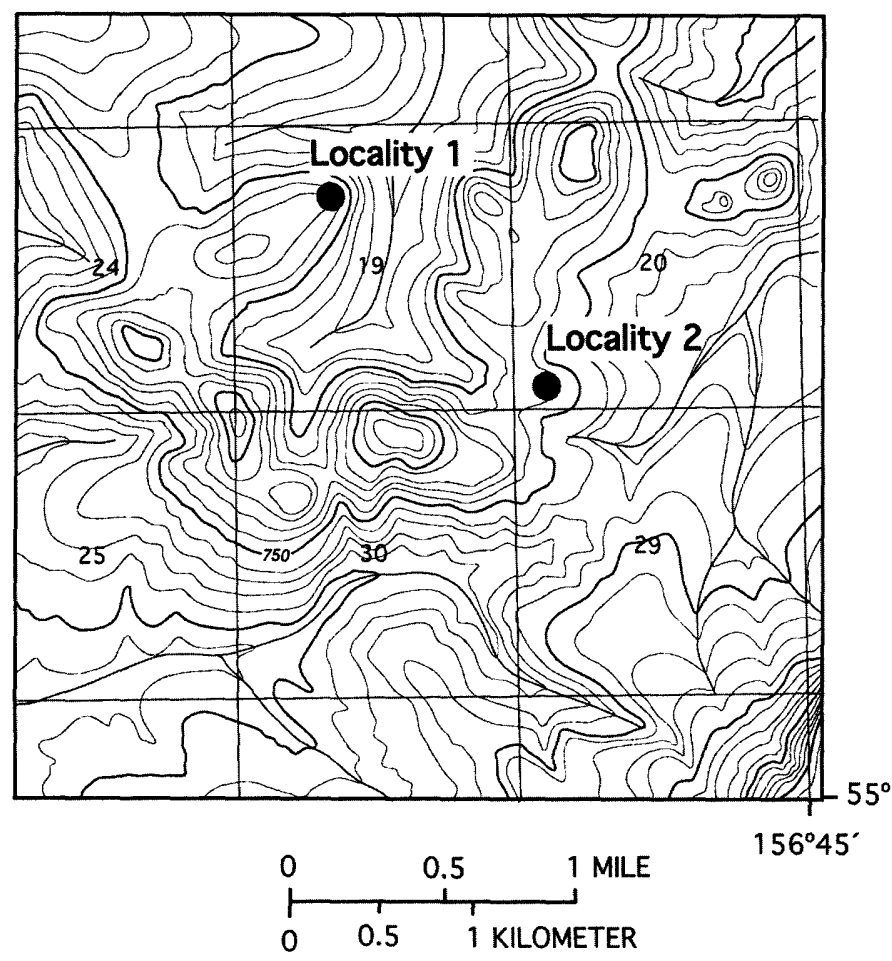

Figure 2. Part of the Taylor Mountains D-3 quadrangle, southwestern Alaska (see fig. 1 for location), showing both localities discussed in text. 63,360-scale quadrangle. The uppermost part of the succession is a thick sequence of medium- to thick-bedded siliceous argillite, chert, and minor lithic sandstone and (or) siltstone locally bearing undeformed, three-dimensional belemnoid cephalopods. The total thickness of the entire Upper Triassic succession is unknown because of the reconnaissance nature of the fieldwork conducted to date in the study area, the relatively poor quality of exposures in the dominantly tundra covered lowland, and the structural complexity of the regional geology, although a minimum thickness of $300 \mathrm{~m}$ is reasonable. No formal stratigraphic name has been applied to the Triassic rocks of the Taylor Mountains D-2 and D-3 quadrangles. These rocks were previously assigned to the now-abandoned Holitna Group of Cady and others (1955, pl. 1). This stratigraphic term was applied to all Paleozoic carbonates exposed along the middle course of the Holitna River and surrounding area; no subdivisions were designated for this group. Fossils of Silurian and Devonian age were reported by Cady and others, who inferred that Ordovician strata might also be present because of their occurrence in correlative rocks in the Medfra quadrangle to the northeast, as well as from the fact that the Silurian and Devonian fossils were recovered from only the upper part of the Holitna Group. They estimated the thickness of the group at 1,524 to 3,048 m (Cady and others, 1955, p. $24)$. On the basis of fieldwork conducted in the region since 1983, it is now obvious that this depositional sequence has a much greater total thickness and includes strata as old as Late Proterozoic and as young as Triassic. Adrain and others (1995, p. 724) suggested that the term "Holitna Group" was too broadly defined and should be abandoned in favor of betterdivided stratigraphic units. LePain and others (2000) were the only workers who recognized Triassic strata in the Taylor Mountains D-2 and D-3 quadrangles; they designated these strata as unit Tzrlc (silty limestone and chert) on their geologic map and briefly discussed it (LePain and others, 2000, p. 9).

\section{Fossil-Locality Descriptions and Repository}

The two fossil localities reported on here (fig. 2) both occur in Upper Triassic (Norian) carbonate rocks of the Taylor Mountains D-3 1:63,360-scale quadrangle. All type and illustrated specimens are deposited at the University of Alaska Museum in Fairbanks.

Locality 1.-A conspicuous band of fossiliferous strata from the east end of a conspicuous rubble-crop exposure (approx $45 \mathrm{~m}$ wide) visible from the air, composed of yelloworange-weathering, platy, silty lime mudstone beds that strike N. $45^{\circ} \mathrm{W}$. and $\operatorname{dip} 25^{\circ} \mathrm{NE}$. in the $\mathrm{SW}^{1 / 4} \mathrm{NE}^{1 / 4} \mathrm{NW}^{1 / 4} \mathrm{sec} .19, \mathrm{~T}$. 10 N., R. 42 W., Taylor Mountains D-3 1:63,360-scale quadrangle. Collected by R.B. Blodgett in 1984 and 1999, his field Nos. 84RB32 and 99RB35, respectively. Fossil fauna composed of numerous mollusks (bivalves, gastropods) and lesser brachiopods.

Locality 2.-Fossiliferous bed in the central part of a rubble-crop exposure of light-yellow-gray-weathering, platy, 
silty lime mudstone that strikes N. $85^{\circ} \mathrm{E}$. and consists almost entirely of brachiopods and much rarer bivalves. Rubble crop is situated at the northwest end of a low ridge in the SW $1 / 4 \mathrm{SW}^{1 / 4}$ sec. 20, T. 10 N., R. 42 W., Taylor Mountains D-3 1:63,360-scale quadrangle. Collected by R.B. Blodgett in 1999, his field No. 99RB37.

\section{Systematic Paleontology}

\section{Class BIVALVIA Linné 1758}

[Materials for this class were prepared by C.A. McRoberts]

Discussion.-A total of 8 distinct bivalve species (Table 1) are recognized from more than 150 individual specimens of varying preservational quality. From locality 1 (fig. 2), the most diverse fauna contains seven species: Cassianella cordillerana n.sp. (pl. 1, figs. 1-11). Gryphaea arcuataeformis Kiparisova, 1936 (pl. 1, figs. 12-19), Maoritrigonia sp. (pl. 1, figs. 20,21), Minetrigonia cf. M. suttonensis (Clapp and Shimer, 1911 ) (pl. 1, fig. 22), Minetrigonia sp. (pl. 1, figs. 23, 24), Tutcheria densestriata (Körner, 1937) (pl. 2, figs. 1-6), Astarte sp. (pl. 2, figs. 7, 8), and Septocardia cf. S. peruviana (Cox, 1949) (pl. 2, figs. 9-14). All but one species (Maoritrigonia sp.) is from locality 1 (fig. 2).

The bivalves are dominated by shallow-burrowing infaunal suspension feeders within the orders Veneroida and Trigonoida. No infaunal detritus feeders (orders Nuculoida and Solemyoida) were identified. Although two epifaunal reclining bivalves are described (orders Pterioida and Ostreoida: Gryphaeidae), it is surprising that no epifaunal scallops (for example, Pectinoida) or cementing bivalves (for example, Ostreoida: Paleolophidae) were recognized because both bivalves are common in coeval mollusk-dominated faunas from low-latitude terranes (for example, Newton and others, 1987).

Except where indicated otherwise, higher-level systematic assignments and morphologic terms follow those of Cox and others (1969).

\section{Subclass PTERIOMORPHIA Beurlen, 1944 [emend. Waller, 1978]}

\section{Order PTERIOIDA Newell, 1965}

\section{Family CASSIANELLAUDAE Ichikawa, 1958}

\section{Genus CASSIANELLA Beyrich, 1862}

\section{Cassianella cordillerana n.sp.} (pl. 1, figs. 1-11)

?Cassianella angusta Bittner. Newton, 1986, pl. 2.1. figs. 1-5; Newton and others, 1987, p. 24, figs. 18.7-18.17, 19.1-19.17.

Material.-The collection consists of 42 specimens, all of which are left valves. All specimens are from locality 1 (fig. 2).
Etymology.-The species name refers to its only known occurrence in the North American Cordillera.

Diagnosis.-Large Cassianella specimens exhibiting broad umbo, smooth exterior with short anterior auricle possessing notch at lower junction with anterior flank, with centrally located triangular ligament pit and well-developed anterior septum.

Description.-Left valve of moderate size for genus (length of holotype, $17.9 \mathrm{~mm}$; width of holotype, $9.9 \mathrm{~mm}$ ), left valve exterior smooth, highly convex, and torted, with nearly centrally positioned incurved beak extending well above hinge margin. Central part of flank rounded and steeply sloping to posterior and anterior valve margins. Anterior auricle relatively short $(5-7 \mathrm{~mm})$, with upper surface slightly sloping $\left(6^{\circ}-12^{\circ}\right)$ with respect to hingeline, and lower margin joining valve flank at around $120^{\circ}$ (although in some specimens this angle may be as great as $160^{\circ}$ ). Anterior auricle separating from flank by a single furrow and, in at least two specimens, a lower anterior margin with a distinct notch (see pl. 1, figs. 5, 6). Posterior auricle is likely slightly more extended than anterior auricle and joins posterior flank at a more acute angle (approx $115^{\circ}$ ) and lacking a notch. Hinge plate broad and slightly concave, with numerous very fine lines paralleling hinge margin. Single triangular ligament pit conspicuous below beak is well developed in some valves (for example, pl. 2, fig. 9) and poorly so in others. Left-valve interior with anterior septum sloping obliquely from hinge plate to anterior-ventral position where auricle joins valve flank. Right valves unknown.

Remarks. - The species favorably compares with Cassianella gravinaensis, which Smith (1927) erected on the basis of poorly preserved internal molds from Gravina Island, southeastern Alaska. The new species differs from those described by Smith in that it is more upright, with a more extended anterior and posterior auricles and a straighter hingeline. Although this species compares well with $C$. angusta from the Carnian of northern Italy, the Carpathians, and Turkey (Bittner, 1891, 1895, 1901, Zardini, 1981), it has a distinctively broader umbo. Additionally, the Tethyan species clearly has a more anterior ligament pit, in contrast to the centrally located ligament pit of the new species. Although Newton (1986) and Newton and others (1987) assigned Cassianella specimens from Lower Norian rocks of the Wallowa terrane, Oreg., to $C$. angusta, they noted that their specimens were generally more compressed than their Alpine counterparts. C. cordillerana appears to differ less from the Wallowa material than from the Tethyan species in the positions of its ligament pit and anterior auricular notch, yet the Alaskan species has a typically more extended posterior auricle. This species also favorably compares with $C$. beyrichi, also from the Carnian St. Cassian fauna of northern Italy (Bittner, 1895; Zardini, 1981), but is considerably less inflated. C. cordillerana most certainly differs from the much-larger $C$. lingulata Gabb, well known from Rhaetian rocks of the New York Canyon section in west-central Nevada (Muller and Ferguson, 1939; Laws, 1982) and common in the Tyaughton Creek area of the Cadwaller terrane of British Columbia (McLearn, 
Table 1. Norian bivalvesfrom the Taylor Mountains quadrangle, Alaska.

[Life habits: $B$, byssate; $F$, free lying; $M$, mobile; $N b$, non-siphonate burrower; $R$, reclining; $S$, suspension feeder; Se, sessile. Biogeographic affinities: AL, Alexander terrane; $\mathrm{CH}$, Chulitna terrane; $\mathrm{CR}$, North American craton; $\mathrm{SA}$, South America; WA, Wallowa terrane; WR, Wrangellia composite terrane]

\begin{tabular}{|c|c|c|}
\hline Taxon & Life habit & Biogeography \\
\hline Astarte sp ---.- & $\mathrm{MNbS}$ & ?WA, ?SA \\
\hline Cassianella cordillerana n.sp------ & SeRBS & ?WA \\
\hline Gryphaea arcutaeformis Kiparisova & SeRF & $\mathrm{AL}, ? \mathrm{SA}, \mathrm{CR}$ \\
\hline Maoritrigonia sp -- & MNbS & --- \\
\hline Minetrigonia cf. M. suttonensis (Clapp \& Shimer) ----- & $\mathrm{MNbS}$ & WR, WA \\
\hline Minetrigonia sp------ & $\mathrm{MNbS}$ & --- \\
\hline Septocardia $\mathrm{cf}$. S. peruviana $(\mathrm{Cox})$ & $\mathrm{MNbS}$ & $\mathrm{AL}, \mathrm{CH}$, ?WA, SA \\
\hline Tutcheria densestriata (Körner)------.. & MNbS & WA, SA, WR \\
\hline
\end{tabular}

1942). Much systematic work needs to be done regarding the affinities of Late Triassic cassianellids, which are quite common through the Tethys, Panthalassa, and Arctic seas. For example, Krumbeck (1914) illustrated several smooth cassianellids (Cassianella katialotica and C. verbeeki) from Upper Ladinian or Lower Carnian rocks of Sumatra that, apart from their broad inflation and large size, are nearly identical to both $C$. angusta and $C$. cordillerana. As pointed out by Newton and others (1987), those species from the Arctic, such as C. tectiformis (Böhm, 1903), and from Siberia, illustrated as C. lingulata Gabb by Kiparisova and others (1966), are in need of further study.

Illustrated specimens.-Holotype, UAM No. 2591 (pl. 1, figs. 1, 2); paratypes, UAM Nos. 2592 through 2597 (pl. 1, figs. $3-11$ ).

Order OSTREOIDA Férussac, 1822 [emend. Waller, 1978]

Superfamily OSTREACEA Rafinesque, 1815 [emend. Waller, 1978]

\section{Family GRYPHAEIDAE Vyalov, 1936}

\section{Genus GRYPHAEA Lamarck, 1801}

\section{Gryphaea arcutaeformis Kiparisova, 1936} (pl. 1, figs. 12-19)

Gryphaea arcuataeformis Kiparisova, 1936, p. 133, pl. 4, figs. 1, 2, 4, 6-10; Kiparisova, 1938, pl. 7, figs. 17-21, pl. 8, figs. 1, 2, 11; Vyalov, 1946, p. 30, pl. 2, figs. 1-7, pl. 3, figs. 1, 2; Kiparisova and others, 1966, p. 157, pl. 27, figs. 14-17; McRoberts, 1992, p. 33, figs. 6.1-6.8.

Gryphaea chalkii McLearn, 1937, p. 96, fig. 8.

Material.-The collection consists of two right valves and more than 200 left valves. All specimens are from locality 1 (fig. 2).
Description.-Shells are moderately small (max height, $22.1 \mathrm{~mm}$ ), somewhat narrow (mean height/width ratio, 0.74 ), moderately inflated (mean inflation/height ratio, 0.49 ), with a prosogyrous and occasionally strongly incurved umbo (mean height/periphery ratio, 0.68 ); posterior lobe moderately developed and conical; lobe separated from main part of shell by weak radial sulcus originating from just posterior of beak; surface generally smooth but sometimes covered with faint to moderate commarginal growth lines; attachment area (AA) commonly present but varying in size $(0.5-2.8 \mathrm{~mm})$. Right valve smaller than left, flat to slightly concave and spatulate, with moderately conspicuous commarginal growth lines.

Remarks.-The specimens illustrated here are similar in size, shape (fig. 3; table 2), and external sculpture to those of the syntypes (Kiparisova, 1936), as well as to other specimens of the species (see McRoberts, 1992). Statistical analysis of shape and size variables led McRoberts (1992) to include McLearn's (1937) Gryphaea chalkii within G. arcuataeformis. Additional specimens collected by the first author in the Norian Pardonet Formation of the Williston Lake area are also assigned to this species. Though similar in many regards to G. keilhaui, which mainly occurs in the Arctic regions of Spitsbergen, Russia, Canada, and Alaska (Böhm, 1903; Kiparisova and others, 1966; McRoberts, 1992), G. arcuataeformis has a significantly narrower left-valve breadth and less pronounced posterior flange. G. arcutaeformis is known from Carnian mudrocks of the Wallowa terrane, Oreg. (McRoberts, 1992), and probably also in Norian fauna of the Alexander terrane (Newton, 1983). It is also widespread in Carnian and Norian craton-bound strata mainly from middle to high paleolatitudes in northeastern British Columbia, Arctic Canada, and Siberia (Kiparisova and others, 1966; McRoberts, 1992). A possible Southern Hemisphere occurrence is in the Norian of Chile (Hayami and others, 1977).

Illustrated specimens.--UAM Nos. 2598 through 2602 (pl. 1, figs. 12-19). 
Table 2. Left-valve measurements on Gryphaea arcuataeformis Kiparisova.

[AA, diameter of attachment area]

\begin{tabular}{ccccc}
\hline $\begin{array}{c}\text { Height } \\
(\mathrm{mm})\end{array}$ & $\begin{array}{c}\text { Width } \\
(\mathrm{mm})\end{array}$ & $\begin{array}{c}\text { Periphery } \\
(\mathrm{mm})\end{array}$ & $\begin{array}{c}\text { Inflation } \\
(\mathrm{mm})\end{array}$ & $\begin{array}{c}\text { AA } \\
(\mathrm{mm})\end{array}$ \\
\hline & & & & \\
15.6 & 10 & 24.5 & 8.8 & 2.3 \\
18.4 & 12.7 & 27 & 9.8 & 1.1 \\
20.4 & 15.9 & 33.5 & 9.7 & 2.1 \\
12.3 & 9.6 & 18 & 5.4 & .5 \\
14.6 & 11.7 & 19 & 7.1 & 1.0 \\
15.8 & 14.2 & 23 & 8.1 & 1.5 \\
15.0 & 11.9 & 22 & 8.9 & 1.3 \\
15.6 & 10.3 & 19.5 & 7.7 & 1.3 \\
22.1 & 22.8 & 31 & 11.6 & .6 \\
17.5 & 12.1 & 38 & 8.8 & .6 \\
16.6 & 13 & 25 & 6.6 & 2.8 \\
14.8 & 10.7 & 19 & 6.5 & 1.6 \\
19.9 & 11.9 & 31 & 10 & 2.2 \\
15.2 & 11.7 & 23 & 8.7 & 1.7 \\
17.6 & 9.9 & 26 & 7.9 & 2.7 \\
17.4 & 10.4 & 22 & 7.2 & 1.7 \\
\hline
\end{tabular}
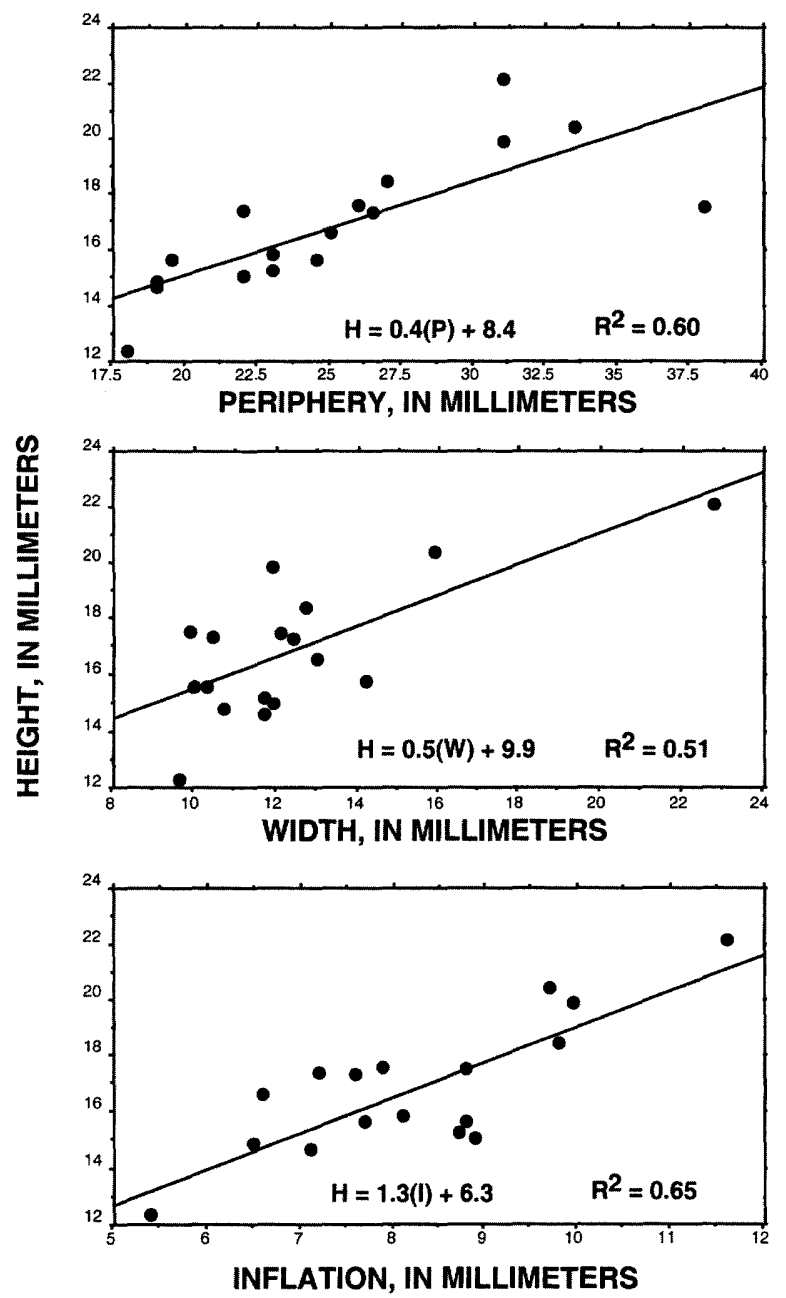

Figure 3. Scatterplot of measurements on Gryphaea arcuataeformis Kiparisova.
Order TRIGONIOIDA Dall, 1889

Superfamily TRIGONIACEA Lamarck, 1819

Family MINETRIGONIIDAE Fleming, 1982

Genus MAORITRIGONIA Fleming, 1962

Maoritrigonia sp.

(pl. 1, figs. 20, 21)

"Myophoria"sp. Tozer, 1963, p. 26, pl. 12, fig. 10.

Material.-The collection consists of one partial left valve and one fragmented articulated valve pair. Both specimens are from locality 2 (fig. 2).

Description.-Shell small, triagonal to subtrapezoidal in outline, longer than high, flank covered with about seven angular tubercular radial ribs with relatively rounded and smooth interrib spaces; valve interiors not observed.

Remarks. - The specimens are somewhat small for the genus and may represent juveniles. Tozer (1963) illustrated a nearly identical specimen from the Norian Sutton Formation of Vancouver Island. They are similar to Maoritrigonia columbiana (McLearn) from British Columbia, Canada. M. multicostata from the Norian of Peru (listed as Myophoria multicostata by Körner, 1937, pl. 7, fig. 3) is also similar in size and subtrapezoidal shape and in details of sculpture but has more pronounced commarginal ribs across the valve flank. These differences in sculpture may reflect the relatively poor preservation of the Taylor Mountains fauna. These specimens are distinguishable from the New Zealand species Maoritrigonia waddicki described by Fleming (1987) by their smaller size and absence of distinct ornament on the area.

Illustrated specimens.-UAM Nos. 2603 and 2604 (pl. 1, figs. 20-21).

\section{Genus MINETRIGONIA Kobayashi and Katayama, 1938}

\section{Minetrigonia cf. M. suttonensis (Clapp and Shimer, 1911) (pl. 1, fig. 22)}

Myophoria suttonensis Clapp and Shimer, 1911, p. 433, pl. 41, figs. 12-14; Smith, 1927, p. 110, pl. 105, fig. 2; Tozer, 1963, p. 26, pl. 12, figs. 9a, 9b; Tozer, 1970, pl. 18, figs. 16a, $16 \mathrm{~b}$.

Material.-A single right valve from locality 1 (fig. 2).

Description.-The specimen is large (height, 16.4 $\mathrm{mm}$; length, $14.8 \mathrm{~mm}$ ), and moderately inflated (valve inflation, $6.1 \mathrm{~mm}$ ), trigonally suboval in outline, with a rounded anterior; beak situated slightly anterior, sculpted with about 18 radial ribs covered with numerous small knoblike projections that appear to be extensions of commarginal ornament; posterior dorsal area separated from flank by angular marginal carina radiating from beak and extending to posterior ventral margin; marginal carina gen- 
erally smooth; area covered with less conspicuous, slightly curved, radial ribs; valve interior unknown.

Remarks.-The specimen at hand is almost identical to Minetrigonia suttonensis (Clapp and Shimer), known primarily from Cowichan Lake, Vancouver Island, Canada (Wrangellia composite terrane), and, possibly, the Shasta area, Calif. (Eastern Klamath terrane). It may be conspecific with "Myophoria cairnes" from the Tyaughton Creek area, British Columbia, Canada (Caldwaller terrane). It is distinguishable from the other Minetrigonia specimens from locality 1 (fig. 2) in its smaller size and difference in sculpture on the area. The specimen differs from other Carnian minetrigoniids, such as Myophorigonia kobayashi from the Wallowa terrane, Oreg. (Tamura and McRoberts, 1993), which is ornamented by a transverse trellised ornament in the posterior area.

Illustrated specimen.-UAM No. 2605 (fig. 3.22).

\section{Minetrigonia sp.}

(pl. 1, figs. 23, 24)

Material.-The collection consists of a partial right valve. Two additional fragments are questionably assigned to this species. All specimens are from locality 1 (fig. 2).

Description.-Shell large, oval to trigonal in outline; umbo broad and rounded; surface of flank covered with numerous fine radial ribs; ribs generally rounded, with small and smooth interspaces and crossed with fine commarginal costellae; marginal carina weakly angular; posterior area mostly smooth early in ontogeny, later becoming transversed by oblique to almost-commarginal costellae. Trigoniid-grade dentition with conspicuous diverging cardinal teeth; anterior cardinal tooth (3a) nearly vertical, sloping slightly anterior, and about half the length of posterior tooth ( $3 b$ ) that is slightly narrower and runs at a less steep angle nearly parallel to hinge; both teeth covered with transverse ridges somewhat obscured by poor silicification.

Remarks.-The specimens are somewhat large for the genus but clearly have external sculpture and dentition characteristic of the genus. A survey of Triassic minitrigoniids reveals no described species similar in size and sculpture to that illustrated here; therefore, they probably represent a new species.

Illustrated specimen.-UAM No. 2606 (pl. 1, figs. 23, 24).

\section{Order VENEROIDA Adams and Adams, 1854-58}

\section{Superfamily CARDITACEA Fleming, 1822}

\section{Family CARDITIDAE Fleming, 1828}

\section{Genus TUTCHERIA Cox, 1946}

Tutcheria densestriata (Körner, 1937)

(pl. 2, figs. 1-6)
Table 3. Measurements on Tutcheria densestriata (Körner).

\begin{tabular}{|c|c|c|}
\hline Valve & $\begin{array}{c}\text { Length } \\
(\mathrm{mm})\end{array}$ & $\begin{array}{c}\text { Height } \\
(\mathrm{mm})\end{array}$ \\
\hline Left & 6.5 & 6.4 \\
\hline Right -...--..- & 7.2 & 7.7 \\
\hline Left - - & 7.1 & 6.9 \\
\hline Left - - - & 7.9 & 7.8 \\
\hline
\end{tabular}

Cardium densestriatum Körner, 1937, p. 196, pl. 12, figs. $9 \mathrm{a}-9 \mathrm{c}$.

Tutcheria densestriata (Körner) Cox, 1949, p. 30, pl. 2, fig. 8; Newton, 1986, p. 13, pl. 21, figs. 8, 9; Newton and others, 1987 , p. 69 , figs. 52.1-52.5.

Tutcheria cf. T. densestriata (Körner) Tozer, 1963, pl. 12, figs. 20a, 20b.

Material.-The collections consists of four left valves and one partial right valve. All specimens are from locality 1 (fig. 2).

Description.-Shells small (mean height, $7.2 \mathrm{~mm}$; mean length, $7.2 \mathrm{~mm}$ ), moderately inflated, circular in outline, beak central (table 3 ). Surface covered with numerous (more than 50) thin radial ribs that run rather straight in central part of disc and slope slightly away from medial position in an anterior and posterior direction; one or more widely spaced but distinct commarginal growth lines may be present. Lunule deep. Left-valve interior with long ligament groove above moderately narrow hinge plate. Leftvalve cardinal dentition poorly preserved, consisting of a triangular socket below beak, presumably to accept triangular cardinal tooth $(3 \mathrm{~b})$ of the right valve; with a short anteriorly sloping tooth (2) just in front of socket; welldeveloped posterior lateral tooth (P II) extending nearly horizontally, comprising lower margin of hinge, continuing for about a third of the distance to posterior extremity of hinge margin; anterior lateral shorter and less well developed but joining lunule margin. Right-valve dentition not observed.

Remarks.-External and internal morphology permit confident assignment to the genus Tutcheria as defined by Cox (1946). Although the material is somewhat smaller than the original type specimens of this species from Peru (Körner, 1937), the specimens from the Taylor Mountains quadrangle exhibit similar shape, external morphology, and hinge features. With the examination of additional material, Cox (1949) transferred Körner's type from the Norian of southern Peru to this genus. They also appear to be identical to those illustrated from the Wallowa terrane, Oreg., by Newton and others (1987).

Illustrated specimens._UAM Nos. 2607 through 2609 (pl. 2, figs. 1-6). 
Superfamily CRASSATELLACEA Férussac, 1822

Family ASTARTIDAE d'Orbigny, 1844

Genus ASTARTE J. Sowerby, 1815-21

Astarte sp.

(pl. 2, figs. 7, 8)

Material.-The collection consists of three articulated valve pairs and a single right valve. All specimens are from locality 1 (fig. 2).

Description.-Shells small (mean height, $5.2 \mathrm{~mm}$, mean length, 4.9), moderately compressed, subtrigonal in outline, beak slightly anterior. Surface ornamented with five or six commarginal concentric folds more conspicuous in beak and becoming weaker later in ontogeny; one specimen (pl. 2, fig. 7) exhibits very faint radial sculpture. Valve interiors not observed.

Remarks.-Although valve interiors are not observable on any of the specimens, their small size, shape, and distinctive commarginal ornament permit assignment to Astarte. Small sample size and absence of valve interior preclude specific designation. This genus is common through out much of the marine Triassic. Newton and others (1987) described externally similar species from the Wallowa terrane, Oreg.

Illustrated specimens.-UAM Nos. 2610 and 2611 (pl. 2, figs. 7, 8).

\section{Superfamily CARDIACEA Lamarck, 1809}

\section{Family CARDIIDAE Lamarck, 1809}

\section{Genus SEPTOCARDIA Hall and Whitfield, 1877}

\section{Septocardia ef. S. peruviana (Cox, 1949)}

\section{(pl. 2, figs. 5-14)}

Pascoella peruviana Cox, 1949. p. 35, pl. 1, figs. 9, 12a, 13, 14, non pl. 2, fig. 5 .

?Septocardia sp. Newton and others, 1987, p. 77, fig. 60.

Material.-The collection consists of five left valves and four right valves, and numerous fragments from at least 21 individuals. All specimens are from locality 1 (fig. 2).

Description.-Valves moderately large (mean height, 18.8; mean length, $19.3 \mathrm{~mm}$ ) and moderately convex (mean valve inflation, $7.8 \mathrm{~mm}$ ), equivalved and nearly equilateral, with beaks positioned only slightly anterior (see table 4 ). Shell exterior sculpted by numerous angular ribs radiating from beak. Number of ribs varies (19-24, mean 21), yet they do not divide or intercalate with interrib spaces. Radial ribs are crossed by numerous fine, evenly spaced commarginal sculpture. Hinge sloping from beak; dorsal region consists of flattened ligamental groove bordered by nymphs; dentition consists of trigonal, centrally located, cardinal tooth in right valve and corresponding socket in left valve. Lateral dentition
Table 4. Measurements on Septocardia cf. S. peruviana (Cox).

\begin{tabular}{cccccc}
\hline Valve & $\begin{array}{c}\text { Length } \\
(\mathrm{mm})\end{array}$ & $\begin{array}{c}\text { Height } \\
(\mathrm{mm})\end{array}$ & $\begin{array}{c}\text { Inflation } \\
(\mathrm{mm})\end{array}$ & $\begin{array}{c}\text { Umbonal } \\
\text { angle }\left(^{\circ}\right)\end{array}$ & $\begin{array}{c}\text { Rib } \\
\text { number }\end{array}$ \\
\hline Right & 19.4 & 17.6 & 8.3 & 111 & 24 \\
Right & 18 & 16.8 & 7.6 & 108 & 22 \\
Left & 15.7 & 16 & 6.3 & 93 & 21 \\
Left & 23.5 & 23.3 & 8.5 & 120 & 19 \\
$?$ & -- & -- & 8.1 & 111 & 21 \\
Left & 19.7 & 20.1 & 8.2 & 98 & 20 \\
\hline
\end{tabular}

consists of a single, sloping anterior lateral tooth in right valve and two anterior laterals in left valve. Posterior lateral dentition well developed. Anterior (and ventral) to lateral dentition is deep circular anterior-adductor scar positioned immediately ventral to hinge margin; anterior scar is separated from rest of valve interior by septum present in both valves. Interior margins crenulated for first 2 or $3 \mathrm{~mm}$ from valve margin, corresponding to exterior radial ribs.

Remarks.-Specimens attributed to Septocardia from locality 1 (fig. 2) appear to be most similar to those from the Norian of Peru (originally named Pascoella peruviana by Cox, 1949). Some distinct differences exist between the Taylor Mountains specimens and the genotype S. typica named by Hall and Whitfield (1877) from Nevada. Although the type locality and horizon of this Nevada material are unclear, further examination of the specimens led L.R. Cox to accept them as a possible senior synonym of his Peruvian species (see Silberling, 1959, p. 60). Other specimens from Nevada, such as those that Silberling illustrated of Septocardia sp., appear to be similar in size and external morphology; however, their valve interiors remain unknown. Similar specimens are also known from the Wallowa terrane, Oreg. (Newton and others, 1987). This species shows several differences in both shape and interior characteristics from those from Alaska that were illustrated by Keen $(1969$, p. N586, fig. E85, 1d, 1e). The locality of Keen's specimen was never reported, but it probably came from a silicified Norian fauna from Keku Strait, Alaska (N.J. Silberling, written commun., 2001). These specimens may be from the same locality as those reported from Keku Strait by Newton (1983), who, using the name "S. pascoensis (Cox)," noted that they are thicker shelled than other Septocardia from North America. Although other occurrences of Septocardia from Alaska are known (see Newton, 1983; Blodgett and others, 2000), they have not been described or illustrated. Additionally, as pointed out by Newton and others (1987), the relation between Septocardia and Palaeocardita remains unclear at best. For example, specimens reported as Palaeocardita globiformis by Vu Khuc (1991) may likely be transferred to Septocardia once internal structures become known.

Two of the specimens (pl. 2, figs. 9, 13) exhibit small ( 3 $\mathrm{mm}$ diam) circular holes that are centrally positioned on the umbo, approximately $4.5 \mathrm{~mm}$ from beak, which may represent predatory drill holes similar to those produced by naticid gastropods.

Illustrated specimens.-UAM Nos. 2612 through 2614 (pl. 2, fig. 9-14). 
Class GASTROPODA Cuvier, 1797

[Materials for this class were prepared by R.B. Blodgett]

Discussion.-Many silicified gastropods are present in the fossil collection from locality 1 (fig. 2). Altogether, 11 species appear to be present (table 5); however, the state of preservation is so poor and incomplete that several of the taxa remain generically indeterminate. The following forms can be identified with some degree of confidence: Neritaria nuetzeli n.sp. (pl. 2, figs. 16-19), Zygopleura? sp. (pl. 3, fig. 15), Chulitnacula alaskana (Smith, 1927) (pl. 2, fig. 15), Andangularia wilsoni n.sp. (pl. 3, figs. 1, 2), Cryptaulax aff. C. tilarniocensis Haas, 1953 (pl. 3, figs. 3-9), Coelostylina cf. C. cylindrata Haas, 1953 (pl. 3, fig. 12), Omphaloptycha aff. O. jenksi Haas, 1953 (pl. 3, figs. 13, 14), Omphaloptycha? sp. (pl. 3, figs. 10, 11), and Toxoconcha cf. T. gracilis Haas, 1953 (pl. 3, figs. 20, 21). No gastropods were recovered from locality 2 (fig. 2 ).

\section{Subclass NERITOMORPHA Golikov \& Starobogatov, 1975}

\section{Superfamily NERITOIDEA Rafinesque, 1815}

\section{Family NERITIDAE Rafinesque, 1815}

\section{Subfamily NERITINAE Rafinesque, 1815}

\section{Genus NERITARIA Koken, 1892}

\section{Neritaria nuetzeli n.sp.}

(pl. 2, figs. 16-19)

Material.-A total of 17 specimens from locality 1 (fig. 2).

Etymology.-The species name is in honor of the gastropod worker Alexander Nützel of Erlangen, Germany.

Diagnosis - Globose species of Neritaria with narrow, subpyriform aperture and strongly thickened inner and outer lips.

Description.-Small, strongly globose, smooth naticiform shell; spire low, rounded, not protruding, number of whorls uncertain due to sutures not being impressed, but probably few in number, protoconch not preserved; aperture subpyriform, narrow for genus; parietal lip with wide bandlike callus bearing a strong, rounded swelling on lower part just above its juncture with inner lip, which is strongly thickened; outer lip also thick but less so than inner lip; base seemingly anomphalous or cryptomphalous. Dimensions of holotype: height, 4.1 $\mathrm{mm}$; width, $3.8 \mathrm{~mm}$.

Remarks.-The strongly globose shell shape of Neritaria nuetzeli $\mathrm{n}$.sp. with its nonprotruding spire readily distinguishes it from most species attributed to this genus. It differs from the type species, $N$. similis Koken [=N. plicatilis (Klipstein)], from the Raibler Schichten of the southern Alps in being more rounded, lower spired, and lacking subsutural ribs developed on the spiral whorls. Among the species of this genus described by Haas (1953) from Norian strata of Peru, it most closely approaches $N$. dicosmoides Haas, in that both species are rather globose. Nevertheless, it is easily distinguished by
Table 5. Gastropod taxa recognized at locality 1 (fig. 2).
Number of specimens
Andangularia wilsoni $\mathrm{n} . \mathrm{sp}-----------$ Chulitnacula alaskana (Smith) ---------------------Coelostylina cf. C. cylindrata HaasCryptaulax aff. C. tilamiocensis Haas --.---.---.--Genus and species indeterminate 1 (high spired) --Genus and species indeterminate 2 (low spired) ---Katosira sp

Neritaria nuetzeli $\mathrm{n.sp}-$

Omphaloptycha aff. O. jenksi Haas-----------------

Omphaloptycha? sp-

Toxoconcha cf. T. gracilis Haas----------------------

its much more rounded shell shape, narrower aperture, and much thicker outer lip. It differs from $N$. hologyroides Haas in lacking teeth on its inner lip and in being much lower spired, and from $N$. ninacacana Haas in being much more globose, in lacking the well-impressed sutures of $N$. ninacacana Haas, and in having a much more markedly thickened outer lip. It differs from $N$. obliqua Haas in having a more globose, distinctly lower spired shell shape, and from $N$. distincta Haas in being more globose, less high spired, and lacking the well-developed growth striae exhibited by this species.

Illustrated specimens.-Holotype, UAM No. 2616 (pl. 2, figs. 16, 17); paratype, UAM No. 2617 (pl. 2, figs. 18, 19).

\section{Subclass CAENOGASTROPODA Cox, 1960}

\section{Order PTENOGLOSSA Gray, 1853}

\section{Family PROTORCULIDAE Bandel, 1991}

\section{Genus CHULITNACULA Frýda \& Blodgett, 2001}

\section{Chulitnacula alaskana (Smith, 1927) \\ (pl. 2, fig. 15)}

Protorcula alaskana Smith, 1927, p. 109, pl. 103, figs. 9, 10. Chulitnacula alaskana (Smith, 1927) new combination, Frýda and Blodgett, 2001, p. 217, figs. 2.1-2.4, 3.1-3.3.

Material.-Nine poorly preserved specimens from locality 1 (fig. 2).

Remarks.-Chulitnacula alaskana is represented here by nine specimens that represent the largest gastropod species in the collection. The teleoconch of this species closely resembles that of gastropods from the Chulitna terrane in general shape; however, the coarsely silicified characteristics of gastropods from the Farewell terrane did not allow for preservation of the finer spiral elements of ornamentation.

This species also is very abundant in late Norian strata of the Chulitna terrane of south-central Alaska (Blodgett and Clautice, 2000; Frýda and Blodgett, 2001). The type material of Chulitnacula alaskana (Smith, 1927), which is from the Chulitna terrane of south-central Alaska, was collected on 
July 15,1917 , by S.R. Capps of the U.S. Geological Survey (USGS), who was leading a USGS geologic field-mapping party in the upper Chulitna region. The locality cited by Smith (1927, p. 109) is USGS Mesozoic locality 10093, which is noted as "Copeland Creek at Camp July 14." This locality, consisting of stream gravels along Copeland Creek, is in the Healy A-6 1:63,360-scale quadrangle. Further information on this locality was reported by Martin (1926, p. 44), who cited it as a "stream bar of Copeland Creek." Subsequently, Smith named the species Protorcula alaskana on the basis of material collected by Capps at USGS Mesozoic locality 10093, and indicated it to be of probable Carnian age. Two specimens were illustrated by Smith (1927, pl. 103, figs. 9, 10), with the holotype designated as the specimen shown in his figure 9. Additional specimens of this species were discovered at three localities (118, 120, and 151 of Blodgett and Clautice, 2000) during the 1997-98 field-mapping effort by the Alaska Division of Geological and Geophysical Surveys in the Healy A-6 1:63,360-scale quadrangle of south-central Alaska.

Chulitnacula alaskana (Smith) also is present in the Alexander terrane of southeastern Alaska (Blodgett and Frýda, 2001; Frýda and Blodgett, 2001; Sandy and others, 2001), where it is known from USGS Mesozoic locality M1912, collected by N.J. Silberling and L.J.P. Muffler in 1963. The locality is in limestone beds of late Norian age within the Hound Island Volcanics on Kuiu Island in the Port Alexander D-1 1:63,360-scale quadrangle (Muffler, 1967, pl. 1, loc. 29). According to Muffler (1967, p. C43), this locality is on a cove $3 \mathrm{~km}$ north of the west end of Kadak Bay on Kuiu Island and is of late Norian age.

Illustrated specimen.-UAM No. 2615 (fig. 5.15).

\section{Order CERITHOMORPHA Golikov \& Starobogatov, 1975}

\section{Family PURPURINIDAE Zittel, 1881-95}

\section{Genus ANDANGULARIA Haas, 1953}

\section{Andangularia wilsoni $\mathrm{n.sp}$.}

(pl. 3, figs. 1, 2)

Material.--One specimen from locality 1 (fig. 2).

Etymology.-This species is named in honor of Frederic H. ("Ric") Wilson of the USGS, Anchorage, Alaska.

Diagnosis.-Andangularia with a relatively short, squat shell and strong, transverse ribs that extend entire length of spiral whorl surface and more than half of final whorl surface.

Description.-Small (height, $\max 7.0 \mathrm{~mm}$ ), high-spired, turreted shell of relatively squat appearance; as many as six whorls, protoconch not preserved, sutures weakly impressed; upper whorl surface flat, ramplike, delimited by conspicuous angulation with outer whorl surface; base elongate and rounded, anomphalous, strong transverse ribs developed, numbering about six per volution, extending full length of spiral whorls and more than half the length of final whorl, extending outward as pointed spikelike projections at their upper termi- nation at angulation separating outer and upper whorl surfaces; inner lip rounded, characteristics of outer lip unknown.

Remarks.--The purpurinid gastropod genus Andangularia was previously known from only two species described from the Norian of Peru. A. wilsoni n.sp. differs from the Peruvian type species A. armatus (Jaworski, 1923) in having a slightly broader, squatter shell. In addition, its transverse ribs are much less numerous, more widely spaced, and extend much farther over the whorl surface. Another distinct Peruvian species of Andangularia was described and illustrated by Haas (1953) as Andangularia aff. A. subarmatae (Jaworski). This species also differs in having a narrower shell, but it more closely approaches the new Alaskan species in having more welldeveloped transverse ribs, although the ribs in Haas' species are more numerous and more closely spaced.

An undescribed new species of Andanguaria is also present in the late Norian or Rhaetian "Lewiston fauna" of Idaho (belonging to the Wallowa terrane). The gastropods of this fauna are currently being studied by Alex Nützel of Erlangen, Germany, who graciously sent photographs of the Idaho species. It differs from the Alaskan species in being much narrower, having relatively higher whorls, and having transverse ribs that are less continuous over the whorls.

Illustrated specimen.--Holotype, UAM No. 2620 (pl. 3, figs. 1,2).

\section{Biogeographic Remarks and Conclusions}

Taxonomic composition and paleoecologic associations suggest similarities to other low-latitude accreted terranes of southern Alaska. At least for the bivalves, the greatest similarity appears to be with the Alexander terrane, whose fauna (listed by Newton, 1983) has not been adequately illustrated but includes Cassianella, Septocardia, Gryphaea, and Minetrigonia. Limited similarity in bivalve species exists with inboard island-arc terranes (for example, the Wrangellia composite terrane and the Wallowa terrane); however, except for the Wallow terrane, Oreg. (for example, Newton and others, 1987), too little is known about the Norian bivalve faunas of other terranes to make any meaningful comparison. Striking similarities also exist between the bivalve faunas from the Norian of Peru and those from the Taylor Mountains quadrangle. Most notable among the similarities is the cooccurrence of Septocardia peruviana (Cox), which is quite distinct from other species of North America Septocardia (see Newton, 1983). Except for some widespread species, such as Gryphaea arcuataeformis Kiparisova, there is very little similarity with craton-bound Norian strata in British Columbia, Canada, and para-allochthonous strata of the Great Basin (for example, the Luning and Gabbs Formations in Nevada).

The most obvious gastropod in the collection, Chulitnacula alaskana (Smith, 1927), is a common to dominant element in late Norian strata of three separate accreted terranes of southern Alaska: the Chulitna, Farewell, and Alexander terranes. The common presence of this taxon may indicate 
that these terranes were in close reproductive communication during Late Triassic time (Blodgett and Frýda, 2001; Frýda and Blodgett, 2001). We note that this species is not known from coeval strata of either the Wrangellia composite terrane or the Wallowa terrane. Much of the remaining gastropod fauna illustrated here includes several taxa that appear to be closely allied, if not conspecific, with Norian gastropods described from Peru by Haas (1953). None of these Norian gastropod species occurs in craton-bound Norian strata of Nevada (notably from the Clan Alpine Mountains) and Sonora (Jiri Frýda and R.B. Blodgett, unpub. data). The strong similarity of the gastropod fauna from the Farewell terrane to that of Peru is also supported by the features of the two new species established here, Neritaria nuetzeli and Andangularia wilsoni, both of which find their closest related forms among Norian species described from Peru.

\section{Acknowledgments}

We are grateful to Norman J. Silberling of Denver, Colo. (formerly of the USGS), for making known the unpublished occurrence of Upper Triassic rocks at locality 1 (fig. 2) to us in 1984, and to the Sohio Oil Co. and especially Bob Egbert and Ray Sullivan of San Francisco State University, who were helpful in the field reconnaissance of the region and during an earlier visitation together with the second author to locality 1 in late June 1984. We also thank Frederic H. ("Ric") Wilson of the USGS, Anchorage, Alaska, for providing logistical helicopter support in 1999, which made possible detailed collection of both studied localities. The first author was supported by National Science Foundation grant EAR-9706040. We thank the National Geographic Society's Committee for Exploration and Research for funding a study of the Late Triassic gastropod faunas of western North America. We thank Tom Yancey, Art Boucot, and Jacqueline Scallan for their reviews of the manuscript, and George Havach, Jim Hendley, and Peter Stauffer for their editorial remarks.

\section{References Cited}

Adams, Henry, and Adams, Arthur, 1854-58, The genera of recent Mollusca; arranged according to their organization: London, John van Voorst, $484 \mathrm{p}$.

Adrain, J.M., Chatterton, B.D.E., and Blodgett, R.B., 1995, Silurian trilobites from southwestern Alaska: Journal of Paleontology, v. 69, no. 4, p. 723-736.

Bandel, Klaus, 1991, Über triassische “Loxonematoidea” und ihre Beziehungen zu rezenten und paläozoischen Schnecken: Paläontologisches Zeitschrift, v. 65, no, 3-4, p. 239-268.

Beurlen, Karl, 1944, Beiträge zur Stammesgeschichte der Muscheln: München Akademie Sitzungsberichte, v. 11, p. 113-131.

Beyrich, Ernst, 1862, Zwei aus dem deutschen Muschelkalk noch nicht bekannte Avicula-artige Muscheln: Zeitschrift der Deutscher Geologischer Gesellschaft, v. 14, p. 9-10.
Bittner, Alexander, 1891, Triaspetrefakten von Balia in Kleinasien: Jahrbuch der K.K. Geologischer Reichsanstalt Abhandlung, v. 41, p. 97-116.

1895, Lamellibranchiaten der alpine Trias. I Theil, Revision der Lamellibranchiaten von St. Cassian: Geologische Reichsanstalt Abhandlungen, v. 18, no.1, p. 1-235.

_- 1901, Trias Brachiopoda and Lamellibranchiata, pt. 2 of Himálayan fossils (Palaeontology of India, ser. 15): Geological Survey of India Memoir 3, p. 1-76.

Blodgett, R.B., 1998, Emsian (Late Early Devonian) fossils indicate a Siberian origin for the Farewell terrane, in Clough, J.G., and Larson, Frank, eds., Short notes on Alaska geology 1997: Alaska Division of Geological and Geophysical Surveys Professional Report 118, p. 53-61.

Blodgett, R.B., and Boucot, A.J., 1999, Late Early Devonian (late Emsian) eospiriferinid brachiopods from Shellabarger Pass, south-central Alaska, and their biogeographic importance; further evidence for a Siberian origin of the Farewell and allied Alaskan accreted terranes: Senckenbergiana Lethaea, v. 79, no. 1, p. 209-221.

Blodgett, R.B., and Brease, P.F., 1997, Emsian (late Early Devonian) brachiopods from Shellabarger Pass, Talkeetna C-6 quadrangle, Denali National Park, Alaska indicate Siberian origin for Farewell terrane [abs.]: Geological Society of America Abstracts with Programs, v. 29, no. 5, p. 5.

Blodgett, R.B., and Clautice, K.H., 2000, Fossil locality map for the Healy A-6 Quadrangle, south-central Alaska: Alaska Division of Geological \& Geophysical Surveys Report of Investigations 2000-5, 42 p., scale 1:63,360.

Blodgett, R.B., and Frýda, Jiri, 2001, Upper Triassic gastropod biogeography of western North America [abs.]: Geological Society of America Abstracts with Programs, v. 33, no. 3, p. A-53.

Blodgett, R. B., Frýda, Jiri, and Stanley, G.D., Jr., 2001, Delphinulopsidae, a new neritopsoidean gastropod family from the Upper Triassic (Carnian) of the Wallowa terrane, northeastern Oregon: Czech Geological Society Journal, v. 46, no. 3-4, p. 221-232.

Blodgett, R.B., Rohr, D.M., and Boucot, A.J., in press, Paleozoic linkages among some Alaskan accreted terranes and Siberia based on megafossils, in Miller, E.L., Grantz, Art, and Klemperer, Simon, eds., Tectonic evolution of the Bering Shelf-Chukchi Sea-Arctic margin and adjacent landmasses: Geological Society of America Special Paper.

Blodgett, R.B., and Wilson, F.H., 2001, Reconnaissance geology north of the Hoholitna River, Taylor Mountains D-1 1:63,360-scale quadrangle, southwestern Alaska, in Gough, L.P., and Wilson, F.H., eds., Geologic studies in Alaska by the U.S. Geological Survey, 1999: U.S. Geological Survey Professional Paper 1633, p. 1-10.

Blodgett, R.B., Wilson, F.H., Stanley, G.D., Jr., McRoberts, C.A., and Sandy, M.R., 2000, Upper Triassic stratigraphy and fauna of the Taylor Mountains D-2 and D-3 quadrangles (SW part of the Farewell terrane), southwest Alaska [abs.]: Geological Society of America Abstracts with Programs, v. 32, no. 6, p. A-4.

Böhm, Johannes, 1903, Über die obertriadische Fauna der Bäreninsel: K. Svenska Vetenskapsakademiens Handlingar, v. 37, no. 3, 76 p.

Bundtzen, T.K., Laird, G.M., Blodgett, R.B., Clautice, K.H., and Harris, E.E., 1994, Geology of the Gagaryah River area, Lime Hills C-5 and $\mathrm{C}-6$ quadrangles, southwest Alaska: Alaska Division of Geological \& Geophysical Surveys Public-Data File 94-40, 17 p., scale $1: 63,360$.

Cady, W.M., Wallace, R.E., Hoare, J.M., and Webber, E.J., 1955, The central Kuskokwim region, Alaska: U.S. Geological Survey Professional Paper 268, $132 \mathrm{p}$. 
Clapp, C.H., and Shimer, H.W., 1911, The Sutton Jurassic of the Vancouver Group, Vancouver Island: Boston Society of Natural History Proceedings, v. 47, no. 12, p. 426-438.

Cuvier, Georges, 1797, Tableau élémentaire de l'histoire naturelle des animaux: Paris, $710 \mathrm{p}$.

Cox, L.R., 1946, Tutcheria and Pseudopis, new lamellibranch genera from the Lias: Malacological Society of London Proceedings, v. 27, p. 34-48.

1949, Molluscos del Triásica superior del Perú: Instituto Geológico Perú Boletim, v. 12, p. 1-50.

1960, Thoughts on the classification of the Gastropoda: Malacological Society of London Proceedings, v. 33, p. 239-261.

Cox, L.R., Newell, N.D., Boyd, D.W., Branson, C.C., Casey, R.E., Chavan, André, Coogan, A.H., Dechaseaux, Colette, Fleming, C.A., Haas, F., Hertlein, L.G., Kauffman, E.G., Keen, A.M., LaRocque, Aurèle, McAlester, A.L., Moore, R.C., Nuttall, C.P., Perkins, B.F., Puri, H.S., Smith, L.A., Soot-Ryen, T., Stenzel, H.B., Trueman, E.R., Turner, R.D., and Weir, John, 1969, Bivalvia, v. 1-2 of Mollusca 6, pt. N of Moore, R.C., ed., Treatise on invertebrate paleontology: Boulder, Colo., Geological Society of America, p. N1-N952.

Dall, W.H., 1889, On the hinge of pelecypods and its development with an attempt toward a better subdivision of the group: American Journal of Science, ser. 3, v. 38, no. 3, p. 445-462.

Decker, John, Bergman, S.C., Blodgett, R.B., Box, S.E., Bundtzen, T.K., Clough, J.G., Coonrad, W.L., Gilbert, W.G., Miller, M.L., Murphy, J.M., Robinson, M.S., and Wallace, W.K., 1994, Geology of southwestern Alaska, in Plafker, George, and Berg, H.C., eds., The geology of Alaska, v. G-1 of The geology of North America: Boulder, Colo., Geological Society of America, p. 285-310.

d'Orbigny, A.D., 1844, Lamellibranches, v. 3 of Terrains crétacés (Paléontologie française, ser. 1): Paris, G. Masson, 807 p.

Dumoulin, J.A., Harris, A.G., Gagiev, Mussa, Bradley, D.C., and Repetski, J.E., in press, Lithostratigraphic, conodont, and other fossil links between Lower Paleozoic strata in northern and central Alaska and northeastern Russia, in Miller, E.L., Grantz, Art, and Klemperer, Simon, eds., Tectonic evolution of the Bering Shelf-Chukchi Sea-Arctic margin and adjacent landmasses: Geological Society of America Special Paper.

Férussac, A.E., 1822, Tableaux systématiques des animaux mollusques classés en familles naturelles: Paris, A. Bertrand, $111 \mathrm{p}$.

Fleming, C.A., 1962, Two new genera of Triassic Trigoniidae from New Zealand: Malacological Society of London Proceedings, v. 35, no. 1, p. 1-4.

1982, The family name of radially ribbed Trigoniacea (Bivalvia): Journal of Paleontology, v. 56, no. 3, p. 820-821.

1987, New Zealand Mesozoic bivalves of the superfamily Trigoniacea: New Zealand Geological Survey Paleontological Bulletin, v. 53, p. 1-104.

Fleming, John, 1822, The philosophy of zoology; or a general view of the structure, functions, and classification of animals: Edinburgh, Archibald Constable \& Co., 2 v.

1828, A history of British animals: Edinburgh, Bell \& Bradfute, 565 p.

Frýda, Jiri, and Blodgett, R.B., 2001. Chulitnacula, a new paleobiogeographically distinctive gastropod genus from Upper Triassic strata in accreted terranes of southern Alaska: Czech Geological Society Journal, v. 46, no. 3-4, p. 213-220.

Golikov, A.N., and Starobogatov, Y.I., 1975, Systematics of prosobranch gastropods: Malacologia, v. 15, p. 185-232.

Grant-Mackie, J.A., and Silberling, N.J., 1990, New data on the Upper Triassic bivalve Monotis in North America, and the new subgenus Pacimonotis. Journal of Paleontology, v. 64, no. 2, p. 240-254.
Gray, J.E., 1853, On the divisions of ctenobranchous gasteropodous Mollusca into larger groups and families: Annals \& Magazine of Natural History, 2, v. 11, p. 124-133.

Haas, Otto, 1953, Mesozoic invertebrate faunas of Peru: American Museum of Natural History Bulletin, v. 101, 328 p.

Hall, James, and Whitfield, R.P., 1877, Paleontology, v. 4 of U.S. Geological Survey exploration of the 40th Parallel: U.S. Geological Survey Report 2, p. 197-302.

Hayami, Itaru, Maeda, Shiro, and Fuller, C.R., 1977, Some late Triassic Bivalvia and Gastropoda from the Domeyko Range of north Chile: Palaeontological Society of Japan Transactions and Proceedings, new ser., v. 108, p. 202-221.

Ichikawa, Koichiro, 1958, Zur Taxonomie und Phylogeni der triadschen "Pteriidae" (Lamellibranch), mit besonderer Berücksichtigung der Gattung Claraia, Eumorphotis, Oxytoma und Monotis: Palaeontographica, pt. A, v. 3, p. 131-212.

Jacobson, S.R., Blodgett, R.B., and Babcock, L.E., 1996, Organic matter and thermal maturation of Lower Paleozoic rocks from the Nixon Fork subterrane of the Farewell terrane, west-central and southwestern Alaska, in Moore, T.E., and Dumoulin, J.A., eds., Geologic studies in Alaska by the U.S. Geological Survey, 1994: U.S. Geological Survey Bulletin 2152, p. 81-87.

Jaworski, Erich, 1923, Die marine Trias in Südamerika: Neues Jahrbuch für Mineralogie Beilage-Band, v. 47, p. 93-200.

Jones, D.L., Silberling, N.J., Coney, P.J., and Plafker, George, 1987, Lithotectonic terrane map of Alaska (west of the 141st Meridian): U.S. Geological Survey Miscellaneous Field Studies Map MF-1874-A, scale 1:2,500.000.

Keen, Myra, 1969, Superfamily Cardiacea, in Bivalvia, v. 2 of Mollusca 6, pt. N of Moore, R.C., ed., Treatise on invertebrate paleontology: Boulder, Colo., Geological Society of America, p. N583-N594.

Kiparisova, L.D., 1936, Upper Triassic pelecypods from the KolymaIndigirka Land: Arctic Institute Transactions, v. 30, p. 71-136. 1938, Pelecypoda of the Triassic system of the USSR (Paleontology of USSR Monographs): Leningrad, Central Geological and Prospecting Institute, $42 \mathrm{p}$.

Kiparisova, L.D., Bychkov, Y.M., and Polubotko, I.V., 1966, Upper Triassic bivalve molluscs from the northeast USSR: Magadan, Vsesoyuznyy Nauchno-Issledovatel'skii Instituta, $312 p$.

Kobayashi, Teiichi, and Katayama, Masaru, 1938, Further evidences as to the chronological determination of so-called Rhaeto-Liassic floras with a description of Minetrigonia, a new subgenus of Trigonia: Imperial Academy of Tokyo Proceedings, v. 14, no. 5, p. 184-189.

Koken, Ernst, 1892, Über die Gastropoden der rothen Schlernschichten nebst Bermerkungen über Verbreitung und Herkunft einiger triassischer Gattungen: Neues Jahrbuch für Mineralogie, Geologie und Palaeontologie, v. 2, p. 25-36.

Körner, Karl, 1937, Marine (Cassianer-Raibler) Trias am Nevado de Acrotambo (Nord-Peru): Palaeontographica, pt. A, v. 86, p. 145-237.

Krumbeck, Lothar, 1914, Obere Trias von Sumátra: Palaeontographica, supp. 4, $266 \mathrm{p}$.

Lamarck, J.B., 1801, Système des animaux sans vertèbres: Paris. Verdiér, $432 \mathrm{p}$. 1809, Philosophie zoologique: Paris, $2 \mathrm{v}$. 1819, Histoire naturelle des animaux sans vertèbres: Paris, Verdiér, v. 5, 6.

Laws, R.A., 1982, Late Triassic depositional environments and molluscan associations from west-central Nevada: Palaeogeography, Palaeoclimatology, Palaeoecology, v. 37, no. 2-4, p. 131-149. 
Linné, Carl von, 1758, Systema naturae per regna tria naturae: Stockholm, Laurentius Salvius, $824 \mathrm{p}$.

LePain, D.L., Blodgett, R.B., Clough, J.G., and Ryherd, T.J., 2000, Generalized stratigraphy and petroleum potential of the Holitna region, southwest Alaska: Alaska Division of Geological \& Geophysical Surveys Preliminary Interpretative Report 2000-1, 23 p., scale $1: 250,000$.

Martin, G.C., 1926, The Mesozoic stratigraphy of Alaska: U.S. Geological Survey Bulletin 776, $493 p$

McLearn, F.H., 1937, Contributions to the Triassic of Peace River, B.C.: Canadian Field-Naturalist, v. 51, p. 127-131.

1942, The Neo-Triassic Cassianella fauna of Tyaughton Creek Valley, B.C.: Canadian Field-Naturalist, v. 56, p. 99-103.

McRoberts, C.A., 1992, Systematics and paleobiogeography of Late Triassic Gryphaea (Bivalvia) from the North American Cordillera: Journal of Paleontology, v. 66, no. 1, p. 28-39.

Muffler, L.J.P., 1967, Stratigraphy of the Keku Islets and neighboring parts of Kuiu and Kupreanof Islands, southeastern Alaska: U.S. Geological Survey Bulletin 1241-C, $52 \mathrm{p}$.

Muller, S.W., and Ferguson, H.G., 1939, Mesozoic stratigraphy of the Hawthorne and Tonopah quadrangles, Nevada: Geological Society of America Bulletin, v. 50. no. 10, p. 1573-1624.

Newell, N.D., 1965, Classification of the Bivalvia: American Museum Novitates, v. 2206, 25 p.

Newton, C.R., 1983, Paleozoogeographic affinities of Norian bivalves from the Wrangellian, Peninsular, and Alexander terranes, northwestern North America, in Stevens, C.H., ed., Pre-Jurassic rocks in Western North America suspect terranes: Los Angeles, Society of Economic Paleontologists and Mineralogists, Pacific Section, p. 37-48.

1986, Late Triassic bivalves of the Martin Bridge Limestone, Hells canyon, Oregon, in Vallier, T.L., and Brooks, H.C.. eds., Geology of the Blue Mountains region of Oregon, Idaho, and Washington: U.S. Geological Survey Professional Paper 1436, p. 7-17.

Newton, C.R., Whalen, M.T., Thompson, J.B., Prins, Nienke, and Delalla, David, 1987, Systematics and paleoecology of Norian (Upper Triassic) bivalves from a tropical island arc; Wallowa Terrane, Oregon: Paleontological Society Memoir 22, $83 \mathrm{p}$.

Patton, W.W., Jr., Dutro, J.T., Jr., and Chapman, R.M., 1977, Late Paleozoic and Mesozoic stratigraphy of the Nixon Fork area, Medfra Quadrangle, Alaska, in Blean, K.M., ed., The United States Geological Survey in Alaska; accomplishments during 1976: U.S. Geological Survey Circular 751-B, p. B38-B40.

Patton, W.W., Jr., Moll, E.J., Dutro, J.T., Jr., Silberman, M.L., and Chapman, R.M., 1980, Preliminary geologic map of the Medfra Quadrangle, Alaska: U.S. Geological Survey Open-File Report 80-811-A, scale 1:250,000.

Rafinesque, C.S., 1815, Analyse de la nature; ou, tableau de l'univers et des corps organisés: Palermo, $224 \mathrm{p}$.
Sandy, M.R., Blodgett, R.B., and Frýda, Jiri, 2001, Paleobiogeographic signatures for Upper Triassic brachiopods and gastropods from Kuiu Island and adjacent Keku Strait, SE Alaska [abs.]: Geological Society of America Abstracts with Programs, v. 33, no. 3, p. A-53.

Silberling, N.J., 1959, Pre-Tertiary stratigraphy and Upper Triassic paleontology of the Union District, Shoshone Mountains, Nevada: U.S. Geological Survey Professional Paper 322, 67 p.

Silberling, N.J., Grant-Mackie, J.A., and Nichols, K.M., 1997, The Late Triassic bivalve Monotis in accreted terranes of Alaska: U.S. Geological Survey Bulletin 2151, $21 \mathrm{p}$.

Silberling, N.J., Jones, D.L., Monger, J.W.H., Coney, P.J., Berg, H.C., and Plafker, George, 1994, Lithotectonic terrane map of Alaska and adjacent parts of Canada, in Plafker, George, and Berg, H.C., eds., The geology of Alaska, v. G-1 of The geology of North America: Boulder, Colo., Geological Society of America, scale $1: 2,500,000$.

Smith, J.P., 1927, Upper Triassic marine invertebrate faunas of North America: U.S. Geological Survey Professional Paper 141, $262 \mathrm{p}$.

Sowerby, James, 1815-21, The mineral conchology of Great Britain: London, $194 \mathrm{p}$.

Stanley, G.D., Jr., 1979, Paleoecology, structure, and distribution of Triassic coral buildups in western North America: University of Kansas Paleontological Contributions, v. 65, p. 1-58.

Tamura, Misa, and McRoberts, C.A., 1993, A new species of Myophorigonia from the Upper Triassic of Oregon, with a reference to the Minetrigoniidae of the circum-Pacific: Kumamoto University, Faculty of Education Natural Science Memoirs, v. 42, p. 29-34.

Tozer, E.T., 1963, Illustrations of Canadian fossils; Triassic of western and Arctic Canada: Geological Survey of Canada Paper 62-19, $27 \mathrm{p}$. 1970, Marine Triassic faunas, in Douglas, R.J., ed., Geology and economic minerals of Canada (5th ed.): Geological Survey of Canada Economic Geology Report 1, p. 633-640.

von Zittel, K.A., 1881-85, Mollusca und Arthropoda, v. 2 of Palaeozoologie, pt. 1 of Handbuch der Palaeontologie: München, $893 \mathrm{p}$.

Vu Khuc, Dang, ed., 1991, Mollusca, v. 3 of Paleontological atlas of Vietnam: Hanoi, Geological Survey of Vietnam, Institute of Geology and Mineral Resources, Science and Technics Publishing House, $207 \mathrm{p}$.

Vyalov, O.S., 1936, Sur la classification des huitres: Académie des Sciences de l'URSS Comptes Rendus (Doklady), v. 4, no. 1, p. 17-20. 1946, Triassic oysters from SRSR: Lvov Ivana Franke Univ-Naukovi Zapysky, Seriia Geologichna, v. 3, p. 22-54.

Waller, T.R., 1978, Morphology, morphoclines and a new classification of the Pteriomorphia (Mollusca; Bivalvia): Royal Society of London Philosophical Transactions, ser. B., v. 284, no. 1001, p. 345-365.

Zardini, Rinaldo, 1981, Fossili Cassiani (Trias Medio-Superiore): Cortina d'Ampezzo, Edizione Ghedina, $96 \mathrm{p}$. 



\section{PLATES 1-3}


Plate 1.

Figures 1-11. Cassianella cordillerana McRoberts n.sp.

1, 2. Holotype, UAM No. 2591, exterior and interior of left valve. Magnification, $\times 2$.

3, 4. Paratype, UAM No. 2592, exterior and interior of left valve. Magnification, $\times 2$.

5, 6. Paratype, UAM No. 2593, exterior and interior of left valve. Magnification, $\times 2$.

7, 8. Paratype, UAM No. 2594, exterior and interior of left valve. Magnification, $\times 2$.

9. Paratype, UAM No. 2595 , left-valve interior. Magnification, $\times 2$.

10. Paratype, UAM No. 2596, left-valve interior. Magnification, $\times 2$.

11. Paratype, UAM No. 2597, left-valve interior. Magnification, $\times 2$.

12-19. Gryphaea arcuataeformis Kiparisova.

12, 13. UAM No. 2598, exterior and posterior side views of left valve. Magnification, $\times 2$.

14, 15. UAM No. 2599, interior and exterior of left valve. Magnification, $\times 2$.

16. UAM No. 2600 , left-valve exterior. Magnification, $\times 2$.

17, 18. UAM No. 2601, posterior and interior of left valve. Magnification, $\times 2$.

19. UAM No. 2602, right-valve exterior. Magnification, $\times 3$.

20, 21. Maoritrigonia sp.

20. UAM No. 2603 , right valve or an articulated valve pair. Magnification, $\times 3$.

21. UAM No. 2604 , right-valve exterior. Magnification, $\times 2$.

22. Minetrigonia $\mathrm{cf}$. M. suttonensis (Clapp \& Shimer). UAM No. 2605, right-valve exterior. Magnification, $\times 2$.

23, 24. Minetrigonia sp., UAM No. 2606, exterior and interior of right valve. Magnification, $\times 2$. 



18
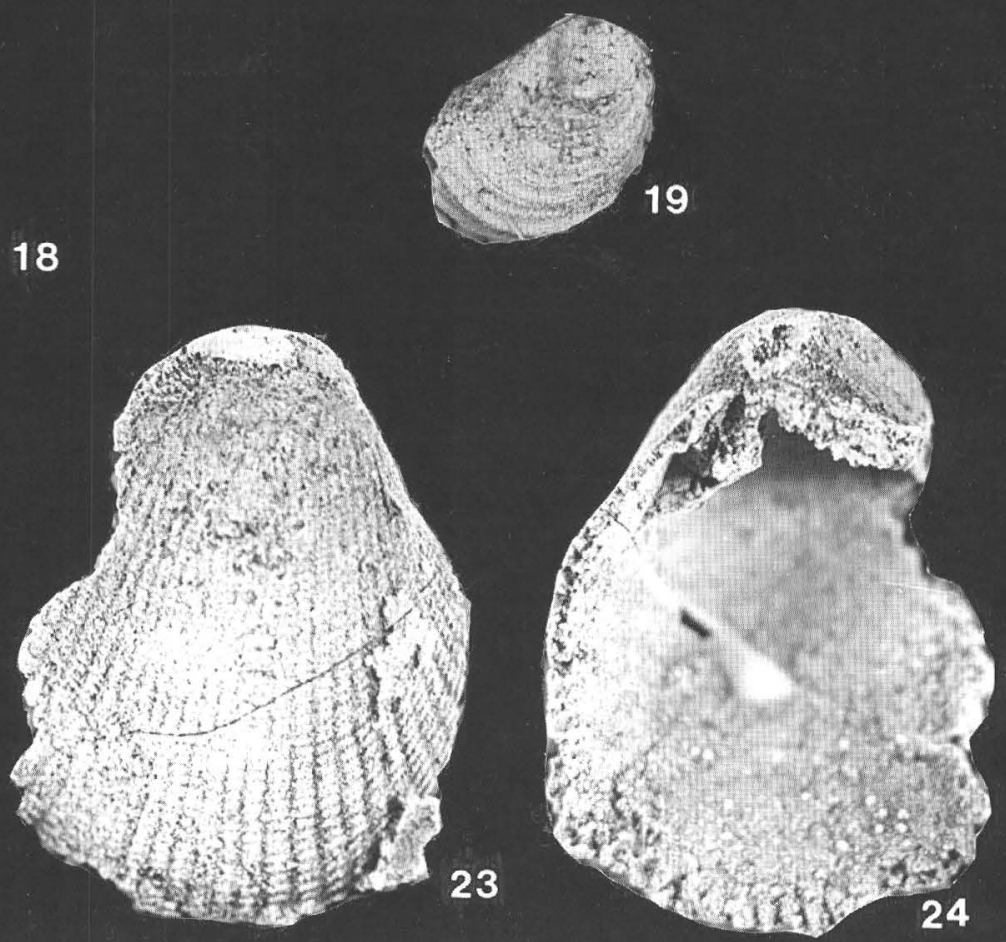

Plate 1. Late Triassic (Norian) bivalves from locality 1 (fig. 2), except for Maoritrigonia sp. (figs. 20, 21) from locality 2. 


\section{Plate 2.}

Figures 1-6. Tutcheria cf. T. densestriata Körner.

1, 2. UAM No. 2607, exterior and interior of right valve. Magnification, $\times 4$.

3. UAM No. 2608 , exterior of ?left valve. Magnification, $\times 4$.

4-6. UAM No. 2609, exterior and interior of left valve. Magnification, $\times 4$ (figs. 4,5 ), $\times 6$ (fig. 6 ).

\section{7, 8. Astarte sp.}

7. UAM No. 2610, left-valve exterior. Magnification, $\times 4$.

8. UAM No. 2611, left-valve exterior. Magnification, $x 4$.

9-14. Septocardia cf. S. peruviana (Cox).

9, 10. UAM No. 2612, exterior and interior of left valve. Magnification, $\times 2$.

11, 12. UAM No. 2613, exterior and interior of right valve. Magnification, $\times 2$.

13, 14. UAM No. 2614, exterior and interior of left valve. Magnification, $\times 2$.

15. Chulitnacula alaskana (Smith). UAM No. 2615, side view. Magnification, $\times 2$.

16-19. Neritaria nuetzeli n.sp.

16, 17. Holotype, UAM No. 2616, apertural and abapertural views. Magnification, $\times 8$.

18, 19. Paratype, UAM No. 2617, apertural and abapertural views. Magnification, $\times 8$.

20, 21. Toxoconcha cf. T. gracilis Haas.

20. UAM No. 2618 , abapertural view. Magnification, $\times 6$.

21. UAM No. 2619 , apertural view. Magnification, $\times 6$. 


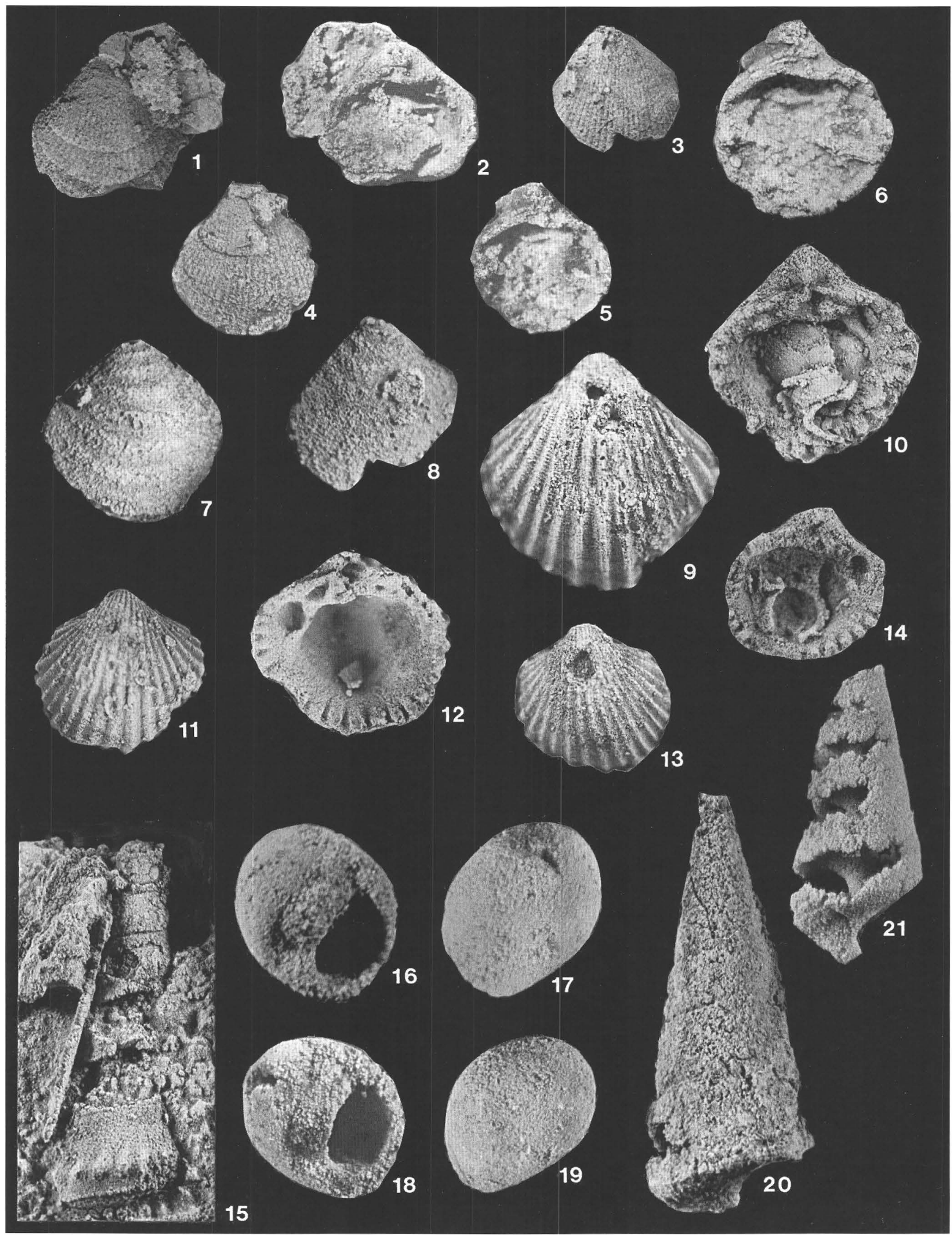

Plate 2. Late Triassic (Norian) bivalves and gastropods from locality 1 (fig. 2). 


\section{Plate 3.}

Figures 1, 2. Andangularia wilsoni Blodgett n.sp. Holotype, UAM No. 2620, abapertural and oblique abapertural views. Magnification, $\times 7$.

3-9. Cryptaulax aff. C. tilarniocensis Haas.

3-5. UAM No. 2621, abapertural, oblique abapertural, and apertural views. Magnification, $\times 7$.

6. UAM No. 2622, apertural view. Magnification, $\times 7$.

7. UAM No. 2623, apertural view. Magnification, $\times 7$.

8. UAM No. 2624, abapertural view. Magnification, $\times 7$.

9. UAM No. 2625, side view of fragmentary spire. Magnification, $\times 7$.

10, 11. Omphaloptycha? sp. UAM No. 2626, side and opposing side views.

Magnification, $\times 6$.

12. Coelostylina cf. C. cylindrata Haas. UAM No. 2627 , apertural view.

Magnification, $\times 6$.

13, 14. Omphaloptycha aff. O. jenksi Haas. UAM No. 2628, abapertural and apertural views. Magnification, $\times 6$.

15. Zygopleura? sp. UAM No. 2629, side view. Magnification, $\times 7$. 


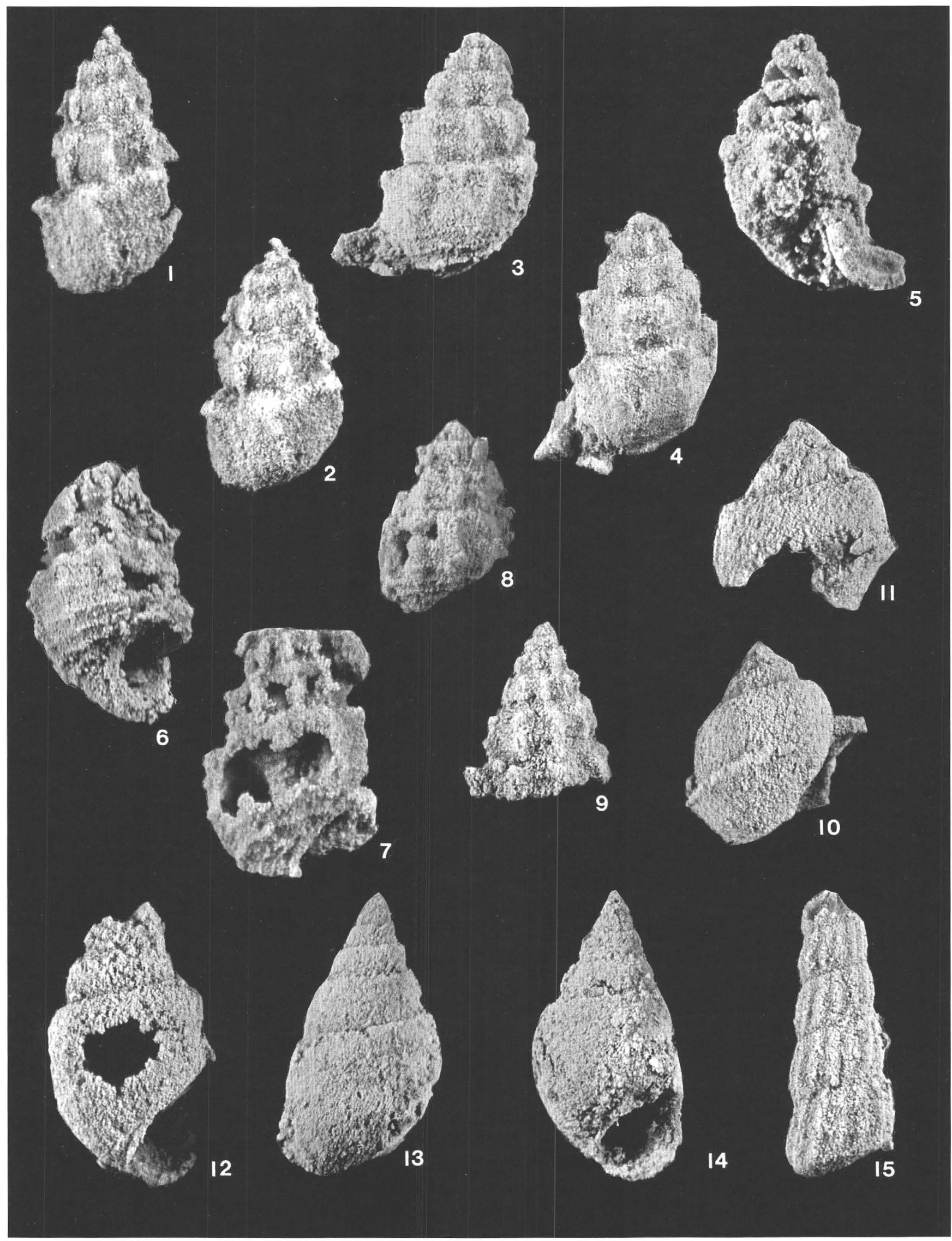

Plate 3. Late Triassic (Norian) gastropods from locality 1 (fig. 2). 



\title{
Notes on the Bedrock Geology and Geography of the Stikine Icefield, Coast Mountains Complex, Southeastern Alaska
}

\author{
By David A. Brew and Richard M. Friedman
}

\section{Abstract}

The Stikine Icefield is the most inaccessible part of the Coast Mountains Complex of southeastern Alaska; its central part has rarely, if ever, been visited by geologists before this study. Recent fieldwork and both published and unpublished investigations of adjacent areas show that the study area is underlain by five generalized map units: (1) polymetamorphic rocks of probably Late Proterozoic and Early Paleozoic protolithic age, whose youngest metamorphic age is middle and Late Eocene; (2) locally foliated and porphyritic granodiorite of middle and late Eocene age - an area associated with these rocks in the upper Baird Glacier area is a possible mineral-exploration target; (3) early Eocene foliated tonalite of the great tonalite sill, herein dated at $56 \mathrm{Ma}$ by the U-Pb method; (4) migmatitic rocks associated with these two plutonic units; and (5) unfoliated tonalite and granodiorite of the Admiralty-Revillagigedo plutonic belt of Late Cretaceous age. In general, metamorphic rocks are most abundant in the southwestern part of the icefield, as is the foliated tonalite of the great tonalite sill. The granodiorite is most common near the Alaska-British Columbia border, and migmatites are scattered throughout the study area. Rocks of the Admiralty-Revillagigedo plutonic belt occur within the metamorphic rocks in the southwestern part of the study area.

\section{Introduction}

The Stikine Icefield is the southernmost part of the Stikine-Tracy Arm-Chutine Icefield, which, as described in the following geographic sketch, is the largest icefield in southeastern Alaska and adjacent British Columbia, Canada (figs. $1,2)$. The bedrock in the Stikine Icefield is part of the Coast Mountains Complex, as formally defined by Brew and others (1995b). The Coast Mountains Complex is the greater than 1,000-km-long, 40- to 100-km-wide backbone of the Coast Mountains. It consists dominantly of granitic rocks and lesser amounts of migmatitic and metamorphic rocks that underlie spectacular peaks, ridges, icefields, and glaciers.

The Stikine Icefield is the last part of southeastern Alaska to be mapped geologically. As background, the bedrock geology of all but two areas in the Coast Mountains Complex in southeastern Alaska was mapped in reconnaissance fashion by the U.S. Geological Survey (USGS) between 1964 and

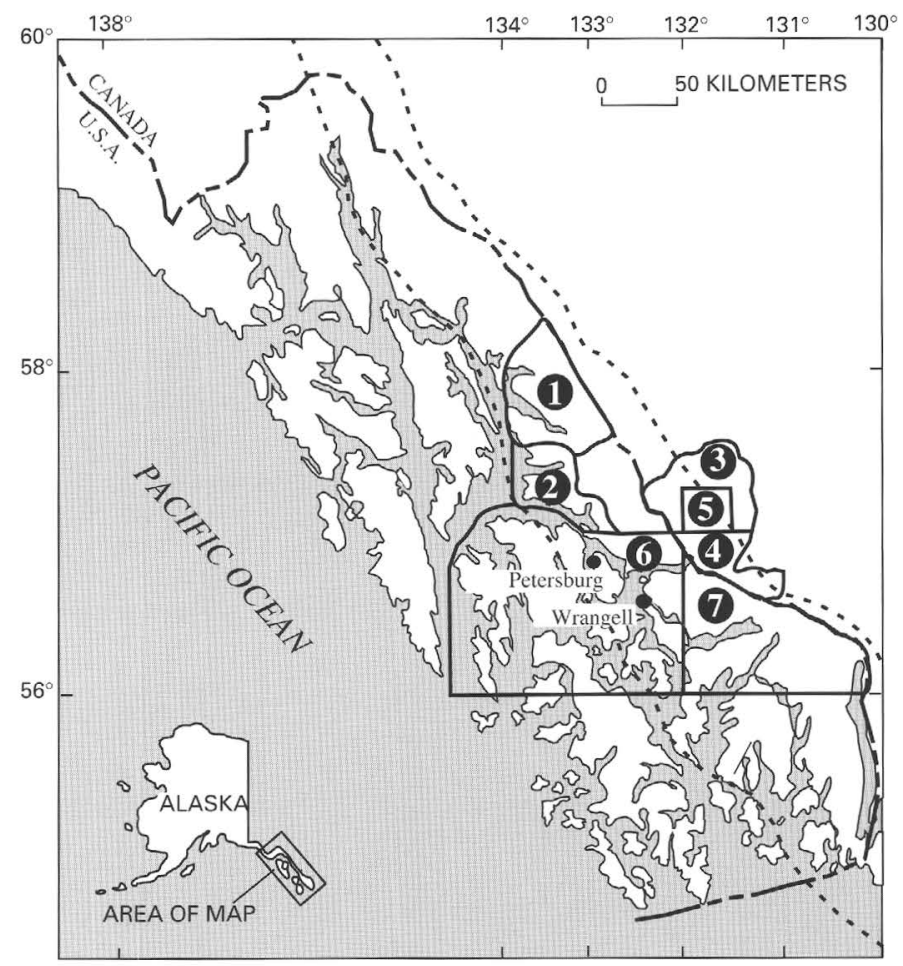

Figure 1. Southeastern Alaska and adjacent British Columbia, Canada, showing locations of the Coast Mountains Complex (dashed outline; after Brew and others, 1995b) and previously mapped adjacent areas (solid outlines): 1, Brew and Grybeck (1984); 2, A.L. Clark, D.A. Brew, and D.J. Grybeck, (unpub. data, 1969); 3, Kerr (1935a); 4, Kerr (1935b), 5, Logan and others (1993); 6, Brew and others (1984); 7, Koch and Berg (1996). All of area in British Columbia mapped by Kerr (1935a, b) east of long $132^{\circ} \mathrm{W}$. was remapped by the Geological Survey of Canada (1957) with essentially the same map units. 
1980 and by the Alaska Division of Geological and Geophysical Surveys in 1980; the locations of previous mapping close to the study area are shown in figure 1. The two areas left unstudied were (1) east and south of Skagway (fig. 1) in northernmost southeastern Alaska; and (2) the central part of the Stikine Icefield, which lies next to the Alaska-British Columbia border north of the Stikine River (fig. 2). The Skagway area was mapped in reconnaissance fashion by using fixed- and rotor-wing-aircraft support in 1995 and 1996 (D.A. Brew, unpub. data, 1995-96). The Stikine Icefield was mapped, also in reconnaissance fashion as a one-person project, in each of the years 1997 through 2000. The reader should note that the level of information gathered at both the approximately 100 ground stations established during this study and during numerous overflights falls far short of the detail characteristic of other USGS reconnaissance mapping in southeastern Alaska.

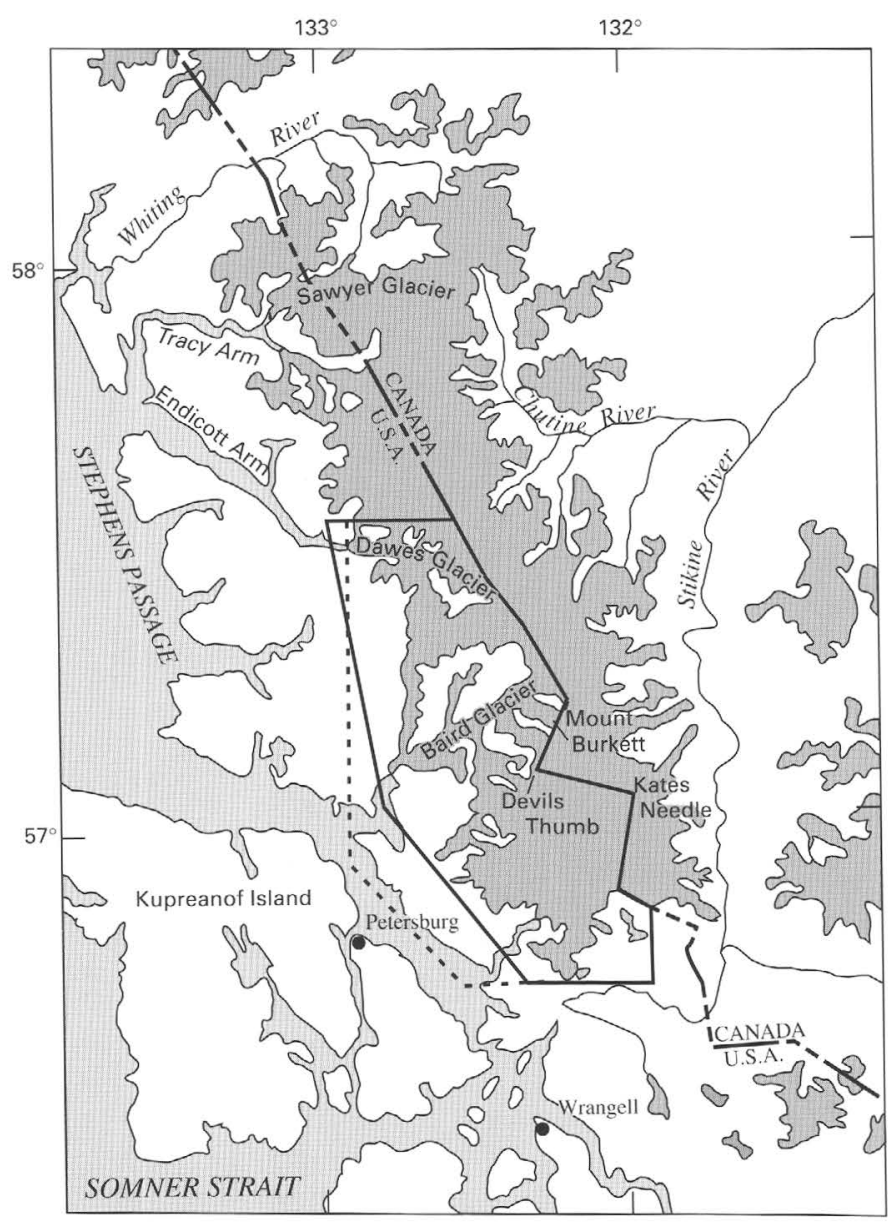

SCALE 1:1,000,000



Figure 2. Stikine-Tracy Arm Icefield, southeastern Alaska and British Columbia, showing Stikine Icefield part (solid outline) and the west limit of figure 4 (dashed heavy line) where it differs from icefield boundary. North of the Stikine Icefield is the Tracy Arm-Chutine Icefield. Base map enlarged to 1,000,000 scale from 1:2,000,000-scale southeastern Alaska sheet of National Atlas.
This chapter reports on generalized findings from 19972000 mapping in the Stikine Icefield and describes the main map units and their distribution. The mapping and compilation were facilitated by the availability of more detailed mapping in the Tracy Arm-Fords Terror area to the north (Brew and Grybeck, 1984) and in the Petersburg quadrangle to the south (Brew and others, 1984), and by nearby reconnaissance mapping to the west (D.A. Brew, D.J. Grybeck, and A.L. Clark, unpub. data, 1969). The pertinent parts of that mapping are generalized in figure 4 . Other nearby mapping is that by Kerr (1935a, 1935b), the Geological Survey of Canada (1957), and Logan and others (1993) in adjacent British Columbia, Canada. Topical studies of value to the interpretation of the study area are those by Gehrels and others (1990) and Samson and others (1991).

The study area (figs. 1,2) is underlain by five generalized bedrock units: (1) polymetamorphic rocks of possibly Late Proterozoic to Early Paleozoic original age, whose youngest metamorphic age is middle to late Eocene; (2) locally foliated and porphyritic granodiorite of middle and late Eocene age; (3) early Eocene foliated tonalite of the great tonalite sill; (4) migmatitic rocks associated with the two plutonic-rock units; and (5) unfoliated tonalite and granodiorite of the AdmiraltyRevillagigedo plutonic belt of Late Cretaceous age.

One of the results of this study is that the central part of the Stikine Icefield is underlain by a greater volume and variety of granodioritic and migmatitic rocks than predicted from the previous mapping in adjacent areas; these units are part of the massive middle and late Eocene biotite granodiorite and granite that dominate the Coast Mountains Complex. Another result is that the abundant and readily recognized high-grade metamorphic rocks that underlie many of the nunataks in the southernmost part of the Stikine Icefield (Brew and others, 1984) apparently grade northward into migmatitic units. One result of possible mineral-resource significance is of a previously unreported, well-exposed, heavily Fe stained contact between an apparently young granitic intrusion and the surrounding and apparently overlying orthogneiss, migmatite, gneiss, and schist.

The Canadian part of the Stikine Icefield is omitted from this discussion. Similarly, the northern part of the StikineTracy Arm-Chutine Icefield (fig. 2), referred to as the Tracy Arm-Chutine Icefield, is omitted because the Alaskan part was described by Brew and Grybeck (1984).

\section{Geographic Sketch}

The bedrock geology of the study area (figs. 1,2) is the main focus of this chapter, but this brief geographic sketch should help the reader understand why this area is the last in southeastern Alaska to be studied geologically, as well as provide information not available elsewhere.

The Stikine Icefield is the southernmost part of the Stikine-Tracy Arm-Chutine Icefield, which is the largest icefield in southeastern Alaska and adjacent British Columbia, 
Canada (fig. 2). The icefield covers an area of about 6,400 $\mathrm{km}^{2}$. The U.S. part of the south end of the icefield, which is here termed the Stikine Icefield, covers an area of about 3,000 $\mathrm{km}^{2}$. The highest peaks in the icefield are above 9,000-ft elevation, and one of the distributary glaciers, the LeConte, reaches tidewater.

The Stikine Icefield as defined here (fig. 2) extends from the south termini of the glaciers that discharge to the south, toward the Stikine River, to the north termini of those that discharge to the north into Endicott Arm, and westward to the limit of distributary glaciers that flow in that direction. According to this definition, the icefield is a total glacier system that includes not only LeConte, unnamed, Patterson, and Baird Glaciers, which flow to the west toward Frederick Sound, but also Mud, Great, Shakes, and Popof Glaciers, which flow toward the Stikine River, and the Dawes Glacier system, which flows to the north into Endicott Arm. As thus defined, the icefield is appreciably larger than the area to which the term was applied by the U.S. Forest Service (1992). The icefield includes the northeastern part of the Petersburg 1:250,000-scale quadrangle and the southeastern part of the Sumdum 1:250,000-scale quadrangle.

The Stikine Icefield is probably the most scenically spectacular, yet least visited, part of the Coast Mountains of southeastern Alaska and adjacent parts of British Columbia and the Yukon Territory, Canada (figs. 1, 3). Most of the infrequent visitors are rock climbers intent on ascending the imposing granitic faces of Devils Thumb, the single most impressive peak in the icefield (for example, Beckey, 1969, p. 263, 276 [first ascents of Devils Thumb at 9,077-ft elevation and Kates Needle at 10,023-ft elevation in 1946, and of nearby Mount Ratz at 10,290-ft elevation in 1964]; Krakauer, 1998; Bebie, 1992) and of Mount Burkett at 9,730-ft elevation. Access to the central part of the Stikine Icefield from tidewater involves traversing many kilometers either over glaciers or across rugged mountains. The central part is the place in all of southeastern Alaska that is farthest from tidewater and from any established community.

Because of these factors and the apparent absence of any mineral resources, the icefield has received little geologic attention. As noted above, until the present study, the only systematic geologic work in or near the icefield was in the southernmost part by Brew and others (1984) and in the northernmost part by Brew and Grybeck (1984); A.L. Clark, D.A. Brew, and D.J. Grybeck mapped along the western margin in 1969, but no report was ever published.

There have been no glacial-geologic studies of the Stikine Icefield, although, on the basis of information and observations from elsewhere in the Coast Mountains, some inferences can be made regarding the glacial history. The glaciers that presently mantle the Coast Mountains here are remnants of Neoglacial and older, probably Late Wisconsin glaciers that covered much of the region. The geomorphology of all the peaks above about 5,500-ft elevation in the west and 7,000-ft



Figure 3. Aerial photograph of central part of the Stikine Icefield. The Stikine River valley in British Columbia, Canada, is dark area in distance. Photograph by D.A. Brew; view northeastward. 
elevation at the Alaska-British Columbia border, together with the absence of erratic boulders and glacial striations above those elevations, indicates that the peaks may have existed as nunataks during all the Pleistocene glaciations. At present, the icefield's distributary glaciers are generally receding; LeConte Glacier has been retreating most rapidly (Motyka and others, 1998); and the upper reaches are downwasting. A conspicuous trimline a few hundred feet above the distributary valley glaciers has not been dated but is inferred to represent an early20th-century stand.

\section{Lithotectonic-Terrane, Metamorphic-Belt, Magmatic-Belt, and Metallogenic-Belt Settings}

Almost all rocks of the Stikine Icefield are part of the Nisling lithotectonic terrane of the Intermontane superterrane, as shown by Brew and Ford (1994, 1998), Brew and others (1995a), and Brew (2001). These rocks were originally included in the Tracy Arm terrane of Berg and others (1978), but subsequent studies, especially those by Brew and others (1984) and Gehrels and others (1990), have shown that the rocks most likely fit the Nisling tectonic assemblage, or terrane, as subsequently described by Wheeler and McFeely (1991). Gehrels and others (1990) referred to these rocks as part of the Yukon-Tanana terrane.

Some of the metamorphic rocks in the southwestern part of the study area (fig. 4) may belong to the Gravina overlap assemblage or other rocks in the Coast Mountains structural zones of Brew and Ford (1998) and Brew (2001). These rocks, which are part of the Insular superterrane, are in the western metamorphic belt of Brew and others (1989, 1992). They are also part of the western granitic belt of the Coast Mountains Complex as originally described by Brew and Morrell (1980, 1983) and Brew and Ford (1984); they contain the great tonalite sill and scattered plutons of the Admiralty-Revillagigedo plutonic belt (Brew and Morrell, 1980, 1983). The Coast Range megalineament (Brew and Ford, 1978), which is a conspicuous component of the Coast Mountains structural zones, lies close to the contact between metamorphic rocks to the southwest and dominantly granitic and migmatic rocks to the northeast (Brew and Ford, 1998; Brew, 2001).

The rocks in the rest of the study area (figs. 1,2,4) are within the central granitic belt of Brew and Ford (1984); the granitic rocks themselves were assigned by Brew and Morrell $(1980,1983)$ to the 50-Ma Coast Mountains plutonic belt, the granitic rocks of which were described in some detail by Brew (1994). When the above-cited reports were prepared, the existence in the Coast Mountains of any granitic rocks older than Late Cretaceous and Tertiary was totally unsuspected. Since then, evidence from orthogneissic and other metamorphic-rock units in the Coast Mountains has established the presence of Paleozoic granitic rocks (Gehrels and others, 1990, 1991; D.L. Kimbrough, unpub. data, 1994; Karl and others, 1996) in both large and small bodies.
The southwesternmost rocks in the study area (figs. 1, $2,4)$ are included in the Juneau metallogenic belt of Brew (1993), with the probability of undiscovered volcanic-rockhosted massive sulfide deposits (Brew and others, 1991; Brew and others, 1996). The rocks in the rest of the study area are in the Coast Mountains metallogenic belt of Brew (1993), with undiscovered porphyry, skarn, and vein deposits related to Cenozoic magmatism, according to Brew and others (1996). These Cenozoic rocks were emplaced within metamorphic rocks of the Nisling terrane. Since Brew's (1993) report, such rocks of the Nisling terrane elsewhere have been reported to host volcanic-rock-hosted massive sulfide deposits (Brew and Ford, 1993).

\section{Descriptions of Generalized Map Units}

Each of the five major generalized map units in the Stikine Icefield (fig. 4) is made up of two or more detailed units. The generalized units are listed in table 1 , together with the names of the detailed units that are shown on a map by D.A. Brew (unpub. data, 2001). The distribution of these generalized map units adjacent to the Alaska-British Columbia border corresponds fairly well to that of the even more generalized map units on the Canadian side (Kerr, 1935a, b; Geological Survey of Canada, 1957). The generalized map units are discussed below from youngest to oldest, except that the last unit, "undivided polymetamorphic rocks," has both the oldest protolithic age and the youngest metamorphic age.

\section{Locally Foliated and Porphyritic Granodiorite}

The locally foliated and porphyritic granodiorite (unit 1, fig. 4) consists mainly of sphene-hornblende-biotite granodiorite, with lesser amounts of porphyritic biotite-hornblende granodiorite and gneissic biotite granite and granodiorite (table 1). These intrusive rocks were emplaced from early to late Eocene time (Douglass and others, 1989; Brew, 1994); some of them were discussed in detail by Webster (1984).

\section{Foliated Tonalite of the Great Tonalite Sill}

The foliated tonalite of the great tonalite sill (unit 2, fig. 4) is an undivided unit that consists mainly of biotite-hornblende tonalite, hornblende-biotite tonalite, and gneissic biotite granodiorite and quartz monzodiorite (table 1). As discussed elsewhere (Brew and Ford, 1998; Brew, 2001) and briefly above, the great tonalite sill is a remarkable series of echelon tabular plutons that extends the length of southeastern Alaska and into British Columbia, Canada, at both the north and south. Its unusual outcrop width in the Stikine Icefield is discussed below.

These intrusive rocks were emplaced from latest Cretaceous through early Eocene time (Douglass and others, 1989; 


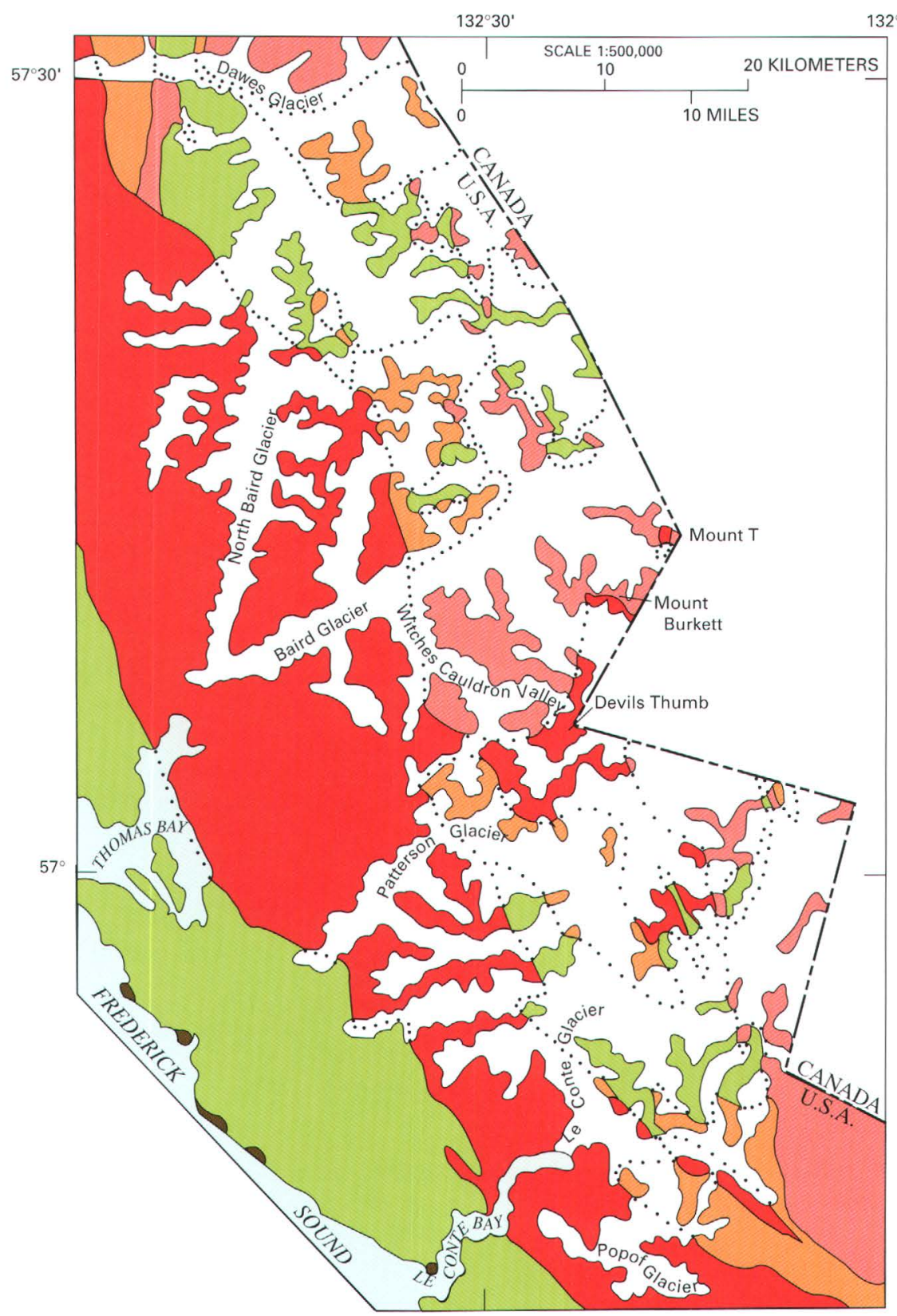

\section{EXPLANATION}

Glaciers and permanent snowfields-Only the larger masses are shown.

Locally foliated and porphyritic granodiorite (late and middle Eocene)-Dominantly biotite granodiorite and granite.

Foliated tonalite (early Eocene)-Dominantly hornblende tonalite and granodiorite; part of the great tonalite sill.

ح..... Contact-Approximately located; dotted where concealed by glaciers or water.
Migmatitic rocks (Eocene)-Variety of rock types associated with the above two units; includes some unassigned granitic rocks.

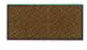

Unfoliated tonalite and granodiorite (early Late Cretaceous) Biotite and garnet-bearing; part of 100- to 90-Ma Admiralty-Revillagigedo plutonic belt.

Polymetamorphic rocks (protolith age, early

Paleozoic and Late Paleozoic)—Dominantly schist and gneiss; youngest metamorphic age, middle and late Eocene.

Figure 4. Generalized geologic sketch map of the Stikine Icefield, southeastern Alaska (see fig. 2 for location). Information compiled from D.A. Brew, D.J. Grybeck, and A.L. Clark, (unpub. data, 1969), Brew and Grybeck (1984), Brew and others (1984), and Brew (unpub. data, 1998-2000); base map modified from Sumdum and Petersburg 1:250,000-scale topographic maps and reduced to 1:500,000 scale. Major glaciers and nunataks are shown in generalized form. 
Table 1. Relations between the generalized map units shown on figure 4 and the detailed units shown on the 1: 250,000-scale map of the Stikine Icefield, southeastern Alaska.

[From D.A. Brew (unpub. data, 2001)].

Map unit (fig. 4)

Detailed units shown on 1:250,000-scale geologic map of the Stikine Icefield

\begin{abstract}
Locally foliated and porphyritic granodiorite ----- Sphene-hornblende-biotite granodiorite. Porphyritic biotite-hornblende granodiorite.

Gneissic biotite granite and granodiorite.
\end{abstract}

Foliated tonalite of the great tonalite sill --

Migmatitic rocks associated with the above two plutonic units.

Unfoliated tonalite and granodiorite of the Admiralty-Revillagigedo plutonic belt.

Polymetamorphic rocks
Biotite-hornblende and hornblende-biotite tonalite, quartz diorite, and minor granodiorite.

Gneissic biotite granodiorite and quartz monzodiorite.

Migmatite consisting of schist and gneiss invaded by tonalite and other rocks of the great tonalite sill.

Migmatite consisting of schist, gneiss, tonalite, and granodiorite invaded by biotite granodiorite of the central Coast Mountains.

Migmatite consisting of hornfelsed phyllite and metagraywacke invaded by all of the plutonic units listed below: Hornblende-biotite tonalite and granodiorite. Quartz monzodiorite, and quartz diorite. Biotite tonalite, quartz diorite, and granodiorite.

Undivided metamorphic rocks.

Metamigmatite.

Undivided sphene-biotite-hornblende (ortho)gneiss.

Marble and calc-silicate granofels.

Undivided biotite schist and (para)gneiss.

Biotite schist.

Biotite (para)gneiss.

Undivided hornblende schist and (para)gneiss.

Hornblende schist and semischist.

Hornblende (para)gneiss.

Undivided schist and hornfels.

Serpentine and other metamorphosed ultramafic rocks.

Phyllite and semischist.
Brew, 1994). The most recent $\mathrm{U}-\mathrm{Pb}$ age determination on the unit, $56 \mathrm{Ma}$, is discussed in detail below. That determination indicates that the K-Ar age of 49.1 to 51.6 Ma reported for the unit by Douglass and others (1989) resulted from resetting by the younger "locally foliated and porphyritic granodiorite" (unit 1, fig. 4), which has a K-Ar age of 49.3 to $51.3 \mathrm{Ma}$ (Douglass and others, 1989). That unit intrudes all the other rock units.

\section{U-Pb Geochronology}

Here, we report new $\mathrm{U}-\mathrm{Pb}$ data on the great tonalite sill (sample 99DB014A, table 2) from a sample near Devils Thumb on the Alaska-British Columbia border in the Stikine Icefield (fig. 4). The sample yielded both zircon and titanite. The zircons are clear, colorless, and consist of stubby euhedral prisms and broken pieces of larger grains. Cores and zoning were not observed during grain selection. The titanites are clear, medium yellow-brown, and consist mostly of broken fragments of larger euhedral grains. U-Pb data are listed in table 2 , and the results are plotted at the $2 \sigma$ level of uncertainty on a standard concordia diagram in figure 5. Analytical techniques were described by Friedman and others (2001).
$\mathrm{U}-\mathrm{Pb}$ data on four analyzed multigrain zircon fractions define a linear array on the concordia plot shown in figure 5. A best-fit line through these data gives a lower intercept of $55.6+2.2 /-2.9 \mathrm{Ma}$ (mean square of weighted deviates, 0.1 ), interpreted to be the crystallization age of this sample. Titanite results of about $53 \mathrm{Ma}$ record cooling of the rock below about $550-650^{\circ} \mathrm{C}$ and so provide a minimum age for the great tonalite sill at this locality. An upper intercept of 289 $+50 /-48$ Ma gives an estimate of the average age of inherited zircon in the analyzed fractions, consistent with the age of late Paleozoic arc basement of the Stikine terrane (Wheeler and McFeely, 1991).

\section{Migmatitic Rocks Associated with the Above Two Plutonic-Rock Units}

The migmatitic rocks (unit 3, fig. 4) include two types of migmatite: one consists of schist and gneiss invaded by rocks of the great tonalite sill, and the other of schist, gneiss, tonalite, and granodiorite invaded by biotite granodiorite of the central Coast Mountains (table 1). 


\section{Unfoliated Tonalite and Granodiorite of the Admiralty-Revillagigedo Plutonic Belt}

The unfoliated tonalite and granodiorite (unit 4, fig. 4) consist mainly of hornblende-biotite tonalite and granodiorite, quartz monzodiorite, quartz diorite, and associated migmatite (Table 1). These intrusive and related rocks were emplaced during the Late Cretaceous (Brew and others, 1984; Burrell, 1984a-c; Douglass and others, 1989).

\section{Polymetamorphic Rocks}

The polymetamorphic rocks (unit 5, fig. 4) are an undivided unit that consists of a great variety of metamorphic rocks, including phyllite, biotite and hornblende schist and semischist, biotite-hornblende (para)gneiss, biotite-hornblende (ortho)gneiss, marble, calc-silicate hornfels, and serpentine (table 1).

The protolithic age of these rocks is probably Late Proterozoic to early Paleozoic (Gehrels and others, 1990; Samson and others, 1991; Wheeler and McFeely, 1991), and the youngest metamorphic age is middle and late Eocene (Brew and others, 1989, 1992). At least some of the phyllite and semischist in the southwestern part of the study area (figs. 1, 2) may belong to the Gravina overlap assemblage and may not be polymetamorphosed. Metamorphic grade ranges from subgreenschist to amphibolite facies.

\section{Upper Baird Glacier Intrusive Contact}

One feature of potential mineral-resource significance was noted during the 1998 mapping: a well-exposed Fe-stained contact between an apparently young granitic intrusive and

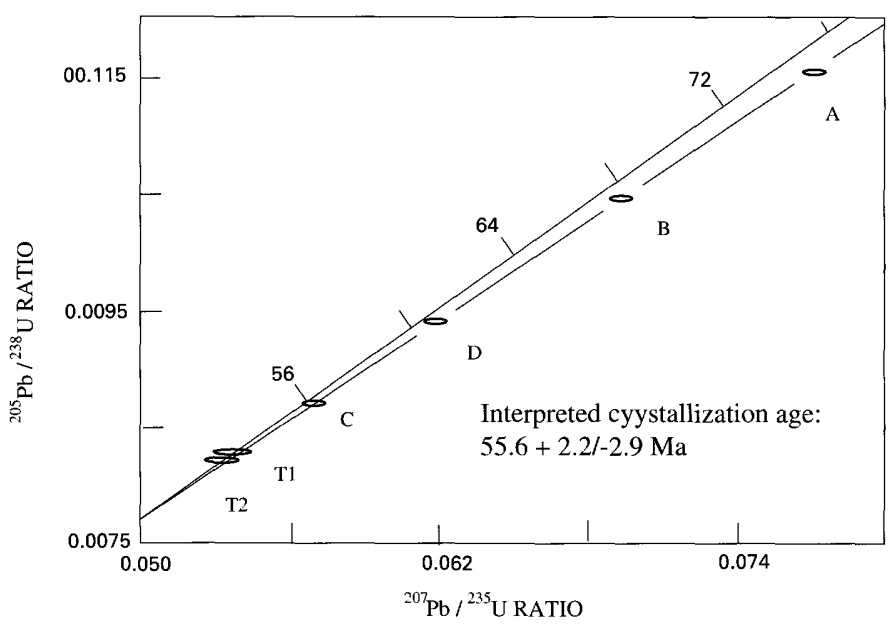

Figure 5. Standard concordia diagram showing zircon and titanite results for sample 99DB014A from the great tonalite sill at the Devils Thumb in the Stikine Icefield, southeastern Alaska (fig. 3). Results plotted at $2 \sigma$ level of uncertainty; analyst, Richard M. Friedman, University of British Columbia.

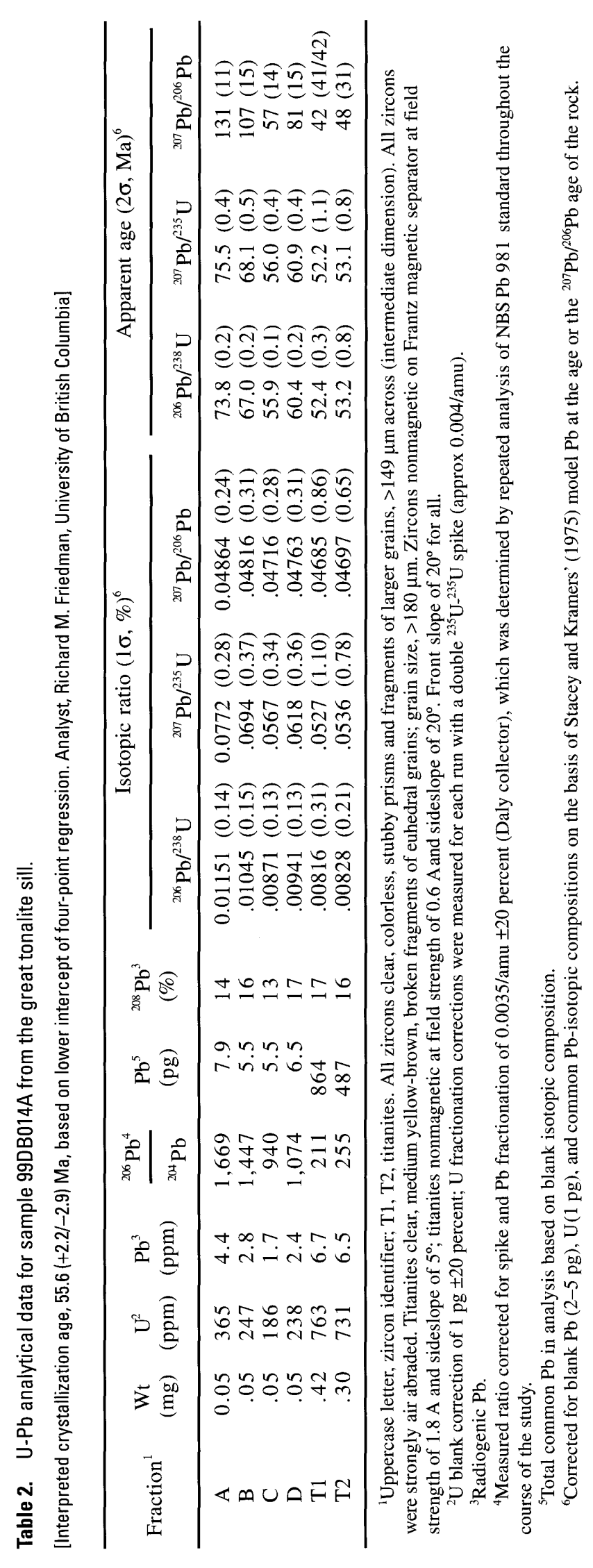


migmatitic country rocks in the upper Baird Glacier area. Somewhat similar situations elsewhere in the Coast Mountains have been investigated for molybdenum resources (Brew and Ford, 1969; Koch and others, 1987; Miller and others, 1997).

At this locality, what appears to be the uppermost part of a 50-Ma or younger granitic body intrudes orthogranitic and migmatitic rocks on the west side of Baird Glacier. The country rocks have been mapped at nearby localities, but the apparent 50-Ma age of the pluton is based on visual resemblance of the outcrop to the locally foliated and porphyritic granodiorite (unit 1, fig. 4) some distance away. The Fe-stained locality, which has not been reported on before, is at approximately lat $57^{\circ} 15^{\prime} 16^{\prime \prime} \mathrm{N}$., long $132^{\circ} 02^{\prime} 40^{\prime \prime} \mathrm{W}$., on the north side of the main Baird Glacier at about 4,100- to 4,500-ft elevation in the Sumdum B-2 quadrangle. It is about $5 \mathrm{~km}$ from the AlaskaBritish Columbia border and is within the Stikine area of Tongass National Forest, between the Stikine-LeConte and Tracy Arm-Fords Terror Wildernesses.

The locality was observed from the air during both fixed-wing-aircraft reconnaissance and helicopter-supported regional geologic mapping in June 1998; whether it has ever been visited by a geologist is unknown. The locality is at the edge of the glacier and should be accessible with care and proper equipment. It is easy to spot because of the conspicuous Fe stain along the contact and on the exposed part of the granitic intrusion. The intrusion crosscuts the uniformly gray K-feldspar-porphyritic/porphyroblastic biotite (ortho)gneiss, well-layered migmatite, schist, and gneiss that make up much of the nearby bedrock. The contact appears to be well exposed; however, in high-snow years (such as 1999 and 2000), the contact is obscured.

It is unclear to which of the several families of intrusive rocks in the icefield that this granitic intrusion belongs. As noted above, one hypothesis is that it is part of the locally foliated and porphyritic 50-Ma granodiorite which is conspicuous at the north boundary of the Petersburg quadrangle south of this locality; that unit is only locally exposed north of LeConte Glacier. Similarly, none of the abundant 50-Ma granodiorite of the upper main Dawes Glacier area to the north has been mapped anywhere south of the north-central part of the Sumdum B-2 quadrangle. An alternative hypothesis is that the intrusion is a younger, different intrusive-rock unit; some such younger intrusions in the Coast Mountains contain significant Mo mineralization (Brew and others, 1991, p. 106).

\section{Discussion}

The distribution and proportion of metamorphic, granitic, and migmatitic rocks in the central part of the Stikine Icefield differ significantly from those to the north in the Tracy ArmFords Terror area and to the south in the Petersburg quadrangle part of the icefield. Though unexpected before the field mapping, this observation is not surprising, given the variations that are known to exist elsewhere along the length of the Coast
Mountains. One interpretation is that the rocks exposed in the Stikine Icefield represent a deeper structural level than those exposed to the north and south, explaining the greater abundance of granitic and migmatitic rocks and the lesser abundance of straightforward metamorphic rocks, including metacarbonate and metavolcanic rocks.

Two other points stand out on the geologic map (fig. 4): (1) the possible presence of undiscovered mineralized graniticrock cupolas associated with the 50-Ma granodiorite or with possibly younger intrusive rocks, similar to the one discussed above; and (2) the width of the great tonalite sill belt (fig. 4) and its extent into the central part of the Stikine Icefield to the vicinity of Devils Thumb.

This first point can be evaluated only through more detailed investigation than that provided by the present study. The second point, together with the relatively low volume of 50-Ma granodiorite (fig. 4), suggests that in this part of the icefield, the crustal extension required to accommodate these rocks was less than in other parts of the Coast Mountains Complex. This part of the icefield contrasts strongly with both the Juneau Icefield, where isolated remnants of the great tonalite sill occur east of the main bulk of the 50-Ma granodiorite (Brew and Ford, 1985; Drinkwater and others, 1995), and the Bradfield Canal quadrangle, where 50-Ma granitic rocks occur across almost all of the Coast Mountains Complex (Koch and Berg, 1996).

\section{Acknowledgments}

Credit for accomplishing the field mapping in previously unmapped parts of the Stikine Icefield belongs primarily to the scientific and support staff of the Stikine area of Tongass National Forest. Everett Kissinger, Stikine-area soil scientist, arranged for fixed- and rotor-wing-aircraft support during the weather-plagued season of 1997 and the successful seasons of 1998, 1999, and 2000. In 1997 the research was also supported by the USGS; in 1998, airfare was provided by Betchart Expeditions and other support was from the USGS; in 1999, the research was also supported by the USGS and the senior author; and in 2000, airfare was provided by Betchart Expeditions, and other support was from the USGS. J.G. Weathers assisted with the preparation of graphic materials. G.R. Himmelberg, R.D. Koch, and S.M. Karl, all of the USGS, reviewed the manuscript.

\section{References Cited}

Bebie, Mark, 1992, Under pressure on the Devil's Thumb: American Alpine Club Journal, v. 34, no. 66, p. 74-80.

Beckey, Fred, 1969, Challenge of the North Cascades: Seattle, The Mountaineers, $280 \mathrm{p}$.

Berg, H.C., Jones, D.L., and Coney, P.J., 1978, Map showing pre-Cenozoic tectonostratigraphic terranes of southeastern Alaska and adjacent areas: U.S. Geological Survey Open-File Report 78-1085, scale 1:1,000,000, 2 sheets. 
Brew, D.A., 1993, Regional geologic setting of mineral resources in southeastern Alaska, in Godwin, L.H., and Smith, B.D., eds., Economic mineral resources of the Annette Islands Reserve, Alaska: U.S. Bureau of Indian Affairs, Division of Energy and Mineral Resources Publication, p. 13-20.

1994, Latest Mesozoic and Cenozoic magmatism in southeastern Alaska, chap. 19 of Plafker, George, and Berg, H.C., eds., The geology of Alaska, v. G-1 of The geology of North America: Boulder, Colo., Geological Society of America, $p$. 621-656.

2001, The Insular-Intermontane Suture Zone (IISZ) of the western Coast Mountains of southeastern Alaska and British Columbia and the Adria-Europe Suture Zone (AESZ) of southern Europe-descriptions and comparison of global-scale tectonic features, in Gough, L.P., and Wilson, F.H., eds., The U.S. Geological Survey in Alaska; geologic studies in Alaska by the U.S. Geological Survey in 1999: U.S. Geological Survey Professional Paper 1633, p. 35-50.

Brew, D.A., Drew, L.J., Schmidt, L.M., Root, D.H., and Huber, D.F, 1991, Undiscovered locatable mineral resources of the Tongass National Forest and adjacent areas, southeastern Alaska: U.S. Geological Survey Open-File Report 91-10, $370 \mathrm{p}$.

Brew, D.A., and Ford, A.B., 1969, Boundary Creek molybdenum-silver occurrence, southeastern Alaska, in Some shorter mineral resource investigations in Alaska: U.S. Geological Survey Circular 615, p. 12-15.

1978, Megalineament in southeastern Alaska marks southwest edge of Coast Range batholithic complex: Canadian Journal of Earth Sciences, v. 15, no. 11, p. 1763-1772.

1984, The northern Coast plutonic complex, southeastern Alaska and northwestern British Columbia, in Coonrad, W.C., and Elliott, R.L., eds., The United States Geological Survey in Alaska; accomplishments during 1981: U.S. Geological Survey Circular 868, p. 120-124.

1985, Preliminary reconnaissance geologic map of the Juneau, Taku River, Atlin and part of the Skagway 1:250,000 quadrangles, southeastern Alaska: U.S. Geological Survey Open-File Report 85-395, 23 p., scale 1:250,000, 2 sheets.

1993, Regional distribution and geologic context of volcanicrock-hosted massive sulfide deposits in southeastern Alaska and adjacent parts of British Columbia [abs.]: Alaska Miner's Association Conference, Juneau, 1993, Abstracts of Professional Papers, p. 33-34.

1994, The Coast Mountains plutonic-metamorphic complex between Skagway, Alaska, and Fraser, British Columbia-geologic sketch and road log: U.S. Geological Survey Open-File Report 94-268, $25 \mathrm{p}$.

1998, The Coast Mountains shear zones in southeastern Alaska-descriptions, relations, and lithotectonic terrane significance, in Gray, J.E., and Riehle, J.R., eds., The U.S. Geological Survey in Alaska; geologic studies in Alaska by the U.S. Geological Survey in 1996: U.S. Geological Survey Professional Paper 1595, p. 183-192.

Brew, D.A., Ford, A.B., and Himmelberg, G.R., 1989, Evolution of the western part of the Coast plutonic-metamorphic complex, southeastern Alaska, U.S.A.-a summary, in Daly, S.R., Cliff, R.A., and Yardley, B.W.D., eds., Evolution of metamorphic belts: Geological Society of London Special Publication 43, p. 447-452.

1995a, Jurassic accretion of Nisling terrane along the western margin of Stikinia, Coast Mountains, northwestern British Columbia; comment: Geology, v. 22, no. 1, p. 89-90.
Brew, D.A., Ford, A.B., Himmelberg, G. R., and Drinkwater, J.L., 1995b, The Coast Mountains Complex of southeastern Alaska and adjacent regions, in Koozmin, E.D., ed., Stratigraphic notes1994: U.S. Geological Survey Bulletin 2135, p. 21-28.

Brew, D.A., and Grybeck, D.J., 1984, Geology of the Tracy Arm-Fords Terror wilderness study area and vicinity, in U.S. Geological Survey and U.S. Bureau of Mines, Mineral resources of Tracy Arm-Fords Terror Wilderness Study Area and vicinity, Alaska: U.S. Geological Survey Bulletin 1525, p. 19-52.

Brew, D.A, Grybeck, D.J., Taylor, C.D., Jachens, R.C., Cox, D.P., Barnes, D.F., Koch, R.D., Morin, R.L., and Drinkwater, J.L., 1996, Undiscovered mineral resources of southeastern Alaska-revised mineral-resource-assessment-tract descriptions: U.S. Geological Survey Open-File Report 96-716, 131 p.

Brew, D.A., Himmelberg, G.R., Loney, R.A., and Ford, A.B., 1992, Distribution and characteristics of metamorphic belts in the southeastern Alaska part of the North American Cordillera: Journal of Metamorphic Geology, v. 10, no. 3, p. 465-482.

Brew, D.A., and Morrell, R.P., 1980, Preliminary map of intrusive rocks in southeastern Alaska: U.S. Geological Survey Miscellaneous Field Investigations Map MF-1048, scale 1: $1,000,000$.

-1983, Intrusive rocks and plutonic belts in southeastern Alaska, in Roddick, J.A., ed., Circum-Pacific plutonic terranes: Geological Society of America Memoir 159, p. 171-193.

Brew, D.A., Ovenshine, A.T., Karl, S.M., and Hunt, S.J., 1984, Preliminary reconnaissance geologic map of the Petersburg and parts of the Port Alexander and Sumdum 1:250,000 quadrangles, southeastern Alaska: U.S. Geological Survey Open-File Report 84-405, 43 p., scale 1:250,000, 2 sheets.

Burrell, P.D., 1984a, Cretaceous plutonic rocks, Mitkof and Kupreanof Islands, Petersburg quadrangle, southeastern Alaska, in Coonrad, W.L., and Elliott, R.L., eds., The United States Geological Survey in Alaska; accomplishments during 1981: U.S. Geological Survey Circular 868, p. 124-126.

-1984b, Late Cretaceous plutonic rocks, Petersburg quadrangle, southeastern Alaska, in Reed, K.M., and Bartsch-Winkler, Susan, eds., The United States Geological Survey in Alaska: accomplishments during 1982: U.S. Geological Survey Circular 939, p. 93-96.

-1984c, Map and table describing the Admiralty-Revillagigedo intrusive belt plutons in the Petersburg 1:250,000 quadrangle, Alaska: U.S. Geological Survey Open-File Report 84-171, 6 p., scale $1: 250,000$.

Douglass, S.L., Webster, J.H., Burrell, P.D., Lanphere, M.L., and Brew, D.A., 1989, Major element chemistry, radiometric values, and locations of samples from the Petersburg and parts of the Port Alexander and Sumdum quadrangles, southeastern Alaska:

U.S. Geological Survey 0pen-File Report 89-527, 66 p., scale 1: 250,000 .

Drinkwater, J.L., Brew, D.A., and Ford, A.B., 1995, Geology, petrography, and geochemistry of granitic rocks from the Coast Mountains Complex near Juneau, southeastern Alaska: U.S. Geological Survey Open-File Report 95-638, 119 p.

Friedman, R.M., Diakow, L.J., Lane, R.A., and Mortensen, J.K., 2001, New U-Pb age constraints on latest Cretaceous magmatism and associated mineralization in the Fawnie Range, Nechako Plateau, central British Columbia: Canadian Journal of Earth Sciences, v. 38, no. 4, p. 619-637.

Gehrels, G.E., McClelland, W.C., Samson, S.D., Patchett, P.J., and Brew, D.A., 1991, U-Pb geochronology and tectonic significance of Late Cretaceous-early Tertiary plutons in the northern 
Coast Mountains batholith: Canadian Journal of Earth Sciences, v. 28, no. 6, p. 899-911.

Gehrels, G.E., McClelland, W.C, Samson, S.D., Patchett, P.J., and Jackson, J.L., 1990, Ancient continental margin assemblage in the northern Coast Mountains, southeast Alaska and northwest Canada: Geology, v. 18, no. 3, p. 208-211.

Geological Survey of Canada, 1957, Stikine River area: Map 9-157, scale 1:253,440.

Karl, S.M., Hammarstrom, J.M., Kunk, M.J., Himmelberg, G.R., Brew, D.A., Kimbrough, D.L., and Bradshaw, J.Y., 1996, Tracy Arm transect; further constraints on the uplift history of the Coast plutonic complex in southeastern Alaska [abs.]: Geological Society of America Abstracts with Programs, v. 28, no. 7, p. A-312.

Kerr, F.A., 1935a, Stikine River area, centre sheet: Canadian Department of Mines Map 310A, scale 1:126,720.

-1935b, Stikine River area, south sheet: Canadian Department of Mines Map 311A, scale 1:126,720.

Koch, R.D., and Berg, H.C., 1996, Reconnaissance geologic map of the Bradfield Canal quadrangle, southeastern Alaska: U.S. Geological Survey Open-File Report 81-728-A, 35 p., scale 1:250,000.

Koch, R.D., Brew, D.A., and Ford, A.B., 1987, Newly discovered molybdenite occurrence near Boundary Creek, Coast Mountains, southeastern Alaska, in Hamilton, T.D., and Galloway, J.P., eds., Geologic studies in Alaska by the U.S. Geological Survey during 1986: U.S. Geological Survey Circular 998, p. 124-125.

Krakauer, Jon, 1998, The Devils Thumb, in Eiger dreams: London, Pan Books, p. 163-186.

Logan, J.M., Koyanagi, V.M., and Rhys, D.A., 1993, Geology and mineral occurrences of the Galore Creek area (NTS 104G/04): British Columbia, Canada, Ministry of Energy, Mines and Petro- leum Resources, Geological Survey Branch Geoscience Map 1993-2, scale 1:50,000.

Miller, L.D., Goldfarb, R.J., Snee, L.W., McClelland, W.C., and Klipfel, P.D., 1997, Paleocene molybdenum mineralization in the eastern Coast batholith, Taku River region, and new age constraints on batholith evolution, in Dumoulin, J.A., and Gray, J.E., eds., Geologic studies in Alaska by the U.S. Geological Survey, 1995: U.S. Geological Survey Professional Paper 1574, p. 125-135.

Motyka, R.J., Begét, J.E., and Bowen, Paul, 1998, Recent retreat of LeConte Glacier and associated calving and iceberg hazards: Alaska Division of Geological \& Geophysical Surveys Report of Investigations 98-15,9 p.

Samson, S.D., Patchett, P.J., McClelland, W.C., and Gehrels, G.E, 1991, $\mathrm{Nd}$ isotopic characterization of metamorphic rocks in the Coast Mountains, Alaskan and Canadian Cordilleras; ancient crust bounded by juvenile terranes: Tectonics, v. 10, no. 4, p. 770-780.

Stacey, J.S., and Kramers, J.D., 1975, Approximation of terrestrial lead isotope evolution by a two-stage model: Earth and Planetary Science Letters, v. 26. no. 2, p. 207-221.

U.S. Forest Service, 1992, The Stikine Icefields; frozen rivers shaping the land: U.S. Forest Service, Alaska Region Leaflet R10-RG$45,8 \mathrm{p}$.

Webster, J.H., 1984, Preliminary report on a large granitic body in the Coast Mountains, northeast Petersburg quadrangle, southeastern Alaska, in Reed, K.M., and Bartsch-Winkler, Susan, eds.:

The U.S. Geological Survey in Alaska; accomplishments during 1982: U.S. Geological Survey Circular 939, p. 116-118.

Wheeler, J.0., and McFeely, Patricia, 1991, Tectonic assemblage map of the Canadian Cordillera and adjacent parts of the United States of America: Geological Survey of Canada Map 1712A, scale $1: 2,000,000$. 


\title{
Mount Griggs: A Compositionally Distinctive Quaternary Stratovolcano Behind the Main Volcanic Line in Katmai National Park
}

\author{
By Wes Hildreth, Judy Fierstein, Marvin A. Lanphere, and David F. Siems
}

\section{Abstract}

Mount Griggs, the highest peak in Katmai National Park, is a fumarolically active andesitic stratovolcano that stands alone $12 \mathrm{~km}$ behind the main volcanic chain of the Alaska Peninsula range crest. K-Ar ages indicate that the volcano is as old as $292 \pm 11 \mathrm{ka}$ and thus predates inception of the nearby volcanic-front centers. The middle Pleistocene edifice was glacially ravaged before construction of the well-preserved modern cone during the late Pleistocene and Holocene. Collapse of the southwest sector early in the Holocene left a $1.5-\mathrm{km}$-wide amphitheater at the summit and shed a $1-\mathrm{km}^{3}$-volume debris avalanche into the valley of Knife Creek. Smaller debris-avalanche deposits later emplaced to the east, north, and west are also of early Holocene age. Postcollapse andesite eruptions built an inner cone that nearly filled the amphitheater and covered the southwest slope of the volcano with a fan of leveed lava flows. The inner cone is topped by a pair of nested craters and supports clusters of mildly superheated, sulfur-precipitating fumaroles. Present-day edifice volume is approximately 20 to $25 \mathrm{~km}^{3}$, of which about $2.2 \mathrm{~km}^{3}$ was erupted during the Holocene. Average productivity is estimated to have been at least $0.12 \mathrm{~km}^{3} / \mathrm{k}$.y. for the lifetime of the volcano and appears to have been in the range $0.2-0.4 \mathrm{~km}^{3} / \mathrm{k}$.y. since about $50 \mathrm{ka}$. Eruptive products are olivine-bearing two-pyroxene andesites rich in plagioclase that have remained especially phenocryst rich throughout the history of the volcano. A total of 77 analyzed samples define a typical Ti-poor, medium-K calcalkaline arc suite, largely ranging in $\mathrm{SiO}_{2}$ content from 55 to 63 weight percent, that shows little systematic change over time. Relative to products of the nearby volcanic-front centers, those of Mount Griggs are slightly depleted in Fe, generally enriched in $\mathrm{Rb}, \mathrm{Sr}, \mathrm{Al}$, and $\mathrm{P}$, and consistently enriched in $\mathrm{K}$ and $\mathrm{Zr}$; its fumarolic gases are notably richer in He. The magmatic plumbing system of Mount Griggs is independent of those beneath the main volcanic chain, probably all the way to mantle depths. Holocene ash from Mount Griggs is inconspicuous beyond the edifice, and no evidence was found for particularly explosive ejection of its crystal-rich andesitic magmas. Future debris flows from any sector of the volcano would have a $25-\mathrm{km}$ runout into Naknek Lake through uninhabited wilderness.

\section{Introduction}

The Quaternary volcanic chain of Katmai National Park is the most tightly spaced line of stratovolcanoes in Alaska (fig. 1). Along the volcanic front, crater-to-crater spacing between adjacent (commonly contiguous) edifices is typically $5 \mathrm{~km}$ or less. A subset of these edifices at the head of the Valley of Ten Thousand Smokes is the Katmai cluster, made up of numerous stratocones and associated lava domes (Hildreth, 1987; Hildreth and Fierstein, 2000). Of the many discrete Quaternary volcanic vents in the Katmai cluster, only Mount Griggs, the subject of this chapter, lies significantly off axis, some $12 \mathrm{~km}$ behind (northwest of) the main volcanic line (fig. 1).

Mount Griggs is one of the larger and better preserved stratovolcanoes in the region, rising about $1,750 \mathrm{~m}$ above the floor of the Valley of Ten Thousand Smokes (fig. 2). With its summit reaching about 7,650 ft $(2,330 \mathrm{~m})$ in elevation, Mount Griggs is the highest peak in Katmai National Park. Present-day symmetry of the apparently little-dissected edifice (fig. 2) reflects numerous effusions of andesitic lava during the late Pleistocene and Holocene that have healed and concealed older scars of glacial erosion. Moderately productive during postglacial time and still fumarolically active, Mount Griggs is also the longest lived center in the Katmai cluster; its construction began nearly $300 \mathrm{ka}$. Although the volcano has not erupted historically, a large volume of Holocene lava covers its southwest slope (figs. 2, 3).

The main volcanic chain from Snowy to Alagogshak (fig. 1) is constructed along the preexisting range crest (Pacific-Bristol Bay drainage divide), where the rugged prevolcanic basement typically reaches 4,000 to $5,500 \mathrm{ft}$ 
$(1,200-1,675 \mathrm{~m})$ in elevation. Because the line of volcanic summits reaches 6,000 to $7,100 \mathrm{ft}(1,830-2,165 \mathrm{~m})$ in elevation and lies in a region of high precipitation, all the rangecrest centers are extensively ice covered. Although Mount Griggs is higher still, its position $12 \mathrm{~km}$ northwest of the frontal axis receives less precipitation, resulting in less glacial ice on the edifice. Five narrow ice tongues (fig. 4) descend from shallow cirques high on the north slopes to termini at 3,000- to 3,800 -ft $(915-1,160 \mathrm{~m})$ elevation, and a sixth extends down the south slope from the summit icefield to a terminus at 5,500-ft (1,675 m) elevation (see figs. 2, 4-7).

All the streams draining Mount Griggs are tributaries of either Ikagluik Creek or the Knife Creek branch of the Ukak River (fig. 3). These streams flow northward and nearly meet just before entering the Iliuk Arm of Naknek Lake (fig. 1). Debris flows resulting from eruptions or avalanches at Mount Griggs would therefore be expected to affect drainage systems only to the north and northwest, not those of the Pacific slope.

Mount Griggs lies in uninhabited national-park wilderness. The base of the volcano is a 1-day hike from the hill west of Three Forks (fig. 3), which is in turn accessible in summer months by dirt road from Brooks Camp (fig. 1). Many aircraft—cargo, passenger, and sightseeing-commonly overfly the volcano, but only a handful of the 100-odd backpackers who roam the Valley of Ten Thousand Smokes each summer ever venture onto the slopes of Mount Griggs.

\section{Earlier Work}

Little fieldwork has previously been undertaken at Mount Griggs. The National Geographic Society expeditions of 1915-19 led by Robert Fiske Griggs (1881-1962) identified the mountain as a volcano on the topographic map they prepared of the Katmai region, and the first photographs of Mount Griggs (then known as Knife Peak) are in their publications (Griggs, 1922; Allen and Zies, 1923), but no mention of its lavas, structure, or fumaroles appears in their reports. Charles Yori climbed the mountain alone on August 20, 1923, photographed the summit icefield, and took an ande-

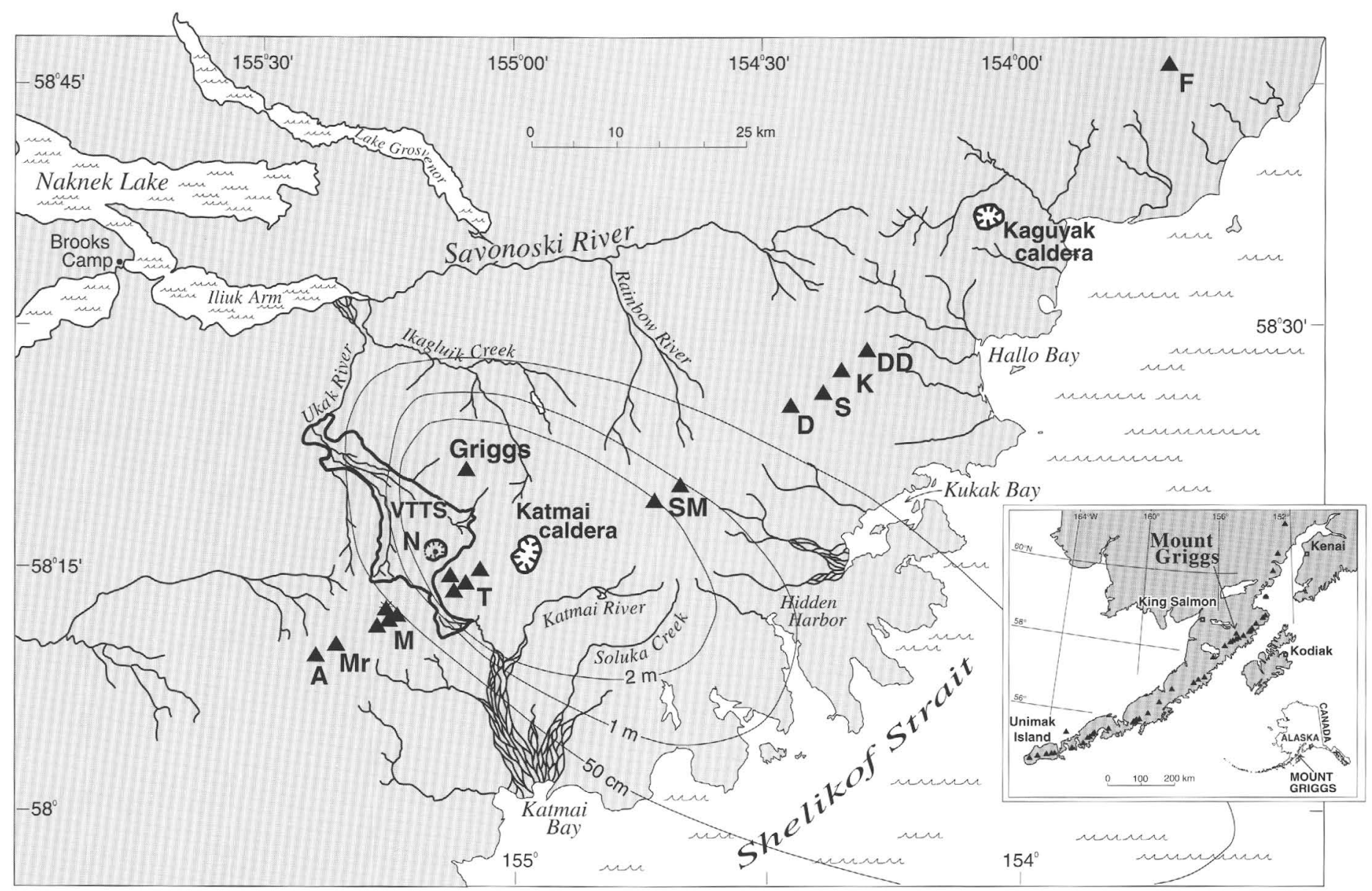

Figure 1. Southern Alaska, showing location of Mount Griggs stratovolcano about $12 \mathrm{~km}$ behind late Quaternary volcanic axis, which straddles drainage divide along this stretch of the Alaska Peninsula. Triangles indicate andesite-dacite stratovolcanoes, identified by letter: A, Alagogshak; D, Denison; DD, Devils Desk; F, Fourpeaked; K, Kukak; M, Mageik (cluster of four); Mr, Martin; S, Steller; SM, Snowy Mountain (two cones); T, Trident (cluster of four). VTTS, the Valley of Ten Thousand Smokes ash-flow sheet (outlined area), which erupted at Novarupta (N) in June 1912. Isopachs show thickness of cumulative 1912 plinian fallout, originally 2 to 5 m thick across Mount Griggs. Were pyroclastic flows or debris flows to originate at Mount Griggs itself, they would be confined to Ikagluik Creek or the VTTS, both of which drain to the Iliuk Arm of Naknek Lake. 
site sample (later analyzed by C.N. Fenner) from an outcrop "about 100 feet below summit" (Fenner, 1926, p. 684). To the best of our knowledge, the fumaroles high on the volcano were first mentioned by Muller and others (1954).

In 1959, Professor Griggs received a letter from the president of the National Geographic Society informing him that the U.S. Board of Geographic Names was changing the name of Knife Peak to Mount Griggs (Higbie, 1975). In 1963, the ashes of Griggs and his wife joined volcanic ash from the 1912 eruption of Novarupta scattered on the airy summit of the volcano.

Kosco (1980) joined our field party in 1976 and produced some chemical and petrographic data for Mount Griggs lavas. Hildreth (1987) and Wes Hildreth (in Wood and Kienle, 1990) composed short summaries of what was then known about the volcano. A more inclusive summary was given by Hildreth and Fierstein (2000), but in this chapter, based on helicopter-supported fieldwork in 1997-99, we document the present state of our knowledge of Mount Griggs. Although our study is a moderately detailed field reconnais- sance, better understanding of the eruptive and erosional history of Mount Griggs could certainly be achieved by means of additional fieldwork and radiometric dating. The 1912 fallout that so thickly mantles the young southwest sector of the cone (fig. 2) makes it difficult to find organic material, the dating of which might help unravel the emplacement history of the Holocene lava apron.

\section{Basement Rocks}

The volcanic edifice of Mount Griggs has been constructed upon a set of glaciated ridges carved from subhorizontal marine siltstone and sandstone of the Jurassic Naknek Formation (Riehle and others, 1993; Detterman and others, 1996). These stratified rocks are intruded locally by several porphyritic granitoid stocks of Tertiary age, one of which is abutted by Mount Griggs lavas on the northwest side of the volcano (fig. 4). Although Mount Griggs lavas descend to as low as 1,900-ft $(580 \mathrm{~m})$ elevation to the north and southwest

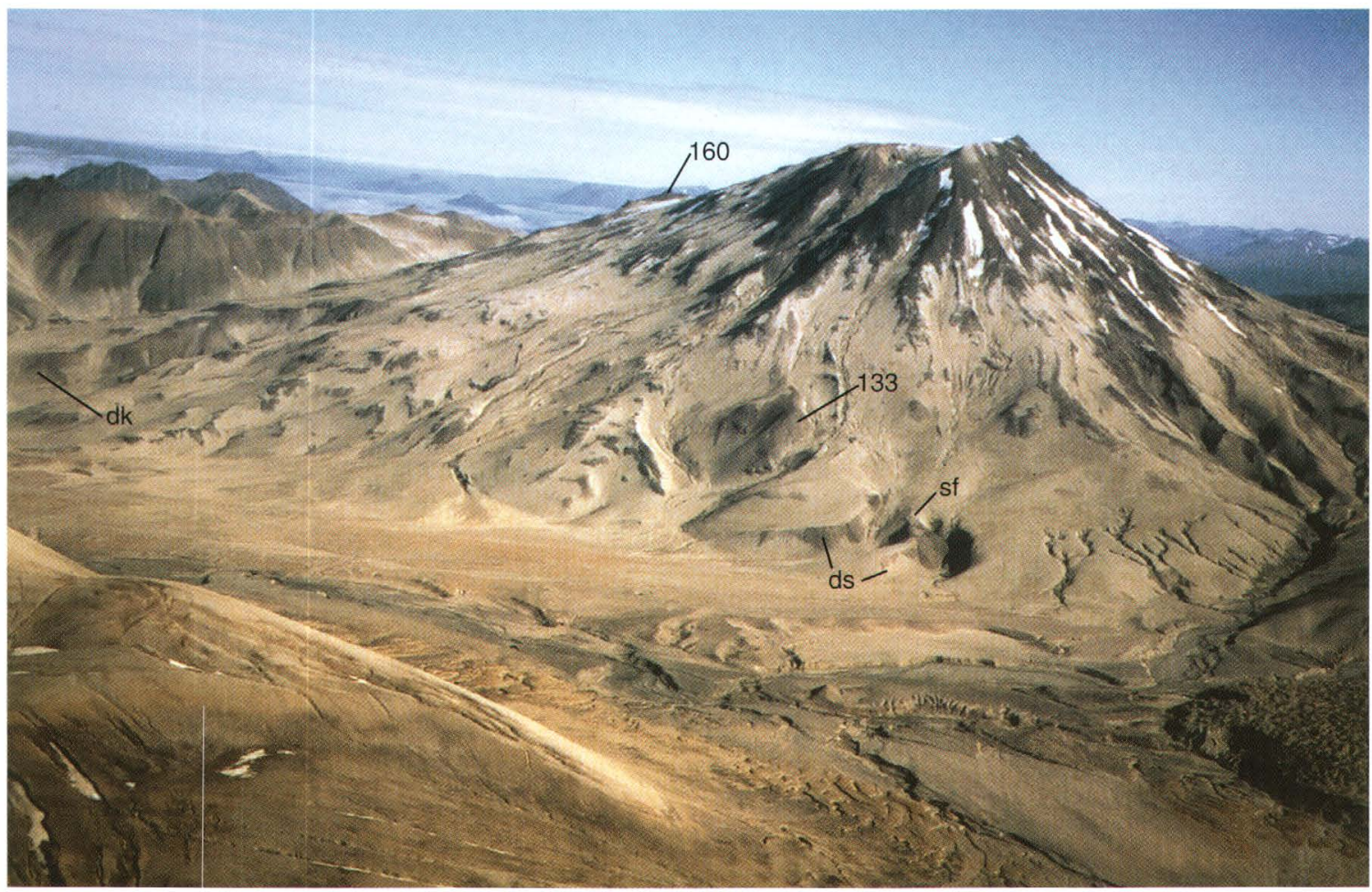

Figure 2. Oblique aerial photograph of Mount Griggs stratovolcano. Right (southeast) half of visible edifice, including 7,650-ft (2,332 m)-elevation summit, consists largely of late Pleistocene lava flows; left (southwest) slope and amphitheater-filling black inner cone consist principally of Holocene lava flows and proximal agglutinate. Massive exposure at far-left base of cone is debris-avalanche deposit (unit $\mathrm{dk}$ ) as much as $200 \mathrm{~m}$ thick. Two windows of middle Pleistocene lava flows are designated by their ages, 133 and $160 \mathrm{ka}$. At foot of cone in foreground, remnants of a late Pleistocene scoria flow from Mount Katmai (unit sf; see fig. 10) form rims of gulches cut into all-andesite diamict (unit ds). Knife Creek tributary streams bounding volcano are the Griggs Fork (right) and the Juhle Fork (left). Beyond the Juhle Fork is Mount Juhle, which consists largely of Jurassic marine sedimentary strata of the Naknek Formation, intruded by a Tertiary porphyritic granitoid pluton (see fig. 4). Broken Mountain (lower left), Knife Creek valley (part of the Valley of Ten Thousand Smokes), and glacier (lower right) are covered by pyroclastic-flow and fall deposits from 1912 eruption of Novarupta (out of view, slightly behind and to left). Pale-gray mantle draping Mount Griggs is 1912 dacitic pumice-fall deposit, which on lower slopes rests also on thin pink run-up sheets of 1912 rhyolitic ignimbrite. View northward across upper Knife Creek. 


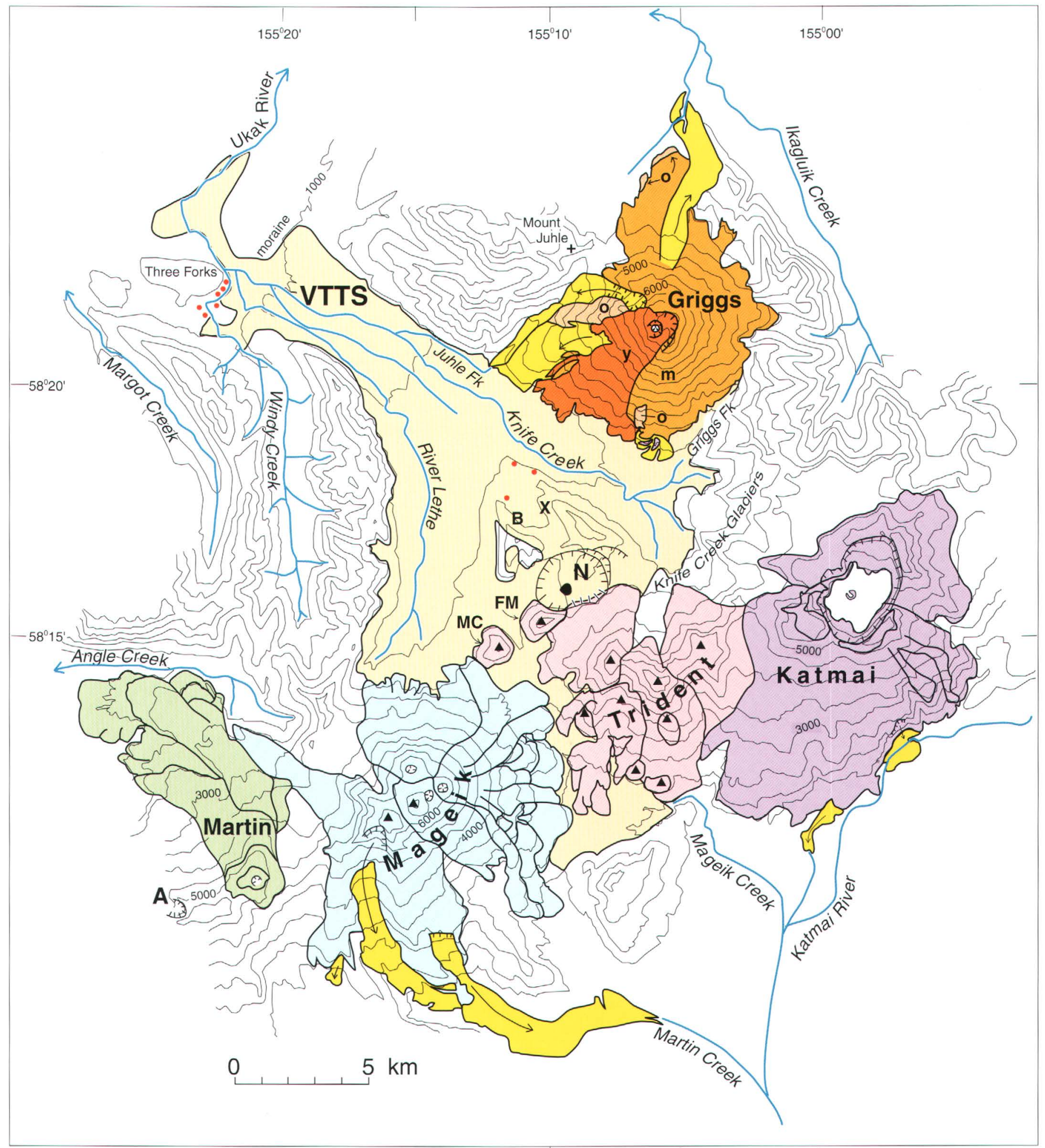

Figure 3. Topographic map of Mount Griggs and vicinity, showing main drainages, nearby volcanoes, and places mentioned in text. A, Alagogshak Volcano; B, Baked Mountain; FM, Falling Mountain dome; MC, Mount Cerberus dome; N, Novarupta dome; X, Broken Mountain. On Mount Griggs: 0, m, y, oldest, middle, and youngest lavas, respectively, as discussed in text; glaciers are omitted for clarity. Bright yellow areas, debrisavalanche deposits. Red dots, remnants of Knife Peak debris-avalanche deposit beyond limits of Mount Griggs edifice itself. Pale-tan valley fill is 1912 ignimbrite in the Valley of Ten Thousand Smokes (VTTS). Near Three Forks in lower VTTS is valley-crossing Neoglacial moraine discussed in text (see Hildreth, 1983; Fierstein and Hildreth, 1992). For geology of volcanoes on main volcanic line, see Hildreth and Fierstein (2000). 
(fig. 4), basement rocks crop out at as high as 4,400-ft (1,340 $\mathrm{m})$ elevation at the northwestern and eastern margins of the cone, attesting to the rugged prevolcanic relief draped by the volcanic pile.

Although Permian to Jurassic sedimentary rocks that regionally underlie the Naknek Formation (itself $2 \mathrm{~km}$ thick) do not crop out in the Katmai area, the stratigraphic framework of the Alaska Peninsula (Detterman and others, 1996) suggests that such rocks are as much as $3.5 \mathrm{~km}$ thick beneath Mount Griggs.

A few remnants of Pliccene or early Quaternary volcanic rocks cap peaks and ridges near Mount Griggs (fig. 4), but most such rocks (more extensive farther eastward; see Riehle and others, 1993) have been eroded from the study area (fig. 1).

\section{Compound Edifice}

The apparent symmetry of the andesitic stratovolcano as viewed from the Valley of Ten Thousand Smokes (fig. 2) belies a complex history that is partly revealed by its three concentric summit craters. The outer rim defines a $1.5-\mathrm{km}-$ wide amphitheater that is open to the west but is largely filled by a postglacial andesite cone topped by a nested pair of inner craters. The amphitheater apparently formed by sector collapse during the early Holocene, when the largest of several debris-avalanche deposits was emplaced. The edifice now exposed thus consists of several components of different ages, which are clescribed below within the following framework: (1) three windows of severely eroded lavas of middle Pleistocene age; (2) the main late Pleistocene cone, only lightly eroded, and its amphitheater-forming debrisavalanche deposit; and (3) the Holocene inner cone that filled the amphitheater and created the southwesterly apron of leveed lava flows, virtually uneroded.

\section{Middle Pleistocene Exposures}

The oldest lavas exposed at Mount Griggs are two or more flows of plagioclase-rich pyroxene andesite (60 weight percent $\mathrm{SiO}_{2}$ ) that form 150-m-high cliffs along the Juhle Fork of Ikagluik Creek at the north foot of the volcano (fig. 4). These distal, devitrified to partly glassy lava flows rest on Jurassic basement and are overlain by a sheet of till that obscures their contact with younger Mount Griggs lavas. The two noncontiguous cliff exposures are formed by discrete lava flows that are similar in thickness, petrography, and composition (samples 2294, 2309, table 1), yet differ significantly from the more mafic lava flows that crop out a few hundred meters southwest. The more easterly lava of the pair yielded a whole-rock K-Ar age of $292 \pm 11 \mathrm{ka}$ (table 2) and so is the earliest eruptive product recognized at Mount Griggs.

A second exposure of glacially eroded middle Pleistocene lava flows forms the ridge that rims the south wall of the Juhle Fork of Knife Creek and culminates in a craggy shoulder at $6,200-\mathrm{ft}(1,890 \mathrm{~m})$ elevation about $2 \mathrm{~km}$ west of the summit (figs. 2-4, 6). The crags are eroded from four or five slabby flows of flow-foliated silicic andesite (59-62 weight percent $\mathrm{SiO}_{2}$ ) that dip about $20^{\circ} \mathrm{W}$. and thicken downslope to the west, each to 25 to $40 \mathrm{~m}$ thick. They are underlain by a stack of several thinner (10-20 m thick) flows of more mafic andesite (56 weight percent $\mathrm{SiO}_{2}$ ) marked by oxidized rubbly zones that forms the 600-m-high wall which extends downward to the glacier flooring the upper Juhle Fork. The topmost flow capping the highest crag gave a whole-rock K-Ar age of $160 \pm 8 \mathrm{ka}$ (fig. 4; table 2).

The third window of glaciated lavas that unequivocally predates construction of the main late Pleistocene cone crops out at 2,500- to 3,500-ft (760-1,065 m) elevation near the south base of the volcanic edifice (figs. $2,4,6$ ). The 400 - by 750-m-wide, reddish-brown-weathering exposure stands out as a glacially smoothed bulge that branches downslope into a pair of steep rubbly spurs. At least five andesitic lava flows (56-58 weight percent $\mathrm{SiO}_{2}$ ) are present, but neither the base nor the top of the stack is exposed. Gray-brown to pale-purple massive zones support 8 - to $15-\mathrm{m}$-high benches that are separated by oxidized flow-breccia zones, some of which are tens of meters thick. The toe of the stack is concealed by thick scree and alluvium (dominantly reworked 1912 pumice), and the top is covered by wind-deflated diamicton-either till or avalanche rubble-armored by a lag of varied andesite blocks. A flow midway through the stack, third from the bottom, yielded a whole-rock K-Ar age of $133 \pm 25 \mathrm{ka}$ (fig. 4; table 2).

Locally mantling the east rim of this southerly window of older lavas is a 25-m-wide remnant of a black scoria deposit ( 53 weight percent $\mathrm{SiO}_{2}$ ), only $1 \mathrm{~m}$ thick. Contained in a fines-poor matrix dominated by coarse crystal ash, most scoria is smaller than $1 \mathrm{~cm}$ across, and the largest is only 4 $\mathrm{cm}$ across. Much of the deposit is poorly sorted, unstratified, and infiltrates the rough rubbly surface of the underlying lava, but the undisturbed top $20 \mathrm{~cm}$ looks like primary fallout. The remnant is lithic poor and locally indurated by orange secondary minerals. The scoria is notably lower in $\mathrm{K}$ and $\mathrm{Zr}$ contents than the array of eruptive products at Mount Griggs, but in its composition it closely matches the suite erupted at nearby Mount Katmai.

\section{Late Pleistocene Outer Cone}

After glacial destruction of the volcanic edifice(s) from which the lavas of the older windows just described were erupted, late Pleistocene activity sufficiently outpaced erosion to permit accumulation of a fairly symmetrical cone, about 8 $\mathrm{km}$ across and $1.5 \mathrm{~km}$ high. Much of that cone remains conspicuous today, somewhat degraded but little dissected (fig. 2 ). Its south and east slopes are near-primary concave surfaces (fig. 2), its north half is shallowly incised by five narrow ice tongues (fig. 4), and its southwesterly quadrant was destroyed by sector collapse during the early Holocene. No flank vents have been recognized, and all the flows exposed appear to be summit derived, cut off from a slightly higher former source 


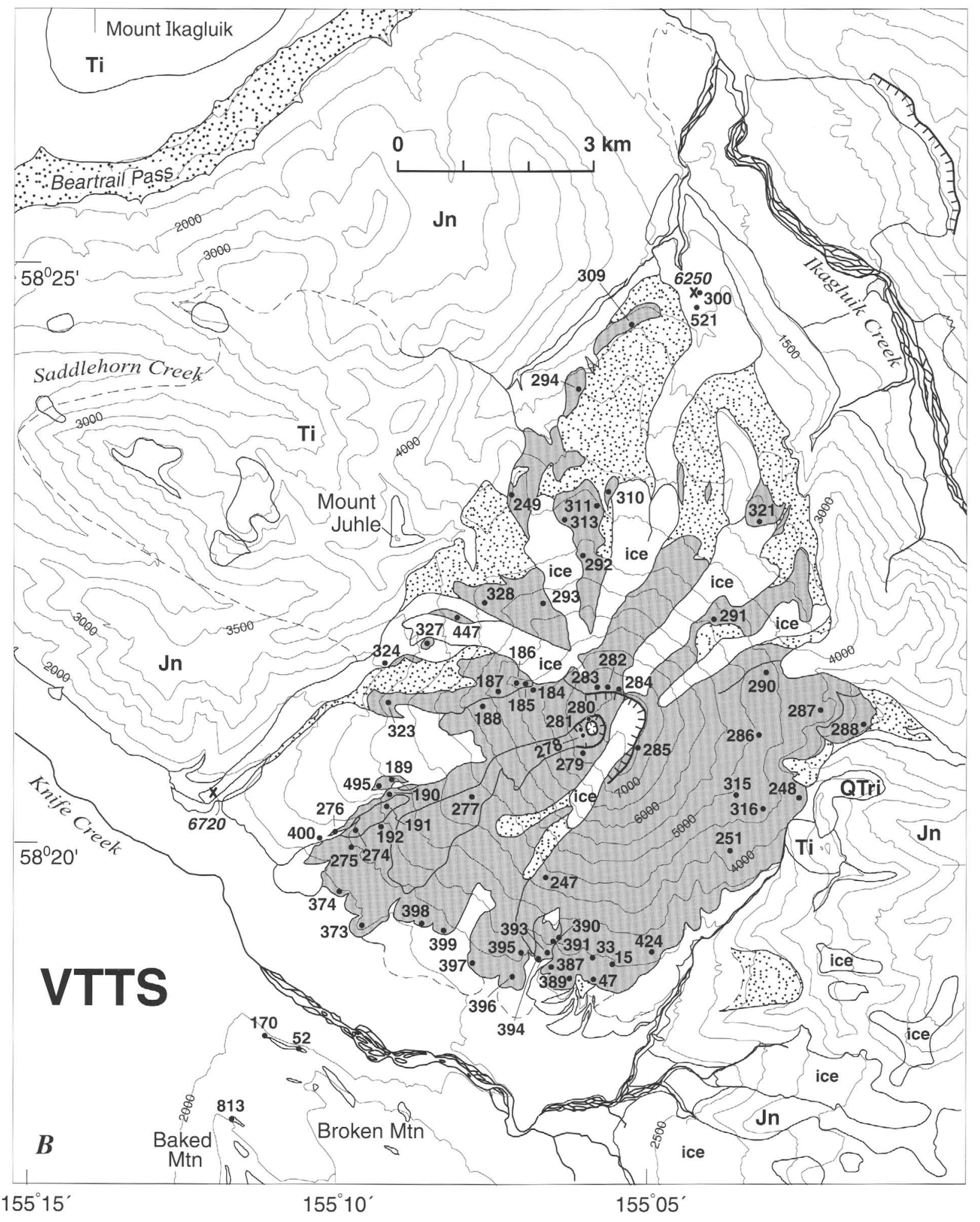

ignimbrite, undated; QTv, basaltic, andesitic, and dacitic lava remnants, mostly Pliocene, northwest of Mount Griggs; Ti, Tertiary porphyritic granitoid intrusions. Red stippling along northern margin of northwestern glacier denotes hydrothermally altered zone at source of Juhle Fork debris-avalanche deposit. Red X's, sample sites for K-Ar ages listed in table 2; adjacent numbers give ages (in thousands of years). At south-central edge, two ignimbrite-mantled ridges defined by 2,500-ft contour are noses of Baked and Broken Mountains (see fig. 3), where blocks of avalanche-deposited andesite of Mount Griggs overlie basement rocks in scattered windows. $B$, Placenames and sample locations. All samples listed in table 1 are indicated except those from avalanche blocks 2350-A, 2350-B, and 2352, which are in the Windy Creek embayment of the Valley of Ten Thousand Smokes. x6250 and x6720, sites of two radiocarbon-dated samples atop debris-avalanche deposits, as discussed in text. Same base as in figure $4 \mathrm{~A}$. 


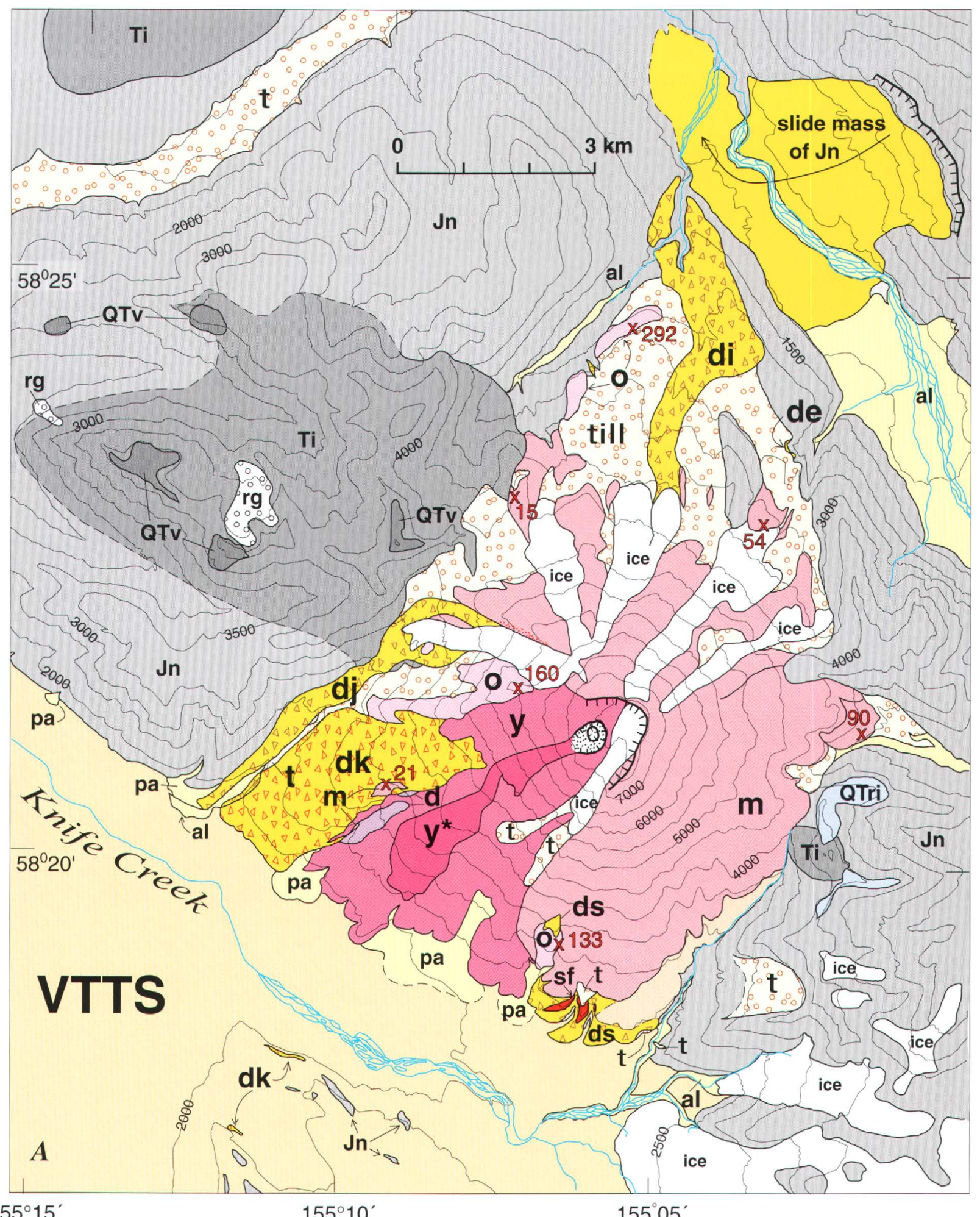

$155^{\circ} 15^{\prime}$

$155^{\circ} 10^{\prime}$

$155^{\circ} 05^{\prime}$

Figure 4. Reconnaissance geologic map of Mount Griggs area, southern Alaska (fig. 1). Topography simplified from U.S. Geological Survey 1:63,360-scale Mount Katmai B-4 quadrangle; contour interval, $500 \mathrm{ft}$. $A$, Geologic units. Paletan unit in the Valley of Ten Thousand Smokes (VTTS) is ignimbrite from 1912 eruption of Novarupta. On Mount Griggs edifice: d, dacite lava flow; m, late Pleistocene andesite cone; o, old andesite windows (middle Pleistocene); y, postcollapse Holocene andesite cone and lava fan; $\mathrm{y}^{*}$, youngest set of andesitic lava flows. Mass-flow deposits (bright yellow): de, diamict of Ikagluik Creek; di, Ikagluik Creek debris-avalanche deposit; dj, Juhle Fork debris avalanche; dk, Knife Peak debris avalanche; ds, diamict of Griggs Fork. Surficial deposits: al, alluvium; pa, pumiceous alluvial fans of remobilized 1912 fallout; rg, rock glaciers; sf (red), late Pleistocene dacitic scoria flow from Mount Katmai; t, glacial till. Basement rocks: Jn, Jurassic Naknek Formation, subhorizontal marine siltstone and sandstone; QTri, rhyolitic 
Table 1. Chemical analyses of eruptive products from Mount Griggs, Alaska.

[Major-oxide contents in weight percent, normalized to $\mathrm{H}_{2} \mathrm{O}$-free totals of 99.6 weight percent (allowing 0.4 weight percent for trace oxides and halogens), determined by wavelength-dispersive X-ray-fluorescence analysis in the U.S. Geological Survey laboratory at Lakewood, Colo.; analyst, D.F. Siems. Rb, Sr, and Zr contents in parts per million, determined by energy-dispersive X-ray-fluorescence analysis; analyst, D.F. Siems. Precision and accuracy were discussed by Bacon and Druitt (1988). FeO*, total Fe calculated as FeO. LOI, weight loss on ignition at $900^{\circ} \mathrm{C}$. Original total, volatile-free sum of 10 major-oxide analyses before normalization, with total Fe calculated as $\mathrm{Fe}_{2} \mathrm{O}_{3}$ ]

\begin{tabular}{lllllllllllllllll}
\hline Sample & $\mathrm{SiO}_{2}$ & $\mathrm{TiO}_{2}$ & $\mathrm{Al}_{2} \mathrm{O}_{3}$ & $\mathrm{FeO} *$ & $\mathrm{MnO}$ & $\mathrm{MgO}$ & $\mathrm{CaO}$ & $\mathrm{Na}_{2} \mathrm{O}$ & $\mathrm{K}_{2} \mathrm{O}$ & $\mathrm{P}_{2} \mathrm{O}_{5}$ & LOI & Original & $\mathrm{Rb}$ & $\mathrm{Sr}$ & $\mathrm{Zr}$
\end{tabular}

\section{Inner cone}

\begin{tabular}{|c|c|c|c|c|c|c|c|c|c|c|c|c|c|c|c|}
\hline 2184 & 57.5 & 0.86 & 17.59 & 7.13 & 0.14 & 3.80 & 7.38 & 3.70 & 1.26 & 0.23 & 0.09 & 99.41 & 24 & 384 & 140 \\
\hline 2188 & 57.4 & .88 & 17.71 & 7.16 & $\begin{array}{r}.14 \\
.14\end{array}$ & 3.66 & 7.16 & 3.87 & $\begin{array}{l}1.20 \\
1.31\end{array}$ & .28 & .14 & 99.27 & 23 & 371 & 140 \\
\hline 2190 & 57.3 & .88 & 17.64 & 7.28 & .14 & 3.76 & 7.42 & 3.65 & 1.27 & .24 & $\begin{array}{r}.14 \\
-.06\end{array}$ & 98.86 & 21 & 374 & 137 \\
\hline 2192 & 59.1 & .81 & 17.45 & 6.79 & .14 & 3.15 & 6.53 & 3.84 & 1.54 & .23 & .16 & 99.21 & 28 & 357 & 162 \\
\hline 2275 & 58.7 & .81 & 17.61 & 6.76 & .14 & 3.20 & 6.66 & 3.90 & 1.52 & .26 & .29 & 99.04 & 32 & 362 & 154 \\
\hline 2276 & 57.4 & .86 & 17.64 & 7.21 & .14 & 3.73 & 7.36 & 3.69 & 1.29 & .25 & -.05 & 99.32 & 25 & 392 & 145 \\
\hline 2277 & 57.2 & .87 & 17.65 & 7.33 & .14 & 3.83 & 7.45 & 3.61 & 1.26 & .23 & -.06 & 99.23 & 20 & 390 & 141 \\
\hline 2278 & 60.2 & .81 & 17.19 & 6.36 & .13 & 2.88 & 6.20 & 3.93 & 1.64 & .22 & -.03 & 98.96 & 34 & 348 & 171 \\
\hline 2279 & 55.1 & .89 & 18.48 & 7.55 & .15 & 4.32 & 8.32 & 3.50 & 1.03 & .23 & .38 & 98.38 & 18 & 371 & 122 \\
\hline 2280 & 59.3 & .83 & 17.56 & 6.73 & .13 & 3.07 & 6.38 & 3.84 & 1.48 & .24 & .54 & 98.20 & 29 & 367 & 169 \\
\hline 2281 & 60.4 & .78 & 17.22 & 6.27 & .13 & 2.84 & 6.13 & 3.91 & 1.65 & .22 & .66 & 98.55 & 33 & 347 & 157 \\
\hline 2373 & 61.0 & .75 & 17.05 & 6.22 & .13 & 2.70 & 5.89 & 3.93 & 1.74 & .23 & .25 & 98.36 & 29 & 333 & 179 \\
\hline 2374 & 59.6 & .79 & 17.41 & 6.56 & .14 & 2.95 & 6.38 & 3.92 & 1.59 & .23 & .16 & 98.96 & 33 & 346 & 167 \\
\hline 2395 & 56.9 & .86 & 17.90 & 7.22 & .14 & 3.82 & 7.47 & 3.79 & 1.27 & .27 & .01 & 99.22 & 24 & 360 & 137 \\
\hline 2396 & 58.7 & .84 & 17.60 & 6.82 & .14 & 3.19 & 6.69 & 3.86 & $\begin{array}{l}1.49 \\
1.49\end{array}$ & .22 & .15 & 99.45 & 31 & 342 & 161 \\
\hline 2397 & 55.9 & .87 & 18.17 & 7.38 & .14 & 4.11 & 7.93 & 3.68 & 1.14 & .23 & -.04 & 99.08 & 24 & 367 & 127 \\
\hline 2398 & 60.7 & .76 & 17.12 & 6.30 & .13 & 2.75 & 5.98 & 3.90 & 1.72 & .22 & .00 & 98.85 & 35 & 345 & 176 \\
\hline 2399 & 61.9 & .74 & 16.72 & 6.04 & .13 & 2.50 & 5.49 & 3.91 & 1.90 & .22 & .21 & 98.86 & 40 & 328 & 190 \\
\hline
\end{tabular}

Outer cone

\begin{tabular}{|c|c|c|c|c|c|c|c|c|c|c|c|c|c|c|c|}
\hline 47 & 55.7 & 0.90 & 18.50 & 7.82 & 0.16 & 3.81 & 7.53 & 3.87 & 1.10 & 0.21 & 0.25 & 99.59 & 20 & 432 & 142 \\
\hline 2189 & 56.3 & .89 & 18.38 & 7.69 & .15 & 3.70 & 7.28 & 3.82 & 1.15 & .24 & -.04 & 99.06 & 27 & 429 & 140 \\
\hline 2191 & 63.0 & .69 & 16.53 & 5.52 & .12 & 2.30 & 5.19 & 3.97 & 2.04 & .23 & .29 & 98.95 & 41 & 328 & 204 \\
\hline 2247 & 59.2 & .75 & 17.51 & 6.36 & .13 & 3.39 & 6.76 & 3.74 & 1.55 & .23 & .26 & 99.02 & 30 & 361 & 151 \\
\hline 2248 & 59.3 & .81 & 17.55 & 7.04 & .15 & 2.85 & 6.10 & 4.10 & 1.45 & .25 & .01 & 99.07 & 28 & 403 & 164 \\
\hline 2249 & 57.9 & .76 & 17.84 & 6.68 & .14 & 3.81 & 7.21 & 3.69 & 1.32 & .21 & -.09 & 99.34 & 28 & 400 & 139 \\
\hline 2251 & 60.1 & .82 & 17.44 & 6.50 & .14 & 2.68 & 5.81 & 4.22 & 1.61 & .26 & .09 & 99.06 & 33 & 382 & 178 \\
\hline 2274 & 57.6 & .75 & 18.07 & 6.71 & .14 & 3.78 & 7.38 & 3.59 & 1.33 & .24 & .29 & 99.36 & 28 & 415 & 137 \\
\hline 2274-A & 63.4 & .67 & 16.52 & 5.39 & .12 & 2.16 & 5.01 & 3.97 & 2.09 & .22 & .44 & 98.87 & 43 & 315 & 203 \\
\hline 2282 & 55.1 & .85 & 17.86 & 7.93 & .15 & 5.00 & 8.15 & 3.20 & 1.15 & .21 & .88 & 98.41 & 26 & 336 & 112 \\
\hline 2283 & 55.2 & .89 & 18.96 & 7.83 & .14 & 4.30 & 7.79 & 3.25 & 1.03 & .20 & 2.04 & 96.72 & 20 & 339 & 114 \\
\hline 2284 & 58.0 & .85 & 18.01 & 7.29 & .15 & 3.26 & 6.57 & 3.93 & 1.28 & .26 & .36 & 98.69 & 28 & 417 & 147 \\
\hline 2285 & 55.5 & .86 & 18.18 & 7.64 & .14 & 4.10 & 8.44 & 3.34 & 1.12 & .22 & .00 & 98.58 & 22 & 383 & 114 \\
\hline 2286 & 59.8 & .80 & 17.41 & 6.78 & .14 & 2.89 & 5.92 & 4.06 & 1.55 & .27 & .10 & 99.02 & 33 & 395 & 168 \\
\hline 2287 & 60.3 & .77 & 18.10 & 5.67 & .13 & 2.50 & 5.90 & 4.39 & 1.58 & .26 & .23 & 98.89 & 32 & 380 & 169 \\
\hline 2288 & 62.7 & .69 & 17.98 & 4.54 & .12 & 1.59 & 5.10 & 4.70 & 1.88 & .26 & .35 & 98.65 & 43 & 370 & 205 \\
\hline 2290 & 59.0 & .79 & 18.04 & 6.14 & .13 & 3.18 & 6.46 & 4.16 & 1.42 & .27 & .06 & 99.02 & 32 & 389 & 157 \\
\hline 2291 & 59.1 & .82 & 17.54 & 7.05 & .14 & 3.12 & 6.16 & 4.00 & 1.46 & .24 & .16 & 98.92 & 30 & 383 & 162 \\
\hline 2292 & 57.1 & .76 & 17.44 & 7.22 & .15 & 4.20 & 7.70 & 3.57 & 1.23 & .24 & .00 & 99.39 & 27 & 369 & 132 \\
\hline 2293 & 60.2 & .72 & 17.43 & 6.15 & .14 & 3.18 & 6.06 & 3.82 & 1.68 & .23 & 1.06 & 97.34 & 40 & 351 & 165 \\
\hline 2310 & 58.6 & .78 & 17.64 & 7.17 & .15 & 3.29 & 6.57 & 3.88 & 1.32 & .24 & .18 & 98.65 & 27 & 386 & 129 \\
\hline 2311 & 57.2 & .76 & 17.29 & 7.23 & .15 & 4.36 & 7.60 & 3.55 & 1.24 & .25 & -.04 & 99.24 & 28 & 363 & 135 \\
\hline 2313 & 57.1 & .75 & 17.27 & 7.26 & .15 & 4.41 & 7.61 & 3.52 & 1.24 & .24 & .11 & 99.07 & 26 & 360 & 130 \\
\hline 2315 & 59.1 & .81 & 17.51 & 7.12 & .15 & 2.94 & 6.07 & 4.15 & 1.46 & .29 & .17 & 99.32 & 35 & 414 & 158 \\
\hline 2316 & 59.3 & .81 & 17.54 & 7.02 & .15 & 2.86 & 6.10 & 4.07 & 1.45 & .25 & -.03 & 99.23 & 28 & 391 & 152 \\
\hline 2321 & 57.3 & .81 & 17.67 & 7.12 & .14 & 3.91 & 7.41 & 3.62 & 1.35 & .22 & -.14 & 99.10 & 30 & 346 & 140 \\
\hline 2328 & 59.8 & .73 & 17.46 & 6.24 & .14 & 3.21 & 6.42 & 3.80 & 1.62 & .24 & .57 & 98.32 & 38 & 360 & 158 \\
\hline 2387 & 57.8 & .86 & 18.03 & 7.26 & .15 & 3.31 & 6.67 & 3.94 & 1.33 & .26 & -.04 & 98.84 & 26 & 415 & 154 \\
\hline 2389 & 56.9 & .81 & 17.76 & 7.39 & .14 & 3.78 & 7.77 & 3.52 & 1.27 & .22 & .10 & 99.90 & 28 & 400 & 136 \\
\hline 2424 & 54.9 & .81 & 17.63 & 7.61 & .14 & 5.12 & 8.92 & 3.22 & 1.05 & .21 & -.05 & 99.24 & 22 & 367 & 109 \\
\hline 2495 & 57.2 & .87 & 18.29 & 7.45 & .15 & 3.48 & 6.81 & 3.86 & 1.25 & .24 & .34 & 98.86 & 22 & 409 & 144 \\
\hline KNM-15 & 62.5 & .71 & 16.86 & 5.70 & .12 & 2.32 & 5.53 & 3.84 & 1.86 & .16 & .25 & 98.65 & 38 & 330 & 189 \\
\hline KNM-33 & 55.5 & .88 & 18.15 & 7.51 & .14 & 4.18 & 8.15 & 3.78 & 1.09 & .17 & .28 & 99.34 & 19 & 364 & 133 \\
\hline
\end{tabular}

Old windows

\begin{tabular}{|c|c|c|c|c|c|c|c|c|c|c|c|c|c|c|c|}
\hline 2185 & 61.9 & 0.63 & 17.14 & 5.72 & 0.14 & 2.45 & 5.51 & 4.12 & 1.71 & 0.25 & 0.06 & 99.20 & 36 & 365 & 151 \\
\hline 2186 & 59.0 & .72 & 17.59 & 6.44 & .14 & 3.43 & 6.84 & 3.78 & 1.44 & .23 & -.07 & 99.10 & 28 & 404 & 137 \\
\hline 2187 & 55.2 & .81 & 18.11 & 7.55 & .15 & 4.50 & 8.75 & 3.27 & 1.06 & .16 & -.06 & 99.54 & 18 & 379 & 106 \\
\hline 2294 & 60.1 & .68 & 17.44 & 6.15 & .14 & 3.11 & 6.33 & 3.92 & 1.55 & .23 & .09 & 99.04 & 33 & 377 & 146 \\
\hline 2309 & 60.1 & .72 & 17.50 & 6.52 & .15 & 2.86 & 6.03 & 4.02 & 1.46 & .22 & .15 & 98.87 & 29 & 373 & 131 \\
\hline 2323 & 57.0 & .77 & 18.09 & 6.85 & .14 & 4.02 & 7.63 & 3.56 & 1.30 & .25 & -.12 & 99.01 & 22 & 428 & 130 \\
\hline 2327 & 57.8 & .75 & 17.66 & 6.98 & .14 & 3.96 & 7.29 & 3.63 & 1.13 & .24 & .00 & 98.61 & 23 & 429 & 114 \\
\hline 2390 & 57.8 & .75 & 17.91 & 6.87 & .15 & 3.62 & 7.47 & 3.60 & 1.24 & .22 & -.06 & 98.89 & 21 & 418 & 122 \\
\hline 2391 & 56.2 & .88 & 18.23 & 7.86 & .16 & 3.83 & 7.21 & 3.85 & 1.08 & .28 & .02 & 98.86 & 20 & 428 & 144 \\
\hline 2393 & 58.2 & .74 & 17.80 & 6.73 & .14 & 3.49 & 7.25 & 3.70 & 1.30 & .27 & .10 & 99.14 & 24 & 422 & 127 \\
\hline 2394 & 58.1 & .74 & 17.96 & 6.74 & .14 & 3.44 & 7.26 & 3.69 & 1.27 & .21 & .00 & 98.99 & 26 & 431 & 128 \\
\hline 2447 & 59.2 & .77 & 17.19 & 6.94 & .15 & 3.59 & 6.47 & 3.82 & 1.30 & .20 & .11 & 98.70 & 23 & 368 & 122 \\
\hline $2447 \mathrm{~A}$ & 50.9 & .90 & 19.27 & 8.48 & .15 & 6.31 & 1.04 & 2.70 & .67 & .14 & .77 & 98.36 & 10 & 478 & 78 \\
\hline
\end{tabular}


Table 1. Chemical analyses of eruptive products from Mount Griggs, Alaska-Continued.



Avalanche blocks

\begin{tabular}{|c|c|c|c|c|c|c|c|c|c|c|c|c|c|c|c|}
\hline 52 & 59.6 & 0.67 & 17.42 & 6.25 & 0.13 & 3.44 & 6.54 & 3.85 & 1.48 & 0.18 & 0.38 & 98.36 & 33 & 339 & 169 \\
\hline 170 & 57.0 & .75 & 17.27 & 7.21 & .14 & 4.29 & 8.03 & 3.53 & 1.20 & .19 & $<.01$ & 99.79 & 23 & 371 & 138 \\
\hline 813 & 57.4 & .66 & 18.25 & 6.23 & .13 & 3.82 & 7.96 & 3.63 & 1.33 & .15 & $<.01$ & 100.42 & 24 & 352 & 141 \\
\hline 813i & 53.6 & .79 & 18.38 & 7.57 & .14 & 5.54 & 9.38 & 3.09 & .93 & .14 & $<.01$ & 100.27 & 13 & 349 & 109 \\
\hline 2300 & 60.2 & .76 & 17.35 & 6.60 & .14 & 3.00 & 6.04 & 3.84 & 1.49 & .22 & .47 & 98.75 & 29 & 344 & 151 \\
\hline 2324-A & 55.5 & .84 & 17.76 & 7.65 & .15 & 4.85 & 8.12 & 3.32 & 1.19 & .20 & -.04 & 98.76 & 24 & 352 & 121 \\
\hline 2350-A & 59.1 & .71 & 17.28 & 6.63 & .15 & 3.48 & 6.64 & 3.95 & 1.44 & .27 & .02 & 98.61 & 32 & 375 & 153 \\
\hline $2350-B$ & 57.5 & .74 & 17.28 & 7.00 & .15 & 4.51 & 7.14 & 3.74 & 1.29 & .24 & -.13 & 99.01 & 26 & 353 & 141 \\
\hline 2352 & 56.5 & .76 & 17.07 & 7.31 & .15 & 4.86 & 7.95 & 3.53 & 1.19 & .25 & .35 & 98.35 & 20 & 361 & 128 \\
\hline $2400 \mathrm{~A}$ & 55.9 & .86 & 18.32 & 7.83 & .14 & 3.96 & 8.24 & 3.11 & 1.00 & .19 & .76 & 98.51 & 22 & 396 & 120 \\
\hline 2400B & 58.5 & .75 & 17.32 & 6.92 & .15 & 3.76 & 7.01 & 3.67 & 1.35 & .18 & 1.01 & 97.86 & 26 & 373 & 144 \\
\hline 2521A & 59.2 & .67 & 16.88 & 6.37 & .15 & 4.41 & 6.68 & 3.62 & 1.43 & .20 & .41 & 98.52 & 33 & 337 & 138 \\
\hline $2521 i$ & 53.9 & .81 & 17.50 & 7.77 & .16 & 6.93 & 8.53 & 3.04 & .84 & .11 & .35 & 98.49 & 11 & 350 & 94 \\
\hline
\end{tabular}

Table 2. Whole-rock K-Ar ages and analytical data for Mount Griggs samples.

[Analysts: K, D.F. Siems; Ar, F.S. McFarland and J.Y. Saburomaru. Constants: $\lambda=0.581 \times 10^{-10} \mathrm{yr}^{-1} ; \lambda_{\beta}=4.962 \times 10^{-10} \mathrm{yr}^{-1}$; $\left.{ }^{40} \mathrm{~K} / \mathrm{K}=1.167 \times 10^{-4} \mathrm{~mol} / \mathrm{mol}\right]$

\begin{tabular}{|c|c|c|c|c|c|c|}
\hline \multirow[t]{2}{*}{ Sample } & \multirow{2}{*}{$\begin{array}{l}\text { Location } \\
\text { (fig. } 4 \text { ) }\end{array}$} & \multicolumn{2}{|c|}{ Weight percent } & \multicolumn{2}{|c|}{$\underline{\text { Radiogenic }{ }^{40} \mathrm{Ar}}$} & \multirow{2}{*}{$\begin{array}{l}\text { Calculated } \\
\text { age }(\mathrm{ka})\end{array}$} \\
\hline & & $\mathrm{SiO}_{2}$ & $\mathrm{~K}_{2} \mathrm{O}$ & $10^{-13} \mathrm{~mol} / \mathrm{g}$ & percent & \\
\hline $\mathrm{K}-2186$ & $\begin{array}{l}\text { Crag at } 6,200+\text {-ft elevation } \\
\text { on WNW. shoulder. Top } \\
\text { flow of old glaciated stack. }\end{array}$ & 59.0 & $1.552 \pm 0.004$ & 3.581 & 15.1 & $160 \pm 8$ \\
\hline $\mathrm{K}-2189$ & $\begin{array}{l}\text { West slope. Top flow on } \mathrm{N} \\
\text { rim of gorge at } 3,400-\mathrm{ft} \\
\text { elevation, } 200 \mathrm{~m} \text { E. of hill at } \\
3,500+-\mathrm{ft} \text { elevation. Over- } \\
\text { lain directly by unit dk. }\end{array}$ & 56.3 & $1.197 \pm 0.003$ & .3694 & 1.4 & $21 \pm 11$ \\
\hline $\mathrm{K}-2249$ & $\begin{array}{l}\text { Northern distal lava flow. } \\
\text { Thick ice-scoured flow on } \\
4100 \text {-ft ridge atop basement } \\
\text { rocks, } 400 \mathrm{~m} \text { N. of hill at } \\
4,230 \text {-ft elevation. }\end{array}$ & 57.9 & $1.384 \pm 0.001$ & .2914 & .3 & $15 \pm 18$ \\
\hline $\mathrm{K}-2288$ & $\begin{array}{l}\text { Eastern basal distal lava } \\
\text { flow. Intracanyon flow, } 150 \\
m \text { thick, in fork of Ikagluik } \\
\text { Creek. }\end{array}$ & 62.7 & $2.027 \pm 0.006$ & 2.644 & 11.4 & $90 \pm 7$ \\
\hline K-2309 & $\begin{array}{l}\text { Northern basal distal lava } \\
\text { flow on } 2,500 \text {-ft rim of can- } \\
\text { yon tributary to Ikagluik } \\
\text { Creek. }\end{array}$ & 60.1 & $1.515 \pm 0.002$ & 6.357 & 14.8 & $292 \pm 11$ \\
\hline $\mathrm{K}-2321$ & $\begin{array}{l}\text { Northeastern basal distal } \\
\text { lava flow, } 80 \text { m thick, on } \\
3,200-\mathrm{ft} \text {. rim of gorge } \\
\text { above glacier snout; } 350 \mathrm{~m} \\
\mathrm{~S} \text { of map location } \times 3060 \text {. }\end{array}$ & 57.3 & $1.479 \pm 0.001$ & 1.143 & 5.4 & $54 \pm 8$ \\
\hline $\mathrm{K}-2390$ & $\begin{array}{l}\text { South window, } 3.5 \mathrm{~km} \mathrm{~S} \text {. of } \\
\text { summit crater. Middle flow } \\
\text { of old stack at } 3,000 \text {-ft ele- } \\
\text { vation. }\end{array}$ & 59.0 & $1.254 \pm 0.001$ & 2.395 & 2.6 & $133 \pm 25$ \\
\hline $\mathrm{K}-2274 \mathrm{~A}$ & $\begin{array}{l}\text { Convolutely foliated dacite } \\
\text { lava flow at } 2,400 \text { - to } 3,500- \\
\text { ft elevation, W. slope. }\end{array}$ & 63.4 & 2.09 & 0 & 0 & $\begin{array}{c}\text { no age } \\
\text { (failed twice) }\end{array}$ \\
\hline
\end{tabular}


vent by the present-day rim of the amphitheater (fig. 5). A total of 33 samples, representing all parts of the late Pleistocene cone, range in $\mathrm{SiO}_{2}$ content from 55 to 63 weight percent (table 1).

The well-preserved south and east slopes of the cone are radially corrugated by blocky to rubbly levees of numerous overlapping andesitic lava flows. Many such flows bifurcate, most thicken downslope (typically from less than $15 \mathrm{~m}$ proximally to $60 \mathrm{~m}$ or more on gentler slopes at the foot of the cone), and a few flows grade into distal lobes of disintegrated rubble. Some of the interlevee channels have been deepened into icy couloirs or, lower on the cone, by snowmelt runoff into sharp unglaciated gulches, thus accentuating the radially furrowed aspect of the surface (fig. 2). Only a few such gullies cut deeply enough to expose two or more lava flows.

The north slopes of the outer cone are more eroded, supporting five small present-day glaciers, but the slopes retain their grossly concave constructional form, and parts of the interfluves between the thin ice tongues are near-primary surfaces. In particular, the most easterly of the five glaciers heads $200 \mathrm{~m}$ lower than the amphitheater rim and $800 \mathrm{~m}$ east of it, in a spoon-shaped cirque that is sharply but shallowly cut into an otherwise-unglaciated surface of steeply leveed andesite flows. Unlike the single narrow glacier that issues from the southwest notch (figs. 4-7), none of the five northerly glaciers is fed from the summit icefield, which remains confined on its north and east sides by the well-preserved amphitheater rim (figs. 5, 7). All five northerly glaciers head in shallow cirques high on the outer slopes of the cone and end on the cone's lower apron in complex accumulations of till, avalanche debris, and reworked 1912 pumice. Even during their maximum advances $(2-3 \mathrm{~km}$ beyond present termini), all five glaciers terminated on the cone itself, did not coalesce into a unified slope glacier, and left no evidence of ever having joined the broad glacial valleys of Ikagluik and Knife Creeks, which were shaped by the Pleistocene ice that extended many tens of kilometers northwestward (Muller, 1952, 1953; Riehle and Detterman, 1993). We thus infer that all the glaciers now on the cone originated after late Pleistocene recession of major trunk glaciers and that surface lavas armoring the outer cone of Mount Griggs postdate the Last Glacial Maximum (LGM, 25-15 ka).

Four exposures of lava flows that crop out around the base of the cone warrant special discussion because each flow has undergone moderate erosion but appears to underlie with approximate conformity the little-modified surface flows just described. First, at the north toe of the cone, a till-strewn, cliff-forming andesite lava flow (57.9 weight percent $\mathrm{SiO}_{2}$ ) that drapes the contact between Jurassic and Tertiary basement rocks is at least $100 \mathrm{~m}$ (possibly $150 \mathrm{~m}$ ) thick; it may have been ponded or otherwise obstructed there, conceivably by ice during the LGM. A fine fresh sample of the lava yielded only 0.3 percent radiogenic $\mathrm{Ar}$ and a nominal $\mathrm{K}-\mathrm{Ar}$ age of $15 \pm 18 \mathrm{ka}$ (fig. 4 ; table 2 ), thereby supporting our field interpretation that this glaciated flow is young and belongs to the late Pleistocene edifice.

Second, isolated by ice and till at the northeast toe of the volcano, a lightly glaciated andesitic lava flow (57.3 weight percent $\mathrm{SiO}_{2}$ ), at least $80 \mathrm{~m}$ thick, rests directly on Jurassic basement and dips moderately outboard, consistent with being an early flow from the existing outer cone. Although the flow interior crops out slabby and strongly jointed on cliffs facing the adjacent glacial trough, the flow surface (though scoured) retains blocky remnants that suggest a rather limited history of glacial erosion. The lava gave a whole-rock K-Ar age of $54 \pm 8$ ka (fig. 4; table 2), in agreement with that inference.

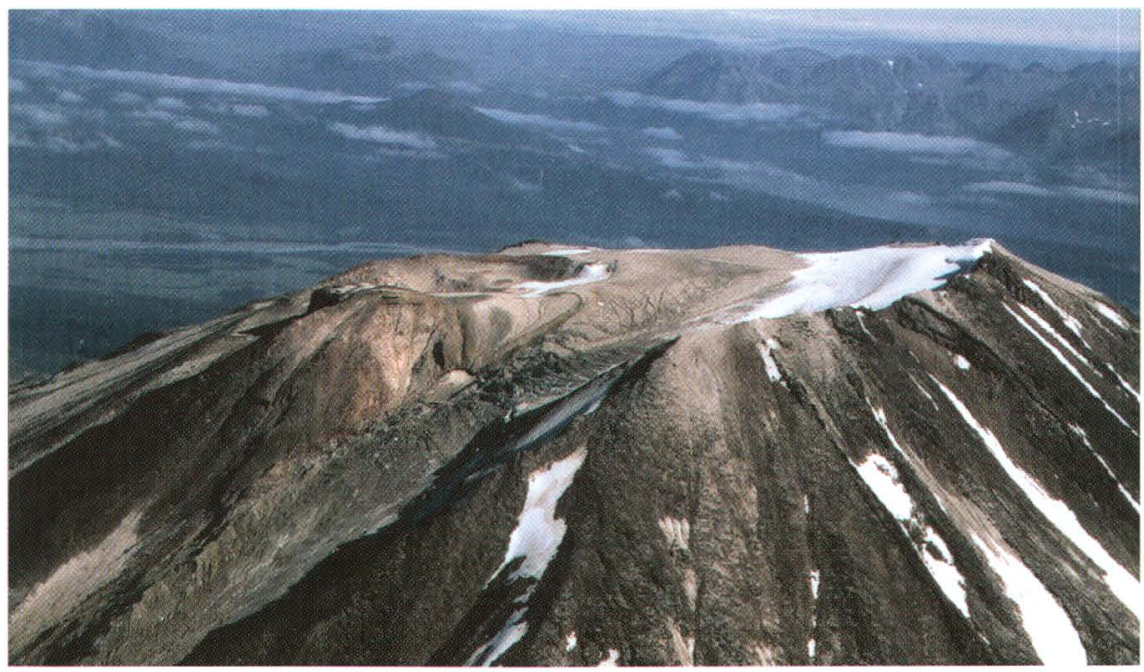

Figure 5. Aerial photograph of summit of Mount Griggs. Amphitheater wall and true summit are visible at right; beheaded lava flows are visible at rim of outer cone. Holocene inner cone topped by nested craters is visible at left. Icefield fills semiannular moat that separates inner cone from outer (amphitheater) wall, and it spills southwestward into steep debris-covered glacier tongue at lower left. Fresh white snow covers right half of icefield; left half (tan) is mantled by fallout from 1912 eruption of Novarupta, through which crevasses in underlying ice are visible. Ikagluik Creek is in lowland background. View northward. 

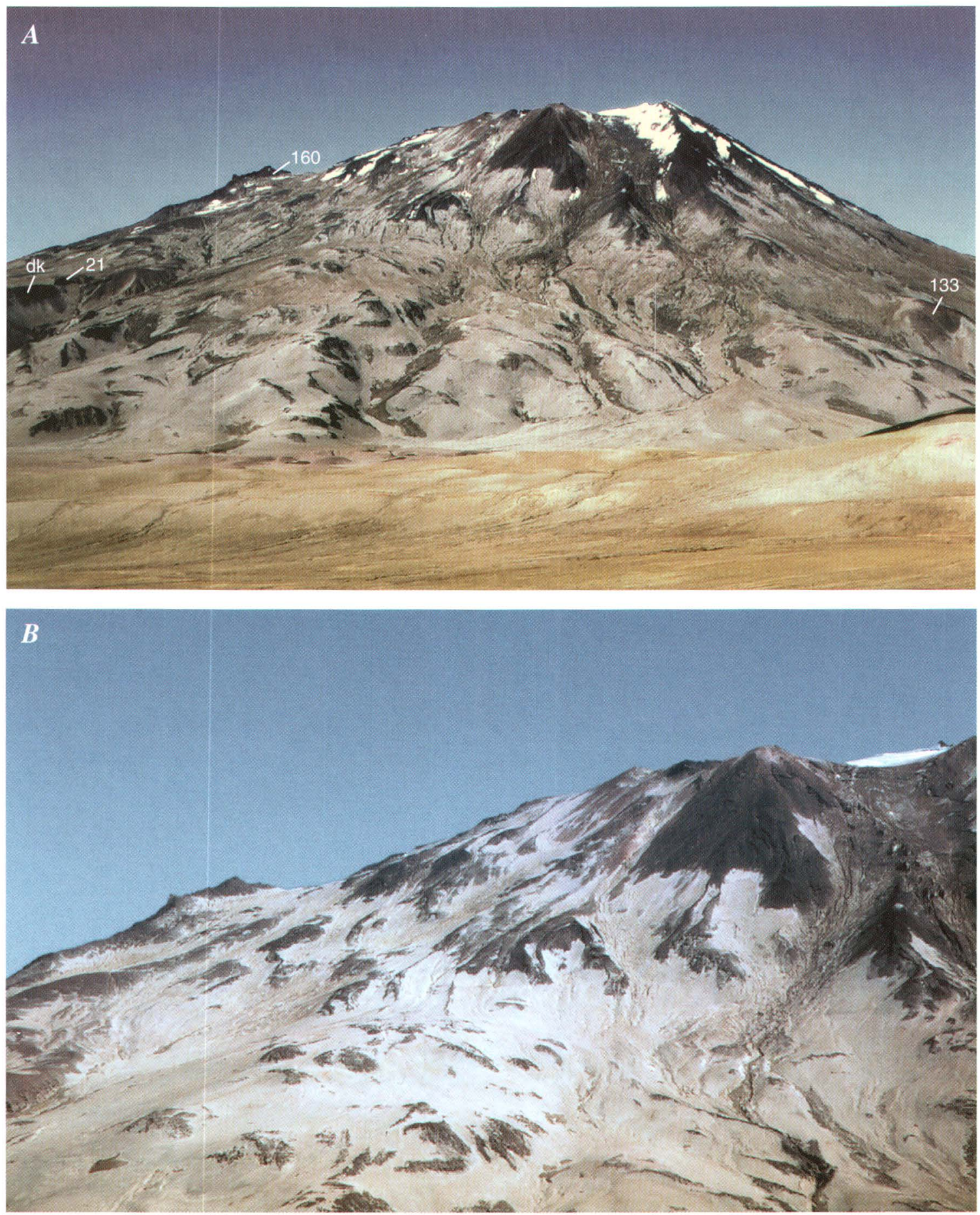

Figure 6. Mount Griggs. A, View from floor of the Valley of Ten Thousand Smokes. Near summit, gray-brown debriscovered glacier separates white snowclad east wall of amphitheater in older edifice from black Holocene cone filling it. Foreground slope is Holocene fan of leveed andesitic lava flows, heavily mantled by pumice-fall deposits from 1912 eruption of Novarupta. Toes of lavas are buried by 1912 pyroclastic deposits (oxidized tan where underlain by thick 1912 ignimbrite) and 1-km-wide alluvial fan of 1912 pumice reworked from higher slopes of Mount Griggs. Windows of middle Pleistocene lavas (see fig. 2) crop out at lower right (133 ka) and on left skyline (160 ka). At left edge, Knife Peak debrisavalanche deposit (unit dk) drapes and fills paleorelief cut into stack of andesite lava flows ( $21 \pm 11$ ka). View northeastward. $B$, Closeup of upper-central part of figure $6 A$. Debris-covered glacier issues from white snow-covered icefield separating black inner cone from wall of amphitheater at upper right. True summit pinnacle rises behind bergschrund at right rear. Steep black slope of Holocene inner cone consists of andesitic agglutinate, thin spatter-fed lava tongues, and scoriaceous rubble. On left skyline, frost-shattered crags are a window of middle Pleistocene lavas. At center, youngest lava-producing eruption at Mount Griggs issued from top of inner cone and left a steep narrow leveed channel, which (below slope break) spread into a heap of overlapping lava lobes (unit ${ }^{*}$, fig. 4), conspicuous in foreground beneath mantle of 1912 pumice. 


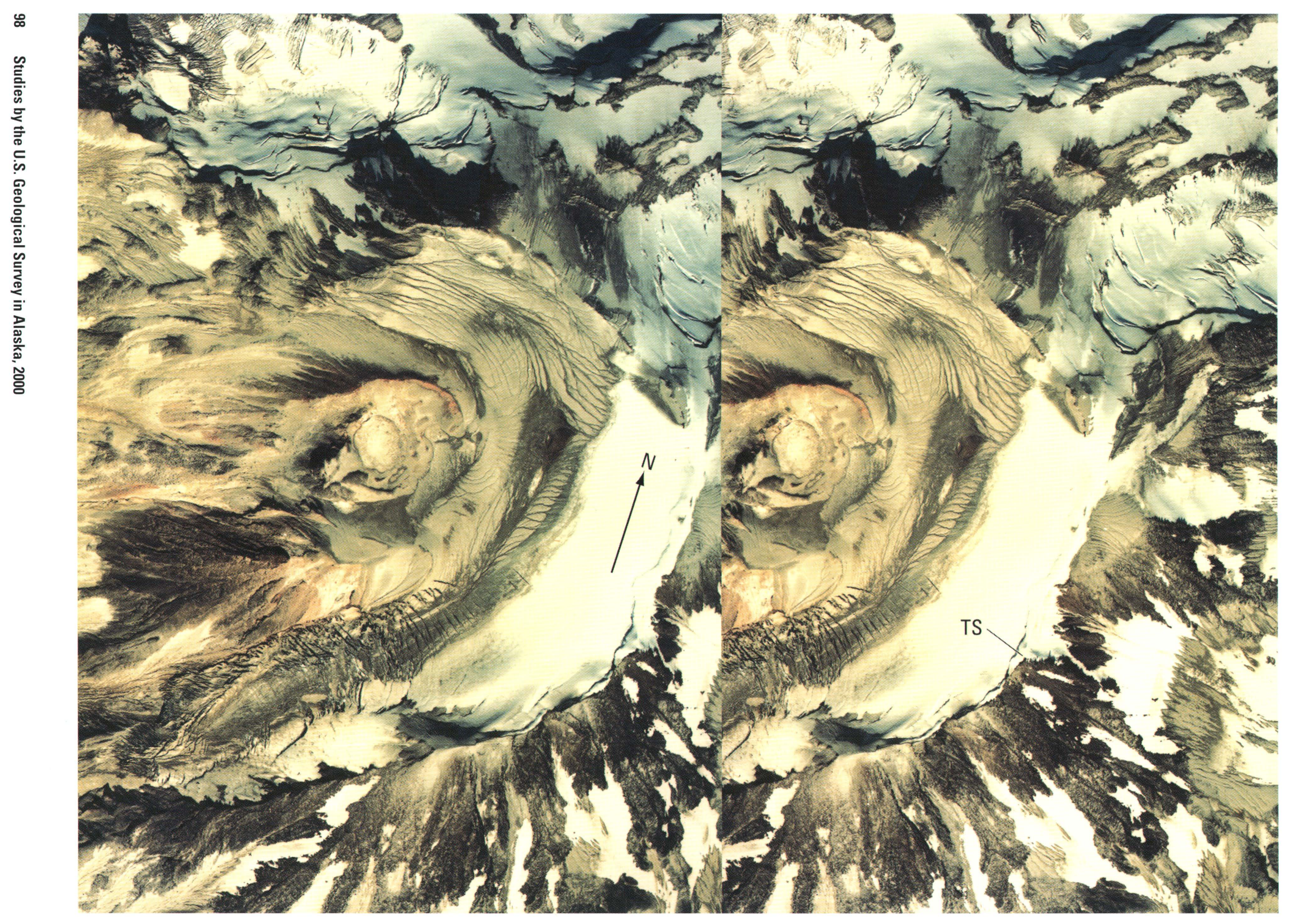


Third, at the east base of the volcano, a black glassy lava flow of silicic andesite ( 62.8 weight percent $\mathrm{SiO}_{2}$ ), as much as $200 \mathrm{~m}$ thick - the thickest flow recognized at Mount Griggsdirectly underlies an uneroded summit-derived andesite flow (60.3 weight percent $\mathrm{SiO}_{2}$ ) with apparent conformity. Only the distal $500 \mathrm{~m}$ of the thick flow is exposed, owing to the overlap of younger lava flows. Uniquely among Mount Griggs lavas on the east side of the mountain, this thick flow descends to the floor of a deep canyon, here a tributary of Ikagluik Creek (figs. 3,4 ). The steep present-day front of the flow has been erosively modified, but its great thickness, its pervasive glassiness, its blocky top, and the extensive columnar joints that dominate its lower half all suggest an intracanyon lava lobe that ponded against a valley-filling glacier. Ice flooring this canyon would presumably have been a branch of a more extensive precursor of present-day Ikagluik Glacier, which is fed by icefields on the north side of Mount Katmai. The thick flow, which yielded a whole-rock K-Ar age of $90 \pm 7 \mathrm{ka}$ (table 2), may predate construction of the main late Pleistocene cone or, alternatively, could be the oldest exposed product of that cone.

Fourth, along a gorge on the lower west flank of Mount Griggs, a radial strip of glacially eroded lavas is exposed beneath a major debris-avalanche deposit and an adjacent fan of postglacial lava flows (figs. 2, 4,6). On the north wall of the 150 -m-deep gorge, a northwest-dipping stack of three or more andesitic lava flows (56.3-57.2 weight percent $\mathrm{SiO}_{2}$ ) is exposed beneath the avalanche deposit. The platy interior of the top flow gave a whole-rock K-Ar age of $21 \pm 11$ ka (table 2), consistent with the stack being a component of the late Pleistocene outer cone (rather than a window into a deeply eroded older edifice). Across the gorge and forming much of its south wall is a convolutely flow-foliated dacitic lava flow (63.0-63.4 weight percent $\mathrm{SiO}_{2}$ ), pervasively glassy and vesicular and exposed to a thickness of $50 \mathrm{~m}$. The surface of the gray-brown-weathering lava has been moderately scoured, either by ice or by passage of the debris avalanche (part of which overlaps the upper end of the dacite outcrop). Although its contact with the stack of andesites across the gorge is concealed by pumiceous scree, the dacite appears to be inset against them and thus younger. Farther down the gorge, the dacite overlies a locally exposed ledge of andesitic lava (57.6 weight percent $\mathrm{SiO}_{2}$ ) similar to those in the stack. Two attempts to date the dacite failed to yield measurable radiogenic Ar, supporting the inference that this lava flow, the

Figure 7. Stereopair of vertical aerial photographs illustrating summit-crater complex atop Mount Griggs. North arrow (N) and true summit (TS) are labeled on semiannular icefield confined between outer amphitheater rim and inner cone, which has two nested craters and a plug remnant. Crevassed icefield spills leftward into narrow southern glacier. Visible at top are source cirques, steep but shallow, of glaciers on outer slopes of edifice (fig. 4). Coarse stratified ejecta of inner cone stand out on its oxidized north rim and its steep south slope, where light colored owing to fumarolic alteration. Steep black slope southwest of craters consists of leveed andesitic lava flows, many of them thin and spatter fed. On all but steepest slopes, gullied tan deposit of fallout from 1912 eruption of Novarupta obscures surface details, covering all but highest levees of Holocene lava-flow apron to west (left). most silicic and most potassic recognized at Mount Griggs, was a fairly late product of the late Pleistocene outer cone.

\section{Early Holocene Sector Collapse}

The southwest quadrant of the upper part of the late Pleistocene cone slid away into what is now the Valley of Ten Thousand Smokes at some poorly constrained point in early postglacial time-probably early in the Holocene, when the Knife Creek glaciers still occupied the valley as far as Three Forks (fig. 3). The sector collapse left a 1,500-m-wide amphitheater, around which a horseshoe-shaped, 2.5 -km-long outer rim is still well preserved (figs. 4, 5,7). We have recognized no evidence that the failure was accompanied by a magmatic eruption, although neither intrusive triggering of collapse nor eruptive accompaniment would be unusual or unexpected, or, on the other hand, necessary. Weakening of the central core of the upper edifice by (locally focused) acid alteration certainly played a role, because the avalanche deposit is rich in altered debris. The amphitheater depth (and thus the avalanche volume) is unknown because it was later largely filled by the inner andesite cone. How far down the mountain's flank the primary basal slip plane of the detaching slide mass extended is also unknown, because the $12-\mathrm{km}^{2}$-area fan of younger lavas wholly covers the scar. Nonetheless, because the area from which the avalanche separated appears to have been no smaller than $3 \mathrm{~km}^{2}$, the volume excavated is likely to have been no less than $1 \mathrm{~km}^{3}$. The main remnant of the slide mass, an internally chaotic deposit, locally as much as $200 \mathrm{~m}$ thick, mantles a $5-\mathrm{km}^{2}$ area of the volcano's lower west slope (fig. 4). Hummocks and other small remnants of avalanche breccia are found as far away as Windy Creek (fig. 3), 10 to $12 \mathrm{~km}$ from the base of Mount Griggs, suggesting that the volume excavated could have been as great as $2 \mathrm{~km}^{3}$. A large fraction of the debris-avalanche sheet must have been emplaced on the floor of Knife Creek valley, where it was reworked as till by Holocene glaciers or concealed by 1912 ignimbrite. An unknown fraction of the avalanche material probably transformed into water-rich debris flows down the valley of the Ukak River. Evidence limiting the age of the sector collapse, and characteristics of the avalanche deposit (here called the Knife Peak debris-avalanche deposit, to distinguish it from younger, similar but smaller examples), are discussed below in the section entitled "Debris-Avalanche Deposits."

\section{Holocene Inner Cone}

The amphitheater excavated from the main outer cone by sector collapse has been nearly filled by growth of a new inner andesite cone, which consists predominantly of lava flows, accompanied by subordinate proximal ejecta. A total of 18 samples range in $\mathrm{SiO}_{2}$ content from 55 to 62 weight percent (table 1). The new cone was fed centrally, with its conduit directly below the previously destroyed summit or, possibly, slightly west of it. The best-exposed part of the inner cone is its black southwest shoulder (fig. 6), which is 
steep enough to have been swept free of the mantle of 1912 fallout. Though capped by about $10 \mathrm{~m}$ of poorly sorted, unconsolidated, stratified ejecta, the black shoulder itself consists mostly of sheets of varyingly agglutinated scoria and spatter, as well as thin, spatter-fed lava flows (55 weight percent $\mathrm{SiO}_{2}$ ), a few of which were substantial enough to feed narrow, kilometer-long leveed tongues of rubbly lava (fig. 6). Wrapping the south slope of the black shoulder is a debriscovered glacier that issues from the summit icefield and follows a gulch which marks the contact between the amphitheater wall of the old cone and the fan of younger lavas from the inner cone (figs. 2, 4-7). The younger cone almost filled the amphitheater but did not quite reach its rim except at the extreme northwest end, where the young lava fan overspilled the rim, buried it, and poured downslope to the cliffs above the northwestern glacier, where some flows broke up over the cirque headwall and others banked against the crags of the 160-ka window.

The lava fan itself covers a $12-\mathrm{km}^{2}$ area, extending from the summit craters to the floor of Knife Creek, where some flows continue an unknown distance beneath valleyfilling 1912 ignimbrite. On the fan are exposed as many as 20 separate lobes and overlapping leveed tongues of lava, but an unknown (probably far larger) number of flows are buried by those on the surface. Many bifurcate downslope, especially on the gentler lower half of the cone. In particular, the youngest flow (57.2 weight percent $\mathrm{SiO}_{2}$; unit y*, fig. 4), which emerges near the base of the innermost summit crater, changes at 4,500-ft ( $1,370 \mathrm{~m})$ elevation from a steep, narrow, leveed channel to a bulging piedmont lobe marked by several subordinate distributary lobes (fig. 6).

Because the gullies between flows are shallow and choked with remobilized 1912 pumice (fig. 6), flow thicknesses are hard to estimate, but some distal lobes are at least $60 \mathrm{~m}$ thick. On steeper slopes higher on the cone, they are far thinner. Owing to the pumice scree, flow bases have not been observed, although fused flow-breccia zones (presumed to be near basal) are exposed in a few distal gulches.

Flow surfaces are glassy, vesicular (commonly scoriaceous), and rubbly to blocky; distally, a few are marked by crags and spires, as much as 3 to $4 \mathrm{~m}$ high. Though virtually uneroded, flow surfaces apparently show a modest range in degradation of such primary roughness that may reflect a range of ages. The variation in composition likewise suggests that the lava-flow fan represents more than a single eruptive episode. One of the youngest andesite flows crossed over the dacitic lava on the west apron and poured down the gorge cut through the Knife Peak debris-avalanche deposit (fig. 4). Although this rubbly scoriaceous intracanyon lava is readily erodible, the gorge has still not everywhere reestablished a channel completely through it. No soils, accumulations of loess, or tephra layers (all common on nearby surfaces of comparably low relief) have been found atop the young lava fan, although the several meters of 1912 pumice might well conceal some such deposits. Many lavas on the fan surface are probably of late Holocene age, but no evidence is at hand to date them more closely.

\section{Nested Craters and Fumaroles}

Inside the 1,500-m-wide amphitheater, the Holocene inner cone is topped by two nested craters (figs. 5,7 ), each shallow but steep walled, the outer of which has a maximum (northsouth) dimension of $500 \mathrm{~m}$ and (like the amphitheater) is also open to the west. The innermost crater is a closed depression, 150 by $200 \mathrm{~m}$ wide, slightly elongate north-south, and floored by snow, ice, and the 1912 pumice-fall deposit. These relations and the features described below are best illustrated by the stereopair shown in figure 7 .

Where not obscured by 1912 fallout, the rims of both craters are seen to consist of a combination of agglutinate and outboard-dipping lava flows (both effusive and spatter fed) beheaded by the crater walls and draped by poorly sorted blocky ejecta. Stacks of thin overlapping lavas ( 55 weight percent $\mathrm{SiO}_{2}$ ) are best exposed on the black shoulder (fig. 6) that forms the southwest slope of the cone, but a similarly steep outboard slope of thin rubbly flows starts at the northwest rim of the outer crater. The east rim of the innermost crater is pumice mantled, but its west rim is well exposed, consisting of thin, west-dipping andesitic lavas (59-60 weight percent $\mathrm{SiO}_{2}$ ) and an 80-m-wide knob of massive andesite (60.4 weight percent $\mathrm{SiO}_{2}$ ) that may be a plug remnant.

Locally derived ejecta is best exposed on walls of the outer crater, where coarse, poorly sorted, stratified deposits mantle its rim and make up many of the exposures inside the rim. A rubble-rich coarse-ash matrix encloses angular blocks of dense glassy lava, as large as 1 to $3 \mathrm{~m}$ across. Prismatically jointed blocks occur sparsely, and strongly vesicular blocks and scoriae are notably uncommon. Nearly all the ejecta observed appears to have been emplaced by phreatomagmatic or phreatic explosions, probably partly during excavation of the innermost crater. The only scoria-fall deposit observed is on the northwest rim of the amphitheater, where scattered andesitic scoria bombs ( 55 weight percent $\mathrm{SiO}_{2}$ ) armor a winddeflated surface.

Two clusters of sulfur-depositing fumaroles are active (1) at 7,200- to 7,400-ft $(2,195-2,255 \mathrm{~m})$ elevation on the north and west walls of the innermost crater and just downslope outside the west rim, and (2) farther downslope at 6,400- to $6,700-\mathrm{ft}(1,950-2,040 \mathrm{~m})$ elevation along a conspicuous gully about $500 \mathrm{~m}$ southwest of the rim. The near-rim group releases boiling-point gas from dozens of orifices with weak to moderate discharge; the lower group also has lots of weak fumaroles but includes at least three vigorous jets that emit superheated gas. In July 1979, D.A. Johnston of the U.S. Geological Survey (USGS) measured gas temperatures as high as $108^{\circ} \mathrm{C}$ (fig. 8) for the lower group and as high as $99^{\circ} \mathrm{C}$ for the upper group. Repeatedly remeasured by R.B. Symonds (oral commun., 1998) from 1994 to 1998, the maximum July temperature of the lower cluster had declined to $99^{\circ} \mathrm{C}$, and of the upper cluster to the boiling point. Several gas samples taken by Johnston and by Symonds consisted of 97 to 99 volume percent steam but also contained significant amounts of $\mathrm{CO}_{2}$ and $\mathrm{H}_{2} \mathrm{~S}$ and yielded $\mathrm{C}$ - and $\mathrm{He}$-isotopic ratios typical of magmatic gas from arc volcanoes. Relative to fumarolic 
gases sampled at Mageik and Trident Volcanoes on the nearby arc front, those from Mount Griggs are notably He enriched, have higher $\mathrm{He} / \mathrm{Ar}$ ratios, and have elevated ${ }^{3} \mathrm{He} /{ }^{4} \mathrm{He}$ ratios $(7.7$ times the atmospheric value), probably indicative of a larger proximate contribution from the mantle (Poreda and Craig, 1989; Sheppard and others, 1992).

\section{Composition of Eruptive Products}

Most lava flows exposed on Mount Griggs and a few near-vent scoria bombs were sampled, as were lava blocks from several debris-avalanche deposits. Some 77 samples were analyzed by X-ray-fluorescence spectroscopy (fig. 9; table 1). Nearly all samples are mafic to silicic andesite (54.9-63.4 weight percent $\mathrm{SiO}_{2}$ ), and only a single lava flow (63.0-63.4 weight percent $\mathrm{SiO}_{2}$ ), low on the west flank, is formally a dacite. In addition, a single mafic lava (probably olivine accumulative) and two mafic magmatic enclaves contain 50.9, 53.6, and 53.9 weight percent $\mathrm{SiO}_{2}$, respectively. The range in $\mathrm{SiO}_{2}$ content for the eruptive suite at Mount Griggs is similar (not identical) to those of nearby Alagogshak, Martin, Mageik, Trident, and Snowy Mountain volcanoes but is far more restricted than those of Mount Katmai and Novarupta (Hildreth and Fierstein, 2000).

All rocks collected are plagioclase-rich two-pyroxene andesites, with subordinate olivine and Fe-Ti oxides in every sample. Though seldom abundant, olivine is virtually ubiquitous in the eruptive products of Mount Griggs and is certainly more common than at any of the neighboring volcanoes. Remarkably, not a single Mount Griggs sample fails to be phenocryst rich; virtually all samples contain 25 to 60 volume percent crystals larger than $0.1 \mathrm{~mm}$ across. Kosco (1981) point-counted thin sections of 13 Mount Griggs lavas, obtaining a range of 31-58 volume percent phenocrysts. Nearly all samples have a glassy or partly glassy groundmass, and (where exposed by erosion) even the platy interior zones of many lava flows retain a little glass. Polycrystalline clots of the main phenocryst phases (in varied combinations and proportions) are common, as are microdioritic clots and still-finer-grained mafic blebs. As in many andesites, plagioclase crystals of several generations, reflecting mixed origins and contrasting histories of dissolution and growth (Singer and others, 1995; Coombs and others, 2000), are present in most samples. Magmatic enclaves, typically 1 to $15 \mathrm{~cm}$ across and generally finer grained and more mafic than the host andesite, occur in many Mount Griggs lavas, but they are much less abundant than at nearby Trident Volcano.

Fully opacitized ovoids and prisms sparsely present in a few samples may once have been amphiboles, but no relict amphibole has been positively identified. Although no biotite has been observed, apatite needles are included within plagioclase phenocrysts in most or all samples. Kosco (1981) reported traces of quartz in two olivine-bearing andesite samples (57 and 59 weight percent $\mathrm{SiO}_{2}$ ) from Mount Griggs, and, consistent with xenocrystic disequilibrium, he mentioned reaction rims around them. Kosco also reported traces of sanidine in two samples ( 60 weight percent $\left.\mathrm{SiO}_{2}\right)$, and because the sanidine is untwinned and unzoned $\left(\mathrm{Or}_{65}\right)$,

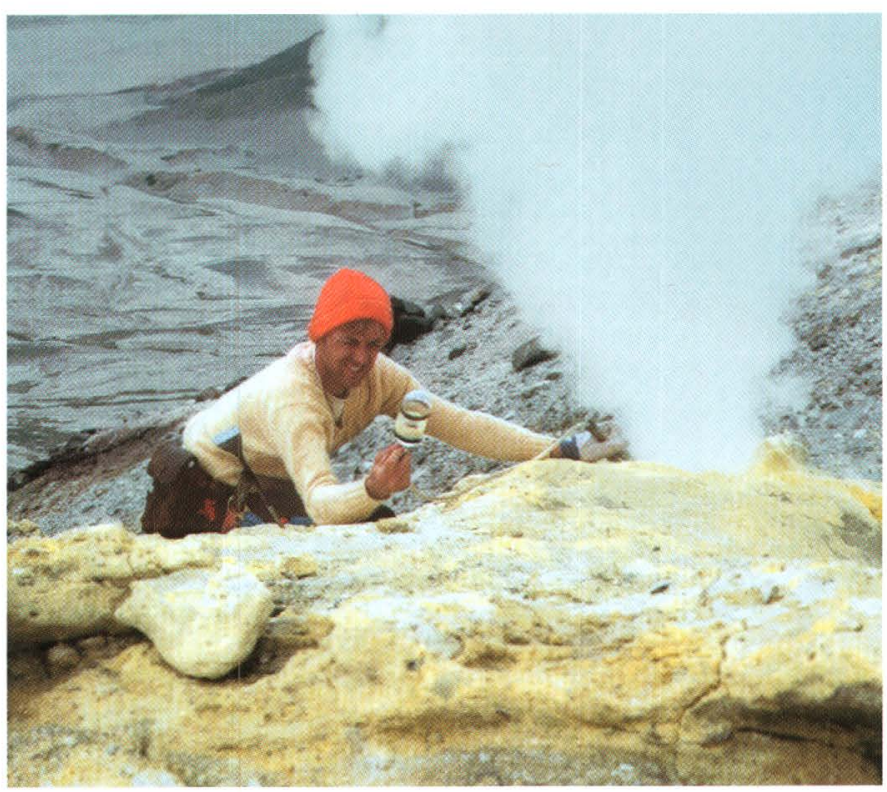

Figure 8. David A. Johnston sampling gas emitted vigorously at one of several sulfur-precipitating fumaroles along a gulch about $400 \mathrm{~m}$ southwest and downslope from rim of innermost crater of Mount Griggs (where additional fumaroles also occur). The Juhle Fork of Knife Creek and the Valley of Ten Thousand Smokes are in left background. Hottest fumarole measured was $108^{\circ} \mathrm{C}$ in 1979 . Photograph by Peter Shearer, then of the U.S. Geological Survey, taken July 2, 1979. Some 321 days later, Johnston was swept away (in all but memory) by the May 18, 1980, eruption of Mount St. Helens.

it might be cognate, possibly reflecting the advanced crystallinity of the phenocryst-rich magmas. Microprobe determinations by Kosco for the major phenocryst phases in several Mount Griggs samples (for which he did not provide locations) yielded the following: (1) olivine is $\mathrm{Fo}_{64-82}$ and has limited normal zoning in individual crystals, (2) pyroxenes have only slight (normal or reversed) zoning and are confined to the augite and hypersthene compositional ranges, and (3) complexly zoned plagioclase has compositional ranges of $\mathrm{An}_{55-82}$ in clear phenocrysts and $\mathrm{An}_{52-87}$ in sieved crystals replete with glass inclusions.

Whole-rock data for all 77 samples from Mount Griggs (table 1) plot as a narrow array virtually central to the medium-K field of figure $9 \mathrm{~A}$. The $\mathrm{K}_{2} \mathrm{O}-\mathrm{SiO}_{2}$ panel further illustrates that the eruptive products of Mount Griggs are consistently $\mathrm{K}$ enriched relative to the neighboring volcanoes, providing a ready discriminant for samples of uncertain provenance. Nearly all Mount Griggs samples fall in the calc-alkaline field on the conventional tholeiitic-versus-calc-alkaline discrimination diagram $\left(\mathrm{FeO} * / \mathrm{MgO}\right.$ ratio versus $\mathrm{SiO}_{2}$ content; not shown) of Miyashiro (1974). The alkali-lime intersection falls at 61 to 62 weight percent $\mathrm{SiO}_{2}$ (fig. 9B), also defining a calc-alkaline suite, according to the original scheme of Peacock (1931). In this respect, Mount Griggs contrasts with the nearby volcanic-front centers, which all have calcic intersections at 63 to 64 weight percent $\mathrm{SiO}_{2}$ (Hildreth, 1983; Hildreth and others, 1999, 2000, 2001).

The eruptive products of Mount Griggs represent a typical low-Ti arc suite, containing only 0.63 to 0.90 weight percent 
$\mathrm{TiO}_{2}$. None of the samples is notably primitive, because $\mathrm{MgO}$ content ranges from only 1.6 to 5.1 weight percent for the main array, and the three mafic mavericks are only slightly more magnesian. Kosco (1981) provided X-ray-fluorescence data that included 10 to $14 \mathrm{ppm} \mathrm{Ni}$ for 7 Mount Griggs samples and 16 to $60 \mathrm{ppm} \mathrm{Cu}$ and 60 to $75 \mathrm{ppm} \mathrm{Zn}$ for 25 Mount Griggs samples.

$\mathrm{Al}_{2} \mathrm{O}_{3}$ and $\mathrm{P}_{2} \mathrm{O}_{5}$ contents are ordinary for arc suites, ranging from 16.5 to 19.3 weight percent and from 0.14 to 0.28 weight percent, respectively, although both components are somewhat elevated relative to products of the neighboring centers. Sr contents (table 1) are scattered, ranging from 315 to $432 \mathrm{ppm}$, but tend (along with many Trident lavas) to be elevated relative to other volcanoes in the Katmai cluster (Hildreth and Fierstein, 2000). Rb contents range from 18 to $43 \mathrm{ppm}$ (with the three mafic mavericks at $10-13 \mathrm{ppm}$ ). On a plot of $\mathrm{Rb}$ versus $\mathrm{SiO}_{2}$ content (not shown), the Mount Griggs suite is elevated in $\mathrm{Rb}$ relative to the volcanic-front arrays, but it partly overlaps them rather than providing the nearly clean discrimination shown by the $\mathrm{K}_{2} \mathrm{O}-\mathrm{SiO}_{2}$ panel (fig. $9 \mathrm{~A}$ ). Similarly but conversely, most Mount Griggs lavas are slightly Fe poorer than products of the neighboring volcanoes, although the arrays again show partial overlap (see Hildreth and Fierstein, 2000, fig. 10).

Like the $\mathrm{K}_{2} \mathrm{O}-\mathrm{SiO}_{2}$ panel, a plot of $\mathrm{Zr}$ versus $\mathrm{SiO}_{2}$ content (fig. 9C) provides a first-order distinction between arrays for neighboring volcanoes on the main volcanic line and the Mount Griggs suite, which has relatively elevated $\mathrm{Zr}$ contents of 106 to $205 \mathrm{ppm}$ (with the three mafic mavericks having 78 , 94, and $109 \mathrm{ppm}$ ). Moreover, the $\mathrm{Zr}-\mathrm{SiO}_{2}$ plot is the only variation diagram that suggests any systematic compositional change over time among the eruptive products of Mount Griggs. Figure $9 C$ shows that most (but not all) samples from the middle Pleistocene windows are $\mathrm{Zr}$ deficient relative to the main late Pleistocene and Holocene data array.

In summary, the andesitic suite at Mount Griggs resembles those of the contemporaneous centers on the nearby volcanic front but contains more olivine, has marginally lower $\mathrm{Fe}$ contents, tends to be relatively enriched in $\mathrm{Al}, \mathrm{P}, \mathrm{Rb}$, and $\mathrm{Sr}$, and is consistently more enriched in $\mathrm{K}$ and $\mathrm{Zr}$. Moreover, the Mount Griggs array lacks silicic members.

\section{Geochronology}

We measured K-Ar ages on whole-rock samples from each of the three glaciated windows of older lavas and from five distal exposures around the base of the late Pleistocene cone (fig. 4; table 2). Sample-selection criteria and analytical methods were described by Hildreth and Lanphere (1994). Seeking high-precision ages for late Pleistocene rocks, we used the multiple-collector mass spectrometer (Stacey and others, 1981) at the USGS laboratories in Menlo Park, Calif.

The north, west, and south windows yield K-Ar ages of $292 \pm 11,160 \pm 8$, and $133 \pm 25 \mathrm{ka}$, respectively (table 2 ). Such widely spaced ages for glaciated remnants exposed, respectively, $1,600,500$, and $1,300 \mathrm{~m}$ lower than the modern summit signify that much of a long-lived middle Pleistocene edifice had been eroded away before being extensively covered by the late Pleistocene cone.

The stratigraphically lowest lava that appears to have been erupted from the late Pleistocene cone flowed eastward to the floor of a glacial canyon tributary to Ikagluik Creek; it yielded an age of $90 \pm 7 \mathrm{ka}$. A second thick basal lava flow resting on Jurassic basement rocks at the northeast toe of the cone gave an age of $54 \pm 8 \mathrm{ka}$. If these lavas indeed issued from the central vent of the main late Pleistocene cone (rather than from a wrecked predecessor edifice), their antiquity implies exposure to erosion for several tens of thousands of years for interim slopes of the cone that are now concealed by the carapace of little-modified lava flows that evidently postdate the LGM.

We attempted to date three additional lava flows from other parts of the late Pleistocene cone. To the north, a thick distal andesite flow that overlies the contact between Jurassic and Tertiary basement rocks (fig. 4) gave an age of $15 \pm 18 \mathrm{ka}$. On the west slope, the top andesite flow underlying the Knife Peak debris-avalanche deposit gave an age of $21 \pm 11 \mathrm{ka}$. Adjacent to the top andesite flow, the lone dacitic lava flow exposed at Mount Griggs failed to yield measurable radiogenic $\mathrm{Ar}$ despite repeated extractions. Erosion and scour of the dacite may not have been glacial, as we had first assumed, but may instead reflect passage of the debris avalanche and subsequent Holocene incision of the adjacent gorge.

Radiocarbon ages for Holocene surficial deposits that limit the emplacement ages of debris avalanches at Mount Griggs are discussed below in the section entitled "DebrisAvalanche Deposits."

\section{Eruptive Volumes}

Mount Griggs has undergone glacial erosion throughout its existence; the modern climate being globally one of the mildest during its 300-k.y. lifetime. During glacial maximums, ice sheets blanketed the regional topography to above $4,000-\mathrm{ft}$ (1,220 m) elevations (Riehle and Detterman, 1993; Mann and Peteet, 1994), locally extended higher against horns and nunataks, and repeatedly ravaged the edifice of Mount Griggs. Partly for this reason, the pre-late Pleistocene eruptive volume cannot be estimated with any accuracy.

Mount Griggs today covers an area of about $60 \mathrm{~km}^{2}$. The amphitheater rim is now as high as $2,330 \mathrm{~m}$, and so the precollapse summit certainly reached at least $2,350 \mathrm{~m}$. On the apron, lavas extend as low as $1,800 \mathrm{ft}(550 \mathrm{~m})$ elevation on the north and southwest and down to 2,800- to 3,000-ft (855-915 m) elevation in other sectors. Basement rocks, however, crop out at as high as 4,400-ft $(1,340 \mathrm{~m})$ elevation on the east and west flanks of the cone and at 3,100- to 3,500-ft (945-1,070 m) elevation along the north toe but are not exposed along the south toe of the cone where it meets the valley floor at 1,800 - to $2,300-\mathrm{ft}$ (550-700 m) elevation. Using these data, various sectorial cone-model approximations yield volumes in the range 23-30 $\mathrm{km}^{3}$; the main uncertainty is in the basement topography buried by the edifice. Taking in account the concavity of the cone's 

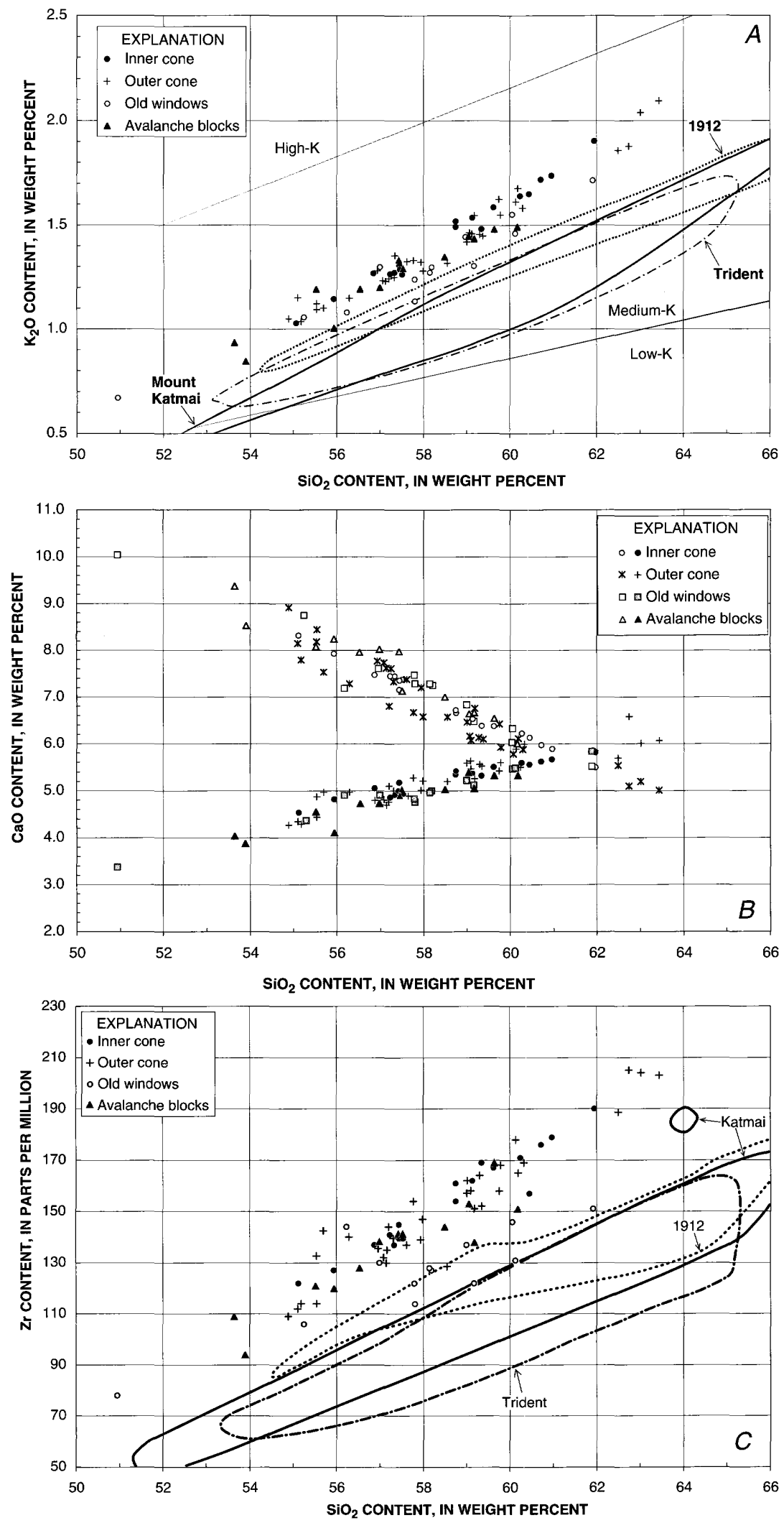

Figure 9. Whole-rock compositional data for 77 samples from Mount Griggs (table 1), as identified in inset. $A, \mathrm{~K}_{2} \mathrm{O}$ versus $\mathrm{SiO}_{2}$ contents. $\mathrm{B}, \mathrm{CaO}$ (upper trend) and total alkalies (lower trend) versus $\mathrm{SiO}_{2}$ contents. $C$, $\mathrm{Zr}$ versus $\mathrm{SiO}_{2}$ contents. Enclosed fields in figures $9 A$ and $9 C$ show comparative arrays from neighboring volcanoes, Mount Katmai and Trident, and from zoned suite from 1912 eruption of Novarupta (Hildreth and Fierstein, 2000). Mount Katmai and 1912 arrays extend off panel to rhyolitic compositions, whereas those of Mount Griggs and Trident are limited to andesite-dacite range. 
slopes, a conservative estimate places the present-day total volume of the volcano in the range $20-25 \mathrm{~km}^{3}$.

Eruptive volumes of older eroded components of the edifice are even harder to reconstruct with acceptable accuracy. The southern and northern windows are basal-distal, and the craggy western window exposes a stack of lava flows at $6,200-\mathrm{ft}(1,890 \mathrm{~m})$ elevation that dips $20-25^{\circ} \mathrm{W}$., away from a former summit that may well have been as high or higher than today's. If the middle Pleistocene edifice had indeed been as large as the present one, then the distribution of old windows suggests that at least half of it had been removed before construction of the late Pleistocene cone, implying an erosive loss of at least $10 \mathrm{~km}^{3}$ and thus a total eruptive volume in the range $30-35 \mathrm{~km}^{3}$. Such an estimate is surely conservative because (1) off-edifice fallout (probably limited) and intracanyon lavas and mass flows (possibly substantial) later wholly removed by erosion are not taken into account; and, perhaps more important, (2) the argument condenses Pleistocene glacial erosion into a continuous process that resulted in a net loss of $10 \mathrm{~km}^{3}$, although we know that the edifice underwent episodes of constructive growth at about 292, 160, 133, and 90 ka. How many times it was partly torn down is unknown.

For a 300-k.y. lifetime, an eruptive volume of $35 \mathrm{~km}^{3}$ implies an average productivity of $0.12 \mathrm{~km}^{3} / \mathrm{k}$.y. Such longterm averaging surely obscures sporadic episodes of far greater productivity. If most of the late Pleistocene cone was constructed between 54 and $10 \mathrm{ka}$, our estimates yield $15 \mathrm{~km}^{3} \div 44$ $\mathrm{k} . \mathrm{y} .=0.34 \mathrm{~km}^{3} / \mathrm{k} . \mathrm{y}$. for an interval that probably itself consisted of several cone-growth episodes. Finally, for the inner cone and southwest lava fan, the Holocene eruption rate is estimated at $2.2 \mathrm{~km}^{3} \div 10 \mathrm{k} . \mathrm{y} .=0.22 \mathrm{~km}^{3} / \mathrm{k}$.y. These productivities are in the normal range for well-studied stratovolcanoes but far below those of major episodes ( $\geq 5 \mathrm{~km}^{3} / \mathrm{k}$.y.; Hildreth and Lanphere, 1994). Locally, the long-term eruption rate for Mount Griggs is similar to that of the Trident cluster, greater than that of Snowy Mountain, and lower than those of Mounts Katmai and Mageik, both of which have produced volumes similar to or larger than that of Mount Griggs in a third the time (Hildreth and Fierstein, 2000; Hildreth and others, 2000, 2001).

\section{Debris-Avalanche Deposits}

Five poorly sorted, chaotic deposits dominated by andesite blocks have been recognized on the lower slopes of Mount Griggs, one of late Pleistocene age and the others of early Holocene age. All of these deposits appear to have resulted from avalanches that broke loose high on the volcano. We discuss them below in apparent order of emplacement.

\section{Diamict of Griggs Fork}

A coarse diamict, as thick as $70 \mathrm{~m}$, is exposed for about 2 $\mathrm{km}$ along a scarp bounding the valley floor at the south foot of the volcano (unit ds, fig. 4). West of the Griggs Fork of Knife
Creek, it underlies an area of at least $1.2 \mathrm{~km}^{2}$, probably as much as $2 \mathrm{~km}^{2}$. The unstratified deposit is overlain variously by till, andesitic lava flows of the late Pleistocene cone, indurated remnants of a scoria-flow deposit from Mount Katmai, and 1912 ignimbrite and fallout. Though widely obscured by these deposits, the diamict is exposed (fig. 10) along two deep gorges (figs. 2,4) that interrupt the scarp at the south toe of Mount Griggs. A lag of andesite blocks typically armors deflated surfaces and sideslopes (fig. 10). The diamict may rest on Jurassic basement at the Griggs Fork (fig. 3), but in the gorges and elsewhere it rests on till (fig. 4), which is distinguishable by its varied clast assemblage.

Stones in the till deposits here are predominantly Jurassic sandstone and siltstone of the Naknek Formation, along with subordinate andesites and porphyritic Tertiary intrusive rocks. In contrast, coarse clasts in the diamict are almost exclusively massive to scoriaceous andesite, mostly angular to subangular, abundantly 0.2 to $2 \mathrm{~m}$ across, some as large as $3 \mathrm{~m}$ across. Many of the dense angular blocks retain reddened joint surfaces that were oxidized during posteruptive cooling, and both black and oxidized scoria is common among clasts smaller than $10 \mathrm{~cm}$ across. Most blocks are fresh andesite, dark gray or brick red, and a few have alteration rinds 1 to $2 \mathrm{~cm}$ thick. Hydrothermally altered andesite clasts, ochre to cream yellow, are present but not abundant, and few are larger than $10 \mathrm{~cm}$ across. Unlike many debris-avalanche deposits (including the others at Mount Griggs), no large (10- to 100-m scale), quasicoherent, incompletely disaggregated domains are observed, and big composite blocks are sparse. Rounding of dense clasts is virtually absent, as are the streamlined shapes and striae that mark some clasts in the subjacent till.

The matrix is poorly sorted, fines-poor, dark-gray-brown, dominantly sand- to gravel-grade andesitic debris, evidently partly derived by breakage of the enclosed blocks. The deposit is barren of vegetation, in contrast to the underlying till, which supports scattered patches of mosses, grasses, and dwarf willows (fig. 10A), probably owing to the greater silt and clay fraction in the till matrix.

The characteristics of the deposit suggest that it was not the product of a sector collapse and that its source area was not an extensively altered part of the edifice. The diamict is not a glacial deposit, as shown by the absence of fines, the absence of the main basement-rock types exposed nearby, and its contrasts with the directly subjacent till. The deposit appears not to have resulted from breakup of a lava flow actively extruding high on the edifice because the deposit is unstratified, very thick $(25-70 \mathrm{~m})$, and shows little or no evidence of hot emplacement. Our tentative conclusion is that a stack of lava flows on a relatively unaltered part of the edifice failed abruptly, avalanched down the steep rubbly dipslope of the stratocone, broke up extensively during transit, and was emplaced as a single chaotic sheet, possibly impounded thickly against a valley-filling glacier. Much of the deposit has subsequently been removed by the Knife Creek Glaciers.

No evidence for a source scar remains high on the edifice because construction of the leveed lava-flow surface of the late Pleistocene cone postdates the avalanche and several of 

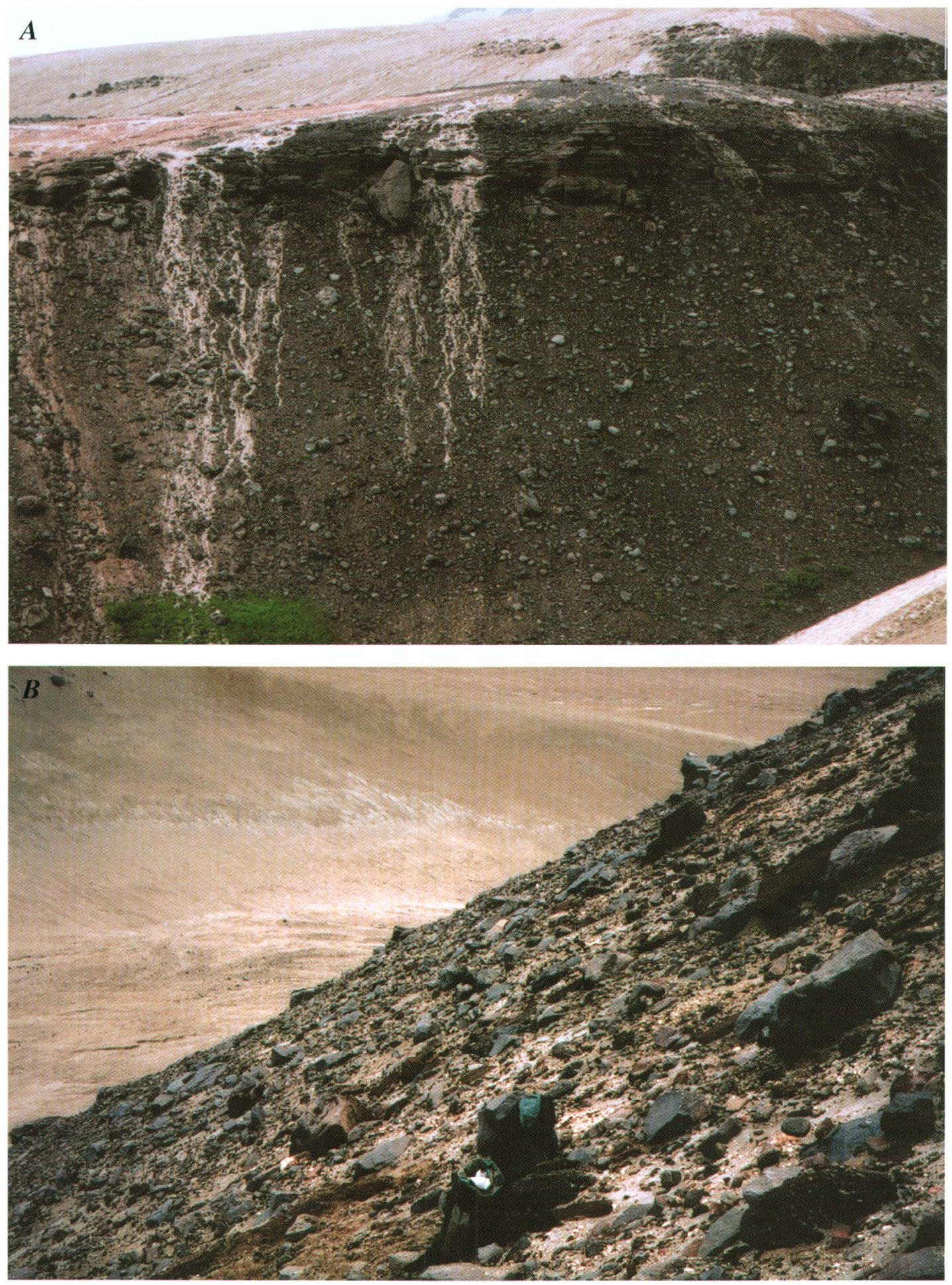

Figure 10. All-andesite diamict west of the lower Griggs Fork of Knife Creek (unit ds; fig. 4). A, Eastern of a pair of deep gorges that cut diamict at south foot of Mount Griggs. Black dacitic scoria-flow deposit from Mount Katmai, vaguely stratified, sintered, and 2 to $10 \mathrm{~m}$ thick, rests directly on deposit, which is here about $30 \mathrm{~m}$ thick. Many blocks on sideslope are 1 to $3 \mathrm{~m}$ across. Willow patch at lower left marks top of underlying heterolithologic till, which is fines richer and consists predominantly of nonandesitic basement-rock types. Western gorge (rim in right background) has same stratigraphic sequence. Plateau surfaces are mantled by pale-gray to pinkish-tan fallout and ignimbrite from 1912 eruption of Novarupta, which supply mud dribbling down gorge wall. View northwestward. $B$, Closeup of same diamict shown in figure 10A, where exposed on northwest wall of western gorge. Two packs in central foreground provide scale. Angular to subangular andesite clasts, commonly 20 to $150 \mathrm{~cm}$ across, form surface-armoring lag that is concentrated by wind deflation of deposit's dark-gray-brown fines-poor matrix, which consists of andesitic sand-and-gravel-grade debris. Pale-gray surface material is 1912 pumice. Gorge floor is at left. The Knife Creek arm of the Valley of Ten Thousand Smokes is visible in distance. 
its little-modified surface lavas overlap the deposit. Further evidence of a late Pleistocene age is provided by a sintered black dacitic scoria-flow deposit (itself glacially scoured) that was erupted at Mount Katmai near the end of the Pleistocene and banked against the base of Mount Griggs, directly atop the diamict (fig. 10). Although we have been unable to date the avalanche material directly, its preservation along the valley margin, along with the overlying scoria flow and leveed lava flows, suggests emplacement during waning millennia of the Pleistocene, since the LGM.

\section{Diamict of Ikagluik Creek}

At 2,300-m elevation on the rim of a sheer-walled canyon tributary to Ikagluik Creek, a rusty-orange to cream-yellow diamict (unit de, fig. 4) rests directly on Jurassic basement rocks at the brink of the cliff. The deposit is 4 to $12 \mathrm{~m}$ thick, crops out along the cliff for $400 \mathrm{~m}$, and contains many 1-m blocks of dark-gray andesite (some with alteration rinds), as well as an abundance of orange, yellow, and white pervasively altered clasts (generally smaller than $20 \mathrm{~cm}$ across), in a paleorange, clay-bearing, silty-sandy matrix. Along with $12 \mathrm{~m}$ of overlying gray till, which lacks the altered clasts, the deposit forms a steep unstable slope at the rim of a 200-m-high cliff. Because the outcrop is only $1 \mathrm{~km}$ downslope from the presentday snout of the northeastern glacier, the till is likely to be of Neoglacial age, an interpretation strengthened by the thinness of "soil" atop the till. Here, the combined thickness of eolian silt and organic-rich soil is only 10 to $15 \mathrm{~cm}$, whereas on many nearby surfaces the postglacial accumulation is in the range $50-100 \mathrm{~cm}$. The diamict rests on a bedrock surface that may have been scoured clean during the LGM, and if so, its age would be latest Pleistocene or early Holocene. The deposit was evidently emplaced as a modest avalanche that probably originated on the headwall of the northeastern glacier, where its source included hydrothermally altered andesite.

\section{Knife Peak Debris-Avalanche Deposit}

By far the most voluminous diamict that originated on Mount Griggs is the avalanche deposit (unit dk, fig. 4) resulting from sector collapse of the late Pleistocene cone. The 1,500-m-wide amphitheater left by catastrophic removal of 1 to $2 \mathrm{~km}^{3}$ of the edifice was discussed above in the subsection entitled "Early Holocene Sector Collapse," as was extensive healing of the scar by growth of the inner cone and its southwesterly fan of Holocene lava flows.

The $5-\mathrm{km}^{2}$-area remnant that forms the lower west slope of the volcano (figs. 2-4) is essentially an "overbank" facies of the avalanche deposit, downslope from the amphitheater and adjacent to the main sector excavated and subsequently refilled by younger lavas. It crops out as high as 5,700-ft $(1,740 \mathrm{~m})$ elevation, where it is overlapped by the younger lavas, but its upper expanse is relatively thin (10-30 m thick). At 3,500-ft $(1,070 \mathrm{~m})$ elevation, it thickens abruptly to as much as 200



Figure 11. Pale-pinkish-orange debris-avalanche deposit (unit dj, fig. 4), valley confined along the Juhle Fork of Knife Creek. Irregular brown slope on near side of the Juhle Fork is older, larger Knife Peak debris-avalanche deposit (unit dk), through which the Juhle Fork valley had been cut. In background is lower part of the Valley of Ten Thousand Smokes (VTTS), filled by ignimbrite from 1912 eruption of Novarupta and flanked by brown ridges of subhorizontally stratified Jurassic sedimentary rocks. Salient of pale ignimbrite in top center is Windy Creek embayment of VTTS, where numerous hummocks of larger debris avalanche (figs. 3,12 ) are preserved, 10 to $12 \mathrm{~km}$ from foot of Mount Griggs. Crossvalley Neoglacial moraine (fig. 3 ) is discernible in right distance as dark irregular ridge surrounded by pale ignimbrite. View westward.

$\mathrm{m}$, apparently filling steep paleotopography where it drapes a stack of lava flows, the uppermost of which yields an age of $21 \pm 11 \mathrm{ka}$. Here, too, the deposit's surface is marked by a $30-$ m-high radial ridge. The surface of the deposit downslope (fig. 11 ) is gray brown, undulating but not hummocky, subdued but not glaciated, and slopes an average of $14^{\circ}$ to the floor of the Valley of Ten Thousand Smokes. Its toe is truncated by a small scarp, probably a former cutbank adjacent to the alluvial plain of Knife Creek, that is now largely buried by 1912 ignimbrite and fallout.

Mostly chaotic internally, the deposit nonetheless includes quasi-coherent domains, as much as $200 \mathrm{~m}$ long, of disrupted but fresh andesitic lavas. Nearby domains, as large as $40 \mathrm{~m}$ across, are yellowish orange and rich in shattered blocks of hydrothermally altered andesite. Most exposures look thoroughly scrambled, consisting of lithologically varied andesite clasts in a varicolored matrix that can be pale red, orange brown, yellow, or gray. The matrix is poorly sorted, fines bearing but not fines rich, and predominantly sandy or gravelly. Blocks are commonly 1 to $3 \mathrm{~m}$, and nearly all the larger ones are angular fresh andesite. Some large blocks consist of hydrothermally altered andesite, but most clasts of such weakened material are subrounded and small, typically smaller than 10 $\mathrm{cm}$ across. Among fragments smaller than $5 \mathrm{~cm}$ across, the proportion of altered clasts may equal or exceed that of fresh ones. Although the blocks are largely fresh material, much, possibly half, of the deposit came from altered parts of the former edifice.

There is good evidence that the $5-\mathrm{km}^{2}$-area remnant preserved on the west slope of the edifice is only a modest 
fraction of the original avalanche deposit. Windows through 1912 ignimbrite expose accumulations of angular blocks of the andesite of Mount Griggs (as verified chemically; fig. 9; table 1) across Knife Creek on the north noses of Broken and Baked Mountains (figs. 3, 4). Remnants of similar material occur as hillocks and lenses in the Windy Creek embayment of the Valley of Ten Thousand Smokes (fig. 3). On both sides of Windy Creek, conical hummocks, as much as $18 \mathrm{~m}$ high, consist of angular fragments of the andesite of Mount Griggs that represent shattered megablocks which crumbled in place (fig. 12).

Some andesite hummocks appear to rest directly on sheets of till, and others rise from stream terraces cut on such till. The till everywhere includes abundant basement clasts (Jurassic sedimentary rocks and Tertiary porphyry), and few or none of the andesitic stones in the till are conspicuously olivine-bearing like the Mount Griggs andesites that make up the hummocks. Some of this till is likely to have been deposited during waning phases of the latest Pleistocene glacial recession, but the local situation here is ambiguous. The receding ice front may not have withdrawn upvalley from Three Forks (fig. 3) until well into the conventional Holocene (that is, later than $10 \mathrm{ka})$. Moreover, a composite Neoglacial moraine was constructed across the Valley of Ten Thousand Smokes near Three Forks (fig. 3) until as recently as 8-7 ka, either by still-receding ice or by Holocene readvances, although such ice need not (in either scenario) have fully reoccupied the Windy Creek embayment. Inferring the age of the hummocks from their local relations with till thus requires caution and site-specific radiocarbon ages because lithologically similar till of at least three ages is present locally.

Our constraints and reasoning concerning the emplacement age of the Knife Peak debris-avalanche deposit and

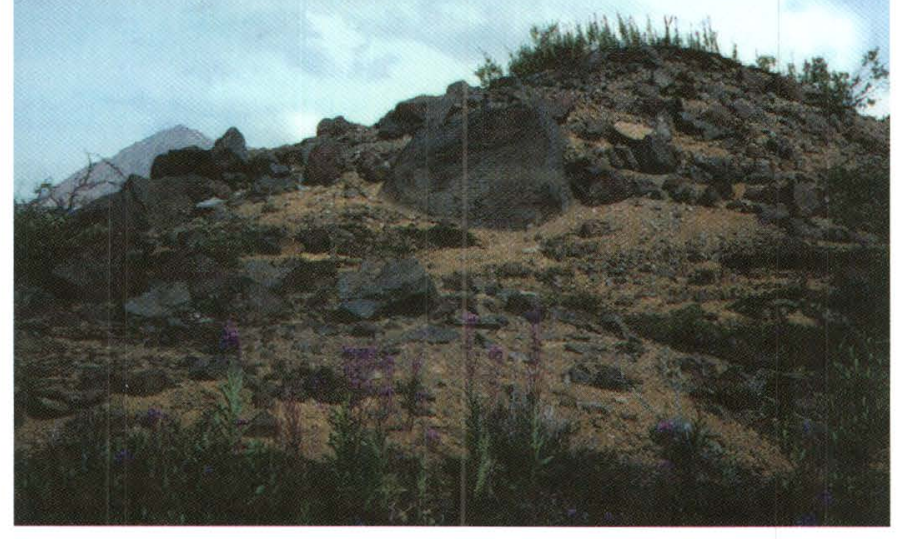

Figure 12. One of many conical hummocks preserved along both sides of lower Windy Creek (see fig. 3). Hummocks are 8 to $18 \mathrm{~m}$ high, overlie till or alluvial terraces cut on till, and contain angular to subangular blocks of andesite of Mount Griggs (as large as $3 \mathrm{~m}$ across) in a dark-gray, poorly sorted matrix of andesitic sand and rubble. All blocks analyzed have distinctive compositions enriched in $\mathrm{K}$ and $\mathrm{Zr}$, locally diagnostic of Mount Griggs lavas. All subjacent and nearby glacial deposits are rich in basement clasts that are absent or rare in hummocks. its distal hummocks are as follows. On the slopes of Mount Griggs, no direct age evidence has been obtained for the main $5-\mathrm{km}^{2}$-area remnant, but the younger Juhle Fork debris-avalanche deposit (unit dj, fig. 4; see below) overlies its northwestern margin. As discussed below, the Juhle Fork deposit is itself older than $6,720 \pm 140{ }^{14} \mathrm{C}$ yr, and so the larger underlying deposit must be still older. We infer that a valley glacier still occupied part of the Knife Creek valley when the sector collapse took place because (1) valley-floor remnants survive only at sites topographically shielded from erosion by such ice; and (2) hummocks and sheets of avalanche debris are absent axially in the Knife Creek valley, both at the crossvalley Holocene moraine near Three Forks (fig. 3) and in exposures (of till) beneath 1912 ignimbrite along the lower gorges of Knife Creek. Moreover, the absence of a continuous avalanche sheet (even in the Windy Creek embayment) suggests that much of the deposit could have been emplaced supraglacially and subsequently removed by glacial transport and by meltwater from the wasting ice. The hummocks (fig. 12) and a few lenses of angular avalanche blocks, all of which overlie till along Windy Creek, would by this reasoning largely represent megablocks that were shunted to the margin of a valley-floor glacier. Transport of andesite megablocks $12 \mathrm{~km}$ downvalley to produce the Windy Creek hummocks (now 6-18 m high) is consistent with mobility enhanced by sliding over ice, but the 1,500-m drop in elevation would have provided adequate momentum for such a runout, even without the roughnessreducing contribution of an icy substrate. Until we recognized their all-andesite constitution and Mount Griggs provenance, we had assumed that the Windy Creek hummocks were glacial kames. For those megablocks that may have been emplaced atop wasting ice, rather than marginal to it, the kame-versushummock distinction blurs.

In summary, because neither the postcollapse lavas, nor many of the youngest precollapse lavas, nor the hummocks, nor the surface of the main $5-\mathrm{km}^{2}$-area remnant of the avalanche deposit have been glacially overrun, the sector collapse clearly took place after major withdrawal of the regionally extensive, kilometer-thick ice sheets of the LGM (Riehle and Detterman, 1993; Mann and Peteet, 1994). During the latest Pleistocene and early Holocene, however, a thin valley-floor glacier nonetheless continuously or recurrently occupied the Knife Creek valley, at least as far downvalley as Three Forks and possibly until as recently as $8-7 \mathrm{ka}$. When the avalanche occurred, ice had partly withdrawn from the Windy Creek embayment but not from the Three Forks area. The sectorcollapse event thus predated $8 \mathrm{ka}$, an inference sustained by a minimum age of $6,720 \pm 140{ }^{14} \mathrm{C}$ yr B.P. for the Juhle Fork debris-avalanche deposit (see next section), which overlies (and occupies a valley cut into) the Knife Creek debris-avalanche deposit (figs. 4, 11). Four regionally distributed Holocene tephra layers are preserved atop one of the Windy Creek hummocks. Because none of the tephras is older than $6 \mathrm{ka}$ and less than $5 \mathrm{~cm}$ of sandy "soil" separates the lowest tephra layer from the top of the hummocky debris, emplacement of the avalanche is unlikely to have been much earlier than $8-7 \mathrm{ka}$, and so it probably occurred during the early Holocene. 


\section{Juhle Fork Debris-Avalanche Deposit}

Also during the early Holocene, another small but substantial debris avalanche broke loose from the headwall of the northwestern glacier of Mount Griggs and filled the canyon of the Juhle Fork of Knife Creek, a gorge that had not long previously been cut into the much larger Knife Peak debris-avalanche deposit. As much as $50 \mathrm{~m}$ thick at its narrowest point (at 3,000-3,400 ft [915-1,035 m] elevation), the intracanyon Juhle Fork debris-avalanche deposit (unit dj, fig. 4) crops out today over a $2.8-\mathrm{km}^{2}$ area, but originally it must have been much more extensive because it remains $30 \mathrm{~m}$ thick distally where it adjoins 1912 ignimbrite on the floor of the Valley of Ten Thousand Smokes (fig. 11).

Hummocks are few and subdued on the relatively planar sloping surface of what appears to have been a highly shattered, relatively fluidly flowing avalanche mass. The largest is a 10-m-high conical hummock (fig. 13) at the narrows where the westward proximal flowpath changes abruptly into the southwest-flowing canyon of the Juhle Fork (fig. 4). Relatively few blocks in the deposit are larger than $4 \mathrm{~m}$ across, although near the same narrows we did observe an 8-m block of shattered fresh andesite and a 7-m block of yellow to ocher acid-altered andesite, likewise shattered internally. Near the lower end of the deposit, most blocks are smaller than $1 \mathrm{~m}$ across, but shattered 2- to 5-m blocks are still present, with many of the acid-altered ones disintegrating into pale-gray, white, or yellow piles of rubble laced with rusty-orange-brown fracture fillings. Virtually all clasts are of andesite, fresh or altered. The matrix is poorly sorted, fines bearing, but mostly sandy to rubbly. Locally, the matrix has brick-red, yellowishocher, and gray-brown domains, but in broad view most of the deposit is pale orange, especially along its intracanyon reach, in contrast to its dominantly gray-brown older neighbor (fig. 11). The orange color reflects the alteration zone at the avalanche source, which is now largely ice covered but still partly exposed along the upper north wall of the northwestern glacier (red-stippled zone, fig. 4).

Atop the distal part of the avalanche deposit (and beneath fallout from the 1912 eruption of Novarupta), five thin tephra layers are intercalated within an accumulation of eolian silt and soil, $1.3 \mathrm{~m}$ thick. Organic-rich silt just beneath the lowest tephra layer (and separated from the top of the avalanche deposit by approx $20 \mathrm{~cm}$ of silt) yielded a radiocarbon age of $6,720 \pm 140{ }^{14} \mathrm{C}$ yr B.P. (Geochron Gx-23625). The second tephra layer is widespread regionally and known from many sections to have fallen about $6 \mathrm{ka}$. If the $20 \mathrm{~cm}$ of eolian silt below the dated horizon accumulated at the same rate as the $74 \mathrm{~cm}$ of silt within the section above it $(74 \mathrm{~cm} \div 6.72 \mathrm{k} . \mathrm{y} .=11$ $\mathrm{cm} / \mathrm{k} . \mathrm{y}$. ), then the avalanche deposit could be about 1,800 years older, or about 8,500 years old. Despite the uncertainties, it was clearly emplaced during the early Holocene.

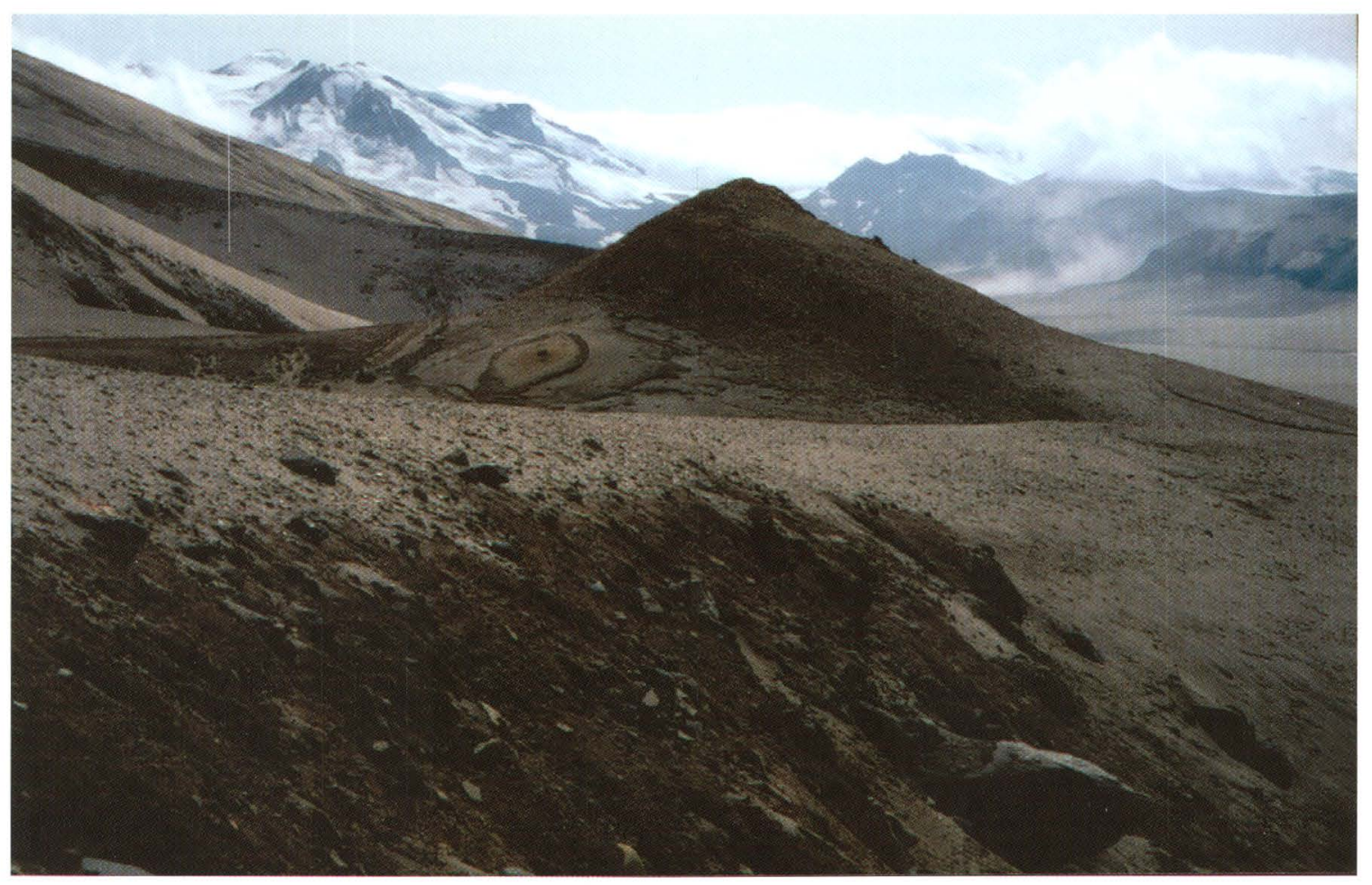

Figure 13. Conical hummock standing $10 \mathrm{~m}$ above surface of Juhle Fork debris-avalanche deposit, where its steeper westward proximal path funneled into narrower southwest-trending valley of the Juhle Fork (fig. 4). Note abundance of brown matrix, richer in fines than block-rich deposit shown in figure 12. Andesite clasts visible here are as large as $1.5 \mathrm{~m}$ across, but other intact (though internally shattered) blocks nearby are as large as $8 \mathrm{~m}$ across. Pale-gray surface veneer is fallout from 1912 eruption of Novarupta. West slope of Mount Griggs is at left in middle distance. View southwestward toward Mount Mageik (left skyline) and the River Lethe arm of the Valley of Ten Thousand Smokes (distant right). 
Along the lower $2 \mathrm{~km}$ of the Juhle Fork canyon, the avalanche overtopped its left-bank (southeast) wall, first covering a Neoglacial left-lateral moraine and then, near the canyon mouth, spilling out over the Knife Peak debris-avalanche deposit. The moraine consists of gray-brown andesitic debris, showing that the ice excavated a source of rubble much larger than the altered source of the orange avalanche deposit. For several kilometers, the canyon-marginal moraine bounds a paleovalley filled to 30 - to $50-\mathrm{m}$ depth by the avalanche deposit, showing that the narrow Juhle Fork valley glacier had receded considerably before the avalanche took place. The observation that the narrow intracanyon moraine is inset against the older Knife Peak avalanche deposit (the surface of which is unglaciated) supports the evidence previously discussed that valley glaciers occupied the lower Knife Creek valley well into the early Holocene. It remains ambiguous, however, whether the ice tongue then on the floor of the Juhle Fork or the larger Knife Creek valley glacier that still extended to Three Forks represented early Holocene readvances or simply recessional stillstands that belonged to a discontinuous Pleistocene-ending withdrawal which itself persisted into the early Holocene.

\section{Ikagluik Creek Debris-Avalanche Deposit}

On the north apron of Mount Griggs, another pinkish-orange debris-avalanche deposit extends from the snout of the north-northwestern glacier to the canyon rim of Ikagluik Creek (unit di, fig. 4). As preserved today, the deposit covers an area of about $3.5 \mathrm{~km}^{2}$, but because the avalanche filled and laterally overspilled a gorge tributary to Ikagluik Creek, a large additional fraction was evidently reworked downstream as alluvium. Along the tributary gorge, which has reincised the deposit down to Jurassic basement, the poorly sorted avalanche deposit is 20 to $30 \mathrm{~m}$ thick, and on the gently sloping plateau adjacent to the gorge it is generally 10 to $15 \mathrm{~m}$ thick and topped by numerous mounds and hummocks. Many such mounds are shattered blocks of monolithologic andesite that have disintegrated into piles as much as $3 \mathrm{~m}$ high and $15 \mathrm{~m}$ wide. Others are lithologically composite, and many $1-\mathrm{m}$ blocks are acid altered, but all are (or were) andesitic. The largest coherent andesite block seen was $5 \mathrm{~m}$ across. Two chemically analyzed blocks contain 59 to 60 weight percent $\mathrm{SiO}_{2}$, and some are unusually rich (for Mount Griggs) in fine-grained mafic enclaves. The fines-bearing matrix is generally pale orange or pink, owing in part to comminution of friable clasts of hydrothermally altered material that can also be white or pale yellow but are commonly laced with orange-brown fracture fillings and crusts.

The avalanche came down over the north-northwestern glacier, probably from its steep-walled cirque (now ice filled) at about $6,000-\mathrm{ft}(1,830 \mathrm{~m})$ elevation. Its source was not at the summit because the amphitheater rim on this side is unbroken. For $2 \mathrm{~km}$ downstream from the snout of the glacier, orange-colored rubble is reworked as till along the trough, whereas Neoglacial lateral moraines adjacent to the trough are dark gray brown (consisting mostly of unaltered andesite).

The gently sloping distal surface of the avalanche deposit is directly overlain by an accumulation of eolian silt and soil, as much as $75 \mathrm{~cm}$ thick, within which we found three tephra layers. The 8 -cm-thick middle tephra layer is constrained by regional data to be about $5,500{ }^{14} \mathrm{C}$ years old. Beneath that layer, $24 \mathrm{~cm}$ of silt/soil is underlain by a 2 -cm-thick layer of fine gray ash that rests only a few millimeters above blocks in the avalanche deposit. Organic-bearing silt directly atop that near-basal ash layer yielded a radiocarbon age of 6,250 \pm 190 ${ }^{14} \mathrm{C}$ yr B.P. (Geochron Gx-23623), suggesting that the avalanche took place about $7 \mathrm{ka}$.

\section{Behavior of Glaciers}

Six active glaciers descend the slopes of Mount Griggs. For convenience, we refer to these six radially flowing ice tongues (fig. 4) as the southern, east-northeastern, northeastern, north-northeastern, north-northwestern, and northwestern glaciers. The southern glacier is fed from the amphitheaterenclosed icecap, and the other five glaciers from shallow spoon-shaped cirques high on the steep outer slopes of the cone. All six glaciers are thin, narrow, and much less voluminous than those on nearby Mageik, Katmai, and Snowy Mountain volcanoes, each of which stands on the peninsular drainage divide. The 20th-century termini of five of the Mount Griggs glaciers have lain at 3,000 - to $3,800-\mathrm{ft}(915-1,160 \mathrm{~m})$ elevation (not far below the break-in-slope from steep cone to gentler apron) but at about 5,000-ft $(1,525 \mathrm{~m})$ elevation for the southern glacier. The lower third or so of each glacier remains mantled by 1912 fallout, which has been disrupted and commonly thickened by surface reworking and glacier movement. Generally, however, the upper half to two-thirds of each glacier is active, heavily crevassed, and now free of 1912 pumice cover. Neoglacial till preserved at as low as 2,000-ft $(610 \mathrm{~m})$ elevation (fig. 4) shows that the northerly glaciers were 2 to 3 $\mathrm{km}$ longer earlier in the Holocene.

Inspection of aerial photographs taken in 1951 and 1987 reveals marked differences in behavior of the six glaciers during that 36-year interval. (We are aware of no measurable changes in terminal positions since 1987, although small ones may have occurred.)

Alone among the six glaciers, the southern glacier is confined to the steep part of the cone and has no terminal lobe of gentler gradient. It is unique in having southerly exposure and in being younger than the other glaciers, having originated in the middle or late Holocene after growth of the inner cone created the annular moat where its icefield source accumulates (figs. 5, 7). Its steep terminal reach is covered by 1912 fallout, as well as by andesitic rubble. Although debris obscures the wasting terminus, the active ice front appears to have receded about $400 \mathrm{~m}$ (in plan view), withdrawing from 4,800-ft $(1,465 \mathrm{~m})$ elevation in 1951 to about 5,500-ft (1,675 m) elevation by 1987 . 
Of the five northerly glaciers, two have retreated since 1951, two show little change, and one has advanced slightly. Among them, the easternmost (east-northeastern) glacier exhibits the most negative ice budget for the interval 1951-87. Both of its lower lobes (fig. 4) became stagnant piles of icecored debris, and its active ice front receded $800 \mathrm{~m}$, from a low of 3,150-ft ( $960 \mathrm{~m})$ elevation in 1951 to about $4,500-\mathrm{ft}$ $(1,370 \mathrm{~m})$ elevation by 1987 .

The adjacent northeastern glacier also retreated, but by less than $100 \mathrm{~m}$ in plan view, from 2,950-ft (900 m) elevation in 1951 to about $3,100-\mathrm{ft}(945 \mathrm{~m})$ elevation by 1987 . Although its distal $300 \mathrm{~m}$ or so has thinned and shrunk noticeably, recession of the terminus has probably been minimized by its steep inclination in a narrow gorge (fig. 4).

The bilobate north-northeastern glacier appears to be the healthiest of the Mount Griggs glaciers; both lobes have steep bulging flow fronts at about $3,500 \mathrm{ft}(1,065 \mathrm{~m})$ elevation. The terminal position of neither lobe changed appreciably between 1951 and 1987.

The north-northwestern glacier shows apparently contradictory behavior. Its lower $400 \mathrm{~m}$ forms a bulging pumice-covered lobe at about 3,700 -ft $(1,130 \mathrm{~m})$ elevation that actually advanced about $40 \mathrm{~m}$ between 1951 and 1987. During the same interval, however, the kilometer-long medial reach of the glacier wasted severely, exposing bedrock knobs and stranding an abundance of supraglacial debris.

Finally, the snout of the northwestern glacier showed little change. Its steep but stagnant, pumice-covered terminus maintained an elevation of about 3,500 ft $(1,065 \mathrm{~m})$ between 1951 and 1987.

All six glaciers appear to have either retreated or thinned (or both) during the 36-year interval, with the generally negative ice budget probably reflecting gross climatic influence. The absence of a consistent pattern may simply reflect vagaries imposed by some combination of (1) complex responses to the 1912 pumice mantle, (2) localized effects of bed steepness and roughness on flow behavior, and (3) short-term variations in avalanche-supplied contributions of snow and rubble to mass budgets. More systematic patterns of glacier behavior have been observed nearby at Mageik, Trident, Katmai, and Snowy Mountain volcanoes (Hildreth and others, 2000, 2001).

\section{Discussion}

Mount Griggs is a steep stratovolcano marked by fumarolic alteration near its summit, ice in its craters, and glaciers on its flanks. Thus, a new eruptive episode would make the cone susceptible to generation of debris flows and possibly, as during the early Holocene, to triggering of debris avalanches. The volcano lies in uninhabited wilderness, however, and the runout distance is $25 \mathrm{~km}$ to Naknek Lake (fig. 1). Hazards posed by such events would principally threaten fish and wildlife resources, summer backpackers, and observers attracted by precursory activity. The USGS' Alaska Volcano Observatory has installed several seismometers near Mount Griggs, and were signs of unrest to be detected, additional instrumental and observational monitoring would be implemented, and the land-management authorities, the media, and the aviation community would be notified. In marked contrast to the nearby volcanic-front centers, the area beneath Mount Griggs is today virtually aseismic (Jolly and McNutt, 1999).

Any volcanic-ash plume, associated even with minor eruptions, poses a potential hazard to aircraft, and both local sightseeing flights and scheduled commercial flights (King Salmon to Kodiak) commonly pass close to Mount Griggs. Although layers of Holocene ash fall from other volcanoes are common in the surrounding area, no ash layers attributable to Mount Griggs itself have been identified away from the edifice. To the contrary, no evidence exists that the typically effusive or spatter-fed eruptions of consistently crystal rich andesitic magma at Mount Griggs are accompanied by particularly explosive activity or dispersal of widespread ash clouds. Although Mount Griggs has been fairly active during the Holocene, its characteristic activity has been notably less explosive than that of its more silicic, tephra-producing neighbors Mageik, Martin, Trident, and, of course, Katmai and Novarupta.

Mount Griggs is older than any of its active neighbors, yet, uniquely among them, it has maintained a stable central conduit system, apparently throughout its 300-k.y. lifetime. Mageik and Katmai Volcanoes are both younger than $100 \mathrm{ka}$, and although each volcano matches or exceeds Mount Griggs in total eruptive volume, their products have issued from several different vents in the course of constructing compound edifices (Hildreth and Fierstein, 2000; Hildreth and others, 2000). Trident, likewise, has built four discrete but overlapping cones and several flanking lava domes during its 140-k.y. eruptive lifetime. What properties of the magma generation, storage, or transport systems (or of the crystal-rich andesitic magma itself) might account for the relative stability that has permitted construction of the centrally symmetrical volcanic edifice of Mount Griggs?

Are such properties related to the position of Mount Griggs $12 \mathrm{~km}$ behind the volcanic line? The unresolved question of why so many, closely spaced andesite-dacite stratovolcanoes are perched single file atop the peninsular drainage divide (fig. 1) in Katmai National Park was addressed by Hildreth and others (2001). Equally interesting, however, is why Mount Griggs stands alone, nearby, so exceptionally.

Several other volcanic vents in this part of the Alaska Peninsula, like Mount Griggs, are well behind the main volcanic line, but none are large active cones. Several glaciated scraps of Pliocene basaltic to dacitic lava cap ridges northwest of Mount Griggs (fig. 4), and probably all were erupted there or nearby. Additionally, five small glaciated volcanoes (mapped by Riehle and others, 1993), likewise basaltic to dacitic, are scattered around the upper Savonoski River basin, 25 to $45 \mathrm{~km}$ northeast of Mount Griggs and 11 to $21 \mathrm{~km}$ behind (northwest of) the Dennison-Steller-Kukak-Devils Desk reach of the volcanic front (fig. 1). In addition, $90 \mathrm{~km}$ southwest of Mount Griggs, a brief phreatomagmatic outburst in 1977 produced the Ukinrek Maars and a sheet of basaltic ejecta at a site $10 \mathrm{~km}$ behind (northwest of) the frontal stratovolcano Mount Peulik. 
These scattered minor volcanic centers have in common with voluminous Mount Griggs not only positions well behind the volcanic front but also magmatic compositions that suggest contributions from the subducting plate which are proportionately smaller than in eruptive products of the main volcanic line. Products of all the volcanoes here, whether on or behind the main chain, have compositions typical of convergent-margin-arc magmas that reflect a significant slab-derived contribution. Nonetheless, the slab geochemical signature is consistently weaker in Mount Griggs lavas than in those of the volcanic-front centers nearby. In particular, samples from Mount Griggs have lower $\mathrm{Ba} / \mathrm{Zr}, \mathrm{Ba} / \mathrm{La}, \mathrm{Ba} / \mathrm{Ta}$, and $\mathrm{Ba} / \mathrm{Th}$ ratios (characteristically elevated in arc magmas) than those from Katmai, Trident, Mageik, Martin, and Novarupta. The inference that the magmas erupted at Mount Griggs thus contain a proportionately larger contribution from the subarc mantle wedge is a topic of continuing investigation.

\section{Acknowledgments}

Dave Johnston alerted us to the possibility that Mount Griggs might be worth studying, in the course of a memorable field campaign in the summer of 1979 , when we were joined by Terry Keith, Anita Grunder, and Peter Shearer (who took the photograph in fig. 8). On the first author's initial visit to Mount Griggs in 1976, he was joined by Larry Jager and Dan Kosco. Michelle Coombs helped on Mount Griggs in 1997. In 1997 and 1998, helicopter pilots Paul Walters and Bill Springer took us everywhere we wanted to go on and around Mount Griggs. Joel Robinson took the lead in digitally compiling our Katmai geologic map, of which figures 3 and 4 are localized adaptations. We are grateful to James Saburomaru and Forrest McFarland for K-Ar dating at the USGS laboratories in Menlo Park, Calif., and to John Paskievitch for his patience and expertise in arranging field logistics. We thank Kevin Scott and Terry Keith for their reviews of the manuscript and the editors for their labors. For encouraging this study, we are especially grateful to Terry Keith, then at the helm of the Alaska Volcano Observatory.

\section{References Cited}

Allen, E.T., and Zies, E.G., 1923, A chemical study of the fumaroles of the Katmai region: National Geographic Society Contributed Technical Papers, Katmai Series, no. 2, p. 75-155.

Bacon, C.R., and Druitt, T.H., 1988, Compositional evolution of the zoned calcalkaline magma chamber of Mount Mazama, Crater Lake, Oregon: Contributions to Mineralogy and Petrology, v. 98 , no. 2, p. 224-256.

Coombs, M.L., Eichelberger, J.C., and Rutherford, M.J., 2000, Magma storage and mixing conditions for the 1953-1974 eruptions of Southwest Trident volcano, Katmai National Park, Alaska: Contributions to Mineralogy and Petrology, v. 140, p. 99-118.
Detterman, R.L., Case, J.E., Miller, J.W., Wilson, F.H., and Yount, M.E., 1996, Stratigraphic framework of the Alaska Peninsula: U.S. Geological Survey Bulletin 1969-A, 74 p.

Fenner, C.N., 1926, The Katmai magmatic province: Journal of Geology, v. 35, no. 7, pt. 2, p. 673-772.

Fierstein, Judy, and Hildreth, Wes, 1992, The plinian eruptions of 1912 at Novarupta, Katmai National Park, Alaska: Bulletin of Volcanology, v. 54, no. 8, p. 646-684.

Griggs, R.F., 1922, The Valley of Ten Thousand Smokes: Washington, D.C., National Geographic Society, 340 p.

Higbie, R.G., 1975, The Katmai eruption and the Valley of Ten Thousand Smokes, in Oehser, P.H., ed., National Geographic Society research reports, 1890-1954: Washington, D.C., National Geographic Society, p. 141-170.

Hildreth, Wes, 1983, The compositionally zoned eruption of 1912 in the Valley of Ten Thousand Smokes, Katmai National Park, Alaska: Journal of Volcanology and Geothermal Research, v. 18 , no. 1-4, p. 1-56.

1987, New perspectives on the eruption of 1912 in the Valley of Ten Thousand Smokes, Katmai National Park, Alaska: Bulletin of Volcanology, v. 49, no. 5, p. 680-693.

Hildreth, Wes, and Fierstein, Judy, 2000, Katmai volcanic cluster and the great eruption of 1912: Geologic al Society of America Bulletin, v. 112, no. 10, p. 1594-1620.

Hildreth, Wes, Fierstein, Judy, Lanphere, M.A., and Siems, D.F., 1999, Alagogshak volcano; a Pleistocene andesite-dacite stratovolcano in Katmai National Park, in Kelley, K.D., ed., Geologic studies in Alaska by the U.S. Geological Survey, 1997: U.S. Geological Survey Professional Paper 1614, p. $105-113$

2000, Mount Mageik; a compound stratovolcano in Katmai National Park, in Kelley, K.D., and Gough, L.P., eds., Geologic studies in Alaska by the U.S. Geological Survey, 1998: U.S. Geological Survey Professional Paper 1615, p. 23-41. 2001, Snowy Mountain; a pair of small andesite-dacite stratovolcanoes in Katmai National Park, in Gough, L.P., and Wilson, F.H., eds., Geologic Studies in Alaska by the U.S. Geological Survey, 1999: U.S. Geological Survey Professional Paper 1633, p. 13-34.

Hildreth, Wes, and Lanphere, M.A., 1994, Potassium-argon geochronology of a basalt-andesite-dacite arc system; the Mount Adams volcanic field, Cascade Range of southern Washington: Geological Society of America Bulletin, v. 106, no. 11, p. 1413-1429.

Jolly, A.D., and McNutt, S.R., 1999, Seismicity at the volcanoes of Katmai National Park, Alaska; July 1995-December 1997: Journal of Volcanology and Geothermal Research, v. 93, no 3-4, p. 173-190.

Kosco, D.G., 1981, Characteristics of andesitic to dacitic volcanism at Katmai National Park, Alaska: Berkeley, University of California, Ph.D. thesis, $249 \mathrm{p}$.

Mann, D.H., and Peteet, D.M., 1994, Extent and timing of the Last Glacial Maximum in southwestern Alaska: Quaternary Research, v. 42, p. 136-148.

Miyashiro, Akiho, 1974, Volcanic rock series in island arcs and active continental margins: American Journal of Science, $v$. 274, no. 4, p. 321-355.

Muller, E.H., 1952, The glacial geology of the Naknek district, the Bristol Bay region, Alaska: Urbana, University of Illinois, Ph.D. thesis, $98 \mathrm{p}$.

Muller, E.H., 1953, Northern Alaska Peninsula and eastern Kilbuck Mountains, Alaska, in Péwé, T.L., Wahrhaftig, C.A., Fernald, 
A.T., Hopkins, D.M., Karlstrom, T.N.V., Krinsley, D.B., and Muller, E.H., Multiple glaciation in Alaska; a progress report: U.S. Geological Survey Circular 289, p. 2-3.

Muller, E.H., Juhle, R.W., and Coulter, H.W., 1954, Current volcanic activity in Katmai National Monument: Science, v. 119, no. 3088, p. 319-321.

Peacock, M.A., 1931, Classification of igneous rock series: Journal of Geology, v. 39, no. 1, p. 54-67.

Poreda, R.J., and Craig, Harmon, 1989, Helium isotope ratios in circum-Pacific volcanic arcs: Nature, v. 338, no. 6215, p. 473-478.

Riehle, J.R., and Detterman, R.L., 1993, Quaternary geologic map of the Mount Katmai quadrangle and adjacent parts of the Naknek and Afognak quadrangles, Alaska: U.S. Geological Survey Miscellaneous Investigations Series Map I-2032, scale 1:250,000.

Riehle, J.R., Detterman, R.L., Yount, M.E., and Miller, J.W., 1993, Geologic map of the Mount Katmai quadrangle and adjacent parts of the Naknek and Afognak quadrangles, Alaska:
U.S. Geological Survey Miscellaneous Investigations Series Map I-2204, scale 1:250,000.

Sheppard, D.S., Janik, C.J., and Keith, T.E.C., 1992, A comparison of gas geochemistry of fumaroles in the 1912 ash-flow sheet and on active stratovolcanoes, Katmai National Park, Alaska: Journal of Volcanology and Geothermal Research, v. 53, no. 1-4, p. 185-197.

Singer, B.S., Dungan, M.A., and Layne, G.D., 1995, Textures and Sr, $\mathrm{Ba}, \mathrm{Mg}, \mathrm{Fe}, \mathrm{K}$, and $\mathrm{Ti}$ compositional profiles in volcanic plagioclase; clues to the dynamics of calc-alkaline magma chambers: American Mineralogist, v. 80, no. 7-8, p. 776-798.

Stacey, J.S., Sherrill, N.D., Dalrymple, G.B., Lanphere, M.A., and Carpenter, N.V., 1981, A five-collector system for the simultaneous measurement of argon isotope ratios in a static mass spectrometer: International Journal of Mass Spectrometry \& Ion Physics, v. 39, p. 167-180.

Wood, C.A., and Kienle, Jürgen, eds., 1990, Volcanoes of North America: Cambridge, U.K., Cambridge University Press, 354 p. 


\title{
Treeline Biogeochemistry and Dynamics, Noatak National Preserve, Northwestern Alaska
}

\author{
By Robert Stottlemyer, ${ }^{1}$ Dan Binkley, ${ }^{2}$ and Heidi Steltzer ${ }^{2}$
}

\section{Abstract}

The extensive boreal biome is little studied relative to its global importance. Its high soil moisture and low temperatures result in large below-ground reservoirs of carbon $(\mathrm{C})$ and nitrogen $(\mathrm{N})$. Presently, such high-latitude ecosystems are undergoing the largest temperature increases in global warming. Change in soil temperature or moisture in the large pools of soil organic matter could fundamentally change ecosystem $\mathrm{C}$ and $\mathrm{N}$ budgets. Since 1990, we have conducted treeline studies in a small (800 ha) watershed in Noatak National Preserve, northwestern Alaska. Our objectives were to (1) gain an understanding of treeline dynamics, structure, and function; and (2) examine the effects of global climate change, particularly soil temperature, moisture, and $\mathrm{N}$ availability, on ecosystem processes. Our intensive site studies show that the treeline has advanced into tundra during the past 150 years. Inplace and laboratory incubations indicate that soil organic-layer mineralization rates increase with a temperature change $>5^{\circ} \mathrm{C}$. N availability was greatest in soils beneath alder and lowest beneath willow or cottongrass tussocks. Watershed output of inorganic $\mathrm{N}$ as $\mathrm{NO}_{3}^{-}$was 70 percent greater than input. The high inorganic-N output likely reflects soil freeze-thaw cycles, shallow flowpaths to the stream, and low seasonal biological retention. Concentrations and flux of dissolved organic carbon (DOC) in streamwater increased during spring melt and in autumn, indicating a seasonal accumulation of soil and forest-floor DOC and a shallower flowpath for meltwater to the stream. In sum, our research suggests that treeline transitionzone processes are quite sensitive to climate change, especially those functions regulating the $\mathrm{C}$ and $\mathrm{N}$ cycles.

\section{Introduction}

The boreal biome covers an area of 15 million $\mathrm{km}^{2}$, second in extent only to tropical forest. Boreal lakes and ponds cover

'U.S. Geological Survey.

${ }^{2}$ Colorado State University. approximately 10 percent of the biome. In the taiga-tundra treeline of northwestern Alaska, temperatures have increased since 1950, especially in spring (Herrmann and others, 2000). The rate of regional climate change may be more significant than its magnitude (Solomon and Bartlein, 1992). The level of research on boreal forests does not match the extent or importance of this ecosystem (Botkin and Simpson, 1990; Mooney and others, 1991).

In the boreal biome, warming temperatures and change in moisture could increase above-ground production or belowground respiration (Shaver and others, 1992). A change in available soil $\mathrm{N}$ may alter above- or below-ground $\mathrm{C} / \mathrm{N}$ ratios, possibly also accelerating above-ground production or belowground respiration. Which process is greater in magnitude may determine whether the ecosystem becomes a C source or sink (Oechel and others, 1995; McKane and others, 1997). To assess the effect of climate shift on the boreal $\mathrm{C}$ cycle requires knowledge of how temperature and moisture change affect soil organic reservoirs and other element cycles, especially $\mathrm{N}$.

The boreal biome contains large, but mostly unavailable, reservoirs of $\mathrm{C}, \mathrm{N}$, and P. High-latitude terrestrial ecosystems contain from 20 to 45 percent of the global pool of soil organic C. Typically, $>95$ percent of tundra ecosystem C, N, and $\mathrm{P}$ occurs in soil organic matter (SOM) (Shaver and others, 1992). In such ecosystems, the nutrient and C storage in SOM pools is a function of high soil moisture and low temperature, both of which slow decomposition.

In the taiga-tundra transition zone at the northernmost extent of the boreal biome, most SOM is below the annual thaw depth (soil active layer) and not readily available for biological uptake. Any factor that increases the depth of the soil active layer or the depth to permafrost could change soil moisture and temperature, SOM decomposition, nutrient availability, and respiration rates (Chapin and others, 1995; Jonasson and others, 1999). Research in Michigan shows that slight gains in soil temperature result in an increase of SOM decomposition and available nutrients as inorganic $\mathrm{N}$ in amounts greater than the sum of other $\mathrm{N}$ sources, such as precipitation and fixation (Stottlemyer and Toczydlowski, 1999).

The National Park Service (NPS) manages an area of 7 million ha in northwestern Alaska, or about 25 percent of 
the Nation's total land in national parks. The northwestern Alaska region stretches inland from the Chukchi Sea almost $600 \mathrm{~km}$, mainly along the Brooks Range, encompassing much of Alaska's taiga-tundra treeline transition zone. Much of this NPS land is in Noatak National Preserve, which, along with the western part of Gates of the Arctic National Park, contains the entire 500-km-long Noatak River Basin (Kepner and Stottlemyer, 1990). Ecologic studies in the region are few and largely confined to wildlife. Except for the National Science Foundation studies at Toolik Lake and vicinity in east-central Alaska, few studies of ecosystem processes have been conducted within the region.

In 1989, studies were begun in Noatak National Preserve to assess surface water quality, treeline dynamics, ecosystem processes that may regulate terrestrial nutrient and energy cycles, and terrestrial and aquatic ecosystem linkages. In this chapter, we summarize results from several intensive studies in a small (800-ha area) watershed to (1) relate changes in upstream and downstream water chemistry to soil conditions and possible changes in hydrologic flowpath, (2) investigate the relations between soil temperature and moisture in regulating soil $\mathrm{N}$ supply in major ecosystems in and adjacent to the watershed, and (3) quantify the extent to which forest stands have invaded tundra along transects in and adjacent to the watershed.

\section{Site Description}

\section{Noatak National Preserve}

Noatak National Preserve is just north of the Arctic Circle. Its south boundary is the Baird Mountains, and its north boundary is the De Long Mountains near the west end of the Brooks Range (fig. 1), which represents the west end of the Rocky Mountain Physiographic Division of Alaska.

The geology of the preserve is dominated by Quaternary deposits at low elevations; Permian, Triassic, and Jurassic volcanic rocks in the western part; and Mississippian conglomerate, shale, limestone, and dolomitic rocks along its north border. Some Precambrian bedrock is present, and much of the rest of the preserve is underlain by Upper Devonian shale, sandstone, chert, and conglomerate (Plafker and Berg, 1994); however, loess and volcanic ash cover most of the Noatak Basin. Much of the region is characterized by continuous permafrost, but large areas of discontinuous permafrost are present, especially along forested southern aspects (Ferrians, 1965).

Air and soil temperatures in the region have warmed since 1950 (fig. 2). The mean annual temperatures at National Oceanographic and Atmospheric Administration (NOAA) stations in Bettles (lat $66^{\circ} 55^{\prime} \mathrm{N}$., long $151^{\circ} 31^{\prime}$ W.) and Kotzebue, Alaska, have increased $(p<0.01)$ by about $0.04^{\circ} \mathrm{C} / \mathrm{yr}($ Herrmann and others, 2000), with most of the increase occurring in April $\left(p<0.01, r^{2}=0.16, b=0.16^{\circ} \mathrm{C} / \mathrm{yr}\right)$. The warming at high latitudes is consistent with other findings (Illeris and Jonasson, 1999).
The NOAA weather stations show considerable annual variation (fig. 2). Winter temperatures are extreme, and most of the annual precipitation (mean, $35 \mathrm{~cm}$ ) occurs during the summer months. The snowpack rarely exceeds $1 \mathrm{~m}$ in depth in protected areas. Wind redistributes the snow in exposed areas, and the depth and duration of the snowpack are major factors regulating vegetation (Lavoie and Payette, 1994).

Bailey (1998) classified the region of the Noatak National Preserve as a westward extension of the subarctic-regime mountains. Tundra dominates in the northern part of the preserve, taiga-tundra treeline in the central and western parts, and taiga along the south boundary with Kobuk National Park. Forested areas are characterized by spodosols, with histosols in wetter sites (Rieger and others, 1979).

\section{Asik Research Watershed}

The 800-ha-area Asik watershed (lat $67^{\circ} 58^{\prime} \mathrm{N}$., long $162^{\circ} 15^{\prime}$ W.) is in the south-central part of Noatak National Preserve, $95 \mathrm{~km}$ northeast of Kotzebue (fig. 1). The watershed is at treeline, and its first-order stream drains from the north and west into the Agashashok River, which in turn feeds into the Noatak River. Since 1996, the daily mean air temperature in the watershed has ranged from -47 to $20^{\circ} \mathrm{C}$ (fig. 2). Annual precipitation averages $30 \mathrm{~cm}$, with about $10 \mathrm{~cm}$ falling during the growing season (June to mid August). The peak snowpack averages about $1 \mathrm{~m}$ in depth in the more sheltered lower and middle elevations of the watershed.

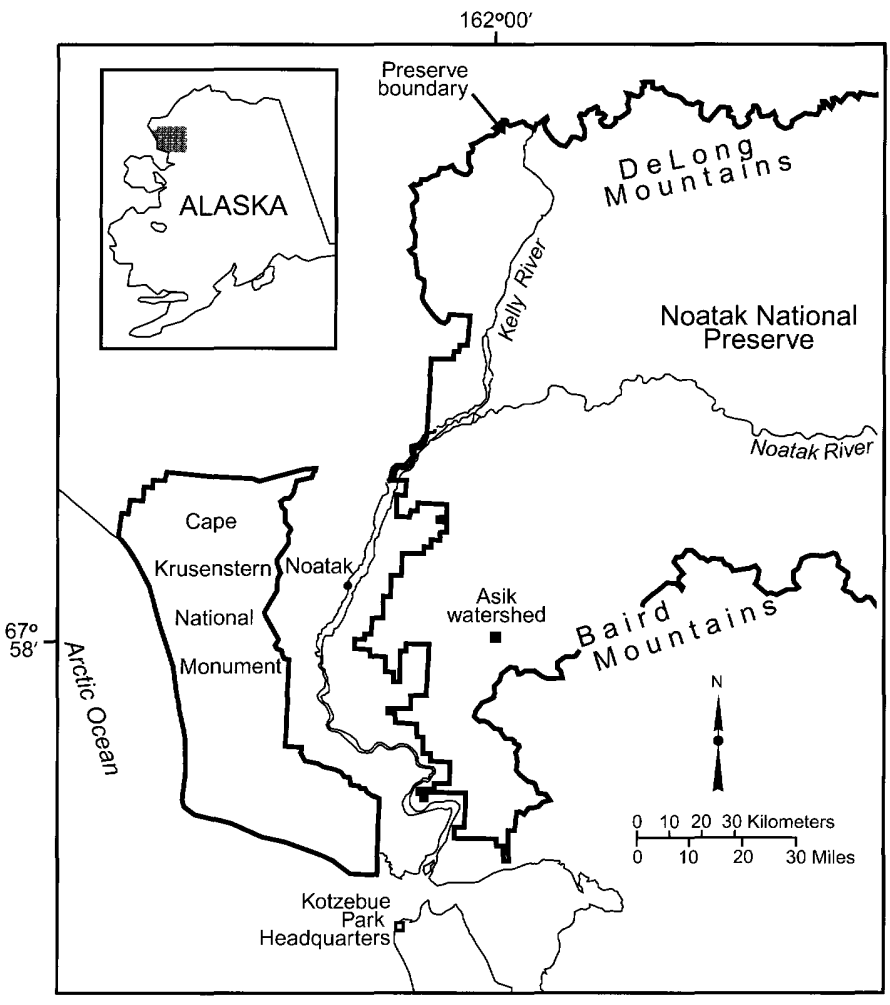

Figure 1. Northwestern Alaska, showing location of the Asik watershed, Agashashok River drainage, Noatak National Preserve. 
The soil association is gravelly, hilly to steep pergelic cryaquepts/pergelic cryorthents (Rieger and others, 1979). The association consists of poorly drained to well-drained soils, most with permafrost. Soils are poorly drained along long gradual slopes, valley bottoms, and on steeper northern aspects. Well-drained soils occur along ridges and on steeper southern-aspect slopes. Frost features are common. In the Agashashok River flood plain, soils are loamy. Along steeper slopes of the Asik watershed, soils are shallow and rocky, with a clay-loam texture. In the Asik watershed, the bulk density of the decomposed surface organic layer $(\mathrm{O} 2$ horizon) averages from 0.3 where the silt content is low to about 0.7 where the silt content is high. The $\mathrm{O} 2$-horizon $\mathrm{pH}$ ranges from 4.6 in tussock tundra to 6.0 beneath spruce, total $\mathrm{C}$ content from 15 weight percent beneath alder to 40 weight percent in tussock tundra, and total $\mathrm{N}$ from 0.8 weight percent beneath alder to 1.7 weight percent below tussock tundra. Discontinuous permafrost exists in the watershed, especially where there is no forest. The soil surface (uppermost $5 \mathrm{~cm}$ ) is frozen from late September to May, except for upper reaches with southern aspects. The bedrock is Silurian and Devonian limestone, dolomite, marble, and shale (Plafker and Berg, 1994). About 5 to 7 percent of the watershed area consists of talus slopes. The Noatak River drainage was unglaciated during the last ice age.

The lower two-thirds of the watershed area is dominated by white spruce (Picea glauca [Moench] Voss). Spruce basal area ranges from $4 \mathrm{~m}^{2} / \mathrm{ha}$ on south aspects to $23 \mathrm{~m}^{2} / \mathrm{ha}$ in bottom land (Suarez and others, 1999). The spruce forest understory consists primarily of Hylocomium splendens
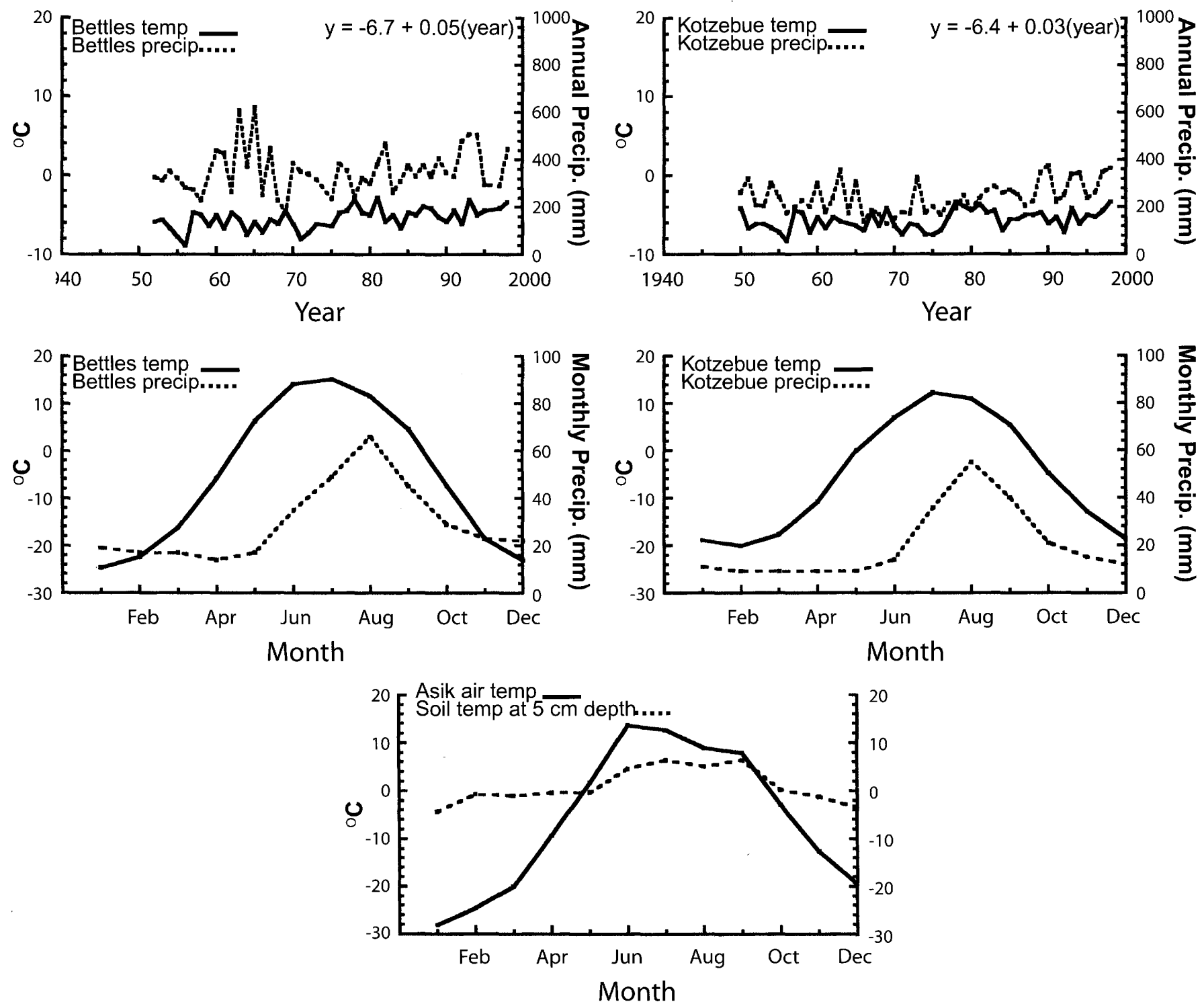

Figure 2. Mean annual (1951-98) and monthly temperature and precipitation for National Oceanographic Atmospheric Administration (NOAA) stations, Bettles and Kotzebue, Alaska; and (bottom) seasonal change (average, 1996-99) in air and soil temperature, Asik watershed, Noatak National Preserve, Alaska. Equations are given where time trend was significant. 
(Hedw.) B.S.G., Equisetum arvense L., and Boykinia richardsonii (Hook.) Gray, with shrubs of Salix spp. and Vaccinium uliginosum $\mathrm{L}$. The understory of the taiga-tundra transition zone and tundra is dominated by tussocks of Eriophorum vaginatum L., Vaccinium uliginosum, Potentilla fruticosa L., and Betula nana L. The upper 20 percent of the watershed area is dominated by such shrubs as Betula nana, scattered Alnus crispa (Ait.) Pursh on more northern aspects, and mesic nontussock tundra. The stream alluvial area is dominated by Salix spp.

\section{Methods}

\section{Hydrology and Streamwater Chemistry}

Because of the important role of hydrology in biogeochemical cycles and the need to study the ecosystem as an integrated unit, we chose the watershed-ecosystem design for most of our intensive studies of terrestrial processes and their linkages to the aquatic ecosystem (Likens and Bormann, 1995). In 1991, we began intensive study of the first-order, 800-ha-area treeline Asik watershed, which was selected for its central location in the taiga-tundra treeline, its small size, and its proximity to a river bar for relative ease of access by bushplane.

A 10-m-high meteorologic tower with data logger and solar panel was located in the lower third of the watershed. Air and soil temperature (at 5- and 10-cm depth), relative humidity, radiation, windspeed, and wind direction were monitored year round. In the alpine tundra, a data logger monitored air (1 $\mathrm{m}$ ) and soil temperature (at 5- and 10-cm depth). Precipitation was sampled by using bulk collectors. During winter, the sampler was a 20 -cm-diameter, 1.5-m-long tube lined with custom-fitted heavy plastic liners. During the growing season, a 10-cm-diameter plastic tube with funnel was used with a prerinsed qualitative filter in place to minimize dust and particulates entering the sample. Precipitation samples were collected weekly during the growing season and early fall.

Stream discharge was measured at a natural weir. Since 1996, stage height was monitored by standing stake and pressure transducer. Each year a discharge curve was developed by measuring cross sections and velocity (pygmy meter) at varying stage heights. Daily water temperature was monitored year round and recorded by data logger. Streamwater was sampled weekly at the mouth and five upstream stations from late May to mid-September. Sampling was daily or more frequent at the mouth during periods of rapid hydrograph change. The stream was frozen, with little or no flow from mid-October to late April or early May.

For analyses of precipitation and streamwater samples, $\mathrm{pH}$, specific conductance, and alkalinity (titration with $0.02 \mathrm{~N}$ $\mathrm{H}_{2} \mathrm{SO}_{4}$ to $\mathrm{pH} 4.5$, streamwater samples only) were measured in the field laboratory. Separate filtered (prerinsed, $0.45 \mu \mathrm{m}$ ) subsamples were shipped in coolers to our laboratory in Fort Collins, Colo., for ion-chromatographic analysis, and an addi- tional filtered sample was sent to the Michigan Technological University, Houghton, for dissolved-organic-carbon (DOC) analysis.

\section{Nitrogen Mineralization Response to Temperature and Moisture}

In 1990-91, we located three subplots beneath each of five vegetation types in or adjacent to the Asik watershed (Binkley and others, 1994). Willow and Dryas spp. subplots were located on the Agashashok River terraces across from the watershed. The alder subplots were on a north-facing slope upstream of the willow subplots, and the spruce subplots were along the north side of the watershed, with the tundra plots above the spruce.

To examine the effects of soil-temperature and moisture change on $\mathrm{N}$ transformations, principally mineralization (microbial breakdown of organic $\mathrm{N}$ to inorganic $\mathrm{NO}_{3}^{-}$and $\mathrm{NH}_{4}^{+}$) and immobilization (microbial uptake), we conducted a series of laboratory incubations. First, a composite sample from the soil surface organic layer, or $\mathrm{O} 2$ horizon, was collected from each subplot, placed in a cooler, and shipped to our laboratory in Fort Collins, Colo., where the samples were sieved. A 10-g subsample was extracted with $50 \mathrm{~mL}$ of $2 \mathrm{M} \mathrm{KCl}$ to determine the initial inorganic- $\mathrm{N}\left(\mathrm{NO}_{3}^{-}\right.$and $\left.\mathrm{NH}_{4}^{+}\right)$concentrations. Additional 10-g subsamples were incubated in the laboratory for a month at 5 and $12^{\circ} \mathrm{C}$ at four frequencies of wetting and drying (one to four times during laboratory incubation). At the end of a month, all samples were extracted with $2 \mathrm{M} \mathrm{KCl}$ to determine the net change in mineralized $\mathrm{N}$. Net $\mathrm{N}$ mineralization is the sum of mineralized $\mathrm{NH}_{4}^{+}$plus $\mathrm{NO}_{3}^{-}$from organic $\mathrm{N}$, minus immobilization of $\mathrm{NH}_{4}^{+}$and $\mathrm{NO}_{3}^{-}$during the incubation period; net nitrification is the sum of $\mathrm{NO}_{3}^{-}$from both organic $\mathrm{N}$ and $\mathrm{NH}_{4}^{+}$minus immobilization of $\mathrm{NO}_{3}^{-}$.

A subsample from the incubated samples was retained for a ${ }^{15} \mathrm{~N}$ pool-dilution experiment to estimate gross, or total, $\mathrm{N}$ mineralization and immobilization during a 24-hour period. The gross results provide an estimate of the total $\mathrm{NH}_{4}^{+}$and $\mathrm{NO}_{3}^{-}$ cycled within a given time period. For details on the procedures used, see Kirkham and Bartholomew (1954) and Brooks and others (1989).

\section{Expansion of Forest into Tundra}

After a 1995 aerial survey of the Asik watershed, five stands of spruce that showed an apparent expansion pattern into tundra were selected for intensive study (Suarez and others, 1999). The normal vegetation transition was from pure spruce to forest mixed with tundra plants, then to tundra with numerous trees, then to treeless tundra. The spruce understory and tundra vegetation composition was similar to that described above. In each stand, three transects perpendicular to the direction of spruce expansion were located. The stand age of each plot was determined by sampling the five trees 
larger than $20 \mathrm{~mm}$ in diameter nearest each plot center. The diameter, height, and age of each sample tree were determined. In the transect with the oldest vegetation in each plot, cores were collected from 35 trees to determine annual growth increments. From each five-tree plot, seedlings by size class were recorded and aged, and dead trees and seedlings were tallied. For further details on data analysis, see Suarez and others (1999).

\section{Results and Discussion}

\section{Streamwater Solute Concentrations and Budgets}

Runoff in the Asik watershed averaged 45 percent of precipitation. Concentrations of streamwater base cations $\left(\mathrm{C}_{\mathrm{B}}\right)$ (the sum of $\mathrm{Ca}^{2+}, \mathrm{Mg}^{2+}, \mathrm{Na}^{+}$, and $\mathrm{K}^{+}$), and $\mathrm{HCO}_{3}^{-}$were higher than observed in most watersheds in North America (fig. 3; Kaufmann and others, 1991). Measured concentrations were similar to those in Rock Creek, Denali National Park, Alaska (Stottlemyer, 1992).

Streamwater $C_{B}$ concentrations can provide indications of seasonal change in water source and age (Rice and Bricker, 1995). In early June and mid-June, low $\mathrm{Ca}^{2+}$ concentrations suggest that discharge from the watershed was dominated by "new water" from melting of snow and ice (McNamara and others, 1997). Later, in summer, the increase in streamwater $\mathrm{Ca}^{2+}$ concentrations suggests greater contributions from "old" water deeper in the soil and longer flowpaths to the stream.

Asik alpine-streamwater $\mathrm{Ca}^{2+}$ concentrations suggest that a combination of factors-short flowpath, less reactive soil and more talus, and domination by new water-contribute to low solute concentrations. In alpine streamwater, the absence of much seasonal change in $\mathrm{Ca}^{2+}$ concentration suggests rapid penetration of precipitation and meltwater through porous soil and talus before it enters the stream, with little contribution from substrate exchange or weathering (Stottlemyer and others, 1997).

Asik streamwater $\mathrm{NO}_{3}^{-}$concentrations were also higher than observed in most surface waters, even in regions where atmospheric $\mathrm{NO}_{3}^{-}$inputs are elevated (Kaufmann and others, 1991). However, undisturbed Alaskan streams commonly have high $\mathrm{NO}_{3}^{-}$concentrations year round, with outputs exceeding inputs (Stednick, 1981; Stottlemyer and Rutkowski, 1987; Stottlemyer, 1992). Asik streamwater $\mathrm{NO}_{3}^{-}$concentrations likely reflect a shallow soil active layer or discontinuous permafrost channeling runoff through near-surface soil source areas where pools of dissolved inorganic $\mathrm{N}\left(\mathrm{NH}_{4}^{+}+\mathrm{NO}_{3}^{-}\right)$are greater (Stottlemyer and Toczydlowski, 1990; Creed and Band, 1998; Stottlemyer and Troendle, 1999), with seasonal low biological uptake (especially in the alpine), and soil freeze/thaw cycles releasing biologically usable $\mathrm{C}$ and $\mathrm{N}$ from the microbial biomass (Mitchell and others, 1996).

Streamwater $\mathrm{NO}_{3}^{-}$concentrations at the mouth of the Asik watershed varied little during the growing season and declined only slightly during late summer and early fall, when streamwater discharge increased. Alpine-streamwater $\mathrm{NO}_{3}^{-}$ concentrations especially suggest low biological uptake during the growing season, because precipitation inputs were small. In alpine headwaters where talus dominates, a small amount of soil and vegetation can still dominate inorganic- $\mathrm{N}$ concentra-
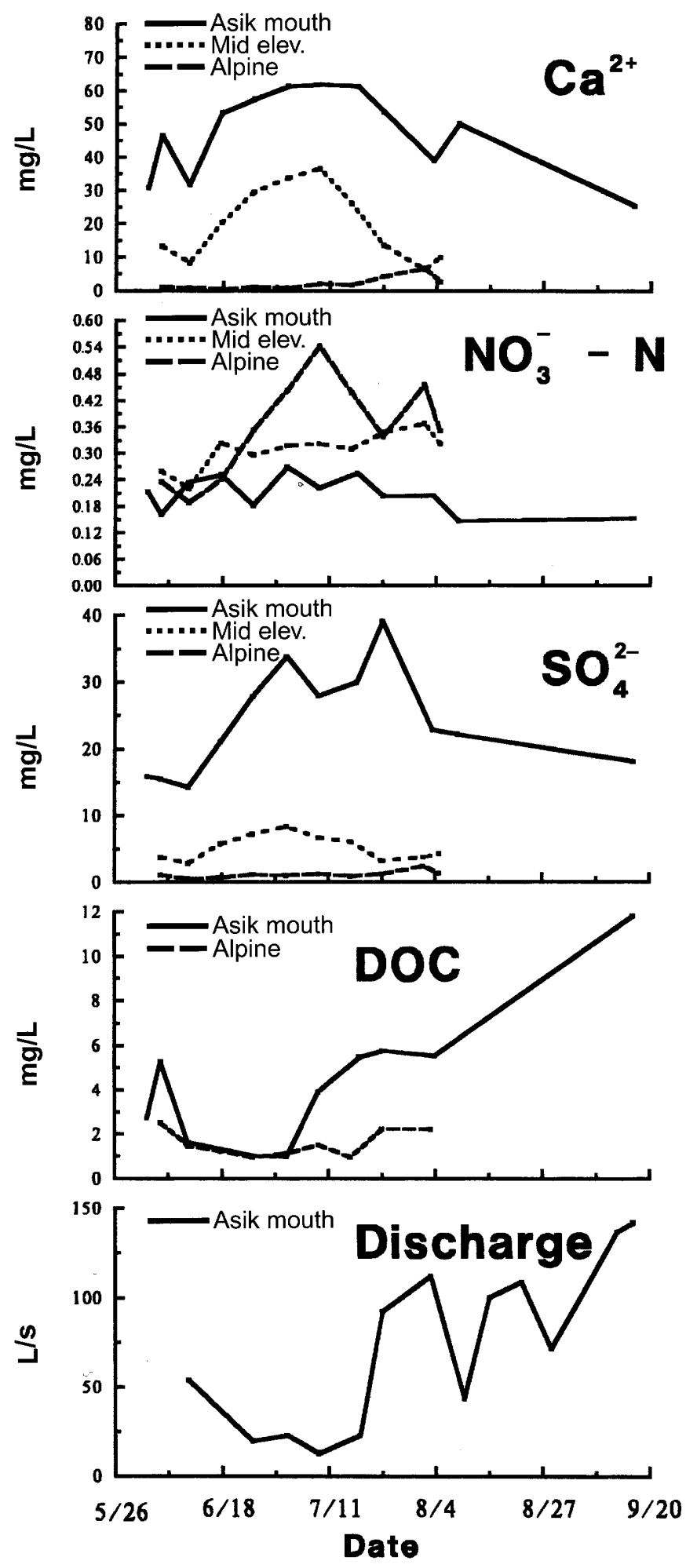

Figure 3. Mean weekly streamwater ion and DOC concentrations at different elevations and discharge from the Asik watershed, Noatak National Preserve, Alaska, in 1999. 
tions in soil and streamwater (Campbell and others, 1995). The Asik watershed inorganic- $\mathrm{N}$ output, primarily $\mathrm{NO}_{3}^{-}$, exceeded input by 70 percent.

The increase in streamwater DOC concentrations during spring melt suggests that large soil and forest-floor DOC reservoirs accumulated during the previous fall and winter. The increases in late summer streamwater DOC concentration and flux at the watershed mouth indicate considerable growingseason soil $\mathrm{C}$ mineralization, coupled with greater subsurface flow to the stream. Streamwater DOC output averaged 0.015 $\mathrm{mg} / \mathrm{m}^{2}$ per day, and dissolved-inorganic-carbon (DIC) output $0.3 \mathrm{mg} / \mathrm{m}^{2}$ per day. The amount of $\mathrm{C}$ exported in streamwater was small relative to terrestrial $\mathrm{CO}_{2}$ losses to the atmosphere in the Asik watershed and other study areas in northern Alaska (Oechel and others, 1995; McKane and others, 1997).

DOC concentrations in soil water below the rooting zone and in streamwater are hypothesized to be low where inorganic $\mathrm{N}$ is relatively high, because large amounts of biologically usable $\mathrm{C}$ are needed to fuel the $\mathrm{N}$-immobilization processes in SOM (Aber, 1992). A synthesis of the European NITREX data, however, did not support this hypothesis (Gundersen and others, 1998), nor do the Asik watershed data. We suspect that the high Asik DOC export is a function of the large SOM pool, soil warming, and a larger proportion of the subsurface flow moving through shallower flowpaths to the stream.

\section{Climate and Soil-N-Mineralization Rates}

In our study of soils beneath five vegetation types in and adjacent to the Asik watershed, inorganic- $\mathrm{N}$ availability was highest beneath alder and lowest in plots dominated by willow or tussock-tundra (Binkley and others, 1994). However, all soils from the five vegetation types sampled responded strongly to an increase in the frequency of wetting and drying cycles, which raised the net $\mathrm{N}$-mineralization rates 150 to 300 percent in laboratory incubations (fig. 4). An increase in the frequency of wetting and drying cycles is one potential effect predicted with global warming.

Net $\mathrm{N}$-mineralization rates also responded strongly to temperature changes. Rates at $12^{\circ} \mathrm{C}$ were 5 to 10 times the rate at $5^{\circ} \mathrm{C}$. The response of net $\mathrm{N}$ mineralization to both temperature and moisture treatments was consistent in soils from all the five vegetation types; however, the response to a change in soil-moisture content was much less than the response to an increase in temperature.

Net N-mineralization rates reflected the strong effect of temperature and moisture treatments on both gross (total) soil-microbial $\mathrm{N}$ release (mineralization) and uptake (immobilization) (fig. 5). However, the response to temperature and moisture by mineralization processes differed in magnitude from the response by immobilization processes. For example, if the $\mathrm{N}$-immobilization rate responds more strongly to temperature increases than does the total $\mathrm{N}$-mineralization rate, net $\mathrm{N}$-mineralization rates would decline with increasing temperature, as may also be reflected in the seasonal pool size of soil inorganic $N$. Thus, the effect of climate change and, especially, temperature on the available soil inorganic $\mathrm{N}$ in these ecosystems will depend on the relative magnitude of response in these opposing processes of microbial mineralization and immobilization. We also suspect that the balance of these opposing processes varies seasonally and with available, or labile, $\mathrm{C}$.

\section{Expansion of Forest into Tundra}

Warming during the past 150 years appears to have increased spruce growth rates in the Asik watershed and resulted in forest expansion into the conterminous tundra ecosystem. The forest/tundra transition zone has moved about 80 to $100 \mathrm{~m}$ into the tundra. Our primary evidence is the progressive decline in maximum tree age from the spruce forest into the tundra and the frequency distribution of trees in spruce forest, forest-tundra, and areas where tundra is more prevalent than forest (fig. 6). The increase over time in spruce frequency where tundra was dominant is also associated with a broad

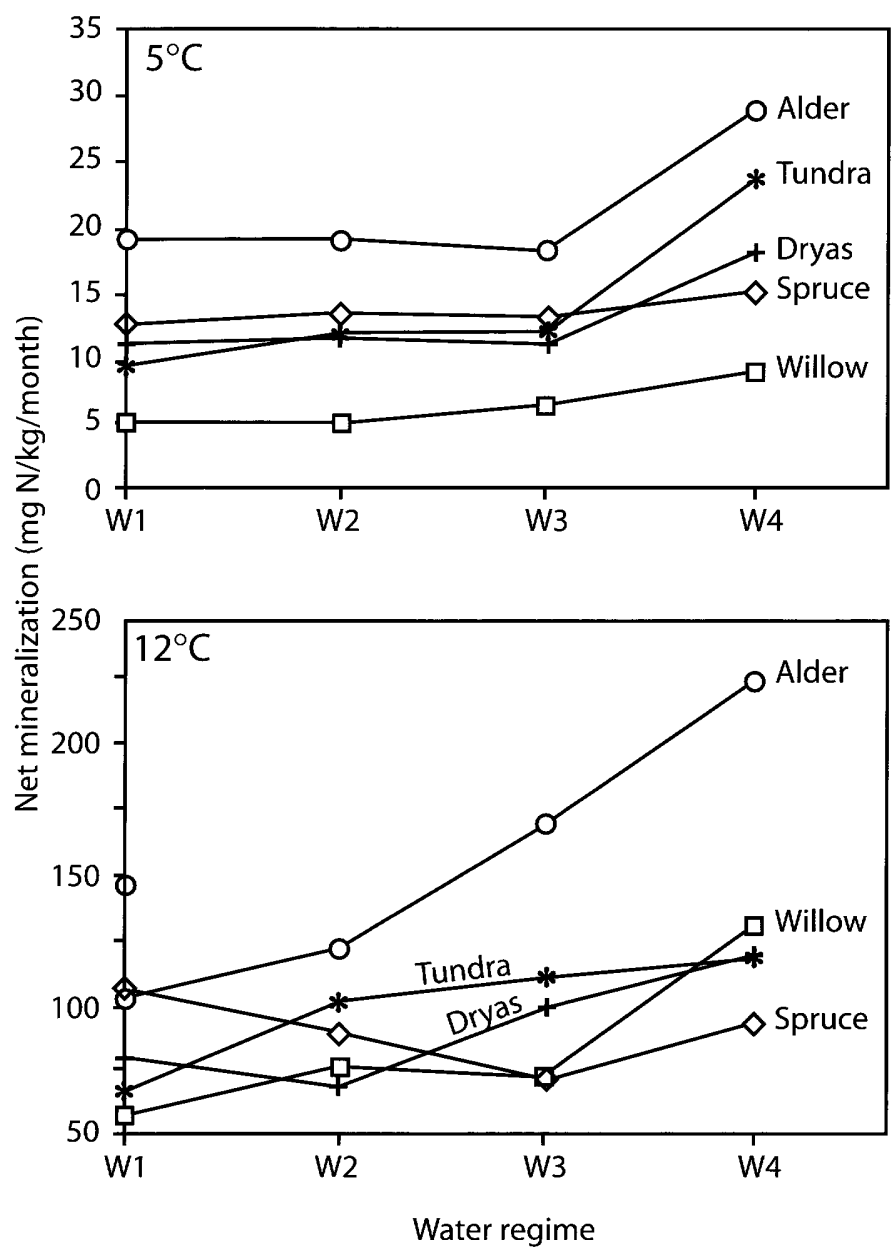

Figure 4. Laboratory net $\mathrm{N}$ mineralization in response to changes in temperature $\left(5\right.$ and $\left.12^{\circ} \mathrm{C}\right)$ and moisture. Responses to moisture and temperature were significant $(p<0.05)$. Water treatments: W1, one moisture addition at beginning of 30-day incubation; $W 2$, two moisture additions or two wet/dry periods; W3, three wet/dry treatments; W4, four wet/dry treatments. From Binkley and others (1994). 
trend of increasing tree growth. The climate conditions that led to increasing tree growth appear to have promoted tree establishment in the tundra. The recent expansion of spruce forest occurred across topographic boundaries and in areas of both well-drained soils on slopes and poorly drained, flat tundra areas. However, future advance of spruce may be limited by increased topographic exposure to wind and snow (Sturm and others, 2001) and by the higher soil moistures characteristic of most tundra.

During the past several centuries, changes in Alaska treeline have been small (Brubaker and others, 1983). At the Asik watershed, however, the encroachment of spruce forest into tundra was characterized initially by a few trees and later by increased density. This process of infilling has also been observed along the north side of the Noatak River (Rowland, 1996) and elsewhere. Changes in spruce density in response to climate may have been missed in the past during the more synoptic surveys of treeline advance, which focused more on only the presence or absence of spruce trees.
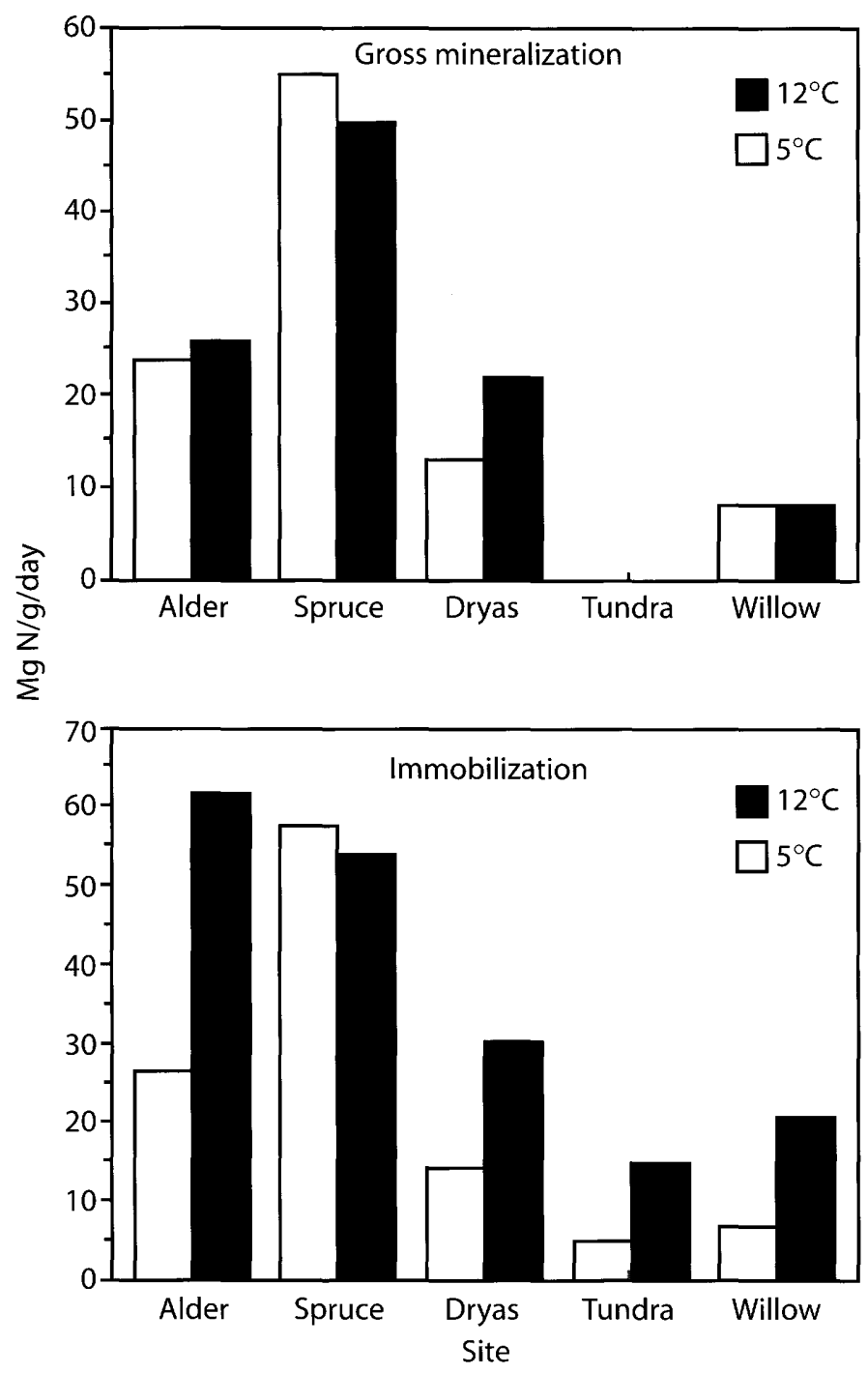

Figure 5. Laboratory 24-hour gross $\mathrm{N}$-mineralization and -immobilization rates in response to a change in temperature $\left(5\right.$ and $\left.12^{\circ} \mathrm{C}\right)$. From Binkley and others (1994).

\section{Acknowledgments}

This research was supported by the National Park Service's Alaska Region, the National Park Service's Small Watershed Research Program, the U.S. Department of the Interior's Global Change Program, and the U.S. Geological Survey's Long-Term Ecosystem Studies Program. Special thanks are due Dave Spirtes, superintendent, and Lois Dalle-Molle, chief of research and resources management, Northwest Areas, National Park Service, Kotzebue, Alaska, for their considerable logistic support and advice in carrying out our fieldwork; and to Buck Maxson, Jim Roode, and John St. Germain for their professionalism in safely flying countless support trips for us in a unique and wonderful part of North America. The manuscript was reviewed by Kelly Elder, Department of Earth Sciences, Colorado State University; Jennifer Harden, U.S. Geological Survey, Menlo Park, Calif.; and Ric Wilson, U.S. Geological Survey, Anchorage.
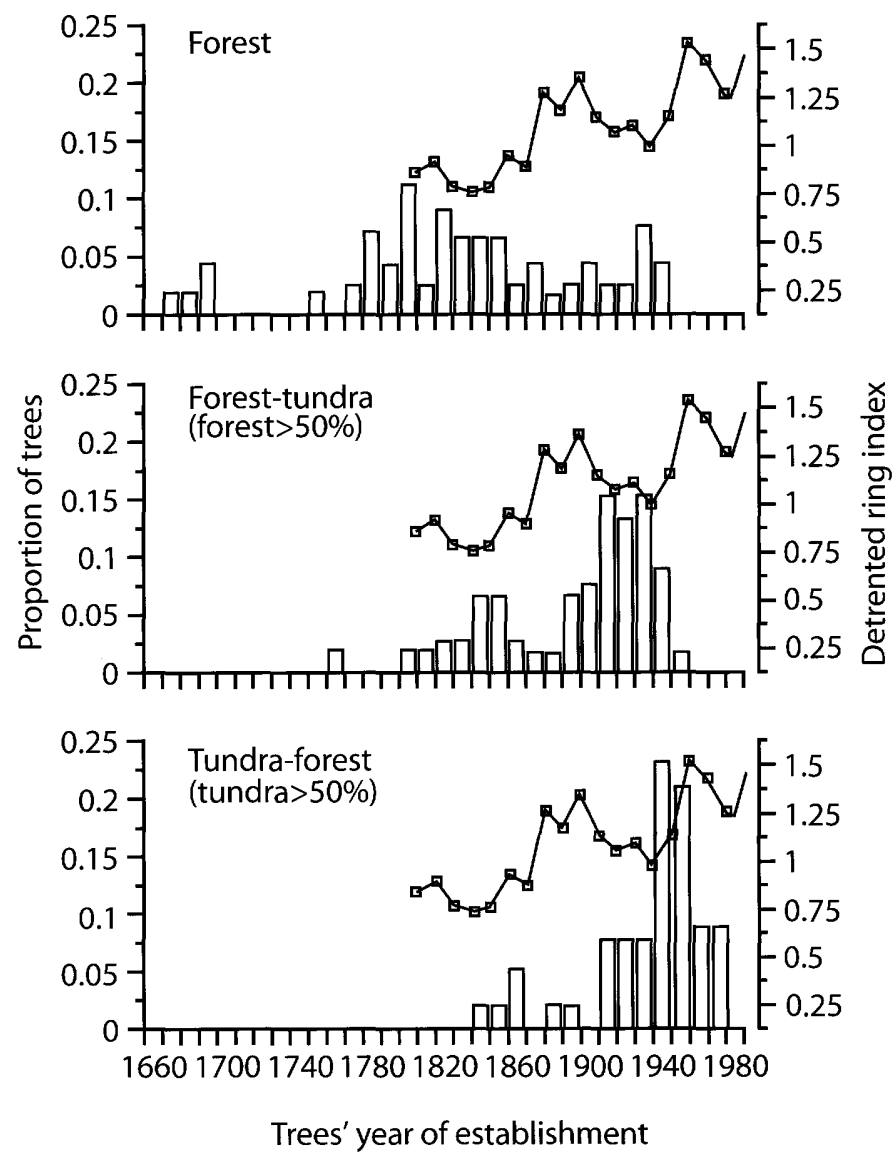

Figure 6. Relative-frequency histograms (10-year age classes) for spruce across five expanding stands, with detrended tree-ringgrowth index. From Suarez and others (1999). 


\section{References Cited}

Aber, J.D., 1992, Nitrogen cycling and nitrogen saturation in temperate forest ecosystems: Trends in Ecology and Evolution, v. 7, p. 220-223.

Bailey, R.G., 1998, Ecoregions; the ecosystem geography of the oceans and continents: New York, Springer, $176 \mathrm{p}$.

Binkley, Dan, Stottlemyer, Robert, Suarez, F., and Cortina, J., 1994, Soil nitrogen availability in some arctic ecosystems in northwest Alaska-responses to temperature and moisture: Ecoscience, v. 1, p. 64-70.

Botkin, D.B., and Simpson, L.G., 1990, Biomass of the North American boreal forest: Biogeochemistry, v. 9, p. 161-174.

Brooks, P.D., Stark, J.M., McInteer, B.B., and Preston, T., 1989, Diffusion method to prepare soil extracts for automated nitrogen-15 analysis: Soil Science Society of America Journal, v. 53, p. 1701-1711.

Brubaker, L.B., Garfinkel, H.L., and Edwards, M.E., 1983, A late Wisconsin and Holocene vegetation history from the Central Brooks Range-implications for Alaskan paleoecology: Quaternary Research, v. 20, no. 2, p. 194-214.

Campbell, D.H., Clow, D.W., Ingersoll, G.P., Mast, M.A., Spahr, N.E., and Turk, J.T., 1995, Processes controlling the chemistry of two snowmelt-dominated streams in the Rocky Mountains: Water Resources Research, v. 31, no. 11, p. 2811-2821.

Chapin, F.S., III, Shaver, G.R., Giblin, A.E., Nadelhoffer, K.J., and Laundre, J.A., 1995, Responses of arctic tundra to experimental and observed changes in climate: Ecology, v. 76, no. 3, p. 964-711.

Creed, I.F., and Band, L.E., 1998, Export of nitrogen from catchments within a temperate forest-evidence for a unifying mechanism regulated by variable source area dynamics: Water Resources Research, v. 34, no. 11, p. 3105-3120.

Ferrians, 0.J., 1965, Permafrost map of Alaska: U.S. Geological Survey Miscellaneous Geologic Investigations Map 1-445, scale 1: 2,500,000.

Gundersen, Per, Emmett, B.A., Kjonaas, O.J., Koopmans, C.J., and Tietema, Albert, 1998, Impact of nitrogen deposition on nitrogen cycling in forests - a synthesis of NITREX data: Forest Ecology and Management, v. 101, p. 37-55.

Herrmann, Raymond, Stottlemyer, Robert, Zak, J.C., Edmonds, R.L., and Van Miegroet, Helga, 2000, Biogeochemical effects of global change on U.S. National Parks: American Water Resources Association Journal, v. 36, no. 2, p. 337-346.

Illeris, L., and Jonasson, Sven, 1999, Soil and plant $\mathrm{CO}_{2}$ emission in response to variations in soil moisture and temperature and to amendment with nitrogen, phosphorus, and carbon in Northern Scandinavia: Arctic, Antarctic and Alpine Research, v. 31, no. 3, p. 264-271.

Jonasson, Sven, Michelsen, A., Schmidt, I.K., and Nielsen, E.V., 1999, Responses in microbes and plants to changed temperature, nutrient, and light regimes in the arctic: Ecology, v. 80, no. 6, p. 1828-1843.

Kaufmann, P.R., Herlihy, A.T., Mitch, M.E., and Messer, J.J., 1991, Stream chemistry in the Eastern United States 1. Synoptic survey design, acid-base status, and regional patterns: Water Resources Research, v. 27, no. 4, p. 611-627.

Kepner, R.L., Jr., and Stottlemyer, Robert, 1990, Baseline surface water quality, Noatak National Park and Preserve, Alaska: Great Lakes Area Resource Studies Unit Technical Report 42, $38 \mathrm{p}$.

Kirkham, D., and Bartholomew, W.V., 1954, Equations for following nutrient transformations in soil, using tracer data: Soil Science Society of America Proceedings, v. 18, p. 33-34.
Lavoie, Claude, and Payette, Serge, 1994, Recent fluctuations of the lichen-spruce forest limit in subarctic Quebec: Journal of Ecology, v. 82, p. 725-734.

Likens, G.E., and Bormann, F.H., 1995, Biogeochemistry of a forested ecosystem: New York, Springer-Verlag, $159 \mathrm{p}$.

McKane, R.B., Rastetter, E.B., Shaver, G.R., Nadelhoffer, K.J., Giblin, A.E., Laundre, J.A., and Chapin, F.S., III, 1997, Reconstruction and analysis of historical changes in carbon storage in Arctic tundra: Ecology, v. 78, no. 4, p. 1188-1198.

McNamara, J.P., Kane, D.L., and Hinzman, L.D., 1997, Hydrograph separations in an Arctic watershed using mixing model and graphical techniques: Water Resources Research, v. 33, no. 7, p. 1707-1719.

Mitchell, M.J., Driscoll, C.T., Kahl, J.S., Likens, G.E., Murdoch, P.S., and Pardo, L.H., 1996, Climatic control of nitrate loss from forested watersheds in the northeast United States: Environmental Science and Technology, v. 30, no. 8, p. 2609-2612.

Mooney, H.A., Drake, B.G., Luxmoore, R.J., Oechel, W.C., and Pitelka, L.F., 1991, Predicting ecosystem responses to elevated $\mathrm{CO}_{2}$ concentrations: BioScience, v. 41, no. 2, p. 96-104.

Oechel, W.C., Vourlitis, G.L., Hastings, S.J., and Bochkarev, S.A., 1995, Change in arctic $\mathrm{CO}_{2}$ flux over two decades-effects of climate change at Barrow, Alaska: Ecological Applications, v. 5, p. 846-855.

Plafker, George, and Berg, H.C., eds., 1994, The geology of Alaska, v. G-1 of The geology of North America: Boulder, Colo., Geologic Society of America, 1,055 p.

Rice, K.C., and Bricker, O.P., 1995, Seasonal cycles of dissolved constituents in streamwater in two forested catchments in the midAtlantic region of the eastern USA: Journal of Hydrology, v. 170, no. 1-4, p. 137-158.

Rieger, S., Schoephorster, D.B., and Furbush, C.E., 1979, Exploratory soil survey of Alaska: Washington, D.C., U.S. Department of Agriculture, Soil Conservation Service, 208 p.

Rowland, E.L., 1996, The recent history of tree-line at the north-west limit of white spruce in Alaska: Fairbanks, University of Alaska, M.Sc. thesis.

Shaver, G.R.., Billings, W.D., Chapin, F.S. III, Giblin, A.E., Nadelhoffer, K.J., Oechel, W.C., and Rastetter, E.B., 1992, Global change and the carbon balance of Arctic ecosystems: BioScience, v. 42, no. 6, p. 433-441.

Solomon, A.M., and Bartlein, P.J., 1992, Past and future climate change-response by mixed deciduous-coniferous forest ecosystems in northern Michigan: Canadian Journal of Forest Research, v. 22, p. 1727-1738.

Stednick, J.D., 1981, Hydrochemical balance of an alpine watershed in southeast Alaska: Arctic and Alpine Research, v. 13, no. 4, p. 431-438.

Stottlemyer, Robert, 1992, Nitrogen mineralization and streamwater chemistry, Rock Creek Watershed, Denali National Park, Alaska, U.S.A.: Arctic and Alpine Research, v. 24, no. 4, p. 291-303.

Stottlemyer, Robert, and Rutkowski, D., 1987, Baseline stream water chemistry for watersheds of Glacier Bay National Park and Preserve, Alaska: GLARSU Technical Report 22, $118 \mathrm{p}$.

Stottlemyer, Robert, and Toczydlowski, David, 1990, Pattern of solute movement from snow into an Upper Michigan stream: Canadian Journal of Fisheries and Aquatic Sciences, v. 47, no. 2, p. 290-300.

1999, Nitrogen mineralization in a mature boreal forest, Isle Royale, Michigan: Journal of Environmental Quality, v. 28, no. 2, p. 709-720. 
Stottlemyer, Robert, and Troendle, C.A., 1999, Effect of subalpine canopy removal on snowpack, soil solution, and nutrient export, Fraser Experimental Forest, CO: Hydrologic Processes, v. 13, p. 2287-2299.

Stottlemyer, Robert, Troendle, C.A., and Markewitz, Daniel, 1997, Change in snowpack, soil water, and streamwater chemistry with elevation during 1990, Fraser Experimental Forest, Colorado: Journal of Hydrology, v. 195, p. 114-136.
Sturm, M., McFadden, J.P., Liston, G.E., Chapin, F.S., III, Racine, C.H., and Holmgren, Jonathan, 2001, Snow-shrub interactions in Arctic tundra - a hypothesis with climatic implications: Journal of Climate, v. 14, no. 3, p. 336-344.

Suarez, F., Binkley, Dan, Kaye, M.W., and Stottlemyer, Robert, 1999, Expansion of forest stands into tundra in the Noatak National Preserve, Northwest Alaska: Ecoscience, v. 6, no. 3, p. 465-470. 



\title{
Environmental-Geochemical Study of the Slate Creek Antimony Deposit, Kantishna Hills, Denali National Park and Preserve, Alaska
}

\author{
ByRobert G. Eppinger, Paul H. Briggs, James G. Crock, Allen L. Meier, Stephen J. Sutley, and Peter M. Theodorakos
}

\section{Abstract}

We undertook a reconnaissance environmental-geochemical investigation in 1998 at the Slate Creek antimony deposit in Denali National Park and Preserve, Alaska. This cooperative study between the U.S. Geological Survey and the National Park Service focused on identifying and characterizing environmental geochemical signatures associated with this historical mining area. The deposit, which is hosted by quartzite, quartz-mica schist, marble, and greenstone, is a locally brecciated fissure quartz vein system containing stibnite and lesser pyrite, stibiconite, kermesite, boulangerite, cervantite, and arsenopyrite. About $800,000 \mathrm{lb}(362,400 \mathrm{~kg})$ of $\mathrm{Sb}$ was produced from 1905 through 1983.

Samples collected include water, stream-sediment, rock, and soil samples from 13 sites upstream of, downstream from, and at the mineralized area. Stream-water samples collected outside the disturbed mining area were bicarbonate dominant and had near-neutral $\mathrm{pH}$ values, conductivities ranging from 130 to $300 \mu \mathrm{S} / \mathrm{cm}$, alkalinities ranging from 60 to $130 \mathrm{mg} / \mathrm{L}$, and total-dissolved-solids (TDS) contents of as much as $316 \mathrm{mg} / \mathrm{L}$. Two samples of naturally mineralized spring water collected outside the disturbed mining area had $\mathrm{pH}$ values of 5.6 and 7.7, conductivities of 300 and 750 $\mu \mathrm{S} / \mathrm{cm}$, alkalinities of 57 and $180 \mathrm{mg} / \mathrm{L}$, and TDS contents of 230 and $544 \mathrm{mg} / \mathrm{L}$. One of the springs was sulfate dominant, and the other mixed sulfate-bicarbonate dominant. Surface waters draining the minesite proper were sulfate dominant and had $\mathrm{pH}$ values ranging from 2.7 to 5.8 , conductivities ranging from 770 to $1,700 \mu \mathrm{S} / \mathrm{cm}$, alkalinities ranging from 0 to $110 \mathrm{mg} / \mathrm{L}$, and TDS contents ranging from 671 to $993 \mathrm{mg} /$ L. Stream waters from Slate Creek below the mine and mineralized area were mixed sulfate-bicarbonate dominant and had near-neutral $\mathrm{pH}$ values, conductivities ranging from 260 to $280 \mu \mathrm{S} / \mathrm{cm}$, alkalinities ranging from 63 to $78 \mathrm{mg} / \mathrm{L}$, and TDS contents of less than $250 \mathrm{mg} / \mathrm{L}$. Metallic-ion concentrations in stream waters all steadily decreased with distance from the deposit. Parameters measured in waters draining the minesite that exceeded established Alaska drinking-water standards include $\mathrm{pH}$ value and $\mathrm{SO}_{4}^{2-}, \mathrm{As}, \mathrm{Fe}, \mathrm{Mn}, \mathrm{Ni}, \mathrm{Sb}$, and
TDS contents. Waters in Slate Creek immediately below the mine exceed drinking-water standards for $\mathrm{As}, \mathrm{Fe}, \mathrm{Mn}$, and $\mathrm{Sb}$ contents. At the mouth of Slate Creek, about $1.8 \mathrm{mi}(2.9$ $\mathrm{km}$ ) downstream from the mine, only $\mathrm{Mn}$ and $\mathrm{Sb}$ contents exceed drinking-water standards. Interestingly, stream- and spring-water samples collected from areas unaffected by the minesite also exceed drinking-water standards for $\mathrm{pH}$ value and $\mathrm{SO}_{4}^{2-}, \mathrm{As}, \mathrm{Fe}, \mathrm{Mn}, \mathrm{Sb}$, and TDS contents. Aquatic-life standards are exceeded only by minesite waters for $\mathrm{As}, \mathrm{Cd}$, $\mathrm{Cu}, \mathrm{Ni}$, and $\mathrm{Zn}$ contents.

Elements measured in highly anomalous concentrations in stream-sediment, rock, and soil samples collected outside the minesite include As, Mn, and Sb. Mine waste and mineralized outcrops at the minesite have highly anomalous $\mathrm{As}$ and $\mathrm{Sb}$ contents. Stream-sediment samples downstream from the mineralized area have highly anomalous $\mathrm{As}, \mathrm{Mn}$, and Sb contents.

The low $\mathrm{pH}$ value and predominance of sulfate in mine-related waters are due largely to the dissolution of pyrite. Stream waters downstream from the minesite have major-anion compositions that reflect mixing of bicarbonatedominant, near-neutral $\mathrm{pH}$ waters with mineralized, acidic, sulfate-dominant waters. Metallic ions abundant in the minerelated waters are quickly coprecipitated with $\mathrm{Fe}$ oxide flocs upon mixing with bicarbonate waters, resulting in heavily $\mathrm{Fe}$ oxide-stained alluvium downstream from the deposit. Ionic species in high concentrations that remain mobile at higher $\mathrm{pH}$ values, such as $\mathrm{Mn}, \mathrm{Sb}, \mathrm{SO}_{4}^{2-}$, and $\mathrm{Zn}$, remain in solution downstream.

The presence of natural springs within the mineralized area but outside the disturbed mining area suggests premining spring waters that naturally ranged from acidic to neutral in $\mathrm{pH}$ value, had relatively high conductivities and varyingly high TDS contents, were Fe rich, and were metalliferous. Redstained alluvial gravel along Slate Creek, natural Fe oxide-rich springs near the head of the Slate Creek basin, and ferricrete deposits probably were present before, and aided prospectors in, the discovery of the Slate Creek antimony deposit. However, the naturally degraded waters that were likely present, as well as the extent of iron staining along Slate Creek, have certainly both been worsened by historical mining activities. 


\section{Introduction}

We undertook a reconnaissance environmental-geochemical investigation in the Slate Creek drainage of Denali National Park and Preserve in 1998. Surface-water, bedload-stream-sediment, rock, and mine-waste samples were collected from the Slate Creek antimony deposit near the head of the drainage and at intervals downstream along Slate Creek to its confluence with Eldorado Creek, about $1.8 \mathrm{mi}(2.9 \mathrm{~km})$ downstream. Historically, the Slate Creek antimony deposit has also been referred to as the "Antimony" or "Taylor mine" (Capps, 1918; Cobb, 1972; Dames \& Moore, 1992). The purpose of this cooperative study with the National Park Service (NPS) was to characterize the geochemistry of the mineralized area, to identify potential environmental-geochemical hazards, and to determine baseline levels for selected elements. The focus of this report is on the hydrogeochemical media, the principal avenue for movement of metals from rocks and sediment into the aquatic biota.
The fieldwork was conducted over a 1-week period from August 9 to 15, 1998. Summer 1998 was an unusually wet period, with numerous rainstorms occurring throughout park during the season (Ken Karle, oral commun., 1998). As a result, springs issued from numerous points in and around the Slate Creek antimony deposit, and surface flow was observed in all intermittent drainages.

The Slate Creek antimony deposit is located in the northwestern part of Denali National Park and Preserve, about $5 \mathrm{mi}(8 \mathrm{~km})$ southwest of Kantishna and about 6 mi (10 km) due west of Wonder Lake (fig. 1). Low, rolling, heavily vegetated hills typify the topography of the Kantishna Hills in the vicinity of the Slate Creek antimony deposit (fig. 2A). Elevations range from about 2,100 ft (640 $\mathrm{m})$, at the confluence of Slate and Eldorado Creeks, to 3,774 $\mathrm{ft}(1,150 \mathrm{~m})$, on Brooker Mountain immediately north of the deposit. Access to the area is by foot along an old tractor trail from Kantishna.

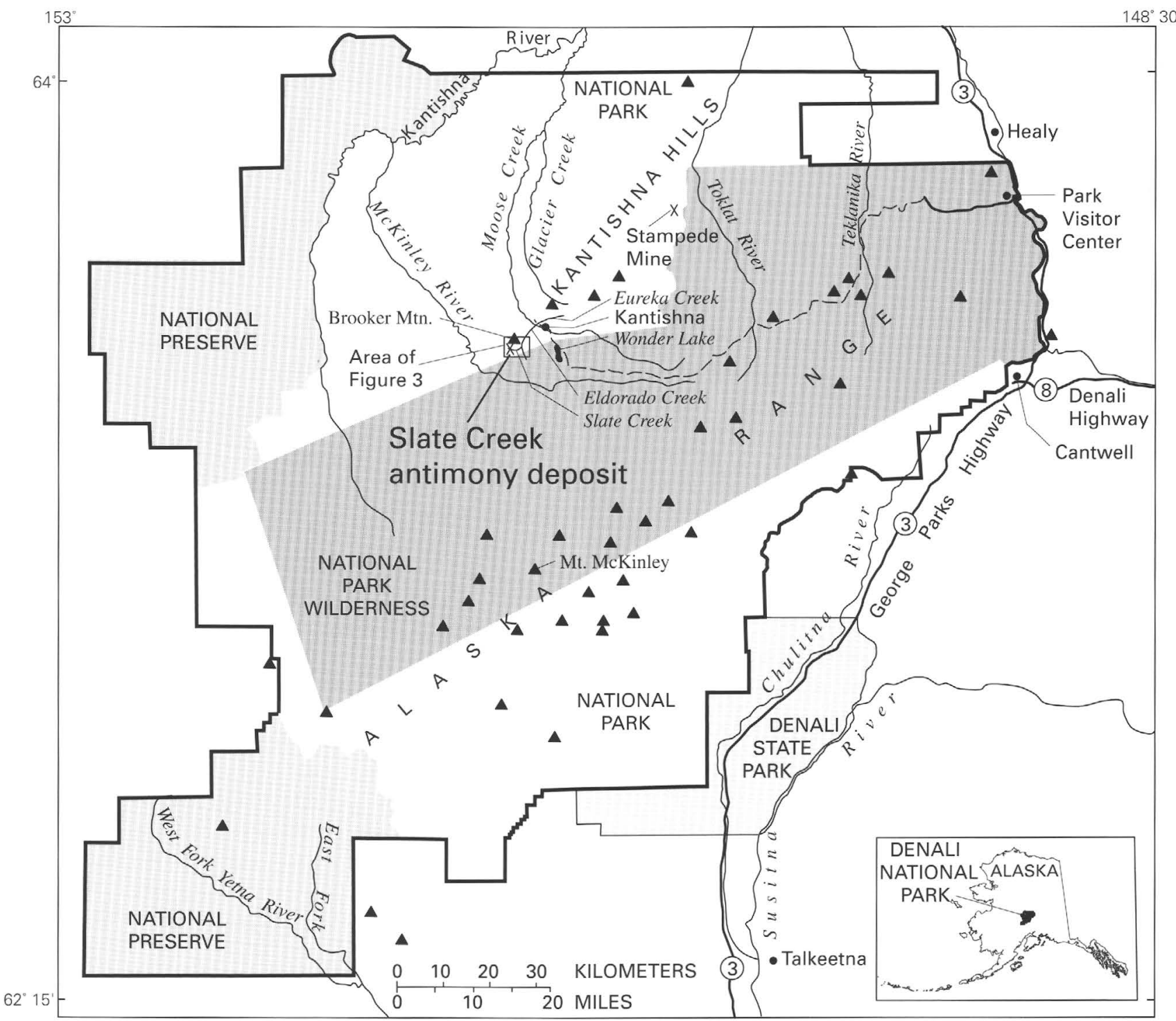

Figure 1. Denali National Park and Preserve, south-central Alaska, showing location of the Slate Creek antimony deposit 
In 1997, the NPS recontoured slopes at the Slate Creek antimony deposit, filling in pits and open cuts with mine waste. Just before this study in 1998, the NPS installed rubber dams within the recontoured fill to confine and redirect ground-water flow to a plastic drainpipe (fig. $2 B$ ). Ground water from the drainpipe was intended to flow into a buried anoxic carbonate-filtration mechanism to neutralize the acidic water. At the time of this study, the carbonate-filtration mechanism was under construction, and the drainpipe was not yet connected to it (Ken Karle, oral commun., 1998). Thus, the water samples collected at the minesite for this study were pretreatment samples.

\section{Geologic Setting}

The earliest geologic and mineral-deposit descriptions of the Kantishna region date from during and immediately after the early 1900s' Gold Rush to interior Alaska (Prindle, 1907; Brooks and others, 1909, p. 56; 1910, p. 44; 1912, p. 38; 1913, p. 45; 1914, p. 68; Brooks, 1916). More extensive studies of the region were conducted by Capps (1918), Davis (1922), Moffit (1933), and Ebbley and Wright (1948). The most extensive recent studies of the geology and mineral deposits of the Kantishna Hills area were by Bundtzen (1978, 1981, 1983, 1994) and Bundtzen and Turner (1978). Mineral-resource reports by the U.S. Bureau of Mines include those by Hawley (1978), Jeske (1984), Fechner and Hoekzema (1986), and White and others (1986).

Basement rocks in the Kantishna Hills area are regionally metamorphosed, range in age from Precambrian to late Paleozoic, and consist of four principal rock units. The oldest and most aerially extensive rocks are Precambrian metamorphic rocks, composed of quartzite, quartz-mica schist, feldsparbiotite schist, gneiss, marble, and greenstone (called the Birch Creek Schist by Bundtzen, 1981). The unit consists of a shallow-water continental-shelf sequence that was metamorphosed to amphibolite facies and later retrograded to greenschist facies (Bundtzen, 1981). The remaining three principal rock units, the Spruce Creek sequence, the Keevy Peak Formation, and the Totatlanika Schist, are regionally metamorphosed to a lower grade than, and tectonically juxtaposed against, the Precambrian metamorphic rocks (Bundtzen, 1981).

Metamorphosed volcanic and sedimentary rocks of the early Paleozoic(?) Spruce Creek sequence (Bundtzen, 1981) consist of chlorite and graphitic schist, marble, and metavolcanic rocks. This sequence, which may represent an early Paleozoic rift environment formed on the Birch Creek shelf deposits (Bundtzen, 1983), is correlated with the Cleary sequence in the Fairbanks district (Bundtzen, 1994). Metasedimentary and metavolcanic rocks of the Keevy Peak Formation (early Paleozoic) and Totatlanika Schist (Late Devonian and Mississippian) are the youngest crystalline rocks in the Kantishna Hills area (Bundtzen, 1981). These deep-water marine and submarine-fan units apparently interfinger locally (Bundtzen, 1983).
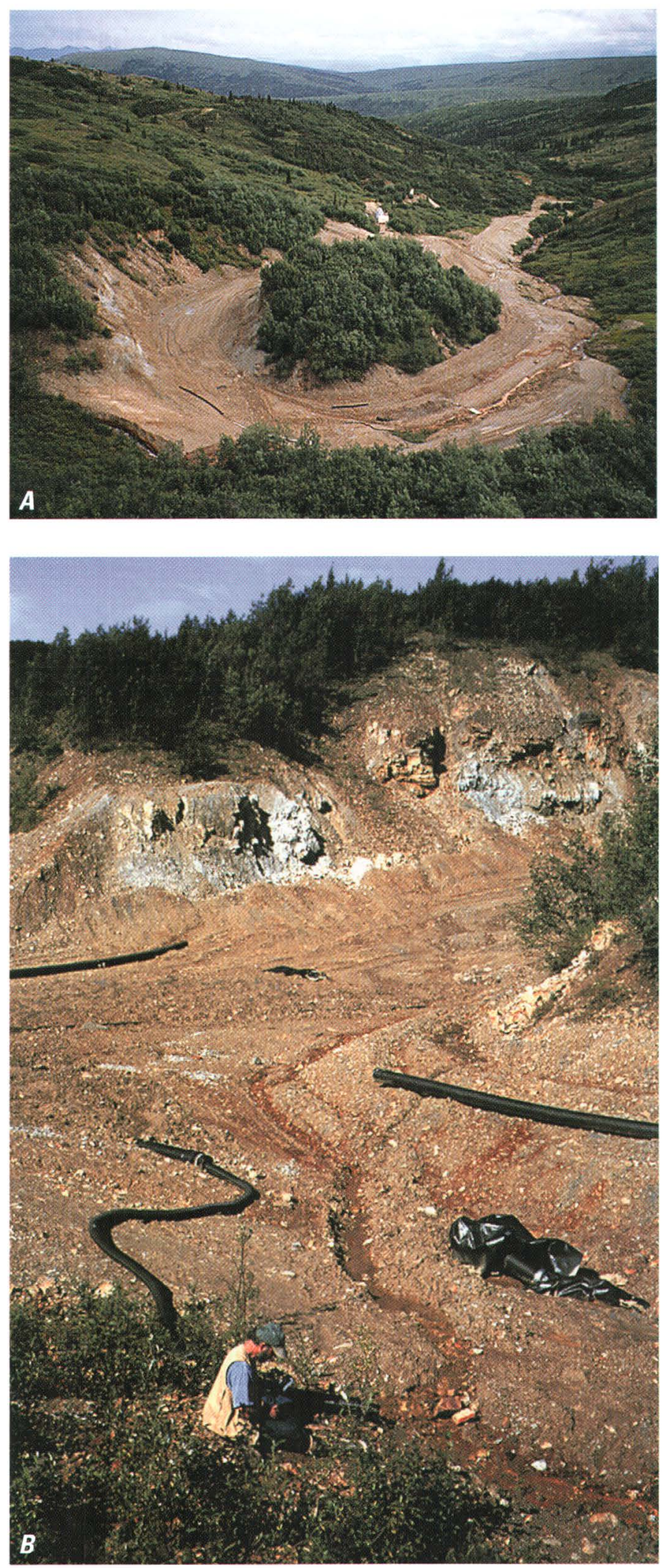

Figure 2. Setting of the Slate Creek antimony deposit (fig. 1) in August 1998. A, Overview of minesite, showing mine drainage at lower right. Slate Creek flows along right side of disturbed area. Tents in center indicate scale. $B$, Site $98 \mathrm{SCO} 10$ (pH value, 2.7; conductivity, $1,700 \mu \mathrm{S} / \mathrm{cm}$; total-dissolved-solids content, $993 \mathrm{mg} / \mathrm{L}$ ), showing details of minesite, mineralized outcrop, recontoured mine waste, and plastic pipe draining impounded groundwater. 
The Kantishna region has been uplifted with the Alaska Range since the middle Tertiary. Undeformed Tertiary mafic to felsic dike swarms and plugs intrude the metamorphic rocks along the crest of the Kantishna Anticline, a major fold structure in the region. Isoclinal to open folds and faults are common. Miocene sandstone and shale, and Quaternary gravel overlie older rock types (Bundtzen, 1981).

As mapped by Bundtzen (1981), the Slate Creek antimony deposit is hosted by undifferentiated medium- to coarsegrained Precambrian garnetiferous quartz-mica schist, massive to laminated quartzite, and feldspar-biotite schist and gneiss. A large plug of Tertiary light-gray porphyritic felsite is mapped about $2.5 \mathrm{mi}(4 \mathrm{~km})$ northeast of the mine along Eldorado Creek. No carbonate-bearing units are mapped in the vicinity of the Slate Creek antimony deposit, nor were carbonate minerals observed in the present study.

\section{Mineral Deposits}

Mineral deposits in the Kantishna region consist of polymetallic vein deposits, tactite and stratiform occurrences, and placer gold deposits. The vein deposits follow faults and fractures along a semicontinuous, northeast-trending zone extending from Slate Creek to Stampede, about $27 \mathrm{mi}$ $(45 \mathrm{~km})$ to the northeast (fig. 1) (Bundtzen, 1981). The vein faults strike N. $30^{\circ}-70^{\circ} \mathrm{E}$. and dip steeply generally southeast but locally northwest. Larger lode deposits occur where the northwestern and southeastern veins intersect. The veins are classified into three types: (1) quartz-arsenopyrite-pyritescheelite-gold, (2) galena-sphalerite-tetrahedrite-pyrite-chalcopyrite with siderite gangue, and (3) stibnite-quartz veins free of other sulfides. Locally, a continuum exists from one type to another (Bundtzen, 1981). Following Lingren (1932), the veins are categorized by depth of formation by Bundtzen (1981) as follows: type 1 veins are hypothermal to mesothermal, type 2 veins are mesothermal to epithermal, and type 3 veins are epithermal. The Spruce Creek sequence, which hosts most of the polymetallic vein deposits, is believed to be a principal metal source for vein deposits in the Kantishna mining district (Bundtzen, 1981). However, the type 3 stibnite-quartz veins are more commonly hosted by Precambrian metamorphic rocks (Bundtzen, 1981).

The Slate Creek antimony deposit is a type 3 epithermal stibnite-quartz(-pyrite) vein deposit, generally lacking other sulfides, that is hosted by Precambrian metamorphic rocks (Bundtzen, 1981). As described by Capps (1918), the deposit is a fissure vein that trends N. $50^{\circ} \mathrm{E}$. and dips $82^{\circ} \mathrm{SE}$. The vein ranges in thickness from about 2 to $15 \mathrm{ft}(0.5-4.6 \mathrm{~m})$ and is composed of a "broken and confused" stockwork of quartz and stibnite in decomposed clay-rich schist (Capps, 1918, p. $325)$. Red secondary oxidation products include the antimony ochers stibiconite $\left[\mathrm{Sb}^{3+} \mathrm{Sb}_{2}^{5+} \mathrm{O}_{6}(\mathrm{OH})\right]$ and kermesite $\left(\mathrm{Sb}_{2} \mathrm{~S}_{2} \mathrm{O}\right)$ (Capps, 1918). Bundtzen (1981) noted massive stibnite $\left(\mathrm{Sb}_{2} \mathrm{~S}_{3}\right)$ and quartz, with minor pyrite, boulangerite $\left(\mathrm{Pb}_{5} \mathrm{Sb}_{4} \mathrm{~S}_{11}\right)$, cervantite $\left(\mathrm{Sb}^{3+} \mathrm{Sb}^{5+} \mathrm{O}_{4}\right)$, and arsenopyrite (FeAsS). In this study, stibnite, pyrite, and their alteration products were observed on mine wastepiles, and stibnite-pyrite-quartz cobbles were observed in alluvium downstream. The Slate Creek antimony deposit appears to share most descriptive characteristics with the "simple antimony deposit" model of Bliss and Orris (1986) and, to a lesser degree, with the "stibnite-quartz deposit" model of Seal and others (1995).

\section{Mining History}

Bundtzen (1978) reported that Judge James Wickersham first discovered placer gold in the northern Kantishna Hills in 1903 while on his way to an unsuccessful climb of Mount McKinley. Other placer gold discoveries followed shortly - in 1904 by Joe Dalton in the central Kantishna Hills, and in 1905 by Joe Dalton and Joe Quigley on Eureka and Glacier Creeks. A brief, but short-lived, placer gold rush ensued. Sulfide cobbles in sluicebox riffles prompted the search for and discovery of lode deposits.

By 1919 , numerous mineralized vein faults containing antimony and base and precious metals were located in a 27 mi (45 km)-long belt trending northeast from Slate Creek to Stampede (Bundtzen, 1981, 1994). Discoveries on upper Slate Creek resulted in the Antimony Nos. 1 through 4 lode and the Antimony Nos. 1 and 2 placer claims (Dames \& Moore, 1992). Antimony was sporadically recovered from the Slate Creek antimony deposit, as well as other deposits in the belt, generally during World Wars I and II, the Korean War, and the Vietnam War, because of high antimony prices during these times (Bundtzen, 1983; Dames \& Moore, 1992). In 1915-16, a $97-\mathrm{ft}(29.6 \mathrm{~m})$-long tunnel and associated crosscuts were driven near the level of Slate Creek into a wide mineralized shear zone. Drifts were also driven during the early 1940s (Capps, 1918; Ebbley and Wright, 1948). Sporadic surface mining (pits and open cuts) and placering continued on upper Slate Creek from the 1940s until 1983, when mining activities ceased (Bundtzen, 1983; Dames \& Moore, 1992). Although records are unclear, the Slate Creek antimony deposit produced about $800,000 \mathrm{lb}(362,400 \mathrm{~kg})$ of antimony, principally by hand-sorting stibnite (Jeske, 1984). Unknown amounts of gold and, probably, antimony were produced by placer operations along Slate Creek downstream from the lode deposits (Dames \& Moore, 1992). About 40 percent of the antimony produced in Alaska through 1983 came from the Kantishna mineral belt, principally from the Slate Creek and Stampede deposits (Bundtzen, 1983).

\section{Methods}

Water, stream-sediment, rock, and soil samples were collected (1) within the disturbed mining area, (2) within the undisturbed mineralized zone surrounding the mining area, and (3) from areas beyond the mineralized zone. Surface water 
was collected at 13 sites from small streams, springs, and from a standing prospect pit pool (fig. 3).

Bedload-stream-sediment samples were collected at seven of the stream-water sample sites-six along Slate Creek and its tributaries and one from Eldorado Creek just above its confluence with Slate Creek. Naturally occurring and mine-related mineralized rocks were collected from eight sites, representing mine waste, outcrop, and colluvium. Two soil samples were collected from vegetated tundra that appeared to be undisturbed by historical mining activity, above the naturally mineralized spring at site $98 \mathrm{SC} 011$ (fig. 3) and above the prospect pit at site 98SC012. Elements determined, methods used, and details on sample collection and preparation are listed in table 1 ; site-specific information for the samples collected is listed in table 2.

Stream-water samples collected at each site include (1) an unacidified, filtered water sample for anion analysis; (2) an acidified, filtered sample for trace- and major-cation analysis of dissolved species; and (3) a preserved, filtered sample for mercury content. Before analysis, the unacidified samples were kept on ice in a cooler while in the field, and in a laboratory refrigerator upon return. Samples were filtered $(0.45 \mu \mathrm{m})$ and acidified to a $\mathrm{pH}$ value of $<2$ to prevent precipitation of metals and bacterial growth (table 1). Other water data col- lected and recorded on site include temperature, an estimate of the waterflow rate, $\mathrm{pH}$ value, conductivity (a measure of electrical conductance: the more ions a solution contains, the higher its conductivity), qualitative turbidity, dissolved-oxygen content, total acidity (a measure of water's base-consuming capacity; done on samples with $\mathrm{pH}$ values $<5$ ), and total alkalinity (a measure of water's acid-consuming capacity; done on samples with $\mathrm{pH}$ values $>4.5$ ). These data are listed in table 3 , along with sample site descriptive information. Instruments used include Orion $\mathrm{pH}$ (model 250A) and conductivity (model 115) meters, calibrated at each site. Also used on site were CHEMetrics kits for alkalinity (titration) and dissolved oxygen (visual comparison), and a Hach acidity kit (titration). The waterflow rate was either determined by a qualitative visual estimate or calculated by timing the fill of a 1-L-volume bottle (table 3).

Many chemical elements were determined by using various analytical techniques (table 1). For descriptions and quality-assurance/quality-control (QA/QC) protocols for most of the analytical methods used, see Arbogast (1996). During the study, QA/QC concerns were addressed by using internal reference standards, field blanks, sample-site duplicates, and analytical duplicates. Reference standards were interspersed with batches of samples, and the analyses of the standards

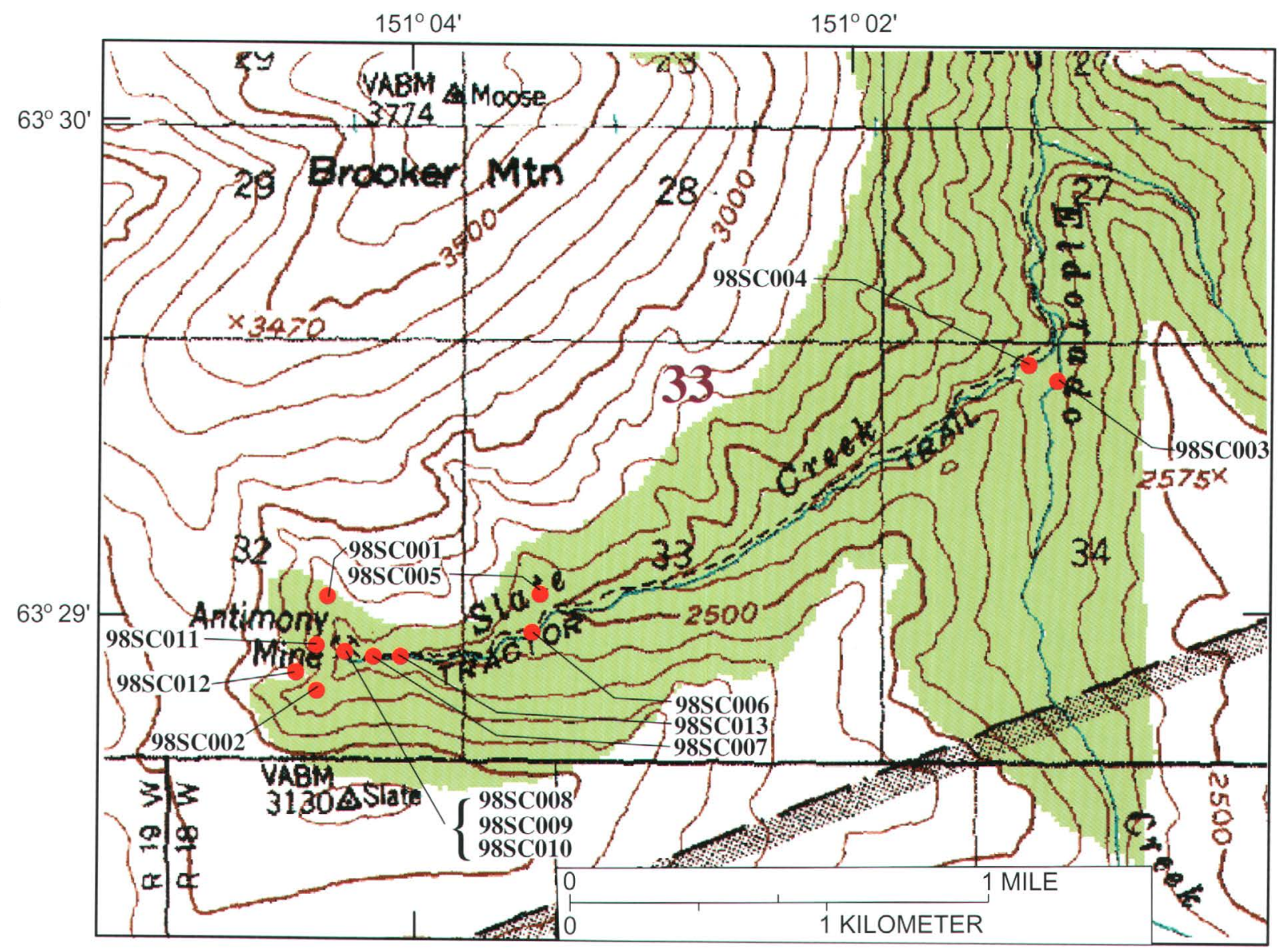

Figure 3. Slate Creek antimony deposit (fig. 1), showing locations of sites where samples were collected. Topography from U.S. Geological Survey Mount McKinley B-3, B-4, C-3, and C-4 1:63,360-scale topographic maps. 
Table 1. Elements determined, analytical methods, and collection/preparation procedures used.

[Water samples were filtered at $0.45 \mu \mathrm{m}$ with disposable filters, collected in acid-rinsed polypropylene bottles, and acidified with ultrapure $\mathrm{HNO}_{3}$. Water samples for $\mathrm{Hg}$ analysis were filtered as above, collected in acid-rinsed glass bottles with Teflon lids, and preserved with $\mathrm{K}_{2} \mathrm{Cr}_{2} \mathrm{O}_{7} / \mathrm{HNO}_{3}$. Stream sediments were composited $1-\mathrm{kg}$ samples from active alluvium. In the laboratory, samples were air dried, sieved to minus -80 mesh $(<0.177 \mathrm{~mm})$, and pulverized for chemical analysis. Clean quartz sand was pulverized between samples to reduce risk of contamination. Composited rock-chip samples were coarsely crushed to pea-size pieces, split with a Jones splitter, and pulverized as described for sediments. Soil samples were collected from single pits dug in undisturbed B-horizon tundra. Laboratory preparation of the soils followed the same procedures as those used for the sediment samples. Methods: AF, atomic fluorescence; CV, cold-vapor atomic absorption; EP, solid by partial-extraction 10-element inductively coupled plasma atomic-emission spectrometry; ET, solid by total-extraction 40 -element inductively coupled plasma atomic-emission spectrometry; EW, water by inductively coupled plasma atomic-emission spectrometry; FA, fire-assay atomic absorption; $\mathrm{HY}$, hydride-generation atomic absorption; IC, ion chromatography; $\mathrm{MW}$, water by inductively coupled plasma mass spectrometry; TS, Leco automated total sulfur analyzer. See Arbogast (1996) for operational details]
Sample media
Method
Elements determined

Water,

filtered/acidified

MW

EW $\mathrm{Ag}, \mathrm{Al}, \mathrm{As}, \mathrm{B}, \mathrm{Ba}, \mathrm{Be}, \mathrm{Ca}, \mathrm{Cd}, \mathrm{Co}, \mathrm{Cr}, \mathrm{Cu}, \mathrm{Fe}, \mathrm{K}, \mathrm{Li}, \mathrm{Mg}, \mathrm{Mn}$,

AF $\quad \mathrm{Hg}$

Water, filtered/not IC acidified

Sediment, rocks, and soils
IC $\quad \mathrm{Cl}^{-}, \mathrm{F}^{-}, \mathrm{NO}_{3}^{-}, \mathrm{SO}_{4}^{2-}$

ET

$\mathrm{Ag}, \mathrm{Al}, \mathrm{As}, \mathrm{Au}, \mathrm{Ba}, \mathrm{Be}, \mathrm{Bi}, \mathrm{Ca}, \mathrm{Cd}, \mathrm{Ce}, \mathrm{Co}, \mathrm{Cr}, \mathrm{Cu}, \mathrm{Eu}, \mathrm{Fe}, \mathrm{Ga}$, $\mathrm{Ho}, \mathrm{K}, \mathrm{La}, \mathrm{Li}, \mathrm{Mg}, \mathrm{Mn}, \mathrm{Mo}, \mathrm{Na}, \mathrm{Nb}, \mathrm{Nd}, \mathrm{Ni}, \mathrm{P}, \mathrm{Pb}, \mathrm{Sc}, \mathrm{Sn}, \mathrm{Sr}$,

Ta, Th, Ti, U, V, Y, Yb, Zn

EP Ag, As, $\mathrm{Au}, \mathrm{Bi}, \mathrm{Cd}, \mathrm{Cu}, \mathrm{Mo}, \mathrm{Pb}, \mathrm{Sb}, \mathrm{Zn}$

HY As, Sb, Se, Te, Tl

FA $\mathrm{Au}$

$\mathrm{CV} \quad \mathrm{Hg}$

TS total S were checked to assure that reported values were within \pm 20 percent of the accepted values. Sample-site duplicates were collected for waters and sediment at one site (sites 98SC007, 98SC007D, fig. 3), and qualitative inspection of the data tables indicates good agreement in analyses between the duplicates. This result suggests minimal combined sample-site and analytical variance.

In discussing water chemistry, we emphasize the following significant inorganic parameters listed in the Alaska Department of Environmental Conservation (ADEC)'s drinking-water standards (Alaska Department of Environmental Conservation, 2000) and by the U.S. Environmental Protection Agency (EPA) (Environmental Protection Agency, 1999a): $\mathrm{pH}$ value and $\mathrm{Ag}, \mathrm{Al}, \mathrm{As}, \mathrm{Ba}, \mathrm{Be}, \mathrm{Cd}, \mathrm{Cl}^{-}, \mathrm{Cr}, \mathrm{Cu}, \mathrm{F}^{-}, \mathrm{Fe}, \mathrm{Hg}, \mathrm{Mn}$, $\mathrm{Na}, \mathrm{Ni}, \mathrm{NO}_{3}^{-}, \mathrm{Pb}, \mathrm{Se}, \mathrm{SO}_{4}^{2-}, \mathrm{Tl}$, and $\mathrm{Zn}$ contents. Primary maximum contaminant levels (MCLs) are regulatory water-quality action levels established by the ADEC, whereas secondary MCLs are nonregulated, recommended water-quality goals. We also emphasize the following toxic pollutants listed by the EPA (Environmental Protection Agency, 1993) with respect to freshwater aquatic-life standards: $\mathrm{Ag}, \mathrm{Cd}, \mathrm{Cr}(\mathrm{III}), \mathrm{Cu}, \mathrm{Pb}, \mathrm{Ni}$, and $\mathrm{Zn}$ contents.
The water classifications used herein, based on relative amounts of major cations and anions, follow those of Piper (1944), Hem (1985), and Drever (1997, app. 1, fig. 2). For water samples where carbonate $\left(\mathrm{CO}_{3}^{2-}\right)$ and bicarbonate $\left(\mathrm{HCO}_{3}^{-}\right)$are present, bicarbonate is overwhelmingly dominant; thus, the term "bicarbonate" is used exclusively when discussing these species. Carbonate and bicarbonate concentrations were determined from measured $\mathrm{pH}$ and total alkalinity, using the equations of Deutsch (1997, p. 13-14), which assume that carbonate alkalinity is about equal to total alkalinity, a reasonable assumption for most natural waters (Hem, 1985, p. 106; Drever, 1997, p. 46).

The subjective term "anomalous" is used in a relative sense with respect to the average crustal abundances listed by Smith and Huyck (1999, table 2.8), to the background data on various rock types and sample media provided by Rose and others (1979) and Levinson (1980), and to the examination of data distributions for the samples collected in this study. The term "highly anomalous" indicates concentrations two or more orders of magnitude above the threshold values, whereas "lower-level anomalous" concentrations are higher than, but within an order of magnitude of, the threshold values. 
Table 2. Site-descriptive information for samples collected from the Slate Creek antimony deposit.

[Latitude and longitude determined with high-precision Global Positioning System (GPS) unit; datum and spheroid used were NAD27AK and Clarke 1866, respectively. XY error, GPS latitude/longitude location error. $\mathrm{Fe} 0 \mathrm{x}$, iron oxides; $\mathrm{MnOx}$, manganese oxides; NPS, National Park Service. Do., ditto]

\begin{tabular}{|c|c|c|c|c|c|c|}
\hline $\begin{array}{l}\text { Site } \\
\text { (fig. 3) }\end{array}$ & $\begin{array}{l}\text { Latitude } \\
{ }^{\circ} \mathrm{N} .\end{array}$ & $\begin{array}{l}\text { Longitude } \\
{ }^{\circ} \mathrm{W} .\end{array}$ & $\begin{array}{l}X Y \text { error } \\
( \pm f t)\end{array}$ & $\begin{array}{l}\text { Elevation } \\
\quad(\mathrm{ft})\end{array}$ & $\begin{array}{c}\text { Date } \\
\text { collected }\end{array}$ & Location information \\
\hline \multicolumn{7}{|c|}{ Naturally mineralized } \\
\hline 98SC001 & 63.48269 & 151.07249 & 45 & 2720 & $8 / 11 / 1998$ & NW fork, head of Slate Creek; below junction of two small streams. \\
\hline $98 \mathrm{SC} 002$ & 63.48036 & 151.07497 & 26 & 2760 & $8 / 11 / 1998$ & SW fork, head of Slate Creek; below junction of two small streams. \\
\hline 98SC011 & 63.48187 & 151.07275 & 27 & 2770 & $8 / 14 / 1998$ & $\begin{array}{l}\text { About } 150 \mathrm{ft} \mathrm{W} \text {. of Slate Creek antimony deposit; topographic depression above } \\
\text { ferricrete bank along Slate Creek; located along old roadcut to nearby prospect pit } \\
\text { to south. }\end{array}$ \\
\hline $98 \mathrm{SC} 013$ & 63.48166 & 151.06240 & 26 & 2610 & $8 / 14 / 1998$ & $\begin{array}{l}\text { Spring along S side of Slate Creek about } 1,800 \mathrm{ft} \text { below waste piles; appears to be } \\
\text { unaffected by mining. }\end{array}$ \\
\hline \multicolumn{7}{|r|}{ Mine } \\
\hline 98SC008 & 63.48216 & 151.07153 & 30 & 2710 & $8 / 13 / 1998$ & $\begin{array}{l}\text { Hand-dug trench; upper end of rubber barrier in mine waste; trench/dam recently } \\
\text { installed by NPS for remediation work; site is within recently recontoured mine } \\
\text { waste. }\end{array}$ \\
\hline 98SC009 & 63.48172 & 151.07089 & 22 & 2670 & $8 / 13 / 1998$ & $\begin{array}{l}\text { Mine drainage at Slate Creek antimony deposit; on mine waste; site is within recently } \\
\text { recontoured mine waste. }\end{array}$ \\
\hline $98 \mathrm{SC} 010$ & 63.48178 & 151.07172 & 21 & 2690 & 8/13/1998 & $\begin{array}{l}\text { Inlet to carbonate-filtration mechanism recently installed by NPS on mine wastepile; } \\
\text { site is within recently recontoured mine waste. }\end{array}$ \\
\hline 98SC012 & 63.48149 & 151.07357 & 34 & 2810 & $8 / 14 / 1998$ & Hillside about $300 \mathrm{ft}$ southwest of Slate Creek antimony deposit reclamation site. \\
\hline
\end{tabular}

\section{Downstream from and influenced by mine}

\begin{tabular}{|c|c|c|c|c|c|c|}
\hline 98SC004 & 63.49183 & 151.02053 & 28 & 2160 & $8 / 12 / 1998$ & $\begin{array}{l}\text { Mouth of Slate Creek upstream of junction with Eldorado Creek. } \\
\text { Slate Creek, about } 100 \mathrm{ft} \text { upstream from side drainage at site } 98 \mathrm{SC} 005 \text { (fig. 3), about }\end{array}$ \\
\hline 98SC006 & 63.48331 & 151.05628 & 32 & 2520 & $8 / 12 / 1998$ & $\begin{array}{l}0.5 \mathrm{mi} \text { downstream from Slate Creek antimony deposit. } \\
\text { Slate Creek just downstream from mine wastepiles, about } 100 \mathrm{ft} \text { below small stream }\end{array}$ \\
\hline 98SC007 & 63.48165 & 151.06550 & 32 & 2630 & $8 / 13 / 1998$ & flowing behind camp. \\
\hline 98SC007D & 63.48165 & 151.06550 & 32 & 2630 & $8 / 13 / 1998$ & Duplicate of site $98 \mathrm{SC} 007$. \\
\hline
\end{tabular}

\section{Distal from mine and mineralized area}

\begin{tabular}{|c|c|c|c|c|c|c|}
\hline 98SC003 & 63.49155 & 151.01726 & 27 & 2150 & $8 / 12 / 1998$ & Eldorado Creek, about $500 \mathrm{ft}$ above confluence with Slate Creek. \\
\hline 98SC005 & 63.48345 & 151.05612 & 29 & 2530 & $8 / 12 / 1998$ & $\begin{array}{l}\text { Unnamed tributary to Slate Creek entering from the north about } 0.5 \text { mi downstream } \\
\text { from Slate Creek deposit. }\end{array}$ \\
\hline
\end{tabular}


Table 2. Site-descriptive information for samples collected from the Slate Creek antimony deposit-Continued.

Site (fig. 3) Site description Bedrock geologic information

98SC001 Flowing stream; undisturbed site upstream of mine workings in heavy alder and willow cover; moderate gradient, swift; site is probably representative of premining conditions at the Slate Creek antimony deposit; no visible contamination.

98SC002 Flowing stream; undisturbed site upstream of mine workings; approximately on NE. strike of the mineralized vein system; site is probably representative of premining conditions at the Slate Creek antimony deposit; no visible contamination.

98SC011 Naturally mineralized spring; abundant FeOx precipitating on leaves, twigs, and other organic debris; site is probably representative of premining conditions at the Slate Creek antimony deposit; no visible contamination.

98SC013 Naturally mineralized spring; site is probably representative of premining conditions at the Slate Creek antimony deposit; no visible contamination.

98SC008 Flowing seep at minesite; trench with ponded spring water.

98SC009 Flowing mine drainage; within the last month, fine carbonate was scattered over the mine wastepiles and is evident locally in sediment in the mine drainage.

98SC010 Mine drainage; ground water flowing from black plastic pipe coming up from below ground; this pipe will be attached to the buried carbonate filter downgradient from this spot.

98SC012 Standing pool of spring/rain water in prospect pit; no visible contamination.

98SC004 Flowing stream; swift, about $12 \mathrm{ft}$ wide, 6-10 in. deep; downstream of mine and mineralized area.

98SC006 Flowing stream; orange-stained alluvium common from here upstream; about 10-15 ft wide, 4-6 in. deep, swift; downstream of mine and mineralized area.

98SC007 Flowing stream below mine; orange-stained, no vegetation or algae in active channel; about $12 \mathrm{ft}$ wide, 4-6 in. deep; steel cable, milled wood in channel.

98SC007D Duplicate of site 98SC007.

98SC003 Flowing stream; upstream of confluence with Slate Creek; about $6 \mathrm{ft}$ wide, about 10 in. deep, swift; no visible contamination; distal from minesite.

98SC005 Flowing stream; drainage about $3 \mathrm{ft}$ across, $1 \mathrm{ft}$ deep, swift, moderate to high gradient; no visible contamination; distal from minesite.

None at site.

Shattered, siliceous muscovite-quartzite; cut by thin quartz veins; FeOx and lesser $\mathrm{MnOx}$ on cleavage surfaces; possibly disseminated pyrite.

Ferricrete cementing muscovite schist in switchback $30 \mathrm{ft}$ above site; site is on strike with the NE.-trending vein system at the Slate Creek deposit.

None at site.

Pyritic quartz-mica schist (with stibnite); horizons of graphite schist well-cleaved/friable; sparse green mineral (epidote?); ore-bearing quartz vein has been mined out, leaving mineralized wallrock.

Well-foliated quartz-muscovite schist with graphite schist horizons; local yellow-green staining and $\mathrm{FeOx}$ suggest weathering sulfides.

Pyritic quartz-mica schist (with stibnite); horizons of graphite schist well-cleaved/friable; sparse green mineral (epidote?); ore-bearing quartz vein has been mined out, leaving mineralized wallrock.

Highwall along pit is ferricrete-cemented muscovite schist; pit is on strike with NE.-trending vein at mine; abundant disaggregated stibnite in wastepile.

Interbedded muscovite schist/quartz-muscovite schist; contains minor graphitic schist horizons; two cleavage sets orthogonal to foliation; FeOx-stained joints.

None at site.

Do.

Do.

Do.

Do. 
Table 3. Onsite data for water samples collected from the Slate Creek antimony deposit and vicinity.

[cfs, cubic feet per second; diss., dissolved. Alkalinity and acidity are expressed as equivalent $\mathrm{CaCO}_{3}$. Flow rate: -v, qualitative visual estimate, $-\mathrm{c}$, calculated. Do., ditto]

\begin{tabular}{|c|c|c|c|c|c|c|c|c|c|c|c|}
\hline $\begin{array}{c}\text { Site } \\
\text { (fig. 3) }\end{array}$ & $\begin{array}{l}\text { Temp } \\
\left({ }^{\circ} \mathrm{C}\right)\end{array}$ & $\begin{array}{l}\text { Flow } \\
\text { rate }\end{array}$ & $\begin{array}{c}\text { Flow } \\
\text { unit }\end{array}$ & $\mathrm{pH}$ & $\begin{array}{l}\text { Conductivity } \\
(\mu \mathrm{S} / \mathrm{cm})\end{array}$ & $\begin{array}{c}\text { Diss. } \mathrm{O}_{2} \\
(\mathrm{mg} / \mathrm{L})\end{array}$ & $\begin{array}{c}\text { Alkalinity } \\
(\mathrm{mg} / \mathrm{L})\end{array}$ & $\begin{array}{l}\text { Acidity } \\
(\mathrm{mg} / \mathrm{L})\end{array}$ & $\begin{array}{l}\text { Water } \\
\text { color }\end{array}$ & $\begin{array}{l}\text { Water } \\
\text { odor }\end{array}$ & $\begin{array}{c}\text { Qualitative } \\
\text { turbidity }\end{array}$ \\
\hline
\end{tabular}

\begin{tabular}{|c|c|c|c|c|c|c|c|c|c|c|c|}
\hline \multicolumn{12}{|c|}{ Naturally mineralized } \\
\hline 98SC001 & 6 & $3-v$ & $\mathrm{cfs}$ & 6.9 & 200 & 9 & 60 & -- & clear & none & none \\
\hline $98 \mathrm{SCOO2}$ & 5.3 & $1-v$ & cfs & 7.2 & 300 & 9 & 130 & -- & clear & none & none \\
\hline $98 \mathrm{SC} 011$ & 4.6 & $23-v$ & $\mathrm{~L} / \mathrm{min}$ & 5.6 & 750 & 3 & 180 & -- & clear & strong sulfur & none \\
\hline $98 \mathrm{SC} 013$ & 7.1 & $11-\mathrm{c}$ & $\mathrm{L} / \mathrm{min}$ & 7.7 & 300 & 9 & 57 & -- & clear & strong sulfur & none \\
\hline \multicolumn{12}{|c|}{ Mine } \\
\hline 98SC008 & 10.3 & $0-\mathrm{v}$ & standing & 2.9 & 1,320 & 6 & 0 & 520 & clear & none & none \\
\hline $98 \mathrm{SC} 009$ & 11 & $40-\mathrm{c}$ & $\mathrm{L} / \mathrm{min}$ & 4.9 & 770 & 5 & $<10$ & 280 & clear & none & slightly tan \\
\hline 98SC010 & 9.6 & $6-c$ & $\mathrm{~L} / \mathrm{min}$ & 2.7 & 1,700 & 5 & 0 & 620 & clear & none & slight \\
\hline 98SC012 & 6.7 & $0-\mathrm{v}$ & standing & 5.8 & 990 & 5 & 110 & -- & clear & none & none \\
\hline \multicolumn{12}{|c|}{ Downstream of and influenced by mine } \\
\hline 98SC004 & 6.2 & $12-\mathrm{v}$ & $\mathrm{cfs}$ & 7.5 & 260 & 9 & 63 & -- & clear & none & slight \\
\hline 98SC006 & 7 & $6-v$ & $\mathrm{cfs}$ & 7.5 & 280 & 9 & 70 & -- & clear & none & slight \\
\hline 98SC007 & 7.6 & $4-\mathrm{v}$ & cfs & 6.9 & 260 & 9 & 78 & -- & clear & none & none \\
\hline 98SC007D & 7.6 & $4-\mathrm{v}$ & $\mathrm{cfs}$ & 6.9 & 260 & 9 & 76 & -- & clear & none & none \\
\hline \multicolumn{12}{|c|}{ Distal from mine and mineralized area } \\
\hline $98 \mathrm{SC} 003$ & 3.6 & $6-v$ & cfs & 7.3 & 200 & 10 & 85 & -- & clear & none & none \\
\hline 98SC005 & 6.1 & $2-\mathrm{v}$ & $\mathrm{cfs}$ & 7.8 & 130 & 9 & 60 & -- & clear & none & none \\
\hline
\end{tabular}

\section{Results}

\section{Water Samples}

Analytical results for water samples are listed in table 4. The charge balance (a ratio of cations to anions for major cations and anions) ranged from 1.0 to 1.2 (mean, $1.08 ; n=11$ ) for most samples; however, three water samples collected from the Slate Creek antimony deposit proper (sites 98SC008, 98SC009, 98SC010, fig. 3) had charge balances of 0.7, 0.8, and 0.7 , respectively. This divergence from unity probably results from their highly acidic, metalliferous composition, which can cause analytical interferences, or, possibly, from the abundance of ionic species that were not included in the charge balance.

The waters draining the Slate Creek antimony deposit were found to have the lowest $\mathrm{pH}$ values $(2.7-5.8)$ (table 3). The lowest $\mathrm{pH}$ values were measured in samples of minerelated waters directly derived from the recontoured mine waste (sites 98SC008, 98SC009, 98SC010, fig. 3); these three water samples also had total acidities ranging from 280 to $620 \mathrm{mg} / \mathrm{L}$ (as equivalent $\mathrm{CaCO}_{3}$ ). All other streamwater samples had near-neutral $\mathrm{pH}$ values. Samples from the naturally mineralized springs had $\mathrm{pH}$ values of 5.6 and 7.7 (sites 98SC011 and 98SC013, respectively). Conductivities ranged from 130 to $200 \mu \mathrm{S} / \mathrm{cm}$ in water samples from the two distal streams (sites 98SC003, 98SC005), from 200 to 300 $\mu \mathrm{S} / \mathrm{cm}$ in water samples from the two naturally mineralized streams (sites 98SC001, 98SC002), from 770 to $1,700 \mu \mathrm{S} / \mathrm{cm}$ in water samples from the four minesites, and from 260 to $280 \mu \mathrm{S} / \mathrm{cm}$ in water samples from the three sites along Slate Creek downstream from the mineralized area (sites 98SC004, 98SC006, 98SC007, 98SC007D). Samples from the naturally mineralized springs had conductivities of 750 and $300 \mu \mathrm{S} / \mathrm{cm}$ (sites 98SC011 and 98SC013, respectively). Dames \& Moore (1992) noted the naturally mineralized spring sampled at site 98SC011 and stated that this "groundwater seep" had a $\mathrm{pH}$ value of 6.4 , a conductivity of $650 \mu \mathrm{S} / \mathrm{cm}$, and a "severe orange-brown discoloration," as also observed in this study.

Alkalinities (as equivalent $\mathrm{CaCO}_{3}$ ) at the minesite ranged from $0 \mathrm{mg} / \mathrm{L}$ ( $\mathrm{pH}$ value, $<3$; sites $98 \mathrm{SC} 008,98 \mathrm{SC} 010$, fig. 3 ; table 3) to $110 \mathrm{mg} / \mathrm{L}$, in a sample of standing water from a prospect pit ( $\mathrm{pH}$ value, 5.8; site 98SC012). Alkalinities in samples from the naturally mineralized springs were 180 $\mathrm{mg} / \mathrm{L}$ ( site $98 \mathrm{SC} 011$, the highest value measured in this study) and $57 \mathrm{mg} / \mathrm{L}$ (site $98 \mathrm{SC} 013$ ). Alkalinities in water samples from the two distal streams were 60 and $85 \mathrm{mg} / \mathrm{L}$, and those in water samples from the two naturally mineralized streams were 60 and $130 \mathrm{mg} / \mathrm{L}$. Alkalinities in water samples from Slate Creek below the mine and mineralized area ranged from 63 to $78 \mathrm{mg} / \mathrm{L}$ (mean, $72 \mathrm{mg} / \mathrm{L} ; / n=4$ ), only slightly lower than those in water samples from the distal streams. 
Waters ranged in major-anion composition from bicarbonate to sulfate dominant and were calcium-magnesium waters with respect to major cations (fig. 4). The four minerelated water samples (sites 98SC008, 98SC009, 98SC010, $98 \mathrm{SC012}$, fig. 3) were all sulfate dominant. This contrasts with the bicarbonate dominance in water samples from the two distal streams and the two naturally mineralized streams (sites 98SC003, 98SC005, 98SC001, and 98SC002, respectively). Water samples collected along Slate Creek downstream from the mine and mineralized area were intermediate in composition with respect to carbonate and sulfate. The sample from the naturally mineralized spring at site $98 \mathrm{SC} 013$ was sulfate dominant, whereas the sample from the naturally mineralized spring at site $98 \mathrm{SC} 011$ was intermediate in composition with respect to carbonate and sulfate. Both of these springs had strong sulfurous odors and the latter was precipitating abundant iron oxide.

TDS contents were highest in the four mine-related water samples (table 4), ranging from 671 to $993 \mathrm{mg} / \mathrm{L}$, followed by those in the water sample from the naturally mineralized spring within the mineralized zone ( $544 \mathrm{mg} / \mathrm{L}$; site $98 \mathrm{SC} 011$, fig. 3), and in the water sample from a naturally mineralized stream (316 mg/L; site 98SC002). This stream-water sample was collected upstream from the minesite, approximately on strike with the northeastward trend of the mineralized vein system. TDS contents dropped quickly in stream waters along Slate Creek immediately below the minesite and continued to drop at sites downstream (table 4).
The naturally mineralized springs (sites 98SC011, 98SC013, fig. 3) exceeded ADEC primary and secondary drinking-water MCLs for $\mathrm{SO}_{4}^{2-}, \mathrm{As}, \mathrm{Fe}, \mathrm{Mn}, \mathrm{Sb}$, and TDS contents (Alaska Department of Environmental Conservation, 2000). The $\mathrm{pH}$ value in the sample from one of the naturally mineralized springs (site $98 \mathrm{SC011}$ ) was outside the acceptable MCL range of 6.5 to 8.5 . The $\mathrm{Mn}$ and $\mathrm{Sb}$ contents in water samples from the naturally mineralized streams collected above the minesite (sites 98SC001, 98SC002) were close to, but nevertheless exceeded, MCLs, and Fe content was high but below the MCL. The distal streams did not exceed MCLs.

With respect to the surface-water averages of Martin and Whitfield (1983), Meybeck (1988), and Hem (1985), the following elements were found to be abundant in waters from the four mine-related sites: $\mathrm{SO}_{4}^{2-}, \mathrm{Al}, \mathrm{As}, \mathrm{Co}, \mathrm{Fe}, \mathrm{Mn}$, $\mathrm{Ni}, \mathrm{Sb}, \mathrm{Zn}$, TDS, and, to a lesser degree, $\mathrm{Ba}, \mathrm{Cd}, \mathrm{Cu}, \mathrm{Th}, \mathrm{U}$, and rare-earth-elements. As indicated in table 4, several of these cations and anions ( $\left.\mathrm{SO}_{4}^{2-}, \mathrm{As}, \mathrm{Fe}, \mathrm{Mn}, \mathrm{Ni}, \mathrm{Sb}\right)$ exceeded ADEC primary and secondary MCLs for drinking water. The $\mathrm{pH}$ values at these four sites were also outside the acceptable MCL range. However, at site $98 \mathrm{SC} 007$ (fig. 3) below the mine wastepiles, all of the above-listed elements quickly dropped in concentration shortly upon mixing with Slate Creek. Persisting downstream along Slate Creek from site 98SC007 at concentrations exceeding established MCLs were As $(23 \mu \mathrm{g} / \mathrm{L}$, site 98SC007), Fe (0.87-2.3 $\mathrm{mg} / \mathrm{L}$, still exceeding the MCL at site 98SC006), Mn (61-330 $\mu \mathrm{g} / \mathrm{L}$, still exceeding the MCL at site

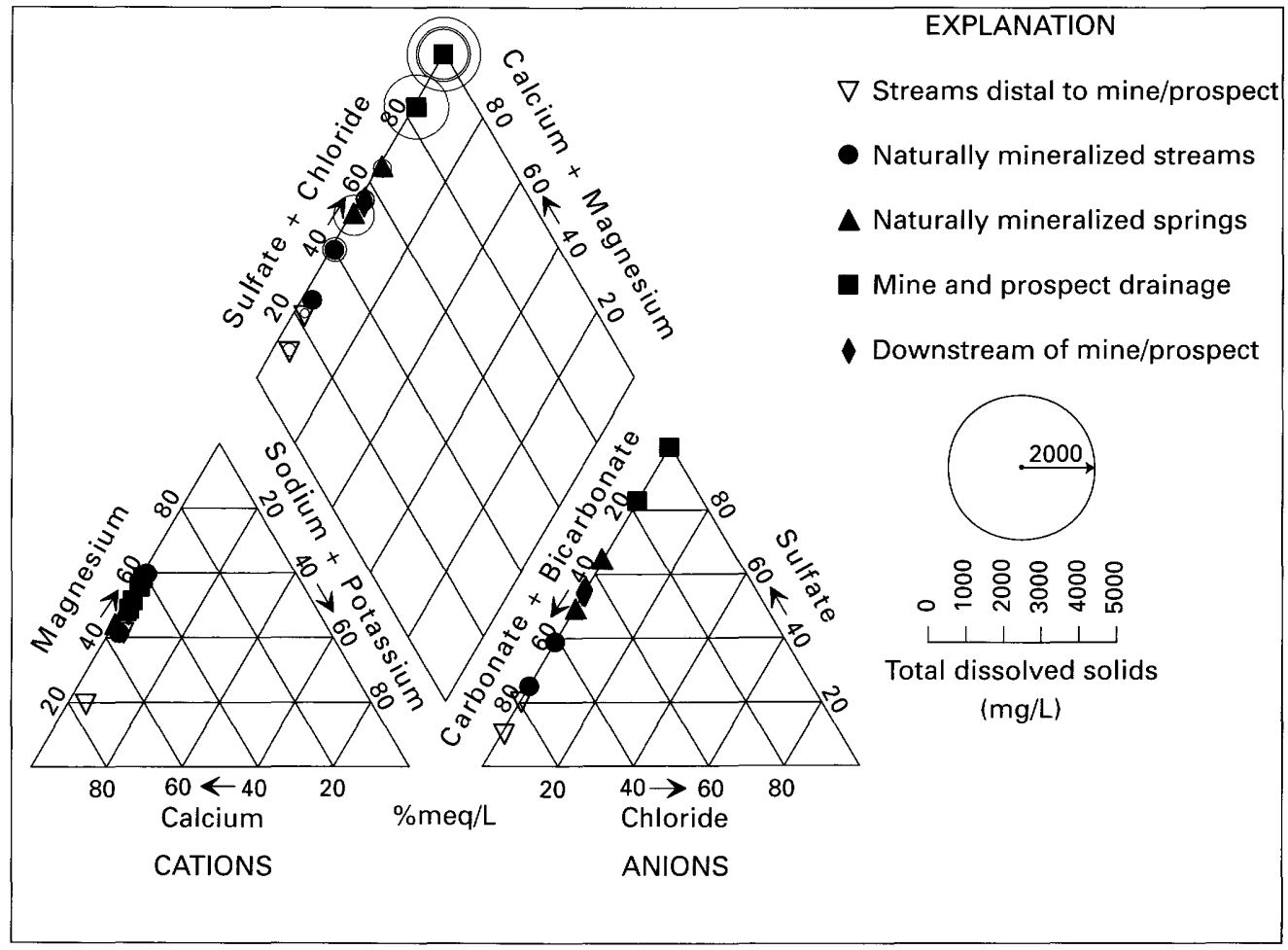

Figure 4. Piper diagram showing major-ion compositions in surface waters. Squares, samples from mine and prospect; inverted triangles, samples from streams distal from mine and prospect; dots, samples from naturally mineralized streams; triangles, samples from naturally mineralized springs; diamonds, samples from mixed stream downstream from mine and mineralized area. After Piper (1944). 
Table 4. Analytical data for water samples collected from the Slate Creek antimony deposit and vicinity.

[The following elements were not detected at the lower detection limits (in micrograms per liter): $\mathrm{Au}(0.01), \mathrm{B}(10), \mathrm{Bi}(0.01), \mathrm{Hf}(0.05), \mathrm{Hg}(0.005), \mathrm{Nb}(0.02), \mathrm{Re}$ (0.02), $\mathrm{Ta}(0.02), \mathrm{Te}(2), \mathrm{W}(0.02)$, and $\mathrm{Zr}(0.05)$. $\mathrm{mg} / \mathrm{L}$, milligrams per liter; $\mu \mathrm{g} / \mathrm{L}$, micrograms per liter; $\mathrm{EW}$, inductively coupled plasma atomic-emission spectrometry; IC, ion chromatography; MW, inductively coupled plasma mass spectrometry. HDN, calculated hardness; TDS, calculated total dissolved solids. $\mathrm{H}_{2} \mathrm{O}$ sources: DN, downstream from minesite; DS, distal from mineralized area; MINE, minesite; NM, naturally mineralized; SP, spring; ST, stream. MCL, primary maximum contaminant level (bold); $2 \mathrm{MCL}$, secondary maximum contaminant level (italic). See text for explanation of MCL values]

\begin{tabular}{|c|c|c|}
\hline Site (fig. 3) & Water source & Channel-bed description \\
\hline 98SC001 & Stream & $\begin{array}{l}\text { Heavy orange FeOx precipitate on alluvium; alluvium is dominantly muscovite schist and } \\
\text { quartzite, with lesser vein quartz; pyrite and stibnite in vein quartz. }\end{array}$ \\
\hline $98 \mathrm{SC} 002$ & Stream & Organic-rich, very heavily coated with FeOx; in willow thicket; sparse FeOx-coated pebbles. \\
\hline 98SC011 & Seep spring & Extensive orange FeOx coating organic debris and minor mica schist colluvium. \\
\hline $98 \mathrm{SC} 013$ & Spring & Leaves and other organic debris on mica schist; no FeOx staining. \\
\hline 98SC008 & $\begin{array}{l}\text { Mine } \\
\text { drainage }\end{array}$ & Fine mud settled on mine waste used as fill. \\
\hline 98SC009 & $\begin{array}{l}\text { Mine } \\
\text { drainage }\end{array}$ & $\begin{array}{l}\text { Heavy FeOx slime covering mine waste; sparse stressed willow and alder along drainage in less } \\
\text { disturbed areas. }\end{array}$ \\
\hline $98 \mathrm{SC} 010$ & $\begin{array}{l}\text { Mine } \\
\text { drainage }\end{array}$ & Black plastic pipe. \\
\hline $98 \mathrm{SC} 012$ & $\begin{array}{l}\text { Pool in } \\
\text { prospect pit }\end{array}$ & FeOx mud and slime on leaves, organic debris, and angular rock fragments. \\
\hline 98SC004 & Stream & Rocky, sparsely vegetated; willow-spruce-grass banks. \\
\hline 98SC006 & Stream & $\begin{array}{l}\text { Open, rocky, no algae growth and rocks are not slippery along entire length of Slate Creek; } \\
\text { pervasive FeOx staining. }\end{array}$ \\
\hline 98SC007 & Stream & Rocky, angular cobbles, heavily coated with $\mathrm{FeOx}$, abundant FeOx fines. \\
\hline 98SC007D & Stream & Do. \\
\hline 98SC003 & Stream & Rocky, algae-covered; no obvious staining; creek in grass-moss-willow meadow. \\
\hline 98SC005 & Stream & Heavily overgrown with willow, algae in stream. \\
\hline
\end{tabular}

Site (fig. 3) $\quad \mathrm{H}_{2} \mathrm{O}$ source $\quad \mathrm{F}_{-}^{-} \mathrm{mg} / \mathrm{L} \_\mathrm{IC} \quad \mathrm{Cl}_{-}^{-} \mathrm{mg} / \mathrm{L} \_\mathrm{IC} \quad \mathrm{SO}_{4}^{2-} \_\mathrm{mg} / \mathrm{L} \_\mathrm{IC} \quad \mathrm{NO}_{3}^{-} \_\mathrm{mg} / \mathrm{L} \_\mathrm{IC} \quad \mathrm{Ag} \_\mu \mathrm{g} / \mathrm{L} \_\mathrm{MW} \quad \mathrm{Al} \_\mu \mathrm{g} / \mathrm{L} \_\mathrm{MW} \quad \mathrm{As} \_\mu \mathrm{g} / \mathrm{L} \_\mathrm{MW} \quad \mathrm{Ba} \_\mu \mathrm{g} / \mathrm{L} \_\mathrm{MW}$

\begin{tabular}{|c|c|c|c|c|c|c|c|c|c|}
\hline MCL $2 M C L$ & --- & 4 & 250 & 250 & 44 & -- & -- & 10 & 200 \\
\hline $98 \mathrm{SC} 001$ & NM, ST & .1 & .1 & 20 & $<.4$ & .01 & 6.7 & 4.4 & 5 \\
\hline $98 \mathrm{SC} 002$ & NM, ST & .2 & .3 & 81 & $<.4$ & $<.01$ & 2.2 & 6.7 & 8.2 \\
\hline $98 \mathrm{SC} 011$ & $\mathrm{NM}, \mathrm{SP}$ & .2 & 6 & 180 & $<.4$ & .20 & 230 & 32 & 27 \\
\hline $98 \mathrm{SC} 013$ & NM, SP & .2 & .1 & 100 & $<.4$ & $<.01$ & 7.7 & 27 & 4 \\
\hline $98 \mathrm{SC} 008$ & MINE & 1.1 & 1.6 & 570 & $<.4$ & .02 & 2,000 & 460 & 3 \\
\hline 98SC009 & MINE & .8 & 6 & 520 & $<.4$ & .06 & 1,100 & 36 & 32 \\
\hline $98 \mathrm{SC} 010$ & MINE & 1.5 & 2.0 & 800 & $<.4$ & .02 & 3,700 & 970 & 3 \\
\hline $98 \mathrm{SC} 012$ & MINE & $<.1$ & .5 & 520 & $<.4$ & .03 & 3.7 & 2 & 5 \\
\hline $98 \mathrm{SC} 004$ & DN, ST & .1 & .2 & 70 & .8 & $<.01$ & 14 & 4.5 & 7.8 \\
\hline $98 \mathrm{SC} 006$ & DN, ST & .4 & .2 & 84 & $<.4$ & $<.01$ & 31 & 9.7 & 7.7 \\
\hline $98 \mathrm{SC} 007$ & DN, ST & .1 & .2 & 89 & $<.4$ & $<.01$ & 54 & 23 & 7.6 \\
\hline 98SC007D & DN, ST & .1 & .2 & 88 & $<.4$ & $<.01$ & 50 & 22 & 7.7 \\
\hline $98 \mathrm{SC} 003$ & DS, ST & .1 & .3 & 11 & .9 & $<.01$ & 6.5 & 2 & 15 \\
\hline $98 \mathrm{SC} 005$ & DS, ST & .1 & .1 & 16 & .5 & .03 & 6.5 & 3.9 & 5 \\
\hline
\end{tabular}

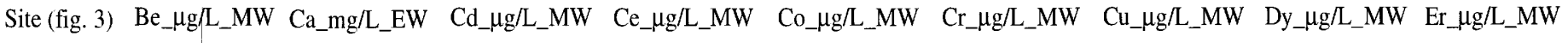

\begin{tabular}{|c|c|c|c|c|c|c|c|c|c|}
\hline MCL $2 M C L$ & 4 & -- & 5 & -- & -- & 100 & 1,300 & -- & -- \\
\hline $98 \mathrm{SC} 001$ & $<.05$ & 18 & $<.02$ & .02 & .08 & $<1$ & 2 & .01 & $<.005$ \\
\hline $98 \mathrm{SC} 002$ & $<.05$ & 37 & $<.02$ & .01 & .5 & $<1$ & .8 & $<.005$ & $<.005$ \\
\hline 98SC011 & .2 & 86 & $<.02$ & 1.5 & 4 & $<1$ & 1 & .24 & .22 \\
\hline $98 \mathrm{SC} 013$ & $<.05$ & 35 & $<.02$ & $<.01$ & .07 & $<1$ & .7 & $<.005$ & $<.005$ \\
\hline 98SC008 & 1.1 & 40 & 3.4 & 40 & 160 & 6 & 140 & 4.4 & 2.3 \\
\hline 98SC009 & .7 & 57 & 1.9 & 16 & 140 & $<1$ & 54 & 1.8 & .98 \\
\hline $98 \mathrm{SC} 010$ & 1 & 45 & 4.4 & 54 & 220 & 8 & 190 & 6.1 & 3.3 \\
\hline $98 \mathrm{SC} 012$ & $<.05$ & 110 & .05 & .09 & 17 & $<1$ & 2 & .01 & .02 \\
\hline 98SC004 & $<.05$ & 29 & .06 & .05 & .8 & $<1$ & 2 & .008 & $<.005$ \\
\hline $98 \mathrm{SC} 006$ & $<.05$ & 31 & .05 & .2 & 3.6 & $<1$ & 2 & .02 & .02 \\
\hline $98 \mathrm{SC} 007$ & $<.05$ & 33 & .1 & .4 & 5.4 & $<1$ & 3 & .04 & .04 \\
\hline 98SC007D & $<.05$ & 33 & .07 & .4 & 5.4 & $<1$ & 3 & .04 & .03 \\
\hline $98 \mathrm{SC} 003$ & $<.05$ & 33 & $<.02$ & $<.01$ & .3 & $<1$ & $<.5$ & $<.005$ & $<.005$ \\
\hline 98SC005 & $<.05$ & 15 & .2 & .03 & 2.8 & $<1$ & 1 & .008 & .008 \\
\hline
\end{tabular}


Table 4. Analytical data for water samples collected from the Slate Creek antimony deposit and vicinity-Continued.

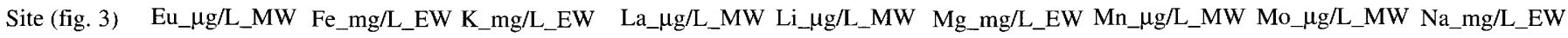

\begin{tabular}{|c|c|c|c|c|c|c|c|c|c|}
\hline $\mathrm{MCL} / 2 \mathrm{MCL}$ & - - & 0.3 & - - & -- & - - & - - & 50 & _- & 250 \\
\hline $98 \mathrm{SC} 001$ & $<.005$ & .064 & .24 & .03 & 1.1 & 8.1 & 12 & .2 & .76 \\
\hline $98 \mathrm{SC} 002$ & $<.005$ & .35 & .34 & $<.01$ & 2 & 34 & 60 & .03 & .52 \\
\hline 98SC011 & .053 & 19 & .62 & .92 & 5 & 41 & 1,000 & 3 & .49 \\
\hline $98 \mathrm{SC} 013$ & $<.005$ & $<.05$ & .15 & $<.01$ & 1.7 & 20 & .95 & $<.02$ & .52 \\
\hline 98SC008 & 1 & 100 & .5 & 18 & 3.4 & 26 & 5.000 & .4 & .46 \\
\hline $98 \mathrm{SC} 009$ & .35 & 78 & .64 & 7.9 & 4 & 34 & 5,700 & .98 & .63 \\
\hline $98 \mathrm{SC} 010$ & 1.3 & 170 & .61 & 24 & 2.8 & 35 & 6,500 & .3 & .46 \\
\hline $98 \mathrm{SC} 012$ & $<.005$ & 2.4 & .51 & .2 & 4.2 & 94 & 3,000 & .56 & .39 \\
\hline $98 \mathrm{SCO} 04$ & $<.005$ & .13 & .29 & .04 & 1.7 & 17 & 61 & .07 & .8 \\
\hline $98 \mathrm{SC} 006$ & .008 & .87 & .3 & .1 & 1.8 & 19 & 240 & .05 & .68 \\
\hline $98 \mathrm{SC} 007$ & .007 & 2.3 & .29 & .2 & 1.3 & 21 & 330 & .1 & .73 \\
\hline 98SC007D & .008 & 2.2 & .28 & .2 & 1.7 & 21 & 330 & .07 & .7 \\
\hline $98 \mathrm{SC} 003$ & $<.005$ & $<.05$ & .52 & $<.01$ & 2 & 5.5 & 1.1 & .4 & 1.8 \\
\hline $98 \mathrm{SC} 005$ & $<.005$ & $<.05$ & .26 & .04 & 1.1 & 7.4 & 11 & .55 & .67 \\
\hline
\end{tabular}

Site (fig. 3) $\quad N d \_\mu g / L \_M W N i \_\mu g / L \_M W \quad G d \_\mu g / L \_M W \quad P \_\mu g / L \_E W \quad P b \_\mu g / L \_M W \quad P r \_\mu g / L \_M W \quad R b \_\mu g / L \_M W \quad S b \_\mu g / L \_M W \quad S c \_\mu g / L \_M W$

\begin{tabular}{|c|c|c|c|c|c|c|c|c|c|}
\hline MCL/2MCL & -- & 100 & -- & - - & 15 & - - & - - & 6 & $\ldots$ \\
\hline $98 \mathrm{SC} 001$ & .03 & 1.5 & .005 & $<50$ & $<.05$ & .01 & .2 & 2.3 & $<.1$ \\
\hline $98 \mathrm{SC} 002$ & .01 & 3 & $<.005$ & $<50$ & $<.05$ & $<.01$ & .2 & 14 & $<.1$ \\
\hline $98 \mathrm{SC} 011$ & .78 & 14 & .24 & $<50$ & .2 & .2 & 6 & .7 & $<.1$ \\
\hline $98 \mathrm{SC} 013$ & $<.01$ & 1.9 & $<.005$ & $<50$ & $<.05$ & $<.01$ & .1 & 8.9 & $<.1$ \\
\hline $98 \mathrm{SC} 008$ & 17 & 320 & 4.4 & 170 & 2.4 & 4.5 & 1.6 & 120 & 5 \\
\hline $98 \mathrm{SC} 009$ & 6.3 & 290 & 1.6 & $<50$ & 4 & 1.7 & 1.7 & 35 & .9 \\
\hline $98 \mathrm{SC} 010$ & 24 & 450 & 6.1 & 320 & 4.5 & 6.2 & 2 & 220 & 6.2 \\
\hline $98 \mathrm{SC} 012$ & .02 & 53 & .02 & $<50$ & $<.05$ & $<.01$ & .9 & .3 & $<.1$ \\
\hline 98SC004 & .02 & 4.9 & .007 & $<50$ & $<.05$ & .01 & .2 & 100 & $<.1$ \\
\hline $98 \mathrm{SC} 006$ & .06 & 11 & .03 & $<50$ & $<.05$ & .03 & .3 & 190 & $<.1$ \\
\hline $98 \mathrm{SC} 007$ & .2 & 14 & .03 & $<50$ & $<.05$ & .05 & .3 & 120 & $<.1$ \\
\hline $98 \mathrm{SC} 007 \mathrm{D}$ & .2 & 14 & .056 & $<50$ & $<.05$ & .03 & 3 & 120 & $<.1$ \\
\hline $98 \mathrm{SC} 003$ & .01 & 1.1 & $<.005$ & $<50$ & $<.05$ & $<.01$ & .1 & .52 & .2 \\
\hline $98 \mathrm{SC} 005$ & .05 & 2.3 & .01 & $<50$ & $<.05$ & .01 & .3 & 1.3 & $<.1$ \\
\hline
\end{tabular}

Site (fig. 3) Se $\_$gg/L_MW Si_mg/L_EW Sm_ $\mu g / L \_M W \quad S n \_\mu g / L \_M W \quad S r \_\mu g / L \_E W \quad T b \_\mu g / L \_M W \quad T h \_\mu g / L \_M W \quad T i \_\mu g / L \_M W \quad T l \_\mu g / L \_M W$

\begin{tabular}{|c|c|c|c|c|c|c|c|c|c|}
\hline $\mathrm{MCL} / 2 \mathrm{MCL}$ & 50 & -- & -- & -- & -- & -- & -- & -- & 2 \\
\hline 98SC001 & $<.2$ & 2.6 & $<.01$ & $<.05$ & 68 & $<.005$ & $<.005$ & $<.1$ & .2 \\
\hline $98 \mathrm{SC} 002$ & $<.2$ & 1.8 & $<.01$ & .07 & 100 & $<.005$ & $<.005$ & 1.4 & $<.05$ \\
\hline $98 \mathrm{SC} 011$ & .4 & 3.2 & .1 & .1 & 210 & .05 & .006 & 2.3 & $<.05$ \\
\hline $98 \mathrm{SC} 013$ & $<.2$ & 2 & $<.01$ & $<.05$ & 150 & $<.005$ & $<.005$ & 1.3 & $<.05$ \\
\hline 98SC008 & 2 & 3.2 & 3.7 & .05 & 170 & .78 & 34 & 6.6 & .07 \\
\hline $98 \mathrm{SC} 009$ & .8 & 4.1 & 1.2 & .05 & 220 & .32 & .04 & 5.3 & $<.05$ \\
\hline $98 \mathrm{SC} 010$ & 2 & 3.8 & 5.3 & $<.05$ & 210 & 1.1 & 44 & 8.4 & .1 \\
\hline $98 \mathrm{SC} 012$ & .5 & 1.8 & $<.01$ & $<.05$ & 250 & $<.005$ & $<.005$ & 7.2 & $<.05$ \\
\hline $98 \mathrm{SC} 004$ & $<.2$ & 2.6 & $<.01$ & $<.05$ & 120 & $<.005$ & .006 & 1 & $<.05$ \\
\hline $985 C 006$ & .3 & 2.4 & .01 & $<.05$ & 120 & .006 & .02 & .8 & $<.05$ \\
\hline $98 \mathrm{SC} 007$ & .3 & 2.4 & .02 & .06 & 110 & .009 & .04 & 1.2 & .05 \\
\hline 98SC007D & $<.2$ & 2.4 & .04 & $<.05$ & 110 & .009 & .03 & .8 & $<.05$ \\
\hline $98 \mathrm{SC} 003$ & .4 & 4.4 & $<.01$ & $<.05$ & 130 & $<.005$ & $<.005$ & $<.1$ & .1 \\
\hline $98 \mathrm{SC} 005$ & $<.2$ & 2.6 & $<.01$ & $<.05$ & 69 & $<.005$ & $<.005$ & .2 & .7 \\
\hline
\end{tabular}

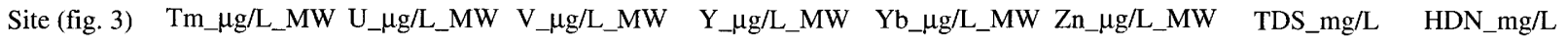

\begin{tabular}{|c|c|c|c|c|c|c|c|c|}
\hline $\mathrm{MCL} / 2 \mathrm{MCL}$ & -- & -- & -- & -- & -- & 5,000 & 500 & -- \\
\hline $98 \mathrm{SC} 001$ & $<.005$ & .18 & $<.1$ & .04 & $<.01$ & 1 & 126 & 78 \\
\hline $98 \mathrm{SC} 002$ & $<.005$ & 2.2 & $<.1$ & .03 & $<.01$ & 2 & 316 & 232 \\
\hline $98 \mathrm{SC} 011$ & .04 & .04 & .5 & 2.6 & .2 & 20 & 544 & 383 \\
\hline $98 \mathrm{SC} 013$ & $<.005$ & .02 & $<.1$ & $<.01$ & $<.01$ & 2 & 230 & 170 \\
\hline $98 \mathrm{SC} 008$ & .33 & 20 & 3 & 21 & 1.7 & 1,200 & 710 & 207 \\
\hline $98 \mathrm{SC} 009$ & .13 & 5.7 & $<.1$ & 11 & .75 & 800 & 671 & 282 \\
\hline $98 \mathrm{SC} 010$ & .43 & 25 & 5.1 & 30 & 2.5 & 1.600 & 993 & 256 \\
\hline $98 \mathrm{SC} 012$ & $<.005$ & .02 & $<.1$ & .66 & $<.01$ & 240 & 868 & 661 \\
\hline $98 \mathrm{SCOO4}$ & $<.005$ & .85 & $<.1$ & .08 & $<.01$ & 10 & 201 & 142 \\
\hline 98SC006 & $<.005$ & .67 & $<.1$ & .2 & .02 & 20 & 227 & 156 \\
\hline $98 \mathrm{SC} 007$ & .005 & .95 & $<.1$ & .4 & .02 & 34 & 246 & 169 \\
\hline 98SC007D & $<.005$ & .93 & $<.1$ & 4 & .03 & 28 & 243 & 169 \\
\hline $98 \mathrm{SC} 003$ & $<.005$ & .38 & $<.1$ & .02 & $<.01$ & $<.5$ & 166 & 105 \\
\hline 98SC005 & $<.005$ & .15 & $<.1$ & .06 & $<.01$ & 62 & 119 & 68 \\
\hline
\end{tabular}


98SC004, at the mouth of Slate Creek), and Sb (100-190 $\mu \mathrm{g} /$ $\mathrm{L}$, still 100 times the MCL at site 98SC004). To summarize, (1) As, Fe, Mn, and Sb contents exceeded MCLs immediately below the mine and mineralized area; (2) by about $0.5 \mathrm{mi}(0.8$ $\mathrm{km})$ downstream from the mine and mineralized area, $\mathrm{Fe}$, $\mathrm{Mn}$, and $\mathrm{Sb}$ contents exceeded MCLs, and the As content was very close to, but still below, the MCL; and (3) at the mouth of Slate Creek, about $1.8 \mathrm{mi}(2.9 \mathrm{~km})$ downstream from the mine and mineralized area, only $\mathrm{Mn}$ and $\mathrm{Sb}$ contents exceeded MCLs, and $\mathrm{Fe}$ and As contents were high but below MCLs and below concentrations in a naturally mineralized stream above the mineralized area.

In a limited study with two water samples, one above and one immediately below the mine and mineralized area, Dames \& Moore (1992) measured Fe contents exceeding the MCL in the upstream naturally mineralized sample, and $\mathrm{Sb}$ and $\mathrm{Fe}$ contents exceeding MCLs at the lower site. They did not detect As or $\mathrm{Hg}$ (at $0.2 \mu \mathrm{g} / \mathrm{L}$ ), and they did not analyze for $\mathrm{Mn}$ in their reconnaissance study. In this study, $\mathrm{Hg}$ was not detected in any water samples (at $0.005 \mu \mathrm{g} / \mathrm{L}$ ).

The dissolved-cation concentrations listed in table 4 were compared against EPA freshwater aquatic-life standards (Environmental Protection Agency, 1993) for the following toxic pollutants: $\mathrm{Ag}, \mathrm{As}, \mathrm{Cd}, \mathrm{Cr}(\mathrm{III}), \mathrm{Cu}, \mathrm{Pb}, \mathrm{Ni}$, and $\mathrm{Zn}$ (all but As are hardness dependent). Only total $\mathrm{Cr}$, not individual Cr species, was determined in this study. However, in all samples, total $\mathrm{Cr}$ contents were a tenth of the EPA threshold values for $\mathrm{Cr}(\mathrm{III})$. Only three minesite waters contained metallic-ion concentrations in excess of EPA standards for freshwater aquatic life (table 5), and none of the other water samples collected exceeded EPA freshwater aquatic-life standards. The acute and chronic standards listed in table 5 should be considered only as guidelines; the ADEC may have aquatic-life guidelines that supercede these. Furthermore, the EPA is currently establishing new guidelines for aquatic life (Environmental Protection Agency, 1999b). Acute and chronic standards are hardness dependent and thus vary from sample to sample in table 5 .

\section{Solid Samples}

Analytical results for stream-sediment, rock, and soil samples are listed in table 6 . The following elements were not detected in any samples at the parenthetical lower detection limits (in parts per million): $\mathrm{Ag}(0.08), \mathrm{Eu}(2), \mathrm{Ho}$ (4), $\mathrm{Ta}$ (40), and $\mathrm{U}(100)$. For comparison with the following discussion, worldwide crustal abundances are 1.7 to $5 \mathrm{ppm}$ for As and 0.15 to $1 \mathrm{ppm}$ for $\mathrm{Sb}$, and average concentrations in U.S. soils are $5.2 \mathrm{ppm}$ for As and $0.5 \mathrm{ppm}$ for Sb (Smith and Huyck, 1999). Threshold values, above which concentrations are considered anomalous in this study, are listed in table 6.

Arsenic and antimony stand out, with highly anomalous contents in stream-sediment and soil samples relative to crustal abundances (Smith and Huyck, 1999) and to background concentrations in the various rock types listed by Rose and others (1979). Minus-80 mesh $(<0.177 \mathrm{~mm})$ sediment
Table 5. Analytical data for three water samples from the Slate Creek antimony deposit and vicinity containing metallic-ion concentrations exceeding EPA standards for freshwater aquatic life.

[All values in micrograms per liter. Acute standard, 1-hour exposure; chronic standard, 4-day exposure]

Sample

Element

$98 \mathrm{SC} 008 \quad 98 \mathrm{SC} 009 \quad 98 \mathrm{SC} 010$

\begin{tabular}{|c|c|c|c|}
\hline 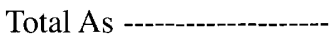 & 460 & - - & 970 \\
\hline Acute standard -------- & 360 & -- & 360 \\
\hline Chronic standard ------ & 190 & -- & 190 \\
\hline Total Cd-------------- & 3.4 & -- & 4.4 \\
\hline Chronic standard ----- & 2.03 & -- & 2.4 \\
\hline 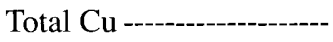 & 140 & 54 & 190 \\
\hline Acute standard -------- & 35.7 & 46.8 & 43.6 \\
\hline Chronic standard ------ & 22.3 & 28.5 & 26.8 \\
\hline 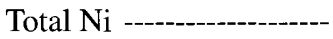 & 320 & -- & 450 \\
\hline Chronic standard ------ & 295 & -- & 354 \\
\hline 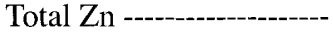 & 1,200 & 800 & 1,600 \\
\hline Acute standard -------- & 219 & 280 & 263 \\
\hline Chronic standard ------ & 199 & 254 & 238 \\
\hline
\end{tabular}

samples from the two distal streams (sites 98SC003, 98SC005, fig. 3) contained 60 and $440 \mathrm{ppm} \mathrm{As,} \mathrm{respectively.} \mathrm{Sediment}$ samples from the two naturally mineralized streams (sites 98SC001, 98SC002) had highly anomalous As contents of 830 and 2,300 ppm-the highest As content in stream sediment found in this study. Samples of naturally mineralized tundra soils (sites 98SC011, 98SC012) had lower-level anomalous As contents of 56 and $63 \mathrm{ppm}$, respectively. Stream-sediment samples downstream from the mine and mineralized area had As contents ranging from 1,100 to $2,100 \mathrm{ppm}$ (mean, 1,700 ppm; $n=4$; sites 98SC004, 98SC006, 98SC007, 98SC007D), decreasing from site $98 \mathrm{SC} 007$ just below the wastepiles to the mouth of Slate Creek (fig. 3). Sediment samples from the two distal streams contained 12 and $84 \mathrm{ppm} \mathrm{Sb}$, with the lowest value from Eldorado Creek. Sediment samples from the two naturally mineralized streams contained 130 and $450 \mathrm{ppm} \mathrm{Sb}$, and samples from the naturally mineralized soils contained 43 and $85 \mathrm{ppm}$ Sb. Highly anomalous Sb contents $(1,200-6,000$ ppm; mean, $3,850 \mathrm{ppm} ; n=4$ ) were measured in the streamsediment samples from Slate Creek downstream from the mineralized area.

Several other elements were measured in anomalously high concentrations in stream-sediment and soil samples. A highly anomalous Mn content (29,000 ppm) was measured in naturally mineralized sediment at site $98 \mathrm{SC} 002$ (fig. 3), and lower-level anomalous Mn contents of 1,500 to 2,600 ppm (mean, $1,740 \mathrm{ppm} ; n=5$ ) were measured in nearly all the other stream-sediment samples, whether from the distal streams or at sites downstream from the mine and mineralized area. Other elements measured in varyingly high concentrations in one or more of the samples include (1) lower-level anomalous contents of $\mathrm{Bi}, \mathrm{Cd}, \mathrm{Fe}, \mathrm{Hg}, \mathrm{Zn}$, and, possibly, $\mathrm{Se}, \mathrm{Te}$, and $\mathrm{Zn}$ in sediment samples from the distal streams; (2) highly anoma- 
Table 6. Descriptive and analytical data for sediment, rock, and soil samples collected from the Slate Creek antimony deposit and vicinity.

[Field No. suffixes: D, soil; DS, site duplicate sediment; R, rock; S, stream sediment. CV, cold-vapor atomic absorption; EP, partial-extraction inductively coupled plasma atomic-emission spectrometry; ET, total-extraction inductively coupled plasma atomic-emission spectrometry; FA, fire-assay atomic absorption; HY, hydride-generation atomic absorption; PCT, percent; PPM, parts per million; Tot, total sulfur by Leco analyzer. Sources: DN, downstream from minesite; DS, distal from mineralized area; MINE, minesite; NM, naturally mineralized. Threshold, concentration above which content is considered anomalous in this study. FeOx, iron oxides; $\mathrm{MnOx}$, manganese oxides; $\mathrm{XRD}$, X-ray diffraction]

\begin{tabular}{|c|c|c|}
\hline Field No. & Source & Sample description \\
\hline 98SC001R & NM & $\begin{array}{l}\text { Colluvium; vein quartz with stibnite, pyrite, and possible arsenopyrite, in greenish-yellow-stained muscovite schist; fairly abundant sulfide-rich cobbles } \\
\text { in colluvium; some sulfides are prismatic (probably stibnite). }\end{array}$ \\
\hline 98SC002R & NM & $\begin{array}{l}\text { Outcrop; shattered, siliceous, muscovite-quartzite cut by thin quartz veins; FeOx and lesser MnOx on cleavage planes; possible disseminated pyrite in } \\
\text { vein quartz; local thin graphitic schist. }\end{array}$ \\
\hline 98SC004R & NM & $\begin{array}{l}\text { Outcrop; } 3 \text {-ft-thick quartz-muscovite schist horizon in muscovite schist; cut along foliation by quartz veins; yellow-green staining and minor salts in } \\
\text { protected areas suggest oxidized sulfides; graphite clots in quartz veins. }\end{array}$ \\
\hline 98SC008R1 & MINE & $\begin{array}{l}\text { Outcrop; quartz-muscovite-pyrite schist wallrock adjacent to mined-out pyrite-stibnite-quartz vein; from S. face; pyritic/silicified schist cut by numerous } \\
\text { quartz veins/veinlets; pervasive yellow-green color from oxidizing sulfides. }\end{array}$ \\
\hline 98SC008R2 & MINE & $\begin{array}{l}\text { Outcrop; salts from protected areas on quartz-muscovite schist wallrock adjacent to mined-out pyrite-stibnite-quartz vein: XRD results are quartz, } \\
\text { vanadian-barian muscovite, aluminocopiapite }\left[(\mathrm{Mg}, \mathrm{Al})(\mathrm{Fe}, \mathrm{Al})_{4}\left(\mathrm{SO}_{4}\right)_{6}(\mathrm{OH})_{2} \cdot 20 \mathrm{H}_{2} \mathrm{O}\right] \text {, hexahydrite }\left(\mathrm{MgSO}_{4} \cdot 6 \mathrm{H}_{2} \mathrm{O}\right) \text {, magnesiocopiapite } \\
{\left[\mathrm{MgFe}_{4}\left(\mathrm{SO}_{4}\right)_{6}(\mathrm{OH})_{2} \cdot 20 \mathrm{H}_{2} \mathrm{O}\right] \text {, biotite. }}\end{array}$ \\
\hline 98SC010R & MINE & Mine waste; sulfide-rich mine waste around drainpipe; sample is pyrite-muscovite-quartz schist containing stibnite. \\
\hline 98SC011R & NM & $\begin{array}{l}\text { Outcrop; old road switchback } 30 \mathrm{ft} \text { above watersite; ferricrete, very FeOx-rich, and probably MnOx; ferricrete cements small angular clasts of muscovite } \\
\text { schist. }\end{array}$ \\
\hline $98 \mathrm{SC} 012 \mathrm{R}$ & MINE & $\begin{array}{l}\text { Prospect waste; gray with fine stibnite in white to clear, highly sheared vein quartz; muscovite-rich; ferricrete cements muscovite schist fragments; local } \\
\text { fresh pyrite; slickensides and shearing suggest fault. }\end{array}$ \\
\hline 98SC001S & NM & Sediment; low organic content; cobbles are FeOx stained; muscovite schist and quartzite dominant, minor vein quartz. \\
\hline 98SC002S & NM & $\begin{array}{l}\text { Sediment; very fine, orange sediment in willow thicket; bog iron or mineralization(?); potential naturally mineralized sample; high organic content; } \\
\text { FeOx sediment with sparse muscovite schist pebbles. }\end{array}$ \\
\hline 98SC003S & DS & Sediment; abundant moss/algae on rocks; moderate organic content; no FeOx staining; muscovite schist dominant. \\
\hline 98SC004S & DN & $\begin{array}{l}\text { Sediment; abundant FeOx-rich fine mud interstitial to boulders; low organic content; muscovite schist and quartz-muscovite schist dominant; minor vein } \\
\text { quartz. }\end{array}$ \\
\hline 98SC005S & DS & $\begin{array}{l}\text { Sediment; deeper gravel has a lot of } \mathrm{FeOx} \text { in fines-very orange; low organic content; slight FeOx on surface cobbles; muscovite schist dominant, } \\
\text { minor vein quartz. }\end{array}$ \\
\hline 98SC006S & DN & $\begin{array}{l}\text { Sediment; fines to small boulders, all FeOx stained; sparse vegetation in active alluvial channel; no organic content; muscovite schist and quartzite } \\
\text { dominant, minor vein quartz. }\end{array}$ \\
\hline 98SC007S & DN & $\begin{array}{l}\text { Sediment; overbank cobbles appear to be less FeOx stained than those in active channel; no organic content; muscovite schist and quartzite dominant, } \\
\text { vein quartz with pyrite and stibnite. }\end{array}$ \\
\hline 98SC007DS & DN & Sediment; duplicate of field No. 98SC007S. \\
\hline 98SC011D & NM & B-horizon soil; undisturbed tundra just above watersite; tan, micaceous, muddy, with dark-gray ferricrete; low organic content. \\
\hline 98SC012D & NM & $\begin{array}{l}\text { B-horizon soil; undisturbed tundra just above prospect; tan, micaceous, with FeOx clots and platy quartz-muscovite fragments that look like sheared } \\
\text { vein quartz with muscovite partings; low organic content. }\end{array}$ \\
\hline
\end{tabular}


Table 6. Descriptive and analytical data for sediment, rock, and soil samples collected from the Slate Creek antimony deposit and vicinity-Continued.

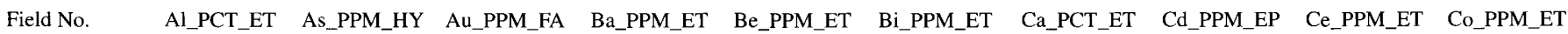

\begin{tabular}{|c|c|c|c|c|c|c|c|c|c|c|}
\hline Threshold & -- & 30 & 0.02 & 1,500 & 5 & 4 & -- & 1 & 100 & 50 \\
\hline 98SC001R & 3.6 & 2,400 & .032 & 210 & $<1$ & $<10$ & .22 & $<.05$ & 31 & $<2$ \\
\hline $98 \mathrm{SC} 002 \mathrm{R}$ & 3.8 & 77 & .008 & 570 & 1 & $<10$ & .011 & .16 & 32 & 4 \\
\hline $98 \mathrm{SC} 004 \mathrm{R}$ & 6.8 & 8.3 & .011 & 590 & 2 & $<10$ & .16 & .38 & 57 & 10 \\
\hline $98 \mathrm{SC} 008 \mathrm{R} 1$ & 4.5 & 65 & .011 & 700 & 1 & $<10$ & $<.005$ & .06 & 44 & $<2$ \\
\hline 98SC008R2 & 4.2 & 120 & .08 & 190 & 1 & $<10$ & .83 & 5 & 82 & 37 \\
\hline 98SC010R & 2.7 & 1,300 & .025 & 300 & $<1$ & $<10$ & .038 & .17 & 27 & $<2$ \\
\hline $98 \mathrm{SC} 011 \mathrm{R}$ & 4.2 & 700 & .021 & 640 & 2 & $<10$ & .016 & .35 & 53 & 49 \\
\hline $98 \mathrm{SC} 012 \mathrm{R}$ & 2.8 & 390 & .034 & 420 & $\overline{1}$ & $<10$ & .016 & 1.2 & 26 & 21 \\
\hline $98 \mathrm{SC} 001 \mathrm{~S}$ & 7.4 & 830 & .013 & 880 & 2 & 16 & .52 & .6 & 81 & 19 \\
\hline $98 \mathrm{SC} 002 \mathrm{~S}$ & 3.5 & 2,300 & .021 & 740 & 1 & $<10$ & 1.2 & .76 & 40 & 230 \\
\hline $98 \mathrm{SC} 003 \mathrm{~S}$ & 7 & 60 & .013 & 980 & 2 & $<10$ & 1.2 & 1.9 & 71 & 17 \\
\hline 98SC004S & 5.9 & 1100 & .028 & 630 & 2 & 11 & .42 & .93 & 62 & 28 \\
\hline 98SC005S & 7.3 & 440 & .02 & 780 & 2 & 27 & .55 & 4.1 & 96 & 20 \\
\hline $98 \mathrm{SC} 006 \mathrm{~S}$ & 6.1 & 1,500 & .03 & 720 & 2 & 10 & .4 & .28 & 81 & 36 \\
\hline $98 \mathrm{SC} 007 \mathrm{~S}$ & 5.7 & 2,100 & .041 & 710 & 2 & 10 & .25 & .09 & 84 & 10 \\
\hline 98SC007DS & 6 & 2,100 & .035 & 700 & 2 & $<10$ & .23 & $<.05$ & 91 & 12 \\
\hline $98 \mathrm{SC} 011 \mathrm{D}$ & 12 & 56 & $<.005$ & 1,300 & 3 & 12 & .12 & .21 & 110 & 11 \\
\hline $98 \mathrm{SC} 012 \mathrm{D}$ & 8.1 & 63 & .007 & 1,200 & 2 & $<10$ & .34 & .12 & 86 & 6 \\
\hline
\end{tabular}

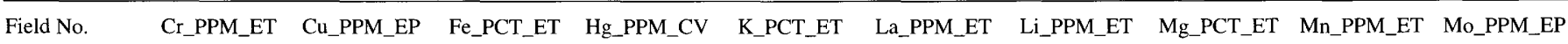

\begin{tabular}{|c|c|c|c|c|c|c|c|c|c|c|}
\hline Threshold & 200 & 75 & 5 & 0.1 & 5 & 50 & 75 & -- & 1,000 & 5 \\
\hline 98SC001R & 10 & 68 & 1.4 & 1.3 & 1.1 & 16 & $<2$ & .11 & 51 & .6 \\
\hline $98 \mathrm{SC} 002 \mathrm{R}$ & 9 & 8.3 & 1.6 & .04 & 1.5 & 16 & 69 & .16 & 240 & .4 \\
\hline $98 \mathrm{SC} 004 \mathrm{R}$ & 11 & 38 & 2.8 & $<.02$ & 2 & 29 & 39 & .41 & 300 & .7 \\
\hline 98SC008R 1 & 3 & 5.8 & 1.1 & .12 & 2 & 21 & 8 & .19 & 17 & .2 \\
\hline 98SC008R2 & 17 & 69 & 4.9 & .08 & 1.8 & 36 & 6 & 2.2 & 1,700 & .2 \\
\hline 98SC010R & 5 & 30 & 1.5 & .17 & 1 & 13 & 5 & .11 & 33 & .5 \\
\hline 98SC011R & 16 & 15 & 12 & .13 & 1.4 & 24 & 42 & .16 & 9,900 & .8 \\
\hline $98 \mathrm{SC0} 12 \mathrm{R}$ & 4 & 18 & 6.5 & .2 & 1.2 & 14 & 23 & .12 & 6,700 & .7 \\
\hline $98 \mathrm{SC} 001 \mathrm{~S}$ & 61 & 49 & 5.3 & .13 & 2.5 & 46 & 36 & .66 & 2,500 & .7 \\
\hline $98 \mathrm{SC} 002 \mathrm{~S}$ & 29 & 22 & 21 & .11 & 1.1 & 21 & 22 & .39 & 29,000 & 1.3 \\
\hline $98 \mathrm{SC} 003 \mathrm{~S}$ & 42 & 33 & 3.7 & .37 & 1.8 & 33 & 51 & .89 & 2,600 & -- \\
\hline 98SC004S & 32 & 35 & 5.4 & .1 & 2 & 34 & 26 & .57 & 2,300 & .5 \\
\hline $98 \mathrm{SC} 005 \mathrm{~S}$ & 100 & 36 & 5.5 & .1 & 2.2 & 46 & 42 & .82 & 1,500 & .7 \\
\hline $98 \mathrm{SC} 006 \mathrm{~S}$ & 37 & 37 & 6.9 & .1 & 2.1 & 37 & 27 & .58 & 2,100 & .5 \\
\hline $98 \mathrm{SC} 007 \mathrm{~S}$ & 40 & 34 & 9.1 & .12 & 2.3 & 42 & 18 & .37 & 820 & .6 \\
\hline 98SC007DS & 40 & 35 & 8 & .31 & 2.3 & 44 & 19 & .36 & 740 & 6 \\
\hline 98SC011D & 110 & 37 & 5.5 & .17 & 4 & 55 & 38 & .74 & 760 & 1.2 \\
\hline $98 \mathrm{SC} 012 \mathrm{D}$ & 74 & 26 & 4 & .06 & 2.6 & 40 & 41 & .54 & 550 & 2.3 \\
\hline
\end{tabular}

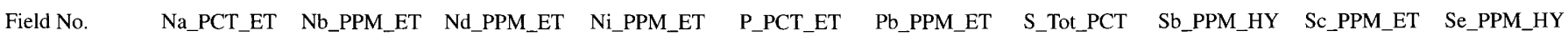

\begin{tabular}{|c|c|c|c|c|c|c|c|c|c|c|}
\hline Threshold & -- & 50 & -- & 80 & 0.1 & 40 & -- & 4 & -- & 1.5 \\
\hline 98SC001R & .038 & $<4$ & 16 & $<3$ & .01 & 67 & 3.4 & 99,000 & 6 & 1.3 \\
\hline $98 \mathrm{SC} 002 \mathrm{R}$ & .071 & 5 & 16 & 10 & .015 & 11 & $<.05$ & 10 & 4 & $<.2$ \\
\hline $98 \mathrm{SC} 004 \mathrm{R}$ & 1.1 & 10 & 27 & 30 & .015 & 20 & .21 & 4.6 & 9 & .2 \\
\hline $98 \mathrm{SC} 008 \mathrm{R} 1$ & .071 & 4 & 22 & 4 & .005 & 32 & 6 & 150 & 5 & $<.2$ \\
\hline 98SC008R2 & .071 & 7 & 48 & 100 & .075 & 15 & 7 & 90 & 13 & $<.2$ \\
\hline 98SC010R & .052 & $<4$ & 14 & 4 & .01 & 1,200 & 1.5 & 13,000 & 3 & $<.2$ \\
\hline $98 \mathrm{SC} 011 \mathrm{R}$ & .071 & 5 & 46 & 86 & .035 & 18 & $<.05$ & 53 & 5 & $<.2$ \\
\hline $98 \mathrm{SC} 012 \mathrm{R}$ & .052 & $<4$ & 27 & 58 & .02 & 120 & .11 & 380 & 4 & $<.2$ \\
\hline $98 \mathrm{SC} 001 \mathrm{~S}$ & .45 & 17 & 54 & 60 & .08 & 34 & .08 & 130 & 12 & .3 \\
\hline $98 \mathrm{SC} 002 \mathrm{~S}$ & 2 & $<4$ & 60 & 430 & .06 & 10 & .07 & 450 & 5 & .4 \\
\hline $98 \mathrm{SC003S}$ & .98 & 13 & 42 & 56 & .1 & 20 & .06 & 12 & 12 & 2.1 \\
\hline $98 \mathrm{SC} 004 \mathrm{~S}$ & .47 & 6 & 42 & 59 & .055 & 40 & .31 & 1,200 & 10 & .2 \\
\hline $98 \mathrm{SC} 005 \mathrm{~S}$ & 6 & 23 & 54 & 69 & .09 & 34 & .08 & 84 & 13 & .2 \\
\hline $98 \mathrm{SC} 006 \mathrm{~S}$ & .32 & 5 & 47 & 63 & .05 & 43 & .87 & 3,000 & 10 & .2 \\
\hline $98 \mathrm{SC} 007 \mathrm{~S}$ & .22 & 10 & 55 & 20 & .05 & 50 & .9 & 6,000 & 11 & .3 \\
\hline 98SC007DS & .23 & 10 & 57 & 23 & .05 & 52 & .78 & 5,200 & 10 & $<.2$ \\
\hline $98 \mathrm{SC} 011 \mathrm{D}$ & .28 & 21 & 63 & 30 & .045 & 51 & $<.05$ & 85 & 20 & .4 \\
\hline 98SC012D & .54 & 16 & 45 & 27 & .095 & 68 & .05 & 43 & 11 & 1.2 \\
\hline
\end{tabular}

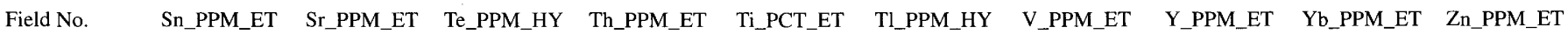

\begin{tabular}{|c|c|c|c|c|c|c|c|c|c|c|}
\hline Threshold & 10 & -- & 0.05 & 20 & -- & -- & 100 & 50 & -- & 150 \\
\hline $98 \mathrm{SC} 001 \mathrm{R}$ & $<5$ & 55 & .4 & $<6$ & .012 & 2.3 & 5 & 6 & $<1$ & 270 \\
\hline $98 \mathrm{SC} 002 \mathrm{R}$ & $<5$ & 36 & $<.1$ & 11 & .11 & .5 & 30 & 4 & $<1$ & 62 \\
\hline $98 \mathrm{SCO04R}$ & $<5$ & 76 & $<.1$ & 12 & .19 & .7 & 62 & 11 & 2 & 60 \\
\hline 98SC008R 1 & $<5$ & 53 & $<.1$ & 6 & .13 & .9 & 34 & 4 & $<1$ & 20 \\
\hline 98SC008R2 & $<5$ & 68 & $<.1$ & 40 & .16 & 8 & 37 & 27 & 4 & 420 \\
\hline 98SC010R & $<5$ & 31 & $<.1$ & $<6$ & .05 & .8 & 11 & 5 & $<1$ & 21 \\
\hline $98 \mathrm{SC} 011 \mathrm{R}$ & 7 & 39 & .2 & 16 & .11 & .5 & 39 & 18 & 2 & 220 \\
\hline $98 \mathrm{SC0} 12 \mathrm{R}$ & $<5$ & 26 & 2 & $<6$ & .08 & 6 & 24 & 12 & 2 & 140 \\
\hline $98 \mathrm{SC} 001 \mathrm{~S}$ & $<5$ & 120 & $<.1$ & 15 & .43 & .7 & 83 & 14 & 2 & 140 \\
\hline $98 \mathrm{SC} 002 \mathrm{~S}$ & 5 & 110 & .2 & 16 & .12 & .4 & 50 & 15 & 2 & 280 \\
\hline $98 \mathrm{SC} 003 \mathrm{~S}$ & $<5$ & 170 & $<.1$ & 10 & .38 & 6 & 110 & 17 & 2 & 190 \\
\hline $98 \mathrm{SC} 004 \mathrm{~S}$ & $<5$ & 91 & .1 & 12 & .35 & .9 & 64 & 12 & 2 & 240 \\
\hline $98 \mathrm{SCO} 05 \mathrm{~S}$ & $<5$ & 120 & $<.1$ & 17 & 62 & 9 & 91 & 14 & 2 & 570 \\
\hline $98 \mathrm{SC} 006 \mathrm{~S}$ & $<5$ & 90 & $<.1$ & 16 & .31 & $<1$ & 65 & 13 & 2 & 160 \\
\hline $98 \mathrm{SC} 007 \mathrm{~S}$ & $<5$ & 84 & .1 & 15 & .22 & .8 & 54 & 23 & 2 & 68 \\
\hline 98SC007DS & $<5$ & 87 & $<.1$ & 16 & .27 & 1 & 56 & 20 & $\overline{2}$ & 84 \\
\hline $98 \mathrm{SC} 011 \mathrm{D}$ & $<5$ & 86 & .1 & 23 & .38 & 1.5 & 110 & 17 & 3 & 110 \\
\hline 98SC012D & 6 & 120 & $<.1$ & 17 & .33 & 1 & 110 & 10 & 2 & 170 \\
\hline
\end{tabular}


lous contents of $\mathrm{Co}, \mathrm{Fe}$, and $\mathrm{Ni}$ and lower-level anomalous contents of $\mathrm{Au}, \mathrm{Bi}, \mathrm{Hg}$, and $\mathrm{Zn}$ in naturally mineralized sediment; (3) lower-level anomalous contents of $\mathrm{Bi}, \mathrm{Ce}, \mathrm{Fe}, \mathrm{Hg}$, $\mathrm{La}, \mathrm{Pb}$, Th, and, possibly, $\mathrm{V}$ and $\mathrm{Zn}$ in naturally mineralized soils, and (4) lower-level anomalous contents of $\mathrm{Au}, \mathrm{Bi}, \mathrm{Fe}$, $\mathrm{Hg}, \mathrm{Pb}$, and $\mathrm{Zn}$ in stream sediment downstream from the mine and mineralized area.

Dames \& Moore (1992) collected one soil sample above and four soil samples within the disturbed mining area. Although their suite of element determinations was limited, they measured high $\mathrm{As}, \mathrm{Fe}$, and $\mathrm{Pb}$ contents in the soil collected above and high $\mathrm{As}, \mathrm{Cu}, \mathrm{Fe}, \mathrm{Ni}, \mathrm{Pb}, \mathrm{Sb}$, and $\mathrm{Zn}$ contents in one or more of four samples from the disturbed mining area. $\mathrm{Hg}$ was not detected, and $\mathrm{Au}, \mathrm{Bi}, \mathrm{Co}$, and $\mathrm{Mn}$ were not determined, in their study.

Mine waste and mineralized outcrop within the disturbed mining area (field Nos. 98SC008R1, 98SC008R2, 98SC010R, 98SC012R, table 6) contained highly anomalous contents of $\mathrm{As}, \mathrm{Sb}, \mathrm{Fe}$, and $\mathrm{Pb}$ and lower-level anomalous contents of $\mathrm{Au}, \mathrm{Cd}, \mathrm{Hg}, \mathrm{Mn}, \mathrm{Ni}, \mathrm{S}, \mathrm{Th}, \mathrm{Zn}$, and, possibly, Te. Colluvium and outcrop samples collected away from the disturbed mining area (field Nos. 98SC001R, 98SC002R, 98SC004R, 98SC011R, table 6) had elemental suites similar to those of the mine waste and mineralized outcrop at the minesite, with highly anomalous contents of $\mathrm{As}$ and $\mathrm{Sb}$ and lower-level anomalous contents of $\mathrm{Au}, \mathrm{Hg}, \mathrm{Mn}, \mathrm{Ni}, \mathrm{Pb}, \mathrm{Zn}$, and, possibly, Te.

\section{Conclusions}

The low $\mathrm{pH}$ values and predominance of sulfate in minerelated waters are due largely to the dissolution of pyrite and related chemical reactions, as described by Nordstrom and Alpers (1999). Stream waters downstream from the minesite are intermediate in composition with respect to bicarbonate and sulfate and have near-neutral $\mathrm{pH}$ values, which probably reflect mixing of bicarbonate-dominant, near-neutral $\mathrm{pH}$ waters with mineralized, acidic, sulfate-dominant waters. As mixing occurs and $\mathrm{pH}$ values rise, $\mathrm{Fe}$ oxide is deposited from the Ferich waters as flocs and coatings on alluvial cobbles, resulting in the conspicuous red-stained alluvial cobbles along most of the upper reach of Slate Creek (fig. 5). Metals mobile at low $\mathrm{pH}$ values, such as $\mathrm{Al}, \mathrm{As}, \mathrm{Co}, \mathrm{Cu}$, and $\mathrm{Ni}$, are abundant in the mine-related waters but are quickly coprecipitated with the $\mathrm{Fe}$ oxide flocs and coatings upon mixing with bicarbonate waters. Concentrations of these species are continually building up over time in the Fe oxide flocs and coatings. Other abundant species in mine-related waters, such as $\mathrm{Mn}, \mathrm{Sb}, \mathrm{SO}_{4}^{2-}$, and $\mathrm{Zn}$, are still mobile at higher $\mathrm{pH}$ values and remain in solution downstream but in lower concentrations, owing to dilution.

Alkalinities in stream waters above and below the Slate Creek antimony deposit had a mean of $78 \mathrm{mg} / \mathrm{L}$ (as equivalent $\mathrm{CaCO}_{3}$ ). The alkalinity at site $98 \mathrm{SC} 007$ (fig. 3), immediately below the mine wastepile and associated acidic mine drainage, was also $78 \mathrm{mg} / \mathrm{L}$ (fig. 5). Though not high, these alkalinities

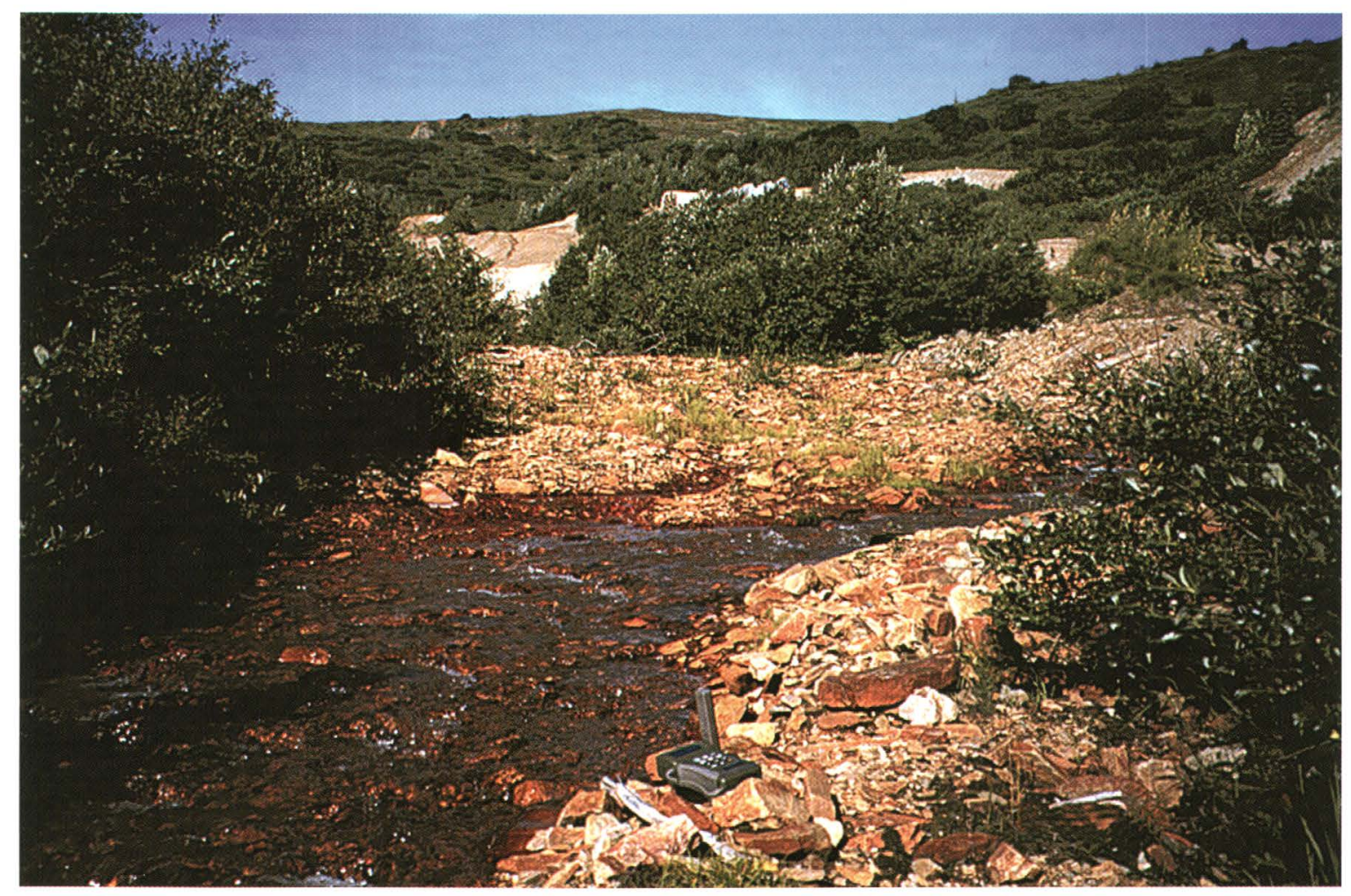

Figure 5. Site $98 \mathrm{SC007}$ (pH value, 6.9; conductivity, $260 \mu \mathrm{S} / \mathrm{cm}$; total-dissolved-solids content, $246 \mathrm{mg} / \mathrm{L}$ ) on Slate Creek immediately below the Slate Creek antimony deposit (see figs. 1, 3 for location). Red Fe oxide coatings on alluvial cobbles are common along much of lower Slate Creek. Mine wastepiles are visible in distance; Global Positioning System (GPS) unit in foreground for scale. 
suggest that the streams still have the capacity to consume acid. Thus, if hydrologic conditions at the minesite change and the flow of acidic water is increased, the ecosystem should be able to consume some, if not all, of this acidic water. We note that precipitation and snowmelt would be the most likely causes of increased flow of acidic mine water and that corresponding flow increases would be expected for surrounding bicarbonate-dominant streams, a feature that would aid the natural reduction of acid and metal lodes in the water. The origin of the bicarbonate in the spring and stream waters could be calcium carbonate; however, no megascopic calcite was observed at the minesite or in the surrounding rocks. Accessory calcite may be present in the Precambrian metamorphic rocks. Alternatively, the bicarbonate and associated alkalinities could be derived from atmospheric $\mathrm{CO}_{2}$ and produced by organic matter, as described in Hem (1985), or from reactions with accessory mafic minerals within the Precambrian metamorphic rocks, as described by Nesbitt and Jambor (1998) and Desborough and others (1998).

The naturally mineralized springs at site 98SC011 (fig. 6; located within the same mineralized zone as the mine but outside the disturbed mining area) and at site $98 \mathrm{SC} 013$ (at 1,800$\mathrm{ft}[550 \mathrm{~m}]$ elevation, below the minesite but draining ground from the opposite side of the valley from the mine and wastepiles) probably provide conservative estimates for premining spring-water compositions at the minesite. With $\mathrm{pH}$ values of 5.6 and 7.7 and conductivities of 750 and $300 \mu \mathrm{S} / \mathrm{cm}$, respectively, these springs indicate premining spring waters that naturally ranged from acidic to neutral in $\mathrm{pH}$ value, had relatively high conductivities, had varyingly high TDS contents, were Fe rich, and were metalliferous. However, these naturally degraded waters were further degraded by historical mining activities in upper Slate Creek. The water presently flowing from the minesite has lower $\mathrm{pH}$ values, higher conductivities, and much higher metallic-ion contents relative to the naturally mineralized springs, as a result of several factors - surface disruption, concentration of sulfides (principally pyrite, but also arsenopyrite and stibnite) in mine wastepiles, particle-size reduction in the mine wastepiles relative to the solid bedrock from which they are derived (which exposes more sulfide surface area to weathering), and exposure of sulfides in the wastepile to oxidation processes. The original adits were long ago destroyed by weathering, structural failure, and subsequent surface-mining activities, but the collapsed openings presently provide conduits for ground-water passage through the mineralized bedrock into the mine wastepiles. The red-stained alluvial gravel along the upper reach of Slate Creek (see fig. 5 ) and the naturally mineralized Fe oxide-rich springs at the head of the Slate Creek basin (see fig. 6) were probably present before, and aided prospectors in, the discovery of the Slate Creek antimony deposit, although the extent of iron staining of alluvial cobbles along Slate Creek has been exacerbated by the historical mining activity.

Even though none of the sampled stream waters exceeded EPA aquatic-life standards, aquatic life along Slate Creek is

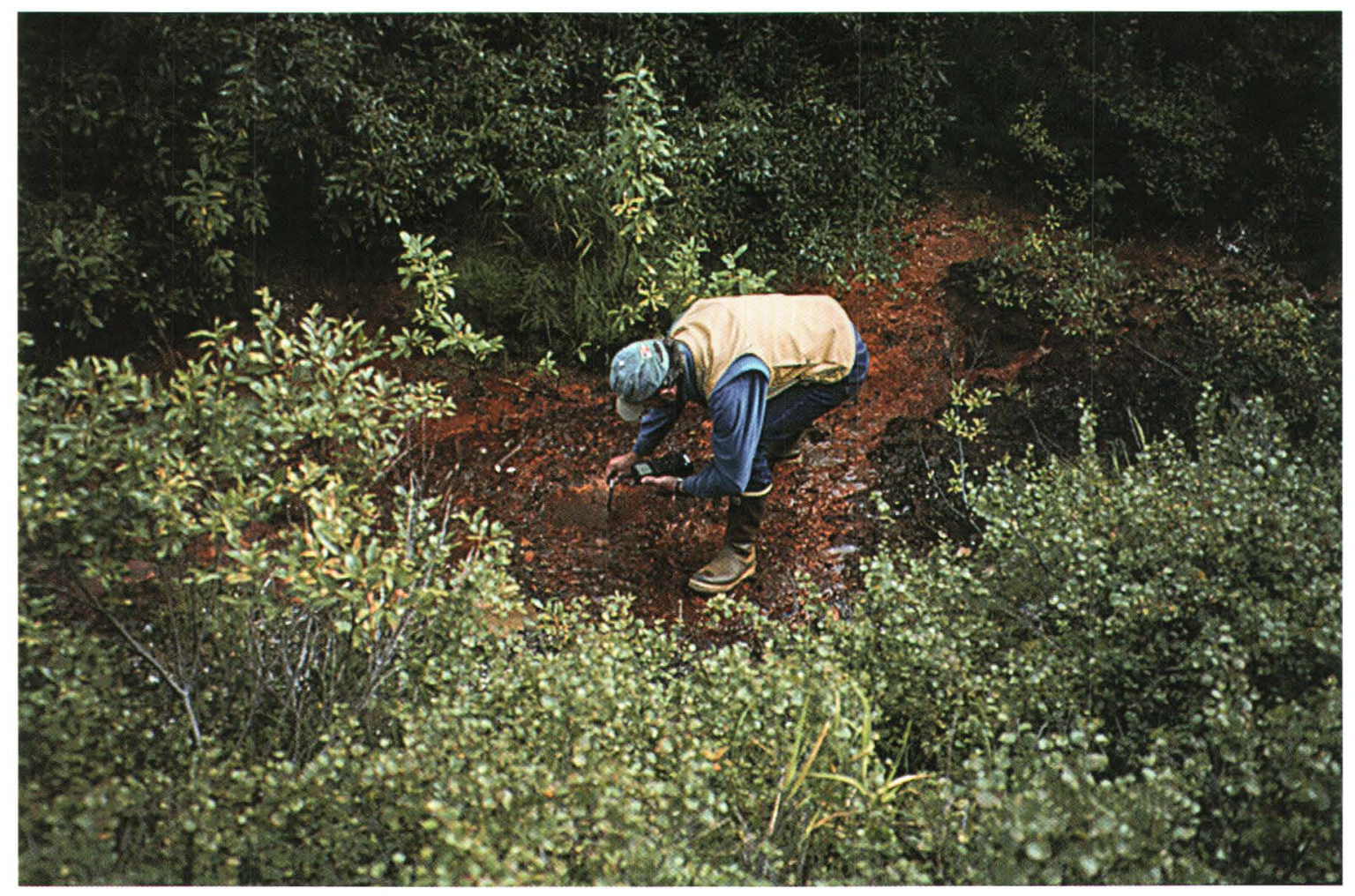

Figure 6. Site $98 \mathrm{SC} 011$ ( $\mathrm{pH}$ value, 5.6 ; conductivity, $750 . \mu \mathrm{S} / \mathrm{cm}$; total-dissolved-solids content, $544 \mathrm{mg} / \mathrm{L}$ ), showing natural spring within mineralized zone adjacent to the Slate Creek antimony deposit (see figs. 1, 3 for location). Extensive orange and red $\mathrm{Fe}$ oxide precipitates coat and cement together organic debris and mica schist colluvium. 
evidently compromised because no algae were observed in the creekbed from the confluence with Eldorado Creek to the Slate Creek antimony deposit, a reach of nearly $2 \mathrm{mi}(3.2 \mathrm{~km})$. Qualitatively, the alluvium in Slate Creek was not at all "slippery," as is commonly observed in streambeds with a healthy algal population, and sparse to no vegetation was growing in the active stream channel. In contrast, Eldorado Creek and the side drainages flowing into Slate Creek contained abundant algae, and active channels were well vegetated. EPA nonregulatory water-quality-guideline concentrations for $\mathrm{Sb}$ are 1,600 $\mu \mathrm{g} / \mathrm{L}$ (freshwater chronic standard) and 9,000 $\mu \mathrm{g} / \mathrm{L}$ (freshwater acute standard) (Environmental Protection Agency, 1980), 10 times larger than the highest value of $220 \mu \mathrm{g} / \mathrm{L}$ found in mine drainage in the present study (table 4). The EPA also states that "toxicity to algae can occur at concentrations as low as $610 \mu \mathrm{g} / \mathrm{L}$ " (Environmental Protection Agency, 1980). The stream waters along Slate Creek below the mine area range in $\mathrm{Sb}$ content from 100 to $190 \mu \mathrm{g} / \mathrm{L}$ (table 4 ). If the Sb content of stream waters is responsible for the absence of algae and vegetation along Slate Creek, then the above nonregulatory guidelines for antimony may be too high. Clearly, more work needs to be done along Slate Creek to determine the cause for the absence of algae and vegetation.

Stream-sediment, rock, and soil samples, both from sites affected by historical mining activities and from sites unaffected by mining, have highly anomalous $\mathrm{As}$ and $\mathrm{Sb}$ contents. Several other elements, including $\mathrm{Au}, \mathrm{Bi}, \mathrm{Cd}, \mathrm{Ce}$, $\mathrm{Co}, \mathrm{Fe}, \mathrm{Hg}, \mathrm{La}, \mathrm{Mn}, \mathrm{Ni}, \mathrm{Pb}, \mathrm{S}$, Th, and $\mathrm{Zn}$, also are present in anomalous concentrations in one or more of these samples. The widespread presence of anomalous concentrations of this suite of elements in samples from the mineralized area, but outside the disturbed mining area, and in samples collected elsewhere in the Slate Creek drainage suggests that mineralized rocks (and the soils and sediment derived from them) are present beyond the known boundaries of the minesite, as demonstrated at site $98 \mathrm{SC} 002$, located upstream of the mine but approximately on strike with the mineralized vein system. The stream-sediment sample from this site had the highest As, $\mathrm{Co}, \mathrm{Fe}, \mathrm{Mn}$, and Ni contents of all the streamsediment samples, including those from just below the mine wastepiles, and also had high Sb contents. The orange-red, Fe-rich, fine sediment present at site 98SC002 is a metallic-ion sink that likely has been accumulating metals derived from upstream rocks and transported by spring and stream waters for thousands of years. Metalliferous ferricrete sampled from a spring at site $98 \mathrm{SC} 011$ (figs. 3, 5), and ferricrete deposits several feet thick observed in alluvium at several places downstream along Slate Creek, both indicate probable premining metallic-ion accumulations transported by Fe-rich spring and stream waters.

Anomalous $\mathrm{Hg}$ contents $(0.1-1.3 \mathrm{ppm}$; mean, $0.25 ; n=14)$ were measured in 14 of the 18 stream-sediment, rock, and soil samples collected within and outside the minesite, and in sediment samples downstream from the mineralized area. The presence of anomalous $\mathrm{Hg}$ contents in stream sediment, rocks, and soils outside the mine area indicates that the mercury is natural and not anthropogenic. No mercury was detected in water samples in this study or in Dames \& Moore's (1992) study (detection limits, 0.005 and $0.2 \mu \mathrm{g} / \mathrm{L}$, respectively), suggesting that the mercury present in stream sediment, rocks, and soils occurs in a stable mineral phase under surficial conditions. Anomalous $\mathrm{Hg}$ contents are not uncommon in simple antimony deposits (Bliss and Orris, 1986), and the mineral phase is commonly cinnabar, a mercury sulfide mineral highly stable in the surficial environment (J.E. Gray, written commun., 1999). Thus, it is unlikely that mercury poses a threat to the aquatic environment.

Bundtzen (1981) listed several stibnite-quartz vein deposits within the Kantishna belt that appear to be similar to the Slate Creek antimony deposit, including the Stampede deposit, the largest antimony producer in the district. If, as appears likely, these vein deposits also contain pyrite, then acid-generation and mine-drainage waters similar to those at Slate Creek would be expected. The geochemical data from this study indicate that the stibnite-antimony vein system at the Slate Creek antimony deposit extends beyond the disturbed mining area, and demonstrate that naturally high concentrations of potentially toxic metals are present in the surrounding area. These environmental-geochemical features are not unique to the Slate Creek antimony deposit and should be considered before remediation efforts at other historical antimony deposits within the Kantishna belt.

\section{Acknowledgments}

We thank the staff of Denali National Park and Preserve for their cooperation in allowing us access to the Slate Creek basin. We especially thank Ken Karle, DENA staff hydraulic engineer, for providing camp, helicopter, and other logistic support during our fieldwork, and for reviewing the manuscript. Vanessa Ballestrazze drafted the illustrations.

\section{References Cited}

Alaska Department of Environmental Conservation, 2000, Drinking water: Report 18-ACC-80, 244 p. [URL: http://www.state.ak.us/ dec/title18/18aacdnl.htm, accessed October 22, 2001].

Arbogast, B.F., ed., 1996, Analytical methods manual for the Mineral Resource Surveys Program, U.S. Geological Survey: U.S. Geological Survey Open-File Report 96-525, $248 \mathrm{p}$.

Bliss, J.D., and Orris, G.J., 1986, Descriptive model of simple Sb deposits, in Cox, D.P., and Singer, D.A., eds., Mineral deposit models: U.S. Geological Survey Bulletin 1693, p. 183-186.

Brooks, A.H., 1916, Antimony deposits of Alaska: U.S. Geological Survey Bulletin 649, p. 67-69.

Brooks, A.H., and others, 1909, Mineral resources of Alaska; report on progress of investigations in 1908: U.S. Geological Survey Bulletin $379,418 p$

1910, Mineral resources of Alaska; report on progress of investigations in 1909: U.S. Geological Survey Bulletin 442, 432 p. 1912, Mineral resources of Alaska; report on progress of investigations in 1911: U.S. Geological Survey Bulletin 520, 360 p. 
-1913, Mineral resources of Alaska; report on progress of investigations in 1912: U.S. Geological Survey Bulletin 542, 308 p. 1914, Mineral resources of Alaska; report on progress of investigations in 1913: U.S. Geological Survey Bulletin 592, 413 p.

Bundtzen, T.K., 1978, A history of mining in the Kantishna Hills: Alaska Journal, v. 8, no. 2, p. 150-161.

-1981, Geology and mineral deposits of the Kantishna Hills, Mount McKinley Quadrangle, Alaska: Fairbanks, Alaska, University of Alaska M.S. thesis, $238 \mathrm{p}$.

-1983, Mineral-resource modeling, Kantishna-Dunkle minestudy areas, Alaska: Alaska Division of Geological and Geophysical Surveys Report of Investigation 83-12, 51 p. 1994, Kantishna district, in Nokleberg, W.J., Brew, D.A., Grybeck, D.J., Yeend, W.E., Bundtzen, T.K., Robinson, M.S., Smith, T.E., Berg, H.C., Andersen, G.L., Chipp, E.R., Gaard, D.R., Burton, P.J., Dunbier, John, Scherkenbach, D.A., Foley, J.Y., Thurow, Gregory, Warner, J.D., Freeman, C.J., Gamble, B.M., Nelson, S.W., Schmidt, J.M., Hawley, C.C., Hitzman, M.W., Jones, B.K., Lange, I.M., Maars, C.D., Puchner, C.C., Steefel, C.I., Menzie, W.D., Metz, P.A., Modene, J.S., Plahuta, J.T., Young, L.E., Nauman, C.R., Newkirk, S.R., Newberry, R.J., Rogers, R.K., Rubin, C.M., Swainbank, R.C., Smith, P.R., and Stephens, J.E., Metallogeny and major mineral deposits of Alaska, in Plafker, George, and Berg, H.C., eds., The geology of Alaska, v. G-1 of The geology of North America: Boulder, Colo., Geological Society of America, p. 872-873.

Bundtzen, T.K., and Turner, D.L., 1978, Geochronology of metamorphic and igneous rocks in the Kantishna Hills, Mount McKinley Quadrangle, Alaska: Alaska Division of Geological and Geophysical Surveys Geological Report 61, p. 25-30.

Capps, S.R., 1918, Mineral resources of the Kantishna region: U.S. Geological Survey Bulletin 662-E, p. 279-332.

Cobb, E.H., 1972, Metallic mineral resources map of the Mt. McKinley quadrangle, Alaska: U.S. Geological Survey Miscellaneous Field Studies Map MF-366, scale 1:250,000.

Dames \& Moore, 1992, Final level I and level II hazardous substance survey report SP-36 Antimony Lode \#1-4 and Antimony Placer \#1 and 2 Claims, Kantishna Hills, Denali National Park: Anchorage, report to the National Park Service, August 10, 1992.

Davis, J.A., 1922, The Kantishna region: Alaska Territorial Department of Mines Report MR-66-0, $85 \mathrm{p}$.

Desborough, G.A., Briggs, P.H., Mazza, N.A., and Driscoll, Rhonda, 1998, Acid-neutralizing potential of minerals in intrusive rocks of the Boulder batholith in northern Jefferson County, Montana: U.S. Geological Survey Open-File Report 98-364, 21 p.

Deutsch, W.J., 1997, Groundwater geochemistry, fundamentals and applications to contamination: New York, Lewis, 221 p.

Drever, J.I., 1997, The geochemistry of natural waters; surface and groundwater environments (3d ed.): Upper Saddle River, N.J., Prentice Hall, $436 \mathrm{p}$.

Ebbley, N.E., Jr., and Wright, W.S., 1948, Antimony deposits in Alaska: U.S. Bureau of Mines Report of Investigations 4173, 41 p.

Environmental Protection Agency, 1980, Ambient water quality criteria for antimony: Office of Water Document EPA 440-5-80-020, 7 p. [URL: http://www.epa.gov/clhtml/pubalpha.html, accessed October 22, 2001]

-1993, EPA Region VIII Clean Water Act Section 304(a) criteria chart, July 1, 1993: 12 p. [URL: http://www.epa.gov/Region8/ water/wqs/wqsdocs.html, accessed October 22, 2001]. 1999a, National primary drinking water standards: Office of Water Document EPA 810-F-94-001, 4 p. [URL: http:// www.epa.gov/safewater/mcl.html, accessed October 22, 2001]. 1999b, National recommended water quality criteria, correc- tion: Office of Water Document EPA 822-Z-99-001, 25 p. [URL: http://www.epa.gov/OST/standards/wqcriteria.html, accessed October 22, 2001].

Fechner, S.A., and Hoekzema, R.B., 1986, Distribution, analysis, and recovery of gold from Kantishna placers, Alaska: U.S. Bureau of Mines Open-File Report 1-86, $54 \mathrm{p}$.

Hawley, C.C., 1978, Mineral appraisal of lands adjacent to Mount McKinley National Park, Alaska: U.S. Bureau of Mines OpenFile Report 24-78, $184 \mathrm{p}$.

Hem, J.D., 1985, Study and interpretation of chemical characteristics of natural water, third edition: U.S. Geological Survey WaterSupply Paper 2254, 263 p.

Jeske, R.E., 1984, Regional distribution of critical and strategic minerals in the Kantishna Hills area, Denali National Park and Preserve, Alaska: U.S. Bureau of Mines Open-File Report 214-84, 101 p.

Levinson, A.A., 1980, Introduction to exploration geochemistry (2d ed.): Wilmette, III., Applied Publishing Ltd., 924 p.

Lingren, Waldemar, 1932, Mineral deposits (4th ed.): New York, McGraw-Hill, $930 \mathrm{p}$.

Martin, J.M., and Whitfield, Michael, 1983, The significance of the river input of chemical elements to the ocean, in Wong, C.S., Boyle, E.A., Bruland, K.W., Burton, J.D., and Goldberg, E.D., eds., Trace metals in sea water: New York, Plenum Press, $p$. 265-296.

Meybeck, Michel, 1988, How to establish and use world budgets of riverine materials, in Lerman, Abraham, and Meybeck, Michel, eds., Physical and chemical weathering in geochemical cycles: Dordrecht, Kluwer Academic Publishers, p. 247-272.

Moffit, F.H., 1933, The Kantishna district: U.S. Geological Survey Bulletin 836-D, p. 301-338.

Nesbitt, H.W., and Jambor, J.L., 1998, Role of mafic minerals in neutralizing $A R D$, demonstrated using a chemical weathering methodology, in Cabri, L.J., and Vaughan, D.J., eds., Modern approaches to ore and environmental mineralogy (Short Course Handbook, v. 27): Ottawa, Ontario, Canada, Mineralogical Association of Canada, p. 403-421.

Nordstrom, D.K., and Alpers, C.N., 1999, Geochemistry of acid mine waters, in Plumlee, G.S., and Logsdon, M.J., eds., Environmental geochemistry of mineral deposits, part A-processes, techniques and health issues (Reviews in Economic Geology, v. 6A): Littleton, Colo., Society of Economic Geologists, p. 133-160.

Piper, A.M., 1944, A graphic procedure in the geochemical interpretation of water analyses: American Geophysical Union Transactions, v. 25, no. 6, p. 914-923.

Prindle, L.M., 1907, The Bonnifield and Kantishna regions, Alaska: U.S. Geological Survey Bulletin 314-I, p. 205-226.

Rose, A.W., Hawkes, H.E., and Webb, J.S., 1979, Geochemistry in mineral exploration ( $2 \mathrm{~d}$ ed.): London, Academic Press, $657 \mathrm{p}$.

Seal, R.R., II, Bliss, J.D., and Campbell, D.L., 1995, Stibnite-quartz deposits, in du Bray, E.A., ed., Preliminary compilation of descriptive geoenvironmental mineral deposit models: U.S. Geological Survey Open-File Report 95-831, p. 204-208.

Smith, K.S., and Huyck, H.L.O., 1999, An overview of the abundance, relative mobility, bioavailability, and human toxicity of metals, in Plumlee, G.S., and Logsdon, M.J., eds., Environmental geochemistry of mineral deposits, part A-processes, techniques and health issues (Reviews in Economic Geology, v. 6A): Society of Economic Geologists, p. 29-70.

White, L.P., White, B.A., and Dillon, J.T., 1986, Quantifying the economic potential of undiscovered mineral resources - a case study of Kantishna Hills, Alaska: U.S. Bureau of Mines Mineral Issues, $24 \mathrm{p}$. 

Studies by the U.S. Geological Survey in Alaska, 2000

\title{
U.S. Geological Survey Reports on Alaska Released in 2000
}

\author{
Compiled by John P. Galloway
}

[Some reports dated 1999, 1998, or 1997 that did not become available until 2000 are included]

Ager, T.A., 2000, Postglacial vegetation history of the Kachemak Bay area, Cook Inlet, south-central Alaska, in Kelley, K.D., and Gough, L.P., eds., 2000, Geologic studies in Alaska by the U.S. Geological Survey, 1998: U.S. Geological Survey Professional Paper 1615, p. 147-165.

Berg, H.C., 1999, Alaska resource data file, Ketchikan quadrangle: U.S. Geological Survey Open-File Report 99-525, 433 p.

Brabets, T.P., Wang, Bronwen, and Meade, R.H., 2000, Environmental and hydrologic overview of the Yukon River basin, Alaska and Canada: U.S. Geological Survey Water-Resources Investigations Report 99-4204, $106 \mathrm{p}$.

Bradley, D.C., Parrish, Randall, Clendenen, William, Lux, Daniel, Layer, P.W., Heizler, Matthew, and Donley, D.T., 2000, New geochronological evidence for the timing of early Tertiary ridge subduction in southern Alaska, in Kelley, K.D., and Gough, L.P., eds., 2000, Geologic studies in Alaska by the U.S. Geological Survey, 1998: U.S. Geological Survey Professional Paper 1615, p. 5-21.

Bradley, D.C. and Wilson, F.H., 2000, Reconnaissance bedrock geology of the southeastern part of the Kenai quadrangle, Alaska, in Kelley, K.D., and Gough, L.P., eds., 2000, Geologic studies in Alaska by the U.S. Geological Survey, 1998: U.S. Geological Survey Professional Paper 1615, p. 59-63.

Brosgé, W.P., and Reiser, H.N., 2000, Geologic map of the Christian quadrangle, Alaska: U.S. Geological Survey Open-File Report 00-192, 13 p., scale 1:250,000.

Bruhn, R.L., 1998, Earthquake hazard of the Upper Cook Inlet Fold Belt, greater Anchorage area, Alaska: U.S. Geological Survey report under contract 1434-H1-96-GR-02743, $9 \mathrm{p}$.

Day, W.C., Gamble, B.M., Henning, M.W., and Smith, B.D., 2000, Geologic setting of the Fortymile River area-polyphase deformational history within part of the eastern Yukon-Tanana uplands of Alaska, in Kelley, K.D., and Gough, L.P., eds., 2000, Geologic studies in Alaska by the U.S. Geological Survey, 1998: U.S. Geological Survey Professional Paper 1615, p. 65-82.

Dorava, J.M., and Love, Andra, 1999, Concentrations of fecal coliform bacteria in creeks, Anchorage, Alaska, August and September 1998: U.S. Geological Survey Open-File Report 99-236, 9 p.

Dumoulin, J.A., Bradley, D.C., and Harris, A.G., 2000, Paleozoic strata of the Dyckman Mountain area, northeastern Medfra quadrangle Alaska, in Kelley, K.D., and Gough, L.P., eds., 2000, Geologic studies in Alaska by the U.S. Geological Survey, 1998: U.S. Geological Survey Professional Paper 1615, p. 43-57.

Eppinger, R.G., Briggs, P.H., Rosenkrans, Danny, and Ballestrazze, Vanessa, 2000, Environmental geochemical studies of selected mineral deposits in Wrangell-St. Elias National Park and Preserve, Alaska: U.S. Geological Survey Professional Paper 1619, 41 p.

Evans, KR., Carlson, P.R., Hampton, M.A., Marlow, M.S., and Barnes, P.W., 2000, Map of distribution of bottom sediments on the continental shelf, Gulf of Alaska: U.S. Geological Survey Miscellaneous Field Studies Map MF-2335, scale 1:1,000,000.

Farmer, G.L., Goldfarb, R.J., Lilly, M.R., Bolton, Bob, Meier, A.L., and Sanzolone, R.F., 2000, The chemical characteristics of ground water near Fairbanks, Alaska, in Kelley, K.D., and Gough, L.P., eds., 2000, Geologic studies in Alaska by the U.S. Geological Survey, 1998: U.S. Geological Survey Professional Paper 1615, p. 167-178.

Fleming, M.D., 1999, AVHRR images for developing a circumpolar arctic vegetation map, in Markon, C.J., and Walker, D.A., eds., Proceedings of the Third International Circumpolar Arctic Vegetation Mapping Workshop: U.S. Geological Survey Open-File Report 99-551, p. 26-27.

Ford, A.B., and Brew, D.A., 2000, Summary information about platinumgroup elements and other trace metals in greenstones of the Wrangellia terrane and the Gravina belt, southeastern Alaska: U.S. Geological Survey Open-File Report 00-256, 44 p.

Freeman, C.J., and Schaefer, Janet, 1999, Alaska resource data file, Livengood quadrangle: U.S. Geological Survey Open-File Report 99-574, $464 \mathrm{p}$.

Frenzel, S.A., 2000, Selected organic compounds and trace elements in streambed sediments and fish tissues, Cook Inlet basin, Alaska: U.S. Geological Survey Water-Resources Investigations Report 00-4004, 39 p.

Frenzel, S.A., and Dorava, J.M., 1999, Water-quality data for the Talkeetna River and four streams in National Parks, Cook Inlet Basin, Alaska, 1998: U.S. Geological Survey Open-File Report 99-459, $58 \mathrm{p}$.

Freymueller, J.T., 1997, Regional tectonics of southern Alaskaextracting the "gold" from existing GPS data: U.S. Geological Survey report under contract 1434-HQ-97-GR-03056, 9 p.

Galloway, J.P., and Toussaint, Susan, 2000, Reports on Alaska in nonUSGS publications released in 1998, in Kelley, K.D., and Gough, L.P., eds., 2000, Geologic studies in Alaska by the U.S. Geological Survey, 1998: U.S. Geological Survey Professional Paper 1615 , p. 223-224.

2000, U.S. Geological Survey reports on Alaska released in 1998, in Kelley, K.D., and Gough, L.P., eds., 2000, Geologic studies in Alaska by the U.S. Geological Survey, 1998: U.S. Geological Survey Professional Paper 1615, p. 221-222. 
Gray, J.E., Lee, G.K., O'Leary, R.M., and Theodorakos, P.M., 1999, Geochemical data for stream-sediment, heavy-mineral-concentrate, and rock samples collected from the Fortyseven Creek gold-arsenic-antimony-tungsten prospect, southwestern Alaska: U.S. Geological Survey Open-File Report 99-584, 22 p.

Greninger, M.L., Klemperer, S.L., and Nokleberg, W.J., 1999, Geographic information systems (GIS) compilation of geological and geophysical data from the Circum-North Pacific, in Nokleberg, W.J., and Diggles, M.F., eds.: U.S. Geological Survey Open-File Report 99-422 [CD-ROM].

Hildreth, Wes, Fierstein, Judy, Lanphere, M.A., and Siems, D.F., 2000, Mount Mageik-a compound stratovolcano in Katmai National Park, in Kelley, K.D., and Gough, L.P., eds., 2000, Geologic studies in Alaska by the U.S. Geological Survey, 1998: U.S. Geological Survey Professional Paper 1615, p. 23-41.

Hudson, Travis, 1999, Alaska resource data file, Solomon quadrangle: U.S. Geological Survey Open-File Report 99-573, 360 p.

Hudson, T.L., and Saltus, R.W., 2000, Bedrock assemblages of the Bering Strait region-implications for offshore metal sources in the marine environment, in Kelley, K.D., and Gough, L.P., eds., 2000, Geologic studies in Alaska by the U.S. Geological Survey, 1998: U.S. Geological Survey Professional Paper 1615, p. 111-125.

Johnsson, M.J., and Sokol, N.K., 2000, Stratigraphic variation in petrographic composition of Nanushuk Group sandstones at Slope Mountain, North Slope, Alaska, in Kelley, K.D., and Gough, L.P., eds., 2000, Geologic studies in Alaska by the U.S. Geological Survey, 1998: U.S. Geological Survey Professional Paper 1615, p. 83-100.

Kelley, K.D., and Gough, L.P., 2000, Introduction, in Kelley, K.D., and Gough, L.P., eds., 2000, Geologic studies in Alaska by the U.S. Geological Survey, 1998: U.S. Geological Survey Professional Paper 1615, p. 1-3.

eds., 2000, Geologic studies in Alaska by the U.S. Geological Survey, 1998: U.S. Geological Survey Professional Paper 1615, $224 \mathrm{p}$.

Kelley, K.D., Leach, D.L., and Johnson, C.A., 2000, Sulfur-, oxygen-, and carbon-isotope studies of $\mathrm{Ag}-\mathrm{Pb}-\mathrm{Zn}$ vein-breccia occurrences, sulfide-bearing concretions, and barite deposits in the north-central Brooks Range, with comparisons to shale-hosted stratiform massive sulfide deposits, in Kelley, K.D., and Gough, L.P., eds., 2000, Geologic studies in Alaska by the U.S. Geological Survey, 1998: U.S. Geological Survey Professional Paper 1615, p. 189-201.

Markon, C.J., 1999, Characteristics of the Alaskan 1-km advanced very high resolution radiometer data sets used for analysis of vegetation biophysical properties: U.S. Geological Survey Open-File Report 99-410, $86 \mathrm{p}$.

Markon, C.J., and Walker, D.A., eds., 1999, Proceedings of the Third International Circumpolar Arctic Vegetation Mapping Workshop: U.S. Geological Survey Open-File Report 99-551, 80 p.

McNamara, Daniel, and Hansen, R.A., 2000, Determination of source parameters and wave attenuation characteristics in Alaska: U.S. Geological Survey report under contract 98-HQ-GR-1007, 7 p.

Miller, M.L., Tucker, R.D., Layer, P.W., and Bundtzen, T.K., 2000, Isotopic ages from intrusive rocks near the Stuyahok gold placer deposits, south-central Holy Cross quadrangle, Alaska, in Kelley, K.D., and Gough, L.P., eds., 2000, Geologic studies in Alaska by the U.S. Geological Survey, 1998: U.S. Geological Survey Professional Paper 1615, p. 179-188.

Miller, Tom, 1999, Volcanic ash hazards to aviation across the North Pacific, in Guffanti, M.C., Bacon, C.R., Hanks, T.C., and Scott,
W.E., eds., Proceedings of the workshop on present and future directions in volcano-hazard assessments: U.S. Geological Survey Open-File Report 99-339, p. 12.

Moore, T.E., Houseknecht, D.W., and Potter, C.J., 2000, Apatite fissiontrack analysis of twelve outcrop samples from the Chandler Lake and Killik River 1:250,000-scale quadrangles, south-central North Slope, Alaska: U.S. Geological Survey Open-File Report 00-220, $31 \mathrm{p}$.

Muhs, D.R., Ager, T.A., Been, J.M., Rosenbau, J.G., and Reynolds, R.L., 2000, An evaluation of methods for identifying and interpreting buried soils in late Quaternary loess in Alaska, in Kelley, K.D., and Gough, L.P., eds., 2000, Geologic studies in Alaska by the U.S. Geological Survey, 1998: U.S. Geological Survey Professional Paper 1615, p. 127-146.

Nelson, S.L., and Miller, M.L., 2000, Assessment of mineral resource tracts in the Chugach National Forest, Alaska: U.S. Geological Survey Open-File Report 00-26, $21 \mathrm{p}$.

Patton, W.W., Jr., and Moll-Stalcup, E.J., 2000, Geologic map of the Nulato quadrangle, west-central Alaska: U.S. Geological Survey Geologic Investigations Series I-2677, 41 p., scale 1: 250,000

Pilcher, S.H., 2000, Alaska resource data file, Atka quadrangle: U.S. Geological Survey Open-File Report 00-21, 4 p. 2000, Alaska resource data file, Attu quadrangle: U.S. Geological Survey Open-File Report 00-28, 6 p. 2000, Alaska resource data file, Bristol Bay quadrangle: U.S. Geological Survey Open-File Report 00-119, 4 p. 2000, Alaska resource data file, Rat Islands quadrangle: U.S. Geological Survey Open-File Report 00-29, 8 p. 2000, Alaska resource data file, Simeonof Island quadrangle: U.S. Geological Survey Open-File Report 00-121, 4 p. 2000, Alaska resource data file, Sutwik Island quadrangle: U.S. Geological Survey Open-File Report 00-120, 17 p. 2000, Alaska resource data file, Ugashik quadrangle: U.S. Geological Survey Open-File Report 00-122, 31 p. 2000, Alaska resource data file, Umnak quadrangle: U.S. Geological Survey Open-File Report 00-118, $31 \mathrm{p}$. 2000, Alaska resource data file, Unimak quadrangle: U.S. Geological Survey Open-File Report 2000-117, 13 p.

Post, Austin, and Viens, R.J., 2000, Preliminary bathymetry of Shoup basin and Late Holocene change of Shoup Glacier, Alaska: U.S. Geological Survey Water-Resources Investigations Report 94-4093, 11 p., 2 sheets, scale 1:10,000.

Richter, D.H., Ratté, J.C., Leeman, W.P., and Menzies, Martin, 2000, Geologic map of the McCarthy D-1 quadrangle, Alaska: U.S. Geological Survey Geologic Investigations Series Map 1-2695, scale $1: 63,360$.

Sampson, J.A., and Rodriguez, B.D., 2000, Magnetotelluric data along the Talkeetna Mountains transect, Alaska: U.S. Geological Survey Open-File Report 00-486, 138 p.

Schmidt, J.M., 2000, Geology and geochemistry of $\mathrm{Zn}-\mathrm{Pb}-\mathrm{Ag}$ veinbreccias at Whoopee Creek, Alaska, in Kelley, K.D., and Gough, L.P., eds., 2000, Geologic studies in Alaska by the U.S. Geological Survey, 1998: U.S. Geological Survey Professional Paper 1615, p. 203-219.

Talbot, S.S., and Markon, C.J., 1999, Prototype map of southwestern Alaska for the circumpolar arctic vegetation map, in Markon, C.J., and Walker, D.A., eds., Proceedings of the Third International Circumpolar Arctic Vegetation Mapping Workshop: U.S. Geological Survey Open-File Report 99-551, p. 28.

Walker, D.A., 1999, An integrated vegetation map for northern Alaska-a prototype for circumpolar arctic vegetation mapping, 
in Markon, C.J., and Walker, D.A., eds., Proceedings of the Third International Circumpolar Arctic Vegetation Mapping Workshop: U.S. Geological Survey 0pen-File Report 99-551, p. 32.

Wanty, R.B., Wang, Bronwen, Vohden, Jim, Briggs, P.H., and Meier, A.L., 2000, Regional baseline geochemistry and environmental effects of gold placer mining operations on the Fortymile River, eastern Alaska, in Kelley, K.D., and Gough, L.P., eds., 2000, Geologic studies in Alaska by the U.S. Geological Survey, 1998: U.S. Geological Survey Professional Paper 1615, p. 101-110.

Wesson, R.L., Frankel, A.D, Mueller, C.S., and Harmsen, S.C., 1999, Probabilistic seismic hazard maps of Alaska: U.S. Geological Survey Open-File Report 99-36, 43 p.

Williams, Anita, 1999, Alaska resource data file, Kotzebue quadrangle: U.S. Geological Survey Open-File Report 99-579, 12 p.

2000, Alaska resource data file, Baird Mountains quadrangle: U.S. Geological Survey Open-File Report 00-024, 50 p.

2000, Alaska resource data file, Candle quadrangle: U.S. Geo- logical Survey Open-File Report 00-025, 109 p.

2000, Alaska resource data file, De Long Mountains quadrangle: U.S. Geological Survey Open-File Report 00-023, 37 p.

-2000, Alaska resource data file, Selawik quadrangle: U.S. Geological Survey Open-File Report 00-005, 21 p.

-2000, Alaska resource data file, Shungnak quadrangle: U.S. Geological Survey Open-File Report 00-022, $33 \mathrm{p}$.

Wilson, F.H., Detterman, R.L., and DuBois, G.D., 1999, Geologic map of the Alaskan Peninsula, southwest Alaska: U.S. Geological Survey Open-File Report 99-317, scale 1:500,000.

Winkler, G.R., 2000, A geologic guide to Wrangell-Saint Elias National Park and Preserve, Alaska-a tectonic collage of northbound terranes: U.S. Geological Survey Professional Paper 1616, $166 \mathrm{p}$.

Wyss, Max, and Hansen, Roger, 1999, Seismicity parameters for seismic hazard assessment in Alaska: U.S. Geological Survey report under contract 1434-HQ-97-GR-03073, 12 p. 



\title{
Reports on Alaska in Non-USGS Publications Released in $\mathbf{2 0 0 0}$ That Include U.S. Geological Survey Authors
}

\author{
Compiled by John P. Galloway \\ [Some reports dated 1999 that did not become available until 2000 are included; USGS authors are marked with an asterisk $\left({ }^{* * \prime}\right)$ ]
}

Anderson, S.P., Kraal, E.R., Anderson, R.S., Longacre, S.A., *Trabant, Dennis, and Fountain, Andrew, 2000, Comparison of the 1999 and 2000 Hidden Creek Lake outbursts-same peak flow, different lake volumes [abs.]: Geological Society of America Abstracts with Programs, v. 32, no. 7, p. 116.

*Anderson, V.M., and *Taylor, C.D., 2000, Alteration mineralogy and zonation in host rocks to the Greens Creek deposit, southeastern Alaska [abs.]: Geological Society of America Abstracts with Programs, v. 32, no. 6, p. 2.

*Ayuso, R.A., *Kelley, K.D., *Slack, J.F., and Young, L.E., 2000, Pb and $\mathrm{Sr}$ isotopic evolution of the Red Dog Pb-Zn-Ag deposit, Brooks Range, Alaska [abs.]: Geological Society of America Abstracts with Programs, v. 32, no. 7, p. 84.

${ }^{*}$ Bacon, C.R., 2000, Preeruptive volatiles in the most recent eruptions of Aniakchak volcano, Alaska [abs.]: Eos (American Geophysical Union Transactions), v. 81, no. 48, p. 1376-1377.

Blodgett, R.B., *Wilson, F.H., Stanley, G.D., Jr., McRoberts, C.A., and Sandy, M.R., 2000, Upper Triassic stratigraphy and fauna of the Taylor Mountains D-2 and D-3 quadrangles (SW part of the Farewell terrane), southwest Alaska [abs.]: Geological Society of America Abstracts with Programs, v. 32, no. 6, p. 4.

${ }^{*}$ Brew, D.A., 2000, Landforms+generalized bedrock-lithologic units in Glacier Bay National Park, southeastern Alaska-are they a partial basis for eco(sub)system units? A study still in progress! [abs.]: Geological Society of America Abstracts with Programs, v. 32, no. 7, p. 264.

*Carlson, P.R., Cowan, E.A., Powell, R.D., and Cai, Jinkui, 1999, Growth of post-Little Ice Age submarine fan, Glacier Bay, Alaska: GeoMarine Letters, v. 19, no. 4, p. 2227-2236.

Chapin, F.S., *McGuire, A.D., and Randerson, James, 2000, Feedbacks from high-latitudes ecosystems to climate [abs.]: Eos (American Geophysical Union Transactions), v. 81, no. 48, p. 223.

*Chouet, B., 2000, Near-surface magmatic-hydrothermal interactions-a seismological perspective [abs.]: Geological Society of America Abstracts with Programs, v. 32, no. 7, p. 111.

Coe, R.S., Zhao, Xixi, Lyons, J.J., Pluhar, C.J., and *Mankinen, E.A., 2000, Revisiting the 1964 collection of Nunivak lava flows [abs.]: Eos (American Geophysical Union Transactions), v. 81, no. 48, p. 350.

Copass, C.D., Beringer, Jason, *McGuire, David, Chapin, F.S., and Walker, D.A., 2000, Characterization of vegetation biomass and structure along a gradient from tundra to forest at tree line in Council, Alaska [abs.]: Eos (American Geophysical Union Transactions), v. 81, no. 48, p. 228.
*Dusel-Bacon, Cynthia, and Cooper, K.M., 1999, Trace-element geochemistry of metabasaltic rocks from the Yukon-Tanana Upland and implications for the origin of tectonic assemblages in eastcentral Alaska: Canadian Journal of Earth Sciences, v. 36, no. 10, p. 1671-1695.

*Dusel-Bacon, Cynthia, *Wooden, J.L., and Hoffmann, B.L., 2000, U-Pb dating and trace-element geochemistry track Late Devonian intra-arc extension and formation of Bonnifield vms deposits and sedex occurrences in the Yukon-Tanana terrane, interior Alaska [abs.]: Geological Society of America Abstracts with Programs, v. 32, no. 6, p. 12.

Edwards, M.E., Anderson, P.M., Brubaker, L.B., *Ager, T.A., Andreev, A.A., Bigelow, N.H., Cwynar, L.C., Eisner, W.R., Harrison, S.P., Hu, F.-S., Jolly, Dominique, Lozhkin, A.V., MacDonald, G.M., Mock, C.J., Ritchie, J.C., Sher, A.V., Spear, R.W., Williams, J.W., and Yu, G., 2000, Pollen-based biomes for Beringia $18,000,6,000$ and $0{ }^{14} \mathrm{C}$ yr BP: Journal of Biogeography, v. 27, no. 3, p. 521-554.

Ernst, G.J., Henderson, L.J., Rose, W.I., Bluth, G.J., Riley, C.M., *Schneider, D.J., and *McGimsey, R.G., 2000, Observations of 1992 Crater Peak/Spurr volcanic clouds in the first few days of atmospheric residence [abs.]: Eos (American Geophysical Union Transactions), v. 81, no. 48, p. 1287.

Fountain, Andrew, *Walder, Joseph, Lindsay, Don, Cunico, Michelle, and Anderson, Suzzane, 2000 Outburst of a glacier-dammed lake, Kennicott Glacier-the importance of storage [abs.]: Geological Society of America Abstracts with Programs, v. 32, no. 7, p. 116.

*Frankel, A.D., * Mueller, C.S., Barnhard, T.P., *Leyendecker, E.V., *Wesson, R.L., ${ }^{*}$ Harmsen, S.C., ${ }^{*}$ Klein, F.W., ${ }^{*}$ Perkins, D.M., *Dickman, N.C., *Hanson, S.L., and *Hopper, M.G., 2000, USGS National seismic hazard maps: Earthquake Spectra, v. 16, no. 1, p. 1-20 [Hazard model for Alaska, p. 6]

*Gardner, C.A., Cashman, K.V., and Roman, Diana, 2000, Decreasing magma ascent rates inferred from groundmass textures during the 1986 eruption of Augustine Volcano, Alaska [abs.]: Geological Society of America Abstracts with Programs, v. 32, no. 7, p. 111.

*Goldman, M.R., *Catchings, R.D., * Gandhok, Tini, *Hanson, S.A., ${ }^{*}$ Kiger, L.E., * Lester, Alana, and *Nelson, Gordan, 2000, Preliminary results of a high-resolution seismic imaging investigation on St. George Island, Pribilof Islands, Alaska [abs.]: Eos (American Geophysical Union Transactions), v. 81, no. 48, p. 876.

*Haeussler, P.J., *Bradley, Dwight, *Miller, Marti, and *Wells, Ray, 2000, Life and death of the Resurrection Plate-evidence for 
an additional plate in the NE Pacific in Paleocene-Eocene time [abs.]: Geological Society of America Abstracts with Programs, v. 32, no. 7, p. 382.

*Haeussler, P.J., Bruhn, R.L., and *Pratt, T.L., 2000, Potential seismic hazards and tectonics of the upper Cook Inlet basin, Alaska, based on analysis of Pliocene and younger deformation: Geological Society of America Bulletin, v. 112, no. 9, p. 1414-1429.

Hammer, J.E., Rutherford, M.J., and *Hildreth, Wes, 2000, Pre-eruptive storage conditions for the andesite magma of the 1912 eruption in the VTTS, AK [abs.]: Eos (American Geophysical Union Transactions), v. 81, no. 48, p. 1375.

*Harden, J.W., O'Neill, K.P., Neff, Jason, *Manies, K.L., Ottmar, Roger, Meier, Rose, and *Cannon, William, 2000, Interactions among soil drainage, fire disturbance, and carbon cycling at plot and landscape scales of the boreal forest [abs.]: Eos (American Geophysical Union Transactions), v. 81, no. 48, p. 259.

*Hildreth, Wes, and *Fierstein, Judy, 2000, Katmai volcanic cluster and the great eruption of 1912: Geological Society of America Bulletin, v. 112, no. 10, p. 1594-1620.

Hines, M.E., and *Bailey, E.A., 2000, Relative activities of methylmercury formation and degradation in natural habitats [abs.]: Geological Society of America Abstracts with Programs, v. 32, no. 7, p. 418.

Keating, B.H., *Waythomas, C.F., and Dawson, A.G., 2000, Introduction, in Landslides and tsunamis: Pure and Applied Geophysics, v. 157, no. 6-8 (special issue), p. 871-874.

*Kelley, K.D., Leach, D.L., Anderson, V.M., Slack, J.F., and Ridley, W.I., 2000, Textural and compositional variations of sphalerite from the Red Dog shale-hosted $\mathrm{Zn}-\mathrm{Pb}-\mathrm{Ag}$ massive sulfide deposits, western Brooks Range, Alaska [abs.]: Geological Society of America Abstracts with Programs, v. 32, no. 7, p. 84.

*Kolak, J.J., Short, J.W., and *Carlson, P.R., 2000, Particulate coal accumulation in Gulf of Alaska sediments-delineation of sources, transport pathways, and geochemistry [abs.]: Geological Society of America Abstracts with Programs, v. 32, no. 7, p. 82.

Kraal, E.R., Anderson, S.P., Longacre, Sharon, Anderson, R.S., *Trabant, Dennis, Cunico, Michelle, and Fountain, Andrew, 2000, Hidden Creek Lake outburst-timing of fluvial and sympathetic lake response to a glacial outburst flood [abs.]: Geological Society of America Abstracts with Programs, v. 32, no. 7, p. 116

*Long, K.R., *DeYoung, J.H., and *Ludington, Steve, 2000, Significant deposits of gold, silver, copper, lead, and zinc in the United States: Economic Geology, v. 95, no. 2, p. 629-644.

*Lu, Zhong, Mann, Dörte, Freymueller, J.T., and Meyer, D.J., 2000, Synthetic aperture radar interferometry of $0 \mathrm{kmok}$ volcano, Alaska-radar observations: Journal of Geophysical Research, v. 105, no. B5, p. 10791-10808.

*Lu, Zhong, *Wicks, Charles, *Dzurisin, Daniel, *Power, J.A., and *Thatcher, Wayne, 2000, Satellite radar interferometry detected surface deformation at a dormant Aleutian volcano [abs.]: Eos (American Geophysical Union Transactions), v. 81, no. 48, p. 1354.

${ }^{*}$ Lu, Zhong, *Wicks, Charles, ${ }^{*}$ Dzurisin, Daniel, ${ }^{*}$ Thatcher, Wayne, Freymueller, J.T., McNutt, S.R., and Mann, Dörte, 2000, Aseismic inflation of Westdahl volcano, Alaska, revealed by satellite radar interferometry: Geophysical Research Letters, v. 27, no. 11, p. 1567-1570.

*Mangan, Margaret, *Trusdell, Frank, *Miller, Thomas, and *Waythomas, Christopher, 2000, Events and geochemistry of the initial calderaforming eruption at Emmons Lake volcanic complex [abs.]: Eos (American Geophysical Union Transactions), v. 81, no. 48, p. 1353.

Mann, Dörte, Freymueller, J.T., and *Lu, Zhong, 2000, The pre-, co-, post-eruptive sequence of the $19970 \mathrm{kmok}$ eruption from defor- mation observations [abs.]: Eos (American Geophysical Union Transactions), v. 81, no. 48, p. 1376.

*Marlow, M.S., *Stevenson, A.J., *Chezar, Henry, and McConnaughey, R.A., 1999, Tidally generated sea-floor lineations in Bristol Bay, Alaska, USA: Geo-Marine Letters, v. 19, no. 4, p. 219-226.

*McGimsey, R.G., *Neal, C.A., and Riley, C.M., 2000, Isomass maps of the tephra fall deposits from the 1992 eruptions of Crater Peak vent, Mount Spurr volcano, Alaska [abs.]: Eos (American Geophysical Union Transactions), v. 81, no. 48, p. 1312.

*McGuire, A.D., Meier, R.A., Zhuang, Qianlai, Macander, Matt, Rupp, T.S., Kasischke, Eric, Verbyla, David, Kicklighter, D.W., and Melilo, J.M., 2000, The role of fire disturbance, climate, and atmospheric carbon dioxide in the response of historical carbon dynamics in Alaska from 1950 to 1995-the importance of fire history [abs.]: Eos (American Geophysical Union Transactions), v. 81, no. 48, p. 260.

* McNamara, D.E., 2000, Frequency dependence of Lg attenuation in south-central Alaska [abs.]: Eos (American Geophysical Union Transactions), v. 81, no. 48, p. 877.

Meier, Rose, *Harden, Jennifer, Silapaswan, Cherie, Swanson, David, Zhuang, Qianlai, and *McGuire, A.D., 2000, Characterization of soil drainage classes for the study of soil carbon storage in Alaska [abs.]: Eos (American Geophysical Union Transactions), v. 81, no. 48, p. 239.

*Miller, M.L., *Bradley, D.C., and Bundtzen, T.K., 2000, Late Cretaceous and Tertiary strike-slip faulting and its relationship to Au and $\mathrm{Hg}$ ore-forming events in the Kuskokwim mineral belt, southwestern Alaska [abs.]: Geological Society of America Abstracts with Programs, v. 32, no. 6, p. 31.

${ }^{*}$ Miller, T.P., 2000, Volcanic ash hazards at the start of the 21st Century-status and mitigation [abs.]: Eos (American Geophysical Union Transactions), v. 81, no. 22, supplement, p. 226.

*Miller, T.P., *Mangan, M.T., and *Trusdell, F.A., 2000, Physical volcanology of large Late-Quaternary caldera-forming eruptions at the Emmons Lake volcanic center, Alaska Peninsula [abs.]: Eos (American Geophysical Union Transactions), v. 81, no. 48, p. 1353.

*Moore, T.E., and *Potter, C.J., 2000, Torok-Fortress Mountain duplex, north-central Brooks Range foothills, Alaska [abs.]: Geological Society of America Abstracts with Programs, v. 32, no. 6, p. 32.

*Moran, S.C., 2000, Volcano-tectonic earthquakes at Katmai National Park, Alaska: Evidence for more than one source process [abs.]: Eos (American Geophysical Union Transactions), v. 81, no. 48, p. 1375.

Mueller, S.H., Farmer, G.L., ${ }^{*}$ Goldfarb, R.J., ${ }^{*}$ Sanzolone, Richard, *Adams, Monique, and Richmond, S.A., 2000, Controls on the concentration and mobility of arsenic in groundwaters, Fairbanks, Alaska [abs.]: Geological Society of America Abstracts with Programs, v. 32, no. 6, p. 57.

Mull, C.G, Harris, E.E., Reifenstuhl, R.R., and *Moore, T.E., 2000, Geologic map of the Coke Basin-Kukpowruk River area, DeLong Mountains D-2 and D-3 quadrangles, Alaska: Alaska Division of Geological and Geophysical Surveys Report of Investigations $2000-2$, scale $1: 63,360$.

*Neal, C.A., 2000, Communication of volcano hazards-approach of the Alaska Volcano Observatory [abs.]: Geological Society of America Abstracts with Programs, v. 32, no. 7, p. 335.

*Nokleberg, W.J., Bundtzen, T.K., Dawson, K.M, Monger, J.W.H., Khanchuk, A.I., Parfenov, L.M., and Shpikerman, V.I., 2000, Tectonic controls for Phanerozoic metallogenesis of the Russian Far East, Alaska, and the Canadian Cordillera [abs.]: Geological Society of America Abstracts with Programs, v. 32, no. 6, p. 59. 
*Nokleberg, W.J., Bundtzen, T.K., Goryachev, N.A., Shpikerman, V.I., Khanchuk, A.I., Ratkin, V.V., and Parfenov, L.M., 1999, Metallogenesis of the Russian Far East and Alaska as part of the Circum-North Pacific tectonic regime [abs.]: Mongolian Geoscientist, no. 14, p. 89-90.

*Nokleberg, W.J., Khanchuk, A.I., Naumova, V.V., Badarch, Gombosuren, Parfenov, L.M., ${ }^{*}$ Miller, R.J., and NE Asia Metallogenesis Team, 1999, Geographic information systems compilation of geodynamic, mineral resource, and geophysical maps being developed for the Northeast Asia metallogenesis project [abs.]: Mongolian Geoscientist, no. 14, p. 52-53.

*Nokleberg, W.J., Scotese, C.R., Khanchuk, A.I., Monger, J.W.H., Dawson, K.M., Norton, I.O., and Parfenov, L.M., 2000, Dynamic computer model for the Phanerozoic tectonic and metallogenic evolution of the Circum-Pacific [abs.]: Geological Society of America Abstracts with Programs, v. 32, no. 6, p. 59.

*Nordstrom, D.K., 2000, Advances in the hydrogeochemistry and microbiology of acid mine waters: International Geology Review, v. 42, no. 6, p. 499-515.

*Parris, T.M., and *Burruss, R.C., 2000, Syntectonic fluid flow and fracturing, eastern Brooks Range, Alaska [abs.]: Geological Society of America Abstracts with Programs, v. 32, no. 7, p. 236.

*Power, J.A., *Moran, S.C., McNutt, S.R., Stihler, S.D., and Sanchez, J.J., 2000, Triggered seismicity beneath the Katmai volcanoes following the December 6, 1999, magnitude 7.0 Karluk Lake earthquake, Alaska [abs.]: Eos (American Geophysical Union Transactions), v. 81, no. 48, p. 917.

*Richmond, S.A., and Braddock, J.F., 2000, Geochemical characterization of anaerobic ground water in subarctic Alaska, in Kane, D.L., ed., Water resources in extreme environments: American Water Resource Association meeting, Middleburg, Va., 2000, p. 141-145.

Riley, C.M., Rose, W.I., Textor, Christiane, Graf, H.F., Bluth, G.J.-S., and *McGimsey, R.G., 2000, Modeling particle aggregation and microphysical processes in the August 1992 Spurr eruption plume using ATHAM [abs.]: Eos (American Geophysical Union Transactions), v. 81, no. 48, p. 1288.

Roeske, S.M., McClelland, W.C., and ${ }^{*}$ Snee, L.W., 2000, Extrusion of the Ruby terrane from the Brook Range, Alaska, during Early Cretaceous right-lateral strike-slip [abs.]: Geological Society of America Abstracts with Programs, v. 32, no. 6, p. 64.

*Saltus, R.W., *Haeussler, P.J., and *Doucette, J.P., 2000, Anchorage Urban Region Aeromagnetics (AURA) - preliminary geophysical results [abs.]: Eos (American Geophysical Union Transactions), v. 81, no. 48, p. 1218.

Sauber, Jeanne, and *Molnia, B.F., 2000, Glacial fluctuations and the rate of deformation in south central Alaska [abs.]: Eos (American Geophysical Union Transactions), v. 81, no. 48, p. 325.

*Schneider, D.J., Dean, K.G., and Dehn, Jonathan, 2000, Use of satellite remote sensing for volcano monitoring and ash cloud tracking by the Alaska Volcano Observatory [abs.]: Eos (American Geophysical Union Transactions), v. 81, no. 22, supplement, p. 227.

Schuur, E.A.G., Trumbore, S.E., *Harden, Jennifer, and Chapin, F.S., 2000, The isotopic composition of carbon dioxide from a boreal forest fire [abs.]: Eos (American Geophysical Union Transactions), v. 81, no. 48, p. 237.

Scotes, C.R., *Nokleberg, W.J., *Scholl, D.W., Khanchuk, A.l., Monger, J.W.H., Dawson, K.M., Norton, I.O., and Parfenov, L.M., 2000, Interactive demonstration of dynamic computer model for the Phanerozoic tectonic and metallogenic evolution of the Circum-North Pacific [abs.]: Geological Society of America Abstracts with Programs, v. 32, no. 6, p. 67.
Silapaswan, C.S., Verbyla, D.L., and *McGuire, A.D., 2000, Land cover change on the Seward Peninsula - the use of remote sensing to evaluate the potential influences of climate change on historical vegetation dynamics [abs.]: Eos (American Geophysical Union Transactions), v. 81, no. 48, p. 231-232.

*Stottlemyer, Robert, 2000, Climate change and treeline watershed nutrient exports, Noatak National Preserve, Alaska [abs.]: AAAS Arctic Science Conference, 51st, Whitehorse, Yukon, Canada, 2000, Program and Abstracts, p. 161-162.

*Stottlemyer, Robert, and Herrmann, Reimer, 2000, Relationship between soil processes and stream chemistry in a small taigatundra watershed, Alaska [abs.]: Eos (American Geophysical Union Transactions), v. 81, no. 48, p. 379.

Synolakis, Costas, Borrero, Jose, Yalciner, Ahmet, *Plafker, George, Greene, H.G., and Watts, Phil, 2000, Modeling the 1994 Skagway, Alaska tsunami [abs.]: Eos (American Geophysical Union Transactions), v. 81, no. 48, p. 748.

*Taylor, C.D., *Premo, W.R., and Lear, K.G., 2000, The Greens Creek massive sulfide deposit-premier example of the Late Triassic metallogeny of the Alexander terrane, southeastern Alaska and British Columbia [abs.]: Geological Society of America Abstracts with Programs, v. 32, no. 6, p. 71.

*Trabant, D.C., and *March, R.S., 1999, Mass-balance measurements in Alaska and suggestions for simplified observations programs: Geografiska Annaler, v. 81A, no. 4, p. 777-789.

*Trabant, D.C., Cunico, Michelle, Walder, J.S., Anderson, S.P., and Fountain, A.G., 2000, Ice-dam kinematics before, during, and after an outburst flood [abs.]: Eos (American Geophysical Union Transactions), v. 81, no. 48, p. 437.

Wallace, K.L., and *Waythomas, C.F., 2000, Further investigation of geologic setting and characterization of a large volcanic debris avalanche deposit in the Copper River basin, Alaska [abs.]: Eos (American Geophysical Union Transactions), v. 81, no. 48, p. 1353.

*Waythomas, C.F., 2000, Dam-break floods caused by failure of volcanic debris dams in the Chakachatna River valley associated with eruptions of the Spurr volcanic complex, Alaska [abs.]: Geological Society of America Abstracts with Programs, v. 32, no. 7, p. 510.

2000, Reevaluation of tsunami formation by debris avalanche at Augustine Volcano, Alaska: Pure and Applied Geophysics, v. 157, no. 6-8, p. 1145-1188.

*Waythomas, C.F., *Miller, T.P., *Mangan, M.T., ${ }^{*}$ Trusdell, F.A., and Wallace, K., 2000, Fire and ice on the Alaska Peninsula stratigraphic records of pyroclastic eruptions and glaciation, Emmons Lake caldera and vicinity, southwestern Alaska [abs.]: Eos (American Geophysical Union Transactions), v. 81, no. 48, p. 1352-1353.

Zhang, Xinxian, *McQuire, A.D., and Ruess, R.W., 2000, Modeling stand-level canopy maintenance respiration of black spruce ecosystems in Alaska-implications for spatial and temporal scaling [abs.]: Eos (American Geophysical Union Transactions), v. 81 , no. 48 , p. $239-240$.

Zhuang, Qianlai, *McGuire, A.D., ${ }^{*}$ Harden, Jennifer, O'Neill, K.P., and Yarie, John, 2000, Modeling the carbon dynamics of a fire chronosequence in interior Alaska [abs.]: Eos (American Geophysical Union Transactions), v. 81, no. 48, p. 238.

Zumsteg, C.L., Himmelberg, G.R., *Karl, S.M., and *Haeussler, P.J., 2000, High-temperature/low-pressure metamorphism within the fore arc on Baranof Island, southeast Alaska [abs.]: Geological Society of America Abstracts with Programs, v. 32, no. 7, p. 151. 
